\author{
Universidade de São Paulo
}

Faculdade de Educação

Beatriz Aparecida Caprioglio de Castro

\title{
O Professor de Física em Formação: seus motivos, ações e sentidos
}



Beatriz Aparecida Caprioglio de Castro

\section{O Professor de Física em Formação: seus motivos, ações e sentidos}

Tese apresentada como requisito necessário à obtenção do título de doutor em Educação pelo programa de pósgraduação em Educação na área de concentração de Ensino de Ciências e Matemática.

Orientadora: Profa. Dra. Maria Lucia Vital dos Santos Abib

São Paulo 
AUTORIZO A REPRODUÇÃO E DIVULGAÇÃO TOTAL OU PARCIAL DESTE TRABALHO, POR QUALQUER MEIO CONVENCIONAL OU ELETRÔNICO, PARA FINS DE ESTUDO E PESQUISA, DESDE QUE CITADA A FONTE.

Catalogação na Publicação Serviço de Biblioteca e Documentação

Faculdade de Educação da Universidade de São Paulo

\section{$371.12 \quad$ Castro, Beatriz Aparecida Caprioglio de}

C355p O professor de física em formação: seus motivos, ações e sentidos / Beatriz Aparecida Caprioglio de Castro; orientação Maria Lúcia Vital dos Santos Abib. São Paulo: s.n., 2015.

372 p.; tabs.; anexos; apêndices

Tese (Doutorado - Programa de Pós-Graduação em Educação. Área de Concentração: Ensino de Ciências e Matemática) - - Faculdade de Educação da Universidade de São Paulo.

1. Formação de professores 2. Estágios supervisionados 3. Sentidos 4. Teoria da atividade 5. Licenciatura 6. Física (Ensino) 7. Leontiev, Alexi I. Abib, Maria Lúcia Vital dos Santos, orient. 


\section{FOLHA DE APROVAÇÃO}

\section{Beatriz Aparecida Caprioglio de Castro}

O Professor de Física em Formação: seus motivos, ações e sentidos

Tese apresentada à Faculdade de Educação da Universidade de São Paulo para obtenção do título de Doutor. Área de Concentração: Ensino de Ciências e Matemática

Aprovado em:

Banca Examinadora

Prof. Dr.

Instituição:

Julgamento:

Assinatura:

Prof. Dr.

Instituição:

Julgamento:

Assinatura:

Prof. Dr.

Instituição:

Julgamento:

Assinatura:

Prof. Dr.

Instituição:

Julgamento:

Assinatura:

Prof. Dr.

Instituição:

Julgamento:

Assinatura: 

Tecendo a Manhã

Um galo sozinho não tece uma manhã: ele precisará sempre de outros galos. De um que apanhe esse grito que ele e o lance a outro; de um outro galo que apanhe o grito de um galo antes e o lance a outro; e de outros galos que com muitos outros galos se cruzem os fios de sol de seus gritos de galo, para que a manhã, desde uma teia tênue, se vá tecendo, entre todos os galos.

João Cabral de Melo Neto 

À minha mãe, Reny, pela orientação de vida, pela presença carinhosa e apoio incondicional.

Ao meu pai, Sebastião (in memoriam), pelos ensinamentos para vida.

À minha irmã, Bernadete, pelos momentos compartilhados, pelas discussões e pelo acolhimento.

Aos meus sobrinhos, Ursula, Fernando, Emiliano e Gabriella, pelo carinho, dedicação e amizade. 



\section{Agradecimentos}

À Profa. Dra. Maria Lucia Vital dos Santos Abib minha gratidão, pela orientação, seriedade, confiança, carinho e amizade. As discussões e a convivência no processo desse trabalho foram contribuições fundamentais para minha aprendizagem. Levarei para sempre o sorriso de simpatia, alegria, tranquilizando os momentos mais difíceis.

À Heloisa e Ricardo (nomes fictícios) minha eterna gratidão, por permitirem que essa pesquisa fosse realizada, disponibilizando suas palavras, que os tornaram quem são, com quem estão e estiveram, onde e quando. Que hoje sinto em mim um pouco de vocês. Muito obrigada!

Minha gratidão aos alunos das disciplinas de Metodologia de Ensino de Física que me receberam com respeito e colaboraram prontamente com a pesquisa, sem os quais não seria possível este trabalho.

À Profa. Dra. Lucia Helena Sasseron pela contribuição com essa pesquisa, pelas discussões, pela amizade e amabilidade. Sua colaboração foi especial para a realização desse trabalho.

Ao Prof. Dr. Manoel Oriosvaldo de Moura pela orientação no exame de qualificação, pela contribuição à pesquisa e pela oportunidade das discussões em seu grupo.

À professora Dra. Alice Pierson pela orientação no exame de qualificação e pela contribuição à pesquisa.

Ao Prof. Dr. Cristiano Rodrigues de Mattos pelas contribuições à pesquisa.

Aos membros da banca examinadora por se dedicarem à leitura e discussão desse trabalho.

Ao Prof. Dr. Ernst W. Hamburger que me incentivou incansavelmente ao ingresso no doutorado. Toda minha gratidão pelo aprendizado que me oportunizou durante nossa convivência.

À Profa. Dra. Roseli de Deus Lopes pelo incentivo ao ingresso no doutorado.

Ao Prof. Dr. Ariovaldo U. de Oliveira pelo apoio, incentivo e carinho durante o processo desse trabalho.

Muito obrigada, à minha amiga de jornada e pesquisadora Ana Paula Solino, pela colaboração incansável com esse trabalho, ao tempo dispensado à leitura, as sugestões tão oportunas, pelas discussões e estudos que fizemos juntas, pelo cuidado e carinho, minha imensa gratidão.

Agradeço à minha amiga e pesquisadora Maria Nizete de Azevedo pela colaboração com a leitura deste trabalho, pelas discussões que tanto me ajudaram e pelo carinho.

À amiga de caminhada na pós-graduação e pesquisadora Erika B. Dauanny com quem pude dividir ideias e contar com o apoio, muito obrigada. 
Agradeço com carinho à Christiane I. Yamamoto pela colaboração nesse trabalho e pela amizade que sempre me trouxe apoio.

À Elisa Racy Carlini pela colaboração e atenção.

À Leonardo Testoni pelo apoio e amizade,

Aos amigos do grupo de pesquisa pela colaboração em todos os momentos do trabalho, apoiando a construção desde suas primeiras linhas.

Aos amigos do LaPEF pelo apoio, discussões e carinho. Esse acolhimento foi fundamental para esse percurso.

À amiga Sebastiana A. de Almeida Severo pelo carinho e dedicação dispensados comigo nessa jornada.

À Neusa Mariano e Angelina Sofia Orlandi pelo incentivo, amizade e carinho com que acompanharam essa pesquisa.

À Maria Cecília Toloza de Oliveira e Costa e Marco Antonio pela amizade, carinho e apoio nos momentos necessários.

À Daniela de Oliveira Camargo, João Batista dos Santos, Elisabete Rebollo, Cristiana Cavalcanti, Cristiane Cavalcanti e Dona Paixão Cavalcanti pela amizade e pelo apoio tão carinhoso.

Aos funcionários da secretaria de pós-graduação que sempre me orientaram com muita atenção.

À Welson, Ricardo, Marisa, Vera, Heloisa, Paulo, Ana, Nete e Felipe pelo apoio nos momentos difíceis.

Agradeço aos familiares, amigas e amigos que acompanharam este trabalho, por estarem sempre presentes em minha vida. 
CASTRO, B. A. C. de. O professor de Física em formação: seus motivos, ações e sentidos. 2015. 372 p. Tese (Doutorado) - Faculdade de Educação, Universidade de São Paulo, São Paulo, 2015.

\section{Resumo}

Nesse estudo objetivamos investigar como licenciandos atribuíam sentidos à docência em seu processo de formação inicial, considerando-o contexto das disciplinas de Metodologia do Ensino de Física de um curso de licenciatura de uma universidade pública paulista. Metodologicamente, a pesquisa se caracterizou como qualitativa, do tipo estudo de caso de observação participante, onde consideramos como unidade de análise a "atividade de estágio". Buscamos analisar a trajetória de formação de dois sujeitos em sua historicidade e nas interações estabelecidas por eles no desenvolvimento das ações no processo de aprendizagem da docência. Utilizamos observações e gravações em áudio de aulas das disciplinas, questionários e entrevistas semiestruturadas, bem como procedemos ao acompanhamento das regências das aulas de estágio para os casos focalizados. Baseamos nossas análises na perspectiva histórico-cultural, especialmente na Teoria da Atividade, elaborada por Vigotski e Leontiev e ampliada por Engeström. Organizamos a análise em cinco episódios: memórias do ensino básico; vivências da Licenciatura em Física; organização das aulas de estágio; regências das aulas de estágio; reflexão teórico-prática sobre o estágio, nos quais abordamos os sentidos atribuídos à docência pelos dois sujeitos, como e em que situações ocorreram. Os resultados apontaram alguns eixos articuladores da atribuição de sentidos, como: as memórias e vivências trazidas pelos licenciandos; as interações estabelecidas com os diferentes atores nos diversos contextos; os processos mediacionais conduzidos nas disciplinas pela professora e com os colegas; o movimento da atividade de estágio e suas contradições; bem como, as possibilidades projetadas para o futuro pelos licenciandos, os quais foram indutores de mudanças, por promoverem motivos eficazes para os licenciandos, proporcionando a organização de ações para a aprendizagem da docência. Ressaltamos, que as atribuições de sentidos não se iniciaram nessas disciplinas e nem se esgotam nelas, mas ajudam a compor uma rede dinâmica de sentidos, dentre os quais destacamos: a compreensão da importância da intencionalidade no ensino e na organização de suas ações; a atribuição ao papel do professor de coordenar a atividade de aprendizagem; a importância da relação colaborativa no ensino; o reconhecimento da base teórica associada à prática; o entendimento da educação como processo de intervenção social. Desta forma, apontamos o papel fundamental das ações relativas ao estágio, desenvolvido como processo substantivo da aprendizagem da docência dos futuros professores, cumprindo assim, sua função primordial de aproximação de motivos e sentidos na direção dos significados sociais da profissão docente.

Palavras-chaves: Formação inicial de professores; Estágio supervisionado; Sentidos; Teoria histórico-cultural da atividade; Licenciatura em Física 
CASTRO, B. A. C. de. Teacher of physics in teaching education: their motives, actions and senses. 2015. 372p. Tese (Doutorado) - Faculdade de Educação, Universidade de São Paulo, São Paulo, 2015.

\begin{abstract}
In this study we aimed to investigate how undergraduates senses attributed to teaching in their initial teaching education process, considering the context of the methodology of disciplines of Physics Teaching of a degree program at a public university. Methodologically, the research was characterized as qualitative, case study of participant observation, which we considered as the unit of analysis "traineeship activity." We analyzed the initial teaching education trajectory of two subjects in their historicity and the interactions established by them in the development of actions in the teaching learning process. We used notes and audio recordings of classes of the disciplines, questionnaire and semi-structured interviews as observing the regencies of traineeship classes of the targeted cases. We based our analysis on historical and cultural perspective, especially in the Activity Theory developed by Vygotsky and Leontiev and expanded by Engeström. We organized the analysis in five episodes: primary school memories; experiences of Degree in Physics; organization of traineeship classes; regencies of traineeship classes; theoretical and practical reflection of the traineeship which we discussed the senses attributed to teaching of the two individuals: how and in what situations occurred. The results showed some axes articulating the attribution of senses, such as memories and experiences brought by the licensees; the interactions established with different actors in different contexts; the mediational processes conducted in the disciplines by teacher and colleagues; the movement of the traineeship activity and contradictions; as well as the possibilities for the future designed by undergraduates, which were inducing changes by promoting effective motives for undergraduates, providing the organization of actions for learning teaching. We emphasized that the attributions of senses did not start in these disciplines and did not exhausted them, but help to make up a dynamic network of senses, among which include: understanding the importance of intentionality in teaching and organization of their actions; assigning the role of the teacher in coordinating the learning activity; the importance of collaborative relationship in teaching; the recognition of theoretical basis associated with the practice; the understanding of education as a social intervention process. Concluding, we pointed out the fundamental role of the actions related to the traineeship, developed as a substantive process of teaching learning for the future teachers; fulfilling its primary function of approaching motives and senses towards the social meanings of the teaching profession.
\end{abstract}

Keywords: Initial teacher education; Supervised traineeship; Sense; Cultural-historical activity theory; Physics degree 


\section{Lista de Figuras}

Figura 1: Representação da relação entre estímulo e resposta, feita pela mediação por instrumentos ou signos

Figura 2: Componentes de uma atividade.

Figura 3: Estrutura hierárquica da atividade

Figura 4: Modelo da teoria da atividade da primeira geração

Figura 5: Modelo da teoria da atividade da segunda geração

Figura 6: Modelo da teoria da atividade da terceira geração: dois sistemas de atividade interativo.

Figura 7: Estruturas das disciplinas de Metodologia do Ensino de Física I e II, no ano da coleta dos dados da pesquisa

Figura 8: Movimento ontológico dos sujeitos.

Figura 9: Relação entre o sujeito e as atividades, ações e rede de sentidos, contribuindo para formação docente

Figura 10: Relações entre a atividade de estágio, as ações para docência e os episódios

Figura 11- Representação de uma possibilidade de Rede de Sentidos atribuídos por Heloisa à docência...

Figura 12: Representação de uma possibilidade de Rede de Sentidos atribuídos por Ricardo à docência. 


\section{Lista de Quadros}

Quadro 1: Sujeitos e instrumentos de pesquisa

Quadro 2: Instrumentos de pesquisa, local e período de coleta, tipo de registro e códigos utilizados para análise dos dados.

Quadro 3: Mapa dos sentidos de Heloisa para o episódio 1

Quadro 4: Mapa dos sentidos de Ricardo para o episódio 1

Quadro 5: Mapa dos sentidos de Heloisa para o episódio 2

Quadro 6: Mapa dos sentidos de Ricardo para o episódio 2

Quadro 7: Mapa dos sentidos de Heloisa para o episódio 3

Quadro 8: Mapa dos sentidos de Ricardo para o episódio 3.

Quadro 9: Mapa dos sentidos de Heloisa para o episódio 4

Quadro 10: Mapa dos sentidos de Ricardo para o episódio 4

Quadro 11 Mapa dos sentidos de Heloisa para o episódio 5

Quadro 12: Mapa dos sentidos de Ricardo para o episódio 5

Quadro 13: Mapa dos sentidos de Ricardo para o episódio 5 (cont.).

Quadro 14: Representação das situações apreendidas na pesquisa, nas quais Heloisa e Ricardo atribuíram sentidos à docência.

Quadro 15: Representação dos eixos articuladores da atribuição de sentidos por Heloisa e Ricardo. 


\section{Sumário}

Introdução..................................................................................................................... 19

CAPÍTULO 1 - O professor de Ciências: formação e profissão.............................. 25

1.1 Formação de professores de Ciências.................................................................... 25

1.2 O professor e a profissão docente.................................................................... 29

1.3. Pensamento, ação e reflexão na formação do professor........................................ 35

CAPÍTULO 2 - A formação inicial de professores de Ciências e o estágio para docência............................................................................................................... 42

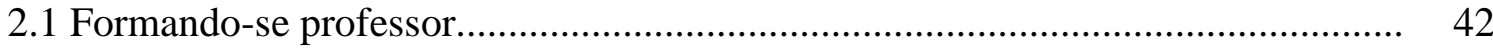

$2.2 \mathrm{O}$ estágio supervisionado para a aprendizagem da docência............................... 45

2.3 A educação como atividade humana................................................................... $\quad 52$

2.4 A metodologia de ensino e o estágio para o licenciando em física....................... 58

CAPÍTULO 3 - Teoria Histórico-Cultural e Teoria da Atividade........................ 61

3.1 Vigotski e a Teoria Histórico-Cultural.......................................................... 61

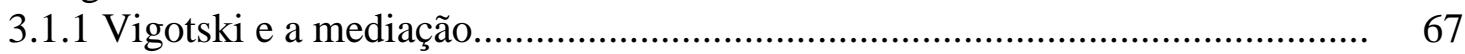

3.1.2 A linguagem como função mediadora......................................................... 72

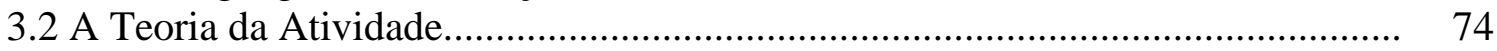

3.2.1 Atividade, ação e operação................................................................... 80

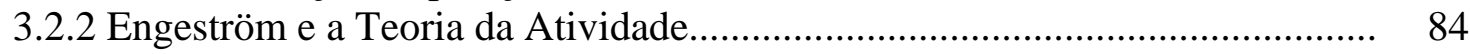

3.2.3 Significado e Sentido.................................................................................. 88

3.3 O processo histórico-cultural na formação do professor..................................... 93

CAPÍTULO 4 - Contexto da pesquisa e metodologia............................................... 98

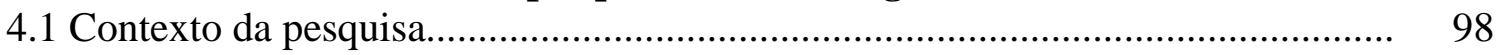

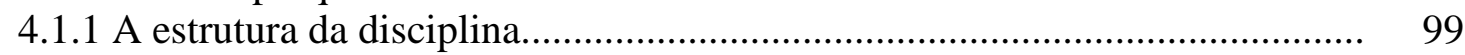

4.1.2 O grupo de licenciandos................................................................... 103

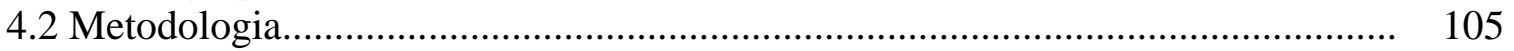

4.2.1 O método histórico-dialético e a unidade de análise..................................... 106

4.2.2 Instrumentos de pesquisa............................................................................ 110

4.2.3 Apresentação dos dados do questionário 1 e 2 ............................................. 114

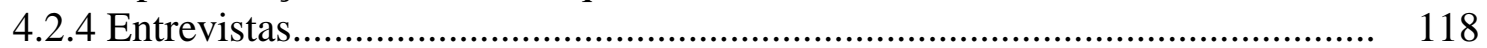

4.3 Os sujeitos da pesquisa...................................................................... 120

CAPÍTULO 5 - Aprendizagem da docência para dois licenciandos...................... 123

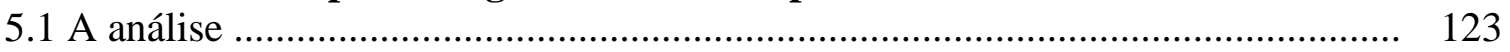

5.2 Os episódios........................................................................................ 126

5.2.1 Episódio 1 - Memórias do Ensino Básico..................................................... 129

5.2.2 Episódio 2 - Vivências da Licenciatura em Física........................................ 144

5.2.3 O estágio nas disciplinas de Metodologia de Ensino de Física I e II.............. 159

5.2.3.1 Episódio 3 - Organização das aulas de estágio........................................ 159

5.2.3.2 Episódio 4 - Regência das aulas de estágio............................................ 207

5.2.3.3 Episódio 5 - Reflexão teórico-prática sobre o estágio ............................ 223

5.3 Rede de sentidos de Heloisa e Ricardo.............................................................. 259

5.4 Aprendizagem da docência e a atribuição de sentidos........................................ 262 
5.5 Eixos articuladores da atribuição de sentidos

CAPÍTULO 6 - Conclusões e considerações finais.

Referências Bibliográficas

Anexos.

A - Cronograma das disciplinas de Metodologia do Ensino de Física I e II, com o programa por aula

Apêndices

A - Questionários 1 e 2, aplicados aos alunos das disciplinas de Metodologia do Ensino de Física I e II...

B - Entrevistas 1 e 2 aplicadas aos alunos das disciplinas de Metodologia do Ensino de Física I e II

C - Transcrição das entrevistas de Heloisa e Ricardo

D - Transcrição da apresentação do planejamento nas disciplinas de Metodologia do Ensino de Física I e II

E - Transcrição da apresentação da reflexão de um momento da regência das aulas nas disciplinas de Metodologia do Ensino de Física I e II 


\section{Introdução}

Aquele que quer aprender a voar um dia precisa primeiro aprender a ficar de pé, caminhar, correr, escalar e dançar; ninguém consegue voar só aprendendo voo.

Friedrich Nietzsche

Essa pesquisa é fruto de nossa jornada no ensino de Ciências e representa ainda uma longa caminhada de aprendizagem, que sabemos, não acaba aqui, mas nos fará dar mais um passo adiante.

A formação do professor é complexa e as discussões sobre o tema são inúmeras, trazendo contribuições que abordam aspectos fundamentais, porém muitas vezes, com enfoques bastante diferenciados. Nesse sentido, julgamos importante apontar que a pesquisa busca entender a formação como uma construção coletiva, na qual os licenciandos na aprendizagem da docência vão se humanizando, como propõem os aportes histórico-culturais.

O contato com a educação básica como aluna foi marcado pela presença de alguns professores que concebiam o ensino com o objetivo da construção do humano, visando uma forma de apropriação significativa da aprendizagem. Isso começou a influenciar minhas primeiras visões sobre a educação formal e o ato de aprender. Mais tarde, o ensino superior trouxe outras possibilidades, prevalecendo, no entanto, a motivação para a docência, norteada por um ideal transformador, um compromisso social e pessoal.

Após a minha formação em licenciatura em Física, a volta à escola básica, agora como professora, permitiu o contato por 18 anos com a cultura escolar, com os alunos, com os colegas de profissão e com as contradições do sistema educacional. Essa experiência possibilitou a busca de mudanças na escola, que nem sempre se realizaram, mas impulsionavam o trabalho cotidiano. As experiências vividas contribuíram para construir uma postura profissional e de vida.

Durante essa trajetória profissional, foi mantida a relação com a universidade como estagiária, pesquisando sobre a evasão de alunos no curso de Física. Passado algum tempo, decidi fazer o mestrado em ensino de Física nessa mesma universidade, com foco na formação de professores. Esse estudo me levou a uma nova experiência profissional, voltada para o contexto do ensino não formal, em um centro de ciências da Universidade de São 
Paulo, a Estação Ciência. As ações permitiam um contato intenso com as escolas, bem como, com público diverso, sendo o objetivo deste centro as ações de extensão, com proposta de divulgação científica e cultural. Trabalhamos também com a formação de estagiários, que eram alunos de graduação, voltada para a mediação entre os diversos públicos e as exposições, equipamentos e objetos que compunham o acervo.

$\mathrm{Na}$ mesma instituição trabalhamos ainda com a formação continuada de professores, em uma proposta de Ensino de Ciências por Investigação, como ação do projeto ABC na Educação Científica, que tinha como foco o Ensino Fundamental e as escolas públicas de São Paulo. Em função deste projeto nosso contato com as escolas foi constante, o que nos permitiu colher com frequência os apontamentos sobre a necessidade da formação continuada e a importância de uma formação inicial consistente com embasamentos teóricos e considerando a prática docente e o contexto escolar.

Essa proximidade com as escolas, as observações in loco, a participação no grupo de estudos, motivaram a pesquisa sobre o papel do coordenador pedagógico na formação do professor no âmbito da escola, o que me levou a elaborar um projeto de doutorado em Educação. O objetivo foi pesquisar os sentidos atribuídos pelo coordenador pedagógico e pelos professores para suas atividades de ensino com foco nas ações docentes. Era compreender como esse processo ocorria, como e quais ações eram desenvolvidas pelos professores, como eram realizados os trabalhos coletivos no contexto de discussão e elaboração de atividades de ensino de Ciências. No entanto, a escola, na qual tínhamos um levantamento prévio de dados, teve o coordenador pedagógico removido, o que nos impossibilitou de continuar desenvolvendo a pesquisa.

Com a inviabilidade da pesquisa que havia sido planejada, nos detivemos em outro foco de nosso interesse que era a formação inicial de professores, mais especificamente, no caso das licenciaturas de Ciências. A disciplina de Metodologia de Ensino de Física oferecida aos alunos da licenciatura em Física contribuiu para definir o foco dessa investigação.

A disciplina de Metodologia de Ensino engloba o Estágio Supervisionado, portanto, a pesquisa visa ações realizadas em dois contextos, na disciplina e no estágio. Essa disciplina tem como perspectiva fundamental a formação para a docência, desenvolvendo para e com os alunos, momentos que possibilitem atuar na prática docente, discutir e conhecer o contexto escolar, assim como, adquirir bases teóricas para que possa contribuir com os licenciandos na sua formação como professores. 
O estágio supervisionado permite aos alunos o contato com a docência em seu processo de aprendizagem, aproximando os licenciandos do contexto escolar, possibilitando as regências em sala de aula, atuando também na elaboração de aulas planejadas e supervisionadas pela professora da disciplina.

A pesquisa se insere em uma perspectiva histórico-cultural, considerando a disciplina e o estágio como sistemas de atividades, com o objetivo de identificar os sentidos que os licenciandos atribuem à docência e como esse processo ocorre durante as ações de estágio, que têm duração de dois semestres, sendo um para cada uma das disciplinas de Metodologia do Ensino de Física (I e II). O estudo sobre os fatores que colaboram para atribuição de sentidos pode permitir que estes sejam utilizados com consciência, ou intensificados pelo professor na organização das disciplinas, pois os sentidos que os licenciandos atribuem à docência se relacionam aos seus motivos que os mobilizam para ações em sua atividade de estudo, portanto, na aprendizagem da docência.

Nossa intenção foi buscar responder, com foco na historicidade do indivíduo, a seguinte questão de pesquisa: Como o licenciando em Física atribui sentidos à docência, nas ações do estágio, ao longo das disciplinas de Metodologia do Ensino? Como perceber se os sentidos mudam ao longo das ações desenvolvidas? Se ocorrerem mudanças dos motivos, é provável os sentidos também mudarem.

Outros aspectos também puderam ser analisados, considerando o foco no contato do licenciando com a escola, tais como: Quais os sentidos atribuídos pelos licenciandos no contato com a escola? Como se dá a relação com o professor que o recebe na escola? O que o licenciando espera atingir com as atividades que prepara para a regência? O licenciando faz uma reflexão sobre as regências que realiza na escola? Que "qualidade" tem essa reflexão?

Consideramos importante estudar essas questões, visto que uma boa parte dos cursos de Licenciatura, em especial da área de Ciências, não aprofundam essas questões relativas aos estágios, principalmente, por não reconhecê-los como uma atividade necessária e fundamental para a formação profissional do licenciando. Nesse sentido, alguns estágios não possibilitam aos licenciandos vivenciarem diferentes práticas e modos de ser professor, limitando-se apenas a denunciar os supostos erros ou problemas das escolas. Não criam espaços de discussões críticas e reflexivas que promovam de fato uma aprendizagem da docência. Nesse estudo, entendemos que o estágio é um momento de interação do licenciando com a escola, dos conhecimentos específicos de sua área de formação com a realidade da escola, da relação entre teoria e prática. 
Essas e outras questões podem futuramente colaborar para a organização de uma formação docente que contenha elementos para propiciar maior possibilidade de atribuições de sentidos para a docência, que resulte em ações estruturantes, colaborativas e formativas para o licenciando. Compreendemos que o processo de formação para docência precisa buscar uma postura de análise crítica, de conhecimento do contexto escolar, do trabalho docente e do papel social do ensino.

A fundamentação do trabalho na Teoria Histórico-Cultural e na Teoria da Atividade, principalmente nos trabalhos de Vigotski, Leontiev e Engeström, foi elaborada segundo o entendimento da aprendizagem para docência como um movimento dialético, que envolve a práxis na construção do trabalho do licenciando. Sendo assim, para percebemos o sentido pessoal atribuído à docência pelos licenciandos foi preciso captá-lo no processo de desenvolvimento do estágio, bem como, nas relações com a escola e nas contradições desses sistemas.

Outras pesquisas contribuíram para a discussão das questões propostas, analisando a formação inicial ou continuada, sob diferentes aspectos, ou discutindo o trabalho docente em sua organização, tais como: Moretti (2007), Cedro (2008), Gamba (2009), Bizerra (2009), Nascimento (2010), Heemann (2011), Martins (2011), Ribeiro (2011), Silva (2013), Rodrigues (2013). Também nos referimos aos trabalhos que abordaram, mais especificamente, os sentidos em algum aspecto do ensino, ou a aprendizagem da profissão dos sujeitos, como: Martins (2001), Asbahr (2005a), Arruda (2006), Ianuskiewtz (2010), Azevedo (2013), Furlanetto (2013), sendo estas as que se aproximam mais de nossa pesquisa.

O trabalho está estruturado em seis capítulos, que se dividem em uma parte teórica, outra de apresentação e análise dos dados e considerações finais.

No Capítulo 1, tratamos de uma visão geral da formação docente com foco no Ensino de Ciências, a profissão, as ações e teoria-prática na docência. Buscamos pensar no trabalho coletivo como promotor das relações e ações no contexto escolar e o processo reflexivo em sua importância para o desenvolvimento do trabalho do professor. O capítulo visa discutir algumas questões que se destacam na formação dos professores neste panorama, as necessidades, possibilidades e contradições que surgem e podem levar às mudanças no trabalho do professor, influenciando seu desenvolvimento profissional.

No Capítulo 2 a discussão foi direcionada à formação inicial de professores de Física, buscando apontar elementos que são importantes nesta formação e, que trazem contribuições para a análise das necessidades da aprendizagem para docência, bem como, os conflitos 
gerados no processo. Nesse capítulo tratamos do estágio, que está intrinsecamente ligado aos cursos de licenciatura, o que coloca em relevância a relação dos licenciandos com a escola, as regências em sala de aula, as possíveis relações entre os licenciandos e o professor da escola, a relação teoria-prática e a colaboração entre a universidade e a escola.

O Capítulo 3 traz os aportes teóricos da Teoria Histórico-Cultural e da Teoria da Atividade nas quais estão baseadas nosso estudo, e também quais são os sentidos atribuídos no decorrer das disciplinas de Metodologia do Ensino de Física, como as ações realizadas pelos licenciandos impactam e estruturam sua formação levando-os a escolher esses referenciais. Assim, nesse capítulo faremos uma breve abordagem das duas teorias bem como dos conceitos que estruturaram nossa pesquisa, a saber: atividade, ação, sentido, contradição, dentre outros. Esses referenciais também definem a concepção de educação que utilizamos, em sua perspectiva social, cultural e histórica, tomando a escola como local da educação sistematizada, com a atuação intencional do professor.

O Capítulo 4 discute o contexto da pesquisa caracterizando as ações fundamentais das disciplinas de Metodologia do Ensino de Física I e II, do estágio e do grupo de alunos. Nesse capítulo também abordamos a metodologia da pesquisa, sendo esta qualitativa do tipo estudo de casos, pois analisamos dois licenciandos na atividade de estágio, durante dois semestres, acompanhando suas ações, usando vários instrumentos de coleta de dados: entrevista, caderno de campo, gravação de áudio, assistindo presencialmente as regências e participando das aulas das disciplinas. Os instrumentos para a coleta e análise dos dados propostos por esses aportes teóricos visaram encontrar uma unidade dos sujeitos em sua historicidade, em movimento. $\mathrm{O}$ Capítulo visou ainda a descrição e análise dos dados de caráter mais geral, isto é, considerando o contexto das disciplinas de MEF com o universo de alunos. Com esses dados buscou-se em um panorama da sala que permitisse uma visão dos motivos que levaram os alunos a escolherem a Licenciatura em Física, bem como, os aspectos que da disciplina que julgavam ter colaborado para a aprendizagem da docência.

No Capítulo 5 a análise centrou-se em dois licenciandos, buscando compreender suas relações à luz de nossos aportes teóricos. Esses dois casos escolhidos tiveram como foco permitir um aprofundamento da análise, pois os dados adquiridos também correspondiam aos dois licenciandos que foram acompanhados em seu estágio na escola, nas ações da disciplina. Para organizarmos a análise, dividimos em cinco episódios, os quais são discutidos separadamente para cada licenciando, tendo no final de cada um uma síntese e um quadro apontando como os sentidos foram atribuídos pelos sujeitos e quais foram esses sentidos, os 
motivos e ações. Ainda nesse capítulo, temos os eixos estruturantes da atribuição de sentidos que a pesquisa nos permitiu apontar.

O Capítulo 6 foi reservado às considerações finais, que buscam a síntese dos resultados e sua conclusão com base no problema de pesquisa.

No início do trabalho nos deparamos com uma frase de Leontiev que nos fez refletir sobre a importância da intencionalidade no ensino e da consciência na profissão docente quando falamos de educação, vendo-a como parte indissociável de um processo histórico e social.

Quanto mais progride a humanidade mais rica é a prática sócio-histórica acumulada por ela, mais cresce o papel específico da educação e mais complexa é a sua tarefa. Razão porque toda a etapa nova no desenvolvimento da humanidade, bem como nos diferentes povos, apela forçosamente por uma etapa no desenvolvimento da educação [...] (LEONTIEV, 1978, p.273). 


\title{
Capítulo 1 \\ O professor de Ciências: formação e profissão
}

\begin{abstract}
A alegria não chega apenas no encontro do achado, mas faz parte do processo da busca. E ensinar e aprender não pode dar-se fora da procura, fora da boniteza e da alegria.
\end{abstract}

Paulo Freire

\subsection{Formação de professores de Ciências}

A formação docente tem sido um campo de pesquisas e debates para a análise do cenário da educação, a situação em que se processa o ensino, as questões referentes à aprendizagem, as políticas públicas, os contextos institucionais, dentre outros pontos que buscam discutir propostas que a fortaleçam, ressignifiquem e compreendam as relações que se estabelecem na escola ou na universidade, na formação continuada e inicial, que envolvem essas instituições.

Essa formação para o Ensino Básico é uma questão imbuída de grande complexidade devido aos fatores políticos, econômicos, sociais, estruturais, curriculares, bem como, a dimensão do sujeito, que a constituem, sejam referentes aos cursos que formam os futuros professores, ou depois desta etapa, quando já atuam nas instituições de ensino. Segundo Imbernón (2010) as mudanças sociais, científicas e educacionais que propiciam o "caráter institucional do sistema educativo" que vêm acontecendo, trouxeram essa complexidade à profissão docente.

O Ensino de Ciências, considerando nesse âmbito o Ensino de Física, nas escolas básicas também compõe este contexto e é tema recorrente nas pesquisas em educação no panorama brasileiro e global, encontrando referenciais teóricos, não só contemporâneos, mas desde os anos 80, que discutem as essencialidades e dificuldades relativas à formação inicial e continuada de professores. Ainda nesse panorama, temos os problemas estruturais e políticas públicas que não atendem às necessidades dos educadores ou desvalorizam a carreira docente, além das diversas concepções que se configuram na educação em ciências.

No caso do Ensino de Ciências, destaca-se ainda a falta de interesse dos alunos pelas aulas, o que se verifica em maior âmbito no desinteresse dos jovens pelas carreiras de 
Ciências o que está relacionado a múltiplos fatores. Esse contexto traz a necessidade de discutir a Educação em Ciências para a escola básica, sua importância, seus conteúdos e estratégias, além de fatores sócio-econômicos e políticos que colaboram com essa crise.

Como analisa Fourez (2003), esse quadro em que se encontra o Ensino de Ciências na escola básica está ligado a uma concepção de professor como um técnico, que deve dominar informações e transmiti-las, e não a uma ideia de educador, o que exigiria uma postura crítica e consciência do papel social do ensino de Ciências, tais questões implicam em repensar o "ser" e o "fazer" docente, como nos coloca este autor: "a formação dos licenciados esteve mais centrada sobre o projeto de fazer deles técnicos de ciências do que fazê-los educadores(op. cit., p.111)".

A perspectiva da docência precisa estar aliada às ações educacionais objetivadas em cada contexto escolar, com a organização do ensino voltada para sua especificidade, porém, intrinsecamente associada a formação do homem como um ser histórico e cultural, que aprende na interação com os outros por também ser social e considerando, ainda, suas singularidades, porque a vivência de cada um é única. Isso faz com que pelo ensino escolar os sujeitos possam capturar o legado das gerações que os antecederam, mas avançar, com isso sofrendo mudanças de caráter diversos: cognitivas, atitudinais, emocionais, dentre outras, assim modificando o contexto que estão inseridos em uma relação dialética. Como explicitam Camillo e Mattos (2014):

Ressalta-se, assim, a complexidade do fenômeno educacional, que não pode estar apoiado simplesmente no campo do saber específico (o da Física, Química ou Biologia, por exemplo), mas também nos campos da psicologia, antropologia, filosofia etc. Se efetivadas as condições para a realização da atividade educacional, os sujeitos podem se tornar, ao mesmo tempo, construtores de sua individualidade e do gênero humano. A educação passa a ser, então, mediadora entre aquilo que os indivíduos são e o que podem vira-ser (p. 219).

Assim, a formação em Ciências não é algo simples de se estruturar para professores que já atuam no ensino, tampouco para aqueles que se preparam para profissão docente. A formação continuada não é considerada por muitos dos professores, por motivos diversos, dos quais elegemos alguns: por considerarem que uma vez formados para profissão estão prontos definitivamente para a atuação no ensino; por terem tempo restrito para participarem de cursos, grupos de estudo ou outra ação além de suas aulas; por não contarem com o oferecimento de cursos de extensão, atualização ou similares pelos órgãos institucionais responsáveis pela educação; ou ainda por terem participado de projetos ou cursos de formação 
continuada e estes não corresponderem às suas expectativas e realidade de trabalho. Tais questões dificultam a participação dos professores em iniciativas de formação continuada que em ações conjunta com o coletivo da escola poderiam conseguir melhorias para o Ensino de Ciências.

Algumas mudanças poderiam ser estimuladas na formação de professores com o objetivo de benefício ao conjunto deles, tais como: além de conhecimento, formar atitudes; adaptar e experimentar, refletindo sobre as situações práticas reais; por isso a importância da formação ser desenvolvida na escola; a formação se adapta à realidade educativa da pessoa que aprende; deve estar ligada às tarefas de desenvolvimento curricular, planejamento e melhoria da instituição (IMBERNÓN, 2010). A inovação perde parte de sua atuação e as melhorias coletivas que poderia alcançar quando é produzida de forma isolada e com caráter de experiência pessoal, isto é dito por Imbernón (op.cit.), que propõe:

A formação também servirá de estímulo crítico ao constatar as enormes
contradições da profissão e ao tentar trazer elementos para superar as
situações perpetuadoras que se arrastam há tanto tempo: a alienação
profissional - por estar sujeito a pessoas que não participam da ação
profissional -, as condições de trabalho, a estrutura hierárquica etc. E isso
implica, mediante a ruptura de tradições, inércias e ideologias impostas,
formar o professor na mudança e para a mudança por meio do
desenvolvimento de capacidades reflexivas em grupo, e abrir caminho para
uma verdadeira autonomia profissional compartilhada, já que a profissão
docente deve compartilhar o conhecimento com o contexto. Isto implica uma
mudança nos posicionamentos e nas relações com os profissionais, já que
isolados eles se tornam mais vulneráveis ao entorno político, econômico e
social. (p.15)

A formação do professor necessita ser focada no trabalho coletivo, pois é um processo histórico e cultural, assim ao mesmo tempo em que o sujeito estabelece as interações com o outro e com o meio, desenvolve as suas singularidades. É no compartilhar que se fortalecem as relações de trabalho, que se enfrentam as contradições da profissão, das instituições, das políticas, se estruturando também, o trabalho do indivíduo.

Ao tratarmos da formação docente é recorrente que se inclua como objetivo as competências que os professores precisam desenvolver, mesmo porque esse conceito faz parte das Diretrizes Curriculares Nacionais. No entanto, em muitos programas de formação as competências aparecem com diferentes conotações, mas, em geral, associada ao professor como sujeito individual. Nessa situação esse sujeito precisa se apropriar de competências que lhe faltam, assim, muitas vezes, a ideia que subjaz é da necessidade de ensinar esse professor, embora não seja essa a que está posta nas diretrizes. 
A concepção de uma formação que visa o trabalho coletivo, na qual o conhecimento também será entendido como histórico e cultural, sendo que sua apropriação é possibilitada pelas interações estabelecidas com os homens e o meio, o que nos leva a não corroborar com a noção de competência visando o individual. Moretti e Moura (2010), também apontam essa questão e comentam a contradição que surge:

A contradição mais evidente que parece surgir quando levantamos a questão da competência diante dos saberes é a oposição existente entre o coletivo e o individual. Sendo a competência entendida como uma qualidade do sujeito (seja ela inata ou aprendida) e, portanto individual, diferencia-se do saber entendido como uma construção social e histórica e, portanto, algo externo ao sujeito e do qual este deve apropriar-se por meio da educação. (p. 350)

A formação do professor não pode ser concebida como algo acabado, o professor tem que refletir em seu papel, escolher caminhos e correr os riscos desta escolha. No entanto, isso não é fácil, é preciso que nele se crie a necessidade de mudança para que atue de forma consciente, o que demanda um grande empenho para consegui-la. Isso pode ser favorecido e ter resultados mais eficientes em contextos de trabalhos colaborativos, bem como, em propostas de formação de educadores que busquem discutir as questões prementes do Ensino de Ciências.

A formação para o Ensino de Ciências precisa considerar as diferentes realidades, assim, necessita ser ampla o suficiente para abarcar os vários contextos, mas também buscar despertar as singularidades para que possa se concretizar para um grupo de docentes, de uma dada instituição de ensino, podendo oferecer contribuições teóricas e de pesquisa em suas próprias realidades, porém, considerando a referência da prática daquele grupo, criando soluções próprias que busquem a renovação, a mudança. Cada grupo precisa construir seu próprio caminho, com as suas condições, seus desejos, em sua realidade, como coloca Freire (2001), se referindo à uma educação que busca a transformação, que é dinâmica, problematizadora e se constrói pela ação e reflexão humana:

A educação problematizadora está fundamentada sobre a criatividade e estimula uma ação e uma reflexão verdadeiras sobre a realidade, respondendo assim à vocação dos homens que não são seres autênticos senão quando se comprometem na procura e na transformação criadoras. [...] A educação crítica considera os homens como seres em devir, como seres inacabados, incompletos, em uma realidade igualmente inacabada e juntamente com ela. [...] O caráter inacabado dos homens e o caráter evolutivo da realidade exigem que a evolução seja uma atividade contínua. A educação é, deste modo, continuamente refeita pela práxis. Para ser, deve chegar a ser. [...] A educação problematizadora - que não aceita nem um 
presente bem conduzido, nem um futuro predeterminado - enraíza-se no presente dinâmico e chega a ser revolucionária. (p. 94-95)

Frente às exigências da docência e da complexidade da estrutura na qual se insere a formação docente há a necessidade de propostas que concebam o professor como educador, isto é, pensando-o como sujeito de um processo que compõe uma tríade, aprendizagem da docência, ensino e aprendizagem na docência, pois aprender a docência em seus elementos teóricos e pensar o ensino associando-o à aprendizagem na realidade escolar proporciona ao professor uma formação como sujeito histórico, social e cultural, que se forma na relação com os outros, como coloca Paro (2010), “todo processo de ensino para o outro é também processo de aprendizado para si próprio (p.49)". Isso envolve a consciência do papel do docente no ensino, que compreende ações intencionais direcionadas a um objetivo, com a reflexão crítica de seu trabalho e a associação entre teoria e prática, trazendo-lhe possibilidades para o enfrentamento das situações adversas, criando espaços de atuação e favorecendo mudanças.

\subsection{O professor e a profissão docente}

A discussão da profissionalização docente, desde o final do século passado, é crescente dentro de uma visão de educação mais ampla voltada a formação de cidadãos críticos que se coloca em contraposição a uma educação transmissiva (FREIRE, 2001; IMBERNÓN, 2010; CACHAPUZ et al., 2005; POZZO e CRESPO, 2009). Pensar a profissão docente requer um olhar que não se restrinja aos conteúdos específicos e pedagógicos, mas, como coloca Freire (2001), é preciso entendê-la como compromisso político, com valores éticos e morais, visando o desenvolvimento da pessoa, a colaboração entre iguais para atuar na transformação da realidade. Assim, o autor aponta a necessidade da aprendizagem das relações na docência, que leva à outra proposta de formação inicial e permanente para dar conta desta questão e de outras funções que são decorrentes, tais como: promover motivação, as lutas contra a exclusão social, dentre outras, que ao lado do contexto de cada instituição de ensino compõem um cenário bastante diverso que influencia e modifica a profissão docente.

As mudanças das estruturas de trabalho, nas unidades escolares, também são necessárias para que o trabalho docente seja dinâmico e o professor tenha possibilidade de cuidar de sua formação permanente. Algumas tentativas de mudança pelos docentes sem o apoio e a alteração dessas estruturas e políticas públicas, podem ocorrer, mas de forma 
pontual e restrita, que acabam se dissolvendo no contexto geral da escola, em seu cotidiano, o que não traz os benefícios efetivos e nem uma compreensão mais consciente do trabalho do professor. Porém, este aspecto é de caráter mais político e sua mudança é de longo prazo e de ação coletiva. No entanto, os espaços coletivos podem gerar trabalhos que levem a atuações que modifiquem o contexto mais restrito, proporcionando discussões, troca de experiências e atividades conjuntas, se tornando um espaço de formação como aponta Nóvoa (1992):

A aprendizagem em comum facilita a consolidação de dispositivos de colaboração profissional. Mas o contrário também é verdadeiro: a concepção de espaços coletivos de trabalho pode constituir um excelente instrumento de formação. (p.30)

Imbenón (2010) afirma que uma das características primordiais da profissão docente é a capacidade reflexiva em grupo, entendida como "processo coletivo para regular as ações, os juízos e as decisões sobre o ensino (p.15)". Neste sentido as ações coletivas são base que constituem e estruturam a profissão docente, na qual a reflexão é inerente ao trabalho desse profissional, que nas interações sociais, em determinados contextos, vão construindo experiências de formação que forjam a historicidade desse professor.

O trabalho coletivo facilita a troca de experiência entre os pares, o diálogo e a reflexão, que podem gerar condições para que propostas de mudança se desenvolvam no interior da escola, criando um ambiente dinâmico, de discussão e ação, proporcionando ao grupo objetivos comuns, pensando o ensino como processo de criação coletiva. As contribuições do trabalho coletivo podem mobilizar no professor tanto aspectos intelectuais como emocionais, ou axiológicos, como destaca Abib (2003), para tanto, é necessário promover na escola:

[...] a organização de atividades nas quais possam ser vivenciados momentos que envolvam a cooperação, que tem como grandes impulsionadores os objetivos comuns que levam ao compartilhar de ideias e emoções, ao diálogo, aos apoios mútuos e a negociação de diferentes pontos de vista, interesses e valores, com o desenvolvimento de atitudes de respeito às diferenças e postura ética (p.99).

A constituição de um grupo de trabalho na escola aparece como uma grande perspectiva para a consolidação de ações que possam iniciar trabalhos coletivos que permitam viabilizar atividades que, aos poucos, mobilizem e provoquem transformações na prática 
pedagógica, de forma significativa, que considere as necessidades do contexto escolar, tentando buscar soluções para a superação de seus problemas, que se tornam possíveis quando enfrentados em equipe, mas são muitas vezes quase intransponíveis quando os professores o fazem de forma isolada.

O compromisso do professor com o processo de ensino e aprendizagem deve ser norteador de seu papel como profissional, fazendo-o buscar um maior conhecimento de como esse processo ocorre, o que é de fato importante para o aluno, encontrando estratégias que facilitem, tornem mais produtivo e gratificante o trabalho docente e o aprendizado dos alunos. Para tanto, há a necessidade do professor se colocar como educador, na concepção de Freire (1996), ao assumir este papel está optando por uma concepção de ensino que privilegia o diálogo e o comprometimento, em busca de uma postura crítica e vinculada ao contexto da realidade do aluno, da escola e da sociedade.

O professor nesse processo requer formação permanente que envolve o conteúdo específico de ciências, sua visão histórica, seu papel social, para ultrapassar o senso-comum e avançar nas discussões com os alunos, em busca de melhor preparar e conduzir atividades para e com os alunos, acompanhar e utilizar inovações, avaliar e analisar os resultados do desempenho dos alunos, considerar os aspectos afetivos envolvidos nas relações estabelecidas nos processos de ensino, desenvolver habilidades, refletir sobre sua prática, dentre outros fatores que são elementos importantes propostos para ensinar Ciências (CARVALHO e GILPÉREZ, 1993; ABIB, 1996; 2010).

A estrutura dos cursos de licenciatura, as limitações na formação de professores e, muitas vezes, o enfraquecimento de fundamentação teórica e pouco desenvolvimento de práticas pedagógicas, ao lado das dificuldades encontradas para manter uma formação docente continuada, aliada à sobrecarga de trabalho, às inadequações das condições profissionais e de infra-estrutura, à saturação do mercado de trabalho, dentre outros fatores, levam à desvalorização profissional, como apontam diversas pesquisas em educação (ABIB, 1996; CARVALHO e GIL-PÉREZ, 1993; CANDAU, 2010; PIMENTA E LIMA, 2012); o que pode afetar a auto estima do professor, gerando desmotivação, isolamento no trabalho docente, concepções de ensino e aprendizagem que promovem poucas interações, colocando o professor, por vezes, em condições de expropriação de seu trabalho.

Um fator para se ponderar na profissão docente é que os professores vêm assumindo cada vez mais responsabilidades, o que torna difícil delimitar suas funções, além de algumas extrapolarem seu âmbito de atuação. Associado a isso, as condições de trabalho adversas, 
tanto no contexto escolar como de políticas públicas, que não sofrem mudanças significativas em prol da melhoria do ensino e da estrutura do trabalho docente, o que se reflete, muitas vezes, na falta de incentivos tanto externos como internos, para ações de atualização ou programas institucionais que levam à pouca atuação, efetivamente, coletiva na escola e à rotinas impostas por uma elevada carga horária, que favorece o afastamento do professor das relações dinâmicas extra classe, colocando-o, quase exclusivamente, circunscrito a sala de aula. Isso acaba promovendo um trabalho individualizado e solitário, que provoca contradições, dado o significado da docência, como intervenção social, cujo caráter coletivo, intelectual e criativo caracterizam essa profissão.

Contreras (2002) coloca ainda, o aumento de funções atribuídas ao ensino, associado aos problemas complexos que esperam que a educação os solucione, o que faz com que o professor aumente certo sentimento de responsabilização e culpa, por questões de âmbito institucional e social. Muitos professores, face a essa situação assumem uma atitude de proteção o que os leva a concentrarem-se nas exigências técnicas de seu trabalho, especificamente na sala de aula, nos problemas imediatos postos pelo cotidiano.

Esses fatores colocam, muitas vezes, os professores em uma visão circular dos problemas que enfrentam no cotidiano, ou seja, sentem a necessidade de mudanças no Ensino de Ciências e na prática docente para alcançarem com isso melhores condições de trabalho e vice-versa (ABIB, 1996). Assim, o que percebemos é que há a necessidade de iniciar as mudanças paulatina e sistematicamente, para que comece um movimento e se viabilize as discussões, mesmo que as condições sejam desfavoráveis, o que não significa deixar de reivindicar uma melhor estrutura de trabalho, pois o ensino não está dissociado das condições em que ele ocorre, porém, há que se fortalecer a profissão para que possa enfrentar as questões sociais e políticas. Para tanto, Esteve (1999) coloca pontos importante a serem considerados na formação do professor:

[...] A formação permanente deve construir-se a partir de uma rede de comunicação, que não se deve reduzir ao âmbito dos conteúdos acadêmicos, incluindo também os problemas metodológicos, pessoais e sociais que, continuamente, se entrelaçam com as situações de ensino. A inovação educativa está sempre ligada à existência de equipas de trabalho que abordam os problemas em comum, refletindo sobre os sucessos e as dificuldades, adaptando e melhorando as práticas de intervenção (objetivos, métodos e conteúdos). O contato com os colegas é fundamental para a transformação da atitude e do comportamento profissional, nomeadamente com os grupos portadores de uma perspectiva inovadora, cuja experiência permite visualizar ações e realidades concretas (p.119). 
A formação continuada do professor é um componente importante no desenvolvimento profissional docente, no entanto, não é a única, pois fatores como: salário, mercado de trabalho, prestígio da profissão, legislação trabalhista, carreira, condições de trabalho nas escolas, relacionamento com os pares, dentre outros, influenciam a profissão docente.

O engajamento de todos os sujeitos da instituição educativa também é fator relevante ao desenvolvimento profissional docente, que está ligado às suas condições de e no trabalho, o que pode começar a provocar mudanças tanto ao nível individual, como no coletivo, indo além da sala de aula, tendo o contexto escolar como local de atuação, mas entendendo a profissão de forma mais ampla, em seu papel social. Isso faz com que o professor tome consciência de seu papel no processo de ensino e no grupo social ao qual pertence, sendo apoiado por este e contribuindo com o mesmo, como explica Moura (2000):

O processo de conscientização sobre o seu valor, enquanto sujeito de uma coletividade que busca resolver problemas, é que lhe permitirá tomar para si o desejo de mudar e ir se formando de modo autônomo em consonância com os objetivos coletivos (p.45).

Outra questão que se coloca para o Ensino de Ciências é a aproximação entre Universidade e Escola de Educação Básica; as interações entre estas instituições de ensino são essenciais para que se possa constituir um processo de colaboração intencional para uma ação que vise a mudança, favorecendo tanto uma atualização curricular, de conteúdos e metodológica, mas principalmente, as relações de trabalho compartilhado direcionadas para um objetivo educacional comum. Para tanto, não cabe situações em que se apresentem propostas já pensadas e estruturadas às escolas para que estas coloquem em prática e, nem tampouco que os educadores busquem receitas prontas na universidade, mas ao contrário, há a necessidade da elaboração conjunta de propostas para que estas realmente se efetivem nas escolas (ABIB, 2009). Por outro lado, as pesquisas realizadas pelas universidades precisam chegar às escolas, para que auxiliem os educadores na compreensão das questões relativas à Educação e às Ciências, porém há de se vivenciar os espaços escolares e as interações que neles ocorrem para que se possa atuar de forma conjunta.

As propostas de formação de professores não se constroem de forma fechada, devem prever sua adequação ao grupo a que se destina, mas alguns pontos são fundamentais e estruturantes para seu desenvolvimento, ao pensarmos nesta formação no sentido de aproximá-la cada vez mais do modelo crítico (SAVIANI, 2003; DINIZ-PEREIRA, 2011) há 
algumas possibilidades para uma proposta de formação com ações que visam uma perspectiva dialógica entre o formador e os educadores, partindo de situações que proponham um problema a ser resolvido e que tenham significado para o grupo (ABIB, 2009). Não há um método de formação ideal, mas podemos priorizar aqueles que favoreçam as questões do contexto, atitudes, valores, políticas e culturais.

Relacionar as discussões e as soluções propostas, pelo grupo em formação, às referencias teóricos, para que estes possam delas se apropriarem, o que também é um ponto importante e, que aproxima as questões das pesquisas na área de ensino dos educadores da escola básica. Trazer para a formação as necessidades do contexto real de vivência dos professores, para que possam refletir sobre ações possíveis para suas práticas, o que se constitui como outra importante abordagem na construção de uma proposta formativa.

[...] um caminho que se mostra promissor é o aprofundamento das pesquisas sobre a aprendizagem da docência e inovações na escola que estimulem a participação criadora dos professores na elaboração de conhecimento e práticas que sejam adequadas aos seus contextos de trabalho e, que possam resultar de um movimento de aproximação crítica dos conhecimentos acadêmicos. Aproximar a pesquisa em ensino da sala de aula requer a construção de caminhos que possibilitem partilhas de interesses, de recursos e papéis. (op. cit., p.236)

O trabalho docente, em função de fatores estruturais, políticos, sociais e pessoais, se faz de forma isolada no sentido de discussões coletivas que busquem aprofundar as questões da prática docente entre o grupo que se constitui na unidade escolar. Para ampliar as discussões, os referenciais teóricos e as trocas de experiências, torna-se importante o intercâmbio com a universidade, bem como com outras unidades de ensino, o que possibilitaria maior aproximação entre a escola básica e a universidade no sentido de busca de um trabalho colaborativo. No entanto, Zeichner (1998) coloca que a colaboração entre escola básica e universidade precisa avançar, em relação às ações que influenciem efetivamente a escola, para que as pesquisas possam ter propostas de ações que a escola tenha participação e possa então discutir suas necessidades e buscar soluções.

Muitos olhares se voltam para o professor em sala de aula, no entanto, há um momento anterior que faz parte do trabalho docente, o qual vem sendo pensado como constituinte de um professor reflexivo. Esses momentos ocorrem em espaços coletivos na escola e, esta reflexão, segundo Pimenta (2010), que cita Gimeno Sacristán ${ }^{1}$ (1999) para trazer

\footnotetext{
${ }^{1}$ GIMENO SACRISTÁN, J. Poderes instáveis em educação. Porto Alegre: Artes Médicas, 1999.
} 
a ideia de que tal situação deve unir prática e teoria, sendo o papel da teoria o de dar condições para que os professores tenham perspectivas de análise do contexto para poder transformá-lo. Outro ponto estruturante desta reflexão está relacionado à três perspectivas colocadas por Zeichner² (1992, apud PIMENTA, 2010) sobre a abrangência da prática reflexiva na profissão docente:

a) a prática reflexiva deve centrar-se tanto no exercício profissional dos professores por eles mesmos, quanto nas condições sociais em que esta ocorre; b)o reconhecimento pelos professores de que seus atos são fundamentalmente políticos e que portanto podem se direcionar a objetivos democráticos emancipatórios; c) a prática reflexiva, enquanto prática social, só pode ser realizada em coletivos, o que leva à necessidade de transformar as escolas em comunidades de aprendizagem, nas quais os professores se apoiem e se estimulem mutuamente.

$\mathrm{Na}$ formação docente é preciso que se enfrente os obstáculos, como a imagem que as Ciências têm para os professores, os modelos de ensino e de aprendizagem que eles têm e praticam, as suas concepções espontâneas e, como reconhecem e trabalham com estas concepções dos alunos, o modelo de currículo e de avaliação que priorizam e aplicam, dentre outros (POZO, 1998), que são questões difíceis de serem tratadas porque estão enraizadas na prática docente e, muitas vezes, automatizadas, por isto, é necessário que primeiro sejam percebidas, compreendidas, aceitas e depois, se desejarem, transformadas pelos professores.

\subsection{Pensamento, ação e reflexão na formação do professor}

Várias são as visões que buscam o entendimento do papel da reflexão na formação dos professores, não se pode negar sua importância, mas cabe discutir como ela pode contribuir, efetivamente, para o trabalho docente e como entendê-la em relação à prática, que são questões relevantes para o ensino.

A reflexão da qual falamos é uma relação constante entre o pensamento que está imbuído de referências teóricas, sociais, históricas, culturais e as ações no trabalho, que são indissociáveis, o que também não ocorre em processos de isolamento, mas sim em trocas com o coletivo, para que, então, se internalize para cada sujeito.

\footnotetext{
${ }^{2}$ ZEICHNER, K. El maestro como profesional reflexivo. Cadernos de Pedagogia, n.220, p.44-49, 1992.
} 
O entendimento de reflexão, ou reflexividade, foi e continua sendo discutido, bem como, muito usado sem conotação embasada em uma concepção do trabalho docente e sim como uma expressão da moda ou slogan, como mencionam Pimenta (2010), Alarcão (2010) e Zeichner (2008), o que faz com que o termo perca sua dimensão político-epistemológica, seja utilizado por todas perspectivas educacionais que pretendam tratar da formação docente. Outro ponto observado por Pimenta (op. cit.) que também compromete o entendimento da reflexão no trabalho docente é o que ela chamou de uma tecnização da reflexão, que se operacionaliza em competências necessárias à formação do professor e para sua avaliação. A visão dada à reflexão é comprometida ainda mais quando em cursos de formação considera-se a prática em si mesma, supervalorizando-a, como se a prática desprovida de teoria fosse possível para um trabalho docente consistente e crítico. A autora propõe que:

A análise crítica contextualizada do conceito de professor reflexivo
empreendida neste texto permite superar as limitações, afirmando-o como
um conceito político-epistemológico que requer o acompanhamento de
políticas públicas conseqüentes para sua efetivação. [...] Assim, a análise das
contradições presentes na apropriação histórica e concreta desse conceito,
evidenciadas na pesquisa teórica e empírica empreendida, subsidia a
proposta de superar-se a identidade necessária dos professores de reflexivos
para a de intelectuais críticos e reflexivos (Ibidem, p.47).

Segundo Libâneo (2010) encontramos três significados para reflexividade: o primeiro como consciência dos próprios atos; segundo com relação direta com situações práticas; o terceiro como reflexão dialética. Nesta última, o autor aponta que: "a realidade ganha sentido com o agir humano" (p.57), assim deve-se considerar que esta realidade está em movimento, pois abarca os acontecimentos, processos e historicidade, sendo captada pelo pensamento, segundo este mesmo autor, o que se constrói é uma explicação do real, em que esta realidade é uma construção teórico-prática.

Esse significado crítico e dialético de reflexão também é apontado por autores como Freire (1996), Sforni (2003), Ghedin (2010), Ribeiro (2011), dentre outros que trazem a concepção de que o conhecimento se constrói pelas relações humanas e suas práticas, no entanto, não podemos deixá-lo circunscrito apenas nelas, pois há uma dimensão teórica ligada àquilo que pensamos, o que associa prática e teoria, assim:

Perceber a teoria e a prática como dois lados de um mesmo objeto é imprescindível para se compreender o processo de construção de conhecimento. Quando dissociamos estas duas realidades simultâneas, 
estamos querendo separar o que é inseparável, pois não existe teoria sem prática e nem prática alguma sem teoria. O que acontece é que por conta de uma percepção alienada, não se percebe a sua dialética. Teoria e prática só se realizam como práxis ao se agir conscientemente de sua simultaneidade e separação dialética. (GHEDIN, 2010, p. 133)

O saber docente se constrói na relação entre a teoria e a prática, que resulta de um processo histórico que é organizado e elaborado pela sociedade e transmitido para o homem, sendo o educador o sujeito que estará na posição de favorecer a aquisição do saber acumulado pela humanidade no âmbito da escola. Cabe ao educador, também, articular o conhecimento que é produzido pelos especialistas com a sua prática, em um processo de internalização e de avaliação, que se faz pela ação desse educador, pela sua experiência e pela cotidianidade,

Para Libâneo (2010), a reflexão se dá no momento de planejamento e de revisão crítica sobre a ação. Com essa consideração, ele aponta três níveis de reflexividade: o primeiro está a um distanciamento da prática, para que permita que esta possa ser vista, entendida e avaliada; no segundo, tem-se a ciência incorporada ao senso comum, mas não há a substituição de um pelo outro; o terceiro é a metarreflexividade, que é pensar sobre os dois primeiros níveis, ou seja, "reflexão sobre a prática da reflexão" (p.70).

Com relação à discussão de várias interpretações e correntes que consideram a reflexão no trabalho docente, Libâneo (op. cit.) aponta o método da reflexão dialética como um deles, que tem sua origem no marxismo humanista, que retornou nos anos 80. Neste se acentua a formação da consciência crítica, cuja unidade teoria-prática, reflexão-ação, tem como base a práxis.

Para considerar a reflexão dialética é preciso conceber o objeto em sua totalidade, inserido em seu contexto, assim a reflexão busca apreendê-lo na realidade concreta, com suas contradições. Para explicar esse movimento dialético Libâneo (2010) se utiliza de um trecho de Ianni (1988) $)^{3}$, que reproduzimos abaixo:

A dialética compreende a realidade como movimento, modificação, devir, história. Trata-se de refletir sobre os fatos, tendo em vista apanhar os nexos internos, constitutivos desses fatos. [...] Assim, parte-se do dado concreto, sensível e, pela reflexão, apanha-se as determinações que constituem o dado. [...] O resultado é o concreto pensado, uma construção teórico-prática, lógico-histórica. [...] A dialética apanha principalmente relações, processos e estruturas; apanha os fatos enquanto nexos de relações sociais, relações essas que os constituem. [...] Esse é o âmbito no qual se expressam as diversidades, as hierarquias, as desigualdades, as divisões e outras formas de relações de antagonismo e contradição (p.59).

\footnotetext{
${ }^{3}$ IANNI, O. Dialética e capitalismo. Petropólis: Vozes, 1988, p.145.
} 
Ao falarmos em reflexividade consideramos as influências do contexto institucional, histórico e social nas ações e pensamento dos professores e estes em um sistema coletivo, o que foi proposto como reflexividade crítica; (CONTRERAS, 2002; GHEDIN, 2010; LIBÂNEO, 2010; BORGES, 2010), que vai além de mudanças nas ações e potencialização do pensar sobre elas, mas é uma leitura crítica da realidade. Nessa perspectiva Borges (op. cit.) comenta como se estrutura o trabalho docente, o que é relevante, assim diz que:

O professor deve ter seu conhecimento trabalhado a partir das informações, do trabalho com essas informações e de produzir novas formas de desenvolvimento na produção desse conhecimento a serviço da vida material, social e existencial da humanidade. Deve saber trabalhar mediando entre a atual sociedade da informação e a reflexão-crítica dos alunos para a permanente construção do humano (p.217).

Toda reflexão está historicamente situada, vinculada aos momentos concretos, ao contexto social, político, econômico e histórico, sendo que o ser humano, pelo trabalho, a realiza por um movimento contínuo e dialético entre o fazer e o pensar. Ela é um processo para ser incorporado ao trabalho dos professores como prática coletiva, dado seu caráter social, para que mais que uma reflexão sobre seu próprio trabalho, os professores possam ter interações que promovam ações conjuntas, podendo modificar seu contexto de atuação, para o que Zeichner (2008) diz que o:

[...] aspecto da maioria dos trabalhos sobre o ensino reflexivo é o foco sobre a reflexão que os professores fazem sobre si mesmos e seu trabalho. Existe ainda muito pouca ênfase sobre a reflexão como uma prática social que acontece em comunidades de professores que se apoiam mutuamente e em que um sustenta o crescimento do outro. Ser desafiado e, ao mesmo tempo, apoiado por meio da interação social é importante para ajudar-nos a clarificar aquilo que nós acreditamos e para ganharmos coragem para perseguir nossas crenças (p.543).

A reflexividade como forma de colaborar no fazer-pensar dos professores, considerada em uma concepção crítica, deveria considerar não apenas os problemas imediatos, mas abrangê-los de forma mais profunda, além da sala de aula.

O professor em sua vivência em uma instituição de ensino imerge na cultura do local, é nesse espaço-tempo que ele constrói-se e reconstrói-se, trazendo suas expectativas e necessidades, fazendo parte desse coletivo no qual surgirão identidades e contradições que podem impulsionar mudanças. 
A instituição escolar influencia a atuação do professor, o que se estende para todo tipo de escola, trazendo o valor de uma missão de grande responsabilidade, na qual os professores representam o Estado diante da sociedade e a eles é destinado o desenvolvimento moral e intelectual dos alunos, dos jovens da sociedade, assim, "vem-se fixada a partir das formas burocráticas pelas quais se estabelece a regulação do ensino, de suas metas e procedimentos, legitimadas em modos de racionalização que se apresentam com um aval científico" (CONTRERAS, 2002, p.150). Este valor trazido pela instituição e a situação concreta de sala de aula, em geral, não coincidem e geram contradições no trabalho do professor, o que promove a reflexão sobre seu papel no ensino e pode influenciar na mudança de suas ações levando-o ao desenvolvimento profissional. Isso alcançando uma dimensão coletiva pode transformar o contexto escolar.

Contudo, a lógica do controle tecnocrático entra em contradição com a forma pela qual as instituições educacionais expressam o sentido da missão encomendada. Enquanto que, por um lado, se formulam as finalidades educativas, como formas de preparação para uma vida adulta com capacidade crítica em uma sociedade plural, por outro lado, a docência e a vida na escola se estruturam negando essas pretensões. (op. cit., p.152)

Essa posição vivida por muitos professores, como forma de redução dos conflitos leva a restrição do ensino à sala de aula e muitas vezes essa contradição faz com que se processe uma transferência da culpabilidade para os alunos, os colegas, o funcionamento da instituição, dentre outros; essa posição carrega um isolamento no trabalho docente que dificulta enxergar o ensino com seus fins, como significado social e desenvolvimento profissional, faz com que os professores atuem como funcionários técnicos em um contexto burocrático. Para alterar esse contexto, Contreras (2002), Libâneo (2010) e Ghedin (2010), propõem que é preciso mais que pensamento e ação, é necessária uma inserção na natureza social e histórica nas práticas da educação, isso seria uma reflexão crítica, que exigiria a organização das pessoas envolvidas por ter um caráter público e uma sistematização para que possa gerar reformulações da teoria e prática social e as condições de trabalho para os professores.

A reflexão crítica não pode ser concebida como um processo de pensamento sem orientação. Pelo contrário, ela tem um propósito muito claro de "definirse" diante dos problemas e atuar, consequentemente, considerando-os como situações que estão além de nossas próprias intenções e atuações pessoais, para incluir sua análise como problemas que têm uma origem social e histórica. (CONTRERAS, 2002, p.163) 
A reflexão crítica traz a proposta de uma formação que possa discutir o ensino problematizando-o para que o professor perceba as contradições existentes entre os objetivos do ensino dado pelas instituições e o que se realiza em sala de aula, as contradições na própria sala de aula, bem como, as relações estabelecidas, concebe também a ideia de olhar de forma histórica e social o desenvolvimento da educação. Busca-se uma visão mais clara do professor sobre o ensino e de seu trabalho, para que se possa ter possibilidade de atuar no contexto escolar visando mudanças que venham transformar seu trabalho e as condições em que ele opera.

Esse aspecto de uma reflexão crítica também é recorrente nos trabalhos de Freire que propõe como fundamental na formação permanente de professores, mas entendemos que cabe também à formação inicial, uma vez que os futuros professores precisam já em sua iniciação à docência, discutir essa questão e, principalmente, vivenciar as instituições escolares. Como coloca Freire (1996), é preciso o referencial teórico associado a uma reflexão muito ligada à prática para que se possa buscar as transformações desejadas.

[...] na formação permanente dos professores, o momento fundamental é o da reflexão crítica sobre a prática. É pensando criticamente a prática de hoje ou de ontem que se pode melhorar a próxima prática. O próprio discurso teórico, necessário a reflexão crítica, tem de ser de tal modo concreto que quase se confunda com a prática... (op. cit., p.39)

A reflexividade na formação do professor nos mostra caminhos que foram sendo aprofundados e colocam pensamento, ação e o contexto, em sentido amplo, de forma associada e complexificada para se tratar do Ensino de Ciências, trazendo questões importantes como a necessidade de romper como o isolamento e o imediatismo, que vêm de uma visão centrada na sala de aula, que precisa ser ampliada para o local onde ela se inclui, onde a instituição de ensino se insere, bem como, as relações que se estabelecem nele. Além de entender o contexto de ensino como histórico, cultural e social, tendo então seu desenvolvimento em uma perspectiva de inter-relações.

O autor coloca ainda, que o professor concebido como intelectual crítico é um profissional que participa ativamente para conseguir desvelar a origem histórica e social da prática de ensino, no cotidiano, que se mostra como "natural", mas está presa em pretensões e valores educativos pré-concebidos, como os valores ideológicos dominantes. As práticas culturais e formas de organização podem influenciar nas ações do professor, bem como, levar 
a uma análise que busque compreender as finalidades educativa e social do ensino, o que, em geral, provoca conflitos.

Nesta perspectiva, o professor busca por uma autonomia, que não é auto suficiência mas, processo coletivo, que tem a intenção de transformar as condições de ensino tanto institucionais como sociais. O modelo do especialista técnico passa uma imagem de autonomia, como algo pessoal que gera uma independência, resistência às influências, traz a ideia de alguém que pode atuar de forma isolada, individualmente. Isto se contrapõe a proposta de autonomia discutida pelo autor, pois esta pressupõe a relação do professor com as pessoas com as quais trabalha, que é algo que se constrói em espaço coletivo, com decisões conjuntas, reflexões críticas, ações direcionadas e, é socialmente participada é, portanto, "uma busca e um aprendizado contínuos, uma abertura à compreensão e à reconstrução contínua da própria identidade profissional" (CONTRERAS, 2002, p.199).

Não é possível prever os resultados de uma formação sob esse modelo dinâmico e complexo que propõe a reflexão crítica, o trabalho coletivo, a práxis, as contradições e o caráter histórico e cultural da docência como propulsores para mudanças no contexto escolar e desenvolvimento profissional do professor. Para isso é necessário promover ações concretas no Ensino de Ciências e buscar um constante repensar dos educadores com muitas trocas, reflexões, que podem trazer algumas soluções e outras dúvidas que levarão a novas buscas, novos conhecimentos, relações diversificadas e assim continua a caminhada, mas mesmo que cada um trace sua trajetória ela se faz em um contexto coletivo, histórico e social, não se dá só em espaço de diálogo, mas de ações. 


\title{
Capítulo 2
}

\section{A Formação inicial de professores de Ciências e o estágio para a docência}

\author{
Os que se encantam com a prática sem a \\ ciência são como os timoneiros que \\ entram no navio sem timão nem bússola, \\ nunca tendo certeza do seu destino. \\ Leonardo da Vinci
}

\subsection{Formando-se professor}

A formação inicial de professores, como a formação daqueles que já exercem a profissão, ocupa lugar de destaque nas pesquisas de ensino, sendo também tema de discussões polêmicas que buscam a compreensão desse processo, mas também apontam a formação inicial como uma das causas das problemáticas da educação.

Ao discutirmos o tema do formar-se professor, consideramos as questões que poderiam e julgamos que seriam necessárias para a formação inicial de todas as áreas do conhecimento e são relevantes para a formação daqueles que já atuam como profissionais, no entanto, pensa-se nos licenciando das áreas de ciências, embora as conceituações sejam gerais.

Ao pensar em mudanças no ensino para melhoria da qualidade e para atender à totalidade da população, a formação inicial de professores é um dos pontos fundamentais para se investir. Isso não pode ser desvinculado da formação continuada, porém no início dessa formação é possível, com menores dificuldades e maior abrangência discutir, colocar em prática e avaliar novas propostas, que possam levar às transformações que possibilitem vislumbrar alterações que busquem um ensino mais eficiente. Ao lado de uma aprendizagem que promova o conhecimento científico construído histórico e culturalmente e, a formação do sujeito, coletiva e para intervenção em seu contexto social.

Nessa fase de formação, na qual se está em aprendizagem da docência, as tarefas colocadas aos licenciandos são muitas, considerando no curso de física, há uma carga grande de disciplinas de conteúdos específicos que visam fundamentá-los nos conhecimentos próprios da área para que possam exercer a profissão, o que é necessário, mas não suficiente. 
Pois, o professor, ao atuar em sua profissão precisa ter uma visão do conteúdo não como mera informação que será transmitida ao aluno, mas como contribuição para formação do indivíduo. Assim, formar-se professor implica assumir um compromisso social, escolher estratégias, abordagens didáticas, atuar no contexto no qual estiver inserido, nesse sentido Hobold e Menslin (2012) colocam que:

[...] a formação inicial deve possibilitar ao futuro professor uma bagagem sólida de conhecimentos que o capacite para assumir a tarefa educativa com rigor e seriedade, refletindo sobre suas escolhas e decisões, analisando suas ações à luz do entorno em que atua e do contexto mais amplo da educação, com a responsabilidade e o compromisso que todo ato educativo requer (p.799).

O Ensino de Ciências tem na escola básica uma pequena inserção comparada à língua portuguesa e matemática. Essa questão é apontada por Ghedin e Almeida (2011) que mencionam a importância da contribuição dos professores e do ensino de Ciências para promoverem mudanças nos indivíduos no mundo atual:

Nesta perspectiva transformadora da sociedade a partir da educação, entendemos ser a formação de professores a principal sustentação desse processo, pois são os docentes os que melhor poderiam e podem contribuir para que essas mudanças ocorram a partir do espaço de sala de aula. Entretanto, o mundo contemporâneo, caracterizado pela globalização, exige indivíduos autônomos e críticos que tenham o mínimo de conhecimentos embasados cientificamente. Apenas as noções da norma culta da língua portuguesa ou de cálculos matemáticos não são suficientes para que o estudante seja inserido neste novo contexto social. É necessário um investimento maciço no ensino de ciências para que os estudantes brasileiros possam, desde a educação básica, enfrentar as mudanças radicais que estão ocorrendo na cultura contemporânea (p.47).

Além desses aspectos há também uma desvalorização dos cursos de Licenciatura em comparação a outros da Universidade, ou mesmo em relação ao Bacharelado, como ocorre no caso de Física. Isto está ligado às questões políticas e culturais que, inevitavelmente, levaram a baixa remuneração da profissão docente no Brasil, e as condições desfavoráveis de trabalho que se impõem ao professor. Na licenciatura em Física, muitas vezes, os alunos formados, acabam se direcionando às outras profissões, ou quando se mantém na docência para o ensino básico, optam pelo trabalho na rede particular de ensino, face à situação com que se deparam na educação pública, ou ainda seguem carreira acadêmica. 
Essas perspectivas não devem ser tomadas como paralisantes no processo de formação docente, mas sem dúvida, é um campo que restringe um pleno desenvolvimento do licenciando em Ciências/Física. Uma mudança, de maneira mais geral, precisa superar essas dificuldades, o que é um desafio para aquele que está em processo de constituir-se professor. Nesse aspecto, a formação inicial é fator importante e estruturante, como coloca Imbernón (2010):

[...] É necessário estabelecer uma formação inicial que proporcione um conhecimento válido e gere uma atitude interativa e dialética que conduza a valorizar a necessidade de uma atualização permanente em função das mudanças que se produzem; a criar estratégias e métodos de intervenção, cooperação, análise, reflexão; a construir um estilo rigoroso e investigativo (p.69).

A formação entendida desse modo é concebida por um conhecimento capaz de promover uma compreensão mais reflexiva e aprofundada do contexto educacional, favorecendo processos de intervenção que sejam mais condizentes para inserção dos licenciandos na profissão e na apropriação da aprendizagem da docência.

O licenciando ao entrar em contato com as contradições no seu próprio processo de formação, se tiver momentos apropriados de vivenciar o contexto escolar, ter ampliada suas interações em diversos planos e poder refletir, a partir deste seu panorama, para ampliá-lo com os dos colegas, pode viabilizar uma visão mais consciente do trabalho docente e de suas possibilidades e limites. Sobretudo, a compreensão da docência em sua complexidade, na relação dialética com a formação permanente, como aponta o autor supracitado, entre a formação teórica e prática, entre o trabalho colaborativo e individual, aliadas à análise desse processo formativo como intrínseca ao trabalho docente.

A formação para docência dada a complexidade e as múltiplas facetas a serem tratadas precisa ser considerada em uma perspectiva processual, que contemple desequilíbrios, mudanças, práticas educativas diferenciadas, a resolução de situações problemas, conhecer contextos diferenciados, dentre outros componentes. Isso forneceria ao licenciando uma amplitude em sua vivência durante a formação, possibilitando momentos de reflexões e apropriações da docência, singulares para cada licenciando, mas construído no social, no coletivo. O que poderia proporcionar uma intervenção mais concreta nas ações docentes, em suas aulas, com escolhas de conteúdos, estratégias, criatividade e outros aspectos que impulsionariam o licenciando a pensar sua formação, seu papel e sua profissão. Assim, o 
estágio no processo da formação para docência é um componente fundamental para o desenvolvimento do licenciando.

\subsection{O estágio supervisionado para aprendizagem da docência}

Os cursos de formação, em grande parte deles, há uma desconexão entre as disciplinas e as relações com o campo de atuação profissional dos licenciandos (PIMENTA e LIMA, 2012), o que pode levar a um distanciamento do significado social e cultural da profissão para o estudante se prepara docência. Esta questão influência na organização do estágio, sobretudo na valorização que se dará ao papel do mesmo na formação docente.

O estágio na formação dos professores proporciona o contato do licenciando com a escola, buscando que ele estabeleça uma relação que permita a aproximação, a compreensão do trabalho e as ações do professor, tão importante quanto isto é poder vivenciar situações reais de ensino com os alunos.

Não se pode deixar de olhar a escola como um sistema de atividade, portanto, com outros atores da comunidade escolar, com regras e divisões de trabalho que o licenciando precisa, pelo menos, percebê-las durante o estágio, bem como, pensá-las em um panorama mais amplo do sistema educacional, para poder analisar o contexto no qual terá experiências com a docência em sala de aula, na realidade escolar.

Pimenta e Lima (op. cit.) apontam diferentes concepções de estágio, sendo uma delas a "prática como imitação de modelos", na qual a partir da observação, imitação, reprodução e pode haver também a reelaboração de modelos que foram considerados bons. Pois, os alunos muitas vezes o experienciaram, com seus professores ou em outras situações, assim fazem uma adaptação às suas experiências, ao conhecimento que adquiriram e ao contexto que o utilizarão. Essa prática é vista por alguns como concebendo uma realidade de ensino e de alunos que não se altera no tempo, não valoriza o professor como intelectual ao formá-lo em um processo por "imitação", procurando um modelo para reproduzir que quanto mais próximo dele melhor será o resultado. Para tanto, as autoras, colocam que neste tipo de modelo a perspectiva do estágio:

(...) reduz-se a observar os professores em aula e imitar esses modelos, sem proceder a uma análise crítica fundamentada teoricamente e legitimada na realidade social em que o ensino se processa. Assim, a observação se limita à 
sala de aula, sem análise do contexto escolar, e espera-se do estagiário a elaboração e execução de "aulas-modelos" (op. cit., p.36).

Outra perspectiva para o estágio colocada pelas autoras é a "prática como instrumentalização técnica", que parte do princípio que no exercício de uma profissão é necessário à utilização da técnica, o que é válido também para o professor, porém só as técnicas não são suficientes para que se enfrente as questões do ensino e a complexidade da profissão docente. Além de poder levar a uma visão não valorizada o conhecimento científico, priorizando apenas as técnicas como solução geral, pode levar a separação entre teoria e prática.

Desta forma, o estágio fica restrito à hora da prática, que leva ao contato com a escola, com a sala de aula, em atividades que propiciam recursos didáticos, atividades, cujo entendimento de prática, segundo as autoras é o "desenvolvimento de habilidades instrumentais necessárias ao desenvolvimento da ação docente”. Essas atividades são importantes, mas o processo educativo não pode estar reduzido a elas, pois ele é mais complexo, as práticas experimentais, oficinas, dentre outras devem fazer parte da formação do professor, porém não como processo único.

O estágio na perspectiva de "teoria e prática" proposto pelas autoras supracitadas carrega o significado da profissão docente como prática social, sendo uma forma de intervenção na sociedade. A prática está ligada a parâmetros das instituições, metodológicos, das possibilidades e condições que o professor dispõe, sendo a ação pedagógica referente ao sujeito, a qual as autoras, definem como: "atividades que os professores realizam no coletivo escolar supondo o desenvolvimento de certas atividades materiais orientadas e estruturadas, tais atividades têm a finalidade da efetivação do ensino e da aprendizagem por parte dos professores e dos alunos". A teoria tem papel de fornecer subsídios para análise e investigação da prática, permite questionar a prática e esta ser questionada. Pimenta e Lima (2012) complementam dizendo que:

[...] no estágio dos cursos de formação de professores, compete possibilitar que os futuros professores compreendam a complexidade das práticas institucionais e das ações aí praticadas por seus profissionais como alternativa no preparo para sua inserção profissional (p.43).

Uma questão importante apontada pelas autoras é a necessidade de um eixo de todas as disciplinas do curso e não só daquelas direcionadas à "prática", pois não deve haver uma dissociação entre teoria e prática na formação docente. Assim, o estágio deve aproximar o 
aluno da realidade do ensino e a partir buscar uma reflexão. Desta forma, traz a ideia de práxis, onde o estágio não é apenas uma atividade prática, mas também teórica, como as autoras colocam:

Nesse sentido, o estágio curricular é atividade teórica de conhecimento, fundamentação, diálogo e intervenção na realidade, esta, sim, objeto da práxis. Ou seja, é no contexto da sala de aula, da escola, do sistema de ensino e da sociedade que a práxis se dá (op. cit., p.45).

Mais uma perspectiva é o estágio "como pesquisa" que visa ampliar as pesquisas e analisar os contextos onde ocorrem os estágios, permite desenvolver no estagiário a postura e habilidade de investigador, que possam lhe permitir analisar e problematizar situação de estágio e buscar a compreensão da mesma. Isto favorece a elaboração de projetos de pesquisa e pode aprofundar mais as observações e ações dos estagiários, bem como possibilitar a formação do professor da escola na relação com o estagiário.

Como diz Pimenta e Lima (2012), o estágio não se faz por si, ele precisa envolver todas as disciplinas do curso e se constituir como projeto político pedagógico para a formação, tendo a pesquisa como impulsionadora, permitindo a relação entre os sabres teóricos e da prática, que estão na universidade e na escola onde o estágio ocorre. Deve preparar o aluno para um trabalho docente coletivo, sendo este trabalho resultado de ações institucionais e coletivas, que ocorrem em um processo sócio-histórico.

Ghedin e Almeida (2011) apontam que o estágio se faz a partir de um olhar crítico, que é alimentado pela literatura. Propõem que os estagiários descrevam suas observações com cunho reflexivo, analisando e fundamentando teoricamente o que relatam. Outro ponto que colocam como relevante é tratar os alunos em sua heterogeneidade, por terem diferentes histórias de vida relacionadas às culturas distintas. Destacam ainda, que é neste processo da formação inicial, que o futuro professor começa a conceber o aluno que deseja formar quando em sua atuação profissional, para o que destacam como importante a pesquisa na formação do licenciando ligada à realidade na qual se dará sua atuação. Os autores apontam que:

(...) ao final da trajetória de estágio nem todos os professores que passaram por um processo de educação científica tornam-se pesquisadores; mesmo assim, após o percurso, o docente em formação terá adquirido elementos que contribuem na legitimação de sua identidade docente (op. cit., p.73).

Os autores entendem a pesquisa como um processo de educação científica relacionada à produção de conhecimento, com o desenvolvimento do senso crítico do futuro professor, da 
autonomia e espírito investigativo, buscando superar a reprodução, atuando de forma ativa, capaz de ressignificar as práticas pedagógicas, contribuindo para a construção de um currículo crítico ao ajustar os conteúdos, tendo em vista a realidade dos estudantes e as perspectivas teóricas atuais.

A identidade do professor, ao constituir-se professor é construída e reconstruída ao longo de sua vida profissional, porém nos cursos de formação são "consolidadas as opções e intenções da profissão que o curso se propõe a legitimar" (op. cit.). No entanto, os significados atribuídos à profissão pela valoração social também estão presentes, permeando a formação e pode provocar conflitos quando se distanciam do sentido pessoal que os licenciando almejam para profissão. Neste aspecto o estágio o aproxima da instituição de ensino permitindo que ele vivencie suas contradições e possa construir sua identidade profissional pautado em condições observadas e analisadas de forma crítica com base na realidade.

\begin{abstract}
A construção e o fortalecimento da identidade e o desenvolvimento de convicções em relação à profissão estão ligados às condições de trabalho e ao reconhecimento e valorização conferida pela sociedade à categoria profissional (PIMENTA e LIMA, 2012, p.66).
\end{abstract}

Consideramos que o estágio pode se valer da imitação, da instrumentação, mas não exclusivamente de uma ou outra, isto seria reduzir as possibilidades de apreensão da realidade de determinado contexto que o licenciando estaria vivenciando. Acreditamos que a práxis precise estar presente na concepção do estágio para que ele não se desvincule dos conhecimentos científicos, teóricos, para que o estágio não passe a ser apenas uma etapa burocrática para formação do professor. Ou, uma etapa importante, mas desconectada do curso, se mantendo como uma realidade paralela, mas é incorporado ao sujeito no processo de interiorização propiciado pelas relações estabelecidas com o contexto, seus atores e as ações efetivadas.

A pesquisa se coloca como uma perspectiva que avança no caminho de uma formação que permite ao licenciando se aprofundar na compreensão da dinâmica da escola e do ensino com a sua inserção nas ações de estágio de forma a buscar a teoria para compreensão da prática e retornar a prática para ressignificá-la, possibilitando um movimento dialético.

Nesse aspecto, pensamos que o estágio pode ser visto como uma ação de uma disciplina, mas seu objetivo deve se direcionar para realizar o motivo da disciplina, que precisa estar alinhado com os motivos dos alunos, que buscam como resultado final a 
aprendizagem da docência. Considerando esta aprendizagem da docência em seu caráter humanizador.

O estágio permite ao aluno se inserir no cotidiano escolar, com maior ou menor intensidade, o que depende da organização proposta para tal estágio, como apontam Pimenta e Lima (2012), o que possibilita que o contato com a realidade e o trabalho do professor na sociedade. Para as autoras pode-se pensar a formação do professor como um projeto único de formação inicial e continuada, neste aspecto a escola se constitui um espaço de trabalho e formação.

A partir do desenvolvimento da ação pedagógica é que se forma a coletividade de formação no processo de estágio e é na relação entre coletividade e sujeito que estes atribuem sentidos às ações que realizam (MOURA, 2002, apud PIMENTA e LIMA, 2012)

[...] podemos entender que os sujeitos são o que são muito mais por conta das circunstâncias que assim os fizeram. E sair da situação em que se encontram implica mudar as circunstâncias, tanto as de contorno como as do próprio sujeito (p.74).

Os trabalhos colaborativo e coletivo podem trazer contribuições importantes para a formação inicial, quer essa relação seja entre a sala toda e o professor que conduz a disciplina da qual faz parte o estágio, quer seja entre os estagiários e uma supervisão que auxilie no desenvolvimento do estágio, ou mesmo entre os próprios estagiários. Esses espaços de trabalho, no qual a mediação implica a relação entre os sujeitos, fazem com que haja uma influência mutua nos comportamentos dos indivíduos, segundo Vigotski, os seres humanos têm domínio sobre si mesmos pelos sistemas culturais e simbólicos (DANIELS, 2003), através do uso de ferramentas e signos, dentre o que está a relação entre os homens e suas ações. Tal processo promove a multivocalidade que está presente em um sistema de atividade onde se tem a discussão e negociação de ideias e a divisão de tarefas entre diferentes sujeitos direcionada a resultados comuns. Como coloca Ribeiro (2011):

A "multivocalidade dos sistemas de atividade" está associada à idéia de que a divisão de trabalho entre diferentes parceiros numa atividade contempla diferentes olhares, percepções e, consequentemente, negociação de idéias, configurando-se em uma rica fonte de problemas ou questionamentos (p.53).

Esse trabalho coletivo permite que desenvolvam uma ação conjunta, cujo objetivo seja comum, mas as metas podem ser individuais ou globais, segundo propõe Leontiev (DANIELS, 2003). Assim, o planejamento de ações do estagiário com o grupo precisa 
considerar as suas necessidades e possibilitar o atendimento as metas de cada um, para que se possa favorecer que o grupo entre em atividade, como explica Moura et al. (2010):

\begin{abstract}
Isoladamente, as ações não garantem a satisfação de uma necessidade, mas compõem e estruturam a atividade e, dessa forma adquirem sentido. O estudante que toma parte da atividade, ao realizar as ações, pode estar mobilizando apenas motivos compreensíveis. Estes, segundo Leontiev (1978), conferem um sentido pessoal à atividade e aos fins das ações. Ainda segundo o autor, são os motivos eficazes que têm uma função impulsionadora da atividade. No caso de uma atividade de aprendizagem, são os motivos eficazes que possibilitam ao estudante estabelecer uma relação entre o motivo objetivo da atividade e a ação desenvolvida para aprender. Se não for assim, suas ações serão vazias de sentido para si (Ibid., p.102).
\end{abstract}

As ações do estágio precisam fazer com que o estagiário busque soluções para problemas reais que enfrentará quando docente, neste aspecto ao planejar e organizar atividades de ensino isto permitirá que reflita e sintetize a realidade observada e como atuar nela. A possibilidade de aplicar o trabalho que planejou, valoriza sua ação pedagógica, lhe traz mais segurança para atuação em sala de aula, o que diminui um pouco sua apreensão e angústia com a docência pela falta de experiência, muitas vezes, o estágio é a primeira oportunidade de vivenciar a docência. Como coloca Rodrigues (2013):

[...] para analisar a formação inicial de professores não podemos trazer a escola apenas abstratamente, esmaecendo suas contradições, dinâmica e heterogeneidade (p.143).

Silvestre (2011) aponta uma questão significativa na formação inicial que é possibilitar a compreensão pelo estagiário da compreensão da educação como experiência humana e forma de intervir no mundo, o que promoverá uma imagem da docência diferente daquela que se coloca no campo da neutralidade ou como tendência vocacional.

Não podemos deixar de considerar a importância do papel do professor formador que conduz o processo de estágio associado à disciplina que ministra, pois é ele que organiza o ensino para as ações de aprendizagem dos licenciando. No entanto, não podemos atribuir somente às disciplinas com estágio a formação inicial, pois ela está inserida na estrutura e na concepção de um curso como um todo. Porém, é forte o impacto que têm aqueles que fazem o contato do licenciando com a escola. O excerto a seguir, aborda o impacto do papel do formador nas concepções pedagógicas daqueles em formação: 
É necessário levar em consideração que o formador influencia diretamente na formação e concepção pedagógica do futuro professor, pois não só os conteúdos, mas as formas de trabalhá-los e os valores a eles associados atuam como uma espécie de modelo na aprendizagem da docência. É também o momento em que se desenvolvem mais significativamente as imagens sobre o que é ser professor, seja pelo contato com os conteúdos das disciplinas, seja pelas experiências, interações e práticas às quais, nessas situações, os estudantes são expostos (HOBOLD e MENSLIN, 2012, p.799).

O contato do estagiário com o professor da escola onde realiza o estágio também oferece grande significação para sua formação, porém os sentidos atribuídos a este contato dependem de múltiplos fatores. Mas, ao contrário do contato com o professor formador da disciplina, este em geral, é mais disperso, na maioria das vezes o professor da escola se envolve muito pouco com o estágio, ou não se envolve nada, se restringindo apenas a disponibilizar sua aula. Não atribuímos isto a uma falta de compromisso do professor, mas a falta do estabelecimento de uma relação mais estreita entre o estágio e a escola, que não ocorre por dificuldades de diversas origens. Há a necessidade de repensar essa relação, em um sistema mais colaborativo que pode trazer vantagens mútuas, como propõe Galindo (2012), onde coloca a figura do professor parceiro como aquele que recebe o estagiário em sua sala de aula:

[...] em termos de possibilidades, o professor parceiro interagindo com o estagiário de forma que essa interação possa ser considerada um trabalho coletivo, é uma possibilidade de se pensar e intervir mais efetivamente nesse espaço como tal, e dentro dessa possibilidade contribuir, a partir de necessidades criadas para a reorganização das instituições na direção de uma cultura mais colaborativa. (...) Em relação ao estágio, a noção de trabalho coletivo também há de ser articuladora do contato entre a universidade e a escola visto que os atores individualmente não podem dar conta das possibilidades de formação, mas coletivamente tem-se um ganho na ligação. Isso significa a criação de espaços para o contato com o professor parceiro (...) (p.194).

O licenciando em sua formação, pela interação com o meio social, com a escola, pela mediação com seus pares, com os docentes dos cursos de graduação, pela sua história de vida e pelo estágio, estabelece relações que o modificam, agem sobre ele e é por esta trajetória que ele se desenvolve como indivíduo e profissionalmente, vai se constituindo professor, professor em permanente formação e desenvolvimento. 


\subsection{A educação como atividade humana}

Na vida do homem a educação sempre ocupou papel essencial, pois é pela educação que nos apropriamos das construções da humanidade adquiridas no seu percurso histórico (LEONTIEV, 1978). Essa educação se dá desde nossos primeiros contatos pessoais, com as trocas que estabelecemos com o outro e com o mundo que nos cercam. Desta forma, vamos nos tornando sujeitos sociais e históricos, assim, precisamos nos apropriar do sistema de referências do contexto no qual vivemos para que possamos participar deste e atuar de modo a promover transformações, com o que também nos transformamos. Rigon, Asbahr e Moretti (2010a), discutem a relação do homem com a educação e explicitam que:

[...] a educação é o processo de transmissão e assimilação da cultura produzida historicamente, sendo por meio dela que os indivíduos humanizam-se, herdam a cultura da humanidade. As aquisições do desenvolvimento histórico do homem estão apenas postas no mundo e, para que cada nova criança possa apropriar-se das conquistas humanas, não basta estar no mundo, é necessário entrar em contato com os fenômenos do mundo circundante pela mediação dos outros homens, num processo de comunicação (LEONTIEV, 1978). O processo educativo é central à formação do homem em sua especificidade histórica, pois permite que não seja necessário reinventar o mundo a cada nova geração, permite que se conheça o estágio de desenvolvimento humano atual para que se possa superá-lo (Ibid., p.27).

Ao compreendermos a construção do conhecimento como um processo sóciohistórico, entendemos que ele é produto da atividade humana. Essa atividade configurada como humana tem uma intencionalidade, relacionada à necessidade que a gerou, buscando assim, satisfazê-la, que pode ser, por exemplo, a construção de um instrumento de trabalho, de um material intelectual, ou de um produto artístico, como propõe Leontiev (1978). A atividade é estimulada pelo produto da divisão do trabalho, que corresponde à necessidade dos indivíduos, portanto, se dá nas relações sociais (LEONTIEV, 1983).

Toda atividade é produto do desenvolvimento social e assim passa a se converter em patrimônio do homem social, em forma ideal, como apontaram Martineli e Lopes (2009), “o material se converte em ideal e o ideal na realidade é atividade produtiva". A atividade humana é impulsionada por uma necessidade, mas é objeto da vontade do homem e da consciência. Eles comentam ainda a concepção de Davidov para a transmissão da herança cultural da humanidade: 
No entendimento de Davidov (1988), as condições e as formas ideais da atividade humana e seu surgimento, estão internamente ligadas com o processo histórico-social durante o qual, as gerações em crescimento herdaram as habilidades (as capacidades mais amplas), para produzir instrumentos, coisas diversas, a comunicação real, material e espiritual. Para que uma geração possa transmitir as outras suas próprias habilidades reais deve previamente criar e formular, de maneira correspondente, os padrões socialmente significativos, universais destas habilidades (capacidades). Mas, sempre no sentido de preparar o sujeito para o novo, em constante transformação; se preparar para as novas necessidades sociais e históricas (MARTINELI e LOPES, 2009, p. 213).

A intencionalidade do homem se dá no movimento da consciência, na qual o trabalho provoca modificações que influenciam e controlam o comportamento humano, que também é voluntário. Oliveira (1993), explicita esta relação exemplificando-a:

O ser humano tem a possibilidade de pensar em objetos ausentes, imaginar eventos nunca vividos, planejar ações a serem realizadas em momentos posteriores. Esse tipo de atividade psicológica é considerada "superior" na medida em que se diferencia de mecanismos mais elementares tais como as ações reflexas (a sucção do seio materno pelo bebê, por exemplo) [...]. Um exemplo ilustra a diferença entre processos elementares e processos superiores: é possível ensinar um animal a acender a luz num quarto escuro. Mas o animal não seria capaz de, voluntariamente, deixar de realizar o gesto aprendido porque vê uma pessoa dormindo no quarto. Esse comportamento de tomada de decisão a partir de uma informação nova é um comportamento superior, tipicamente humano. $\mathrm{O}$ mais importante desse tipo de comportamento é o seu caráter voluntário e intencional (p.26).

Isso nos leva a pensar a educação como atividade, que vem da necessidade da apropriação da cultura humana. Nessa concepção de atividade ligada ao trabalho, sendo uma relação estabelecida com as necessidades humanas, associada à consciência e de caráter voluntário e intencional, a educação se insere nesse processo, considerada como atividade. Rigon, Asbahr e Moretti (2010a), apontam que:

[...] O objeto da atividade pedagógica é a transformação dos indivíduos no processo de apropriação dos conhecimentos e saberes; por meio dessa atividade - teórica e prática, é que se materializa a necessidade humana de se apropriar dos bens culturais como forma de constituição humana (p.24).

Desse modo, a escola como instituição responsável pela educação sistematizada tem papel fundamental na apropriação pelo sujeito do legado cultural da humanidade. Na escola a intenção é tornar acessível aos indivíduos o conhecimento de forma organizada. Rego (1995) discute que a escola é: 
[...] o elemento imprescindível para a realização plena do desenvolvimento dos indivíduos (que vivem em sociedades escolarizadas) já que promove um modo mais sofisticado de analisar e generalizar os elementos da realidade: $o$ pensamento conceitual.

[...] as atividades desenvolvidas e os conceitos aprendidos na escola (que Vigotski chama de científicos) introduzem novos modos de operação intelectual: abstrações e generalizações mais amplas acerca da realidade (que por sua vez transformam o modo de utilização da linguagem). Como consequência, na medida em que a criança expande seus conhecimentos, modifica sua relação cognitiva com o mundo (p.104).

No processo de ensino na escola, estão envolvidos muitos atores, cujo objetivo está direcionado à atividade de aprendizagem dos alunos, entendendo esta, vinculada aos conhecimentos da cultura humana adquiridas no decorrer da história, mas como aquisição do saber sistematizado que visa o conhecimento da ciência, filosofia e arte. Nesse panorama é de suma importância o papel desempenhado pelo professor, tendo o ensino como atividade, ao qual cabe planejá-lo e organizá-lo (RIGON, ASBAHR, MORETTI, 2010b, MOURA et al., 2010), com atividades de ensino que permitam que os alunos se apropriem dos saberes transmitidos na escola, que pertencem ao patrimônio cultural humano. Mas, podendo desenvolvê-los e transformá-los, com a mediação do professor, que cria as necessidades para que se garanta sua existência cultural, porém tendo o ensino como atividade principal (FURLANETTO, 2013).

A atividade de ensino é uma maneira pela qual se faz a realização da educação escolar. Moura et al. (2010) evidencia a semelhança que se estabelece entre essa atividade e os processos de formação das funções psíquicas superiores que ocorre na relação entre sujeito e objeto, com mediação de instrumentos, nesse aspecto caracterizam a atividade de ensino como:

[...] a máxima sofisticação humana inventada para possibilitar a inclusão dos novos membros de um agrupamento social em seu coletivo, dará a dimensão da responsabilidade dos que fazem a escola como espaço de aprendizagem e apropriação da cultura humana elaborada, bem como do modo de prover os indivíduos, metodologicamente, de formas de apropriação e criação de ferramentas simbólicas para o desenvolvimento pleno de suas potencialidades (op. cit., p.82).

A atividade de ensino que o professor planeja deve buscar promover nos alunos um motivo que seja especial para que sua atividade se desenvolva, que deve estar ligado ao objeto da aprendizagem. Ao professor cabe também organizar a atividade de ensino, conduzir as ações em sala de aula fazendo a orientação dos alunos e a avaliação do processo, desta forma, 
buscando promover a atividade de aprendizagem dos alunos. Cedro, Moraes e Rosa (2010) elucidam essas discussões ao colocarem que:

\begin{abstract}
A atividade de ensino é uma particularidade da atividade pedagógica e esta, uma particular atividade no contexto geral das ações humanas no processo de apropriação dos bens culturais produzidos pelos homens ao longo da história. É importante destacar que, sempre que pensamos sobre a atividade de ensino, precisamos nos reportar a um sistema de atividade, já que uma está correlacionada à outra. A situação desencadeadora de aprendizagem se forma por meio da objetivação da atividade de ensino, a qual contempla a elaboração da solução coletiva e a gênese do conceito. Para que a aprendizagem se torne significativa, a atividade de ensino deve desencadear a aprendizagem. Pressupõe-se que o professor crie a necessidade, no estudante, de se apropriar dos conhecimentos teóricos (p.438).
\end{abstract}

Com isso, o professor atua também para a sua atividade de aprendizagem, tomando consciência de seu trabalho, das contradições nele inseridas, nos problemas a enfrentar, na importância do trabalho coletivo, do papel da escola e dos docentes no cenário político e social (MOURA et al., p.90).

De acordo com Moura et al (2010), a aprendizagem "pode ser entendida como um estado ou processo do que se aprende" (p.87), sendo que Rubtsov (1996) destaca que pesquisas mostraram que desenvolver uma "motivação" para aprender se constitui como resultado do processo de interiorização, que a aprendizagem é coletiva e situa-se entre a atividade interpsíquica e intrapsíquica do sujeito. Para uma atividade ser considerada coletiva Rubtsov (p.136) aponta alguns elementos:

- repartição das ações e das operações iniciais, segundo as condições da transformação comum do modelo construído no momento da atividade;

- troca de modos de ação, determinada pela necessidade de introduzir diferentes modelos de ação, como meio de transformação comum do modelo;

- compreensão mútua, permitindo obter uma relação entre, de um lado, a própria ação e seu resultado e, de outro, as ações de um dos participantes em relação a outro;

- comunicação, assegurando a repartição, a troca e a compreensão mútua;

- planejamento das ações individuais, levando em conta as ações dos parceiros com vistas a obter um resultado comum;

- reflexão, permitindo ultrapassar os limites das ações individuais em relação ao esquema geral da atividade (assim é graças a reflexão que se estabelece uma atitude crítica dos participantes com relação às suas ações, a fim de conseguir transformá-las, em função de seu conteúdo e da forma do trabalho em comum).

Cabe salientar que a atividade de ensino e a atividade de aprendizagem estão unidas em um mesmo processo, não podem ser entendidas de forma dissociada, as abordamos separadamente para estudar suas especificidades, porém devem convergir para um mesmo objetivo, a aprendizagem dos alunos. Como explicitam Moura et al. (2010) que "não há 
sentido na atividade de ensino se ela não se concretiza na atividade de aprendizagem, por sua vez, não existe atividade de aprendizagem intencional se ela não se dá de forma consciente e organizada por meio da atividade de ensino" (p. 220-221).

Libâneo (2004) destaca a relação entre cognição e afetividade, o que complementa com o que diz Davidov, que as necessidades e emoções antecedem as ações humanas, então, estas são impregnadas de sentidos subjetivos. Isto também se reflete na escola e na atividade de aprendizagem dos alunos, o que o professor precisa considerar ao organizar uma atividade de ensino, durante seu trabalho e ao avaliar este processo.

A contribuição de Davidov vai além, ele traz que a questão central da aprendizagem é o desenvolvimento mental dos alunos que se dá na cooperação entre adultos e crianças na atividade de ensino (LIBÂNEO, 2004.), ele toma por base as ideias de Vigotski e coloca: "enquanto o aluno forma conceitos científico, incorpora processos de pensamento e viceversa; enquanto forma o pensamento teórico, desenvolve ações mentais, mediante a solução de problemas que suscitam a atividade mental do aluno".

Davidov defendeu que um ensino mais vivo e eficaz que busque o desenvolvimento da personalidade deve ir na direção do pensamento teórico, "que se forma pelo domínio dos procedimentos lógicos do pensamento, que pelo seu caráter generalizador permite sua aplicação em vários âmbitos da aprendizagem” (LIBÂNEO, op.cit.). Moura et al. (2010) colocam que a apropriação do conhecimento teórico como objeto de aprendizagem permite, pela atividade de ensino fazer "um movimento de análise e síntese que vai do geral ao particular e do abstrato ao concreto".

No ensino de ciências, acreditamos ser preciso um repensar que mude a visão preconizada nas escolas de um ensino fora do contexto dos alunos, de pouco significado para eles e que para grande parte promovem um significado estereotipado da ciência e da educação, que às vezes, para alguns é difícil demover, acabando por assumir essa imagem durante a docência (IMBERNÓN, 2010).

Se os alunos não são mobilizados em direção à aprendizagem, poucos se colocam em atividade no ensino de ciências realizado hoje, na maior parte das escolas, isto faz com que seja importante e necessário discutir essas questões na formação inicial de professores, no momento em que a docência é para o aluno um objetivo a ser atingido, ele a tem como meta. Nesta fase as ações realizadas adquirirem sentido para ele coincidente com seu motivo principal, que é formar-se professor, assim, podem vir a resultar em uma formação mais significativa para o enfrentamento das contradições e conflitos da escola básica. 
Desta maneira, a formação que as universidades e as faculdades concebem para os licenciandos não pode deixar de abarcar uma perspectiva que inclua o ensino em um contexto social e cultural, não isolado, que permita que conteúdos sejam tratados, também estratégias diversas que possam dar condições dos formandos conhecerem, discutirem e avaliarem, para que possam saber fazer escolhas com mais segurança e imbuídos teoricamente quando docentes.

Só isto não basta, há a necessidade de contato com o contexto escolar, não apenas observar, mas experienciar o lugar que se almeja se colocar como profissional (discutiremos com mais detalhes, no item: O estágio para docência, o contato com a escola).

A formação inicial, segundo Imbernón (2010), deve proporcionar ao licenciando uma bagagem sólida dos conhecimentos científicos, cultural, contextual, psicopedagógico e pessoal, para que possa capacitá-lo para a docência na sua complexidade. Tendo, desta forma, as condições necessárias para apoiar suas ações, evitando "cair no paradoxo de ensinar a não ensinar, ou em uma falta de responsabilidade social e política", que levam a uma visão funcionalista, um baixo nível de abstração, atitude pouco reflexiva, baixo potencial inovador, dentre outros reflexos.

No processo de ensino, o professor tem em sua aula a intenção da apropriação pelos alunos do saber elaborado e sistematizado, assim o aluno, podemos considerar aqui também o licenciando, é objeto do trabalho do professor, mas precisa ser sujeito de seu próprio aprendizado para que a aprendizagem se realize, o que faz necessário que o aluno esteja em atividade.

Para que seja sujeito e se modifique no processo, tendo assim a aprendizagem, o aluno precisa participar ativamente do processo educativo (RIGON, ASBAHR, MORETTI, 2010a). Desta forma, o processo de educação permitirá, que o aluno em atividade se direcionar ao seu objetivo e ao atingi-lo ele se transformará, como dizem os autores citados, é "a transformação da personalidade viva do estudante, e essa transformação não permanece apenas no ato de ensinar/aprender, mas por toda vida do indivíduo" (p.32). Este conhecimento sendo historicamente acumulado permitirá ao aluno o acesso a um produto da cultura humana, o que o insere em um processo de humanização pelo ensino.

Esse processo não ocorre espontaneamente, sem que haja a intencionalidade e organização do professor, nesse caso é importante que o aluno vivencie um processo de ensino humanizador, para que tenha uma educação significativa, mas tão importante quanto isso, é que o licenciando também conceba esse processo para suas futuras ações como 
docente. Se colocar em atividade é fundamental, para que possa motivar os alunos e colocá-lo em situações de efetiva aprendizagem. A formação que promove transformações e mudanças de sentidos, que provoca emoções positivas tende a ser apropriada pelo indivíduo para utilizar quando em sala de aula em situação de professor.

O trabalho em equipe é um elemento importante na formação inicial, pois leva à socialização de ideias, à postura crítica e à cooperação, sendo que o trabalho coletivo é fundamental na profissão docente. Mas, é difícil a articulação, em grande parte das escolas, para que isso aconteça de forma efetiva e contínua, direcionado para organização de atividades de ensino e propostas de intervenções mais amplas. A formação precisa preparar o licenciando para uma profissão que exigirá que ele estude no percurso de toda sua vida profissional, mas também para as mudanças por fazer parte de um processo dinâmico situado histórco e culturalmente, como coloca Imbernón (2010):

\footnotetext{
Aprender também a conviver com as próprias limitações e com as frustrações e condicionantes produzidos pelo entorno, já que a função docente se move em contextos sociais que, cada vez mais, refletem forças em conflito. Isso significa que as instituições ou cursos de preparação para formação inicial deveriam ter um papel decisivo na promoção não apenas do conhecimento profissional, mas de todos os aspectos da profissão docente, comprometendo-se com o contexto e a cultura em que esta se desenvolve. Devem ser instituições "vivas', promotoras da mudança e da inovação (p.63).
}

Na formação dos licenciandos dos cursos de ciências é preciso que aproxime teoria e prática, não é apenas discutir a prática, mas como propõe Libâneo (2010) é associar ao “ensino do pensar ao processo da reflexão dialética de cunho crítico, a crítica como forma lógico-epistemológica” (p.87). O autor citado comenta que este fazer pensar tão fundamental à formação inicial, se refere ao um pensar epistêmico, que forme um sujeito que possa se apropriar de um momento histórico a pensar e reagir historicamente sobre a realidade.

\subsection{A metodologia de ensino e o estágio para o licenciando em física}

A disciplina MEF é obrigatória no currículo do curso de licenciatura e está indicada no rol daquelas de finalização da graduação, embora a dinâmica real de término do curso não seja programada pela distribuição dada na grade curricular. Contudo, os alunos que frequentam MEF, em geral, são aqueles que já fizeram mais da metade da graduação. Desta 
forma, os licenciandos nesta disciplina carregam a vivência do curso, o que ao lado do estágio pode nos proporcionar a compreensão do movimento da formação para docência.

O processo do indivíduo estar inserido em um curso de graduação consideramos como um contexto de uma atividade de estudo, como era no Ensino Básico, mas agora adquirindo outro caráter, que é a preparação profissional, como coloca Facci (2006), seus motivos são de atividade dirigida para perspectivas futuras. Com isso, o estudo passa a ter maior interesse e controle pelo indivíduo e seus motivos estão mais direcionados ao fim profissional que deseja atingir.

As relações estabelecidas entre o indivíduo e o meio, sendo essas dialéticas, é que vão mover e direcionar cada aluno em seu percurso na graduação. As interações entre os alunos, entre alunos e professores, alunos com os instrumentos de estudos ou signos fazem as mediações no âmbito da atividade de estudo de graduação. A mediação cria uma relação indireta entre o sujeito (aluno) e o curso de licenciatura, se expressando em cada uma das disciplinas desse curso.

Nessa concepção é que consideramos as relações que medeiam o indivíduo e a disciplina de MEF relevantes no processo de sua formação para docência, principalmente no desenvolvimento do estágio de regência. As interações que se estabelecem no contexto da sala de aula da disciplina de MEF e aquelas experienciadas na escola são múltiplas e complexas, as quais envolvem diversos sujeitos e artefatos mediadores.

Para a realização do estágio o licenciando precisa se preparar na disciplina de forma compartilhada, com a colaboração da professora ou dos colegas, textos teóricos, situações concretas vivenciadas etc., para poder refletir, fazer mudanças e avançar em suas propostas. Nessas situações a mediação se evidencia e pode-se perceber os interesses, os motivos, nas ações do estágio, bem como sua intenção futura de ser professor do Ensino Básico, ou talvez, ou de modo algum assumir a docência.

Assim, a aprendizagem da docência, em toda disciplina, especialmente as de caráter pedagógico, precisam considerar que a formação do licenciando se dá desde o momento em que se organiza o ensino, nas atividades de ensino, diante da sala de aula em suas ações e pela sua comunicação, os instrumentos e signos, bem como, as ações propostas que medeiam as relações que se estabelecem na atividade de aprendizagem.

Para concretizar um trabalho que coloque o licenciando em movimento de aprendizagem da docência, que haja o compartilhamento de ações, é necessário que o professor da disciplina prepare atividades de ensino que promovam tal situação, como, por 
exemplo, problemas que possam gerar processos de busca por solução que envolvam ações colaborativas (MOURA et al., 2010). Para o licenciando em física isto significa compreender e se envolver com situações que o leve a pensar em atividades de ensino que promovam ações dos alunos, não uma transmissão de conteúdos, ou listas de experimentos, mas uma coordenação de ações que movimente os alunos para a aprendizagem.

Nessa perspectiva o estágio traz para o ensino de física uma grande contribuição para a formação do licenciando, quando possibilita aos futuros professores um espaço de diálogo, planejamento e reflexão. Assim, ao organizar a atividade de ensino e de aprendizagem, terá como objetivo a aprendizagem dos alunos e em suas ações buscará os instrumentos, métodos, referenciais e conteúdos para que isso ocorra.

O estágio com a regência é o momento de contato do licenciando com o contexto escolar, com o aluno, mesmo que o tempo seja reduzido, é um momento oportuno para vivenciar sua atuação como professor. Essa ação realizada pelo licenciando envolve o fazer concreto do trabalho que ele desenvolverá, mas também a ação pensada, planejada e refletida sobre os resultados obtidos para então, redefinir suas ações posteriores. Esse processo não acontece de forma espontânea, mas é marcado pela intencionalidade do indivíduo, que o leva às escolhas de ações determinadas, das relações que estabelecerá na escola e das experiências que carrega consigo. Esse conjunto de variáveis é que fará o estágio ser único para cada licenciando, mesmo que tenham feito a regência conjuntamente, mas marcado pelo social, pelo cultural e pela história dos indivíduos.

Nessa perspectiva, a disciplina de MEF e o estágio não oferecerão receitas prontas que possam levar o licenciando à aprendizagem da docência de Física, mas podem propor uma organização de ensino que: permita o compartilhamento de ideias e experiências entre os alunos; que busquem as memórias passadas para que ressignifiquem ações do presente; apresente subsídios teóricos; proponha o contato com a escola básica e regências efetivas; crie espaços de reflexão sobre a experiência vivida na escola, seus sucessos e angústias; dentre outras ações.

A relação do licenciando com a escola é fundamental para sua constituição como sujeito que está se formando para o trabalho docente, pois é nessa relação dinâmica e relativa entre o sujeito e o meio, como propôs Vigotski (2010), que o licenciando atua sobre esse espaço escolar, a sala de aula, os alunos, modificando-o, ao mesmo tempo que vai também sendo modificado. 


\title{
Capítulo 3
}

\section{Teoria Histórico-Cultural e Teoria da Atividade}

\author{
Através dos outros, nos \\ tornamos nós mesmos. \\ Lev Vygotsky
}

\subsection{Vigotski e a Teoria Histórico-Cultural}

No período pós-revolução de 1917, na Rússia, o país necessitava se estruturar enfrentando as dificuldades trazidas pela situação política e social, assim, se consolidou com Lenin o comunismo, em 1921, com base nas ideias do materialismo histórico-dialético de Marx e Engels. É nesse contexto que a carreira de Vigotski na psicologia, começa a se desenvolver, com o estudo do comportamento humano, o qual apresenta em congresso, trazendo ideias surpreendentes para os estudiosos da época. Com isso, ele ganha visibilidade e um convite para trabalhar em Moscou, em destacada instituição de psicologia (OLIVEIRA e REGO, 2010).

O objetivo, neste período, era a reconstrução do país, mas também a construção de uma nova sociedade, o que levava a pensar em uma nova Ciência. Essa Ciência acaba sendo promotora de embates, por tomar somente como base o marxismo e não conseguir uma unidade, provocando pensamentos distintos de correntes teóricas, opondo tendências mecanicistas e dialéticas, como aponta o excerto abaixo.

O conhecimento deveria ter sido um dos pilares dessa nova sociedade, considerando que, de acordo com a teoria marxista, ele evita a alienação no trabalho e liberta o homem. Mas, [...], a filosofia marxista contém uma epistemologia materialista e uma lógica dialética que requer o desenvolvimento de uma nova concepção de ciência. (ROSA e MONTERO $^{4}, 1996$, apud LUCCI, 2006, p.3)

4 ROSA, A. e MONTERO, I. O contexto histórico do trabalho de Vygotsky: uma abordagem sócio-histórica. (pp.57-83). In: MOLL,L.C.Vygotsky e a educação: implicações pedagógicas da psicologia sócio-histórica. Porto Alegre, RS, Artes Médicas, 1996. 
Neste meio de reestruturação social, havia também a necessidade de uma nova visão sobre o ensino escolar, sendo que Vigotski atuou na esfera da educação e em pesquisas na área de psicologia. Nesse envolvimento com o ensino e a psicologia, Vigotski já trazia em sua trajetória uma gama de experiências, pois havia lecionado em escola de formação de professores; era crítico literário, fazendo análises psicológicas; enfim contava com uma formação bastante diversificada, o que lhe permitia transitar por várias áreas do conhecimento. Ele foi influenciado pelos pesquisadores que estudavam a relação da linguagem sobre os processos de pensamento, sendo que na escola de formação de professores teve contato com crianças com necessidades especiais, o que o levou também a buscar maneiras de desenvolver as potencialidades dessas crianças, interessando-se por trabalhos acadêmicos de psicologia (LURIA, 2006).

Suas pesquisas em psicologia se aprofundaram na equipe do Instituto de Psicologia de Moscou, em 1924, onde encontrou Leontiev e Luria, se juntando ao grupo chamado troika. Luria (2006) conta que na época queriam criar uma maneira que tratasse os processos psicológicos humanos como um todo e não fragmentado como as correntes de estudos contemporâneas os discutiam. Podemos ter noção da dimensão dos estudos que o grupo de pesquisa, troika, almejava, em um trecho que Luria comenta:

Com Vigotski como líder reconhecido, empreendemos uma revisão crítica da história e da situação da psicologia na Rússia e no resto do mundo. Nosso propósito, super ambicioso, como tudo na época, era criar um novo modo, mais abrangente, de estudar os processos psicológicos humanos. (p.22)

Como podemos notar pelas palavras de Luria (op. cit.), o grupo se empenhou em uma revisão crítica da psicologia na Rússia para que pudessem avançar em seus estudos, assim, Vigotski imbuído na proposta de estudar os processos psicológicos humanos fez uma extensa análise da psicologia da época, como relatou Luria (op. cit.): “é impossível avaliarmos todas as influências que sofremos quando em 1925, empreendemos uma grande revisão da psicologia" (p.24).

O momento histórico no qual o grupo participava, contribuiu para o direcionamento do caminho intelectual que definiram seus trabalhos. Na época, início do século XX, podia-se considerar duas vertentes na psicologia: uma que a tratava como Ciência Natural, com caráter experimental, voltada aos processos sensoriais e reflexos; a outra como Ciência Mental, que abordava os processos psicológicos complexos, sendo então que a primeira focava o corpo e a 
segunda a mente, consciência e espírito. Esse contexto foi discutido por Vigotski analisando as ideias desses dois grupos, como discuti Lucci (2006):

\begin{abstract}
Vygotsky formula sua teoria por entender que os mentalistas e os naturalistas não explicavam cientificamente os processos mentais superiores. No seu entender, os naturalistas, ao aderirem aos métodos das ciências naturais, limitavam-se ao estudo de processos psicológicos relativamente simples, tais como as sensações ou comportamentos observáveis, mas ao se depararem com funções complexas, fracionavam-nas em elementos simples ou adotavam um dualismo que abria espaço para a especulação arbitrária. Já com relação aos mentalistas, ele ponderava que estes, por sua vez, levavam em consideração os fenômenos do "espírito" e, a partir de um apriorismo fenomenológico ou do idealismo, descreviam os processos mentais superiores, mas alegavam que era impossível explicá-los ou explicavam-nos de uma forma arbitrária e especulativa. (Ibid., p.6)
\end{abstract}

Com a análise dos trabalhos dessas duas vertentes, como sendo as principais na psicologia naquele período, o grupo de pesquisadores liderados por Vigotski se propôs a uma síntese entre elas, com isso buscaram desenvolver uma "nova psicologia", seguindo na tentativa de "reunir num mesmo modelo explicativo, tanto os mecanismos cerebrais subjacentes ao funcionamento psicológico como a constituição do sujeito e da espécie humana ao longo de um processo histórico-cultural", como nos coloca Oliveira (2005, p.8).

Vigotski trazia também uma forte influência da teoria marxista, a qual segundo Luria (2006) desempenhou um papel vital na modelação dos trabalhos do grupo. As relações do homem com o mundo são históricas, sendo mediadas por sistemas simbólicos. A linguagem é outro fator que exerce papel importante nos estudos de Vigotski, a qual ele estuda em sua relação com o pensamento.

Influenciado por Marx, Vigotskii concluiu que as origens das formas superiores de comportamento consciente deveriam ser achadas nas relações sociais que os indivíduos mantêm com o mundo exterior. Mas o homem não é apenas um produto de seu ambiente, é também um agente ativo no processo de criação deste meio. (...) Vigotskii gostava de chamar esse modo de estudo de psicologia "cultural", "histórica" ou "instrumental". Cada termo reflete um traço diferente da nova maneira de estudar a psicologia proposta por ele. Cada qual destaca fontes diferentes do mecanismo geral pelo qual a sociedade e a história social moldam a estrutura daquelas formas de atividade que distinguem os homens dos animais. "Instrumental" se refere à natureza basicamente mediadora de todas as funções psicológicas complexas. (op. cit., p.22)

Vigotski teve a influência de outros pesquisadores e filósofos, como aponta Lucci (2006, p.6), que contribuíram para a construção de uma proposta diferenciada daquelas até 
então existentes para a psicologia, além de Marx e Engels, ele se inspirou na dialética de Hegel, no evolucionismo de Darwin e nas ideias de Pierre Janet, dentre outros. No entanto, a concepção do humano é trazida pela teoria histórico-cultural pelas bases do materialismo histórico-dialético, das obras de Marx e Engels, como apontam Rigon, Asbahr e Moretti (2010a) que:

[...] ao se apropriar da cultura e de tudo o que a espécie humana desenvolveu - o homem se torna humano. Dessa forma, assume uma concepção do ser humano em seu processo de desenvolvimento, o que significa compreendêlo no movimento histórico da humanidade, tanto nas dimensões filogenética como ontogenética. (p. 15-16)

Neste contexto de contribuições diversas, a síntese que o grupo buscava propunha uma visão integrada do ser humano, considerando-o como corpo e mente, como ser biológico e cultural, como parte de uma espécie animal e de um processo histórico (OLIVEIRA, 2005). Assim, as funções psicológicas são produto da atividade cerebral, têm, portanto, um caráter biológico, mas também estão baseadas nas relações que o indivíduo estabelece com o mundo, as quais se desenvolvem historicamente.

Vigotski (1994) coloca que desde que nascemos já estamos inseridos em um ambiente social, em um contexto da cultura que vivemos, assim pelas relações que estabelecemos com as pessoas, pelos sentidos que vamos atribuindo ao que vivenciamos, o sujeito se desenvolve em um processo histórico e social. No entanto, o autor não coloca só o meio exercendo influência no sujeito e o modificando, mas sob o aspecto de uma relação recíproca, dinâmica e relativa entre sujeito-meio, que podemos notar quando ele diz que:

[...] cada aspecto do desenvolvimento determinará a maneira pela qual o meio influenciará nesse desenvolvimento, isto é, a relação entre o meio e a criança fica sempre no centro e não unicamente o meio, nem unicamente a criança, em separado.

Chegamos à conclusão de que o meio não pode ser analisado por nós como uma condição estática e exterior com relação ao desenvolvimento, mas deve ser compreendido como variável e dinâmico. Então o meio, a situação de alguma forma influencia a criança, norteia o seu desenvolvimento. Mas a criança e seu desenvolvimento se modificam, tornam-se outros. E não apenas a criança se modifica, modifica-se também a atitude do meio para com ela, e esse mesmo meio começa a influenciar a mesma criança de uma nova maneira (VIGOTSKI, 2010b, p.691).

Os postulados de Vigotski trouxeram as contribuições, sendo que o cérebro tem uma estrutura básica, com a qual nascemos, mas também é um sistema de grande plasticidade, o 
que permite constantes transformações (OLIVEIRA, 2005). Assim, podemos ter o desenvolvimento psicológico ao longo da vida dos indivíduos relacionando-o com o vivido.

A concepção trazida por Vigotski retoma as funções psicológicas em sua dimensão biológica relacionadas à maturação física e processos sensoriais, sendo que a dimensão cultural está associada aos mecanismos pelos quais a sociedade e a história moldam a estrutura humana (REGO, 1995). Desta forma, as funções psicológicas superiores são dadas pela interação entre os fatores biológicos e culturais e se modificam com a história humana. Como essas funções psicológicas superiores estão ligadas à cultura e ao social, ele as considerou características apenas do humano, sendo realizadas por ações intencionais e mediadas, que constituem as formas superiores de comportamento do homem, que a psicologia dialética chamou de processos psicológicos (VYGOTSKI, 2013).

Sua teoria é também chamada de teoria genética da psicologia, "por definir a gênese e a natureza social das funções psicológicas concebendo o homem enquanto processo social e fenômeno histórico" (MOLON, 2008, p. 60), ou seja, por propor a gênese do comportamento humano.

Os processos de desenvolvimento trazem uma indeterminação devido às possibilidades que cada indivíduo tem no decurso de sua vida, o que coloca a concepção de um sistema dinâmico e contraditório, que como diz Oliveira (2005): "precisa ser compreendido como processo em mudança" (p.9). A cultura é parte da natureza humana, assim como o desenvolvimento psicológico, que depende da história de vida de cada indivíduo, não é algo pronto, mas também construído, sendo que a dinâmica de desenvolvimento do sujeito se faz por um movimento dialético, que pode levar a mudanças qualitativas na vida desse sujeito, como coloca Oliveira (op. cit.):

As transformações qualitativas tanto na história do sujeito como na história
cultural, ocorrem por meio da chamada síntese dialética. Esta se refere à
emergência de algo novo, anteriormente inexistente. Esse componente novo
não está presente nos elementos iniciais de uma dada situação, mas é tornado
possível pela interação entre esses elementos, num processo de
transformação que gera novos fenômenos. (p. 9 )

As experiências que os indivíduos adquirem no decorrer de sua vida proporcionam processos de desenvolvimento único, singular, para cada um; pois cada indivíduo, em um momento particular, estabelece interações com o meio exterior que lhe trará possibilidades de ressignificação desse "real" de forma singular. No entanto, o desenvolvimento do indivíduo não se dá fora de seu contexto sócio-cultural, que: “fornece aos sujeitos, e com eles 
constantemente reelabora, conteúdos culturais, artefatos materiais e simbólicos, interpretações, significados, modos de agir, de pensar e de sentir" (OLIVEIRA, 2002, p. 25). Oliveira (2009) aborda a importância de considerarmos a singularidade dos sujeitos:

(...) ao lado dos fatores maturacionais e das circunstâncias culturais, históricas e sociais nas quais o sujeito vive, as experiências particulares de cada sujeito, os fatores idiossincráticos que fazem com que o desenvolvimento psicológico seja um fenômeno irrepetível. (...) Esse olhar para o singular garante que a preocupação com os fatores histórico-culturais na constituição do psiquismo não se transforme em mais uma armadilha determinista (p.45-46).

Vigotski (1994) considerou que há uma unidade que não se dissocia da atividade externa e interna do indivíduo e da atividade social, para o que sua teoria propôs que o desenvolvimento é dado pela internalização dos processos psíquicos, como ele mesmo define dizendo que: "chamamos de internalização a reconstrução interna de uma operação externa" (p.74).

O processo de internalização consiste em transformações que não ocorrem de forma linear, única e universal, mas depende do desenvolvimento cultural (LUCCI, 2006), assim, interiorizamos maneiras históricas e culturais de forma organizada para podermos lidar com as informações que obtemos no meio que estamos inseridos.

A internalização se faz de um processo interpessoal para o intrapessoal. Vigotski (1996) aponta, que no desenvolvimento da criança as funções psicológicas aparecem sempre duas vezes, primeiro no nível social, depois no individual. Assim, a transformação de um processo ao outro é resultado de vários eventos que acontecem ao longo do desenvolvimento, que então, passam a regular o comportamento humano. $\mathrm{O}$ autor coloca que "todas as funções superiores originam-se das relações reais entre os indivíduos humanos" (p.75), como explica Molon (2008):

[...] não são inventadas, nem aparecem de forma repentina e não são funções a priori. São funções que apresentam uma natureza histórica e são de origem sociocultural, são mediadas. [...] Desta forma, tudo que é intrapsicológico no indivíduo, as funções psicológicas superiores, foi antes interpsicológico. Para Vygotsky nada apresenta existência por si mesmo, as funções psicológicas superiores não acontecem na ausência de relações sociais que as potencializam. Sendo assim, é nas relações entre as pessoas e por elas que se constituem as funções psicológicas superiores; é através da relação com os outros que acontece a conversão dos processos na dimensão social em processos na dimensão individual. (p. 14) 
Esse processo ocorre por meio de instrumentos e signos que são mediadores entre o homem e a cultura, assim sendo, fazem parte do desenvolvimento do psiquismo humano trazendo a relação entre o mundo exterior e interior, construindo uma unidade como coloca Martins (2001):

Em suma, a teoria histórico-cultural, em consonância com o aporte filosófico materialista dialético, postula o psiquismo humano como unidade material e ideal construída filo e ontologicamente por meio da atividade, isto é, nos modos e meios pelos quais o homem se relaciona com a realidade, tendo em vista produzir as condições de sua sobrevivência e a de seus descendentes. Graças a essa unidade, o psiquismo firma-se como imagem subjetiva do real. (p.29)

Assim, podemos dizer que a constituição do sujeito é um processo histórico, em cujo desenvolvimento estão entrelaçados o meio, pela cultura, e as funções psicológicas superiores, influindo no comportamento e definindo indivíduos únicos e coletivos, em processos contínuos de mudanças.

\subsubsection{Vigotski e a mediação}

Na perspectiva de Vigotski a cultura faz parte da natureza humana, que em um processo histórico no decorrer do desenvolvimento da humanidade, molda o desenvolvimento psicológico humano. Com essa concepção é que Vigotski estudou os fenômenos psicológicos, trazendo a ideia de que as funções psicológicas superiores são desenvolvidas ao longo da história do homem em sua relação com o mundo. Porém, a relação entre um indivíduo e um determinado objeto não é direta, ela é mediada, esse é um conceito fundamental na proposta vigotskiana, como coloca Oliveira (1992):

As concepções de Vygotsky sobre o funcionamento do cérebro humano fundamentam-se em sua ideia de que as funções psicológicas superiores são construídas ao longo da história social do homem. Na sua relação com o mundo, mediada pelos instrumentos e símbolos desenvolvidos culturalmente, o ser humano cria as formas de ação que os distinguem de outros animais. (p.24)

Essa abordagem traz a mediação como constituinte do psiquismo humano, entendendo que a relação do homem com a natureza se faz de forma mediada por artefatos, que podem ser 
materiais ou não, os quais a humanidade cria e se apropria ao longo de sua história, é assim que Vigotski (1994) propõe a mediação para explicar a interação do indivíduo com o mundo e a formação das funções psicológicas superiores. Isso coloca um novo olhar para a relação entre o sujeito e o objeto, não mais por uma relação direta, mas por um caminho indireto.

A ideia de mediação se opõe a uma interpretação mais determinista que traz a noção de estímulo/resposta, sujeito/objeto, Vigotiski (1994) passa a propor os mediadores entre esses pares, que serão meios pelos quais os indivíduos agirão sobre o mundo, sendo um processo reflexivo, sofrerão a ação do mesmo, neles estão implícitos também os fatores sociais, culturais e históricos (DANIELS, 2003).

O uso de signos conduz os seres humanos a uma estrutura específica de comportamento que se destaca do desenvolvimento biológico e cria novas formas de processos psicológicos enraizados na cultura. (VIGOTSKI, 1994, p.54)

Para Vigotski a atividade mediada se faz pelo uso de instrumentos e signos, mas também, como menciona DANIELS (2003) citando KOZULIN ${ }^{5}$ (1998), ela inclui também os indivíduos como meio mediacional, o que coloca em evidência as relações interpessoais no processo de mediação.

Ao utilizar-se do conceito mediação Vigotski se inspirou nas ideias desenvolvidas por Hegel e Marx. Para Marx a sociedade humana se estrutura com funções específicas e habilidades, como resultado do trabalho (REGO, 1995). Para que possa realizar sua atividade o homem fabrica os instrumentos necessários e estabelece relações com o outro, criando assim, os meios de trabalho. As relações estabelecidas tanto entre os homens, como entre eles e a natureza, são mediadas pelo trabalho.

Com base nessa concepção marxista Vigotski tratou o processo de mediação na atividade humana, realizado pelos instrumentos e signos, sendo o primeiro direcionado para as ações concretas e o segundo para as atividades psíquicas. O uso da mediação, a elaboração de instrumentos, os signos e a transmissão destes para as gerações posteriores é algo característico do humano, é produto do desenvolvimento social, como aborda o autor:

Desde os primeiros dias do desenvolvimento da criança, suas atividades adquirem um significado próprio num sistema de comportamento social e,

5 Kozulin, A. Psychological Tools. A Sociocultural Approach to Education. Londres, Harvard University Press, 1998. 
sendo dirigidas a objetivos definidos, são refratadas através do prisma do ambiente da criança. O caminho do objeto até a criança e desta até o objeto passa através de outra pessoa. Essa estrutura humana complexa é o produto de um processo de desenvolvimento profundamente enraizado nas ligações entre história individual e história social. (Vigotski, 2010, p.40)

Os instrumentos e signos mesmo com o papel análogo de função mediadora, se distinguem nas operações que intermedeiam. Os instrumentos auxiliam na relação entre a atividade do homem e o objeto externo, transformando esse objeto, como coloca Vigotski (1994) "constitui um meio pelo qual a atividade humana externa é dirigida para o controle e domínio da natureza" (p.73). Os signos, segundo Vigotski (op. cit.), “não modificam o objeto da operação psicológica" (p.73), são auxiliares para a solução de tarefas psicológicas, se direcionam internamente ao comportamento do sujeito transformando esse sujeito. $\mathrm{O}$ trecho abaixo, pode explicitar um pouco mais a ideia do autor:

O uso de meios artificiais - a transição para a atividade mediada - muda, fundamentalmente, todas as operações psicológicas, assim como o uso de instrumentos amplia de forma ilimitada a gama de atividades em cujo interior as novas funções psicológicas podem operar. Nesse contexto, podemos usar o termo função psicológica superior, ou comportamento superior com referência à combinação entre o instrumento e o signo na atividade psicológica. (op. cit., p.73)

Vigotski (op. cit.) diz que o comportamento em sua forma elementar estabelece uma reação direta, que pode ser representada por: estímulo $\rightarrow$ resposta, porém na operação com instrumentos e signos necessita-se de uma intermediação, que se dá pela relação que este estabelece entre o estímulo e a resposta, tem-se então uma relação mediada. O indivíduo participa da ligação que é estabelecida de forma ativa, o signo age sobre o indivíduo e não sobre o ambiente, sendo essa ação reversa (BRAGA, 2010a).

$\mathrm{O}$ esquema, apresentado na Fig.1, representa a ação mediada ( $\mathrm{S}=$ sujeito, $\mathrm{O}=$ =bjeto e $\mathrm{Z}=$ função mediadora $\leftrightarrow$ instrumento ou signo).

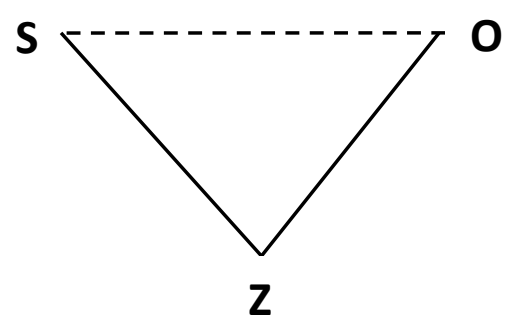

Figura 1: Representação da relação entre sujeito e objeto feita pela mediação, por instrumentos ou signos, baseado em Pino (2001). 
Tratando do uso de signos como mediadores, Vigotski (1994) coloca que esses estão direcionados ao interno, modificam o desenvolvimento e a estrutura das funções psíquicas e ao mesmo tempo também modificam o sujeito, possibilitando o autodomínio do comportamento. Assim:

Na medida em que esse estímulo auxiliar possui a função específica de ação reversa, ele confere a operação psicológica formas qualitativamente novas e superiores, permitindo aos seres humanos, com o auxílio de estímulos extrínsecos, controlar o seu próprio comportamento. O uso de signos conduz os seres humanos a uma estrutura específica de comportamento que se destaca do desenvolvimento biológico e cria novas formas de processos psicológicos enraizados na cultura. (p.54, grifos do autor)

As mudanças no comportamento humano por meio da mediação dos signos são profundas, transformando o espontâneo em volitivo como podemos perceber mais claramente no excerto abaixo, de Martins (2011).

Para Vygotski (1997), o ato instrumental introduz profundas mudanças no comportamento humano, posto que entre a resposta da pessoa e o estímulo do ambiente se interpõe o novo elemento designado signo. O signo, então, opera como um estímulo de segunda ordem que, retroagindo sobre as funções psíquicas, transforma suas expressões espontâneas em expressões volitivas. As operações que atendem aos estímulos de segunda ordem conferem novos atributos às funções psíquicas, e por meio deles o psiquismo humano adquire um funcionamento qualitativamente superior e liberto tanto dos determinismos biológicos quanto do contexto imediato de ação (p.40).

A mediação proposta por Vigotski não representa apenas um meio de ligação entre o sujeito e o objeto, mas como coloca Martins (2001), é um processo no qual um de um objeto age sobre outro objeto tendo em vista o objetivo da atividade que está em questão. Tal processo provoca transformações intencionais, que são construídas socialmente e promove desenvolvimento, o que segundo a mesma autora, é "uma condição externa que, internalizada, potencializa o ato de trabalho, seja ele prático ou teórico" (p.42).

Desta forma, Martins (2001.) sintetiza a mediação com instrumentos e signos proposta por Vigotski, dizendo que:

(...) da mesma maneira que o instrumento técnico modifica o processo de adaptação natural determinando as formas de operações de trabalho, isto é, o domínio da natureza, o uso dos instrumentos psicológicos modifica radicalmente o desenvolvimento e a estrutura das funções psíquicas, 
reconstituindo suas propriedades e possibilitando o autodomínio do comportamento. Eis, pois, para Vigotski, o nexo psicológico real entre o emprego de ferramentas e de signos no curso filo e ontogenético do desenvolvimento humano.

Se pelo trabalho o homem colocou a natureza sob seu domínio, ele, pelo ato instrumental (pelo emprego de signos), dominou a si mesmo, condição requerida à própria atividade laboral. Portanto, esses processos são reciprocamente condicionados e demonstram, ainda que por linhas genéticas diferentes, as vias concretas pelas quais o ser humano ultrapassou os limites de um tipo de atividade circunscrito pelo sistema orgânico, inaugurando as possibilidades sociais de seu desenvolvimento. (p.42)

O psiquismo humano é construído socialmente e os indivíduos se apropriam do conhecimento, das produções culturais no decurso da história pela mediação social. Essa mediação é a intervenção indireta que estabelecemos com o mundo físico e social (BRAGA, 2010a; DAVIS, 2005). Sendo os mecanismos de mediação muito variados, podendo ser a relação entre indivíduos de mesma idade, com o adulto e a criança, ou também essa intervenção pode ser feita por instrumentos ou signos como já mencionados anteriormente. Para Vigotski, como diz Braga (2010a), "a mediação é a marca da consciência humana”, o que Heermann (2011) corrobora apontando que as funções psicológicas superiores se modificam pela mediação:

[...] a consciência não existe situada dentro da cabeça do indivíduo, mas na interação que este realiza por meio da atividade material, na interação entre os indivíduos e as formas objetivas de cultura criadas pelo trabalho humano. (...) Em outras palavras, conforme Vygotsky, as funções mentais superiores modificam conforme as interações sociais e culturais do indivíduo com o ambiente por meio de ferramentas (p.31).

Vigotski coloca que as crianças ao se desenvolverem, ao longo de sua vida, vão estabelecendo relações sociais diferentes, no que o papel do adulto neste processo é importante para o estabelecimento de mediações culturais. Esse é um processo dialético onde a criança se desenvolve, mas o adulto a desenvolve também, como afirma Daniels (2003). Assim, o sujeito vai se construindo nas tensões que estabelece com o outro e com a realidade (BRAGA, 2010b), em um processo que é do ser humano, como coloca Davis (2005):

(...) o ser humano, para sobreviver e ser, constrói uma realidade humana e, nesse processo constrói também a si mesmo. É, portanto, na e pela interação com outros sujeitos humanos, na atividade humana, que formas de pensar são construídas ou transformadas, por sua vez transformando também o entorno. Pode-se dizer, portanto, que é pela apropriação e internalização do saber e do fazer da comunidade em que o sujeito se insere que ele se 
constitui enquanto tal e, ao ser assim constituído, constitui também sua comunidade. (p.44)

A mediação traz um elemento importante à teoria que permite perceber as relações do indivíduo com o mundo que o cerca e principalmente, com os outros indivíduos, indicando que isto não se faz de forma direta, mas por mediadores simbólicos. Nessas relações, o sujeito se constitui em sua realidade, sempre em movimentos de apropriação e internalização (SMOLKA, 2000).

\subsubsection{Linguagem como função mediadora}

Nas relações entre os indivíduos a linguagem surge como o mediador na formação e desenvolvimento das funções psíquicas, associada à função de comunicação, que permite a transmissão, assimilação e preservação dos bens culturais acumulados ao longo da história (REGO, 1995). A linguagem constitui um sistema de signos que é compartilhado pelos indivíduos em um contexto social, que é um sistema de representação da realidade, no qual as palavras adquirem significados que lhe são específicos. O excerto a seguir, de Lucci (2006), pode sintetizar o papel da linguagem como função mediadora:

[...] a linguagem constitui o sistema de mediação simbólica que funciona como instrumento de comunicação, planejamento e auto-regulação. É justamente pela sua função comunicativa que o indivíduo se apropria do mundo externo, pois é pela comunicação estabelecida na interação que ocorrem "negociações", reinterpretações das informações, dos conceitos e significados. (p. 9)

Pela linguagem o homem se apropria do mundo exterior, sendo que seu desenvolvimento está ligado à necessidade de comunicação e generalização. Como disse Vigotski (1994), para as crianças a linguagem as auxilia na resolução de problemas, o que seria mais difícil sem o uso dela, ou seja, ajuda a planejarem a solução antes de uma execução, não agindo de forma impulsiva para resolvê-lo.

A linguagem exerce ação de controle do próprio comportamento da criança. Mas, como pontua Vigotski (op. cit.), os signos e as palavras significam antes para as crianças um meio de contato social com as pessoas. Sendo assim, ele apontou que "as funções cognitivas e comunicativas da linguagem tornam-se, então, a base de uma forma nova e superior de 
atividade nas crianças, distinguindo-as dos animais" (p.38). Ainda, de acordo com Vigotski (op. cit.), temos que:

[...] a linguagem materializa e constitui as significações construídas no processo social e histórico. Quando os indivíduos a interiorizam, passam a ter acesso a estas significações que, por sua vez, servirão de base para que possam significar suas experiências, e serão estas significações resultantes que constituirão suas consciências, mediando, desse modo, suas formas de sentir, pensar e agir (Ibid., p.38).

Dessa forma, a linguagem surge no desenvolvimento da criança, como meio para estabelecer a comunicação entre ela e o outro, em suas atividades sociais, como funções interpsíquicas. Depois de internalizada, linguagem interna, transforma-se em função mental interna, a qual viabiliza os meios para o pensamento da criança, como funções intrapsíquicas Vigotski (1994).

Nesse processo de internalização tem origem a consciência humana, cuja natureza é social e é concebida como uma função psicológica superior, pois é uma forma de apreender o real, mas ao longo de seu desenvolvimento histórico. Isso articula linguagem e pensamento que é postulado por Vigotiski (op. cit.)

A articulação entre linguagem e pensamento permite a construção de conceitos, como discute Vigotski, mas suas origens são diferentes. No entanto, no percurso do desenvolvimento do indivíduo pensamento e linguagem estabelecem uma relação dialética, assim Davis (2005) coloca que:

A linguagem permite a construção de conceitos - elementos centrais do pensamento - e a construção deste último adquire, consequentemente, uma formulação linguística, de modo que a linguagem se converte em ferramenta do pensamento. Dessa forma, pensamento e linguagem, a despeito de terem origens genéticas distintas, acabam por se fundir, dialeticamente, ao longo do desenvolvimento: linguagem converte-se em pensamento e pensamento em linguagem. (p.46)

O papel da linguagem ainda em relação à formação de conceitos, Oliveira (1992) explica que:

A utilização da linguagem favorece, assim, processos de abstração e generalização. Os atributos relevantes têm de ser abstraídos da totalidade da experiência [...] e a presença de um mesmo conjunto de atributos relevantes permite a aplicação de um mesmo nome para objetos diversos [...]. As palavras, portanto, como signos mediadores na relação do homem com o mundo são, em si, generalizações: cada palavra refere-se a uma classe de 
objetos, consistindo num signo, numa forma de representação dessa categoria de objetos, desse conceito. (p.28)

As linguagens são signos mediadores das relações entre os homens, em seu meio, que permitem que estabeleçam relações recíprocas e desenvolvam as funções psicológicas superiores, com isso, influenciando o comportamento, em processos de abstração e generalização da realidade.

\subsection{Teoria da Atividade}

$\mathrm{O}$ conceito de atividade surge nos anos vinte do século XX, sendo fundamental para o desenvolvimento da Teoria da Atividade (CEDRO, 2008, HEERMANN, 2011). A teoria teve sua origem nos estudos do grupo de Vigotski, porém, foi desenvolvida por Lenontiev, outros nomes também estão ligados à ela, mas o de Leontiev tem significado importante por concebê-la desde o princípio. Esta abordagem teórica também chamada de Teoria HistóricoCultural da Atividade teve como as concepções da psicologia histórico-cultural, forte referencial no materialismo dialético.

A mediação proposta por Vigotski é de grande importância uma vez que traz as ideias iniciais para a teoria da atividade. Sob esse aspecto, a mediação estabelece as bases para o estudo da consciência humana, sendo no processo de internalização da atividade pelo indivíduo que ocorre essa mediação. A linguagem como um mediador diferencial, os signos adquirem significado e sentido (LIBÂNEO e FREITAS, 2006), atuando no controle da conduta e na constituição do sujeito. Martins (2011) também aponta o elo entre a teoria histórico-cultural e a atividade humana, estabelecendo assim, sua relação com o psiquismo:

(...) a teoria histórico-cultural, em consonância com o aporte filosófico materialista dialético, postula o psiquismo humano como unidade material e ideal construída filo e ontologicamente por meio da atividade, isto é, nos modos e meios pelos quais o homem se relaciona com a realidade, tendo em vista produzir as condições de sua sobrevivência e a de seus descendentes. Graças a essa unidade, o psiquismo firma-se como imagem subjetiva do real (p.29).

Nessa concepção, a atividade humana é considerada mediadora entre o homem, os objetos e fenômenos do mundo. Assim, o homem atua em seu meio social e cultural e o transforma, com isso transforma a si mesmo. 
Desta forma, a Teoria da Atividade agrega as bases da Teoria Histórico-Cultural, ela traz as contribuições dos estudos de Leontiev e outros seguidores. Embora cada uma delas tenha suas particularidades, ambas pensaram no homem histórico, em seu contexto social e em suas relações com o meio, atuando no mundo para apreender sua herança cultural, transformá-lo e assim também se transforma. Essa teoria tem como foco a atividade para explicar o desenvolvimento do psiquismo humano, como explicita Libâneo e Freitas (2006), ela se apoia nas ideias do marxismo, dado que Leontiev tinha seus estudos embasados nessas concepções, assim os autores colocam que:

No cerne da teoria da atividade está a concepção marxista da natureza histórico-social do ser humano explicada nas seguintes premissas: 1) a atividade representa a ação humana que mediatiza a relação entre o homem, sujeito da atividade, e os objetos da realidade, dando a configuração da natureza humana; 2) o desenvolvimento da atividade psíquica, isto é dos processos psicológicos superiores, tem sua origem nas relações sociais do indivíduo em seu contexto social e cultural (op. cit., 2006).

Leontiev (1978) discute o conceito de trabalho, pois este assume papel importante em seus estudos, como propõe citando Marx ${ }^{6}$ : "o trabalho é primeiramente um ato que se passa entre o homem e a natureza". Leontiev acrescenta, que o trabalho se caracteriza por dois elementos que são independentes, um deles é a construção de instrumentos, o segundo se dá em atividade coletiva, para o que diz ser pelo "intermédio de outros homens que o homem se encontra em relação com a natureza".

O trabalho é, portanto, desde a origem, um processo mediatizado simultaneamente pelo instrumento (em sentido lato) e pela sociedade. (op. cit., p.74)

O instrumento é o produto da cultura, um objeto social no qual estão fixadas as operações de trabalho historicamente elaboradas. [...] A apropriação dos instrumentos pelo homem requer a reorganização dos movimentos naturais e a formação de faculdades superiores. [...] $\mathrm{O}$ que se aplica também aos fenômenos da cultura intelectual (aquisição da linguagem) (op. cit., p.268269).

Esta visão coloca-nos a transmissão das aquisições humanas através das gerações pela inserção cultural, ao lado da capacidade criadora e produtiva que se faz pelo trabalho, o qual é considerado como a atividade humana fundamental (LEONTIEV, 1978).

6 K.Marx: O Capital, Livro I, t.I, Ed. Sociales, p.180, citado em Leontiev (1978). 
O trabalho está ligado ao desenvolvimento cultural do homem, que busca não apenas satisfazer suas necessidades biológicas, mas também aquelas ligadas à cultura, o que faz com que o homem se relacione com a natureza num processo de transformação mútua, como coloca Rigon, Asbahr e Moretti (2010a):

Ao agir intencionalmente sobre a natureza, visando transformá-la de modo a satisfazer suas necessidades, produzindo o que deseja e quando deseja, o homem, ao mesmo tempo que deixa sobre a natureza as marcas da atividade humana, também transforma a si próprio constituindo-se humano (Ibid., p.17).

As características próprias do humano, suas aptidões, não são transmitidas pela hereditariedade, mas são adquiridas no decorrer da vida pela apropriação que o homem faz da cultura das gerações que o precederam, pois, o homem não nasce com essas aquisições construídas pela humanidade em seu percurso histórico, como discute Leontiev (1978):

Cada geração começa, portanto, sua vida, num mundo de objetos e de fenômenos criado pelas gerações precedentes. Ela apropria-se das riquezas deste mundo participando no trabalho, na produção e nas diversas formas de atividade social e desenvolvendo assim as aptidões especificamente humanas que se cristalizam, encarnam nesse mundo. [...] mesmo o pensamento e o saber de uma geração formam-se a partir da apropriação dos resultados da atividade cognitiva das gerações precedentes (p.266).

O trabalho como atividade humana é o ponto crucial para Leontiev (1978) estruturar sua teoria, trazendo para o estudo do psiquismo o conceito de atividade com base na ação humana, na relação do homem com o mundo e no contexto sócio-cultural do indivíduo. Desta forma, ele coloca que:

Pela sua atividade, os homens não fazem senão adaptar-se à natureza. Eles modificam-na em função do desenvolvimento de suas necessidades. Criam os objetos que devem satisfazer as suas necessidades e igualmente os meios de produção destes objetos, dos instrumentos às máquinas mais complexas. Constroem habitações, produzem suas roupas e outros bens materiais. Os progressos realizados na produção de bens materiais são acompanhados pelo desenvolvimento da cultura dos homens; o seu conhecimento do mundo circundante e deles mesmos enriquece-se, desenvolve-se a ciência e a arte (Ibid., p.265).

Conforme explicita Martins (2011), "o desenvolvimento do trabalho exigiu, e continua a exigir, profundas transformações nas características dos homens" (p.43), assim, o trabalho como atividade coletiva, portanto social, tem como resultado ao longo da história, uma 
progressiva complexificação nas relações interpessoais e interpsíquicas do ser humano, isso faz com que este conquiste graus cada vez mais elevados de autocontrole do comportamento.

A complexificação do trabalho leva às formas culturais altamente elaboradas de vida em sociedade, que estão ligadas a uma forma superior de psiquismo, pela formação da consciência, que é comentado por Martins (op. cit.)

Esse tipo superior de psiquismo, postulado tanto por Vigotski quanto por Leontiev, não se institui por desdobramentos naturais do ser orgânico. Tal desdobramento dá origem ao psiquismo dos animais e do homem primitivo. Todavia, a história real do desenvolvimento do psiquismo humano reflete a história da complexificação da vida em sociedade. Evidente, portanto, que o psiquismo humano só possa ser explicado na qualidade de construção social (Ibid., p.43).

A ideia de atividade está ligada a um processo desencadeado no indivíduo por uma necessidade, quer o indivíduo desempenhe ações individuais ou coletivas. Leontiev (1978) coloca que a atividade estabelece relação com o contexto social, não se exclui o lado biológico, mas a sua concepção fundada no trabalho leva a constituição de uma consciência social. Ele argumenta que:

[...] é o mundo de objetos e de fenômenos que rodeiam o homem, criado pelo trabalho e pela luta de inumeráveis gerações humanas. É este mundo que fornece ao homem o que ele tem de verdadeiramente humano. Se, portanto, distinguimos nos processos psíquicos superiores do homem, por um lado, a sua forma, as particularidades puramente dinâmicas que dependem da sua "factura" morfológica e, por outro, o seu conteúdo, isto é, a função que eles exercem e a sua estrutura, então podemos afirmar que o primeiro elemento é determinado biologicamente e o segundo socialmente. Será preciso sublinhar que o aspecto decisivo é o conteúdo? (p.257)

Leontiev (1978) aponta que no psiquismo humano, a passagem à consciência tem seu suporte nas formas humanas de vida e na atividade do trabalho, não estando ligado somente à transformação na estrutura da atividade e ao surgimento de novos reflexos na realidade. Não se liberta dos traços comuns aos estádios do psiquismo animal ou se reveste de traços qualitativamente novos, porém:

(...) o essencial, quando de passagem à humanidade, está na modificação das leis que presidem ao desenvolvimento do psiquismo. No mundo animal, as leis gerais que governam as leis do desenvolvimento psíquico são as da evolução biológica; quando se chega ao homem, o psiquismo submete-se às leis do desenvolvimento sócio-histórico (op. cit., p.68). 
Nesta teoria o psiquismo se manifesta na atividade, que está ligada à realidade objetiva e à consciência, associada a uma realidade subjetiva, na construção da imagem. Tal concepção tem influência no trabalho, definido por Marx como atividade tipicamente humana, dirigida a um fim, que de maneira dialética forma a consciência e é regulada por ela, como explicita Martins (2011, p. 28-29):

\begin{abstract}
Afirmar unidade entre atividade e consciência implica conceber o psiquismo humano como um processo no qual a atividade condiciona a formação da consciência e esta, por sua vez, a regula. Marx, ao propor o conceito de práxis, foi pioneiro na integração entre ação e conhecimento, prática e teoria, tendo no trabalho a atividade intrinsecamente ideacionada pela qual o homem se torna humano. A práxis diferencia-se de outras formas de atividade na medida em que sintetiza matéria e ideia, desenvolvendo-se no atendimento a dadas finalidades que, por sua vez, só existem como produtos da consciência (p. 28-29).
\end{abstract}

Leontiev (1978, 2006) estudou também como a atividade está ligada ao desenvolvimento do psiquismo da criança e diz que a criança depende das pessoas que a cercam. Quando as crianças são bem pequenas dependem das pessoas mais próximas, sendo que as relações com esta determinam as relações com o mundo exterior. Durante seu desenvolvimento, o lugar que ocupa no sistema das relações humanas se altera, pois à medida que a criança atribui ao que sabe um novo significado, seu caráter psíquico se modificará e todo o seu sistema de relações será reorganizado. A mudança do lugar ocupado pela criança no sistema das relações sociais é o primeiro ponto para o estudo do desenvolvimento de sua psique; cujo desenvolvimento depende das condições reais de vida desta criança (LEONTIEV, 2006).

Os estágios do desenvolvimento psíquico caracterizam-se por uma relação explícita entre a criança e a realidade principal, naquele estágio, e por uma atividade específica e dominante. A transição de um estágio para o outro se dá pela mudança na atividade principal, na relação dominante da criança com a realidade. Leontiev (op. cit.), explica que: "a atividade que desempenhava o papel principal começa a se desprender e a passar para um segundo plano. Uma nova atividade principal surge, e com ela começa também um novo estágio de desenvolvimento". (p.82).

As relações que se estabelecem entre a criança e o mundo circundante são relações sociais, pois é a sociedade que constitui sua condição real de vida, que determina tanto o conteúdo como sua motivação. Assim, cada atividade da criança, não expressa, simplesmente, 
sua relação com a realidade objetiva, mas as relações sociais que estão explícitas e implícitas nessas atividades (op. cit.).

O desenvolvimento da consciência da criança tem ligação com a mudança na motivação de sua atividade (op. cit.). Ao analisar as "forças motivadoras" do desenvolvimento da criança, Leontiev diz que isto leva às formas principais de sua atividade, ao sentido que ela atribui aos objetos e aos fenômenos do mundo circundante e vai se apropriando das aquisições humanas. $\mathrm{O}$ autor comenta no excerto abaixo, como o homem vai adquirindo as características do humano.

O homem não nasce dotado das aquisições históricas da humanidade. Resultando estas do desenvolvimento das gerações humanas, não são incorporadas nem nele, nem nas suas disposições naturais, mas no mundo que o rodeia, nas grandes obras da cultura humana. Só apropriando-se delas no decurso de sua vida ele adquiri propriedades e faculdades verdadeiramente humanas (LEONTIEV, 1978, p.282).

Daniels (2003) coloca que os estudiosos da teoria da atividade analisam o desenvolvimento da consciência como "atividade social prática", que carrega relação com práxis da teoria histórico-dialética. Pelos trabalhos de Vigotiski a teoria da atividade tem na mediação um conceito fundamental.

O mesmo autor (op. cit.) cita Kozulin ${ }^{7}$ (1996) ao mencionar que Leontiev continua com o foco nas atividades, ações humanas, que são levadas à interiorização, com a formação de processos mentais internos

Neste processo de relações sociais que se estabelece a atividade humana, Leontiev (1978) diz, citando $\operatorname{Marx}^{8}$, que "na produção os homens não agem apenas sobre a natureza" (p. 75), mas ao produzirem trocam entre si suas atividades, promovendo relações sociais que estabelecem a sua ação sobre a natureza. Leontiev aponta que pode-se compreender este processo para o psiquismo humano quando se olha a atividade se realizando em trabalho coletivo, no qual há a divisão de funções direcionadas a um mesmo fim.

A atividade humana está inserida no sistema de relações da sociedade. O sujeito realiza atividades em um processo contínuo de interação com o meio social. A atividade está estreitamente ligada aos papéis vividos em sociedade, pois tal atividade é o que consolidará o

7 KOZULIN, A. The concept of activity in Soviet Psychology: Vygotsky, his disciples and critics. American Psychologist, 1996, p.264-274.

8 K. Marx: A Nova Gazeta Renana, t,III, Ed. Sociales, p.237, citado em Leontiev (1978). 
sujeito no meio social em que está inserido. A distinção entre as atividades está em seu objeto, sendo que cada atividade possui uma estrutura geral (CEDRO, 2008).

\subsubsection{Atividade, ação e operação}

O homem, de forma diferente dos animais, precisa produzir os meios para satisfazer suas necessidades, a atividade se relaciona com a necessidade, assim seu caráter é mediatizado, pois, Leontiev (1978) enfatiza a mediação entre os indivíduos e as relações sociais que se estabelecem. A relação entre a mediação e o processo de satisfazer as necessidades nas interações humanas com o meio, é destacada por Torriglia e Cisne (2012):

\footnotetext{
Nesse processo de buscar a satisfação de suas necessidades e a produção de sua existência através do trabalho o ser humano lida com dois elementos interdependentes, segundo Leontiev (1978), a fabricação de instrumentos e sua efetuação coletiva, "de modo que o homem no seio deste processo não entra apenas numa relação determinada com a natureza, mas com outros homens, membros de dada sociedade" (LEONTIEV, 1978, p.74). Assim, tanto a fabricação de instrumentos como a relação estabelecida entre os membros do grupo social e a linguagem vão ganhando existência objetiva (p.5).
}

Leontiev (2006) diz que os animais respondem as necessidades puramente biológicas, assim o objeto de sua atividade se confunde com seu motivo biológico, há uma relação imediata entre motivo da atividade e o objeto da atividade (TORRIGLIA e CISNE, 2012). Isto pode ocorre de forma diferente para o ser humano, "não há uma relação imediata entre o motivo e o objeto da atividade, esta é sempre mediada, a atividade não pode ser examinada desgarrada das relações sociais, da vida em sociedade" (p.5).

Leontiev (op. cit.) explicita, que nem todos os processos podem ser considerados atividade, esta se apresenta segundo as delimitações que ele nos coloca:

Não chamamos todos os processos de atividade. Por esse termo designamos apenas aqueles processos que, realizando as relações do homem com o mundo, satisfazem uma necessidade especial correspondente a ele. (...) Por atividade, designamos os processos psicologicamente caracterizados por aquilo a que o processo, como um todo, se dirige (seu objeto), coincidindo sempre com o objetivo que estimula o sujeito a executar esta atividade, isto é, o motivo (p.68). 
No caso do homem, a atividade tem vínculos sociais, trazendo o modo como a sociedade se organiza e produz. Assim, mesmo sendo individual ela se insere em um contexto social, isolada ela não existe. Como destacam Torriglia e Cisne (2012), a ação de um indivíduo ganha "sentido porque existe uma ligação entre a sua ação e as ações de outros homens, que conferem sentido a sua própria ação. Apenas como parte deste grupo social é que a ação individual ganha sentido racional" (p.5).

O que distingue as atividades é seu objeto, é o que lhe confere uma dada direção. $\mathrm{O}$ objeto da atividade é seu motivo real, que pode ter existência real ou mental, assim a atividade não pode existir sem um motivo (LEONTIEV, 1983, p.83). Uma determinada atividade corresponde a uma necessidade do sujeito, ela tende para o objeto desta necessidade, quando esta é satisfeita, a atividade desaparece. Quando a atividade se configura novamente, não se reproduz, pois as condições já não são as mesmas, se modificaram, a atividade é outra (LEONTIEV, 1978). Leontiev (2006) esclarece também que as emoções e sentimentos são experiências que estão ligadas à atividade

As ações pelas quais as atividades se realizam, são componentes fundamentais da mesma, a qual Leontiev (1983) define como:

Denominamos ação ao processo que se subordina a representação daquele resultado a ser alcançado, isto é, o processo subordinado a um objetivo consciente. Do mesmo modo que o conceito de motivo se relaciona com o conceito de atividade, assim também o conceito de objetivo se relaciona com o conceito de ação (p.83, tradução nossa).

Martins (2004) também explicita a definição de ações no contexto da Teoria da Atividade, estabelecendo as conexões a atividade, motivo, ação e objetivo. Ela coloca que:

As ações são componentes da atividade, são processos subordinados à representação do objetivo final a ser alcançado pela atividade e orientadas por seus fins específicos. Graças à complexidade histórica da atividade, esta pode ser decomposta em ações, cujos resultados imediatos não necessariamente coincidem com o motivo da atividade. Isto possibilita a inexistência de coincidência entre o fim específico da ação e o resultado final da atividade. Falamos, portanto, de ação quando o motivo que a subordina não é dado nela mesma, mas na atividade da qual ela é parte integrante. (p.87)

Bizerra (2009), desta que: "uma atividade constitui-se de um conjunto de ações, as ações pertencem à atividade, mas não entendendo como sendo a atividade uma somatória delas" (p.67). 
Os meios pelos quais as ações são desenvolvidas foram chamados de operações, uma ação pode ser desempenhada por várias operações e também uma mesma operação pode pertencer a diferentes ações. As operações são automatizadas, inconscientes, elas consistem em rotinas habituais que são realizadas pelo indivíduo, quando uma ação se automatiza ela se torna uma operação.

A atividade, as ações e operações são componentes de uma estrutura de atividade, precisam ser estudadas em conjunto para que se compreenda suas relações, as quais podem trazer transformações no desenvolvimento da atividade, a Figura 2 mostra uma representação desses componentes.

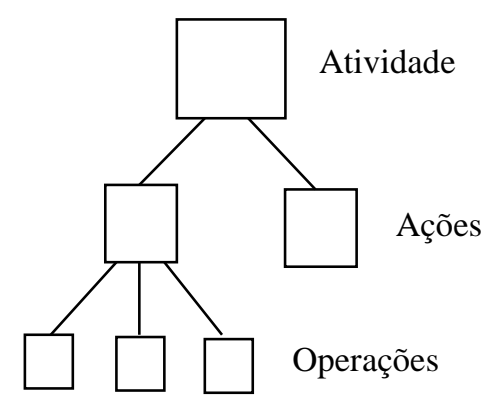

Figura 2: Componentes de uma atividade, modelo apresentado por Leontiev (2004, apud BARBOSA et al, 2011).

A atividade se relaciona com o objeto/motivo, as ações com a meta e as operações com as condições, assim se tem uma estrutura hierárquica da atividade segundo Leontiev, apresentada em Daniels (2003, p.116), que está indicada na Figura 3.

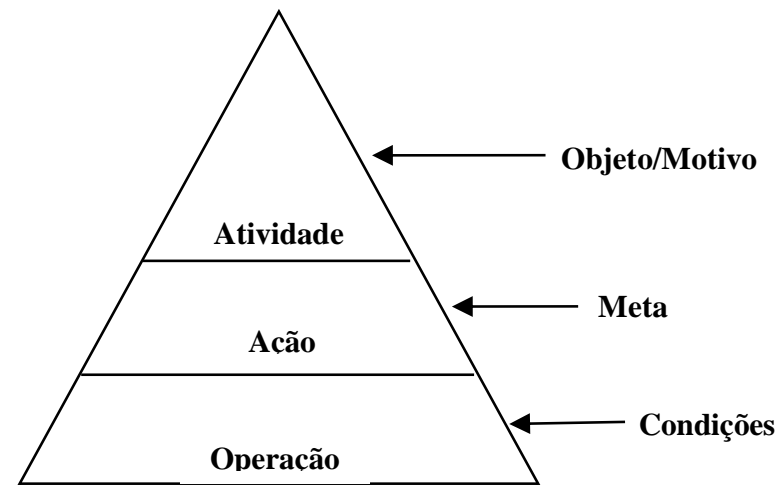

Figura 3: Estrrutura hierárquica da atividade (DANIELS,2003) 
Leontiev (1978) coloca que em uma atividade complexa há a separação em diferentes operações para satisfazer uma necessidade, na atividade coletiva as ações de cada indivíduo estão direcionadas a um objetivo. Desta forma, ao olhar a ação de um indivíduo, que faz parte de um grupo, não se tem a relação direta com seu motivo, mas esta ação faz parte do processo global do trabalho coletivo, no qual está presente o motivo da atividade coletiva. Assim, ao focar o processo todo pode-se compreender as ações individuais e a função delas naquele trabalho coletivo.

Para esclarecer como as ações precisam ser compreendidas no contexto da atividade e a importância da atividade coletiva no processo do humano, Leontiev (1978) apresentou uma caçada como exemplo (p.76). A caçada representa uma atividade coletiva, na qual há indivíduos que exercem a ação de batedores (espantam a caça) e outros de caçadores. Embora, com funções diferenciadas, todos têm suas ações dirigidas para um objetivo comum, o motivo da caçada, que é o de conseguir comida e vestimentas, portanto precisarão abater a caça. No entanto, se a ação do batedor for observada independente da atividade, ela poderá parecer desconexa, pois estará espantando a caça. Mas ela só será compreendida no contexto da atividade social, coletiva, que é a caçada em seu processo todo, na caçada esta função leva a caça na direção dos caçadores, o que cumpre com o objetivo da atividade.

Leontiev (1978) ressalta que a relação estabelecida entre o motivo da atividade e o objeto da ação é social e a necessidade de se ter consciência disto, pois caso contrário, não perceberemos o papel que desempenhamos na atividade e esta não terá nenhum sentido para nós. Assim, ele coloca:

Isto significa que é precisamente a atividade de outros homens que constitui a base material objetiva da estrutura específica da atividade do indivíduo humano; historicamente, pelo seu modo de aparição, a ligação entre o motivo e o objeto de uma ação não reflete relações e ligações naturais, mas ligações e relações objetivas sociais. Assim, a atividade complexa dos animais superiores, submetida a relações naturais entre coisas, transforma-se, no homem, numa atividade submetida a relações sociais desde a sua origem. Esta é a causa imediata que dá origem à forma especificamente humana do reflexo da realidade, a consciência humana. A decomposição de uma ação supõe que o sujeito que age tem possibilidade de refletir psiquicamente a relação que existe entre o motivo objetivo da ação e o seu objeto. Senão, a ação é impossível, é vazia de sentido para o sujeito (p.78-79).

A partir desta concepção, entende-se que mesmo uma atividade "individual", focada somente na atividade de um indivíduo, as ações que realiza estão ligadas às relações sociais estabelecidas com outros indivíduos, assim, não há um sistema isolado. Desta forma, é 
preciso observar o processo como um todo, para então, poder compreender o motivo da atividade, o seu objeto, pois pelo objetivo da ação podemos não percebê-lo.

Isso faz com que olhemos para as atividades como coletivas. Assim, a atividade humana tem caráter intencional, pois ela é planejada, criada pelo homem, ocorre em uma relação social, se insere na cultura e se dá em um processo histórico.

\subsubsection{Engeström e a Teoria da Atividade}

Engeström em seus estudos trouxe contribuições à teoria da atividade, colocando as relações estabelecidas com as instituições, a comunidade, as regras existentes e a divisão de trabalho. Esse autor discute a teoria dividindo-a em três gerações, que como coloca Daniels elas se desenvolvem em seis décadas, contadas após a morte de Vigotski.

Na primeira geração Engeström (1999), Heemann (2011) utilizou a concepção de mediação dada por Vigotski, relacionando, pelo uso de ferramentas, os sujeitos ao motivo e aos resultados obtidos. Assim, a representação feita por Vigotski sobre o processo mediado foi adaptada por Engeström para teoria da atividade da primeira geração, a qual é apresentada na Figura 4. Nesse período, segundo o autor, o foco estava nos indivíduos, era baseada nas concepções de Vigotski, na mediação que relacionou os artefatos culturais às ações humanas, porém não se baseavam nas estruturas sociais agindo na própria atividade.

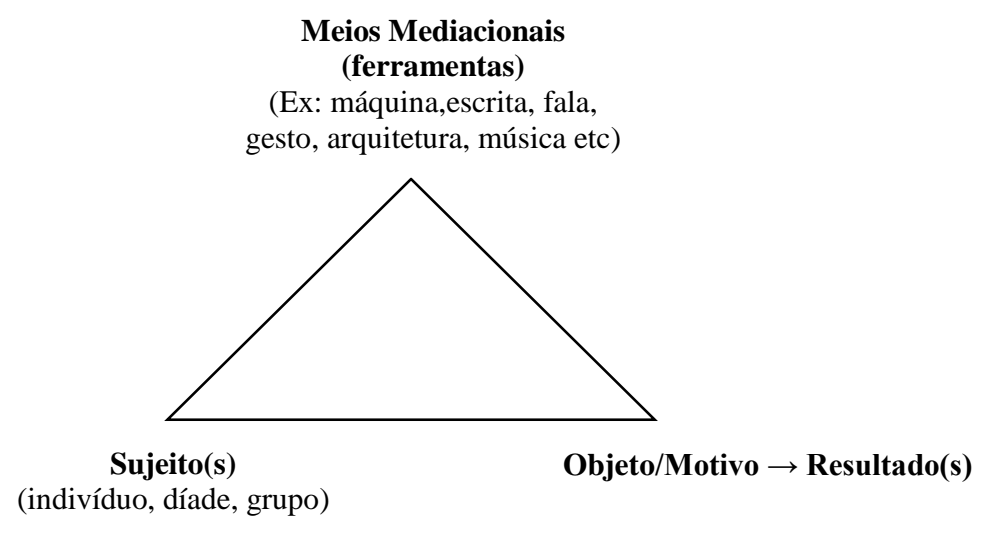

Figura 4: Modelo da teoria da atividade da primeira geração. Fonte: Daniels (2003, p.114) 
Leontiev desmembrou o conceito de atividade discutido por Vigotski e expandiu a proposta incluindo as ações e operações. Desta forma, trouxe a noção de objeto e meta, sendo que o que diferenciava uma atividade de outra eram seus objetos e, a transformação deste objeto/meta é que possibilitava a integração do sistema de atividade (DANIELS, 2003). Ele propõe uma hierarquia: atividade, ação e operação (Figura 3, item 3.2.1). Este sistema hierárquico não é rígido, é uma estrutura fluida, no entanto, como comenta Daniels (op. cit.), "houve pouca tentativa de situar a atividade em regras e estruturas do mundo social (p.117)". Leontiev considera o motivo como ato físico, sendo a atividade impulsionada pelos objetivos, considerava que a atividade poderia ser coletiva, mas as metas seriam individuais.

Engeström propôs que o foco da mediação deva estar na relação com outros componentes do sistema de atividade, além dos artefatos, embora considere estes como integrantes e inseparáveis do "funcionamento humano". A intenção era expandir o sistema de atividade para o coletivo e a comunidade, considerando um nível macro preferencialmente em relação ao foco no sujeito e, a mediação com ferramentas no nível micro. Desta forma, fez uma expansão na representação dada à primeira geração, incluindo os elementos da comunidade, divisão de trabalho e regras, dando ênfase às interações entre todos os elementos do sistema de atividade.

$\mathrm{Na}$ representação, o objeto é uma elipse para a qual as ações estão orientadas e caracterizadas por ambiguidade, inter-relacões, produção de sentidos e com potencial para mudança, o que se dá de forma explícita ou implicitamente (ENGESTRÖM, 1999). O modelo de representação da teoria da atividade passa a mostrar as relações possíveis no sistema de atividade, como apresentado na Figura 5.

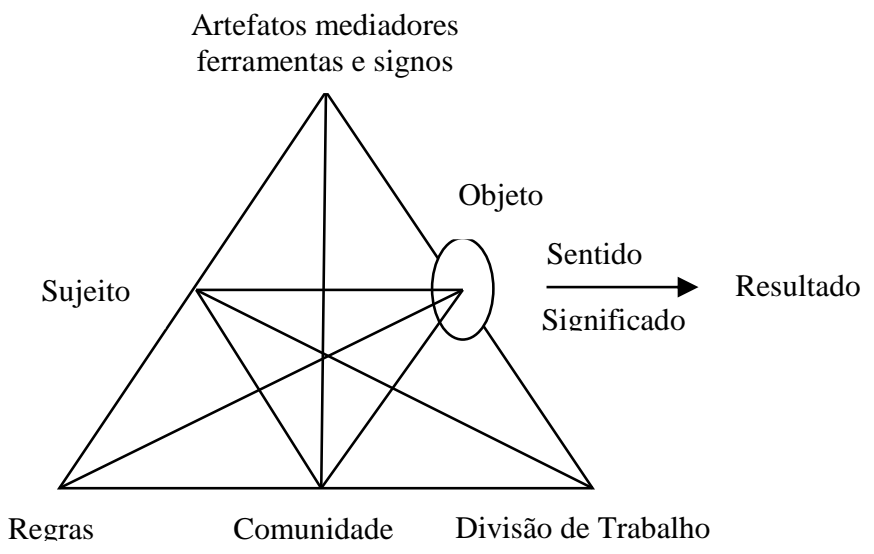

Figura 5: Modelo da teoria da atividade da segunda geração.

A estrutura de um sistema de atividade humano (Engeström, 1987).

Fonte: Daniels (2003, p.119). 
Essa geração da teoria da atividade foca o sujeito e suas inter-relações com a comunidade. No entanto, agrega outro elemento importante que são as contradições no sistema de atividade, que funciona como propulsora das mudanças e de seu desenvolvimento.

A terceira geração da teoria da atividade contempla uma rede complexa de sistemas de atividades que têm influência entre si. Nessa visão, a intenção era desenvolver ferramentas conceituais que permitissem a compreensão das múltiplas perspectivas que se tem em uma rede de atividades, então passa-se a incorporar ao sistema as ideias de multivocalidade e dialogicidade. $\mathrm{Na}$ rede de atividade aparece as contradições e tensões que levam a necessidade de análise das relações de poder e controle.

Em uma atividade coletiva, o sujeito não se mantém o mesmo, isto é, um indivíduo ocupa a posição de sujeito para uma dada ação, mas em outra pode ser outro indivíduo, como propõe Engeström (2006), assim pode-se ter vários indivíduos desempenhando ações que irão compor a atividade, e as metas, como estão associadas às ações, não se vinculam à atividade como um todo. Desta forma, é a negociação entre as diferentes metas daqueles que participam de ações que vão compor a atividade, para a qual Engeström (1999, apud Daniels, 2003) associa a imagem de que: "o objeto e o motivo de uma atividade coletiva são algo como um mosaico em constante evolução, um padrão que nunca está inteiramente acabado".

A Figura 6 representa o modelo da teoria da atividade, no caso um sistema com representação de um modelo mínimo, no qual "um objeto inicial (objeto 1 ) $^{9} \mathrm{em}$ um estado inicial, passa para um objeto coletivamente significativo (objeto 2) e para um objeto potencialmente compartilhado ou conjuntamente construído (objeto 3)”.

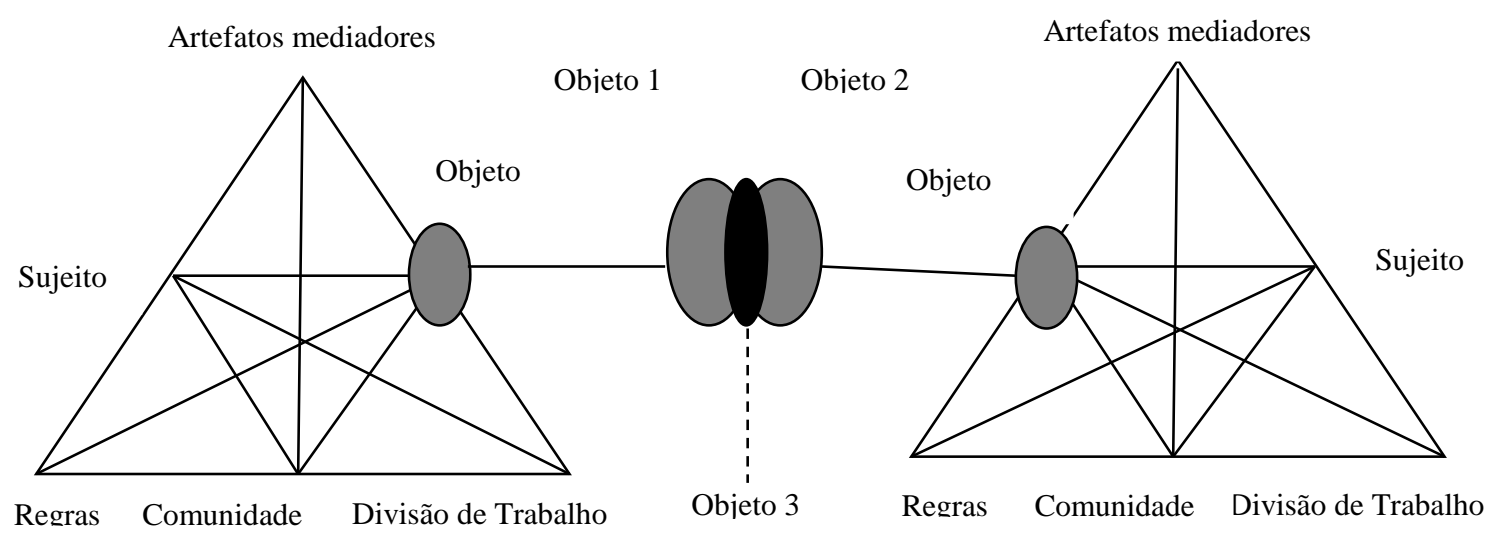

Figura 6: Modelo da teoria da atividade da terceira geração. Dois sistemas de atividade interativos como modelo mínimo para a terceira geração da teoria da atividade (Engeström, 1999).

Fonte: Daniels (2003).

\footnotetext{
${ }^{9}$ Extraído do exemplo dado por Engeström (1999) em Daniels (2003, p.121).
} 
Para Engeström (DANIELS, 2003) as tensões internas e as contradições impulsionam a mudança e o desenvolvimento, mas com isso as transições e as reorganizações surgem nos sistemas de atividades e também entre esses sistemas, levando à evolução. Portanto, esses sistemas, essas redes de atividades são processos dinâmicos, que se modificam no decorrer do tempo, assim o autor diz que têm que ser vistos em sua complexidade.

Outra questão importante, que Engeström afirma (DANIELS, 2003), é que as metas das ações são "reformuladas e revistas à medida que a pessoa age; e, em geral, só retrospectivamente explicadas com clareza" (p.122). Desta forma, a reconstrução ou redefinição do objeto tem relação com a alteração na atividade, relacionada ao seu "potencial criativo", como ele chamou.

Para Engeström (1999) a teoria da atividade é vista por três características fundamentais que podem ser uma base teórica para análise da aprendizagem inovadora, que são:

- contextual e orientada para a compreensão de práticas locais historicamente específicas, seus objetos, artefatos mediadores e organização social;

- baseada em uma teoria dialética do conhecimento e do pensamento, focada no potencial criativo na cognição humana;

- uma teoria desenvolvimental que busca explicar e influenciar mudanças qualitativas nas práticas humanas ao longo do tempo.

Daniels (2003), se refere a Cole e Engeström como autores que tratam do "ciclo expansivo", que representa uma relação de interiorização e exteriorização na atividade, o que ocorre de maneira cíclica, colocando a atividade em constante mudança. A interiorização é vista como relacionada à reprodução da cultura e a exteriorização como produção de novos artefatos culturais.

Engeström (1999), baseado em Vigotsky e Leontiev, associando os aspectos que ampliam a teoria da atividade para as relações além do sujeito, aponta como cinco os princípios que a representam nessa fase atual:

- um sistema de atividade coletivo, com redes de relações com outros sistemas, é a unidade primária de análise, que: "se realizam e se reproduzem ao gerar ações e operações";

- a multivocalidade dos sistemas de atividade, dada pela participação de diferentes sujeitos, com histórias distintas, sendo: "fonte de problemas e inovações, exigindo ações de tradução e negociação";

- a historicidade, o sistemas de atividade só são compreendidos nas bases de sua história;

- as contradições como fonte de mudança e desenvolvimento, as contradições podem causar perturbações ou conflitos, porém trazem a tentativa de mudar a atividade; 
- as transformações expansivas nos sistemas de atividade, que se realiza quando: "o objeto e o motivo da atividade são reconceituados para abraçar um horizonte radicalmente mais amplo de possibilidades".

As contribuições de Engeström ampliam as proposições de Leontiev para a Teoria da Atividade trazendo uma maior complexidade na análise das relações estabelecidas na atividade e com outros sistemas de atividade.

\subsubsection{Significado e Sentido}

A construção de sentido pelo ser humano sobre sua existência é discussão recorrente tanto na psicologia como em outras ciências, mas há diferenciações de ideias e de métodos de como estudar essa questão. Para Vigotski o conceito de sentido vai emergindo da revisão da psicologia de seu momento histórico e de suas reflexões críticas no decorrer de suas pesquisas sobre linguagem e pensamento. Ele colocava que tanto os adeptos à psicologia naturalista como os mentalistas não explicavam o humano no homem partindo de sua própria existência.

Em função das propostas dessas correntes da psicologia da época, o que Vigotski colocava é que o conceito de sentido era concebido com existência exterior, ligado às sensações e percepções, ou pertencente ao interior, mas sem ligação com o cultural. Mesmo a psicologia da Gestalt que propunha certa diferenciação (VIGOTSKI, 1996, BARROS et al., 2009, MARTINS, 2001) considerava o sentido ligado às percepções mais complexas, colocava a ideia de sujeito, mas provinha de uma estrutura centrada em si mesma.

A partir das concepções do materialismo histórico-dialético, Vigotski formulou novas referências para a teoria histórico-cultural, com o estudo da consciência associado às relações sociais e a historicidade dada aos processos psicológicos. Com isso, a linguagem e o pensamento também são incorporados ao estudo da consciência e assim, o conceito de sentido ligado à significação e, portanto, à cultura.

O estabelecimento do conceito de sentido advém dos estudos da linguagem e do pensamento, mais precisamente de um ponto fundamental, colocado por Vigotski, que no decurso do desenvolvimento, em dado momento, linguagem e pensamento se encontram, sendo que essa síntese se faz pela palavra.

A unidade de análise que reflete a unidade da linguagem e do pensamento, entendendo que a unidade contém as propriedades inerentes ao todo, foi encontrada por Vigotski no 
significado da palavra. Segundo ele, o significado da palavra é "indecomponível de ambos os processos", mas não é fenômeno só da linguagem e nem somente do pensamento. Vigotski (2009) elucida esta proposição dizendo que:

A palavra desprovida de significado não é palavra, é um som vazio. Logo, o
significado é um traço constitutivo indispensável da palavra. É a própria
palavra vista no seu aspecto interior. Deste modo, parece que temos todo o
fundamento para considerá-la como um fenômeno de discurso. Mas, como
nos convencemos reiterada vezes, ao longo de toda nossa investigação, do
ponto de vista psicológico o significado da palavra não é senão uma
generalização ou conceito. Generalização e significado da palavra são
sinônimos. Toda generalização, toda formação de conceitos é o ato mais
específico, mais autêntico e mais indiscutível do pensamento.
Consequentemente, estamos autorizados a considerar o significado da
palavra como um fenômeno de pensamento (p.398).

Vigotiski (2009) explicou que o significado da palavra é um fenômeno do pensamento apenas se este estiver relacionado à palavra, ele coloca que "é um fenômeno do pensamento discursivo ou da palavra consciente (p.398)", portanto o significado da palavra é a unidade do pensamento discursivo. Vigotski (1996) aponta que o pensamento se estrutura de maneira diferente daquela como se expressa na fala, o que faz com que não possa ser dado em relação direta com a palavra, sendo que o autor explica que:

(...) o pensamento não é algo acabado, pronto para ser expresso. O pensamento precipita-se, realiza certa função, um certo trabalho. Esse trabalho do pensamento é uma transição das sensações da tarefa - através da construção do significado - ao desenvolvimento do próprio pensamento.

O pensamento é uma nuvem, da qual a fala se desprende em gotas (VIGOTSKI, 1996, p.182).

No entanto, o que ele aponta como mais importante encontrado nesses estudos foi que os significados das palavras se alteram e se desenvolvem. No desenvolvimento histórico da palavra altera-se tanto seu conteúdo concreto quanto sua representação e generalização da realidade. Assim, o significado da palavra é inconstante e se modifica no desenvolvimento da criança

Ao verificar a dinamização do significado da palavra é que Vigotski introduziu o conceito de sentido. Esse conceito daria apoio as suas concepções sobre a linguagem interior, pois, apontava que nas pesquisas de seu grupo conseguiram estabelecer algumas peculiaridades que disseram que construía "a originalidade do aspecto semântico da 
linguagem interior". Uma dessas peculiaridades seria o predomínio do sentido da palavra em relação ao significado.

O sentido da palavra é inesgotável, seu sentido real é determinado pela riqueza dos momentos da consciência em relação ao que é expresso na palavra, segundo Vigotiski (2009, p. 466). Os sentidos mudam as palavras, ou elas permanecem, mas o sentido se desfaz. Vigotski cita exemplos que permitem compreender o dinamismo que promove os diversos sentidos, uma palavra pode ser substituída por outra sem a alteração de seu sentido, assim, o sentido se preserva, porém não mais associado à palavra inicial.

Dos estudos de Vigotski pode-se dizer, como aponta Barros (et al., 2009), que o sentido se produz nas práticas sociais pela relação dialética entre o mundo psicológico e a experiência atual do sujeito, não pode ser entendido como uma relação causal entre o contexto social e o indivíduo, onde ele reflete ou reage ao meio. Dada esta relação dialética tem-se a construção de diversos sentidos que está ligado ao contexto do sujeito e ao processo de interiorização. Portanto, interagem as dimensões cognitivas e afetivas, os processos coletivos e individuais (BARROS et al., op. cit.).

Leontiev (1978) apontou que mesmo com toda divergência na concepção de sentido, todos os estudos o tomam como fenômeno da consciência, mas ele coloca que a consciência não pode ser compreendida a partir dela mesma, assim tem que ser considerada como relação entre o sujeito real e o mundo que o cerca, não pode estar fora dos fenômenos da vida. Desta forma, "o sentido é, antes de mais nada, uma relação que se cria na vida, na atividade do sujeito" (Ibid., p.97). Leontiev o denominou de "sentido pessoal" e diz que está ligado a consciência e a atividade humana.

Vigotski (2009), coloca que tem-se que entender os motivos de um sujeito para entender seu discurso e portanto, para captar os sentidos que atribui às palavras, assim:

Para entender o discurso do outro, nunca é necessário entender apenas umas palavras; precisamos entender o seu pensamento. Mas é incompleta a compreensão do pensamento do interlocutor sem a compreensão do motivo que o levou a emiti-lo. De igual maneira, na análise psicológica de qualquer enunciado só chegamos ao fim quando descobrimos esse plano interior último e mais encoberto do pensamento verbal: a sua motivação (p.481).

Leontiev (1978) propõe que "a consciência do homem é a forma histórica concreta do seu psiquismo (p. 88)", sendo que a consciência individual do homem tem sua existência ligada à consciência social, a primeira só existe se a segunda existir. Por isso, Leontiev (op. cit.) diz que: 
Vimos que a consciência só podia existir nas condições da existência da linguagem, que aparece ao mesmo tempo que ela no processo de trabalho.

Por fim, vimos - e devemo-lo sublinhar particularmente - que a consciência individual do homem só pode existir nas condições em que existe a consciência social. A consciência é o reflexo da realidade, refratada através do prisma das significações e dos conceitos lingüísticos, elaborados socialmente (LEONTIEV, 1978, p.88, grifo do autor)

Os componentes da estrutura interna da consciência segundo Leontiev (op. cit.) são o conteúdo sensível, a significação social e o sentido pessoal. O conteúdo sensível está relacionado às sensações, percepção e representações, dá base e condições a consciência, "ele é aquilo que cria diretamente a transformação da energia do estímulo exterior em fato de consciência". As significações ${ }^{10}$ sociais são entendidas como as sínteses das práticas sociais conjuntas, são refletidas e fixadas na linguagem, a qual lhes dá estabilidade. Leontiev (op. cit.) define:

A significação é a generalização da realidade que é cristalizada e fixada num vetor sensível, ordinariamente a palavra ou a locução. É a forma ideal, espiritual da cristalização da experiência e da prática sociais da humanidade (p.94).

Os significados são produções históricas e sociais que possibilitam a socialização das experiências dos homens, permitem a comunicação, são mais estáveis, mas também se transformam no decorrer da história, alterando a relação que mantêm com o pensamento, sendo isso um processo (VIGOTSKI, 1996). Os significados se relacionam a conteúdos instituídos, que são mais fixos, compartilhados e apropriados pelos sujeitos, como colocam Aguiar e Ozella (2013), no excerto abaixo:

Ao discutir significado e sentido, é preciso compreendê-los como sendo constituídos pela unidade contraditória do simbólico e do emocional. Dessa forma, na perspectiva de melhor compreender o sujeito, os significados constituem o ponto de partida: sabe-se que eles contêm mais do que aparentam e que, por meio de um trabalho de análise e interpretação, pode-se caminhar para as zonas mais instáveis, fluidas e profundas, ou seja, para as zonas de sentido (Ibid., p.305).

\footnotetext{
${ }^{10}$ Significações ou significados - no texto expressarão o mesmo conceito, pois na tradução da obra de Leontiev (1978) foi utilizado o termo significação, porém outros autores utilizam significado para representar o mesmo conceito.
} 
O sentido, desta forma, é mais amplo que o significado, ele articula os eventos psicológicos produzidos pelo sujeito frente a uma realidade, o que Aguiar e Ozella (2013) complementam:

Como diz Rey (2003), o sentido subverte o significado, pois ele não se submete a uma lógica racional externa. $\mathrm{O}$ sentido refere-se a necessidades que, muitas vezes, ainda não se realizaram, mas que mobilizam o sujeito, constituem o seu ser, geram formas de colocá-lo na atividade. A categoria sentido destaca a singularidade historicamente construída (p., 305).

Continuando com a perspectiva que nos coloca Aguiar e Ozella (op. cit.), o sentido está num plano que se aproxima mais da subjetividade, que os autores explicam ser entendida como uma possibilidade humana de organizar experiências, as quais passam a ser convertidas em sentidos. O sentido expressa o sujeito com mais precisão, é configurado pela sua unicidade histórica e social. Assim, quando falamos de sentidos abarcamos uma dimensão subjetiva do sujeito, que está associada às suas ações, às relações sociais, mas também aos processos de internalização, o que fornece ao sujeito uma singularidade, portanto, nesse processo dialético, temos um sujeito histórico e singular.

Leontiev (1978) coloca que o sentido consciente nasce da relação objetiva que é refletida no cérebro do homem, "entre aquilo que o incita a agir e aquilo para o qual a sua ação se orienta como resultado imediato (p.97)", isto é, a relação entre o motivo da atividade e o seu fim. Para tanto o autor (op. cit.) diz que para encontrarmos o sentido pessoal atribuído pelo sujeito precisamos descobrir qual o motivo correspondente na atividade que desenvolve.

Ao falarmos de motivos, Leontiev destaca a necessidade de perceber situações diferenciadas para aos mesmos, que corresponde a motivos compreensíveis ou motivos eficazes, como explica Asbahr (2011):

[...] Leontiev $(1983,1988)$ faz uma distinção entre motivos geradores de sentido, ou motivos realmente eficazes, e motivos estímulos, ou motivos apenas compreensíveis. Os primeiros motivos conferem um sentido pessoal à atividade. $\mathrm{Na}$ atividade gerada por um motivo desse tipo, há uma relação consciente entre os motivos da atividade e os fins das ações. Os motivos estímulos, diferentemente, têm função sinalizadora e não geram sentido, assumem o papel de fatores impulsionadores - positivos ou negativos - da atividade e podemos dizer que são motivos externos à atividade do sujeito (p.8).

Sentido e significação embora pareçam fundidos na consciência, estão ligados, mas como coloca Leontiev (1978), “é o sentido que se exprime nas significações e não as 
significações no sentido (p.98)". Os sentidos se ligam à vida do sujeito e se modificam com ela, Leontiev diz que "o sentido pessoal traduz precisamente a relação do sujeito com os fenômenos objetivos conscientizados (p.98)". Nesse aspecto, podemos notar que para Leontiev a noção de sentido pessoal não se reduz a algo focado apenas no indivíduo, mas na relação deste com o meio em que está inserido, no entanto, esse sentido é particular para cada sujeito, mas se modifica na dinâmica de sua vida.

A estrutura da consciência humana está ligada à estrutura da atividade humana, portanto relacionada às condições históricas, sendo que as significações e sentidos fazem parte dessa estrutura.

Uma situação pode ter múltiplos sentidos por parte de diferentes sujeitos (BAQUERO, 1998), o que depende da experiência histórico-cultural de cada um, contudo há uma unidade no grupo que é o contexto de onde ele se insere, que dará coerência às ações, quando imbuídos por um motivo comum.

Por essa concepção dos processos psicológicos fundamentalmente atrelados ao cultural e as atribuições de sentido, é que se colocam os estudos da psicologia no contexto histórico e social dos indivíduos, o que tem permitido a busca de estudos para a sua utilização na educação, para uma maior compreensão das questões pedagógicas em geral.

\subsection{O processo histórico-cultural na formação do professor}

A Teoria Histórico-Cultural com a riqueza da produção de Vigotski, com a utilização de algumas abordagens de seus estudos e a Teoria da Atividade proposta por Leontiev nos embasarão na busca para identificar a atribuição de sentidos de alunos do curso de Licenciatura em Física, no momento específico do estágio supervisionado, nas disciplinas de Metodologia de Ensino de Física I e II (MEF), em relação à aprendizagem da docência.

Essas teorias, com os estudos de Vigotiski, Leontiev e Engeström colaboram para entender o ensino como apropriação das construções da humanidade. É no trabalho que o homem transforma a natureza e transforma a si mesmo, como dito por Engels, o que pode ser transferido para o professor tomando o ensino como sua atividade de trabalho.

A ideia de mediação por instrumentos e signos, com ênfase na atividade humana, sendo esta última aprofundada por Leontiev, permite compreendermos as relações no ensino, na sala de aula, que não ocorrem de forma direta, mas sempre mediada e esses meios 
mediacionais são importantes para que deles tanto os professores que organizam as atividades de ensino nas disciplinas, como os licenciandos, na aprendizagem da docência tenham consciência. Além disso, é preciso conceber a profissão docente em sua complexidade, nas múltiplas relações que se estabelecem no sistema de atividade, como propõe Engeström, o que amplia a visão do licenciando em relação ao seu trabalho docente. Essa concepção permite deslocar a importância dada apenas à transmissão do conteúdo para o caráter formativo, social e cultural da profissão, que buscando a humanização.

Em todo o processo o papel do professor é fundamental, pois ele é o mediador na aprendizagem dos alunos. Ele propicia situações para que os alunos reflitam sobre um tema, buscando promover interações entre o grupo e a aquisição de novos conhecimentos, permitindo que o aluno possa reelaborar, ou incorporar novos significados as suas concepções de mundo e aos conteúdos tratados nas ciências.

Considerando a necessidade de não reduzir a formação do professor somente à sala de aula, mas incluindo uma dimensão mais global, buscamos concebê-la como um processo histórico-cultural o que pode trazer elementos que permitam uma análise mais complexa e mais aprofundada, tomando o trabalho docente como foco. Como aponta Libâneo (2010), essa teoria "possibilita compreender a formação profissional de professores a partir do trabalho real, a partir das práticas correntes no contexto de trabalho e não a partir do trabalho prescrito, tal como aparece na visão da racionalidade técnica e tal como aparece também na concepção de senso comum" (p.74).

Nesta perspectiva, a educação é um processo pelo qual o homem se apropria da cultura humana. Assim, o professor inserido nesta cultura, tem como atividade o ensino, podemos considerar também como sua atividade a aprendizagem sobre ensinar, as quais se efetivam por ações do professor com objetivos orientados. Nesse processo de ensino e aprendizagem que envolve muitos indivíduos, há a apropriação dos conhecimentos da humanidade de forma sistemática, objeto da própria atividade de ensino e de aprendizagem, que leva à transformação dos indivíduos, os alunos e o próprio professor. Rigon, Asbahr e Moretti (2010a) corroboram com essa ideia, apontando que:

A educação como atividade nos faz refletir, também, sobre as atividades desenvolvidas no processo pedagógico. O objeto da atividade pedagógica é a transformação dos indivíduos no processo de apropriação dos conhecimentos e saberes; por meio dessa atividade - teórico e prática -, é que se materializa a necessidade humana de se apropriar dos bens culturais como forma de constituição humana. (p. 24) 
Neste aspecto, o professor tem a função de aproximar, dos alunos, os conhecimentos que foram elaborados historicamente pela humanidade, para tanto há a necessidade de organizar o ensino. Assim o trabalho docente passa a ser a mediação na formação do indivíduo, constituindo-o como sujeito, como nos colocam os autores supracitados e complementam que "o processo educativo que gera desenvolvimento psicológico é aquele que coloca o sujeito em atividade" (p.25).

O trabalho do professor pensado como uma atividade é movido por seus motivos, que o fazem traçar objetivos que levam às ações intencionais, essas são fundamentais no processo educativo, para que ao trabalho seja atribuído sentido pelo professor, para que não seja mera tarefa que o torne alienante. Para tanto, cabe ao docente preparar as situações didáticas, que gerem nos alunos o motivo de aprender, como sugerem os autores supracitados:

Nesse sentido, uma das responsabilidades do professor é organizar situações didáticas que favoreçam o desenvolvimento, no estudante, de um querer aprender, uma vez que este não é um valor natural, mas construído historicamente. Construir o motivo de aprender é fundamentalmente uma função educativa que, diga-se de passagem, vem sendo menosprezada por grande parte dos educadores. No entanto, é evidente que muitos dos elementos envolvidos na construção do motivo de aprender ultrapassam o âmbito da atuação do educador. (Ibid., p. 24)

Esse movimento, tendo o professor os motivos que o movem, pode levar à internalização dos significados e atribuição de sentidos, o que se dá pelas relações estabelecidas na vida em sociedade, assim criam-se as condições para que se aproprie das produções historicamente construídas pela humanidade e permita a apropriação por seus alunos dos conhecimentos científicos. No entanto, essa apropriação necessita de condições intencionais e sistematizada criadas pelo professor, como colocam Rigon, Bernardes, Moretti e Cedro (2010):

A função da educação escolar, criada para difundir o conhecimento
científico, é a de proporcionar a compreensão do significado de seus
conceitos. Tal objetivo implica criar condições para que as gerações
posteriores a necessidade humana que gerou a criação do conceito, bem
como seu processo de desenvolvimento. Com isso, o estudante se apropria
dos conceitos e compreende que é herdeiro do conhecimento desenvolvido
pelas gerações precedentes. (p.66)

Os momentos de reflexão na escola quando construídos com e pelos professores, favorecem o desenvolvimento de ações educativas que podem assumir maior significado no 
trabalho docente, favorecendo a atribuição de sentidos pelos professores, representando assim um espaço de formação profissional e pessoal. Ghedin (2010) coloca que para que esse processo aconteça tem-se um percurso formativo que é fundamental:

O processo reflexivo não surge por acaso. Ele é resultado de uma longa trajetória de formação que se estende pela vida, pois é uma maneira de se compreender a própria vida em seu processo. Não é algo impossível de realizar-se. É difícil porque a sociedade em que nos encontramos, de modo geral, não propicia espaços para existência da reflexão e a educação, em particular, não raro, reduz-se à transmissão de conteúdos mais do que à reflexão sobre eles e as suas causas geradoras. (p.147)

O movimento da escola, que ocorre no bojo das ações coletivas, de aproximações e distanciamentos entre os sujeitos, de criações e recriações, ao lado da história que carrega e da interação das pessoas que a constituem, só conseguimos perceber quando nos aproximamos de seu cotidiano, quando entendemos sua própria lógica, por isso o estágio assume importante papel na formação do licenciando. Pois, as instituições de ensino guardam um ambiente dinâmico, de pessoas que vêm e vão e, de ideias que se transformam, como nos apontam Ezpeleta e Rockwell (1986):

Na verdade, cada escola é produto de uma permanente construção social. Em cada escola, interagem diversos processos sociais: a reprodução de relações sociais, a criação e transformação de conhecimentos, a conservação ou destruição da memória coletiva, o controle e a apropriação da instituição, a resistência e a luta contra o poder estabelecido, entre outros. Sua interação produz determinada vida escolar, dando sentido exato à relação entre Estado e classes subalternas na escola. A realidade cotidiana das escolas sugere que não se trata de uma relação fixa, "natural", dada onde invariavelmente os professores e as crianças que nela convivem interiorizam valores e conteúdos que os tornarão operários e cidadãos submissos. Ao contrário, trata-se de uma relação em contínua construção e negociação em função de circunstâncias determinadas. Nestas, entram em jogo interesses e histórias imediatas e mediatas da escola, do povoado e dos sujeitos envolvidos (p.58).

O contexto da instituição, social, das relações não pode estar isolado no fazer e no pensar do professor, nem tão pouco este professor pode se constituir de forma isolada, sem um coletivo que o alicerce, assim, desde sua formação inicial o trabalho compartilhado lhe traz a contribuição da reflexão, da diversidade e do coletivo na profissão docente.

No processo de construir um espaço de trabalho coletivo na escola, objetivando ações, mais imediatas, voltadas ao ensino, mas com uma finalidade maior, a de sua formação, essas ações necessitam de uma intencionalidade, que impulsiona o desenvolvimento profissional, 
que não pode se fazer independente do pessoal. Esse processo é social, mediado pelas relações interpessoais, mas o sentido apreendido pelo sujeito é único. Daniels (2003) cmenta as ideias de Vigotski sobre a relação sujeito e meio, e o papel do professor na edução:

Vale dizer especialmente que Vygotsky não reconhecia a presença de
alguma realidade separada, que incluía apenas o professor e a criança. Ele
destacou e estudou o entorno social dinâmico que conecta o professor e a
criança (ou seja, os outros adultos e crianças com quem determinada criançá
realmente vive e interage). O trabalho do professor é particularmente
complexo porque, em primeiro lugar, deve estar bem orientado para as
regularidades da atividade pessoal da criança, ou seja, conhecer a psicologia
da criança; em segundo, o professor deve conhecer as dinâmicas sociais
particulares do cenário social da criança; e, em terceiro, deve saber sobre as
possibilidades de sua própria atividade pedagógica para usá-las com
sensibilidade e, assim, elevar a um novo nível a atividade, a consciência e a
personalidade de seus pupilos. É por isso que o trabalho de um professor
genuíno jamais pode ser estereotipado ou rotineiro; o trabalho do professor
sempre contém um caráter profundamente criativo. (p.43)

O professor ao trabalhar com a participação coletiva dos alunos nas atividades de classe permite que cada aluno realize processos de identificação e de diferenciação no grupo. Leva-o a se constituir como sujeito, porém, sendo um indivíduo pertencente a um grupo, a um contexto social, a uma realidade na qual pode interferir coletivamente e ao mesmo tempo preservar sua identidade. Questões como esta precisam fazer parte da formação para docência, pois ao elaborar uma atividade de ensino o professor precisa pensar em ações que comtemplem os conhecimentos, valores, atitudes e permita a criatividade, mas tenha ações que levem à formação do indivíduo.

Os aspectos históricos sociais e culturais são indissociáveis à formação docente e podem trazer contribuições para olharmos a rede complexa de relações que se estabelece nas instituições de ensino, como se relacionam com o externo, bem como o ambiente mais interno, em uma visão mais micro.

Esse movimento dos licenciandos no decurso da disciplina de MEF e especialmente no estágio, que configura o espaço de atuação mais concreto para desenvolver sua aprendizagem para docência, pensamos que poderá ser marcado por mudanças de sentidos desses licenciandos. Isso não significa que passariam de posições radicais de não quererem ser professor até se convencerem da importância da profissão, embora isso possa ocorrer, mas as mudanças de sentidos podem acontecer também para aqueles que desejam a docência, que durante a disciplina de MEF e o estágio vão se transformando, ou seja, modificando suas ações, seus motivos. 


\title{
Capítulo 4
}

\section{Contexto da Pesquisa e Metodologia}

\author{
O que dá o verdadeiro sentido ao \\ encontro é a busca, e é preciso andar \\ muito para se alcançar o que está perto.
}

José Saramago

\section{1 Contexto da Pesquisa}

O contexto refere-se à disciplina de Metodologia do Ensino de Física I e II, contempladas na grade curricular do curso de Licenciatura em Física da Universidade de São Paulo, obrigatórias para obtenção da conclusão do curso, sendo oferecidas pela Faculdade de Educação em dois semestres independentes.

Essa disciplina, em geral, é oferecida em duas turmas, uma do diurno e outra do noturno, cujos professores são distintos. Na organização da disciplina há um professor e um monitor que o auxilia. A turma que acompanhamos foi a do noturno, no primeiro semestre no decorrer da Metodologia do Ensino de Física I (MEFI) e no segundo semestre em Metodologia do Ensino de Física II (MEFII).

O professor foi o mesmo nas duas disciplinas, sendo que a MEFI teve trinta (30) alunos que a frequentaram, dentre eles alguns (4) eram de outros cursos, Licenciatura em Matemática e Licenciatura em Biologia e Química, que faziam a disciplina como optativa. No segundo semestre, correspondente à MEFII, o total de alunos frequentes foi de vinte e seis (26). Observa-se que a maioria dos alunos aprovados na MEFI seguiram matriculados em MEFII, exceto um que precisou mudar de turma passando para o diurno e os que fizeram apenas a disciplina I como optativa, sendo que a sala recebeu dois alunos que não tinham participado do grupo. 


\subsubsection{A estrutura da disciplina}

A proposta das disciplinas era desenvolver com os alunos elementos teóricos e o estágio, de forma que, pela integração das ações realizadas, levassem os licenciando a se aprofundarem em sua formação profissional, formação para docência.

As disciplinas foram estruturadas com atividades de ensino variadas, que buscavam discutir, em sala de aula, com os alunos questões referentes ao trabalho docente e como trabalhar com os alunos da escola básica os conteúdos curriculares, o papel do professor no ensino e sua importância para sociedade, bem como as influências dos contextos externos na escola e na formação docente.

As atividades de ensino e de aprendizagem da disciplina MEFI apontam três eixos temáticos que foram desenvolvidos ao longo das aulas, eixos A, B e C, o programa com seu cronograma e o resumo da proposta se encontra no Anexo A (Anexo A: Cronograma da disciplina Metodologia do Ensino de Física I e II, com o programa por aula).

O Eixo A, denominado "re-conhecendo a sala de aula de Física", tinha como objetivo conhecer, ou reconhecer, os elementos estruturantes para a organização do trabalho docente com foco na sala de aula, tais como os documentos oficiais que norteiam o ensino básico brasileiro, o currículo sugerido e o que é trabalhado pelo professor, bem como as representações sobre ensino, aprendizagem e Ensino de Física.

Para o Eixo B, chamado de "planejando e intervenções para a sala de aula", a intenção se voltava para discussões sobre a organização de atividades de ensino de Física, neste momento buscando discutir em grupos, organizar pequenas atividades de ensino ou resolver atividades de aprendizagens, com o propósito de refletir sobre as mesmas e começar a pensar no papel do professor na preparação dessas atividades de ensino, em como prepará-las e no desenvolvimento delas com os alunos, nas necessidades e dificuldades que se apresentam para os licenciandos.

O Eixo C, de nome "analisando intervenções em sala de aula", visava uma análise crítica das ações na sala de aula, depois da atuação dos licenciando nas escolas com suas sequências de ensino, das observações do contexto, coleta e análise de materiais e do contato com os materiais teóricos e práticos apresentados nas aulas.

Na disciplina de Metodologia de Ensino de Física II a proposta era dar continuidade ao processo estabelecido em MEFI com maior ênfase nas ações práticas em sala de aula, buscando um contato mais estreito com a escola, no aspecto de maior número de intervenções 
na sala de aula. O que significou a preparação de um programa mais elaborado de atividades de ensino, com planejamento, implementação, análise das atividades de ensino de forma mais aprofundada, visando a atuação direta do licenciando no foco de suas ações docentes, a aula, compreendendo esta aula em todas as suas relações e complexidade, pois para se chegar ao objeto aula existe um processo anterior e posterior que constitui o trabalho docente.

As atividades de ensino propostas, para ambas as partes da disciplina, constavam de textos e resenhas dos mesmos, sendo esta última não obrigatória para todos os textos, assim havia um número mínimo de resenhas a ser entregue. Os textos eram referentes ao papel da ciência, ensino e aprendizagem de ciências, a educação científica, a alfabetização científica, ensino por investigação, problematização na atividade de ensino, a questão da linguagem gráfica no Ensino de Física, como um exemplo de trabalhar com as diferentes linguagens, interações discursivas como investigação na sala de aula, a contextualização nas aulas e a imagem do trabalho científico. Os textos apresentados à leitura constam do programa da disciplina, e estão apresentados no Anexo A.

Os textos tinham como objetivo aprofundar o estudo de questões sobre o ensino que possam, a partir deles, respaldar teoricamente as discussões em sala, para que os alunos não ficassem apenas no senso comum e em suas opiniões sem embasamento teórico no momento das discussões, bem como, para agregar conteúdo teórico à formação, além daquele que já traziam do curso e da experiência de vida de cada um.

Na sala, em geral, era dada uma situação-problema, ou alguma questão que buscasse referenciais no texto indicado para leitura, ou ainda a apresentação de trecho de algum vídeo, que os alunos discutiam em grupo, tentando apresentar propostas para as questões que eram colocadas, cujas reflexões e/ou observações, associadas à leitura dos textos levavam para a discussão geral com sala, mediada pela professora.

O estágio foi componente obrigatório da disciplina, visava o contato dos licenciandos com o contexto escolar, com as ações docentes, aproximando-o tanto do professor da sala de aula do Ensino Básico como dos alunos, principalmente ao atuarem nas regências.

$\mathrm{Na} \mathrm{MEFI}$, foi proposto o desenvolvimento do estágio por várias ações de aproximação, observação e atuação na escola. A primeira não ocorreu na escola, tinha o objetivo de entrevistar alunos egressos do Ensino Médio, para verificar o que lembravam do curso de Física que tinham tido, como havia sido esse curso e a importância que teve para a vida deles. 
A outra ação previa a entrada na escola, buscando conhecer o contexto da escola na qual o estágio ocorreria para cada licenciando, estabelecendo o contato com a direção ou coordenação, observando o ambiente escolar e analisando o projeto político pedagógico daquela unidade de ensino.

Em um segundo momento, na mesma escola, a ação proposta tinha como objetivo a observação da aula do professor que acompanhariam, fazendo uma análise preliminar para verificarem a interação professor-aluno que ocorria na sala de aula.

Após essa fase de reconhecimento do contexto escolar e já decorrida diversas leituras de textos da literatura sobre ensino e realizadas discussões, os licenciandos iniciaram a preparação de uma sequência didática, com duração de 3 a 5 aulas, para aplicação na sala de aula que estavam acompanhando. O tema escolhido, primeiro deveria ser discutido com o professor da escola para verificar se este iria preferir uma atividade de ensino sobre o assunto que estava discutindo em aula ou se o tema poderia ser livre. A atividade de ensino deveria propor uma situação problematizadora que os colocasse os alunos na busca de solução para um problema, que os motivasse na discussão do tema de Ciências proposto.

A atividade de ensino poderia, ou era desejável, ser preparada em dupla, porém nem todos os alunos tinham disponibilidade de horário para isto. Antes de iniciar a aplicação na escola, cada sequência didática era apresentada para sala e recebia os comentários e as contribuições dos colegas, sob a mediação da professora da disciplina. Após esta etapa, a sequência didática era reestruturada e iniciava-se a aplicação em sala de aula.

A atividade de ensino desenvolvida com os alunos na escola era analisada pelos licenciandos e delas trazia-se para a apresentação e discussão com o grupo da disciplina um episódio das aulas que tivesse sido significativo. Esse episódio não representava uma síntese de todo o processo, mas alguma situação relevante do ponto de vista dos licenciandos, que deveria tentar correlacionar com os estudos feitos na disciplina, para o que também contavam com a mediação da professora e as intervenções colaborativas dos colegas da sala. Finalizando, entregavam uma análise crítica por escrito do episódio apresentado.

No final da disciplina foi feita uma avaliação escrita sobre os temas tratados e o ensino, com a intenção de verificar as relações que os licenciandos estabeleceram, a avaliação era individual, mas poderia ser discutida com o colega, visando à ampliação das ideias a serem explanadas.

A disciplina de Metodologia de Física II propunha a continuação e aprofundamento das discussões dos temas propostos em MEFI, acrescentando mais alguns textos, com a ideia 
de ampliar o panorama para a reflexão sobre o ensino de Física e também retomando questões já abordadas no arcabouço teórico visto no primeiro semestre.

Em MEFII ocorreu maior ênfase na elaboração de atividades de ensino para discussão em grupos menores e depois com a sala toda. A partir de um tema dado foi proposto que cada grupo elaborasse uma atividade de ensino que tivesse questão problematizadora que a mobilizasse, sua estrutura, objetivos, quais conteúdos seriam abordados e como estes seriam desenvolvidos, como contextualizariam o tema, dentre outras questões. Os grupos poderiam tomar como possibilidade o ensino por investigação, pois já haviam trabalhado com situações investigativas no semestre anterior e essa era uma oportunidade de aprofundarem-se neste quesito, o que colaboraria com a estruturação posterior das aulas para o estágio.

O estágio foi composto de um maior número de aulas, de 6 a 10, que deveriam ser cumpridas com a regência dos licenciandos. Para essa ação de estágio solicitou-se sua organização em grupos de 2 ou 3 licenciandos, tanto para a elaboração da sequência didática quanto das regências das aulas. Isto, exceto se não fosse possível compatibilizar o local da escola e os horários dos licenciandos, neste caso haveria a elaboração conjunta da atividade de ensino e a aplicação da mesma era feita em escolas distintas pelos licenciandos em separado.

Para o estágio apresentaram-se apontamentos crítico-reflexivos sobre as aulas ministradas, que foram trazidos para discussão com a sala toda, o que permitiu que as experiências fossem trocadas e amadurecidas em relação às observações e interpretações da sala de aula, além de discutirem possibilidades de intervenções no contexto da escola que pudessem levar às mudanças para um ensino mais significativo para alunos e professores, pois nesse momento falavam de um lugar vivenciado e com um trabalho, mesmo que pequeno, realizado.

No final, também nessa disciplina, foi feita uma avaliação individual com consulta às anotações pessoais e resenhas feitas sobre os textos, visando verificar as relações que os licenciandos estabeleceram entre os textos estudados, as práticas realizadas e o ensino. A estruturação das ações das disciplinas de MEF I e II estão apresentadas na Figura 7. 


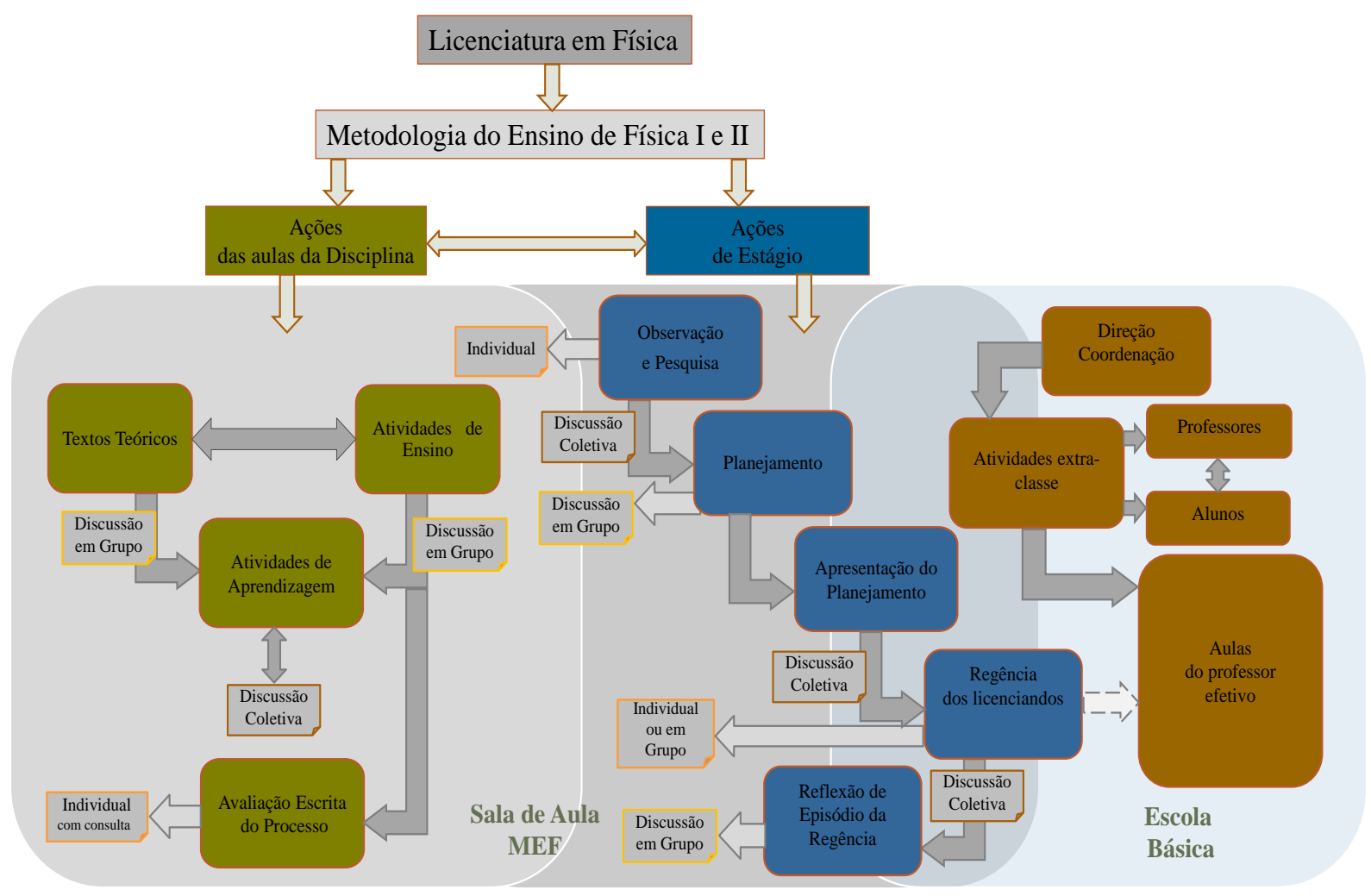

Figura 7: Estruturas das disciplinas de Metodologia do Ensino de Física I e II, no ano da coleta dos dados da pesquisa.

\subsubsection{O grupo de licenciandos}

Para complementar a caracterização do contexto e conhecermos um pouco mais o grupo de alunos participantes da disciplina de Metodologia do Ensino de Física I acrescentamos algumas informações aquelas relativas à escolha do curso e as aspirações referentes à docência, obtidas pelo questionário 1. Esses dados forneceram um panorama da classe, mas não contemplam o total de alunos porque alguns não responderam ao questionário 1 (26\% dos presentes na aula, pois a participação para fornecer dados a pesquisa era voluntária, por isso não havia insistência na devolução do questionário respondido).

Esse questionário visava responder questões gerais que buscavam caracterizar os alunos e trazer uma primeira ideia de seus interesses com a docência. Apresentamos aqui apenas os dados que especificam o contexto, aqueles referentes à docência discutiremos no capítulo de análise. Dentre os trinta (30) alunos que frequentaram a disciplina MEFI, vinte e sete (27) receberam o questionário, os três (3) que não o receberam não compareceram à aula 
nesse dia. Dos questionários distribuídos vinte (20) foram respondidos, o que corresponde a $74 \%$ dos alunos presentes, os outros (7) não foram devolvidos.

A sala de aula era composta por alunos de idades variadas, o que podia-se notar pela observação, assim pedimos que indicassem a idade ao responderem ao questionário, o que nos indicou uma diferenciação nas faixas etárias, mostrando que os alunos se distribuem em 3 faixas etárias principais: de 18 a 23 anos, de 24 a 29 anos e de 30 a 35 anos, nas quais o número total de alunos é bastante próximo. Assim, podemos notar que há uma mescla de idades na composição da sala, o que pode ser mais característico para o curso um realizado no período noturno.

A maioria dos alunos cursou o Ensino Fundamental em escola pública, que podemos verificar também que uma parcela menor frequentou escola particular. Esse quadro se altera um pouco para o Ensino Médio porque surge a escola técnica, que absorve alunos tanto das escolas públicas quanto particulares. Notamos que, no Ensino Médio, com a possibilidade da escola técnica há um ligeiro aumento do número de alunos que passam a cursar a escola pública.

Em relação à entrada no curso superior, os alunos têm a Licenciatura em Física como primeira graduação (14), é minoria aqueles que estão fazendo o curso como segunda graduação (5), nesses casos não finalizaram a primeira graduação, que eram da área de Ciências Humanas ou Exatas.

Do total que respondeu ao questionário, pouco menos da metade $(45 \%)$ pretendia finalizar o curso no mesmo ano em que estavam fazendo a disciplina de MEFI, outra parte (35\%) levaria de 1 a 2 anos para a conclusão e, o restante mais de 2 anos (15\%). No entanto, isto se uma previsão feita pelos licenciando segundo as disciplinas que eles ainda tinham para cursar, para completar seus créditos e poderem concluir o curso, assim isto está condicionado a conseguirem cursar as disciplinas nos semestres previstos e obterem a aprovação e cada uma delas.

Aqueles que responderam ao questionário nos deram uma visão da sala de aula do noturno, nesta disciplina, que foi composta por uma maioria que trabalhava, sendo bem variável o número de horas semanais dedicada a esse trabalho, de 10 horas até mais de 40 horas, o que correspondia a 15 dos licenciandos (75\%). Um detalhamento maior mostra que parte dos licenciandos trabalhava em atividades docentes e parte em áreas técnicas administrativas, sendo as instituições bancárias uma dessas áreas. Cabe observar, que os que 
estavam ligados à docência eram os que trabalhavam, em geral, de 10 a 30 horas semanais e o segundo grupo de 30 a mais de 40 horas por semana.

Os dados referentes ao trabalho remunerado podem indicar alguma correlação com os da faixa etária, para aqueles alunos entre 30 a 35 anos que por trabalharem, às vezes, isto pode levá-los a permanecerem por mais tempo no curso, ou a não começarem a graduação no início da fase adulta. Isto é uma possibilidade, pois não temos dados suficientes para uma afirmação, bem como, essas questões não foram postas para o grupo de licenciandos.

Os dados apresentados aqui buscaram apontar algumas características gerais da sala com o grupo que compõem o contexto da disciplina. Com esse quadro só podemos apreender o conjunto que constitui a disciplina de MEFI, que pode se reorganizar em subgrupos em

função do que olhamos, mas não conseguimos captar sentidos pessoais. Por este motivo o questionário foi complementado com outros dados que pretenderam observar melhor a dinâmica da sala e as relações estabelecidas, para buscar pela aprendizagem da docência e seu sentido para sujeitos deste grupo.

Na disciplina de Metodologia do Ensino de Física II não repetimos a caracterização dos alunos em relação aos dados que colhemos em MEFI, pois o grupo sofreu pouca alteração, tendo ingressado na turma apenas um novo aluno e outros saídos ou reprovados, totalizando 26, assim consideramos o grupo de licenciandos segundo as informações já apresentadas.

\subsection{Metodologia}

A metodologia da pesquisa leva em conta o contexto onde os sujeitos estão em ação e no qual as observações ocorrem, envolve as relações que estes estabelecem com seu processo de aprendizagem da docência, bem como o processo histórico de formação dos sujeitos da pesquisa, disciplina e estágio.

O processo que estrutura as atividades de ensino da disciplina de Metodologia do Ensino de Física e as ações propostas que acontecem no espaço das aulas e do estágio são essenciais para a pesquisa, para a compreensão das interações que ocorrem no contexto estudado e também as possibilidades de uma visão mais ampla destes elementos.

Como nosso interesse principal está no sentido atribuído pelos licenciandos à docência, faz-se importante que se tenha foco na interpretação que os sujeitos da pesquisa 
fazem do processo de formação e como percebem a aprendizagem da docência no aspecto profissional e pessoal. O processo de influências que tiveram antes e na disciplina também é o que buscaremos capturar.

Devido a estes aspectos, a pesquisa tem abordagem qualitativa, sendo que o pesquisador tem contato direto e mais extensivo com a situação estudada, na qual a perspectiva dos participantes é importante e a ênfase no processo, cujas características são encontradas em Lüdke e André (2013, p. 14) ao comentarem pontos significativos da pesquisa qualitativa dados por Bogdan e Biklen (1982). Além disso, esta pesquisa se caracteriza como Estudo de Caso, uma vez que buscamos analisar intensivamente um contexto real específico de formação inicial de professores, tendo como foco os licenciados em Física na disciplina de Metodologia de Ensino e as características particulares desse processo formativo, as quais podem ser reveladas nas ações, nos motivos e sentidos atribuídos pelos sujeitos.

Yin (2010) define o estudo de caso como aquele em que os pesquisadores têm pouco controle sobre os eventos, tendo como foco principal os fenômenos atuais, os quais só podem ser investigados no contexto da vida real. Para capturar o fenômeno e entendê-lo, há necessidade de múltiplas fontes de evidências, para posteriormente serem trianguladas. Em nossa pesquisa utilizamos de diversos instrumentos, que serão apresentados no item 4.2.2.

Além disso, essa pesquisa tem proximidades com a análise microgenética da perspectiva histórico-cultural (GOES, 2000; MEIRA, 1994), uma vez que a nossa atenção centra-se na investigação minuciosa do processo, considerando os aspectos históricos e sociais dos sujeitos, bem como os detalhes e indícios manifestados nas falas e ações. A análise será organizada em forma de episódios, os quais se constituem como fragmentos de dados que contém a essência do fenômeno estudado. A análise desses fragmentos pode ser feita, segundo Abreu e Moura (2013) a partir da escolha de cenas significativas, as quais constituem os episódios. Assim sendo, apresentaremos nesse estudo alguns episódios de modo a evidenciar os sentidos atribuídos pelos licenciandos sobre a aprendizagem da docência, os quais serão aprofundados no capítulo 5.

\subsubsection{O Método Histórico-Dialético e a Unidade de Análise}

Como trabalharemos com o processo dos licenciandos se constituindo professores e os sentidos atribuídos à docência, tomaremos a análise da disciplina como um sistema de 
atividade, as ações propostas neste sistema e seus objetivos, tendo como meta a formação docente, buscando referenciais na Teoria Histórico-Cultural e na Teoria da Atividade, a metodologia de análise se torna mais coerente ao nos aproximarmos do método histórico dialético.

Da maneira como entendemos a formação de professores inicial e continuada, como constituição de uma identidade que busca a humanização no processo de ensinoaprendizagem, é na apropriação sistematizada e intencional dos bens culturais da humanidade que o sujeito constrói sua aprendizagem, se transforma e atua na transformação do seu meio social e cultural.

O professor atua na promoção da aprendizagem do aluno por meio de atividades de ensino que buscam a transformação dos mesmos e a formação do pensamento teórico. No caso da formação inicial, o licenciando atua na atividade de ensino por meio de ações para a docência e nas atividades de aprendizagem como alunos. Este contexto complexo corrobora para a pesquisa se valer do método histórico dialético ao pretender apreender o movimento que é também dialético e histórico. Este método busca a apreensão do fenômeno estudado em sua totalidade, como explica Cedro (2008), destacando o método como análise e síntese do fenômeno.

\begin{abstract}
Dentro do método histórico dialético, Marx faz a distinção entre o método de pesquisa e o método de exposição, mas os mantém em uma unidade. $\mathrm{O}$ método de pesquisa é concebido como a análise que tornará evidentes as relações internas e cada elemento em si mesmo, dentro de uma realidade estudada. Já o método de exposição é concebido como um processo contrário ao da pesquisa, pois a reconstituição, a síntese do fenômeno, é apresentada ao indivíduo como se tivesse sido construída a priori. Logo, o objeto é revelado gradativamente de acordo com certas peculiaridades inerentes a ele (CEDRO, 2008, p.96).
\end{abstract}

Para a abordagem de análise das funções psicológicas superiores Vigotski utiliza três princípios, que podem ser resumidos: 1)análise do processo e não só o foco no objeto; 2)busca por uma explicação e não uma análise descritiva; 3)refere-se ao que chama de comportamento "fossilizado", são aqueles que perderam a aparência original e passam a um caráter automático, mecanizado, é necessário compreender sua origem, "o processo do estabelecimento das formas superiores e não o produto do desenvolvimento, para uma análise mais dinâmica”, (VIGOTSKI, 1996, p.81-85). Cabe destacar que este autor considera necessário um método próprio para psicologia, embora aponte a concordância e proximidade 
com as proposições das bases traçadas pelo método histórico dialético. Esses princípios colaboram para a análise dos sujeitos em seu processo histórico.

Estudar alguma coisa historicamente significa estudá-la no processo de mudança: esse é o requisito básico do método dialético. Numa pesquisa abranger o processo de desenvolvimento de uma determinada coisa, em todas as suas fases de mudanças - do nascimento à morte - significa, fundamentalmente, descobrir sua natureza, sua essência, uma vez que "é somente em movimento que um corpo mostra o que é". Assim o estudo histórico do comportamento não é um aspecto auxiliar do estudo teórico, mas sim sua verdadeira base. (Vigotski, 1996, p.85-86)

O método proposto por Vigotski, para o estudo do pensamento e linguagem, é composto por unidade de análise, o que significa estudar um fenômeno não o dividindo em partes do todo, mas sim em unidade que representa o todo. Assim, a unidade é parte constituinte e a menor parte que guarda as propriedades inerentes ao todo. Vigotski (2009) coloca que:

Deve substituir o método de decomposição em elementos pelo método de análise que desmembra em unidades. Deve encontrar essas propriedades que não se decompõem e se conservam, são inerentes a uma dada totalidade enquanto unidade, e descobrir aquelas unidades em que essas propriedades estão representadas num aspecto contrário para, através dessa análise, tentar resolver as questões que lhe apresentam (p.8).

Em nosso caso, por olharmos as ações dos licenciandos como elementos que estabelecem as ligações entre os motivos da docência e os sentidos que atribuem a essa docência no decorrer da disciplina, consideramos a "ação para docência" como foco de estudo, a qual faz parte de um contexto mais amplo relativo a "atividade de estágio", a qual consideramos como unidade de análise. Ao considerarmos o estágio como unidade de análise buscamos compreender o movimento do sujeito em formação para profissão docente, onde cada ação para a docência dirigida à um objetivo estará se dirigindo à formação do licenciando, sendo que em seu conjunto tenderão a convergir para a profissão docente. Em outras palavras, utilizaremos esta unidade para buscar apreender os sentidos que esses licenciandos atribuem à docência no movimento que se estabelece no processo de formação, o que tem como intenção a compreensão do fenômeno em sua historicidade.

No entanto, nosso olhar direcionado para as ações justifica-se pelo fato de que estas permitem-nos compreender a complexidade da "atividade de estágio", uma vez que elas estão contidas nas atividades das disciplinas de MEF, as quais estão ligadas a outras ações que 
compõem a aprendizagem da docência, bem como, a atividade do curso de Licenciatura em Física, a qual essas disciplinas se inserem.

Cabe ressaltar que os sujeitos inseridos nessa atividade de estágio têm necessidades, as quais surgem das múltiplas interações desses sujeitos com o outro e com o meio, que geram motivos que o levam a agir, sejam estes compreensíveis ou eficazes, sob as normas estabelecidas para o estágio, que não são só normativas legais, mas aquelas colocadas pelas disciplinas, as definidas pelos grupos de trabalho, as das escolas onde o estágio ocorre e outras que possam surgir das interações que vão sendo estabelecidas, o que se coordena por uma divisão de trabalho que para alguns aspectos já está dada e para outros vai se construindo.

Os licenciandos vistos através da ação para docência realizada por eles durante a disciplina, pela abstração que fazem desta para sua formação e como a reelaboram em sentidos pessoais para sua formação profissional, a partir destas promovendo nova ação, permitirá um movimento ao concreto ressignificado. Ao tomarmos a "atividade de estágio" como unidade de análise não excluímos o caráter teórico do processo de formação dos licenciandos, mas, estamos entendendo que essa atividade não ocorre de forma desconectada da teoria e vice-versa. $\mathrm{O}$ excerto abaixo fala sobre a análise de um fenômeno:

É importante ressaltar que o concreto e o abstrato são momentos de desmembração do objeto pela atividade do pensamento. A análise do fenômeno inicia-se pelo real, pelo imediatamente dado, mas, sendo este representado caoticamente, é uma abstração. [...] O processo de ascensão do abstrato ao concreto deve revelar as contradições presentes na abstração inicial. O objeto deve ser tomado, com a ajuda das abstrações, em unidade com o todo, em relação com suas outras manifestações (singularidades), com sua essência e origens universais (RIGON, ASBAHR e MORETTI, 2010a, p.38).

A pesquisa precisa em todo seu desenvolvimento da teoria, desde a concepção do problema, em todo seu caminhar, no trabalho de campo, na análise dos dados, propostas e considerações que possam ser feitas a teoria é estruturante. Os dados, o contato com o real se faz por idas e vindas pela teoria, para se capturar uma realidade ressignificada. Como coloca Azevedo (2013):

Sem a mediação teórica, não há como formular a pergunta, uma vez que esta contém em sua essência os elementos teóricos que guiarão o pesquisador, não apenas para a delimitação dos problemas metodológicos, mas sobretudo para a precisão da unidade de análise [...] (p.106). 
A unidade de análise busca nas ações dos sujeitos, entendendo a ação com um objetivo que faz o sujeito agir e que se este sujeito estiver em atividade seu motivo estará voltado para sua meta e as ações atuarão para que esta meta seja alcançada. Considerando que como objeto os licenciandos têm a aprendizagem da docência, suas ações precisam se dirigir para esta aprendizagem, pois a disciplina, tal como o curso visam à formação do professor. A ação para docência então possuirá a mesma estrutura da atividade como um todo, guardará as características da atividade.

Neste contexto de pesquisa buscamos compreender: Como se constitui o processo de atribuição de sentidos, relativos à docência, pelos licenciandos do curso de Física, nas ações ao longo da disciplina de Metodologia do Ensino?

$\mathrm{Na}$ situação contextual da disciplina de Metodologia do Ensino de Física, consideramos a disciplina como sistema de atividades, que tem como objeto a formação para docência. Os alunos que participam deste sistema têm como meta a aprendizagem da docência e para isto realizam ações com objetivos diversos que juntas tendem a aprendizagem da docência, para as quais os licenciandos atribuirão sentidos rumo a este fim. Isto na situação de estarem em movimento para sua formação para docência, porém podem se alienar do processo e o fim para eles não ser mais a aprendizagem da docência e sua construção sóciohistórica, o que neste caso, perde-se a essência de ser professor.

\subsubsection{Instrumentos de Pesquisa}

Para a proposta de pesquisa a obtenção dos dados foi realizada ao longo do processo de desenvolvimento das disciplinas de Metodologia do Ensino de Física para que se pudesse conseguir captar o movimento dos estagiários na aprendizagem da docência. Como queríamos acompanhar a atribuição de sentidos dos estagiários à docência optamos por vários instrumentos de pesquisa que possibilitassem a apreensão desses sentidos e das mudanças que pudessem ocorrer ao longo das ações da disciplina e do estágio.

A observação das aulas da disciplina foi um dos instrumentos utilizados, que para a obtenção dos dados construiu-se um caderno de campo, no qual eram anotadas as observações imediatas e as informações dadas em momentos individuais ou de trabalho coletivo. Durante as ações realizadas nas aulas, que eram coletivas, a pesquisadora acompanhava as discussões de um dos grupos, alterando o grupo a cada aula, com a intenção de ter um maior contato com 
os licenciandos da sala. Os grupos não eram fixos, mas eles se tornaram fixos no decorrer das aulas, havendo raras mudanças de uma aula para outra.

Em geral, a dinâmica das aulas se dava pela discussão de uma proposta que era sugerida pela professora, muitas vezes um problema, que era refletido no grupo, o qual apresentava sua solução ou possibilidades e em seguida passava-se ao momento de socialização com a sala, buscando as várias visões da mesma questão, ou as soluções dadas para uma mesma situação de modo a ampliar e aprofundar a discussão para depois fazer uma síntese.

Lüdke e André (2013) apontam a importância da observação para pesquisa qualitativa, permitindo que se aproxime dos sujeitos da pesquisa de forma a entender sua visão de mundo, sendo útil ainda para a descoberta de elementos novos no contexto pesquisado. Assim, as autoras apontam algumas vantagens deste instrumento:

[...] a observação possibilita um contato pessoal e estreito do pesquisador com o fenômeno pesquisado, o que apresenta uma série de vantagens. Em primeiro lugar, a experiência direta é, sem dúvida, o melhor teste de verificação da ocorrência de determinado fenômeno. "Ver para crer", diz o ditado popular. [...] permite também que o observador chegue mais perto da "perspectiva dos sujeitos", um importante alvo nas abordagens qualitativa. $\mathrm{Na}$ medida em que o observador acompanha in loco as experiências diárias dos sujeitos, pode tentar apreender a sua visão de mundo, isto é, o significado que eles atribuem à realidade que os cerca e às suas próprias ações (Ibid., p.30-31).

Nos momentos que as socializações ocorriam, dependendo do encaminhamento da discussão, ficava mais difícil conseguir um registro adequado, o que fez com que optássemos pela gravação de alguns desses momentos. No caso, a gravação foi feita nas ocasiões de apresentações que envolviam maiores detalhes sobre a docência, situações de apresentação das propostas de estágio, isto é, o planejamento de cada grupo para ser discutido com a professora e os colegas, na exposição dos resultados, para a qual escolhiam uma situação que consideravam relevante para discutirem criticamente.

Em MEFI e MEFII utilizamos os mesmos procedimentos, porém no segundo semestre necessitamos de uma gravação diferenciada, na apresentação dos grupos de atividade de ensino que prepararam com o tema geral dado pela professora como proposta de discussão para auxiliar quando da preparação da sequência didática para o estágio.

Ainda para compreender o contexto da sala utilizamos um questionário que buscou dados gerais sobre os licenciandos e a relação deles com o curso que escolheram, buscando 
apreender os motivos que o levaram a fazer a licenciatura em Física, bem como o interesse pela docência e a intenção em atuar no ensino básico (Apêndice A - Questionário 1, aplicado aos alunos da disciplina de Metodologia do Ensino de Física I).

Um segundo questionário foi aplicado aos licenciandos no final da disciplina MEFII com o objetivo de obter uma análise das ações desenvolvidas nas aulas da disciplina e no estágio, além da opinião dos licenciandos em relação à contribuição alcançada para a formação docente (Apêndice A - Questionário 2, aplicado aos alunos da disciplina de Metodologia do Ensino de Física II).

Com alguns sujeitos fizemos uma gravação autorizada de entrevista semiestruturada, utilizada como instrumento de pesquisa a um grupo menor que acompanhamos com mais detalhe, com o qual buscamos a resposta para nossa questão de pesquisa mais apuradamente. Para tanto, foram feitas entrevistas em dois momentos da disciplina, uma antes do término de MEFI e outra ao final de MEFII.

A primeira entrevista buscou conhecer a trajetória escolar do licenciando do Ensino Básico até chegarem ao curso de licenciatura em Física. Ela abordava também o estágio e como tinha sido a regência e a impressão sobre a escola.

A segunda entrevista visava verificar se após o contato com as ações da disciplina e do estágio houve alguma mudança para o licenciando, como ele refletia sua ação de regência, com via o papel do professor da escola no estágio, com isso tentarmos captar o que levou a atribuir sentido à sua aprendizagem da docência.

A professora da disciplina também foi entrevistada, por intermédio de entrevista semiestruturada, na qual buscamos o seu percurso no ensino e os objetivos proposto com a estrutura que elaborada para as disciplinas de MEFI. Em MEFII, no final da disciplina, fizemos outra entrevista visando uma avaliação do processo durante $o$ ano $e$ desenvolvimento dos estágios, além de uma reflexão sobre a aprendizagem da docência que ela via como resultado da sala.

As entrevistas nos permitem as informações diretas, de forma mais abrangente, o que possibilita a captação da realidade imediata, como colocam Lüdke e André (2013), no entanto, apontam para ocorrer uma situação de liberdade de expressão do entrevistado, havendo a necessidade de interação entre o pesquisador e o entrevistado, mas a entrevista precisa permitir que isto ocorra, o que indica como opção aquelas não muito estruturadas, nas quais o sujeito da pesquisa pode discorrer sobre o assunto segundo suas experiências. As autoras citadas colocam que: 
É importante atentar para o caráter de interação que permeia a entrevista. (...) Especialmente nas entrevistas não totalmente estruturadas, onde não há a imposição de uma ordem rígida de questões, o entrevistado discorre sobre o tema proposto com base nas informações que ele detém e que no fundo são a verdadeira razão da entrevista. Na medida em que houver um clima de estímulo e de aceitação mútua, as informações fluirão de maneira natural e autêntica. A grande Vantagem da entrevista sobre outras técnicas é que ela permite a captação imediata e corrente da informação desejada, praticamente com qualquer tipo de informante e sobre os mais variados tópicos (Ibidem, p.39).

Os alunos acompanhados para um estudo mais detalhado foram seis, em MEFI, constituindo três grupos de estágio, com os quais foram feitas as entrevistas, exceto um dos sujeitos que não a realizou. No entanto, em MEFII, foram agregados outros participantes em dois dos grupos, o que ampliou o número para nove licenciandos, com os quais as entrevistas foram feitas com o mesmo objetivo, mas não abrangeu todo o grupo e foi realizada uma única entrevista com as questões das duas entrevistas anteriores.

A entrevista é um instrumento que procura nos trazer mais clareza na compreensão dos sentidos atribuídos pelos licenciandos à sua formação, mas como coloca Barros (2009), é necessário buscar não só as palavras, mas o pensamento, os desejos, ou seja, os motivos que mobilizam o sujeito às ações, como ele explicita:

[...] à luz da perspectiva histórico-cultural, não se pode considerar a existência de um "sentido puro" a ser apenas exteriorizado no contato do pesquisador e do sujeito pesquisado. Ao contrário, a partir do pensamento vygotskyano, pode-se afirmar que a linguagem em exercício numa conversação entre entrevistado-entrevistador, sobretudo, viabiliza a construção de sentidos sobre o(s) tema(s) da investigação. (...) mais importante do que se fixar nos conteúdos da fala do(s) sujeito(s) pesquisado(s), torna-se fundamental à investigação se debruçar sobre "as condições de emergência e os modos de elaboração, funcionamento e sustentação da significação, sobre a possibilidade mesmo da produção de sentidos" (Smolka, 2004, p. 9). Dentre essas condições, vale destacar um primeiro conjunto configurado, por exemplo, pelo contexto dos sujeitos pesquisados e pelas nuanças afetivo-volitivas que perpassam a construção do seu pensamento. (Ibidem, p. 180).

Alguns exemplos das entrevistas, na íntegra, se encontram no Apêndice B (Entrevista com alunos de Metodologia do Ensino de Física I), são três dos licenciando acompanhados em seus estágios. Estas transcrições são da primeira entrevista realizada que visava conhecer os licenciandos em seu percurso de ensino, bem como apreender sua visão sobre a docência. 
Desse grupo menor de licenciandos, acompanhamos também as aulas que eles desenvolveram nas diferentes escolas. Isto permitiu que tivéssemos contato, mesmo que reduzido, com o contexto escolar que eles vivenciaram, para sabermos de que "lugar falavam" ao fazerem suas apresentações na disciplina. Porém, o que foi mais relevante acompanhar foram as ações de aprendizagem da docência, a relação estabelecida com os alunos e a representação destes momentos para os licenciandos. Outra questão que este contato permitiu perceber foi a relação entre o professor e os estagiários, assim como, a relação da universidade com a escola.

Para esse grupo acompanhado, como o estágio foi observado na escola e pudemos ter contato com o professor regente, optamos por realizar também com ele uma entrevista, visando entender como à profissão de professor e como concebia o estágio.

Com esses instrumentos de pesquisa buscamos as condições para obtenção dos dados que possam nos encaminhar para algumas respostas de nosso problema, conseguindo traçar como os licenciandos atribuem sentidos à aprendizagem da docência com as ações que desenvolvem, bem como, o que o contato direto com a escola pode promover na aprendizagem da docência.

Os dados para pesquisa foram obtidos segundo diferentes instrumentos, como discutidos anteriormente, com o objetivo de captar um maior número de informações sobre o contexto estudado e sobre os sujeitos. No entanto, os diferentes instrumentos buscam possibilitar a obtenção de dados que se complementem permitindo apreender o fenômeno estudado em maior amplitude e em sua complexidade. Para compreender melhor o perfil dos licenciandos, bem como as características da turma, suas concepções sobre educação, ensino e a própria disciplina de MEF I e II utilizamos de dois tipos de questionários, os quais serão explicitados no item a seguir.

\subsubsection{Apresentação dos dados dos questionários 1 e 2}

O Questionário 1 (Q1) visou obter informações gerais sobre os licenciandos na Metodologia de Ensino de Física I (MEF I), caracterizando alguns pontos do contexto desses alunos, mas também questões referentes à docência em Física no panorama geral da sala. Nesse questionário, cada sujeito $(S)$ que forneceu sua resposta tem um número correspondente, o qual é o mesmo para todas as respostas obtidas nesse questionário, para que mesmo agrupando as respostas semelhantes não sejam perdidos os sujeitos. Ou seja, para que 
as informações fossem mantidas para cada sujeito preservamos os mesmos números atribuídos a eles no Q1 ao Questionário 2 (Q2) aplicado em MEFII, que nos trouxe informações sobre como os licenciandos refletiam sobre as ações realizadas na disciplina para a sua aprendizagem da docência e qual a relevância que a regência teve para os mesmos.

O Questionário 1 (Apêndice A), aplicado no primeiro semestre para os licenciandos, teve como questões referentes aos dados pessoais, atividade profissional que desenvolviam, instituições que cursaram o ensino básico, o porquê da escolha pela licenciatura em Física e o interesse de atuação após formados, se como professor do Ensino Médio ou se o foco da motivação estava em outra perspectiva.

As respostas relacionadas à escolha do curso de Física estão ligadas a uma perspectiva mais subjetiva, se condensam em apenas três grupos, que sugerem sentidos pessoais que a Física imprimiu em cada um, mas que podem estar ligados mais ao significado atribuído a este curso em uma dimensão social de compreensão da natureza, como o fato de a "Física explicar os fenômenos da natureza", por ser "uma ciência exata" e por "ter relações com a matemática”.

Essa questão também engloba respostas que já se aproximam do interesse pela docência e os licenciandos pensam em fazer o curso com essa intenção. Nesses casos, o objetivo é ser professor de física, então o ensino aparece com relevância e não dissociado do curso de Física. Duas respostas fornecidas à questão podem exemplificar essa situação:

\footnotetext{
Q1P4 - S6-Gosto de física e falar sobre ela, sendo assim, dar aulas de física seria uma boa forma de fazer isso.

S17-Inicialmente gostaria de ser professora. Tive algumas decepções com a carreira, embora não tenha desistido e ainda quero ser professora, mas me aproximei também na área de física teórica onde faço iniciação científica atualmente.
}

Outros casos ficam em situações diferenciadas, por quererem outro curso que só podem fazer como pós-graduação e ainda aqueles que vêm de outro curso e fazem a disciplina como optativa, assim a intencionalidade é diferente dos anteriores. Nesse sentido, vemos que a escolha pela licenciatura se faz por diferentes motivações, desde o desejo manifesto de ser professor até por orientação de outra pessoa (um professor) que julga ser o perfil daquele sujeito. As respostas dos alunos podem mostrar a gama de influências que levam a escolha do curso de licenciatura, como por exemplo: "a influência do professor durante a educação básica", "a necessidade de melhorar a educação", "começando pela formação do professor", bem como "a vontade e gosto pelo ensinar". 
É interessante notar que nem sempre os aspectos referentes ao perfil adequado para a Licenciatura em Física são determinantes para a escolha do curso de graduação, na ocasião do ingresso à universidade. Às vezes, a frustração de como teve o contato com a Física no ensino médio pode levar a querer se envolver com o ensino dessa disciplina para fazê-lo de uma maneira diferente. Uma das professoras que recebeu estágio relatou que fez o curso de Física porque no Ensino Médio não entendia os assuntos discutidos, então decidiu que queria compreender esse campo do conhecimento e ingressou na Física, foi para pesquisa e depois para o ensino. As respostas dos licenciandos também podem mostrar esse tipo de motivação, ou desmotivação que resulta em um desejo que impulsiona o sujeito:

Q1P5 - S7-Por ter grande frustração de como me apresentaram a Física no Ensino Médio, pois trabalhar a Física e seus conceitos é muito mais do que resolver exercícios ideais, a Física contextualizada é muito mais instigante e importante para a formação de um cidadão crítico.

S18-Diversas coisas: na Licenciatura os fenômenos são melhores explicados (no Bacharelado o mais importante é saber fazer a conta e não entender o que acontece); conhecer melhor as Teorias de Ensino, eu nunca fui bom em explicar as coisas, me forçando a explicá-las eu vi uma chance de crescimento pessoal.

O outro bloco refere-se às questões que visam o que os licenciandos almejam depois de concluírem o curso. Uma das perguntas é aberta com a intenção de que respondessem o que fosse mais forte em suas perspectivas futuras, bem como perceber em que dimensão os licenciandos colocavam a docência. Dentre os 20 respondentes, somente 1 pretende atuar apenas como professor nas redes de ensino, 9 deles pretendem lecionar e fazer pós-graduação, que é a maior parte deles, ou também atuar na indústria concomitantemente, sendo que 2 desejam atuar como professores, mas não como atividade principal. Os restantes pretendem fazer pós-graduação, outra graduação ou ainda atuar na área financeira por já trabalharem neste setor.

A outra questão desse bloco tem como objetivo verificar aqueles que pretendem ser professores do ensino médio quando licenciados. Nesse caso 13 deles indicaram que têm como intenção à docência na escola básica por diferentes razões, dos quais 2 já atuam como professores. Eles apontam que o fato de quererem ser professor está ligado ao prazer de ensinar, associado à concepção de uma atividade de responsabilidade social, ou como desafio, ou por gostar de trabalhar com adolescente. Há caso em que se quer ser professor, mas não em escola básica, o interesse está voltado ao ensino superior.

Dentre os licenciandos tem-se aqueles cuja intenção futura não está na docência e um deles não tem certeza se será professor, sendo que outros 5 não desejam trabalhar como 
docentes. Nesses casos, o curso representa uma graduação para alguns deles, em ciências exatas que é um foco de interesse, para outros o fato de ser licenciatura é também o ponto de atração, pelo amplo campo de trabalho, assim têm empenho em concluir o curso. Além disso, expressam interesse pelas ações desenvolvidas, percebemos que é dada importância ao ensino ou da aprendizagem da docência. No entanto, não há a docência como motivo para a futura profissão, pois em alguns casos, os licenciandos já estavam envolvidos em trabalhos distintos da docência, ligados às outras áreas, ou ainda isso se dava pelo sentido de desvalorização da profissão docente no mercado de trabalho, bem como as condições de trabalho do professor.

O Questionário 2 (Apêndice A), aplicado no segundo semestre para os licenciandos, tinha como propósito saber se as disciplinas de MEF I e II e o estágio contribuíram para formação da docência. Questões do tipo: quais foram os aspectos relevantes do estágio e as principais dificuldades; quais as concepções sobre a escola, professor e alunos e quais pontos consideram importantes para ser professor em Física foram abordados.

Quanto à contribuição do estágio, grande parte dos licenciandos elogiaram a estruturação do mesmo, bem como a organização da disciplina. Apontaram como aspecto relevante o momento de planejamento e reflexão das atividades planejadas como algo essencial para a formação docente. Outros ainda salientaram que o estágio foi importante para experimentar e colocar em prática o que aprenderam da teoria.

Quanto às dificuldades, os licenciandos mencionaram diversos aspectos, dentre eles, a dificuldade de conciliar o tempo entre o estágio, trabalho e estudo; o trabalho difícil de planejar um estágio em grupo, uma vez que as perspectivas e objetivos são bastantes distintas de um sujeito para o outro, além da dificuldade em trabalhar com algo novo.

Outra questão abordada tinha o objetivo de saber se a disciplina e o estágio contribuíram para mudar as concepções sobre a escola e alunos. A maioria dos licenciandos informaram que não houve mudanças significativas quanto às suas concepções em relação ao contexto escolar. Enquanto alguns afirmavam reconhecer a escola como um espaço de formação de cidadãos, o qual se constitui dentro da cultura e da sociedade, outros concebiam a escola não pelo seu papel, mas pelas ações exercidas pelos sujeitos que dela fazem parte. Esses por exemplo, afirmavam continuar a enxergar a falta de engajamento dos alunos, o pouco compromisso dos professores, a rigidez do currículo escolar, entre outros.

As respostas relacionadas aos pontos importantes que o licenciando considera para ser professor estavam mais direcionadas para aspectos como: ter conhecimento do conteúdo, ter 
uma boa metodologia, ter paciência, gostar do que faz, ser acessível para com os alunos, buscar compreender a realidade dos estudantes e estar aberto ao diálogo.

Observamos, portanto, que as respostas ao Q1 nos deram um panorama da sala quanto as expectativas dos licenciandos frente a escolha do curso e suas aspirações futuras, como docentes ou não. Por outro lado, as respostas relacionadas ao Q2 estavam mais voltadas às experiências vivenciadas no contexto da disciplina e do estágio. Suas respostas podem nos dar indícios de sentidos pessoais atribuídos pelos licenciandos sobre a aprendizagem da docência.

\subsubsection{Entrevistas}

Como vimos, os Questionários 1 e 2 de caráter geral e o acompanhamento das aulas das disciplinas de Metodologia I e II nos remetem a informações da estrutura das aulas, da dinâmica do conjunto da sala de aula, dos principais assuntos discutidos e dos conflitos apontados. No entanto, para compreendermos de forma mais aprofundada se as relações, discussões e ações estabelecidas nas disciplinas passam a ter sentidos para os licenciandos, para um acompanhamento mais detalhado, selecionamos alguns licenciandos com base no Questionário 1 e na localização das escolas nas quais seus estágios se realizariam.

Pelo Questionário 1, analisando as diversas questões, mas dando ênfase aquelas que abordavam a docência, buscamos encontrar sujeitos com motivos distintos no decorrer do curso e que se encontravam na disciplina de Metodologia de Ensino de Física I, assim a escolha se deu por três sujeitos, um que colocou a docência como motivo principal, como sua meta para profissão (S1); o segundo que tinha inicialmente a docência como escolha, mas quase desistiu dela no começo do curso, retomando-a como seu objetivo um pouco mais adiante no desenvolvimento do curso (S17); o terceiro que também declarou ter como sua finalidade de curso ser professor, mas com caráter um pouco diferenciado dos dois primeiros, buscando dar ênfase às opções que privilegiassem as melhores condições salariais (S6).

A proximidade com as escolas onde as regências dos estágios ocorreriam também foi um fator considerado para escolhermos os sujeitos da pesquisa, para que conseguíssemos observar as regências, as aulas nas escolas não poderiam ser coincidentes e teriam que dar a possibilidade de deslocamento de um lugar para outro caso ocorressem em um mesmo dia e período. Além disso, as escolas onde os estágios ocorreriam e o professor responsável pela classe teria que permitir a presença da pesquisadora. Deste modo foi verificado se os sujeitos 
que haviam sido escolhidos pelo Questionário 1 atendiam essas necessidades, o que foi possível nos três casos.

A partir desses três sujeitos escolhidos para acompanhamento foram acrescentados mais três, que eram os colegas que compartilhavam o estágio, assim formavam um grupo para o planejamento, desenvolvimento e avaliação do estágio. O sujeito S1 fez dupla com S19, mas não consideramos sua parceira no decorrer da MEF I porque ela não fez estágio na mesma escola de $\mathrm{S}$, além de ser de difícil acesso devido à distância em relação às outras escolas. A S17 teve seu grupo composto por S16 e S (não respondeu Q1), que passaram a fazer parte da pesquisa. O S6 fez dupla com S25 e que também foi incorporado aos sujeitos da pesquisa. Desta forma, o grupo a ser acompanhado com mais aprofundamento foi constituído por seis sujeitos.

Nosso interesse era o aprofundamento das questões de pesquisa pelo acompanhamento dos sujeitos que foram escolhidos, para tanto, com estes foi feita uma primeira entrevista (E1), realizada em dias e horários diversos, dependendo da disponibilidade de cada licenciando. Essa entrevista visava conhecer a trajetória dos licenciandos do Ensino Básico até chegarem ao curso de Licenciatura em Física; o que os levou a escolha do curso; como pensava o curso para a sua formação profissional; como a disciplina e o estágio colaboravam para a formação docente; se pretendia ser professor no Ensino Básico.

A entrevista não era nossa única fonte de dados, pois acompanhávamos as aulas da disciplina, o estágio e as ações propostas em ambos, porém a entrevista nos fornece dados muito ricos para que possamos compreender melhor as ações dos licenciandos e os sentidos que podem atribuir ao ensino-aprendizagem e a profissão que estão delineando no decorrer do curso. A entrevista busca, com a trajetória escolar do licenciando, captar sua história de estudo, de aprendizado escolar, seus sentidos construídos pelo ensino na escola, mas que não está dissociado de sua vida, nem conseguimos desemaranhar um do outro se o sujeito não nos apontar sua origem. Assim, a entrevista nos permite uma aproximação maior dos sujeitos na tentativa de obter sua história nas atividades de estudo.

$\mathrm{Na}$ disciplina de Metodologia do Ensino de Física II houve uma reestruturação dos grupos de estágio, reiterando a proposta de trabalho coletivo, mas agora com maior ênfase, com a indicação de 2 ou 3 licenciandos por grupo, o que ampliou um pouco dois dos grupos anteriores, acrescentando dois indivíduos, um em cada um deles. Assim, em MEFII tivemos mais dois sujeitos incorporados à nossa pesquisa, S12 e S14. 
Em MEFII também acompanhamos as aulas da disciplina e as ações do estágio, sendo que no final da disciplina fizemos uma segunda entrevista (E2) com os sujeitos da pesquisa. Essa entrevista tinha como objetivo obter a opinião e a reflexão dos licenciandos sobre as MEFI e MEFII, as ações nelas desenvolvidas e o estágio que realizaram, bem como os pontos relevantes para a formação docente que adquiriram sentidos para esses licenciandos.

\subsection{Os sujeitos da pesquisa}

O Quadro 1 mostra os sujeitos envolvidos na pesquisa e os instrumentos de coleta de dados utilizados nas disciplinas de Metodologia que foram obtidos com cada um deles. Os espaços coloridos mostram que obtivemos dados com aquele respectivo instrumento de pesquisa para o sujeito indicado, considerando azul para a MEFI e verde para MEFII.

\begin{tabular}{|c|c|c|c|c|c|c|}
\hline & \multicolumn{6}{|c|}{ Metodologia do Ensino de Física I } \\
\hline & $\begin{array}{l}\text { Sujeitos } \\
\quad \text { da } \\
\text { Pesquisa }\end{array}$ & $\begin{array}{c}\text { Questionário } \\
1\end{array}$ & $\begin{array}{c}\text { Apresentação } \\
\text { Planejamento } \\
\text { do Estágio } \\
\text { MEF I }\end{array}$ & $\begin{array}{c}\text { Acompanhamento } \\
\text { da Regência na } \\
\text { Escola } \\
\text { (3 aulas) }\end{array}$ & $\begin{array}{l}\text { Reflexão } \\
\text { Episódio da } \\
\text { Regência } \\
\text { MEFI }\end{array}$ & $\begin{array}{c}\text { Entrevista } \\
\quad 1\end{array}$ \\
\hline 1 & Ricardo & & & & & \\
\hline 2 & Ana & & & & & \\
\hline 3 & Paulo & & & 2 aulas & & \\
\hline 4 & Heloisa & & & & & \\
\hline 5 & Carlos & & & & & \\
\hline 6 & João & & & 2 aulas & & \\
\hline 7 & Vera & & & & & \\
\hline 8 & Marisa & & & & & \\
\hline 9 & Felipe & & & & & \\
\hline
\end{tabular}

\begin{tabular}{|c|c|c|c|c|}
\hline \multicolumn{5}{|c|}{ Metodologia do Ensino de Física II } \\
\hline $\begin{array}{c}\text { Questionário } \\
2\end{array}$ & \begin{tabular}{|c|} 
Apresentação \\
Planejamento \\
do Estágio \\
MEF II \\
\end{tabular} & $\begin{array}{c}\text { Acompanhamento } \\
\text { da Regência na } \\
\text { Escola } \\
\text { (6 aulas) }\end{array}$ & $\begin{array}{l}\text { Reflexão } \\
\text { Episódio da } \\
\text { Regência } \\
\text { MEFII }\end{array}$ & $\begin{array}{c}\text { Entrevista } \\
2\end{array}$ \\
\hline & & & & \\
\hline & & & & \\
\hline & & & & \\
\hline & & & & \\
\hline & & & & \\
\hline & & & & \\
\hline & & & & \\
\hline & & & & \\
\hline & & & & \\
\hline
\end{tabular}

Quadro 1: Sujeitos da pesquisa e instrumentos de pesquisa utilizados.

Como as ações propostas na disciplina dependem do planejamento, o qual corresponde a uma estrutura organizada intencionalmente para que o processo de ações e reflexão sobre a constituição da docência, julgamos importante também entrevistar a professora da disciplina. Com a professora também foram feitas duas entrevistas. A primeira entrevista foi como a dos licenciandos, em uma primeira parte, pedia que falasse de sua trajetória no ensino básico até o curso de Física, depois julgamos importante a trajetória dela como professora universitária. A entrevista visava ainda conhecer o que havia se estabelecido como intenções a serem alcançadas na disciplina. No final de MEFII fez-se uma segunda entrevista com a professora da disciplina para que ela falasse sobre o planejamento da mesma e a avaliação que fazia dos 
resultados, envolvendo ainda questões sobre como ela refletia sobre o estágio e o desenvolvimento dos licenciandos com as regências, as outras ações da disciplina e a aprendizagem da docência.

Os professores que receberam os alunos nas escolas, por desempenharem um papel importante no estágio, pois são eles os regentes da sala e que acompanham as ações de estágio, mesmo que o envolvimento não seja grande, eles disponibilizam parte de seu trabalho para colaborar com a formação do futuro professor, assim pensamos que seria relevante ouvilos a respeito do estágio, então estes também foram entrevistados. Para os professores das escolas foi feita uma entrevista, na qual perguntamos sobre sua trajetória escolar, a escolha pelo curso de Física, como pensavam o estágio, quais as contribuições que poderiam apontar para o estagiário, para os alunos, para a escola e para eles, bem como, as sugestões que poderiam fornecer para que essa relação se fortalecesse.

Os nomes dos sujeitos da pesquisa que estão no Quadro 1 e que serão utilizados na descrição dos dados, na análise, comentários e em qualquer outra situação foram atribuídos pela pesquisadora e todos são fictícios, não estabelecendo vínculos com os indivíduos que nos forneceram as informações e que nos permitiram sua divulgação para o estudo dessa pesquisa, segundo o termo de consentimento e dentro das normas éticas, preservando a identidade de cada um desses indivíduos.

A Figura 8 representa uma linha de tempo com as atividades do sujeito, em três momentos, o passado de onde ele nos traz as suas referências sobre escola a partir das atividades de estudo no Ensino Básico; o presente que é o foco de observação para o acompanhamento de sua trajetória, no qual consideramos a disciplina de Metodologia de Ensino de Física uma atividade, que compõe a atividade principal que é a de estudo superior; bem como, o futuro que indicará as intenções a serem alcançadas pelo sujeito.

Detalhando um pouco mais a Figura 8, a seta aponta o movimento contínuo no tempo, os triângulos maiores representam as atividades principais, sendo os menores correspondentes às outras atividades. Como o grupo é diverso, podemos ter para um mesmo licenciando o curso de Licenciatura em Física e o trabalho como atividades principais, portanto há a representação destas por triângulos distintos. No sistema de atividades que representa a Licenciatura em Física temos a disciplina de Metodologia de Ensino de Física, bem como outras, com suas ações e operações consideradas como atividades. O passado está representado considerando o estudo como atividade principal tanto para o Ensino Fundamental como para o Médio, pois não foi mencionado por nenhum dos licenciandos, nas 
entrevistas, a situação de trabalho como uma atividade principal durante essa fase, indicamos outras como atividades secundárias, Para o futuro a atividade principal, que representa os planos futuros dos licenciandos, está indicada em duas possibilidades, profissão docente ou não docente, tendo também as secundárias.

Como nos interessa observar a aprendizagem para a docência na disciplina de Metodologia de Ensino de Física, então destacamos essa atividade, em colorido, dentro do sistema de atividades do curso de Licenciatura em Física deixando-as em colorido. Os sistemas de atividades ligados à docência também estão em colorido.

O conjunto configura o movimento do sujeito na atividade de estudo, na qual vamos buscar apreender os sentidos atribuídos à aprendizagem da docência pela disciplina de Metodologia de Ensino de Física.

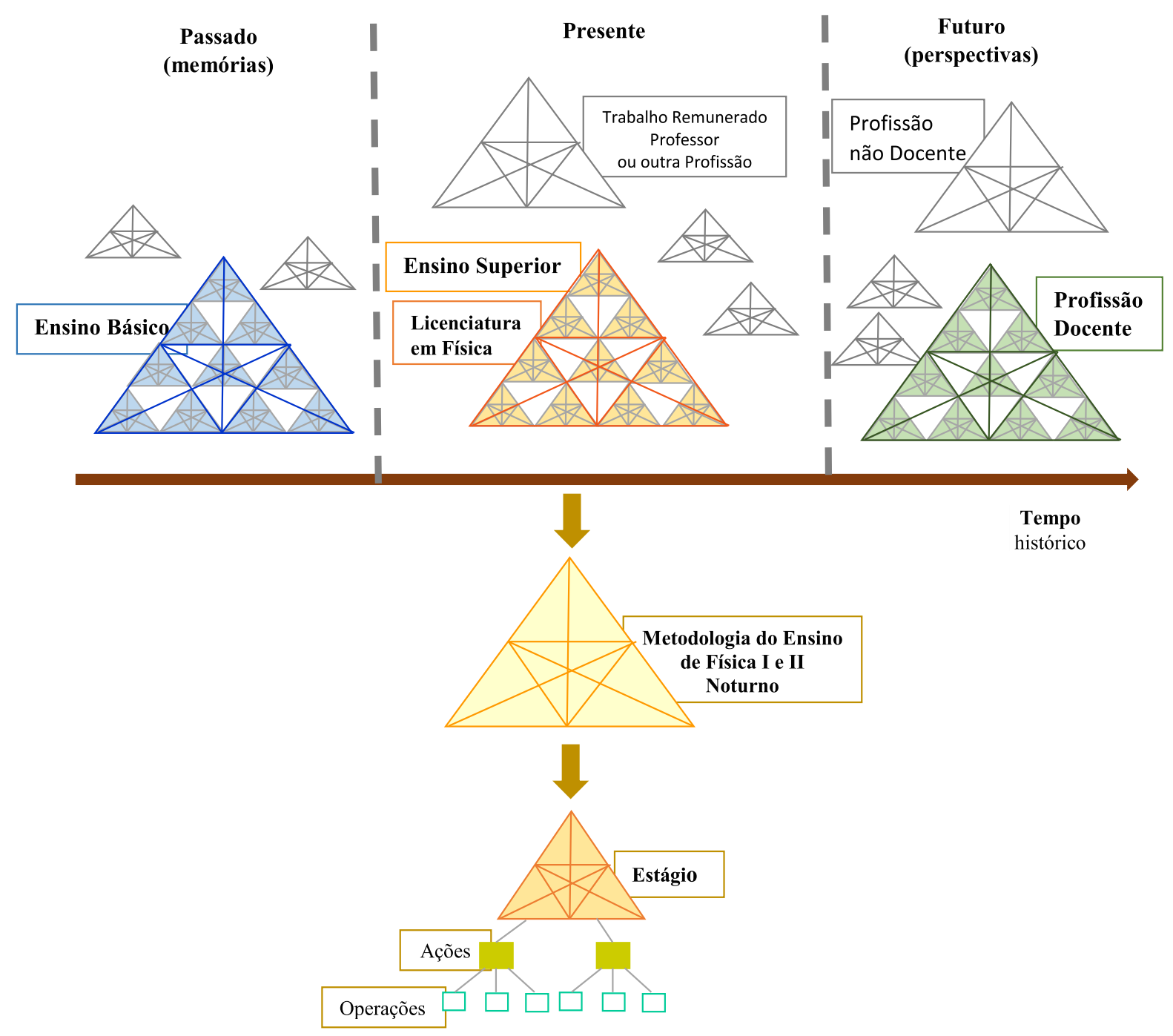

Figura 8: Movimento ontológico dos sujeitos. 


\section{Capítulo 5}

\section{A aprendizagem da docência para dois licenciandos de Física}

\begin{abstract}
Sinto-me viver vidas alheias, em mim, incompletamente, como se o meu ser participasse de todos os homens, incompletamente de cada [?], por uma soma de não-eus sintetizados num eu postiço.
\end{abstract}

Fernando Pessoa

\subsection{A análise}

Os dados obtidos pelos diversos instrumentos de pesquisa nos encaminharam à análise de dois licenciandos, Ricardo e Heloisa, no processo da atividade de estágio. O critério de escolha desses sujeitos deve-se ao fato de que ambos nos forneceram informações referentes a maior parte dos instrumentos utilizados nessa pesquisa (ver Quadro 1) e pertenciam a grupos de trabalhos diferentes, ou seja, não fizeram o estágio supervisionado na mesma escola, escolheram unidades escolares cujos contextos eram diferenciados. Além disso, os sujeitos fizeram o Ensino Básico em escolas com realidades contextuais distintas, embora tenham vivenciado situações similares, em termos de proposta de ação, como, por exemplo, a monitoria para colegas da escola em que estudavam. Entretanto, a organização e as ações de ensino não eram as mesmas.

Para esses dois licenciandos buscamos compreender como atribuíam sentidos à docência, no decorrer de suas ações na atividade de estágio, também coordenadas com as ações dos outros agentes envolvidos nas disciplinas de Metodologia do Ensino de Física I e II. Assim, como foco para nossa análise tomamos as ações dos sujeitos para a docência por essas serem constituintes da "atividade de estágio" por eles desenvolvida, e estabelecerem relação com o fenômeno estudado, sejam elas direcionadas para objetivos definidos ou executadas como tarefas. Para compreendermos uma atividade precisamos conhecer suas ações e para que fim se dirigem, mas não podemos deixar de relacioná-las ao motivo desta atividade que as gerou, para podermos perceber como se coordenam. Essas relações complexificam a análise dos dados, pois só a observação das ações não basta para nos mostrar se os sujeitos estão em atividade, precisamos acompanhar o movimento que ocorre, mas elas são fundamentais para a 
apropriação desse movimento e de sua análise. Martins (2004) aborda a relação entre necessidade, atividade, motivo e as ações em sua complexidade, buscando esclarecer o movimento que se estabelece nesse processo:

O homem, como indivíduo, nasce dotado de necessidades elementares, vitais (biológicas), que inicialmente são satisfeitas pela ação de outrem. À medida que o indivíduo começa a atuar, estabelecem-se vínculos cada vez mais dinâmicos entre as necessidades e os objetos que as elas atendem. Esses vínculos evidenciam que o estado de necessidade do sujeito não está registrado no objeto capaz de satisfazê-lo, ou seja, esse objeto precisa ser descoberto. Apenas como resultado dessa descoberta é que a necessidade vai adquirir sua objetividade e o objeto que é representado por esse processo de descoberta adquire a função estimuladora e orientadora da atividade, quer dizer, converte-se em motivo.

Em contrapartida, se a princípio do desenvolvimento a necessidade é condição para a atividade, quanto mais esta (atividade) se complexifica mais esta premissa se inverte, a tal ponto que a necessidade virá tornar-se seu resultado. Temos, por consequência, que as necessidades se transformam por meio dos objetos durante o seu processo de uso, o que reafirma a tese marxiana segundo a qual as necessidades se produzem, e possuem, portanto, uma natureza histórico-social.

Assim sendo, a atividade sustenta-se por dados motivos e orienta-se teleologicamente constituindo-se sob a forma de ações. (MARTINS, 2004, p.87)

A abordagem de Martins (2004) traz, além da complexidade do processo de uma atividade, também a definição de ação, detalhando um pouco mais a colocada por Leontiev (2006), esclarecendo que ao olharmos a ação poderemos ter dificuldades de perceber o motivo da atividade a qual está ligada, porque esse motivo não é dado na ação, mas estarão associados à atividade de estágio, na qual a ação estará inserida.

Outro ponto importante colocado por Martins é a relação entre a necessidade e o objeto que a satisfaz, que nem sempre é dada, muitas vezes o objeto tem que ser descoberto e isso torna-se o estímulo da atividade, seu motivo. Assim, pensamos que no estágio, nem sempre seu objeto está claro e é dado ao licenciando de forma que ele o apreenda a priori, mas ao descobri-lo, pode tornar-se seu motivo - a aprendizagem da docência. Isso pode então, desencadear a atribuição de sentidos à docência.

Esses sentidos não são atribuídos pelos sujeitos e permanecem sem se relacionarem, mas vão se ampliando e estabelecendo relações, o que se torna importante para a aprendizagem da docência, formando uma rede de sentidos, que é dinâmica e complexa, sendo assim, os sentidos vão mudando ou se ressignificando no movimento histórico do sujeito e sua prática. Essa rede de sentidos dos sujeitos também se relaciona com as dos 
outros sujeitos, onde vários sentidos são coincidentes o que forma um sistema mais abrangente de significações, constituindo uma rede ou teia, como propõem Rossetti-Ferreira, Amorim, Silva e Carvalho (2004), em cuja concepção nos inspiramos para pensar na relação entre os sentidos estabelecidos pelos sujeitos. Assim, essa rede de sentidos do sujeito se forma em sua atividade, nas ações que desenvolve e nas interações que ocorrem nesse sistema.

Na Figura 9, mostramos uma representação das relações que descrevemos, de uma forma bastante simplificada, pois elas não ocorrem de maneira direta e são muito complexas.

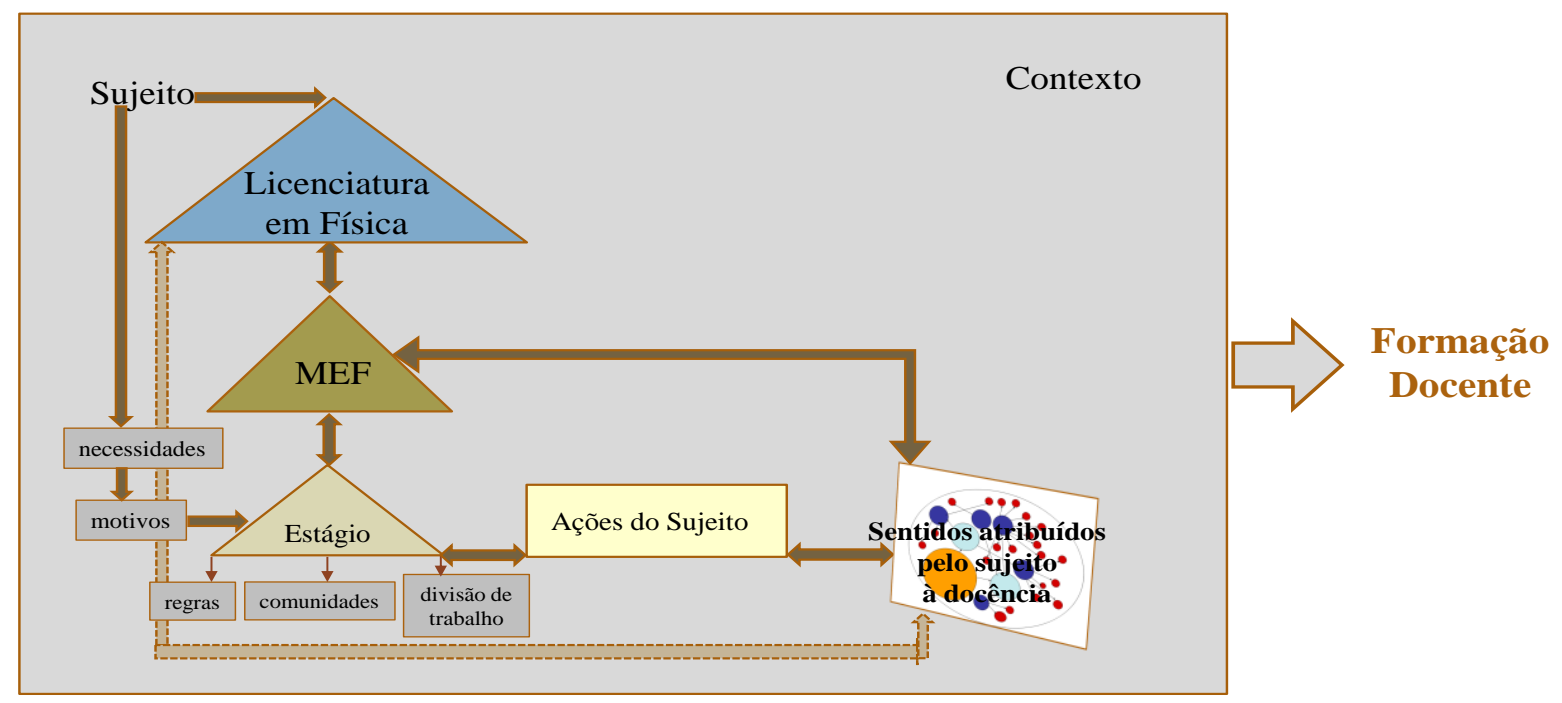

Figura 9: Relação entre o sujeito e as atividades, ações e rede de sentidos, contribuindo para formação docente.

Nessa perspectiva é que analisamos os dados coletados de Heloisa e Ricardo, que discutiremos separadamente pelo fato de o processo ser complexo e a trajetória de cada um ser diferente, além de nos interessar compreender o movimento do sujeito na atividade de estágio, o qual vai lhe permitindo atribuir sentidos à docência. Verificaremos para cada um deles como se dá a atribuição de sentidos e quais os sentidos que atribuem à docência na atividade de estágio, durante as ações para docência. Assim, estaremos analisando os licenciandos sempre em um processo dinâmico, em um movimento dialético e histórico (VIGOTSKI, 2007), no qual as relações do sujeito com outros sujeitos e com o meio, permitem que eles atribuam sentidos novos à docência, mudem seus sentidos, ou os ressignifiquem. As palavras de Vigotski elucidam esse processo de análise:

Estudar alguma coisa historicamente significa estudá-la no processo de mudança: esse é o requisito básico do método dialético. Numa pesquisa, abranger o processo de desenvolvimento de determinada coisa, em todas as suas fases de mudanças - do nascimento à morte -, significa, 
fundamentalmente, descobrir sua natureza, sua essência, uma vez que "é somente em movimento que um corpo mostra o que é" (p.68, grifos do autor).

Para capturarmos como os sujeitos atribuem sentidos e o movimento desses sentidos para docência, vamos acompanhar os dois sujeitos, Heloisa e Ricardo, em sua historicidade. Buscaremos analisar os dados coletados pelos diferentes instrumentos de pesquisa (entrevistas, discussão do planejamento das aulas, regências e reflexão sobre as regências das aulas) analisando-os e fazendo sempre que possível o cruzamento entre eles.

Salientamos que devido às atividades realizadas pelos licenciandos durante a disciplina e o estágio serem organizadas valorizando o trabalho em coletivo, poderemos agrupar mais de um sujeito, além dos pesquisados, para abordarmos um assunto em um determinado processo e contexto. Com a intenção de fazermos um recorte das situações para analisarmos nosso problema, optamos por separar os dados que obtivemos em episódios, cada qual abordando um aspecto relevante acerca da atribuição de sentidos para docência.

\subsection{Os episódios}

O processo desencadeado na atividade de estágio envolve ações que se tornam atividades para os licenciandos. São algumas dessas que vamos tomar como episódios para analisarmos as ações dos sujeitos e a relação com a atribuição de sentidos à docência, buscando evidenciar quais sentidos os sujeitos atribuíram à profissão docente. Assim sendo, selecionamos cinco episódios que permitem mostrar o movimento dos sujeitos na atividade de estágio, em sua aprendizagem da docência, quais sejam: 1- Memórias do Ensino Básico; 2Vivências da Licenciatura em Física; 3- Organização das aulas de estágio; 4- Regências das aulas de estágio; 5- Reflexão teórico-prática sobre o estágio. Os dois primeiros episódios foram selecionados buscando apreender as memórias que os sujeitos trazem de sua atividade de estudo antes da universidade e as vivências que carregam da atividade do próprio curso de Licenciatura e os últimos são aqueles decorrentes da própria disciplina de MEF e do estágio. Na Figura 10, indicamos as relações entre a atividade de estágio, as ações para docência e os episódios. 


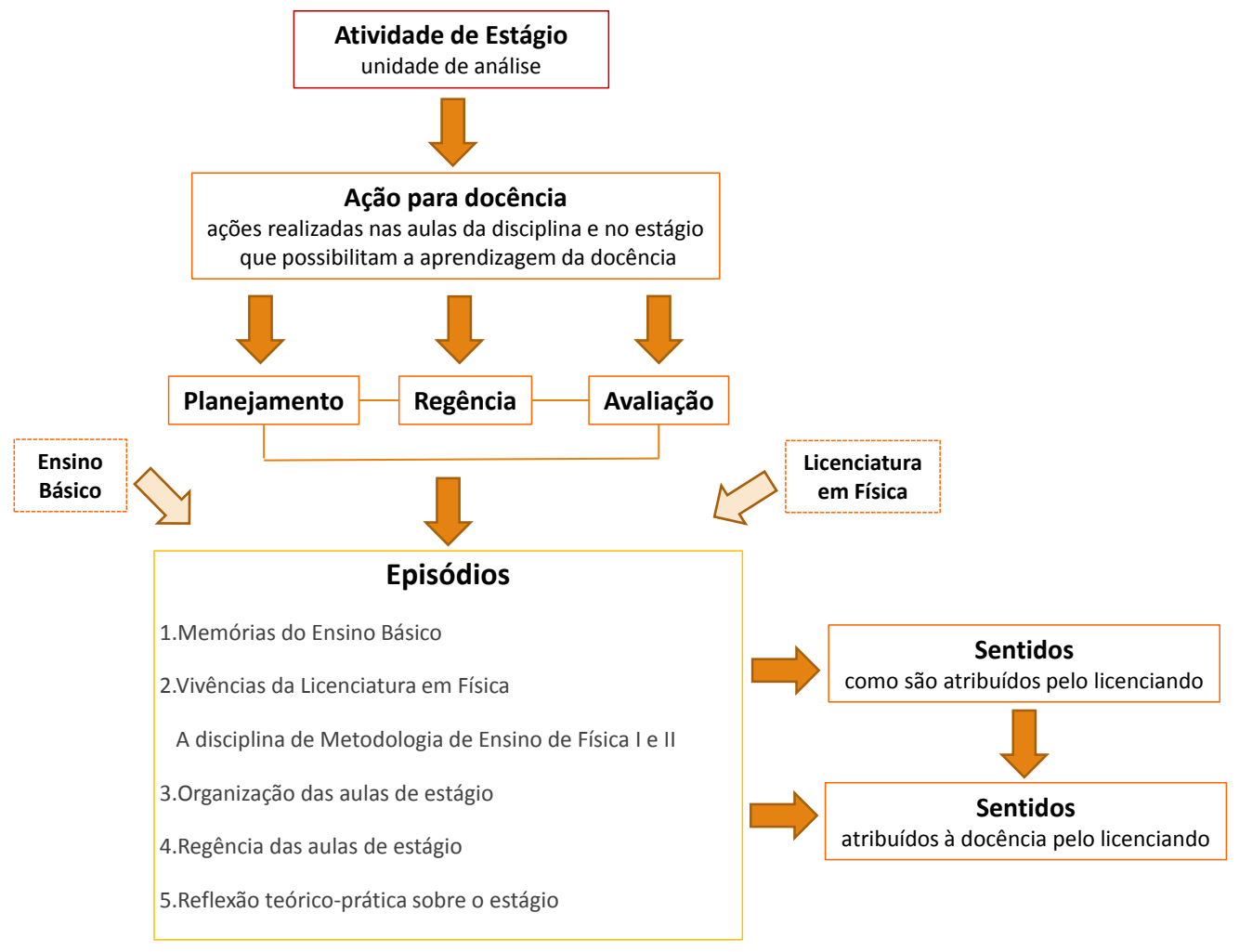

Figura 10: Relações entre a atividade de estágio, as ações para docência e os episódios de análise.

Consideramos como instrumentos de análise para os casos de Heloisa $(\mathrm{H})$ e Ricardo (R) as apresentações dos planejamentos (P1 e P2) em MEF I e II, respectivamente. Outra fonte de dados são as aulas ministradas pelos licenciandos, as regências (R1 e R2), realizadas na escola, em ambas as disciplinas, as quais acompanhamos presencialmente. No final das regências os licenciandos escolhiam algum momento relevante para eles para apresentarem à sala, trazendo reflexões (Ref1 e Ref2) que se ampliavam nas aulas das disciplinas. Esses processos eram realizados, na maior parte dos casos, em grupo, para tanto, utilizaremos a notação Gn para representar o grupo, onde, sendo $n$ o número desse grupo, para o qual consideraremos G1 para Ricardo e G2 para Heloisa.

Conforme mencionamos no capítulo anterior, as entrevistas (E1 e E2) são mais um instrumento de pesquisa que será utilizado na análise, trazendo informações dos sujeitos no contexto das disciplinas de MEF de forma mais aprofundada, uma vez que os licenciandos fornecem informações mais abrangentes que possibilitam conhecer um pouco mais da sua história na atividade de estudo, tanto pelas memórias de um tempo mais distante, onde 
passaram pelo Ensino Básico, como pelas vivências da Licenciatura em Física que se entrelaçam com as disciplinas de MEF.

O caderno de campo da pesquisadora (CC) no qual constam observações de aula das disciplinas e do estágio também é instrumento de pesquisa, utilizado para informações que não aparecerem nas outras fontes ou as explicitando com mais detalhes.

O Quadro 3 apresenta os materiais de análise com os respectivos códigos de identificação, local onde foram obtidos, o tipo de registro e o período em que foi coletado.

\begin{tabular}{|c|c|c|c|c|}
\hline Instrumento & $\begin{array}{c}\text { Código } \\
\text { utilizado na análise }\end{array}$ & Local & Tipo de registro & $\begin{array}{c}\text { Período } \\
\text { Ano de } 2013\end{array}$ \\
\hline Aulas da disciplina de MEFI & - & \multirow{2}{*}{$\begin{array}{c}\text { sala de aula da } \\
\text { disciplina de MEF }\end{array}$} & \multirow{2}{*}{$\begin{array}{l}\text { acompanhamento presencial } \\
\text { anotações no caderno de } \\
\text { campo }\end{array}$} & $1^{\circ}$ semestre \\
\hline Aulas da disciplina de MEFII & - & & & $2^{\circ}$ semestre \\
\hline Entrevista 1 & E1 & \multirow{2}{*}{$\begin{array}{l}\text { indicado pelo } \\
\text { entrevistado }\end{array}$} & \multirow{2}{*}{ gravação em audio } & meados do $1^{\circ}$ semestre \\
\hline Entrevista 2 & E2 & & & final do $2^{\circ}$ semestre \\
\hline $\begin{array}{l}\text { Apresentação e discussão do } \\
\text { Planejamento } 1\end{array}$ & $\mathrm{P} 1$ & \multirow{2}{*}{$\begin{array}{c}\text { sala de aula da } \\
\text { disciplina de } \mathrm{MEF}\end{array}$} & \multirow{2}{*}{$\begin{array}{l}\text { discussão em sala de aula } \\
\text { gravação em audio } \\
\text { cópia do planejamento }\end{array}$} & $1^{\circ}$ semestre \\
\hline $\begin{array}{l}\text { Apresentação e discussão do } \\
\text { Planejamento } 2\end{array}$ & $\mathrm{P} 2$ & & & $2^{\circ}$ semestre \\
\hline Regência 1 & A1 & \multirow{2}{*}{$\begin{array}{l}\text { escola pública } \\
\text { Ensino Básico }\end{array}$} & \multirow{2}{*}{$\begin{array}{l}\text { acompanhamento presencial } \\
\text { anotações no caderno de } \\
\text { campo }\end{array}$} & $1^{\circ}$ semestre \\
\hline Regência 2 & A2 & & & $2^{\circ}$ semestre \\
\hline Reflexão sobre a regência 1 & $\mathrm{R} 1$ & \multirow{2}{*}{$\begin{array}{c}\text { sala de aula da } \\
\text { disciplina de } \mathrm{MEF}\end{array}$} & \multirow{2}{*}{$\begin{array}{l}\text { discussão em sala de aula } \\
\text { gravação em audio }\end{array}$} & final $1^{\circ}$ semestre \\
\hline Reflexão sobre a regência 2 & $\mathrm{R} 2$ & & & final $2^{\circ}$ semestre \\
\hline Caderno de campo & $\mathrm{CC}$ & - & $\begin{array}{l}\text { anotações de todo o processo } \\
\text { acompanhado }\end{array}$ & $\begin{array}{l}\text { durante os dois } \\
\text { semestres }\end{array}$ \\
\hline
\end{tabular}

Quadro 2: Instrumentos de pesquisa, local e período de coleta, tipo de registro e códigos utilizados para análise dos dados.

Em cada um dos episódios indicaremos o caso Heloisa e o caso Ricardo separadamente, apresentando, ao final, uma síntese com um mapa com as atribuições de sentidos destes sujeitos. Concluindo os episódios montaremos a rede de sentidos de cada um dos sujeitos, buscando relacioná-los a fim de nos dar uma visão de suas interligações e das possibilidades geradas para a aprendizagem da docência na atividade de estágio, como consequência também da organização de ensino da disciplina de MEF e das interações e mediações estabelecidas nessas atividades. 


\subsubsection{Episódio 1 -Memórias do Ensino Básico}

O Ensino Básico representou a atividade de estudo para os dois licenciandos com seus motivos direcionados à aprendizagem. Ambos eram alunos dedicados e tinham o estudo como atividade principal, embora em contextos escolares diferenciados.

Ricardo fez o Ensino Fundamental em uma pequena escola particular em seu bairro, se mantendo próximo a sua comunidade, depois, por sugestão dos pais, sai de sua zona de conforto e passa a cursar o Ensino Médio distante de sua casa, em escola técnica pública estadual, o que lhe causo dificuldades de adaptação até se apropriar do novo contexto, mas conforme foi estabelecendo relações com essa outra realidade, outros sentidos foram atribuídos para o ensino, aprendizagem, trabalho compartilhado, papel do professor, dentre outros.

Heloisa teve uma outra história escolar, desde a educação infantil estudou na mesma escola particular, cuja orientação era para formação do aluno, com foco na aprendizagem, mas não só de conteúdos visava também metodologias diferenciadas, trabalho coletivo, pesquisa, dentre outros aspectos, o que proporcionava aos alunos um contexto dinâmico e crítico. As relações estabelecidas nesse processo faziam com que a escola fosse um lugar de estudo e também prazeroso para ela.

Essa retomada da vivência dos licenciandos no Ensino Básico foi relatada por eles em entrevista quando rememoravam sua trajetória por essa fase a pedido da pesquisadora, trouxeram as memórias que para eles vinham de significação construídas e se ligavam também ao nosso contexto de formação para docência. Assim, a ativação da memória no adulto é uma função mediada e é concebida como produto das relações sociais e de processos de significação (VIGOTSKI, 2007; BRAGA, 2000). Segundo Braga, (2010b), onde cita Barlett $^{11}$, "a recordação emerge em função dos interesses do presente e ligada às atividades práticas da vida cotidiana", no caso dos licenciandos, a entrevista despertou esse interesse, foram estimulados por contarem suas vidas escolares, pois a relacionavam com a situação atual de estarem se formando para docência, agora invertendo os papéis, se colocando na situação de professores, mas as memórias traziam significações que poderiam dar novos sentidos para suas formações.

Um aspecto marcante para os dois licenciandos, Ricardo e Heloisa, que trouxeram em suas memórias foi a ação realizada no Ensino Básico na qual atuaram como monitores de

\footnotetext{
${ }^{11}$ BARTLETT, F. C. Remembering: a study in experimental and social psychology, $8^{\mathrm{a}}$ reimp. Cambridge: Cambridge University Press, 1977.
} 
colegas de séries anteriores a deles ou de suas próprias salas. Essa monitoria para eles não foi uma simples tarefa a ser cumprida afim de tirar dúvidas dos colegas, mas sim uma ação na qual se envolveram e puderam perceber pontos importantes para a docência. Tais pontos foram tão relevantes para eles que a memória os fez ressignificá-los como elementos estruturantes para a formação profissional docente.

\section{A. Caso Heloisa}

Ao pedirmos para Heloisa falar de sua trajetória no Ensino Básico, uma vivência que se colocou com importância foi a monitoria que realizou no seu período escolar. A memória dessa monitoria resgata situações vividas por ela que surgem ressignificadas dando-lhe respaldo ao falar de suas escolhas e de sua aprendizagem da docência. Essas memórias trazem às falas, um pensamento do presente, mas com um passado marcado e que permite que a licencianda analise, atualmente, os sentidos que atribui ao ensino e à docência com as experiências que teve e que lhe fizeram escolher ser professora.

Para Heloisa a monitoria se coloca como algo esperado e desejado, pois no colégio em que estudou a prática da monitoria era comum e desenvolvida pela maior parte dos alunos, assim, participou dessa ação desde o início do Ensino Médio. Em um excerto de sua entrevista ela comenta sobre esse assunto:

E1(Heloisa): [...] a primeira oportunidade é quando a gente tá no primeiro ano do colegial, que tem uma atividade de monitoria de matemática pro pessoal da oitava, aí eu sempre fazia parte, sempre fazia parte dessas coisas, então eu era monitora no primeiro para ajudar o pessoal da oitava com matemática, no segundo fui monitora para ajudar o primeiro ano em matemática, e no terceiro fui monitora para ajudar o primeiro também Matemática e Física, então sempre gostei de ensinar e de ter contato.

Há um movimento de ação para o ensino que vem de uma necessidade da escola, mas que encontra nela uma motivação pessoal que acreditamos tornar essa ação importante para ela. Ao atuar na monitoria nos parece que o fato de estar exercendo uma ação voltada ao ensino a estimulava, ao desempenhar essa ação várias vezes fica evidenciado que ensinar, compartilhar um aprendizado do qual já se apropriou é para ela um motivo eficaz nessa monitoria. Com isso ela pretendia auxiliar os alunos das séries anteriores, o que faz com que o 
sentido atribuído ao ensino seja o da aprendizagem, porém não no mesmo patamar que o da professora da turma, mas como colaboração, como complementar a aprendizagem dos alunos.

Ela continua participando das monitorias em todo seu Ensino Médio, seguindo o que já fazia, mas no último ano deste nível de ensino, para participar precisa ter o curso preparatório, como explica em um trecho de sua entrevista:

E1(Heloisa): [...] no $3^{\circ}$ Colegial tem essa atividade pra você monitorar os alunos das outras séries, tem curso preparatório pra isso. Foi um momento de esclarecimento na minha cabeça, porque na primeira série, você tem sete anos, não sabe nem direito o que tá acontecendo e faz um projeto de conhecer o Rio Pinheiros, a nascente do Rio Pinheiros, faz um trabalho assim; daí no segundo ano a gente vai visitar o Rio Pinheiros também, então foi um momento que vi que toda a minha trajetória na escola tinha sido muito bem pensada, que tudo fazia sentido, que tudo estava muito conectado, por exemplo, minhas aulas da quarta série foram muito usadas nas aulas do $3^{\circ}$ Colegial. Foi uma coisa incrível, eu gostei muito de saber disso, entendeu? [...] Eu sempre tive muita vontade de ser professora.

No final do Ensino Médio com curso preparatório para o trabalho de monitoria Heloisa toma consciência que sua trajetória na escola fazia parte de um planejamento intencional da equipe de educadores. Isso lhe trouxe um outro sentido do papel do ensino e do professor que está ligado a organização das atividades de ensino não só pensando nas ações a serem desenvolvidas em cada aula e no decorrer do planejamento, mas também ao longo do processo de escolarização. Essa organização do ensino, associada a teoria e a prática, permite promover a apropriação de conhecimentos, transformações nos sujeitos envolvidos e no contexto escolar (MOURA et al., 2010)

Essa visão mais ampla do ensino traz a noção do papel da educação escolar na sociedade, de sistematizar os conhecimentos produzidos pela humanidade e também permitir que os sujeitos possam, ao apreenderem esses conhecimentos, agir sobre o mundo em que se inserem. Heloisa não expressou dessa forma, mas ficou evidente que ela percebeu com clareza que a escola tinha uma proposta intencional com a sistematização do conhecimento, para que seus alunos dele se apropriassem, o que nos leva a inferir que o significado intencional do ensino escolar e o sentido pessoal captado por ela foram coincidentes.

No mesmo trecho da entrevista aparece a afirmação de que ela sempre quis ser professora, o que nos sugere que a monitoria ao despertar seu sentido para a organização do ensino, do currículo posto em prática, do trabalho coletivo, lhe estimulou a pensar na possibilidade de ser professora, mas de uma forma mais consciente, percebendo a intencionalidade da ação pedagógica. Desta forma, ficando mais evidente para ela o 
significado da atividade do professor de organizar o ensino e propor ações de aprendizagem que busquem colocar os alunos em atividade, para que possam nelas atribuírem o sentido de aprender, como diz Asbahr (2005b):

A significação social da atividade pedagógica do educador é justamente
proporcionar condições para que os alunos aprendam, ou melhor, engajem-se
em atividades de aprendizagem. Para tanto, o professor é responsável por
organizar situações propiciadoras da aprendizagem, levando em conta os
conteúdos a serem transmitidos e a melhor maneira de fazê-lo (p.113).

Em outro excerto da entrevista de Heloisa, a organização da proposta de ensino aparece claramente na ação desenvolvida na monitoria pelos alunos, que fazia parte de uma atividade de aprendizagem elaborada para uma determinada série. Os monitores discutiam com os professores, eram preparados pelos docentes para desenvolverem o trabalho com os outros alunos, tendo como fim a aprendizagem de conteúdo, observação, investigação, avaliação, dentre outros. Desta maneira, nesse tipo de trabalho os processos mediacionais eram orientados pelos monitores, tendo o apoio dos professores.

E1(Heloisa): [...] a gente primeiro tinha uma preparação geral, todos os monitores, depois tinha uma formação específica, daí estavam os monitores da $4^{\mathrm{a}}$ série com a professora da $4^{\mathrm{a}}$ série, e com a coordenadora, pra falar quais eram os objetivos daquele projeto, qual iria ser a metodologia, como que as coisas iriam funcionar. [...]

$\mathrm{Na} 7^{\mathrm{a}}$ série o projeto começava a ficar mais encorpado, eram três dias, visitando várias coisas lá em Parati e arredores. O legal no Colégio Y era que no final de cada dia, à noite depois do jantar, tinha um negócio que chamava plenária, que é uma pergunta polêmica, que os alunos tinham que arranjar alguma alternativa, tinham que resolver o problema, usando tudo que eles aprenderam durante o dia, e daí a gente estava lá pra orientar, tipo a gente não ia dar a resposta, a gente queria que eles pensassem, então a nossa ação era mais de orientar. Por isso que eu tenho extrema dificuldade de dar respostas pros alunos. Não consigo, sempre estou perguntando pra fazer eles pensarem. O Colégio Y me ajudou, assim extremamente, me formou de uma forma muito boa.

A preparação feita pelo Colégio para que os alunos fizessem a monitoria em situações de viagens ou outras, requeria um planejamento da atividade de ensino, das ações a serem desenvolvidas com os alunos. Isso fez com que Heloisa incorporasse uma forma de pensar o ensino que carrega consigo como uma das características para ser professora e que se constituiu como uma forte base em sua formação como aluna, que veio de sua experiência com a monitoria, que está relacionada a conceber o docente como o sujeito que orienta os 
alunos em suas ações na atividade de aprendizagem, promovendo os meios mediacionais, permitindo que atribuam sentidos a essa aprendizagem.

Outro ponto importante para o ensino e aprendizagem que pode ser colocado como um sentido atribuído por ela está ligado a não dar respostas prontas aos alunos, mas fazê-los pensar. Com isso o professor precisa desenvolver ações para orientá-los a refletirem sobre o tema em estudo, trazendo-lhes um problema que os impulsione a buscar soluções, a discutirem, a trabalharem coletivamente, estabelecerem relações, enfim pensarem sobre o tema, organizando o que aprenderam. Essa concepção de ensino foi apreendida por Heloisa pela perspectiva de ensino de seu Colégio.

As memórias que Heloisa traz do Ensino Básico possibilitaram que ela nos apontasse, algumas peças que nos permitiram compreender como alguns sentidos foram atribuídos à docência por ela e como os trouxe explicitados atualmente. A escola que ela estudou, sua trajetória de estudo, antes da universidade, a marcou fortemente, tanto que ela considera que o Colégio a formou de maneira muito boa. Assim, deixou marcas também em sua concepção de ensino e aprendizagem.

\section{B. Caso Ricardo}

A trajetória de Ricardo pelo Ensino Básico foi relatada por ele como duas experiências diferenciadas, uma durante seus estudos no Ensino Fundamental que realizou em uma escola pequena, particular, no bairro onde morava. Essa escola era bastante organizada, tanto nas normas como nas ações dos professores em sala de aula, utilizavam livros, apostilas, o que refletia na mesma exigência para os alunos. Porém, essa característica, não levava os alunos a organizarem sua aprendizagem, ao contrário, recebiam os materiais prontos, precisavam fazer as tarefas.

Esse contexto escolar fez com que Ricardo tivesse uma concepção de instituições de ensino com essas características, bem como, de um ensino no qual os docentes traziam tudo pronto para os alunos, mas estes não participavam ativamente do processo. Isso o leva a atribuir sentido ao ensino ligado a necessidade de uma organização e disponibilidade de materiais para o aluno para que sua aprendizagem possa ocorrer, bem como o sentido para a aprendizagem vinculado a uma ideia do aluno não se posicionar diante daquilo que está estudando. 
Ele relata essa situação em trechos de sua entrevista, quando menciona a mudança de escola, para o Ensino Médio, apontando as diferenças que percebeu e o que sentia, como mostra o excerto abaixo:

E1(Ricardo): E foi engraçado porque eu tive um choque cultural, social e intelectual muito grande, achava que quando os professores faziam discussões, o professor de História trazia textos de diversos pontos de vista e, eu tava acostumado a seguir um livro, uma apostila, de repente a gente tinha que se posicionar, fazer debates, achava que eu não tava aprendendo a estudar, engraçado porque achava que eu tava perdendo tempo, falava: "Como assim, não tem material, não tem livro, estou lendo textos assim aleatórios, como assim?"[...] Aí eu comecei a perceber que vinha gente de tudo quanto era canto, então tinha gente de Taboão, de Cotia, que vinha com pensamentos diferentes, com culturas diferentes e eu tinha que lidar com isso. Então, o primeiro ano foi assim: "O que eu tô fazendo aqui, como isso é diferente pra mim", eu estava acostumado com uma coisa muito certinha, como eu falei. Eu acho que tudo isso é importante porque como falei, definiu muito bem onde eu estou agora. Comecei a entender um pouquinho o sentido das aulas, porque a gente tinha mais debates, porque tinha mais discussões, porque tinha aula vaga, porque tinha professores que eram um pouco mais preparados, outros menos, os problemas da escola pública, esta tensão escola particular e escola pública, isso foi ficando um pouco mais claro conforme o tempo ia passando pra mim [...]

O contato com a nova escola, os professores que lhe trouxeram outra concepção das aulas, do ensino, a relação com os colegas de realidades sociais distintas e o contexto escolar como um todo, foram, paulatinamente, alterando o sentido de ensino para Ricardo, pelas contradições que vivenciou, gerada pela mudança de local de estudo. Essa mudança de escola permitiu o alargamento das relações sociais do sujeito, indo para outro bairro, conhecendo pessoas de outros locais, possibilitou ainda a vivência em uma escola com vários problemas, mas com muitas alternativas, que o fez emitir suas opiniões, fazer escolhas, dando-lhe uma experiência marcante. Ricardo passou a atribuir ao ensino a possibilidade de diálogo, de analisar criticamente uma situação e de junto com o professor também se responsabilizar pela sua aprendizagem.

No decorrer de sua trajetória na escola ele realiza a atividade de estudo com dedicação, por motivos que de certo modo se complementavam, tinha como meta a aprendizagem, mas também pensava em fazer um vestibular no final do Ensino Médio. Como estava movido por motivos eficazes ele tinha um bom desempenho nos estudos e foi convidado para ser monitor de Física pela sua professora. Podemos perceber a importância que essa monitoria teve para ele, tanto que marca decisões futuras, a fala de Ricardo durante a entrevista nos mostra a relação que estabeleceu com essa monitoria: 
E1(Ricardo): [...] também aí surgiu uma coisa inesperada, no final do primeiro ano, quando minha professora de Física me convida, convida outros alunos, não só da minha turma, mas das outras turmas que ela dava aula, pra ser monitor de Física. Até então eu ia ser engenheiro [...].

E eu tomei aquilo como uma coisa muito forte pra mim. Eu falei se eu vou dar aula, vou dar monitoria, vou precisar aprender o que é dar aula. Foi essa a pergunta que essa professora deixou comigo, mas: "Como que se dá aula?", foi a primeira pergunta que eu fiz: "Como é que vou fazer com que meus alunos aprendam?" Aí eu fiquei pensado, tenho que responder essas perguntas pra mim de alguma forma. Mas, tem outro lado, porque, aí eu me perguntei: "Por que os alunos têm dificuldades?" Aí eu comecei a perceber que não adiantava resolver os exercícios com eles, "Se ficar resolvendo exercícios será que eles vão entender, porque parece que eles não entendem a exposição do professor, então não vai adiantar resolver exercícios, eles vão sem saber a Física que está por trás, e se eu tentasse ser professor mesmo, se eu tentasse dar aula?" - Eu pensei assim, mas pensei - "Será que a professora não vai se sentir ofendida, será que ela vai gostar, vai apoiar?", enfim eu fiquei pensando tudo isso. Aí eu falei com a professora -"Professora, eu pensei bastante na proposta eu aceito tudo, mas eu penso uma coisa, acho que os alunos não estão apreendendo não porque eles não saibam fazer os exercícios, mas porque parece que de alguma forma aquelas fórmulas, aquelas coisas não fazem sentido pra eles, eu estava pensando em dar aula mesmo, em ser professor e não ficar resolvendo exercícios. Tudo bem pra senhora? O que a senhora acha?"

Para Ricardo a tarefa proposta pela professora de Física do Ensino Médio de fazer a monitoria para seus colegas, sem uma diretriz determinada, o levou a pensar mais profundamente em como realizar aquela ação, ele não se propôs a desenvolvê-la como uma simples tarefa, mas buscou compreender os motivos que o moveriam para aquela ação, tentando compreender o que desfavorecia o aprendizado dos alunos, ao que atribuiu a falta de sentido na forma como a Ciência era transmitida para eles nas aulas. Quando ele disse que as fórmulas não faziam sentido para seus colegas que iam procurar a monitoria podemos pensar que talvez esses alunos não tivessem se apropriado dos conceitos necessários ao estudo da Física. Assim podem ter se fixado em realizações de tarefas sem sentido para eles, o que não os levava à essência dos conceitos e consequentemente não sabiam transpor as ideias discutidas quando as situações eram modificadas.

Essa observação que Ricardo fez em relação aos conteúdos de Física não fazerem sentido para os alunos nos leva a considerar a necessidade da escola priorizar o pensamento teórico. Segundo Davidov, a escola precisa proporcionar aos indivíduos a apropriação dos conhecimentos teóricos construídos historicamente, ele propõe o estudo dos bens culturais e científicos da humanidade por percurso de investigação dado por ações de aprendizagem. Explicitando um pouco mais: 
[...] faz-se necessária uma estrutura da atividade do aprender incluindo uma tarefa de aprendizagem, as ações de aprendizagem e ações de acompanhamento e avaliação, visando à compreensão do objeto de estudo em suas relações. O resultado disso é que os alunos aprendem como pensar teoricamente a respeito de um objeto de estudo e, com isso, formar um conceito teórico apropriado desse objeto para lidar praticamente com ele em situações concretas da vida (ibidem, p.20).

Ao pensar na ação que teria que realizar na monitoria, Ricardo necessita da análise do contexto da sala de aula e das relações que se estabelecem, onde ele e seus colegas estão inseridos e atuando em conjunto com a professora. Acreditamos que esse processo de análise reflexiva move a elabor/ação, organiz/ação, realiz/ação, avali/ação e análise das ações dos sujeitos e pode levá-los à transformação, entendendo que esta ação não é o fazer em si mas está dialeticamente associada ao pensamento teórico. Desta forma, ao refletir sobre o que levava os colegas a terem dificuldades na disciplina de Física fez com que Ricardo passasse a refletir sobre a organização de aulas com atividades de ensino que mobilizassem os alunos ao estudo da Física e não apenas optasse por resolver exercício com eles, isto fez com que mudasse sua posição, passasse a atuar como um sujeito que tinha como motivo ensinar na monitoria, o que coincidia com o papel de professor. Refletir sobre um problema na abordagem do pensamento teórico e na perspectiva da teoria histórico-cultural, pressupõe a inserção em uma atividade na qual o movimento de mudança faz parte do processo e as ações do sujeito são conscientes. Semenova (1996), aponta a reflexão como um dos elementos do pensamento teórico de Davidov e, de acordo com o autor, ela coloca: “O pensamento teórico decompõe-se em diversos elementos. Comporta, antes de mais nada, a reflexão. Essa consiste na descoberta, por parte do sujeito, das razões de suas ações e de sua correspondência com as condições do problema" (p.166).

$\mathrm{O}$ fato de se propor a ensinar na monitoria e não cumpri-la somente como uma tarefa, levou-o a se aproximar do trabalho docente; o que podemos observar em trechos da entrevista de Ricardo, no entanto, é importante notar que ele assumiu para si esse compromisso e se colocou em atividade, fazendo o problema da aprendizagem dos alunos da monitoria a sua meta e direcionou suas ações para o objetivo de organizar as aulas para promover a compreensão de seus colegas pelos temas de Física estudados. Seus questionamentos aparecem no excerto, abaixo:

E1(Ricardo): [...] Por que vou ensinar Física? Para quê? O que vou ensinar? O que é relevante? Que foram coisas que depois fiz ligação na Universidade, nas matérias de Ensino. Então, essa parte do diálogo, essa parte dos 
questionamentos me influenciaram de forma muito grande, pra no final começar a trabalhar da mesma forma com os alunos. Aí, eu tive na primeira aula dois alunos, uma vez por semana, na sexta-feira, durava uma hora, uma hora e meia a aula. Na segunda semana vieram cinco alunos. Na outra semana vieram 10 alunos, na outra vinte, na outra trinta até que eu estava com 40 alunos semanalmente.

Com isso, pensamos que ele fez da monitoria uma atividade com características de uma pré-formação para a docência, embora ele não estivesse em um curso de licenciatura quando atuando naquele espaço e não tivesse também o papel do professor. No entanto, ele capturou o significado da docência, buscando criar sentidos para ensinar, o que percebemos pelas questões que ele se coloca que pertencem ao universo do professor.

Ricardo tinha as perguntas para direcioná-lo, com a reflexão sobre elas e a convicção de que precisava elaborar aulas para a monitoria que levassem os alunos, seus colegas, a aprendizagem de alguns conceitos de Física. Havia chegado à conclusão que suas aulas não poderiam repetir todas as ações da professora, teria que propor outras ações. Mas ele não tinha clareza do que precisaria mudar e como faria isso, o leva a pedir auxílio às pessoas próximas, então procura sua mãe, como nos relata:

E1(Ricardo): Minha mãe sempre falou que é importante que a gente ouça mais as outras pessoas e fale menos. [...]

[...] Esses livros foram determinantes pra eu decidir também ser professor, que foram: "Pais brilhantes, professores fascinantes" e o outro chamado "Filhos brilhantes, alunos fascinantes".

Com o desafio da monitoria posto, recorreu, primeiramente, a sua mãe para pedir uma orientação, a qual o conduziu à leitura sobre uma introdução às questões de educação e o orientou a ouvir os alunos para que pudesse entender suas dúvidas, como um dos pontos importantes para estabelecer a relação professor-aluno, na qual ao ouvi-los, o professor teria maiores condições de entender as dificuldades dos alunos. Essa foi uma característica importante para ser professor que gerou em Ricardo um sentido para docência.

As leituras indicadas pela mãe sobre educação buscavam uma forma acessível para a idade dele de tratar as relações professor-aluno, com exemplos de sala de aula e como lidar com as angustias das situações decorrentes desse contexto. Esse apoio ao lado dos modelos de professor que tinha em seu curso do Ensino Médio colaborou com Ricardo para que ele fosse organizando e testando seus modelos de aula, com diferentes atividades de ensino.

Pelos diversos modelos de aula que lhe foram apresentados por seus professores do Ensino Básico ele não conseguia ter uma concepção clara sobre as ações de ensino que 
colocariam os alunos em movimento de aprendizagem. Então, decidiu experimentar o modelo de alguns professores, um por causa de sua organização, outro pelas discussões, ou pelas leituras críticas, ou por tantos outros aspectos, assim, tirando de cada um deles uma ação que julgava importante para o seu ensino e a aprendizagem dos alunos na monitoria.

Ao fazer essa opção já havia estabelecido uma seleção entre as aulas, escolheu ações diferenciadas, com isso pensamos que ele julgava existir algo nessas ações que fossem importantes para favorecer a aprendizagem dos alunos e que poderiam fazer parte de seus sentidos estabelecidos para ser professor e que estariam ligados às aulas que também tinha como aluno, por exemplo: organização, promover discussões entre os alunos, utilizar leituras e fazer sua análise, proporcionando assim a participação ativa da classe e o diálogo, que já se colocava como estruturante nas ações docentes para ele. A presença desses mediadores, tanto instrumentais, como principalmente, os signos, as aulas dos professores, as leituras, as conversas com a mãe, as relações com os colegas, as próprias aulas de monitoria etc, foram constituindo o ensinar e o aprender de Ricardo, como coloca Lima (2005):

[...] cada um de nós leva consigo o fantasma do outro, real ou virtualmente presente em nossas vidas. As relações sociais geram efeitos singulares em cada sujeito. Os indivíduos são singulares não porque escapam do social, mas porque sua história pessoal vai sendo forjada na sua relação com o mundo, com os outros e com eles próprios (p.28, grifos do autor).

No decorrer dessas aulas, ele percebeu que ao dialogar com os alunos conseguia um melhor resultado, tanto em relação ao interesse dos alunos, quanto à compreensão dos conteúdos discutidos. Na preparação das atividades de ensino ele buscava ajuda em livros, com sua mãe, na observação que fazia de seus professores e de suas próprias aulas, fazendo disto uma reflexão crítica que ia direcionando-o a organizar suas ações, tanto para planejar as aulas, como para conduzi-las e, depois avaliá-las, buscando uma análise dessa atividade. Isso nos remete, novamente, a pensar Ricardo em um processo de formação de seu pensamento teórico em relação ao estabelecimento de ações para suas aulas, com conotação de ações para docência.

Ele tinha como propósito que os alunos aprendessem, então o processo de preparação, avaliação e redirecionamento, se necessário, das ações era fundamental. Desta forma, pensamos que as ações na monitoria iam criando e recriando seus sentidos para docência, mas ele tinha a consciência de que seu objetivo precisava atingir, como meta, a aprendizagem dos alunos, como explicita Leontiev (2006): 
Para que uma ação surja, é necessário que seu objetivo (seu propósito direto) seja percebido em sua relação com o motivo da atividade da qual ele faz parte. Este é um ponto extremamente importante. Segue-se daí que o propósito de um mesmo ato pode ser percebido diferentemente, dependendo de qual é o motivo que surge precisamente em conexão com ele. Assim, o sentido da ação também muda para o sujeito (p. 72).

Pensamos que todas essas interlocuções atuaram como mediadores para que Ricardo avançasse em seu aprendizado no ensino de Física e nas relações com os alunos, bem como no papel importante da monitoria objetivada nas ações das aulas.

A necessidade da aprendizagem de ações para ensinar o colocou em atividade, o que também modificou seu motivo profissional, antes direcionado para engenharia e depois para o ensino e para o curso de Licenciatura em Física. O excerto abaixo da entrevista de Ricardo mostra a importância da monitoria em seu percurso escolar e de outras ações da escola que provocaram mudanças em sua escolha profissional.

E1(Ricardo): E aí eu comecei a gostar tanto, gostar tanto, tanto desse ato de dar aula, de estar com pessoas, eu era uma pessoa muito tímida, então isso fez eu me soltar bastante, fez eu socializar bastante, tinha um reconhecimento, aí o negócio estressante da engenharia ... foi quando falei: "será que eu quero ser mesmo engenheiro?" (...) Quando eu conheci o Instituto de Física, quando vi aquilo, eu falei é aqui que quero estar. Eu quero ser professor. Eu vi o Instituto, eu vi as pessoas estudando, lembro que vi um aluno com um livro, naquelas mesinhas da lanchonete, estava com um livro de Cosmologia, vi a foto do Universo, eu falei: "quero ser professor".

A mudança de seu motivo em relação à escolha da profissão foi influenciada pela própria ação de ensinar durante a monitoria, pois à medida que valorizava o ato do diálogo com os alunos, eles se envolviam com as atividades de aprendizagem e nas relações com alunos, o que lhe trazia prazer em realizar as aulas e aumentava sua segurança gerando, para ele também, uma aprendizagem. Assim, acreditamos que Ricardo em seu desenvolvimento no ensino e na aprendizagem foi atribuindo um forte sentindo ao ato de ouvir os alunos, estabelecendo um processo dialógico em sala de aula como condição necessária para se aproximar de seu motivo de ensinar e mobilizar nos alunos motivos para a aprendizagem.

Esse processo pode explicar os resultados positivos que ele relata ter alcançado com a monitoria e o fato dos alunos aprenderem alguns conceitos de Física e apreenderem uma outra relação entre professor-aluno, como ele explicita: 
E1(Ricardo): [...] eles sempre me davam resultados positivos, o que estava fazendo estava atingido eles de alguma forma, então pelo fato de ver que o trabalho meu estava sendo reconhecido, por ver que eles estavam aprendendo, eles estavam gostando, queriam que eu, com aquela idade, fosse professor deles, pra mim isso indicava que havia descoberto alguma coisa que eu sabia fazer. Hoje, naquela época eu via como um talento, hoje eu sei que não é um talento, é alguma coisa que eu construí, ou quer dizer, me ajudaram a construir.

A ideia de talento, que Ricardo passou a pensar que havia descoberto, nos remete a algo inato, que ao contato com alguma situação favorável ou pessoas pode ser despertado. No entanto, quando tomamos como referencial a teoria histórico-cultural não entendemos dessa maneira, mas como um processo de internalização que a pessoa faz pelas inter-relações que estabelece com os outros, com a cultura e os conhecimentos historicamente construídos pela humanidade. Como coloca Bock (2004):

O trabalho e a vida em sociedade são duas características da vida humana que vão permitir um salto de qualidade no desenvolvimento humano. $\mathrm{O}$ homem liberta-se de suas limitações biológicas para "inventar" a condição humana. Queremos com isso frisar a ideia de que as habilidades e os comportamentos humanos, a partir daquele momento, não estavam mais previstos pelo código genético. Por isso dizemos que o homem não estava mais submetido às leis biológicas e sim as leis sócio-históricas (p.28).

Pelos resultados obtidos na monitoria, Ricardo percebeu que algo foi mobilizado na relação entre ele e os alunos, para o que diríamos que estavam em atividade com um objetivo comum, a aprendizagem de um determinado conhecimento de ciências. No entanto, naquele momento ele não percebeu que realizavam um trabalho coletivo, não com as mesmas ações, pois estavam em níveis hierárquicos distintos, mas com o mesmo objetivo, assim ele atribuiu os resultados a "alguma coisa que sabia fazer", ao seu talento. Só agora, ao repensar esse processo é que traz à mente outra concepção, a de ensino e aprendizagem como construção coletiva.

Os resultados de seu trabalho como monitor sendo reconhecido pelos alunos foi um fator motivador para Ricardo, para que na organização das ações de ensino conseguisse perceber aquelas que mobilizavam mais os alunos. Acreditamos que essa consciência lhe permitirá a intencionalidade em suas ações de ensino, o que pode levar a maior possibilidade de atividades de ensino que promovam motivos eficazes nos alunos. 


\section{Síntese - Mapa dos sentidos}

Leontiev (2006) nos coloca as mudanças nas etapas de desenvolvimentos aliadas a uma nova posição social da criança. Mesmo não sendo exatamente o processo de Ricardo e Heloisa, que não seja uma mudança de etapa que tenham sofrido nessa ocasião, a monitoria os influenciou bastante, de forma que a citam na entrevista como um marco muito importante em suas formações. Podemos pensar que a experiência com a monitoria os influenciou de maneira significativa fazendo-os passar por uma mudança, que lhes trouxe novas aprendizagens proporcionando novos sentidos para pensarem as ações de ensino. Isto os fez pensar na escolha da futura profissão, o que os levou, mais tarde, a outra situação social, o ensino superior, ampliando suas relações.

Essa motivação pela busca da profissão docente não se fez de forma espontânea, mas pela aquisição de um novo motivo, de ensinar, criado pela necessidade de organizar a monitoria, que se torna um motivo eficaz para ambos. Leontiev explica, em um estágio da criança (podemos pensar para outras fases da vida), como ocorre a mudança de motivação e, consequentemente, de atividade:

[...] a criança não se limita, na realidade, a mudar de lugar no sistema de relações sociais. Ela se torna também consciente dessas relações e as interpreta. $\mathrm{O}$ desenvolvimento de sua consciência encontra expressão em uma mudança de motivação de sua atividade, velhos motivos perdem sua força estimuladora e nascem os novos, conduzindo a uma reinterpretação de suas ações anteriores. A atividade que costumava desempenhar o papel principal começa a se desprender e passar para um segundo plano. Uma nova atividade principal surge e com ela começa também um novo estágio de desenvolvimento (Ibidem, p.82).

Dessa forma, os dois se direcionaram ao vestibular para Licenciatura em Física, um com mais e outro com menos clareza da opção feita, mas se encaminharam para uma nova etapa de vida com a intenção de se formarem professores. Podemos dizer que com contribuições trazidas pelo vivido em suas trajetórias no ensino básico como eles relataram e pelos sentidos que atribuíram à docência. 


\begin{tabular}{|c|c|c|}
\hline \multicolumn{3}{|r|}{ Mapa de Sentidos de Heloisa } \\
\hline \multicolumn{3}{|r|}{ Episódio 1: Memórias do Ensino Básico } \\
\hline & Cod. & 1.1 Monitoria como Ação \\
\hline \multirow{5}{*}{$\begin{array}{l}\text { Situação em } \\
\text { que atribuiu } \\
\text { sentido }\end{array}$} & 011a & Necessidade da Escola e motivação - o movimento de ação para o ensino que vem de uma necessidade da escola, mas que encontra nela uma motivação pessoal \\
\hline & O11b & $\begin{array}{l}\text { Praparação para a monitoria - curso preparatório para a monitoria, no qual toma consciência que sua trajetória na escola fazia parte de um planejamento intencional } \\
\text { da equipe de educadores. }\end{array}$ \\
\hline & $011 \mathrm{c}$ & $\begin{array}{l}\text { Organização do ensino e o propósito pedagógico - a organização do ensino, do currículo posto em prática, do trabalho coletivo, lhe estimulou a pensar na } \\
\text { possibilidade de ser professora, mas de uma forma mais consciente, percebendo a intencionalidade da ação pedagógica. }\end{array}$ \\
\hline & 011d & $\begin{array}{l}\text { Preparação escolar e o apoio à monitoria - preparação feita pelo Colégio para que os alunos fizessem a monitoria em situações de viagens ou outras, que requeria } \\
\text { um planejamento da atividade de ensino, das ações a serem desenvolvidas com os alunos }\end{array}$ \\
\hline & O11e & Concepção de ensino da escola - a apreensão da perspectiva de ensino de seu Colégio. \\
\hline \multirow{6}{*}{ Motivo } & \multirow{2}{*}{ M11a } & ter contato com as pessoas \\
\hline & & gostar de ensinar \\
\hline & M11b & aprender a fazer a monitoria - planejar as aulas \\
\hline & M11c & aprendizagem dos alunos \\
\hline & M11d & aprendizagem dos alunos que leve a atribuição de sentidos \\
\hline & M11e & ensinar os alunos a "pensarem" \\
\hline \multirow{5}{*}{ Ações } & A11a & aulas para os alunos de séries anteriores a da monitora - monitoria \\
\hline & A11b & realização do curso preparatório para monitoria \\
\hline & A11c & reflexão sobre a monitoria \\
\hline & A11d & realização de aulas na monitoria após curso preparatório do Coçégio \\
\hline & A11d & mediação e orientação aos alunos \\
\hline \multirow{5}{*}{$\begin{array}{c}\text { Sentido } \\
\text { atribuído }\end{array}$} & S11a & $\begin{array}{l}\text { Reconheceu a importancia da atuação de monitoria como colaboração. Ou seja, o sentido atribuído ao ensino e aprendizagem, não estava no mesmo patamar que o da } \\
\text { professora da turma, mas como colaboração, como complementar a aprendizagem dos alunos. }\end{array}$ \\
\hline & S11b & $\begin{array}{l}\text { Considerou ser importante a organização das atividades de ensino. O papel do ensino e do professor estavam ligados a organização das atividades de ensino não só } \\
\text { pensando nas ações a serem desenvolvidas em cada aula e no decorrer do planejamento, mas também ao longo do processo de escolarização. }\end{array}$ \\
\hline & S11c & Entendeu que o professor precisa colocar os alunos em atividade, para que possam aprender. \\
\hline & S11d & $\begin{array}{l}\text { Concebeu o docente como o sujeito que orienta os alunos em suas ações na atividade de aprendizagem, promovendo os meios mediacionais permitindo que atribuam } \\
\text { sentidos a essa aprendizagem. }\end{array}$ \\
\hline & S11e & Entendeu que o professor não deve dar respostas prontas aos alunos, mas fazê-los pensar, o professor deve desenvolver ações para orientá-los a refletir. \\
\hline
\end{tabular}


Mapa de Sentidos de Ricardo

\begin{tabular}{|c|c|c|c|c|}
\hline \multicolumn{5}{|c|}{ Mapa de Sentidos de Ricardo } \\
\hline \multicolumn{5}{|c|}{ Episódio 1: Memórias do Ensino Básico } \\
\hline & Cod. & 1.1 Monitoria como Ação & Cod. & 1.2 Monitoria como Atividade \\
\hline \multirow{4}{*}{$\begin{array}{l}\text { Situação em } \\
\text { que atribuiu } \\
\text { sentido }\end{array}$} & 011a & $\begin{array}{l}\text { Contexto escolar do Ensino Fundamental - o contexto escolar do Ensino } \\
\text { Fundamental era bem organizado, tanto nas normas como nas ações dos } \\
\text { professores em sala de aula e nos materiais, o que refletia na mesma exigência } \\
\text { para os alunos, porém, essa característica não os levavam a organizarem sua } \\
\text { própria aprendizagem. }\end{array}$ & 012a & $\begin{array}{l}\text { Reflexões pertencentes ao universo do ser professor: 1) O é relevante ensinar? } \\
\text { 2) Como ensinar? 3) Como lidar com os alunos? }\end{array}$ \\
\hline & 011b & $\begin{array}{l}\text { Mudança de local de estudo no Ensino Médio - nova escola permitiu o } \\
\text { alargamento das relações sociais, indo para outro bairro, conhecendo pessoas de } \\
\text { outros locais, possibilitou ainda a vivência em uma escola com vários problemas, } \\
\text { mas com muitas alternativas, que o fez emitir suas opiniões e fazer escolhas. }\end{array}$ & 012b & \begin{tabular}{|l|} 
Orientação da mãe e leitura sobre questões de educação - orientação da mãe \\
o conduziu à leitura sobre questões de educação, orientação a ouvir os alunos para \\
entender suas dúvidas, como um dos pontos importantes para estabelecer a relação \\
professor-aluno, também a inspiração nos modelos de professor que tinha no Ensino
\end{tabular} \\
\hline & 011c & $\begin{array}{l}\text { Reflexão sobre a dificuldade dos colegas com a disciplina de Física - refletir } \\
\text { sobre o que levava os colegas a terem dificuldades na disciplina de Física passa a } \\
\text { refletir sobre aulas com atividades de ensino que mobilizassem os alunos ao estudo } \\
\text { da Física. }\end{array}$ & $012 \mathrm{c}$ & $\begin{array}{l}\text { Aprendizagem dos seus colegas - atingido seu objetivo, os alunos estavam } \\
\text { aprendendo e manifestavam gostar de suas aulas. }\end{array}$ \\
\hline & - & ( & 012d & $\begin{array}{l}\text { Reconhecimento dos seus colegas - os resultados do trabalho como monitor } \\
\text { sendo reconhecido pelos alunos é um fator motivador para que na organização das } \\
\text { ações de ensino consiga perceber aquelas que mobilizavam os alunos. }\end{array}$ \\
\hline \multirow{4}{*}{ Motivo } & M11a & Aprendizagem dele como aluno & M12a & Aprender a docência \\
\hline & M11b & Aprendizagem dele como aluno & M12b & Ensinar, visando a aprendizagem dos alunos \\
\hline & M11c & Ensinar os colegas na monitoria & M12c & Ensinar, visando a aprendizagem dos alunos \\
\hline & - & - & $\overline{M 12 d}$ & Ensinar como vocação \\
\hline \multirow{4}{*}{ Ações } & A11a & Estudo & A12a & $\begin{array}{l}\text { Fez o problema da aprendizagem dos alunos da monitoria a sua meta e direcionou } \\
\text { suas ações para o objetivo de organizar as aulas para promover a compreensão de } \\
\text { seus colegas pelos temas de Física. }\end{array}$ \\
\hline & A11b & Estudo & A12b & $\begin{array}{l}\text { Experimentar o modelo de alguns professores, um por causa de sua organização, } \\
\text { outro pelas discussões, ou pelas leituras críticas, sobretudo dialogar com os alunos. }\end{array}$ \\
\hline & A11c & Elaborar aulas & A12c & Realizar as aulas de monitoria \\
\hline & - & - & A12d & Realizar as aulas de monitoria \\
\hline \multirow{4}{*}{$\begin{array}{l}\text { Sentido } \\
\text { atribuído }\end{array}$} & S11a & $\begin{array}{l}\text { Considerou a importância da organização e disponibilidade de materiais pelo } \\
\text { professor para o aluno, para que sua aprendizagem pudesse ocorrer, o aluno não se } \\
\text { posicionava diante daquilo que estava estudando. }\end{array}$ & S12a & $\begin{array}{l}\text { Reconheceu a importância de seu papel como monitor para ensinar e refletir sobre } \\
\text { o ensino. }\end{array}$ \\
\hline & S11b & $\begin{array}{l}\text { Reconheceu que o ensino deve ser uma possibilidade de diálogo, de levar os alunos } \\
\text { a analisar criticamente uma situação e do professor se responsabilizar pela } \\
\text { aprendizagem dos mesmos. }\end{array}$ & S12b & $\begin{array}{l}\text { Considerou importante ouvir os alunos, estabelecendo um processo dialógico em } \\
\text { sala de aula como condição necessária para se aproximar de seu motivo de ensinar } \\
\text { e mobilizar nos alunos motivos para a aprendizagem. }\end{array}$ \\
\hline & S11c & $\begin{array}{l}\text { Considerou importante buscar soluções para aulas de monitoria com ações } \\
\text { diferenciadas da professora da sala e elaborar aulas que motivem os alunos para } \\
\text { compreesão do fenômeno a ser estudado deve ser uma preocupação do professor. }\end{array}$ & S12c & Considerou que o ato de ensinar pode ser um talento. \\
\hline & - & & S12d & $\begin{array}{l}\text { Considerou a importância do reconhecimento dos colegas acerca do seu papel } \\
\text { como monitor. }\end{array}$ \\
\hline
\end{tabular}




\subsubsection{Episódio 2 -Vivências da Licenciatura em Física}

A escolha pelo curso de licenciatura foi se construindo para Heloisa e Ricardo e foi se tornando mais consistente quando eles participam da monitoria no Ensino Básico e necessitam pensar no ensino e planejar ações para os alunos realizarem.

Certamente a monitoria foi um ponto forte na escolha profissional feita pelos dois, mas a opinião de seus professores também foi importante, bem como, a dos pais e amigos, como observamos em suas falas nas entrevistas.

O ingresso em um curso superior foi uma etapa também marcante os dois, porém suas expectativas e vivências, embora no mesmo contexto universitário, contemporâneos, trazem aspectos diferentes (VIGOTSKI, 2010). Cada um carrega sua história de vida, as experiências de estudo, que mesmo tendo ações semelhantes, seguiram caminhos próprios, cada qual interage com os outros sociais, com os objetos, com o mundo coletivamente, mas suas experiências são internalizadas de forma individual (OLIVEIRA, 2010). Portanto, o curso de Licenciatura em Física, nas múltiplas interações que promove é internalizado pelos sujeitos de maneira única.

Assim, tomamos o curso de Licenciatura em Física como uma atividade, na qual as vivências dos sujeitos nos permitem compreender um pouco de sua inserção na graduação e como nesse processo atribuíram sentidos para a docência. Para Vigotski (2010) a vivência une indivíduo e meio:

\footnotetext{
A vivência é uma unidade na qual, por um lado, de modo indivisível, o meio, aquilo que se vivencia está representado - a vivência sempre se liga àquilo que está localizado fora da pessoa - e, por outro lado, está representando como eu vivencio isso, ou seja, todas as particularidades da personalidade e todas as particularidades do meio são apresentadas na vivência [...] (p.686).
}

O curso como um todo possibilita aos licenciandos vivências em diversas disciplinas, da Física, da Educação ou de outras áreas do conhecimento, cada qual com organizações de ensino distintas. O que não quer dizer, que não haja uma organização curricular, com objetivos comuns, ou diretrizes para o curso, tem-se regras que priorizam determinadas ações e tal contexto estabelece as relações entre as disciplinas, os sujeitos (alunos, professores e outros envolvidos na estrutura) e nosso objeto, a aprendizagem da docência. No entanto, nem sempre as relações estabelecidas e a vivência no curso geram convergência nos sentidos atribuídos à docência pelos sujeitos desse processo. 


\section{A. Caso Heloisa}

A escolha do curso de graduação foi um momento de dúvidas, de pressões de todos os tipos para direcionar o estudante ao ensino superior, à uma Universidade e sobretudo ao encaminhamento para uma profissão. Isso, mesmo quando o jovem já sabe qual área do conhecimento deseja, no caso de Heloisa, era a Física o que ela pensava em cursar, em seguir como profissão, embora não tivesse tanta certeza da profissão quanto do curso. Desse modo, não sabia se fazia Licenciatura ou Bacharelado.

Isso a levou a recorrer a ajuda de sua professora de Física do Ensino Médio, buscando informações sobre os cursos, pois o ingresso era independente para cada um deles, então precisava fazer uma opção. O excerto abaixo mostra um período de dilema antes e após o vestibular:

E1(Heloisa): Eu já pensava em fazer Física. Falei com a minha professora e ela falou para eu fazer Licenciatura em vez de Bacharelado, eu confiei nela. Mano, eu entrei aqui muito perdida na verdade, agora eu vejo isso, na hora você não acha muito. Daí, fui lá e prestei e passei. Daí você fala tá bom não vou recusar uma vaga na Universidade A, aí comecei a fazer, mas agora eu sou feliz.

Ela fez Bacharelado e Licenciatura. Eu não sei se na época dela já existia essa separação, mas acho que sim. Ela gostava muito mais do curso de Licenciatura e falou assim: "Como você é do Colégio Y, vendo mais ou menos o seu perfil, acho que você vai gostar mais de Licenciatura, dá mais oportunidades, qualquer coisa você pega o Bacharelado depois, pega as outras matérias do Bacharelado, não tem necessidade de fazer Bacharelado, Licenciatura é muito melhor".

Heloisa mesmo tendo o desejo de ser professora há tempo, ao se deparar com a escolha de um curso no vestibular pensou em Física, mas não diretamente na Licenciatura, foi com a opinião de sua professora de Física que se decidiu. Essa dúvida quanto à escolha de uma carreira docente para sua formação pode estar associada à desvalorização salarial e condições de trabalho pouco estimulantes dessa profissão em nosso país. Por outro lado, pode ter passado por um Ensino Médio tão diferenciado como nos relatou, que lhe proporcionou várias possibilidades de estudo, ficando em dúvida ao ter que fazer uma opção por uma área de conhecimento. No entanto, ela não mencionou estas questões políticas, sociais ou afetivas como justificativa para sua indecisão, mas se sentia meio perdida, não sabia muito bem o que queria quando entrou na universidade. 
Esse fato nos leva a pensar que a passagem do Ensino Básico para o Ensino Superior foi um momento de conflito para ela que precedeu uma mudança de posição social, mesmo não estando na situação de sair da atividade de estudo para uma profissão, ela se coloca em uma fase intermediária que é uma formação para uma futura profissão. O contato com a professora foi importante, uma vez que a mesma já havia feito curso superior, podendo apresentar o contexto do qual Heloisa faria parte se entrasse como graduanda, no mesmo curso, na mesma Universidade.

Heloisa, ao se decidir pelo curso de Licenciatura, mesmo não com muita segurança, trazia um comprometimento com a educação, que adquiriu em seu processo de aprendizagem na Escola Básica e em outras instâncias de sua vida. Com uma experiência na qual se destacava a monitoria na escola, permitiu carregar sentidos para ensinar Física, formando em seu movimento no/para o ensino. Trouxe em sua aprendizagem para docência a importância do professor não fornecer respostas prontas aos alunos, mas deixar que reflitam e argumentem sobre um tema.

No decorrer da graduação a licencianda passou de motivada a decepcionada, melhor dizendo, o entusiasmo em relação ao curso diminui, como podemos observar em sua fala, onde aponta algumas questões que influenciavam essa alteração de sua visão sobre o curso. Heloisa se desmotivou depois do primeiro ano de curso pela organização das disciplinas e pela relação entre o ensino e seu desempenho, como aparece nos dois excertos de sua entrevista.

E1(Heloisa): [...] o primeiro semestre a gente faz de boa, é divertido. O segundo semestre tudo bem, daí o terceiro semestre do curso é muito decepcionante, é porque acho que o curso de Física ainda está organizado de uma maneira que era organizado há muito tempo, por exemplo, primeiro Mecânica, depois Relatividade, Física Moderna, eu acho que tudo isso tinha que estar muito mais interligado, entendeu? [...] A gente quer saber Física Quântica, Relatividade, Cosmologia e isso você só vai ver no final do curso, tanto que até no $3^{\circ}$ ano eu pensei em sair da Física, porque o curso estava muito chato, eu só estava tirando nota ruim. Os professores eram muito ruins. Passei em várias matérias com cinco, assim raspando, daí eu falei: "Nossa que saco, não sei o que". [...]

O curso de Física é muito ingrato. Nossa, você estuda, estuda, estuda e vai lá e tira nota ruim, parece que você não aprende. Eu tenho essa sensação até hoje, que parece que muitas coisas eu não aprendi. A parte conceitual mesmo, também tenho uma grande crítica, que no curso de Física você aprende a fazer exercício. Então, a gente meio que decora um exercício, dessa cara, tem que ser resolvido, se muda um pouco, se pede alguma coisa mais conceitual, a gente se perde. [...] E realmente isso é verdade, porque se você for pensar, talvez mesmo os pesquisadores não tenham essa compreensão mais filosófica da coisa, eles sabem fazer as contas, eles sabem 
causa e efeito, mas na hora que vai explicar o que é carga - "Sei lá, porque acontece isso. Sei lá, eu sei que acontece" - e eu não sou assim.

Essa desmotivação da licencianda pode ser por não ficar evidente o curso de Física como um sistema de atividade, no qual as disciplinas, os estágios e outras atividades estão relacionados para a finalidade do ensino de Física e da docência. Grande parte dos professores do curso podem não reconhecê-lo como parte de um sistema de atividades, o que passa a transmitir uma ideia isolada de cada disciplina e, ainda, sem conexão com seus fins e o do curso no geral, voltado para a formação da docência.

No decorrer do curso, parece que houve um descompasso entre os motivos que a levaram a escolha dessa graduação para os quais direcionava seus objetivos e os motivos relacionados a algumas das disciplinas, o que fez com esses dois motivos não coincidissem. Seu motivo, em relação à algumas das disciplinas, é compreensível, mas isso a incomodava (LEONTIEV, 2006), o que pode ter causado sua insatisfação.

Tal relação provocou um conflito, uma contradição entre a atividade de ensino e a de aprendizagem (ENGESTRÖM, 1999, 2000). Sendo o objeto de ensino o conhecimento construído historicamente (DAVIDOV, 1988), envolvendo a sua apropriação e a criação por parte dos indivíduos, o fato de Heloisa fazer exercícios mecanicamente, sem se apropriar dos conceitos envolvidos, levou-a ao desejo de mudança, uma ruptura com o curso. Pensou em desistir da Licenciatura em Física, porém naquele mesmo contexto e também por influencias na esfera pessoal, levaram-na a permanecer e continuar esta graduação.

Outro ponto relevante mencionado por Heloisa é a impressão de não ter aprendido em algumas das disciplinas específicas do curso, sua sensação era de fracasso. O aluno que está em atividade de estudo busca o seu aprendizado, se isso não se objetiva, não apenas pelas notas atribuídas pelo professor, mas pela sua própria avaliação no processo de estudo, esse aluno tem como conclusão que não atingiu sua meta; se não compreender qual foi a ruptura que ocorreu, normalmente sente-se fracassado.

Ela explica esse fracasso e a consequente desmotivação pelo processo de atividade de aprendizagem que estava ligado à resolução de exercícios, que eram ações feitas sem muita reflexão, não resultando uma aprendizagem eficaz, tanto que quando lhe solicitavam questões mais conceituais ela não sabia responder.

Kostiuk (2005) aponta que toda a educação que alcança seus fins, mobiliza as capacidades potenciais dos alunos, buscando o desenvolvimento das mesmas em diversas direções. Ele complementa que toda educação de alguma maneira deixa vestígios no 
desenvolvimento da personalidade da criança, sendo que em alguns casos o resultado não é o que desejamos. Ele analisa em relação à criança, mas podemos refletir para todos os níveis de educação e também para a situação relatada por Heloisa. Desta forma, Kostiuk (op. cit.) considera a compreensão do desenvolvimento importante para a educação a fim de que possa entender os processos que ocorrem com os indivíduos, permitindo-lhes escolher seu modo de atuação:

O desenvolvimento de todo ser humano, incluindo a criança, o seu próprio movimento, a sua própria vida, é condicionado pela totalidade das múltiplas relações com a realidade circundante. Como se observou em outra situação, uma concepção do desenvolvimento como automovimento ${ }^{12}$ não limita em absoluto a tarefa de uma condução Pedagógica, mas indica melhor como empreende-la com êxito. [...] Só uma educação eficiente leva ao desenvolvimento da personalidade da criança, e a educação apenas é eficiente quando toma em consideração as leis e as características do processo de desenvolvimento. Quanto mais conduzida por estas leis é a educação, quanto mais consciente está delas, mais capaz será de guiar com êxito o desenvolvimento da personalidade de acordo com as metas educativas (Ibidem, p.61).

No caso de Heloisa cabe refletir também, no significado do ensino e da aprendizagem no contexto do curso de Licenciatura que ela escolheu, ou em algumas disciplinas que não coincidiram com os motivos dos alunos; não se alinhavam com o sentido que ela tinha concebido ao ensino, o de fazer os alunos pensarem, não terem respostas dadas sem refletirem sobre uma situação ou tema. Essa questão lhe provocou uma contradição, que levou a desmotivação no curso, fazendo com que atribuísse, para certas disciplinas, que naquele momento, para ela representavam o curso, o sentido de não conseguirem explicar os fenômenos estudados do ponto de vista mais filosófico, como ela menciona, sendo que os professores não pareciam se preocuparem com isso. Isso iria requerer dos professores atividades de ensino que colocassem os alunos em ações conscientes de aprendizagem, para que pudessem realizar um trabalho que mudasse a qualidade do ponto de onde partiram, que os fizessem avançar.

\footnotetext{
${ }^{12}$ Automovimento: [...] processos do mundo no seu "automovimento", no seu desenvolvimento espontâneo, na vida real, é o seu conhecimento como unidade dos opostos, das tendências contraditórias no seu interior. Kostiuk, G. S. Alguns aspectos da relação recíproca entre educação e desenvolvimento da personalidade. In: Leontiev, A., et al. Psicologia e pedagogia: bases psicológicas da aprendizagem e do desenvolvimento. São Paulo: Centauro, 2005.
} 


\section{B. Caso Ricardo}

A experiência com a monitoria no Ensino Básico mobilizou Ricardo para o ensino e elaboração de sentidos para a docência lhe trazendo o prazer em ensinar. Ao lado disso, conheceu o Instituto de Física e a Faculdade de Educação em projetos oferecidos às escolas. Tais experiências o levaram a um deslocamento gradual de sua opção de cursar engenharia para a escolha de um curso de formação para professor.

No momento em que Ricardo estava se definindo na escolha de um curso para fazer sua graduação, as influências familiares e as expectativas de mercado de trabalho apontavam para a direção do curso de Engenharia. Desta forma, prestou vestibular para Engenharia, mas não foi bem sucedido, o que o fez pensar sobre o que realmente queria como profissão, ser professor.

Sem dúvida, a atuação de Ricardo como monitor o inseriu em um processo novo, no qual ele modificou o contexto em que atuava e com isso também se modificou. Ele relata que era tímido e essa experiência o mudou, um dos fatores de mudança foi a necessidade de diálogo com os alunos, seus colegas, para que pudessem aprender com as monitorias, dado que a discussão do assunto abordado, isto é, a participação dos alunos; foi um sentido que ele atribuiu como necessário para o ensino e para a aprendizagem. O reconhecimento dos colegas o estimulava a continuar, ao mesmo tempo, avaliava suas ações, fazia com que continuasse, com isso ganhava mais segurança, sua timidez era transformada pelo diálogo como elemento mediacional para seu ensino na monitoria.

Essas condições associadas ao fato de ter conhecido o contexto da universidade por ações pedagógicas de sua professora de Física, fez Ricardo se projetar naquele ambiente, trazendo-lhe o desejo de estudar lá, isso fortaleceu sua decisão em mudar de opção profissional. Conhecendo um pouco de tais instituições universitárias, Ricardo vislumbrava fazer parte daquela realidade, atribuindo o sentido valorativo à inserção naqueles contextos.

Nesse processo de se definir para uma nova etapa, refletiu que o desejo de ser professor era forte e se sobrepunha às razões que o fizeram decidir pela Engenharia anteriormente, como explicita no excerto da Entrevista 1:

E1(Ricardo): [...] "Eu posso ser engenheiro, mas vou aprender as matérias de Educação? Será que eu não estou fugindo daquilo que realmente gosto? Foram os planos que eu fiz pra mim, não vou ficar fugindo, vou fazer o que eu gosto. E qual o curso pra formar professores de Física?" Perguntei pra 
minha mãe. "Ah, Licenciatura, então, é Licenciatura que vou prestar”. [...] Aí estudei com o objetivo de entrar pra ser professor.

Para Ricardo, a passagem do Ensino Básico para o Superior parecer ter gerado o conflito com relação à mudança de posição social, ao mudar de nível de ensino, como Heloisa. Mas para ele isso ocorreu de outra maneira, sua dúvida começou quando a certeza do curso superior que havia escolhido foi abalada, pois tinha clareza que isso determinaria sua profissão e consequentemente mais tarde, influenciaria seu trabalho e as suas relações.

Ser professor já era uma perspectiva para Ricardo, além de outros fatores também devem ser considerados, como o prazer que ele menciona com a relação de ensino, que lhe permitia a comunicação com outros indivíduos, o trabalho compartilhado, a socialização do conhecimento tendo como alvo a aprendizagem dos alunos e o reconhecimento de seu trabalho, bem como, a superação de sua timidez.

Em outras palavras, o resultado de suas ações é que o fizeram refletir sobre sua escolha profissional, pois seu trabalho promoveu uma mudança naquela turma para a qual fez a monitoria e isto o mudou também, levando-o a alterar alguns objetivos, como a escolha do curso de graduação. Isso proporcionou a atribuição de novos sentidos em relação à profissão que desejava alcançar, que estava ligada à satisfação pessoal, a um "saber fazer" e aos resultados desse trabalho, que formavam um ciclo que o mantinha motivado, não um ciclo passando sempre pelos mesmos pontos, mas se modificando em suas relações, fazendo uma espiral. Tal sentido atribuído ao trabalho que passou a almejar, portanto, à docência, provocou mudanças em sua escolha no vestibular, na sua vida. Leontiev (1978) reafirma a ideia desse processo ao apontar que o homem não se insere em um mundo que lhe é dado, mas pela sua prática social apresentada como problema a ser resolvido em um processo histórico, isto leva o homem a interferir no mundo e com isso também se transformar.

O mundo real, imediato, do homem, que mais do que tudo determina a sua vida, é um mundo transformado e criado pela atividade humana. Todavia, ele não é dado imediatamente ao indivíduo, enquanto mundo de objetos sociais, de objetos encarnando aptidões humanas formadas no decurso do desenvolvimento da prática sócio-histórica; enquanto tal, apresenta-se a cada indivíduo como um problema a resolver (Ibidem, p.166).

Desta forma, percebemos que neste momento de mudança entre níveis de escolarização na vida desse licenciando, houve outro conflito associado, uma questão na vida pessoal talvez, fazendo-o mudar a escolha de curso. A escolha de Licenciatura em Física ao invés de Engenharia indicou uma mudança quanto ao significado social da profissão. Quando 
a escolha é ser professor, a despeito de outra profissão mais valorizada, evidencia-se um sentido para profissão conforme a fala de Ricardo: desejava fazer aquilo que lhe dava prazer, que o estimulava, mesmo que não fosse tão valorizada economicamente. Com isso, muda também as relações em sua atividade, muda a atividade.

Em outro trecho da entrevista, Ricardo fala que depois que passou por essa escolha do curso de graduação entrou na universidade já com um direcionamento:

E1(Ricardo): Entrei com foco, porque eu vivenciei antes, acho que isso teve uma importância muito grande, fui direcionado pelos meus pais, pelos meus amigos e principalmente pela professora. Por um convite, por uma responsabilidade que eu tomei pra mim, porque se eu não tivesse tomado talvez não tivesse seguido esse caminho. [...] dizia também: "Vou ser cientista", queria ser detetive quando pequeno, então, de certa forma eu estava sempre com a parte de investigação, descobri que sempre estava com a parte de investigação e sempre lidando com pessoas. Eu tinha, esqueci de falar, uma coisa que me influenciou com certeza, minha mãe me deu uma lousinha, quando eu era pequeno [...]

Quando ele diz que "entrou com foco", se refere ao ingresso no curso superior que, para ele, a Licenciatura em Física tinha como objetivo final a formação para docência, pela qual havia se decidido, pelo que vivenciou e pelas influências de pessoas que eram significativas para ele. Ele menciona como marcante a experiência como monitor, que despertou nele a responsabilidade com a educação e o desejo de ensinar. Além do símbolo presente desde sua infância, a lousa que ganhou de sua mãe, que atribuiu também ter influenciado em seu direcionamento. Isso faz uma referência à figura do professor que já se iniciava nas brincadeiras de criança, uma representação presente na infância, como coloca Oliveira (2011): “A chave para a brincadeira infantil atuar como recurso para produção de símbolo pela criança é a utilização por ela de alguns objetos como brinquedos e a possibilidade de executar com eles um gesto representativo. (p.78)".

Aliado a isto, havia o interesse pela investigação, a curiosidade que se misturavam com a ideia de ser cientista, interesse que pode ter contribuído para se direcionar ao curso de Física. Ricardo ao entrar na Universidade trouxe sentidos atribuídos ao ensino e à docência e ao refazer essa trajetória para nos contar revisita o universo simbólico de seu processo de escolha de um curso superior. Podemos afirmar que houve para ele a construção de significados que estavam ligados à imagem do cientista, do físico (por exemplo: investigação, descobrir coisas, curiosidade); e por outro lado, também a ideia do professor (exemplo: lidar com pessoas, lousa). Esse universo simbólico o leva aos processos internos de mediação 
(VIGOTSKI, 2007; OLIVEIRA, 2009), às internalizações que fazem da profissão docente e de um curso de Licenciatura em Física, que possibilitam suas atribuições de sentidos. Isso o fez avaliar, pelas inter-relações com o meio, a sua meta, seus objetivos. A citação de Oliveira (2009), esclarece essas relações e nos fornece uma síntese do processo que abordamos para a situação de Ricardo, colocando que:

O processo de desenvolvimento do ser humano, marcado por sua inserção em determinado grupo cultural, dá-se "de fora para dentro". Isto é, primeiramente o indivíduo realiza ações externas, que serão interpretadas pelas pessoas a seu redor, de acordo com os significados culturalmente estabelecidos. A partir dessa interpretação é que será possível para o indivíduo atribuir significados a suas próprias ações e desenvolver processos psicológicos internos que podem ser interpretados por ele próprio a partir dos mecanismos estabelecidos pelo grupo cultural e compreendidos por meio dos códigos compartilhados pelos membros desse grupo (p.40).

Para Ricardo o curso de graduação não gerou um momento crítico de desmotivação como no caso de Heloisa, pois como ele mesmo mencionou sua escolha foi feita com objetivo para a profissão docente. Ele relata isto em um trecho de sua entrevista ao falar sobre o curso:

E1(Ricardo): Comecei a fazer os estágios, fui me aprofundando e eu amo as matérias de Ensino. Aí, falei vou fazer Iniciação Cientifica em Educação, aí foi quando que eu descobri que havia a possibilidade de fazer mestrado na área de Ensino, doutorado em Educação, então eu já entrei consciente do que eu queria ser. Então eu não tive problema, eu não tive crise de Curso, não tive.

[...] Resumindo, apesar dos problemas do curso eu amo o curso, como eu entrei, acho que tem uma diferença, por ter vivenciado isso antes de entrar, sabendo que eu queria ser professor só contribuiu para eu poder ter gostado do curso e defendê-lo, enfim porque eu acho que se eu não tivesse passado por essa experiência, tivesse sido como meus amigos nas disciplinas de estágio, talvez eu não tivesse esse pensamento. Acho que têm muitas coisas que precisam ser melhoradas pra poder ser uma coisa mais [pausa] acho que os professores são só pesquisadores, são só bacharéis. Acho que pra você ser professor universitário deveria cursar umas matérias de educação, não quer dizer que você vai ser um bom professor cursando, mas você vai ter contato direto com o pensar da educação [...] Mas eu acho que deveria ser uma coisa parecida com a Medicina, você fazer uma espécie de residência, por exemplo, num sentido lógico há uma diferença, mas não no sentido de formação. Você tem um acompanhamento, poderia ser igual, acho que tem um pouco a ver com a desvalorização social da profissão e do curso. Mais uma coisa que acho bizarra que é importante ressaltar, tem impacto muito grande na formação, é o fato de alguns professores tanto da Faculdade de Educação quanto do Instituto de Física, da Universidade em si, não terem vivenciado a escola pública, a sala de aula [...] 
Ricardo atribuiu à sua vivência com as aulas da monitoria como fator facilitador para seu desenvolvimento no curso e nos estágios, o que percebeu ser diferente para os colegas que não possuíam a mesma experiência. Outro ponto que podemos destacar em suas reflexões é a necessidade de ensino e pesquisa terem a mesma relevância na proposição da universidade; não podemos ter um em detrimento do outro, mas eles devem se complementar, pois ele aponta perceber maior dedicação dos professores à pesquisa. A estrutura colocada aos docentes universitários propiciam uma atenção maior à pesquisa pelas condições exigidas na carreira docente, o que pode ser refletido no curso, para os alunos.

Retomamos na fala desse licenciando a questão tratada também no caso de Heloisa, que nos mostra um descompasso entre a atividade do professor e a atividade dos alunos, parecendo não haver a coincidência de motivos.

A experiência que ele cita parece ser necessária ao professor da universidade podendo colaborar com suas ações de ensino; porém não é garantia de um ensino que coloque os alunos em atividade, se não tiverem como proposta o trabalho compartilhado entre o professor e os alunos, motivos direcionados ao mesmo fim, com ações coordenadas. Contudo, Ricardo, pelas vivências nas disciplinas, atribuiu para algumas, sentido oposto ao que considerava importante para docência, elas não se preocupavam com questões pedagógicas, relacionais, mas só com o conteúdo.

Ele tem como perspectiva um mestrado e doutorado na área de ensino, mas não abandonando a perspectiva de dar aulas depois de formado, pois se sente envolvido na construção de uma profissão docente.

Os estágios também foram mencionados, por Ricardo, como uma ação do curso que precisava ser potencializada. Ele julga ter sido mais fácil passar pelos estágios por já ter tido uma experiência em sala de aula, pois pensa que para alguns, entrar uma primeira vez em contato direto com os alunos pode ser algo desestruturante. Para tanto, tomou como exemplo o caso da residência em Medicina, o que pressupõe um período maior de estágio com supervisão direta de um profissional da área. Observa-se essa mesma comparação, com a residência médica, em artigos originados de pesquisas (MOURA, 1999; GIGLIO et al., 2011; RIBEIRO e MOURA, 2012) para uma reestruturação do estágio com maior aprofundamento na formação profissional.

Isso está ligado à concepção de uma formação profissional na qual, ao ser finalizado o curso superior, o formado continua por algum tempo tendo apoio de professores, mas já atuando na profissão. Ou ainda, pode conceber a ideia de uma preparação para docência, 
principalmente o estágio, com maior aprofundamento teoria-prática, maior tempo de reflexão no exercício da docência. Isso indica, como coloca Ribeiro e Moura (op. cit.), "a necessidade da realização das ações de estágio numa perspectiva de "residência médica", de modo a favorecer oportunidades de organização e retomada de ações do ensino pelos estudantes (p.12)”. Isso nos leva a perceber que Ricardo trouxe da vivência no curso a necessidade de maior duração do estágio, para o qual atribuiu um papel importante na formação do licenciando, que está vinculado ao maior tempo de contato com as escolas, o que possibilitaria organizar e realizar ações no ensino básico, avaliando e refletindo mais nesse processo.

Ricardo reafirma e esclarece seu pensamento em relação a como vê o papel do professor universitário, falando da posição de licenciando, do sujeito que faz um curso para formação docente, o que podemos verificar no excerto de sua entrevista:

E1(Ricardo): [...] às vezes, o licenciado pela oportunidade de trabalhar durante o curso dele como professor, porque falta professor, ele vem de uma realidade e quando vai fazer a discussão na sala, aquele professor com a melhor boa intenção que tenha, por melhor que ele seja não está vivenciado aquilo, não sabe o que é aquilo, por mais que ele tenha toda a teoria, ele tem outras práticas, $[\ldots .$.$] se nesse choque, nesse embate, se ele souber trabalhar$ bem, mas se ele procurar até vivenciar aquilo muito mais a fundo, eu acho que a formação vai ter um impacto diferente na formação do futuro professor, principalmente, porque nessa formação ele está desenvolvendo junto com os alunos uma visão de mundo, uma visão de ciências, que tem a ver com o que ele experimentou, muitas vezes ele aprendeu na teoria, muitas vezes isso é transferido para o aluno, ou reproduzido.

Outra vez Ricardo coloca que percebe uma visão diferente, que às vezes, existe nas disciplinas entre o professor e alunos, principalmente aqueles que já atuam como professores no Ensino Básico. Ele argumentou que muitas vezes há rupturas nas discussões em sala, onde as situações colocadas não coincidem com as vivenciadas pelos licenciandos nas escolas em que atuam. Para tanto, apontou que seria necessário um trabalho mais profundo com os alunos, se aproximando mais da realidade, para que não se coloque apenas uma perspectiva teórica, mas que possa associá-la à prática. Isso foi posto por ele por acreditar que a visão de mundo, de Ciências, que o professor desenvolve com os alunos, pode ter origem em seu próprio processo de aprendizagem, no qual uma maneira de ensinar foi transferida para ele e assim a reproduz. Bergamaschi e Almeida (2013) corroboram com essa ideia e a constatam em pesquisa com licenciandos de pedagogia, para o que apontam uma possibilidade de mudança: 
As experiências escolares podem reverberar em repetições, reproduzindo práticas análogas com seus alunos como, aliás, ocorre na maioria das vezes. Porém, diante de situações reflexivas como a produção do memorial, há a possibilidade de ressignificações (p.32)

Essa situação se não for revertida pelo professor da disciplina, fazendo a aproximação teoria-prática em um movimento dialético, pode gerar alguns conflitos que dificultam o diálogo e limitam a formação do licenciando. Assim, podemos considerar como outro sentido atribuído à aprendizagem da docência por Ricardo, o de que os alunos carregam concepções trazidas por seus professores e as reproduzem quando estão na condição docente.

Neste caso, a vivência do licenciando no contexto escolar, o trabalho conjunto com o professor da escola e o planejamento do professor da disciplina, podem colaborar para que se forme um tripé que alicerce as relações de ensino e a aprendizagem na formação docente. Isso, pode proporcionar a ampliação das ações dos licenciandos e dos professores das escolas, permitindo aprofundar as discussões e avaliar o processo realimentando-o continuamente.

\section{Síntese: mapa dos sentidos}

Ao pensarmos na formação dos licenciandos em um processo no qual o motivo de aprendizagem da docência seja objetivado nas ações do curso, há a necessidade de uma visão mais integrada e integral das disciplinas e dos sujeitos. Martins (2009) coloca que ao se atuar na educação do educador devemos devolver a sua personalidade e promover a humanização como produto de seu trabalho, colocando que:

Há que se pensar portanto, a educação do educador enquanto processo que devolve ao homem a sua própria personalidade, isto é, a sua qualidade de agente da História e que, enquanto trabalhador e junto com outros homens, modifica intencionalmente as condições externas, modificando-se a si mesmo. [...] Assim sendo, este é um processo que ao mesmo tempo exige a transformação das circunstâncias e das coincidências, apenas possível em educação quando o trabalhador-professor objetiva-se no produto de seu trabalho, tendo neste produto, a promoção intencional da humanização do outro e de sua própria humanidade (Ibidem, p.149).

As falas de Heloisa nos levam a pensar que o sentido pessoal que tinha formado sobre o ensinar não coincidia com o ensino que julgava estar recebendo em algumas disciplinas do curso, o que a coloca em conflito, tornando vulnerável sua permanência no curso. Nesta 
situação, Ricardo responde de maneira diferente; ele se apoia mais nas disciplinas voltadas diretamente para tratar do ensino buscando esta coincidência, parece-nos que para se sentir com seu motivo objetivado.

Esse episódio nos mostra uma não coincidência entre o sentido atribuído pelos licenciandos ao ensino e o de algumas das disciplinas do curso. As atitudes dos licenciandos são diferentes, porém não alteram seus sentidos em relação ao ensino, ao contrário, eles apontam suas críticas às disciplinas por não coincidirem com seus sentidos. Isto nos leva a questionar a organização do ensino para a formação docente. É preciso ressignificar as ações direcionadas para docência, para que estas não sejam apenas tarefas a serem cumpridas, mas ligadas à atividade que impulsiona alunos e professores, tendo como objetos o ensino e a aprendizagem, com foco na formação para docência. 
Mapa de Sentidos de Heloisa

\begin{tabular}{|c|c|c|c|c|}
\hline \multicolumn{5}{|c|}{ Episódio 2: Vivências da Licenciatura e Física } \\
\hline & Cod. & 2.1 Antes do Vestibular & Cod. & 2.2 Ingresso na Graduação \\
\hline \multirow{4}{*}{$\begin{array}{l}\text { Situação em } \\
\text { que atribuiu } \\
\text { sentido }\end{array}$} & O21a & $\begin{array}{l}\text { Contato com profissional da área - o contato com a professora do Ensino } \\
\text { Médio, já profissional e tendo passado pelo mesmo curso superior, apresentava o } \\
\text { universo da nova realidade. }\end{array}$ & O22a & $\begin{array}{l}\text { Experiências e aprendizagens - processo de aprendizagem na Escola Básica e } \\
\text { em outras instâncias de sua vida, com uma experiência na qual se destacava a } \\
\text { monitoria na escola. }\end{array}$ \\
\hline & - & - & O22b & $\begin{array}{l}\text { Desempenho no curso - na graduação, Heloisa, pensava em ter contato, } \\
\text { aprender, assuntos ligados à Física Moderna e não encontrou issso, associou ao } \\
\text { desempenho insatisfatório dela na avaliação das disciplinas sua própria na visão, } \\
\text { representados pelas notas ruins mesmo estudando muito, associado à problemas } \\
\text { no curso e com alguns professores. }\end{array}$ \\
\hline & - & - & $022 \mathrm{c}$ & $\begin{array}{l}\text { Descompasso entre os motivos - o conflito que tendia à mudança, a ruptura com } \\
\text { o curso, descompasso entre os motivos da licencianda na escolha dessa graduação } \\
\text { e os motivos que guiavam algumas das disciplinas. }\end{array}$ \\
\hline & - & - & 022d & $\begin{array}{l}\text { Relexão sobre o significado do ensino e aprendizagem - a reflexão sobre o } \\
\text { significado do ensino e da aprendizagem no contexto do curso de Licenciatura, ou } \\
\text { em algumas disciplinas, não coincidiam com os motivos de Heloisa, não se } \\
\text { alinhavam com o sentido concebido ao ensino. }\end{array}$ \\
\hline \multirow{4}{*}{ Motivo } & M21a & $\begin{array}{l}\text { optar pelo curso de graduação, escolher entre Licenciatura e Bacharelado em } \\
\text { Física }\end{array}$ & M22a & aprendizagem dos alunos \\
\hline & - & - & M22b & aprender Física \\
\hline & - & - & $\mathrm{M} 22 \mathrm{c}$ & aprender Física \\
\hline & - & - & M22d & explicar os fenômenos estudados \\
\hline \multirow{4}{*}{ Ações } & A21a & fazer o vestibular & A22a & orirntação e mediação do professor \\
\hline & - & - & A22b & estudo em diversa disciplinas do curso de Licenciatura em Física \\
\hline & - & - & $\mathbf{A 2 2 c}$ & estudo em diversa disciplinas do curso - resolução de exercícios \\
\hline & - & - & A22d & $\begin{array}{l}\text { estudo em diversa disciplinas do curso - preocupação em explicar os fenômenos } \\
\text { estudados }\end{array}$ \\
\hline \multirow{4}{*}{$\begin{array}{l}\text { Sentido } \\
\text { atribuído }\end{array}$} & S21a & Reconhecia-se comprometida com a educação. & S22a & $\begin{array}{l}\text { Considerou, para a aprendizagem, a importância do professor não fornecer } \\
\text { respostas prontas aos alunos, mas deixar que reflitam e argumentem sobre um } \\
\text { tema, uma situação. }\end{array}$ \\
\hline & - & - & S22b & $\begin{array}{l}\text { Reconhecia-se desmotivada pelo curso, inicialmente, pela organização do currículo, } \\
\text { que não correspondia às suas expectativas. }\end{array}$ \\
\hline & & - & S22c & $\begin{array}{l}\text { Reconheceu que a relação que estabeleceu nas disciplinas, que julgava não ter } \\
\text { aprendido, era de fracasso, desmotivação pelo processo de atividade de } \\
\text { aprendizagem que estava ligado à resolução de exercícios, que eram ações feitas } \\
\text { sem muita consciência, então não levaram à aprendizagem, tanto que quando the } \\
\text { solicitavam questões mais conceituais ela não sabia responder. }\end{array}$ \\
\hline & - & - & S22d & $\begin{array}{l}\text { Considerou necessário conseguir explicar os fenômenos estudados do ponto de } \\
\text { vista mais filosófico, sendo que os professores pareciam não se preocuparem com } \\
\text { isso. }\end{array}$ \\
\hline
\end{tabular}




\begin{tabular}{|c|c|c|c|c|}
\hline \multicolumn{5}{|c|}{ Mapa de Sentidos de Ricardo } \\
\hline \multicolumn{5}{|c|}{ Episódio 2: Vivências da Licenciatura e Física } \\
\hline & Cod. & 2.1 Antes do Vestibular & Cod. & 2.2 Ingresso na Graduação \\
\hline \multirow{4}{*}{$\begin{array}{l}\text { Situação em } \\
\text { que atribuiu } \\
\text { sentido }\end{array}$} & O21a & $\begin{array}{l}\text { Mudança na escolha da carreira profissional - o reconhecimento dos colegas, } \\
\text { a superação da timidez e o conhecimento do Instituto de Física e da Faculdade de } \\
\text { Educação, dois polos ligados à profissão de professor de física, levaram Ricardo a } \\
\text { mudar sua opção do curso de graduação de engernharia para licenciatura em física. }\end{array}$ & O22a & $\begin{array}{l}\text { Reconhecimento dos seus colegas - resultado do trabalho como monitor } \\
\text { reconhecido pelos seus colegas do Ensino Médio é fator motivador para a } \\
\text { organização das ações de ensino, conseguindo perceber aquelas que mobilizavam } \\
\text { os alunos. }\end{array}$ \\
\hline & O21b & $\begin{array}{l}\text { Influência da monitoria escolar na escolha profissional - o resultado de ações } \\
\text { na monitoria escolar muda a escolha profissional, ao mesmo tempo em que suas } \\
\text { ações como monitor promoveram mudanças na turma de Ensino Médio. }\end{array}$ & O22b & $\begin{array}{l}\text { Interesse pela licenciatura - o universo simbólico, processos de mediação e } \\
\text { internalizações fazem Ricardo perceber a profissão docente e a Física como } \\
\text { espaço de atuação e interesse pela Licenciatura. }\end{array}$ \\
\hline & - & - & O22c & $\begin{array}{l}\text { Vivências no curso de licenciatura - a vivência no curso faz Ricardo perceber a } \\
\text { necessidade de maior duração de estágio. }\end{array}$ \\
\hline & - & - & O22d & Vivências - vivência na monitoria e no curso \\
\hline \multirow{4}{*}{ Motivo } & M21a & Ser professor & M22a & Ensino de física - ensinar como construção coletiva \\
\hline & M21b & Ingressar no curso de Licenciatrura em Física & M22b & Aprendizagem de física e da docência \\
\hline & - & - & M22c & Aprendizagem da docência \\
\hline & - & & M22d & Aprendizagem da docência \\
\hline \multirow{4}{*}{ Ações } & A21a & Mudar a opção para o vestibular & A22a & Refletir sobre a monitoria do Ensino Médio. \\
\hline & A21b & Fazer o vestibular para o curso de Licenciatrura em Física & A22b & Refletir sobre o ensino de física. \\
\hline & - & - & $\mathbf{A 2 2 c}$ & Realização de estágio em disciplinasdo curso de Licenciatura em Física. \\
\hline & - & - & A22d & Estudo em diversa disciplinas do curso e realização de estágio. \\
\hline \multirow{4}{*}{$\begin{array}{c}\text { Sentido } \\
\text { atribuído }\end{array}$} & S21a & $\begin{array}{l}\text { Reconheceu o valor de sua inserção no contexto do curso de Física, pois tinha } \\
\text { prazer em ensinar. }\end{array}$ & S22a & $\begin{array}{l}\text { Concebeu o ensino e aprendizagem como construção coletiva mudou o sentido } \\
\text { que tinha sobre o ensinar no ensino básico. }\end{array}$ \\
\hline & S21b & $\begin{array}{l}\text { Considerou a importância da profissão que desejava alcançar, que estava ligada a } \\
\text { sua satisfação pessoal, a um "saber fazer" e aos resultados da monitoria, que } \\
\text { formavam um ciclo que o mantinha motivado, não um ciclo passando sempre pelos } \\
\text { mesmos pontos, mas se modificando em suas relações, que fazia Ricardo atribuir } \\
\text { importância à docência, o que provocou mudanças em sua escolha no vestibular. }\end{array}$ & S22b & $\begin{array}{l}\text { Reconheceu a importância da responsabilidade com a educação ao lado do } \\
\text { desejo de ensinar, além de símbolos presentes desde a infância, como a lousa, } \\
\text { que o ajudavam a criar a ideia de ensinar. }\end{array}$ \\
\hline & - & - & $\mathbf{S 2 2 c}$ & $\begin{array}{l}\text { Considerou que a formação do licenciando precisa estar vinculada ao maior tempo } \\
\text { de contato com as escolas, possibilitando organizar e realizar ações no ensino } \\
\text { básico, avaliando e refletindo mais esse processo. }\end{array}$ \\
\hline & - & - & S22d & $\begin{array}{l}\text { Reconheceu que os alunos carregarem concepções trazidas por seus professores } \\
\text { e as reproduzem quando na condição docente. }\end{array}$ \\
\hline
\end{tabular}




\subsubsection{O estágio nas disciplinas de Metodologia de Ensino de Física I e II}

As disciplinas de MEF I e II tiveram em sua estrutura as aulas em sala com toda a turma de licenciandos e o estágio de regência realizado em pequenos grupos. Considerando as disciplinas como atividade, as ações desenvolvidas em sala de aula e as ações de estágio tinham objetivos que se correlacionavam visando a organização, realização, reflexão e avaliação de atividades de ensino, cujo motivo é a aprendizagem da docência, o movimento na direção da formação docente.

O estágio configurou-se como uma das ações estruturantes da disciplina e para uma sala diversificada agregava alunos que já tiveram experiência em dar aulas no Ensino Básico pelas ações desenvolvidas em monitorias, ou por já atuarem como professores neste mesmo nível de ensino, bem como aqueles que só haviam realizado aulas em estágio e alguns que nunca tinham dado aula.

Com a intenção de desvelar as ações realizadas pelos licenciandos que fizeram parte de nossa análise para que possamos relacioná-las na atividade da qual faziam parte, as disciplinas, tomamos alguns episódios que buscam olhar as ações com maior detalhamento e com o objetivo que foi priorizado nela. Esses episódios foram divididos em três: organização das aulas do estágio, regência e reflexão sobre o estágio.

\subsubsection{Episódio 3 - Organização das aulas do estágio}

O momento inicial da preparação da atividade de ensino de estágio era o planejamento das aulas, que os licenciandos elaboravam em pequenos grupos (2 a 3 indivíduos) e apresentavam aos colegas da sala e à professora para discussão. A intenção era de adequar o planejamento às aulas e aos alunos da escola, tanto em relação ao conteúdo, como tempo de desenvolvimento, ações previstas, bem como obter contribuições para a melhoria da proposta.

Os grupos tinham um tema a ser desenvolvido com os alunos, que era escolhido por eles, envolvendo conceitos de Física, sua contextualização histórica, social, sua concepção em relação ao senso comum, dentre outros aspectos que desejassem abordar. Em MEFI o professor da escola que recebia o estagiário era consultado quanto à proposta do tema para a organização da atividade de ensino; deveria opinar sobre o mesmo, concordando ou 
redirecionando-o para outro assunto complementar ao que estava discutindo em suas aulas. No caso de MEFII, foi realizada uma pesquisa com os alunos e com a anuência do professor da escola, para que os estagiários verificassem quais os temas de maior interesse daquela sala com a qual trabalhariam.

A organização da atividade de ensino foi conduzida por uma questão-problema como uma regra colocada para todos pela disciplina. Partindo dessa questão se desencadeariam as elaboração do planejamento e as atividades de ensino do estágio que visavam conduzir os alunos das escolas a um processo investigativo, que se baseava nos pressupostos do Ensino por Investigação ${ }^{13}$. A partir disso, os grupos organizavam os aspectos a serem trabalhados nas regências, visando a aprendizagem dos conceitos, desenvolvimento de habilidades, atitudes e ações dos alunos.

\section{A. Caso Heloisa}

O planejamento (P1) de MEFI, do grupo 2, tinha o objetivo de trabalhar com a história da Ciência, apresentando a visão de Universo, que carrega as marcas do desenvolvimento científico e histórico de épocas distintas. A intenção era que os alunos também entendessem que o processo como a Ciência se constrói não é feito pelo estereótipo que, em geral, é difundido, o de um cientista abstraído de seu contexto cultural, fazendo descobertas sozinho e partindo de um marco zero. Ao contrário, o grupo deseja enfatizar o caráter coletivo, social e histórico no qual a Ciência se desenvolve. Essa ideia é apresentada por um dos membros do grupo, na exposição da organização das aulas do estágio para a professora da disciplina e os colegas da sala, como mostra o trecho a seguir:

P1(G2-Carlos): Basicamente o que a gente vai fazer é uma construção histórica da evolução do comportamento cientifico e pra auxiliar isso a gente vai montando com os alunos uma linha do tempo, de como os pensamentos foram mudando, as ideias

\footnotetext{
${ }^{13}$ Ensino por Investigação: Nas disciplinas de MEFI e II aqui consideradas, o ensino por investigação era concebido como uma abordagem didática, na qual o professor organizava atividade de ensino nas quais propunha um problema (ou mais) aos alunos, que em grupos investigavam de várias formas soluções para resolver tal problema, tendo nesse processo que organizar suas ações, criar modelos, buscar informações, realizar experimentações e apresentar a solução encontrada socializando-a e utilizando de argumentação, associada a uma explicação possível, segundo seus conhecimentos já acumulados e as evidências que conseguiram pelo processo de investigação. Com isso e mais as interações já realizadas durante a atividade em cada grupo, o professor coordena e organiza os dados trazidos pelos grupos, fazendo uma síntese, em busca do conceito científico e outras questões que seriam focos do problema proposto, a partir daí avalia a situação para direcionarse a próxima etapa, avançando no aprofundamento daquele tema.
} 
foram mudando conforme o tempo foi passando. A ideia é mostrar que a Física é algo em construção, não é nada imutável. Essa é uma ideia nossa, que os alunos comecem a pensar na Física de maneira que eles também possam fazer parte disso, ele também pode dar a contribuição dele. É questionável e uma hora isso pode mudar. A nossa ideia é essa, tentar mudar a mente do aluno para que no futuro ele possa fazer questionamentos e participar da construção da Ciência.

Ao apresentarem o que haviam planejado em relação ao assunto a ser desenvolvido com os alunos da escola básica, o grupo ao mesmo tempo abordava algumas ações que utilizariam para trabalhar com o que haviam planejado. Nesse caso, eles propuseram fazer com os alunos o que chamaram de linha do tempo, na qual seriam colocados os marcos do pensamento científico em ordem cronológica e os cientistas que se destacaram em cada um desses momentos históricos.

Tudo isso tinha uma intencionalidade: eles queriam que os alunos percebessem que a Ciência não é imutável, que ideias propostas em determinados momentos podem ser questionadas e modificadas. No entanto, tinham uma intenção mais direcionada ao aluno, o de fazê-los se perceberem como ser histórico que pode participar de todo o movimento que ocorre na sociedade, que ele atua no mundo e o mundo sobre ele. Essa concepção, que o grupo de Heloisa queria transmitir aos alunos da escola, é discutida por Paro (2010), que aborda como o papel da educação insere o homem em sua cultura e o concebe em sua condição histórica, conforme aponta:

O homem faz história, portanto, ao produzir cultura. E ele a produz como sujeito, ou seja, como detentor de vontade, como autor. A necessidade da educação se dá precisamente porque, embora autor da história pela produção da cultura, o homem ao nascer encontra-se inteiramente desprovido de qualquer traço cultural. [...] A educação como apropriação da cultura apresenta-se, pois, como atualização histórico-cultural. [...] Significa que ele vai se tornando mais humano (histórico) à medida que desenvolve suas potencialidades, que à sua natureza vai acrescentando cultura, pela apropriação de conhecimentos, valores, crenças, habilidades artísticas etc. É pela apropriação dos elementos culturais, que passam a constituir sua personalidade viva, que o homem se faz humano-histórico (p.25, grifos do autor).

Essa concepção que o grupo de Heloisa trouxe como objetivo em seu planejamento nos possibilita perceber um sentido atribuído à docência de enfatizar o papel dos alunos como participantes críticos da sociedade onde se inserem, fazendo parte da história, da ciência, buscando provocar mudanças e estimular esses alunos.

A professora da disciplina complementa a ideia do grupo, o de fazer uma linha do tempo assinalando as produções da Ciência e os cientistas que estão associados a cada época. 
Dessa forma registrariam a produção do conhecimento em momentos históricos, podendo perceber que há períodos de maior concentração na produção de conhecimentos. Parte desse diálogo está reproduzida abaixo:

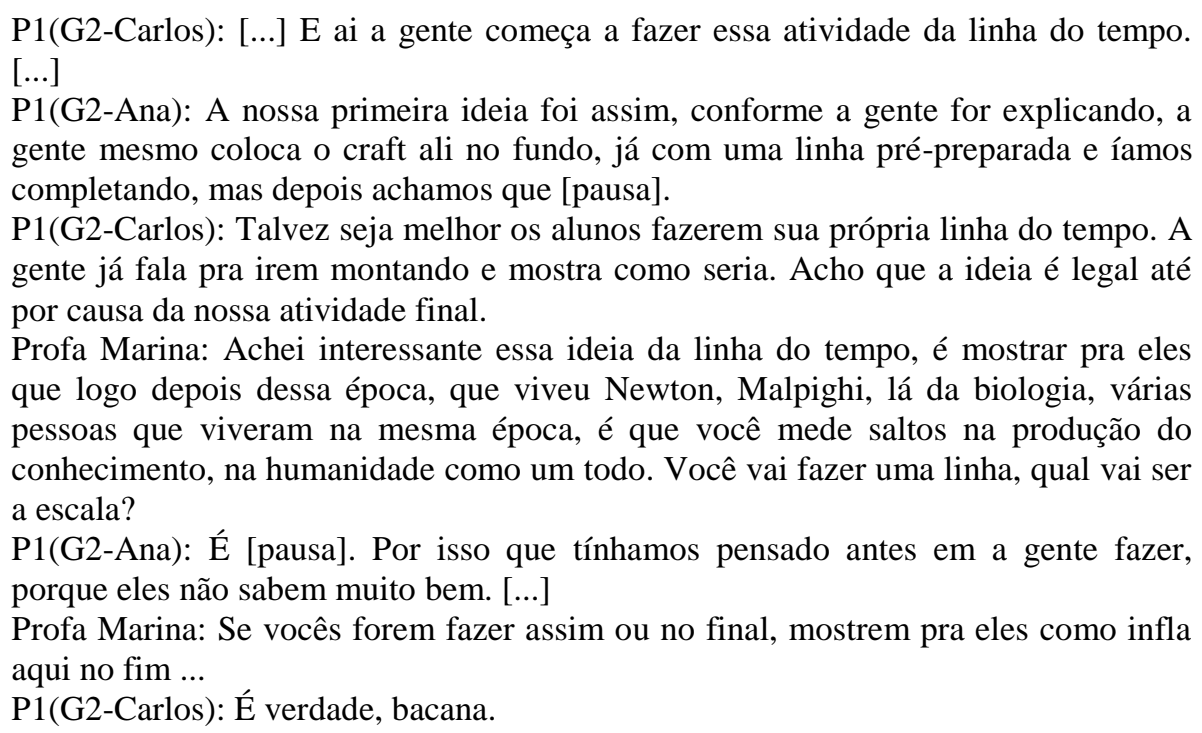

A proposta da discussão do planejamento dos grupos antes de serem finalizados visou a troca e colaboração entre os licenciandos e a professora de MEF, o que auxiliou na organização do conteúdo e em seu detalhamento, proporcionando aos licenciandos aproximálos do contexto escolar. Nesse caso, a professora ao questionar sobre a escala que utilizariam, os faz refletir a necessidade de mostrar aos alunos da escola básica que há uma concentração de eventos científicos a partir da época de Newton, século XVII. Ao serem pontuadas algumas questões do planejamento com o grupo de alunos, foi sendo especificada mais a atividade a ser elaborada e as ações necessárias para as mesmas, possibilitando a aprendizagem dos alunos da escola - é o motivo que os estava guiando.

Os estagiários tinham a noção de fazer a linha do tempo, mas a dúvida era como fazêla? Se eles deveriam construí-la junto com os alunos ou cada aluno fazer a sua. Cada uma das situações envolve ações diferenciadas: a primeira é organizar uma sequência didática para garantir que toda a sala possa acompanhar simultaneamente e compreender o que está sendo feito; a segunda, envolve explicações claras para que todos saibam o que precisam elaborar e se não têm a noção de como construir uma linha do tempo e de escala, essas precisam ser discutidas a priori. Assim a discussão do planejamento faz com que o grupo vá detalhando suas ações em função do que pretende trabalhar com os alunos. Nesse caso, pela intervenção da professora da disciplina, o grupo ficou um pouco indeciso em relação ao que faria, mas percebeu a importância de discutir com mais detalhes com os alunos da escola. Esse 
procedimento pode atribuir sentido à docência, pois induz os licenciandos a seguir essa recomendação na regência.

Continuando a apresentação da atividade que desenvolveriam com os alunos da escola, destacamos outra parte da discussão com os colegas da sala e a professora de MEFI:

P1(G2-Carlos): Na aula quatro a gente vai propor uma atividade de encontro com o passado, na qual os alunos vão para a época de Aristóteles e vão ter que explicar pra ele como que a ciência atual explica a origem do universo, articulando tudo o que a gente apresentou, mostrando a evolução dos conceitos [...]

Profa Marina: Quanto tempo vocês vão deixar pra eles fazerem isso tudo?

P1(G2-Carlos): Uma aula inteira. [...]

Profa Marina: É muita informação pra três aulas.

P1(G2-Ana):Se a gente sentir necessidade de uma quinta aula, pode ser algo que mude. [...]

Aluno 1: Como vocês fariam.

P1(G2-Ana): Acho que seria mais o resultado do que eles conseguiram captar das aulas.

P1(G2-Heloisa): Não, acho que ele tá perguntando você.

P1(G2-Ana): Como eu faria? Eu tentaria reconstruir toda a história, você disse isso, você Aristóteles falou isso. Daqui uns anos vai ter um cara chamado Galileu que vai falar isso e depois um cara... eu ia reconstruir.

P1(G2-Heloisa): Eu ia falar de experimentos, discussão da comunidade [...]

Aluno 3: Fiquei pensando o quanto isso poderia colocar uma imagem pros alunos de que o Aristóteles é algo ruim?

P1(G2-Carlos) Vamos tentar colocar: "Na época dele". Sempre fazendo isso, de construção da época, tenho certeza que eles não vão pensar isso.

Aluno 3: Não é diferente pra quem deve tá lá, "Vai vir um cara que vai falar isso, isso e isso". Ou tenho todo um instrumental que você e o Aristóteles têm na época e explica pra eles. Você poderia falar da questão da experiência, como que você ia convencer ele que o experimento de fato é o caminho?

P1(G2-Ana): Por isso a gente colocou "explicar" e não "convencer" Aristóteles. Porque uma coisa é você explicar como as coisas vão acontecer e outra é você convencer de que é aquilo.

Sala (Aluno 3): Mas você só vai pensar a sua explicação. [...]

Além de um detalhamento maior das atividades de ensino, existe outro fator bastante importante que foi sendo explicitado na discussão e que começou a se organizar de forma uma pouco mais clara: quais são as ações a serem realizadas na efetivação das aulas planejadas. À medida que a professora da disciplina questionava o grupo sobre a organização e o tempo de aula, ela os colocava a tarefa de relacionar com o conteúdo discutido, um intervalo de tempo real em sala de aula para agregar as ações dos alunos e também as dos estagiários. Esse é um momento de interações diversas que necessita ser refletido e bem distribuído no planejamento, segundo os objetivos traçados, cuja noção desse conjunto de relações que compõem a organização da aula, escapa, em alguns aspectos, aos estagiários. O intervalo de tempo para abordar um assunto ou destinado à uma tarefa ao aluno, em geral, é subestimado pelos estagiários. 
A clareza e a viabilidade da segunda tarefa proposta pelo grupo também foi discutida, na situação descrita. Um dos colegas da classe questionou sobre a cautela que os estagiários do grupo precisam ter ao apresentar essa tarefa aos alunos da escola. Também atenção na condução das alunas, para que situem nos respectivos momentos históricos os limites da Ciência, não a deixando confundir com uma verdade dogmática.

Essas discussões referentes ao planejamento dos grupos, mesmo quando não conseguiam se aprofundar, trouxe aos estagiários um momento de repensar muitos pontos da organização das aulas que prepararam e de contribuições em questões mais ligadas ao contexto escolar. Isso os levou a replanejar as aulas de maneira mais refletida, tentando pensar com mais cuidado nas condições encontradas na sala de aula, em especial, naquelas em que já haviam tido contato e observado.

O planejamento do segundo semestre (P2), feito na disciplina MEFII pelo mesmo grupo 2, continuou com ênfase em História da Ciência, mas com abordagem sobre o elétron e a dualidade onda-partícula, no desenvolvimento das ideias científicas em seus contextos históricos. Na apresentação do planejamento das aulas à sala, o grupo falou sobre o tema que desenvolveriam nas aulas de regência e como começariam a discuti-lo com a sala, como podemos verificar no excerto abaixo:

\footnotetext{
P2(G2-Carlos): Então, a nossa ideia é falar com os alunos sobre elétron e o que a gente pensa sobre ele. Em linhas gerais falar sobre a dualidade onda-partícula do elétron, a gente vai dar aula pro $3^{\circ}$ Ano do Ensino Médio, serão 6 aulas.

P2(G2-Heloisa):Com a probabilidade de se estender.

P2(G2-Carlos): É, provavelmente, pelo que a gente viu aqui. Então, nossos objetivos gerais: mostrar o comportamento ondulatório e corpuscular do elétron por meio de atividades e avaliação. A justificativa é apresentar duas formas distintas do mesmo objeto e contextualização histórica, porque a gente gosta dela.

P2(G2-Ana): Essa aula, pra começar a tratar de elétron a gente vai dar uma aula bem introdutória e de ordem de grandeza, até pra gente entender isso também é difícil, pensar em coisas micros e macros. Então, vamos começar falando sobre isso e fazer um experimento.

Essa atividade do papel foi sugestão da professora e foi muito boa. Vamos dar papéis sulfite, pedir para dobrar ao meio e cortar, dobra e corta, o máximo que der. P2(G2-Heloisa): E com isso vai chegar uma hora que não vai dar mais, a professora falou que são mais ou menos 17 vezes, daí a gente questiona: "E se a gente continuasse cortando?"
}

$\mathrm{Na}$ fala notamos que houve uma preocupação do grupo 2 em relação ao tempo total que gastariam para realizar todo seu planejamento, tanto que cogitaram a possibilidade de mais aulas. $\mathrm{O}$ grupo já havia vivenciado o desenvolvimento do planejamento, com a mesma sala de aula, no semestre anterior em MEFI. No entanto, pensamos que para que adquirissem uma dimensão mais adequada e maior segurança ao organizarem aquilo que desejavam fazer 
com os alunos, precisavam de um período maior de contato com a escola, especialmente em sala de aula.

Em outro aspecto, o grupo adquiriu uma maior percepção ao analisar o conteúdo escolhido para abordar com os alunos e perceberam que não era algo trivial, mas que eles poderiam ter dificuldades para lidar com ordem de grandezas que não fazem parte do cotidiano. Para tanto, procuraram uma atividade com essa temática, sugerida pela professora, que permitiria discutir a questão. Assim, podemos considerar que pensar a organização do planejamento nessa segunda etapa, em MEFII, ficou mais complexa; começaram a fazer conexões com o que os alunos poderiam ficar limitados a compreender por não terem subsídio anterior.

Isso levou ao contato com a professora da disciplina, fora das aulas, para debater e buscar auxílio sobre como trabalhar com a noção de unidades micro com os alunos, que para o grupo de Heloisa se colocou como uma contradição (ENGESTRÖM, 1999), provocando outros questionamentos para prosseguirem com o planejamento. Os licenciandos tinham um tema de interesse dos alunos, no entanto, com dificuldades para ser trabalhado pela própria especificidade que requeria não eram trabalhadas com os alunos. Nota-se que não foi estabelecida nenhuma relação para discutir essa questão com o professor da escola, pois a convivência dele com os alunos a mais tempo poderia fornecer informações sobre o que já haviam discutido nas aulas, ou das necessidades e contexto de vida desses alunos, bem como das abordagens didáticas utilizadas. No entanto, essa possibilidade não foi cogitada.

Não havia interação suficiente entre os licenciandos e a escola, nem com o professor, o que gerou uma outra contradição. Os estagiários tinham como pressuposto apreender as relações entre professor-aluno, dentre outras, mas não estabeleciam trabalho conjunto ou discussões com o professor efetivo. Os sistemas de atividades do estágio e da escola são coordenados por regras para cooperarem em ações de interesse de ambos, porém elas não se correlacionam. As situações apontadas geraram contradições que resultaram em mudança na ação do grupo em um caso, mas no outro, na relação com o professor efetivo, pois essa nem foi percebida como possibilidade pelos estagiários. Heemann (2009) coloca que nem todas as contradições geradas em um sistema culminam em mudanças, pois:

Dentro de um sistema de atividade, todos os elementos constantemente interagem uns com os outros e estão sempre sujeitos a funcionarem por meio de mudanças. Mudanças em uma ferramenta podem mudar a orientação do sujeito em relação ao objeto, que, por sua vez, pode influenciar as práticas culturais da comunidade. [...] Apesar do potencial das contradições para 
resultar em transformações nos sistemas de atividade, esta transformação nem sempre ocorre.

Esse tipo de preocupação não aparecia com tanta clareza no primeiro estágio em MEFI, o que nos permite apontar que houve uma mudança ao organizarem as ações para as aulas, uma maior preocupação com a real compreensão dos alunos sobre os assuntos tratados, ou seja, com a aprendizagem desses alunos.

Essa atenção com a aprendizagem dos alunos apresentou-se em várias etapas do planejamento de MEFII, o que podemos relacionar com uma atribuição de sentido que o grupo fez à função docente, a de proporcionar condições que possibilitem a aprendizagem dos alunos, sentido este que se estende à Heloisa, sendo ela membro do grupo, que foi se formando desde MEFI, com as discussões do planejamento na sala e as intervenções da professora da disciplina. As regências realizadas na escola, o contato com os alunos, no qual puderam observar que nem sempre a atividade de ensino poderia focar diretamente no assunto que desejavam discutir, mas precisariam, antes, oferecer condições necessárias aos alunos, para depois levá-los ao tema central de estudo.

Um outro trecho da apresentação de P2 reitera a preocupação que o grupo teve em organizar atividades de ensino que levassem os alunos à compreensão dos conceitos científicos que desejavam discutir. Porém, mostra a dúvida que os acomete com a expectativa do que poderia ocorrer, como podemos perceber na exposição que fizeram na aula de MEFII:

P2(G2-Ana): Estamos com um pouco de medo de trabalhar esse tema, porque não sabemos até que ponto eles são fortes e no que. Segundo nossas pesquisas de ibope eles não tiveram muito ondas.

P2(G2-Heloisa): Ou eles não tiveram ou a gente não sabe o quanto eles tiveram.

P2(G2-Ana): Por isso eu coloquei revisão em itálico, porque não sabemos até que ponto vai ser uma revisão e até que ponto vai ser a primeira vez que eles vão ver. Então, vamos dar uma aula de mecânica e ondas, vai ser uma coisa bem resumida, não vamos falar tudo de mecânica, só o que a gente julgar necessário e ainda não sabemos o que vamos usar, é muita coisa e é difícil pensar nisso, talvez não leve só uma aula. [...]

P2(G2-Heloisa): Acho que aprender sobre ondas é bizarro. O que são ondas? A única coisa de ondas que eu sei fazer é na água. A gente precisa que eles saibam de interferência, de difração, não necessariamente com esses nomes. Então, vamos abordar isso com uma assadeira, vamos colocar pregos, com água e bater pra fazer onda e ver como funciona a difração e interferência.

P2(G2-Carlos):Vão ter ideia de como as ondas interferem e como acontece a difração nos pontos.

P2(G2-Heloisa): Vamos pedir pra desenhar o padrão de interferência.

P2(G2-Ana): Essa ideia estava na tese do menino, ele que nos deu a ideia.

A atenção com a compreensão dos alunos para que o tema em estudo possa gerar aprendizagem continua como preocupação central do grupo, o que causa algumas indecisões 
no número de aulas que iriam utilizar, no aprofundamento da discussão que fariam e na reação dos alunos com as atividades que iriam elaborar. O fato desses estagiários entrarem na sala de aula como pessoas externas ao contexto, sem ligação com as aulas do professor efetivo, não lhes dá uma condição confortável para escolher o tema que mais se adequaria às aulas, embora nesse segundo semestre os alunos tenham sugerido estudar a luz, ou outro tema que os estagiários achassem interessante. Talvez, isso pudesse ser minimizado por ações da atividade de estágio que os aproximassem do professor regente daquela sala, porém isso não correu. Outra questão que percebemos é o pouco tempo de convivência entre os estagiários e os alunos, o que não favorece uma visão mais detalhada dos indivíduos daquela sala e leva o grupo a ter dúvidas na abordagem do tema.

Após uma introdução do tema e dos principais conceitos, o grupo se propôs a falar dos cientistas, de seus experimentos e estudos que os levaram a defender o caráter corpuscular ou ondulatório do elétron, referindo-se a momentos históricos específicos. Eles parecem ter ao longo desse processo de planejamento sempre a elaboração da atividade de ensino com uma clara intencionalidade e as definições das ações a serem realizadas por eles, fazendo uma projeção do que esperam que os alunos compreendam, o que a professora de MEF os questiona em alguns momentos, como mostra um trecho da apresentação do grupo:

\footnotetext{
P2(G2-Heloisa): Depois vamos começar a abordagem histórica falando do experimento do J. J. Thomson, que ele usou tubo de raios catódicos e que não sabemos ainda se vamos conseguir usar, vamos pegar emprestado. Seria pra levar um pra sala inteira. Ele usou carga por massa pra demonstrar o caráter corpuscular do elétron. E depois vamos fazer um paralelo com o mesmo experimento, só que dessa vez feito pelo G. P. Thomson que usou o mesmo aparato experimental com altas tensões, você acelera o elétron e ele forma um padrão de interferência na parede do tubo. E fazendo um paralelo com o que tínhamos falado sobre ondas, eles vão reconhecer, a gente espera, o padrão de interferência e vão ter uma ideia do comportamento ondulatório do elétron.

Profa Marina: Será que eles vão entender o anterior?

P2(G2-Ana): É por isso que a gente colocou isso aqui, porque talvez a gente tenha que mudar a atividade.

P2(G2-Heloisa): Precisaria também de uma introdução do tubo de raios catódicos, ver o que está acontecendo lá.

Profa Marina: Minha pergunta é anterior ainda, é se eles entendem que uma partícula vocês conseguem, em determinado instante, identificar a posição que ela está.

P2(G2-Heloisa): Isso nós vamos trabalhar na aula 2.
}

As ações dos licenciandos do ao longo das disciplinas de MEF parecem ter ficado mais organizadas no planejamento, porém as ações que esperam dos alunos ainda não são tão elaboradas, especialmente em relação à previsão dos resultados, pois não têm muita segurança se o que elaboraram pode gerar uma motivação nos alunos, colocando-os em atividade de 
aprendizagem. Não há certezas para que o planejado motive os alunos fazendo-os agir com motivo eficaz, porém os estagiários precisavam de uma maior confiança nessa possibilidade, ou melhor, mais clareza na proposta que desejavam efetivar, para poderem também conseguir refletir sobre possíveis ações para alterá-la, se necessário. Essa preocupação ficou evidente e foi transmitida, aparecendo na fala da professora da disciplina alertando-os. O que ela apontou estava relacionado à compreensão dos alunos sobre o assunto que abordariam anteriormente, Heloisa tinha essa preocupação também, mas pensando em detalhar mais a abordagem do tema, explicando fenômenos que os alunos não compreenderiam sozinhos e Ana (componente do grupo) pensava até em mudar a atividade se fosse preciso.

Mais uma vez, ao trazer para discussão a organização do planejamento vem à tona as contradições, porém isso não é algo inesperado, mas entendemos como parte do processo de aprendizagem da docência, dado que os licenciandos desse grupo não haviam tido muitos contatos com a elaboração de atividades de ensino para efetivá-las na prática, exceto Heloisa com a vivência da monitoria, mas ela recebia seu plano de trabalho pronto.

Isso, pode ter componente associada ao pouco contato estabelecido com a sala de aula durante o estágio, embora, tenham mantido a mesma escola e sala, a convivência com os alunos foi restrita, ocorreu nos momentos reduzidos atribuídos às ações de estágio. Outra questão, pode ser que não tenham, até esse momento percebido a importância da organização da atividade de ensino, prevendo as possibilidades das ações dos alunos, mesmo que essas não se concretizem da mesma maneira, mas para que possam estar atentos ao processo que os alunos desenvolvem no decorrer da proposta e assim, conseguirem propor mediações e posteriormente avaliar a atividade de ensino e a de aprendizagem. Embora tenham sido expressadas contradições no processo da discussão do planejamento, também nessa etapa, Heloisa e Ana explicitaram soluções distintas, mas não avançaram muito em um replanejamento naquele momento, o que é difícil, dado que demanda uma reflexão mais aprofundada pelo grupo, contudo teriam tempo para fazer isso depois.

No decorrer da apresentação podemos perceber que algumas atividades de ensino que o grupo organizou aumentaram sua motivação, criando mais expectativa para os estagiários em relação à como os alunos a executariam. $\mathrm{O}$ trecho a seguir mostra essa discussão e as sugestões dadas:

P2(G2-Ana): Aula 5, essa aula é minha favorita e se der certo ela vai ser muito boa, porque vamos fazer um debate e vai dividir a sala em dois, um vai ter que falar do comportamento corpuscular e o outro do ondulatório. Como se um defendesse a onda e o outro a partícula. 
P2(G2-Carlos): A gente vai mediar esse debate e dar elementos.

P2(G2-Heloisa): Pra isso a gente usará uma entrevista que um aluno da pós simulou, uma com o G.P. e uma com J.J. que estamos pensando ainda como usar, que vai enriquecer esse debate pra eles terem mais argumentos.

Profa Marina: Ele simulou, mas é real. O que ele fez foi pegar o texto que o G.P. e J.J. publicaram separadamente sobre um experimento deles, ele buscou os principais pontos e colocou como se fosse uma entrevista, porque os textos são grandes, meio chatos.

P2(G2-Ana): E pode ser bem linda essa aula.

Profa Marina: Sim, mas pode ser um desastre também.

P2(G2-Ana): Na verdade depende da gente também.

Profa Marina: É, quais são as informações que vocês vão disponibilizar pro grupo, porque eles podem não ter informação nenhuma e ficar achando que é porque é.

P2(G2-Ana): Esse tipo de argumento talvez venha e essas 4 aulas vem pra isso, se forem bem executadas do jeito que a gente quer vai ser bonito. Esperamos isso.

Aluno 1: Posso dar uma sugestão? Trabalhem com um texto didático falando sobre isso pra eles terem até condições de entender melhor.

P2(G2-Ana): Mas isso no caso das entrevistas, né? Que texto?

Aluno 1: Qualquer texto didático, o do $\mathrm{P}$, o $\mathrm{M}$ tem (referindo-se aos nomes dos professores-autores para indicar o livro), textos que fazem esse debate. Ai vocês fazem uma discussão com eles pra depois vocês terem um background. [...]

Profa Marina: Porque o que eles querem salientar até agora é a questão de que isso era um problema naquele momento, problema histórico.

Aluno 1: Isso o P (referindo-se ao nome do professor-autor para indicar o livro) faz, ele vai traçando até o debate historicamente, mas hoje como é tratado não sei. P2(G2-Heloisa): Hoje como é tratado a gente só vai fazer depois desse debate.

Aluno 2: Esse subsídio que vocês estão procurando já não tem nas primeiras aulas, o fato quando você caracteriza o que é corpuscular e o que é ondulatório? Porque na verdade esse debate vai ser esse background que eles têm, eu entendi que o experimento vai por si só levantar a lebre de que existe um debate.

Nesse aspecto, pensamos que o motivo dos estagiários do grupo, de ver na entrevista entre os dois cientistas uma maneira muito clara de explicar discussões científicas complexas, já era tomado por eles como motivo dos alunos ao se depararem com a atividade de aprendizagem.

As ações que pretendiam desenvolver com os alunos estavam mais claras e mais detalhadas, mas só isso não garantiria o entendimento pelo aluno. Essa questão foi colocada pela professora e também por um colega que apontou sugestão para o grupo. Isso os alertava que precisariam, antes da realização da proposta, dar um suporte dos conceitos científicos e do momento histórico.

No decorrer da discussão, a professora da disciplina e os colegas continuam fazendo questionamentos que são mais para auxiliar na organização da atividade de ensino, o que faz com que o grupo defina melhor as ações que desenvolverão em sala de aula, pois as perguntas feitas os levaram a refletir mais no que planejaram, nos objetivos que desejavam alcançar. Um trecho desse diálogo começa com uma questão da professora, que entende que a atividade de aprendizagem requer que os estagiários permaneçam na escola, por algum período de tempo, para atender os alunos, esclarecendo suas dúvidas, como podemos observar: 
Profa Marina: Vocês estão cientes de que, eventualmente, entre as aulas 4 e 5 vocês vão ter que estar na escola uma hora?

P2(G2-Ana): Por que?

Profa Marina: Porque os alunos podem querer conversar com vocês pra organizar a fala do debate.

P2(G2-Ana): Não, mas não vamos falar que vai ter debate. Vamos dar dicas o tempo todo que em algum momento vai ter uma atividade que eles vão ter que explicar pra gente, do mesmo jeito que fizemos semestre passado, até mesmo porque sentimos que eles não iam anotar nada.

P2(G2-Heloisa): Você acha melhor que a gente deixe explicito?

Profa Marina: Não sei. Porque eles vão se preparando. Se eu chego aqui e divido a turma em 2, um vai defender a onda e o outro a partícula, vocês vão tomar um susto gigantesco.

Aluno 1: Foi por isso que pensei no texto, numa aula de 50 minutos os 15 primeiros trabalham com eles fazendo revisão.

P2(G2-Ana): Ou podemos dar os textos pra casa, assim não ocupa o tempo nosso. P2(G2-Carlos): E fala pra eles, no dia antes do debate, se prepararem.

Profa Marina: Por isso que eu estou dizendo, porque aí eles já sabem quem é o grupo da onda e o da partícula, pode ter eventualmente um grupo mediando.

P2(G2-Ana): Mas aí não precisamos dividir o grupo antes, até mesmo pra todo mundo se preparar dos dois lados.

Aluno 3: Só uma pergunta, vocês vão trabalhar como mediadores e foi proposto, no começo, aos alunos as duas bases e foram bem fundamentadas, como a professora falou, com textos bem enraizados. O que acontece se alguém achar os dois possíveis?

Profa Marina: Aí é lindo.

Aluno 3: Mas ele vai ficar de que lado?

P2(G2-Ana):É mais o lance da argumentação não dele realmente concordar com isso.

O grupo não viu a necessidade de atender os alunos fora do horário da aula, pois argumentaram que a atividade de aprendizagem deveria ser realizada no período de aula, com os subsídios que obtivessem naquele momento, o que julgavam suficiente. Para colaborar com isso, um dos colegas sugeriu que um texto explicativo sobre as duas características do elétron fosse entregue aos alunos antes do debate, como material de apoio, com isso pensamos que ele achava que era necessária uma complementação antes do debate, o que corrobora com a ideia da professora da disciplina, mas utilizando outra estratégia. Tal questão, o grupo não percebeu antes da discussão geral, outras já fazem parte de seu sentido para docência, como nesse caso a importância que mencionam sobre a argumentação, que discutiram nas aulas de MEFI e sempre incorporaram ao planejamento das ações a serem desenvolvidas com os alunos. Isso nos permite considerar que a apresentação do planejamento na disciplina de MEF colabora para a otimização do mesmo e pode levar à mudança na percepção dos licenciandos sobre a organização das aulas e possibilidades de prever as ações dos alunos como condições necessárias à docência. Porém, isso não acontecerá com todos e nem se faz de forma passiva, é um movimento de aceitação, refutação, verificação, reflexão e tantos outros caminhos que 
os licenciandos traçam para atribuírem sentidos à docência nesse processo de interação, assim concordamos com Góes (1997) quando coloca:

[...] o papel do outro revela-se contraditório. O jogo dialógico entre sujeitos não tende a uma só direção; ao contrário, envolve circunscrição, ampliação, dispersão e estabilização de sentidos. Um determinado conhecimento (pretendido, na intencionalidade do outro; ou previsto na perspectiva de um observador) pode ou não ser construído pelo indivíduo, mas, em qualquer caso, é na complicada dinâmica do intersubjetivo que devemos examinar o processo (p.27).

Um ponto que nos chamou a atenção foi o fato dos licenciandos não considerarem a proposta de ficarem algum tempo disponíveis na escola para atenderem aos alunos, acreditamos que isso seria uma oportunidade de conhecerem melhor o aluno, sua vivência, seu contexto social, sua visão da escola, suas expectativas, enfim, o aluno real. A situação foi mencionada no escopo de uma atividade de aprendizagem, o que pode não ter trazido essa ideia mais geral, ter ficado apenas focada no contexto em discussão. Outro ponto, pode estar ligado a falta de horário livre para os estagiários devido ao acúmulo de disciplinas e outros compromissos, alguns ligados ao trabalho regular. No entanto, essa questão poderia agregar grande valor ao estágio, permitindo além do contato com os alunos uma aproximação maior com o contexto escolar, proporcionando transformações nos licenciandos que colaborassem para sua formação docente.

Após a apresentação e discussão do planejamento com a professora da disciplina e os colegas da sala os grupos tinham que finalizar essa ação e começar a organizar as aulas que haviam planejado. Esse momento era de detalhamento das ações e operações com o objetivo de realizá-las com os alunos da escola onde fariam o estágio, portanto, teriam que organizar as atividades de ensino de estágio.

Esse processo de organizar as aulas foi para Heloisa o mais envolvente, o qual mencionou ter sido a parte do estágio que mais gostou. No entanto, isso não significa que não tenha encontrado dificuldades, acreditamos que ele se desenvolveu em momentos de empolgações e outros de angustias, como identificamos abaixo, no excerto de sua entrevista:

E2(Heloisa): A parte que eu mais gostei do estágio foi de preparar a aula.

Pesquisadora: Mas por que isso em relação a preparar a aula? Por que esse envolvimento?

E2(Heloisa): Putz, não sei, sabia? Eu gosto de coisas difíceis. E toda vez que eu ia preparar a aula, pra pensar o projeto, nossa, eu e a Ana, a gente discutia, e ficava na questão e mudava e voltava pra delimitar muito bem. A gente fazia uma coisa muito 
pensada, era muito legal. E mesmo quando cada uma ia planejar sua aula ou quando a gente fazia juntas. [...]

E2(Heloisa): Não sei, eu tenho muita dificuldade de focar num ponto. Eu sempre quero falar de muita coisa ao mesmo tempo e na aula não dá, porque a gente, por exemplo, o estágio do primeiro semestre que a gente estava falando do Big Bang, e a parte que eu ia falar era justamente a parte do Big Bang, evolução do universo, eu comecei a preparar a aula e eu estava já falando do sistema solar, da vida na Terra, dos modelos de expansão do Universo, de Einstein, de Schrödinger, eu já queria falar de tudo e não dava, não ia dar tempo de falar na aula e também não tinha nada a ver. Tinha que recortar, tinha que falar: "Não, vida na Terra não era um dos nossos objetivos, Modelo de Universo também não", ia confundir a cabeça das crianças. Daí eu falei só da evolução do Universo, desde o Big Bang até agora. E no final dei só uma pincelada pra deixar no ar: "E ai, tá se expandindo ou vai contrair?", mas foi só pra dar aquela discussão no final da aula, pra eles poderem escrever o texto depois. É muito difícil você ter que recortar pra falar das coisas.

O fato de desenvolver um tema de Física para trabalhar com alunos do Ensino Básico empolgava a licencianda, trazia o desafio de tratar alguns conceitos escolhendo ferramentas de mediação, envolvia criação e também a elaboração de um problema que desencadeasse a proposta de trabalho para os alunos. A organização do conteúdo era algo envolvente para Heloisa que fazia com que ela pensasse nas ligações que poderiam ampliar as ideias a serem tratadas, principalmente no âmbito da proposta de seu grupo que era trabalhar com a História da Ciência, porque acreditava ser interessante que os alunos tivessem essa visão da Física. Contudo, no percurso da preparação de uma aula ela se perdia na extensão da mesma, ficava difícil delimitar o conteúdo a ser discutido em um tempo reduzido ao da sala de aula de nossas escolas.

Esse tempo da sala de aula, correspondente ao tempo determinado para duração da aula na escola ainda não tinha sido apreendido por ela, pois não estava inserida no ambiente escolar, vivenciando o cotidiano da escola, mas iria ter alguns momentos naquele contexto, nos quais teria que seguir as regras do sistema escolar, que não faziam parte de seu universo, do seu sistema. Assim, organizar as aulas para o tempo requerido pela escola não era fácil regular. Isso cria tensões ao planejar essas aulas, que algumas vezes angustiavam a licencianda, ao lado da empolgação de querer explorar ao máximo o tema proposto, o que gerava uma contraposição, que teria que aprender a balancear, mas que precisava da mediação do outro, sua colega ou a professora da disciplina, para ajudá-la a superar.

Além de regular o tempo previsto para o conteúdo escolhido os licenciandos tinham que lidar com uma questão fundamental do papel docente que era a organização das ações de ensino, quais os instrumentos e como os utilizariam para realizarem essas ações, para que promovessem a aprendizagem dos alunos. Essa preocupação é delineada na fala de Heloisa quando pontua que consegue delimitar o que vai tratar em sua aula e a pergunta que deixará 
para os alunos para mobilizá-los a discutirem o tema e fazerem uma tarefa que ela elaborou. Esses aspectos promovem a atribuição de sentido à docência quando Heloisa sente a necessidade de equilibrar toda a temática que gostaria de abordar com os alunos com o tempo que dispõe para suas regências, mas para isso ela precisa da ajuda de outros, que possam, pelo discurso, símbolos ou instrumentos, mediar as relações entre ela e seu objeto (a aula). Esse processo também faz com que Heloisa vá se autoconhecendo nas suas potencialidades para ensinar, nas ações que executa, nos sentidos que atribui à docência e no contato com os outros, como coloca Molon (2011):

[...] o sujeito não é reflexo, não é comportamento observável, nem reações não manifestadas e nem o inconsciente, mas o sujeito é uma conformação de um sistema de reflexos - a consciência - na qual os estímulos sociais desempenham um papel importante na operacionalização do eu, já que o contato com os outros sujeitos permite o reconhecimento do outro e, através disso, o autoconhecimento (p.84).

Nessa mediação nos processos de elaboração das aulas, pelo outro e nas diversas interações é que Heloisa foi conseguindo estímulos e reconhecimento, como aponta Molon (op. cit.) para conquistar sua própria forma de atuar na regência, porque na sala de aula, cada um do grupo tinha um jeito próprio.

O estágio foi proposto para ser desenvolvido em pequenos grupos, portanto na organização da aula o licenciando não estaria sozinho poderia e era esperado que discutisse com seus colegas quais e como seriam as ações propostas para cada aula. Por isso a pesquisadora questionou Heloisa: "E esse trabalho sendo em grupo ajudou?", com a intenção de verificar como o trabalho em grupo tinha colaborado para o desenvolvimento do processo de organização das aulas do estágio e como era o processo no grupo.

E2 (Heloisa): Se ajudou? Acho que ajudou, porque esse dia que travei eu estava sozinha e a Ana não estava nem na faculdade e normalmente ela tá preparando, quando ela ia dar aula, ela preparava a aula dela lá e se estava com dúvida a gente discutia como ia ser a aula, mas na hora mesmo de preparar os slides, ver figuras era só uma que fazia, a outra estava lá do lado pra ajudar de vez em quando. Nesse dia eu estava preparando a aula e ela não estava, então eu não tinha discutido antes como ia ser a aula e na hora eu não tinha ela pra virar e falar: "Amiga, travei". Eu comecei a chorar, foi engraçado, mas eu estava desesperada também por outras razões, terminei o ano muito mal. E na hora de planejar, com certeza, se não tivesse a Ana eu ia fazer aquele apanhado das coisas pra dar em 6 aulas, mas não, eu tinha que focar, até a Marina ajudou bastante a gente, porque a gente falou: "Aí Marina a gente vai falar disso, disso e disso" e ela falou: "Então meninas, vamos falar só disso, em 6 aulas, porque é esse o projeto". 
Heloisa aponta que o trabalho feito em grupo ajudou porque tinha a possibilidade de discutir a organização da aula e compartilhar decisões, mas ressalta que contavam também com momentos para criarem sozinhos seus instrumentos didáticos, que faziam após a discussão conjunta. Dessa forma, pensavam conjuntamente os conteúdos, as ações gerais dividindo-as, cada um ficava responsável por uma parte delas, se responsabilizando por parte das aulas, organizando e produzindo seus instrumentos para mobilizar as ações que haviam decidido realizar em sala de aula com os alunos, mas recorrendo ao outro quando necessário e para validar o processo após conclui-lo.

Cabe salientar, que esse modo de ação era característico para esse grupo, não foi uma proposta acordada por todos na disciplina, cada um deles ia definindo suas ações, no processo de trabalho para organização da atividade de estágio e das regências.

Essa sistemática de trabalho imprimiu uma característica que foi se tornando própria do grupo para discussão das aulas a serem organizadas e para divisão e coordenação das ações com o objetivo de conseguirem atingir o que planejaram. No grupo do qual Heloisa fez parte, essas ações eram divididas e quando um membro do grupo interferia na ação do outro isso era comentado logo após a aula e na maior parte das vezes queria-se corrigir a atitude tomada, não que agissem de forma desconectada, mas não queriam que as intervenções prejudicassem a organização da aula (anotações do CC - 21/11/2013).

A importância do trabalho compartilhado é discutida por Moura (1999), na perspectiva do estágio, mas na relação do trabalho desenvolvido entre os licenciandos e os professores das escolas. No entanto, o que ele nos apresenta corrobora com a ideia do trabalho em grupo como colaborador para planejar e discutir as atividades de ensino do estágio, que Heloisa nos apontou em excerto de sua Entrevista 2, que acreditamos favorecer a aprendizagem da docência. Segundo Moura:

O pressuposto básico é o de que a atividade de ensino, ao ser planejada conjuntamente, é capaz de gerar elementos de reflexão, proporcionando o desenvolvimento da consciência do futuro professor sobre os vários aspectos a serem considerados na atividade pedagógica. A tomada de decisão sobre os conteúdos que devem ser adotados, qual a metodologia a ser empregada e como avaliar as ações formativas e os seus resultados são, potencialmente, importantes momentos de formação, no professor, de competências que já transcendem o já complexo domínio dos conteúdos (p.11).

[...] A elaboração de atividades de ensino de forma compartilhada é o motor da formação do professor, pois a elaboração inicial de uma proposta, a discussão sobre a sua aplicação e sua posterior avaliação são elementos definidores da capacidade de projetar e, por isso mesmo, definidores da condição humana de criar. (p.11) 
O trabalho de planejar as aulas em grupo foi desencadeador do detalhamento da proposta de ensino para seu desenvolvimento com os alunos, como coloca Moura (op. cit.) permitindo projetar ações tanto dos licenciandos como dos alunos e lhes dando a oportunidade de criar e com isso aprender a pensar o trabalho docente como um processo de escolha, elaboração, objetivo, criação e avaliação.

No final do estágio, na última aula, houve um rompimento no grupo pelo conflito na organização das atividades de ensino e na definição das ações.

E2(Heloisa): Então, eu estava pensando, não sei se daria pra fazer de outro jeito essas ultimas aulas. A gente não gostou do Carlos ter fechado, a gente não gostou do fechamento dele, mas também não faço ideia de como a gente poderia ter encaminhado isso de outra forma. Ficou num impasse. [...]

O problema não é ter que mudar o planejamento, o problema não é ter que mudar a aula, o problema não é ter que diminuir o número de aula ou aumentar o número de aula. O problema é não ter alguém compreensivo pra te ajudar ou pra fazer junto. Acho que é isso.

Um processo de desentendimento ocorrido no grupo reitera a importância que as ações têm no trabalho coletivo, sua definição e sua divisão para os participantes, bem como a clareza do objetivo final que é compartilhado por todos interferem no desenvolvimento e no resultado do trabalho. No caso desse grupo a meta não foi atingida, pois na última aula o grupo cindiu, sendo levando em frente a organização das ações proposta por apenas um membro do grupo.

$\mathrm{Na}$ fala de Heloisa ela menciona que o fato de ter que aumentar ou diminuir uma aula, ou reformular o que havia sido planejado não é um problema que afeta o trabalho do grupo ou a relação entre eles, mas se instala um problema quando passa não existir compreensão na equipe, mesmo que isso seja por parte de um só membro. Ela é clara ao dizer que há necessidade de ajuda mútua, de se fazer junto, o que é de suma importância no trabalho compartilhado, só assim pode-se dividir as ações visando uma meta comum. Conseguindo também apreender tais ações para utilizá-las em outras situações. O sentido do trabalho compartilhado e sua importância à docência foi percebido por ela, com mais força, na ruptura que seu grupo sofreu, na divisão das ações (ENGESTRÖM, 1999), consequentemente na divisão interna de trabalho e nas regras que haviam estipulado.

O planejamento das regências no estágio é um dos pontos considerados mais importante por Heloisa como ela comenta no excerto da Entrevista 2:

E2(Heloisa): Putz, com certeza esse lance do planejamento, de objetivo, planejamento da aula e avaliação, acho que é uma das coisas mais importantes, 
porque no final você já está pensando em tudo, sua aula vai ter um objetivo que vai refletir no que você quer que eles aprendam, não só de conteúdo mas de modo de fazer ou de postura de vida, de reflexões que você quer que eles tenham, enfim, abrange um monte de coisas. Na hora de preparar a aula você tem $\mathbf{n}$ jeitos de preparar, você pode dar uma aula só na lousa, dar aula de experimentos, pode dar uma aula que combine os dois, pode dar uma aula de filme, enfim, todas as possibilidades de aula e a parte da avaliação, que vai fazer você ser um professor. E2(Heloisa): Eu estava falando da parte da avaliação que vai fazer você ser um professor pra cada sala e, você saber moldar os assuntos com o jeito de aula, porque pra várias salas a aula experimental não funciona, então, você já planeja um outro tipo de aula pra essa sala.

E2(Heloisa): Se os alunos gostam mais, mais aproveitam, há maior envolvimento. Isso tudo faz muita diferença, porque não adianta de nada você ser um professor que vai sempre fazer a mesma coisa não importando qual sala é, você dá sempre aquela aula de mecânica pro $1^{\circ}$, não importa se é o $1^{\circ}$ ano de $2003,2004,2005$. São pessoas totalmente diferentes, ou pior ainda, você dá a mesma aula desde os anos 70, que as coisas nem são as mesmas, as pessoas não têm nem a mesma mentalidade e você continua lá na sua aula do tempo em que a galera não tinha TV em casa, pra galera que tem TV que tá aqui na palma da mão.

A licencianda aponta que o planejamento faz pensar em muitas questões que envolvem organizar uma aula, leva a refletir na escolha e organização dos conteúdos a serem tratados, mas vai muito além deles, é necessário ter um objetivo direcionado para o que se quer e como se quer que os alunos aprendam. Essa aprendizagem envolve múltiplos aspectos: os fenômenos físicos (no caso desses licenciandos), história da ciência, epistemologia da Física, atitudes, habilidades, visão de mundo, postura social e política, dentre outros, que fez Heloisa perceber a complexidade do planejamento, por isso o concebeu como um ponto muito importante no estágio e para a docência.

Ela não pensa apenas nas aulas isoladamente, mas também na avaliação, no aspecto de refletir o resultado da aula para cada sala, para cada grupo de alunos, levando-se em consideração que precisam ser feitas alterações quando na organização da aula ao trabalhá-la de um grupo para outro, em épocas ou contextos distintos. Esse planejamento, que está associado à organização do ensino, não pode ficar estagnado no tempo, ele tem que ser dinâmico e relacionado ao contexto a que serve; precisa acompanhar o desenvolvimento histórico e social. Outro ponto mencionado é que o professor precisa se atualizar porque os alunos mudam em função das mudanças que ocorrem na sociedade, portanto, as aulas têm que ser modificadas. Essas questões são fundamentais para serem apreendidas na formação docente, levando à atribuição de sentido que permite, organizar as aulas intencionalmente e direcionadas ao aluno concreto e não ao ideal, o que Heloisa conseguiu pelas apropriações das discussões na disciplina com base nos textos abordados e em suas vivências, bem como ao preparar as aulas e refletir sobre elas e nas regências na escola. 
Ao perceber a extensão do planejamento ela se conscientiza das ações que envolvem a organização de uma aula, a necessidade da escolha de instrumentos que viabilizem essas ações, que são conscientes para ela, são intencionais. Isso ocorre visando que se possa após a concretização da aula ter alcançado os objetivos, tendo como meta a aprendizagem dos alunos.

Para Heloisa, a disciplina de MEF a estimulou a pensar o trabalho docente com possibilidades de realizar aulas que motivassem os alunos para argumentação e outros aspectos importantes para serem desenvolvidos no ensino, bem como, a organização das atividades de ensino pelo professor para que promovesse ações intencionais em direção aos seus objetivos. Além disso, ela também apontou as leitura e discussões dos textos indicados na disciplina como momentos de reflexão, que ela chamou de amadurecimento do que pensava, mas acreditamos que tenha sido momentos de conflito ou coincidência que podem ter levado à mudança de sentido em relação ao papel e ações do professor. O excerto da E2 apresenta a fala de Heloisa:

E2(Heloisa): As aulas aqui, a leitura dos textos, as discussões, todo esse contato com a Alfabetização Científica, sempre uma investigação que eu gostei bastante e amadureceu várias coisas na minha cabeça, de como fazer a sua aula, qual o objetivo da sua aula, como alcançar esse objetivo, quer dizer, não como você vai alcançar, mas como os alunos irão alcançar. Como vai ser a sua postura em sala de aula pra que isso aconteça, o que você tem que fazer pra estimular argumentação. Essa parte da argumentação eu achei maravilhosa.

Nas aulas da disciplina, em geral, os licenciandos tinham a discussão de um texto, o qual liam na semana anterior a aula. Os textos tratavam de pesquisas referentes ao trabalho docente, formação docente, currículo dentre outros, cujo objetivo era dar suporte teórico para que os alunos, em aula, refletissem sobre uma questão do universo da docência. Na discussão que era desencadeada pelo texto como mediador e questões ou alguma atividade que a professora da disciplina inseria, também como mediação para que os licenciandos discutissem um tema com foco em um ponto relevante para a profissão de professor, buscando trazer à tona os sentidos dos alunos sobre o tema e o do autor do texto, claro que os dela iam emergindo no processo. Com isso surgiam contradições, que os alunos não solucionavam naquele locus, mas em interações no grupo, na sala de aula da escola básica, começavam a estabelecer relações que geravam novos sentidos.

Essas discussões é que Heloisa cita em sua entrevista como sendo um fator de amadurecimento que a disciplina lhe proporcionou, que nós preferimos associar às novas atribuições de sentidos para situações já conhecidas ou também novas. A Alfabetização 
Científica foi uma referência forte na disciplina para a maior parte dos alunos, pois muitos ainda não haviam tido contato, mas o sentido apreendido foi de grande importância para o ensino, especialmente, o ensino de física. Com isso, os licenciandos incorporavam na atividade de estágio, a opção de trabalhar com a Alfabetização Científica ao organizar o planejamento. Eles queriam apreender a concepção para seu trabalho por coincidir com o que pensavam e/ou verificar com os alunos qual o resultado que obteriam, por ainda ser difícil a mudança.

A argumentação, para Heloisa foi estimulante, ela se entusiasmou porque, mesmo que não tivesse os subsídios teóricos, ela já atribuía sentido dos mais fundamentais para a aprendizagem e consequentemente para o professor saber promove-la com os alunos. $\mathrm{Na}$ disciplina de MEF ela pode ter aprofundado as relações entre a docência e a argumentação (CHIARO e LEITÂO, 2005; SASSERON e CARVALHO, 2011a), mas a importância dada à esta última vem desde o seu ensino básico, de onde traz o sentido que os alunos devem discutir, pensar e o professor orientá-los nesse processo. Isso leva-a a incorporar a argumentação em suas atividades de ensino, considerando assim como um aspecto importante para a docência, que coincide com muitas pesquisas. Tal sentido também foi incorporado por grande de parte dos alunos da disciplina e se explicitavam nos planejamentos das aulas de cada grupo.

\section{B. Caso Ricardo}

O planejamento elaborado em MEFI (P1), pelo grupo 1, constava de aulas destinadas ao $3^{\circ}$ Ano do Ensino Médio de duas escolas públicas, uma na cidade de São Paulo e outra em São Bernardo do Campo. O grupo tinha dois integrantes que fizeram o planejamento de forma compartilhada, mas aplicaram em escolas distintas, sendo a de Ricardo uma escola técnica.

Dois temas constavam do planejamento, lentes esféricas e filtros polarizadores, porque os estagiários tinham a intenção de trabalharem ótica geométrica e física com os alunos do ensino básico, com a ideia de compararem a diferença entre essas duas áreas de estudo da Física. O grupo tinha como objetivo trabalhar os conteúdos dos temas com uma abordagem investigativa, buscando a alfabetização científica (SASSERON e CARVALHO, 2011b), organizando assim as atividades de ensino com problemas abertos para que os alunos, partindo deles, discutissem o tema proposto, organizassem e realizassem ações, pudendo 
chegar a uma síntese, em um processo compartilhado entre os alunos, bem como com o estagiário (com o papel de professor), porém este hierarquicamente diferenciado no grupo. Um trecho da apresentação do planejamento do grupo para discussão na disciplina de MEF pode mostrar com clareza o objetivo do grupo:

P1(G1-Ricardo): Primeiro, a gente quer desenvolver um estudo fenomenológico e investigativo com os alunos, tomando como base aquilo que a gente aprendeu na disciplina, principalmente com o que diz respeito aos problemas abertos e a alfabetização cientifica. A gente vai desenvolver esse estudo tomando como base as lentes esféricas e os filtros polarizadores, de forma que os alunos possam levantar hipóteses, testar hipóteses, tomar dados, possam analisar séries de informações, organizá-las, classificá-las, ver uma série de evidências e tirar algumas conclusões, então a gente vai tentar fazer com que eles comecem a interagir com essa nova cultura que é a cultura cientifica, o fazer cientifico. Pra isso vamos utilizar problemas abertos. E obviamente nas atividades que vamos propor eles também vão ter que fazer proposições de modelo explicativo e justificar porque estão fazendo isso.

[...] A gente quer sair da zona de conforto, estamos tão acostumados com esse tipo de aula que queremos trazer a alfabetização cientifica pro nosso lado. Então, como vamos fazer? A gente entende que o ensinar física e aprender física, esses dois atos, exigem que haja um espaço de discussão dentro da sala de aula [...] Então a gente acredita que se o ato de ensinar e o ato de aprender física estão diretamente relacionados com as características do fazer cientifico e que promove a alfabetização cientifica nada mais óbvio do que a gente utilizar problemas abertos e análise por parte dos alunos pra gente fazer esse tipo de objetivo geral ser alcançado.

Ao observarmos a apresentação do planejamento do grupo 1 notamos que os estagiários não queriam elaborar o planejamento com aulas expositivas, estavam se propondo a sair de suas zonas de conforto, como disseram, e ao mesmo tempo, desejavam verificar como se desenvolveriam as aulas organizadas com um conjunto de ações coordenadas que promovessem a discussão entre os alunos e entre eles e o estagiário (no papel de professor) buscando a alfabetização científica, aspecto muito discutido na disciplina de MEF. Assim, os licenciandos propunham a apropriação dos conceitos científicos envolvidos nos temas que discutiriam, associados aquilo que os alunos já traziam de seus conhecimentos da escola e da vida, ou seja, de suas vivências, mas que pudessem interagir entre si ao mesmo tempo que agiriam sobre os objetos de ensino, os quais teriam a função de artefatos mediadores da aprendizagem, que provocariam uma mudança nos alunos (DANIELS, 2003) possibilitando a ampliação de seus conhecimentos, podendo relacioná-lo com o mundo ao seu redor.

Para chegarem a meta os estagiários propunham uma organização do planejamento que compunha ações, que coordenadas, chegariam ao objeto a ser alcançado, a aprendizagem dos alunos e suas mudanças nesse processo. Para tal, partiram de um tema, que foi lentes esféricas, que era introduzida aos alunos por um problema aberto, para o qual, divididos em 
pequenos grupos, cada um deles iria discutir e planejar ações na busca da solução daquele problema. Como coloca Ricardo:

P1(G1-Ricardo): A aula 1 -A gente pegou como tema lentes esféricas e os
conteúdos específicos são os tipos de lentes, as classificações das lentes, distância
focal, projeção de imagens e suas características. Os objetivos específicos são
desenvolver de forma fenomenológica e investigativa o conceito de lentes esféricas e
suas classificações pra própria distância focal, projeção de imagens e as suas
características. [...]
Obviamente eles já trabalharam esses conteúdos de forma teórica com a professora
regular da turma. A ideia é ver se eles conseguem ver isso de uma forma
investigativa e fenomenológica, uma abordagem um pouco diferente. Isso duraria
cerca de 15 minutos, essa é a nossa ideia.
Segundo momento da aula, determinação da distância focal da lupa. Mais ou menos
vamos apresentar um problema, junto com os materiais dados, como determinar a
distância focal da lupa? Então eles vão ter que resolver de alguma forma. Eu tenho
uma série de materiais, quais eu preciso usar? Uma régua, uma lupa? Posso usar as
outras lentes, preciso usar os lasers? A vela? Então eles vão selecionar os materiais
relevantes e fazer o modelo explicativo pra isso. Espera-se, obviamente, que de uma
forma mais simples eles projetem a imagem, por exemplo, da luminária com a lupa,
e a partir disso, com a régua eles determinem a distância focal. [...]
Profa Marina: Eles já tiveram ótica?
P1(G1-Ricardo): Já. A professora tá terminando o estudo de lentes esféricas com
eles. Então teoricamente já tiveram tudo isso, mas queremos ver se conseguem fazer
essa transposição para outro tipo de abordagem.

Esta temática, de ótica, foi solicitada pela professora efetiva da escola porque havia trabalhado o conceito com os alunos, ou melhor, discutido o tema mas sem recursos experimentais ou audiovisuais, ou algum outro tipo (BORGES, 2002). Assim, sugeriu que os licenciandos planejassem atividades de ensino com foco experimental, pois era o que ela não conseguia preparar em suas aulas, por falta de condições materiais e de tempo disponível, mas julgava importante e complementar à teoria essa abordagem experimental CC.

O grupo 1 mostra uma organização da aula com uma previsão da duração de cada etapa e ações dos alunos, são apontadas várias possibilidades que podem ser desencadeadas pelos alunos como caminhos para solução do problema, tais caminhos pressupõem ações que precisam ser estrategicamente elaboradas para que em seu conjunto satisfaçam a atividade de ensino proposta. Isso nos faz pensar que essa organização do planejamento mais detalhada mostra a intencionalidade do grupo nas ações de ensino, que foram provocadas pela proposta da disciplina de MEFI e assumidas como motivo do grupo, pois Ricardo cita, em sua apresentação, que pretende fazer com que os alunos da escola montem modelos explicativos, analisem dados, estabeleçam relações etc, buscando a alfabetização científica, assunto bastante discutido nessa disciplina, pela visão de alguns teóricos, pelas consonâncias, contradições e vivências dos licenciandos. 
Esse aspecto do planejamento colocou a alfabetização científica como uma condição importante e necessária ao ensino pelo licenciando, fazendo com que atribuísse esse sentido à docência, pois isso levaria à mudança na abordagem da aula, afastando-o da estratégia de se valer apenas de aulas expositivas.

A apresentação do grupo 1 segue detalhando o planejamento das duas primeiras aulas, no qual continuamos observando uma organização da atividade de ensino em consonância com a atividade de aprendizagem que se deseja que os alunos desenvolvam. As ações dos licenciandos estão distribuídas de acordo com o processo que será desencadeado pela atividade dos alunos, mas seguem uma sequência que visa objetivos sucessivos, como expõe Ricardo:

P1(G1-Ricardo): Ai no terceiro momento da aula a projeção de imagens de objetos escolhidos pelos alunos e sua classificação, então a ideia é que eles peguem coisas da própria mesa, um estojo, uma figura de um caderno e eles projetem imagens. Como eles vão fazer isso vai ser determinado por eles. Que materiais vão usar, como vão fazer as hipóteses, levantamento de dados, etc, tudo com eles. A gente vai entregar uma folha contendo essas perguntas e que eles façam anotações que sejam relevantes pra depois a gente fazer uma discussão, que vai ser na outra aula. Mas ai espera-se que eles observem que com a lupa os objetos vão ser projetados com suas imagens invertidas. A gente quer que eles cheguem mais ou menos nessa ideia, da forma deles, mas também que eles classifiquem essa imagem e expliquem o porquê isso acontece. Quer dizer, o porquê eles vão ver em todos os momentos da aula, a classificação das lentes, por que eles classificaram daquela forma, como classificaram. A determinação da distância focal, mais uma vez, como e por que.

Os estagiários organizaram a atividade de ensino buscando que a atividade de aprendizagem para os alunos, que visa colocá-los em ação partindo de um problema aberto, pudesse fazê-los ao investigarem o problema, também coordenarem suas ações para que conseguissem perceber como obtiveram e organizaram os dados e por que chegaram a tais resultados. Com isso, julgamos que pretendiam que os alunos tivessem consciência de suas ações e refletissem no como e por que conseguiram os resultados, levando-os a se aproximarem do conceito científico envolvido naquele assunto, que mais tarde eles iriam sistematizar, traçando assim uma proposta, com ações organizadas, para trabalharem com a aprendizagem dos alunos. O objetivo da proposta do grupo 1, da atividade de ensino com sua organização e ações que possam promover a atividade de aprendizagem, para que essas duas se objetivem em ensino e aprendizagem para professor e alunos, é atribuída como um sentido para à docência por Ricardo, pela apropriação que fez do que foi apresentado pela disciplina de MEF e pela importância que esse aspecto representou no planejamento elaborado pelo grupo. A organização do ensino e a preparação conjunta de condições para que seja 
promovida a aprendizagem dos alunos encontramos com relevância palavras de Bernardes (2009):

\begin{abstract}
A organização do ensino que possibilite a criação de condições adequadas para que ocorra a aprendizagem consciente por parte dos estudantes é preponderante para que a finalidade da atividade pedagógica se objetive no processo de ensino e aprendizagem. A objetivação da relação entre o motivo e o objetivo da atividade pedagógica por meio das ações e operações realizadas pelo educador e pelo estudante é identificada, segundo os diversos autores do enfoque histórico-cultural, como a atividade orientada para o ensino e a aprendizagem (p.241).
\end{abstract}

Os licenciandos propunham que após os caminhos traçados pelos grupos da sala para responderem ao problema, cada um deles apresentasse sua solução, com o estagiário (no papel de professor) mediando o processo, retomariam o que haviam feito até atingirem a meta. $\mathrm{O}$ trecho da apresentação a seguir nos mostra essa organização da aula pelo grupo 1:

P1(G1-Ricardo): Ai na aula 2, também de lentes esféricas. Agora os conteúdos e princípios são os mesmos e os objetivos específicos agora são reconstruir as etapas e procedimentos, o que eles fizeram, através de perguntas chave. Então, foi o que a gente viu, no caso, das crianças do ensino fundamental trabalhando com a bolinha, quando a gente fez aquela atividade na sala de aula. A gente quer que eles reconstruam o que eles desenvolveram nos três problemas.

Primeiro passo, a gente vai fazer a pergunta como - Como é que eles fizeram pra solucionar cada um dos problemas. Então, vão ter que reconstruir a atividades, os passos, os procedimentos que utilizaram. E depois a gente vai perguntar - Por que aquele fenômeno ocorre, por que é possível determinar a distância focal, por que é possível projetar imagens? Agora vai dar uma relação causal pra cada um dos problemas.

Profa Marina: Quanto tempo vai ter entre uma aula e outra?

P1(G1-Ricardo): Vai ser no mesmo dia, uma antes do intervalo e outra depois.

Profa Marina: Porque senão essas informações vão se perder. Tem que dar um jeito de registrar.

P1(G1-Ricardo): Não, a gente teve essa preocupação, vai ser no mesmo dia. A distância vai ser bem curta.

A retomada do processo realizado pelos grupos pensamos que faz com que os alunos reflitam naquilo que fizeram, na ordem das ações, como poderiam retomá-las para obter o mesmo efeito, ou como alterá-las para mudar, aperfeiçoar algum resultado que tenham obtido, contudo, nessa etapa os alunos buscariam a síntese do tema proposto.

Ao explicarem o planejamento fica claro o caráter intencional dos estagiários com os objetivos de ensino e aprendizagem que desejavam atingir. No entanto, havia outro componente importante nessa retomada que não podemos afirmar que os estagiários tinham consciência, mas que certamente faria parte do processo, que é a socialização das ideias dos grupos dos alunos, possibilitando a ampliação das soluções para o problema, bem como, das 
diferentes organizações de ações para alcançarem um resultado e chegarem ao conceito científico que se desejaria como meta daquela etapa.

Cabe observar, que os licenciandos, do grupo 1, ao elaborarem a atividade de ensino tomaram como referência a atividade de aprendizagem que viram ser desenvolvida por alunos do Ensino Fundamental I ao assistirem um vídeo em MEFI, como parte de uma aula para discutirem uma abordagem didática, o ensino de ciências por investigação, bem como suas possibilidades de aplicação no Ensino Médio e como desenvolvê-lo com os alunos. Essa abordagem parece ter motivado os estagiários na organização do planejamento e mais especificamente na proposta de retomada das ações desenvolvidas em cada grupo de alunos para a elaboração de uma síntese.

Nessa questão, ressaltamos a relação que se estabeleceu entre as discussões teóricas e também com base nas vivências dos licenciandos, com a organização do ensino proposta pelo grupo, o que não se fez por uma cópia ou repetição de um roteiro, mas por uma reelaboração de acordo com as necessidades dos estagiários e alunos da escola, cujo processo que envolve criação e conhecimento daquilo que se necessita. Vigotski (2009) coloca que a criança ao criar combina elementos que conhece de sua vivência com o de sua situação atual, sendo essa capacidade de combinar "o velho de novas maneiras" que fornece a base da criação, esse processo podemos transpor para outras situações, como a dos licenciandos ao criarem suas aulas com diversos elementos de suas experiências e daqueles que a disciplina lhes forneceu.

O gerenciamento do tempo para o desenvolvimento da atividade de aprendizagem que com as múltiplas ações dos alunos e dos licenciandos surgiu como preocupação da professora da disciplina e ela fez uma observação alertando-os. Porém, ela não chama a atenção apenas para a organização da atividade no intervalo de tempo disponível, mas para o registro dos pontos principais da discussão dos alunos no momento da apresentação dos grupos, para que a informação não se perca de uma aula para outra. Para esse segundo apontamento da professora de MEFI os estagiários argumentam que as duas aulas seriam no mesmo dia, portanto, não haveria o problema dos alunos não se lembrarem do que realizaram. Nessa situação, pensamos que independente da sequência das aulas, o registro nos grupos antes e durante a discussão coletiva deve ser garantido como parte do processo, como parte das ações organizadas, tanto pelos alunos como pelo estagiário (no papel de professor). Para que, além de terem o material registrado para utilizarem nas próximas etapas, ele seja fonte de acompanhamento e avaliação para o aluno e para o professor, parece-nos que isso não ficou explicitado. 
Após a apresentação dos grupos e finalizada a síntese de aprendizagem, o grupo propõe a exibição de um vídeo sobre ótica, com a intenção de ampliarem um pouco mais a discussão sobre o tema. Os estagiários haviam planejado que os alunos assistiriam ao vídeo antes de fazerem a síntese, no entanto, na discussão com a professora da disciplina resolveram inverter a ordem do vídeo, exibi-lo para finalizar a reflexão sobre o tema de ótica geométrica. A discussão em relação ao momento de exibir o vídeo está a seguir e mostra os argumentos da professora da disciplina.

Profa Marina: Por que o vídeo vai antes da discussão?

P1(G1-Ricardo): Porque eles vão ter uma revisão do conteúdo teórico, vão fazer a ligação desse conteúdo com o que eles trabalharam nos problemas. Uma forma de enriquecer a sistematização que a gente vai fazer depois.

Profa Marina: Mas não pode ser o contrário? [...]

A ideia é que você vai diminuindo um pouco a distância do pensamento.

Além disso, você possibilita uma construção que é muito mais deles com o que eles experimentaram. Porque senão eles vão de alguma maneira querer forçar colocar informações do vídeo no que eles fizeram, de maneira irrefletida e às vezes pode criar uma confusão. Você pega uma informação que eles obtiveram do experimento e agora eles têm uma informação sistematizada, que eles tão tendo disponibilidade e ai a resposta vai querer ser muito mais aproximada ao que o vídeo traz e não vai exprimir tanto o que eles experimentaram. Entende? [...]

P1(G1-Ricardo): A gente tinha pensado em fazer isso também. A princípio pensamos em discutir aqui mesmo qual seria a melhor abordagem, pensamos nessa interferência do vídeo, mas depois não achamos que fosse significativo, por isso deixamos dessa forma.

Profa Marina: Ia ser muito. Porque assim mostra uma resposta que seria esperada. P1(G1-Ricardo): É, exatamente.

E ai a última parte da aula seria a sistematização do que foi desenvolvido e aprendido. Então invertendo agora, eles fizeram a discussão, explicaram pra gente porque aquilo acontece, ai passamos o vídeo, orientamos os alunos a estabelecer uma relação do vídeo com aquilo que foi trabalhado e depois pedimos que façam uma sistematização do que foi desenvolvido e aprendido nas duas aulas. [...]

Os estagiários planejaram o vídeo antes da síntese com a intenção de oferecer algumas informações que os alunos pudessem relacionar com aquelas que obtivessem na atividade experimental que iriam desenvolver e pudessem, desta forma, ampliar suas análises sobre a soluções do problema. No entanto, com a argumentação da professora da disciplina, os licenciandos, do grupo 1, tiveram a necessidade de repensar a articulação entre a organização do planejamento da aula 1 e 2, pois a proposta da professora de MEFI foi que exibissem o vídeo depois da construção da síntese com os alunos. Assim, estes traçariam as ações que realizaram e que os levaram aos resultados, bem como, fariam sua síntese e também a coletiva com a sala toda, com a colaboração dos estagiários, sem serem influenciados pelas explicações de conceitos, relações com o cotidiano ou aplicações apresentadas no vídeo. 
O grupo 1 resolveu com rapidez a situação, não por apenas terem acatado a alteração que a professora de MEFI propôs, isso era importante, mas, como podemos verificar no trecho do diálogo, os estagiários tinham discutido no grupo também essa outra possibilidade de organização para as aulas. Esse fato, de terem pensado em mais de uma organização das aulas, nos leva a perceber que o trabalho realizado pelos estagiários com a intencionalidade presente em relação à aprendizagem dos alunos, demandava um processo de reflexão e previsões das ações dos alunos, visando os objetivos propostos na atividade de aprendizagem. Como Ricardo relata, discutiram as duas organizações de ações para o ensino porque queriam que os alunos pudessem aprofundar seus conhecimentos sobre o tema, tinham o objetivo de fazê-los entrar em atividade com aquele problema proposto, por isso, tinham muita preocupação e cuidado com suas atividades pedagógicas, o que os colocava nas mesmas condições de um docente, em seu significado mais estrito, a aprendizagem discente.

Ricardo, pelas reflexões sobre o planejamento, atribuiu à docência o sentido de intencionalidade e necessidade da organização de ações de ensino para que os alunos fossem motivados ao estudo e pudessem atingir a aprendizagem.

O grupo 1 planejou, além da abordagem de óptica geométrica, duas aulas para discutir óptica física. Para tanto, propuseram a elaboração de uma atividade investigativa com filtros polarizadores, com o objetivo de trabalharem o conteúdo de polarização da luz. A organização da aula com as ações propostas pelos estagiários segue o mesmo processo da atividade de ensino anterior, com pequena alteração, sendo que para complementação das informações utilizaram a leitura de um texto didático e também vídeo 'com a explicação do fenômeno de polarização da luz e algumas de suas aplicações, cuja descrição está apresentada abaixo:

P1(G1-Vera): [...] tem como objetivo introduzir os alunos à ótica física, a partir do estudo fenomenológico, textual e investigativo dos filtros polarizadores. Como isso vai ser feito? Com uso de filtros polarizadores e um texto didático e a aula vai ser dividida em quatro momentos, sendo que no primeiro distribuiremos os filtros, dois para cada grupo. O problema será de como eles vão bloquear a luz com o uso desses dois filtros. A partir daí vão criar hipóteses, pegar dados, com isso, num segundo momento da aula, a gente entra com a discussão de como eles fizeram pra solucionar aquele problema.

Profa Marina: Seria interessante [pausa], vocês vão fazer isso dentro da sala de aula? Vocês podem falar como bloquear a passagem de luz aqui dentro da sala de aula e depois ir pra fora. Porque eles podem ficar com a ideia de que o filtro bloqueou porque essa luz é fraca, se tiver um dia ensolarado ótimo. Ver diferentes lâmpadas. Têm diferença diferentes lâmpadas?

P1(G1-Ricardo): [...] no mesmo dia vai ter os materiais, a vela por exemplo. A gente tá com lanterna também, eles podem usar dessa forma e depois levamos pra fora se tiver condição.

Aluna 1: Eles podem ter outras opções de fonte de luz? 
P1(G1-Ricardo): É. Porque a gente vai levar numa caixinha o material, as opções estarão lá, então eles podem usar também a lanterna pra verificar isso, além disso, a gente vai levar pra fora.

P1(G1-Vera): E a partir disso, eles podem reconstruir o que foi feito, como eles fizeram pra solucionar o problema e a questão de porque o fenômeno aconteceu, pra ver se eles conseguem explicar, se entenderam o que é o fenômeno. Como eles ainda não tiveram isso, a gente entra com um texto didático, que eles vão fazer a leitura individualmente, grifar, marcar o que acharem importante pra discussão na sequência. Esse texto explica o fenômeno da polarização da luz e traz exemplos de aplicação tecnológica em LCD, etc.

Os licenciandos, para discussão do novo conteúdo proposto utilizarão a mesma abordagem didática das aulas 1 e 2, sobre óptica geométrica, com a diferença que esse tema anterior já havia sido discutido pela professora efetiva dos alunos, assim os estagiários fariam uma outra discussão da temática, com foco em parte do conteúdo e se apoiando em procedimentos que levassem os alunos a agirem com meios mediacionais (experimento, discussão em pequenos grupos etc) para discutirem o fenômeno observado e relacioná-lo com os conceitos científicos estudados. Nas aulas 3 e 4, tinha-se uma situação um pouco diferente porque os estagiários se propuseram a abordar um assunto de óptica física que os alunos da escola não haviam trabalhado. Assim, o grupo 1 decidiu seguir o mesmo processo, com ações semelhantes às da temática anterior, no entanto, os alunos primeiro investigariam sobre o assunto e fariam uma análise para depois complementarem ou contraporem suas ideias com as apresentadas em um texto teórico e em vídeo. Os estagiários tinham como objetivo que os alunos relacionassem os resultados que obtiveram com as informações fornecidas e elaborassem uma síntese sobre o que aprenderam daquele tema.

No excerto abaixo, Ricardo comenta que elaborar o planejamento das aulas tendo como objetivo atividades de ensino com problemas abertos e como proposta para norteá-las o ensino a alfabetização científica, não foi um processo fácil.

P1(G1-Ricardo): A ideia foi trabalhar realmente com problemas abertos, investigativos e alfabetização científica. A gente percebeu o quanto é difícil tentar planejar isso, porque a gente tá tão acostumado com o ensino expositivo, teórico que é difícil quebrar isso. Primeiro a gente pensa que não vai dar certo. A princípio a gente ia propor um problema só, na primeira aula, ao invés dos três problemas de ótica geométrica: "Putz, mas vai ser muito rápido, eles vão sacar muito rápido". Então, a gente não tá acostumado a trabalhar nessa linha investigativa, é complicado no começo, dá pra ver. Espero que dê resultados positivos. E tem a construção do próprio fazer cientifico.

Profa Marina: E essas atividades que vocês estão levando, facilmente obtém o efeito que você quer e o fato de se obter facilmente o que você quer ajuda depois no momento de reconstrução das ideias pra chegar a conceituação disso. Acho que não vai ter grandes problemas não. 
O licenciando colocou a dificuldade do grupo em organizar as aulas utilizando uma concepção que levasse os alunos a terem ações conjuntas e também individuais, o que pressupõe colocar esses alunos em atividade direcionada aos seus estudos, buscando a aprendizagem daquele tema. Para tanto, é necessário que o motivo dos estagiários sendo o ensino dos conceitos envolvidos no tema proposto, ao elaborarem as atividades de ensino precisavam criar condições para mobilizarem os alunos, colocando-os em atividade, para que pudessem desencadear suas ações e interações diversas.

Isso requereu que os licenciandos se arriscassem a mudar o modo de ensinar, não só por aulas expositivas para dar informações, como Ricardo mencionou, que era a forma com a qual fora acostumado, mas possibilitando também outras maneiras de organizar o ensino, pensando a sala de aula como um espaço de criação e comunicação entre indivíduos em atividade de estudo em busca da aprendizagem.

A situação de utilizar uma abordagem didática com a qual não havia ainda trabalhado com alunos deixava Ricardo, e seu grupo, inseguros e ansiosos para o momento da regência na escola, o que a professora da disciplina percebeu e buscou dar-lhes mais segurança. Ela comenta que a atividade de aprendizagem proposta não se complica muito com as ações dos alunos, apontando que, de certa forma, eles chegariam ao objetivo planejado pelo professor. No entanto, o conhecimento elaborado é sistematizado, transmitido e modificado no espaço escolar, na sala de aula, pois leva à produção de sentidos pelo professor (no caso que discutimos este papel tem foco nos licenciandos) e pelos alunos, que no compartilhamento das atividades de aprendizagem, nas discussões e em outras ações, participam dos conhecimentos que são elaborados na escola, como também aponta Smolka et al. (2007):

(...) Ao pensarmos a trama de significações como um trabalho histórico de produção de conhecimentos, na qual, palavras, conceitos e sentidos são também produção social e histórica em constante elaboração, e da qual participam - devem e podem participar - todas as pessoas na sociedade, podemos entender como as muitas formas de participação dos sujeitos estão articuladas a muitos espaços de inter(in)compreensão e como estes são constitutivos do processo de elaboração de conhecimento na escola (grifo do autor, p.33).

No segundo semestre, o grupo 1, na disciplina de MEFII, contou com mais um integrante, porém este fez o estágio em escola diferente dos outros dois, que agora passaram a realizar essa atividade no mesmo local, mas a elaboração do planejamento e ações de ensino eram conjuntas. Nessa disciplina os licenciandos do grupo nos pareceram mais à vontade para lidarem com a abordagem didática proposta, a de utilizar problemas para os alunos 
investigarem um dado tema, tinham maior confiança em conseguir mobilizar os alunos, para colocá-los em atividade de aprendizagem. Tais observações pudemos obter pelo acompanhamento das discussões nas aulas da disciplina, na escola, na entrevista com Ricardo e na apresentação do planejamento em MEFII.

Os estagiários do grupo 1 ao pesquisarem com os alunos qual o assunto que gostariam que eles abordassem nas aulas, tiveram como resultado a indicação de astronomia. Com base nisso decidiram trabalhar com Física Moderna, escolhendo espectroscopia para desenvolver nas regências do estágio. O planejamento do grupo constava com uma introdução ao tema, o estudo do espectro luminoso, emissão, absorção e a composição das estrelas, para o que utilizaram atividades de aprendizagem diversas, propondo textos, vídeo, prática em grupo e construção de espectroscópio para a observação do espectro da luz solar e de lâmpada. Na apresentação do planejamento na disciplina de MEFII o grupo 1 justifica a escolha do tema, como mostra o trecho da fala de Ricardo:

\footnotetext{
P2(G1-Ricardo):[...] O interessante é que as próprias justificativas dos alunos em querer aprender os sistemas relacionados à astronomia tinham a ver com questões emocionais, a questão da curiosidade, do interesse, alguns pensavam em fazer faculdade de astronomia. Então, é interessante porque eles não estão atrelados à questão do vestibular.

E ai, quando estávamos discutindo a questão dos saberes científicos, que superam a transposição didática por uma série de processos [...] surgiu a necessidade de que eles sejam problematizados, contextualizados para que aquilo faça algum sentido para os alunos. Essa é uma justificativa do por que desenvolvemos uma proposta problematizada e contextualizada.

E os aspectos da alfabetização científica, como já estudamos no primeiro semestre e retomamos agora, são aspectos que constituem os objetivos de Ciência, então, trabalhá-los é um dever como professores.

Agora sobre as aulas. A primeira aula é sobre espectros luminosos. E os conteúdos específicos são espectros de emissão e de absorção. [...]

A primeira parte da aula seria a análise e desenvolvimento de um problema aberto por parte dos alunos. Jogaríamos o seguinte problema para eles investigarem: Como podemos conhecer as estrelas a partir da análise de sua luz que chega até nós? $\mathrm{O}$ texto desenvolve isso, mas gostaríamos de trabalhar isso com eles primeiro.
}

Ao apresentar o resultado da pesquisa feita com os alunos, cujo tema que a maioria gostaria de discutir nas aulas era Astronomia, o grupo 1 observou que a manifestação a favor desse assunto vinha mais de interesses pessoais dos alunos que daqueles ligados às necessidades impostas por provas, concursos, como por exemplo, o vestibular como Ricardo citou, ou ainda por um pedido da professora efetiva. Essa situação trouxe condições favoráveis e adequadas, do ponto de vista do ensino, para que os estagiários desenvolvessem o trabalho pedagógico, pois esses alunos já possuíam um motivo eficaz para colocá-los em atividade de aprendizagem, que era o interesse em compreender assuntos ligados à 
Astronomia. No entanto, era necessário que o grupo 1, tivesse seus motivos alinhados com os dos alunos, na atividade de ensino, para que o trabalho conjunto fosse consoante.

Essa situação aponta para a importância dos professores considerarem as necessidades dos alunos ao prepararem a atividade de ensino, para o que Moura et al. (2010) coloca:

[...] é fundamental que no processo de ensino, o objeto a ser ensinado seja compreendido pelos estudantes como objeto de aprendizagem. Isso, para a teoria histórico-cultural, só é possível se este mesmo objeto se constituir como uma necessidade para eles. Assim, os conhecimentos teóricos são ao mesmo tempo objeto e necessidade na atividade de aprendizagem (p.214215)

Dada a situação que o grupo analisou, sobre a motivação da escolha dos alunos, considerando as leituras de pesquisas, as discussões que fizeram nas disciplinas de MEF em relação ao ensino de Ciências e as regências do semestre anterior, os estagiários apontaram a alfabetização científica como parte intrínseca ao trabalho docente, como conduta profissional, para que a Ciência fosse discutida de forma mais ampla com os alunos, o que acreditamos ter sido atribuído como um sentido para a docência. Assumir tal sentido para a docência faz com que se organize o ensino com abordagens didáticas que possibilitem maior ênfase nessa opção, para o que Ricardo coloca que escolheram trabalhar com problema para que os alunos investigassem no decorrer do processo de estudo.

A professora de MEFII considera o problema proposto pelo grupo 1 genuíno e que com ele poder-se-ia trabalhar toda a sequência didática sobre o tema, o que corrobora com a ideia do grupo, pois, o objetivo era finalizar a investigação quando os alunos compreendessem como fazer para verificar a constituição de uma estrela, encerrando com um texto para esclarecimentos e sistematização do assunto. Essa discussão, na sala de aula da disciplina, está apresentada abaixo:

Profa Marina: [...] Porque ele é um problema e bastante genuíno, porque o aluno não sabe mesmo a resposta.

Se vocês estão falando que vão tratar a questão da formação das estrelas e da espectroscopia, me parece que esse problema vai ser discutido ao longo de toda sequência.

P2(G1-Felipe): Na verdade esse problema vai ser o desfeche de todo o trabalho. Porque na atividade final é que eles vão perceber como fazemos para olhar para a estrela e dizer como ela é feita.

Profa Marina: Isso é interessante. [...] quando estamos imaginando uma sequência de ensino ela não é chamada assim porque é um nome bonito, é porque as atividades deveriam estar sequenciadas de tal maneira que você vai trabalhando a complexidade daquele tema ao longo de diferentes aulas. Então, um problema que perpassa toda sequência de ensino tem que estar claro, senão para o aluno, para você 
como professor. Para você sempre voltar a atividade que dê conta do aluno resolver esse problema.

P2(G1-Felipe): Eu imagino que eles vão ler o texto e não vão chegar à resposta. Só vão chegar quando fizermos a atividade, daí ficará claro.

Profa Marina: Vocês têm que ter muito claro que você fala em luz para o aluno, mas o que é luz? Luz para ele é tudo. Aquela luz brilhando na caixinha de som é a mesma luz. Ele não vai diferenciar que aquela pode ser diferente dessa. Até porque você não deu material intelectual a ele para fazer isso. A construção que vocês estão fazendo vai ter que perpassar por isso.

Então, a questão do espectroscópio entra nesse sentido de fornecer material intelectual e físico para que o aluno resolva o problema.

P2(G1-Felipe): Para que o aluno possa perceber que uma luz é diferente da outra. Profa Marina: E que o que não percebemos como luz também é luz.

P2(G1-Ricardo): O segundo momento da aula seria de reconstrução e análise ou de tomada de consciência, como já trabalhamos no primeiro semestre, porque nem sempre tomamos consciência das próprias ações. Então, é importante que algumas perguntas sejam estabelecidas. A primeira é: "Como fizeram para solucionar o problema e por que propuseram esse modelo explicativo e qual a fundamentação".

E a penúltima parte é a leitura e discussão do texto sobre espectroscopia em pequenos grupos e depois uma discussão aberta com todos, sobre os pontos mais importantes, dúvidas que eles possam ter. $\mathrm{Na}$ aula 2 vamos fazer uma sistematização. [...] do que foi desenvolvido e aprendido. [...]

A situação proposta pelo grupo 1, na qual o problema proposto seria respondido ao longo da investigação do tema, trouxe para discussão a organização da sequência didática, que não é apenas elencar os conteúdos a ensinar, mas está ligada à atividade de ensino na qual se insere e a abordagem didática que é escolhida para desenvolver as atividades de aprendizagem. No caso do grupo 1, os estagiários optaram por um problema que nortearia a sequência didática, sendo assim, seria o foco da investigação dos alunos da escola até finalizar o estudo daquele tema, por isso a professora da disciplina alerta para a importância desse problema estar claro para o professor (no caso os estagiários) para que ele saiba conduzi-lo e trabalhar com as mediações necessárias para que as ações dos alunos possam se organizar para o objetivo da compreensão daquilo que será enfatizado em cada momento. Na proposta dessa sequência didática a discussão do tema vai se complexificando para que se chegue a síntese da questão investigada, que precisa ser refletida de forma compartilhada em grupos e com toda a sala, com a orientação e colaboração do estagiário (no papel de professor).

Nesse caso, há indícios de ter ocorrido um aprofundamento no trabalho com a proposta didática, em relação ao primeiro semestre, pois, o grupo propôs a preparação do planejamento de forma mais complexa, tomando um problema inicial e organizando ações de ensino em um eixo condutor que tinha como meta a solução do problema, mas esta iria se construindo a cada etapa para ser objetivada no final do processo, com a apropriação do conceito científico e formação do pensamento teórico. 
Isso, nos mostra que a organização, observação, o contato com os alunos, a avaliação e as interações propiciadas na atividade de estágio em MEFI, pode fazer com que Ricardo e seus colegas do grupo também tivessem um processo de aprendizagem, que foi importante para o estágio em MEFII. Assim, pensamos que isso permitiu que o sentido atribuído ao processo de organização da atividade de ensino, com problemas para investigação tomou um caráter mais detalhado e mais complexo, que veio da práxis, do trabalho compartilhado e interações que permitiram as trocas e reflexões. Como Moura et al. (2010) destaca no excerto abaixo:

O professor que se coloca, assim, em atividade de ensino continua se apropriando de conhecimentos teóricos que lhe permitem organizar ações que possibilitem ao estudante a apropriação de conhecimentos teóricos explicativos da realidade e o desenvolvimento do seu pensamento teórico, ou seja, ações que promovam a atividade de aprendizagem de seus alunos. Além disso, é um profissional envolvido também com a sua atividade de aprendizagem, atividade esta que o auxilia a tomar consciência de seu próprio trabalho e lidar melhor com as contradições e inconsistências do sistema educacional (p.213-214).

A professora da disciplina mencionou ainda, que para os alunos desenvolverem as atividades de aprendizagem era necessário que os estagiários fornecessem, durante o processo, material intelectual e físico para que pudessem buscar a solução do problema que lhes foi proposto. Esse ponto que foi ressaltado, julgamos importante para a formação docente, pelo fato de chamar a atenção dos licenciandos para que as atividades de aprendizagem precisam levar os alunos ao pensamento teórico, não podem se iniciar nas experiências de cada um e permanecer nelas, precisam avançar e a escola é o lugar para a sistematização desse conhecimento.

Ricardo apontou também que outro momento da organização da atividade de aprendizagem era a retomada, pelos alunos, do que haviam feito, para depois fazerem a análise coletiva daquilo que tinham como respostas ao problema, sistematizando o processo que fizeram e o que aprenderam. O estagiário mencionou que essa retomada é uma tomada de consciência para os alunos do que fizeram no decorrer da atividade de aprendizagem, o que também havia citado no planejamento em MEFI, porém agora leva em consideração as ações dos alunos, explicitando julgar importante que se torne consciente essas ações realizadas coletivamente na busca da solução do problema. Consideramos que isso permite que os alunos tenham consciência da organização das ações no trabalho coletivo para atingir a meta desejada, bem como sua aplicação em outras situações, podendo algumas delas se tornarem 
operações, à medida que novas etapas necessitarem de outras ações, sendo as anteriores, já apreendidas, automatizadas. A percepção desse aspecto no trabalho docente demanda que o professor também tenha consciência do processo de ensino e de seus objetivos, para que suas ações e as dos alunos estejam coordenadas.

O tempo disponível para realizar o planejamento proposto foi outro ponto discutido, pois a professora da disciplina manifesta a preocupação de que talvez o tempo considerado para o desenvolvimento da atividade de ensino não fosse suficiente na prática. Ela enfatiza a leitura do texto, que muitas vezes o intervalo de tempo proposto é subestimado, porque os alunos demoram para ler um texto. Porém, não é só a leitura que demanda tempo, mas o próprio problema que não é trivial para ser trabalhado. Contudo, os estagiários não estão tão preocupados, parecem que dispõem de uma certa flexibilidade para conseguir mais uma aula com professora efetiva se for necessário, como podemos observar no diálogo a seguir:

\footnotetext{
Profa Marina: Então não vai dar tempo.

Tem um aluno que acabou de defender o mestrado e pra defender ele foi à aula dele cronometrar quanto tempo os alunos levam para ler um texto. Um texto de 6 páginas os alunos levam 15 minutos.

P2(G1-Ricardo): Semestre passado quando aplicamos deu tempo.

Profa Marina: Mas esse texto ai?

O texto é bom, cheio de informação, é difícil de ler. Eles terão parado para pensar numa questão que é difícil, terão discutido essa questão com o professor, lerão o texto e ainda terá a discussão aberta. Acho que não dá tempo.

P2(G1-Ricardo): Mas se continuarmos na próxima aula e fizermos a sistematização?

Profa Marina: Tudo bem. Você está me colocando que é a aula 1 e a 2.

P2(G1-Felipe): Nós vamos dar 6 aulas e se estender uma aula ou duas não tem problema. A dúvida é se lá no colégio não teremos problemas.

Profa Marina: Não sei, mas estão cientes de que pode ser que demore muito mais. Essa pergunta não é fácil.

P2(G1-Ricardo): A nossa ideia é que a gente controle o tempo que eles terão para pensar sobre isso, porque como vai ser desenvolvido pelo resto das atividades, não vamos querer que eles pensem tanto no primeiro dia, ai que entra o papel do professor. [...]
}

A questão posta é o gerenciamento do tempo que o estagiário planejou para as atividades de aprendizagem e o da execução das mesmas pelos alunos. O contato restrito que os licenciandos têm com a sala de aula parece influenciar nessa distribuição e duração daquilo que planejam para as aulas, podemos pensar que em um primeiro momento isso ocorra pela falta de experiência dos estagiários com a docência e que só será superado quando estiver imerso no trabalho de professor, mas consideramos que a formação docente pode lidar com esse fato, pois ele se expressa, geralmente, em uma contradição entre a grande quantidade de material preparado para desenvolver em sala de aula, em um intervalo de tempo com tudo distribuído linearmente, sem prever o tempo necessário para as interações que ocorrerão 
naquele meio. Isso pode fazer que o que foi organizado para cada instante se disperse e não se consiga finalizar cada aula com o objetivo a que ela se propunha. Assim, essa é uma questão a ser refletida na formação do professor, pois integra o trabalho docente. Ricardo percebeu essa necessidade e apontou como uma atribuição do papel do professor, coordenar o desenvolvimento da atividade de aprendizagem, com as ações dos alunos e o tempo de aula, o que surge como outro sentindo que atribui à docência.

A finalização da proposta do grupo 1 tinha como objetivo a determinação dos elementos químicos que compunham uma estrela, utilizando o espectro dos mesmos para comparação com o da estrela, como explicaram em um trecho da apresentação:

\footnotetext{
P2(G1-Felipe): Vamos fazer a atividade que é a do Astrônomo mirim, em que pretendemos levar as folhas impressas e coloridas. Aqui temos um espectro de uma estrela e os espectros dos elementos químicos. Então, o aluno pode comparar, por exemplo, olhando a franja do ferro e a da estrela e vai achar uma franja muito parecida, assim conclui que naquela estrela tem ferro.

Profa Marina: Vocês podem fazer isso imprimindo essas linhas dos elementos em transparência e coloca em cima. E ai não precisamos imprimir os elementos para todos, pode imprimir por grupo.

P2(G1-Ricardo): Não entendi a questão da transparência.

Profa Marina: Ele pega o ferro e o iodo e coloca um em cima do outro e vê que está dando algo diferente. Com qual ele compara?

P2(G1-Felipe): Ele pode pegar e ir casando uma em cima da outra e vendo qual se aproxima mais.

E aqui, com essa atividade o aluno vai concluir e chegar à resposta da pergunta geral, que é como conseguimos identificar a estrela pela luz que chega.
}

Para essa comparação, dos espectros dos elementos químicos com o das estrelas, a professora da disciplina sugeriu o uso de transparências para que fosse possível fazer a superposição dos espectros, o que facilitaria verificar as semelhanças das linhas espectrais, para que os alunos identificassem os elementos constituintes de cada uma das estrelas e então, conseguissem complementar a resposta à questão inicial do problema proposto. A discussão do planejamento, como nesse caso, levava também ao aprimoramento das atividades de ensino, com sugestões da professora da disciplina ou dos licenciandos dos outros grupos, tanto no conteúdo como na parte operacional, bem como, no desenvolvimento das ações docentes ou naquelas propostas aos alunos. Assim, o planejamento dos grupos, após a apresentação na aula de MEF, era reestruturado em múltiplos aspectos, além de, ao ser discutido, gerar contradições na concepção de ensinar, na aprendizagem da docência, o que provocava mudanças na atividade de estágio (ENGESTRÖM, 1999; ARRUDA, 2006), se configurando um movimento dialético. 
A apresentação do planejamento do grupo 1, trouxe ainda a questão da contextualização do tema para discussão. Os estagiários com base nos referenciais teóricos que haviam estudado na disciplina, segundo os objetivos e organização das aulas que propuseram, tinham como proposta para introduzir o tema aos alunos da escola, fazer uma contextualização utilizando um texto didático, de um livro de Ensino Médio, que contém Física Moderna, sendo um dos autores mencionado como professor P. O texto, segundo os referenciais estudados, fazia uma contextualização do tema que o grupo considerou sóciohistórica e didática. No entanto, essa questão gerou uma extensa, mas proveitosa, discussão na sala, da qual apresentamos um trecho:

P2(G1-Ricardo): [...] Exatamente. Porque a ideia é que nos textos a contextualização feita, principalmente sócio-histórica e didática, então, pela leitura dos textos não temos os aspectos relacionados à alfabetização cientifica. Pelo menos não como da forma que o professor P expõe. Agora, quando formos propor as atividades, por um problema aberto ou outro, esses aspectos aparecerão, por isso estou tentando defender como uma contextualização.

Profa Marina: Tudo bem, mas eu ainda não sei se concordo, vamos vendo ao longo de cada uma das aulas, porque uma atividade de leitura pode ser tradicionalíssima, mas pode ser uma atividade com interação entre os alunos e o próprio texto ou entre o professor e os alunos. Se ela for uma atividade que vocês propõem uma pergunta para que o aluno comece a ler o texto de alguma maneira esse problema qualquer já foi dado aos alunos. Então eles não lerão o texto de maneira passiva. O que eu quero dizer com isso é que eles não lerão o texto só para decifrar informação, lerão buscando algum tipo de resposta para a questão que vocês colocaram para eles. [...] Profa Marina: Eu acho interessantíssimo isso que estamos discutindo, porque a contextualização vai ter um aspecto que não é só do material que é fornecido aos alunos, mas é também de como é que o professor está se preparando para implementar aquele material. Então, se o professor está preparado para dar uma aula em que ele vai discutir com os alunos, ele vai de alguma maneira fazer com que eles se coloquem frente a uma investigação, porque estamos falando em Ciência, e a investigação é própria da Ciência, a questão epistemológica da ciência vai aparecer. P2(G1-Ricardo): Então podemos colocar, inclusive, o epistemológico. [...]

Profa Marina: Mas isso é bem bacana de considerarmos, porque pode ser que quando for implementar nada disso aconteça.

No primeiro trecho da fala de Ricardo, ele se refere ao texto pelo qual começariam abordar o tema de espectroscopia, dizendo que a ideia do grupo era fazer uma contextualização do assunto a ser estudado, cuja abordagem, segundo os estagiários, era sócio-histórica. Após essa etapa trabalhariam com um problema aberto para que os alunos discutissem o tema, organizando ações, colhendo e analisando dados para estabelecerem suas conclusões, para na etapa final apresentarem à sala, fazendo uma reflexão coletiva com a colaboração do estagiário (no papel de professor), buscando uma síntese que pudesse levar ao conceito que envolvia aquele fenômeno, como trabalhavam nas regências anteriores de MEFI. 
Ao colocarem as ações de ensino que tinham traçado, principalmente o início da atividade de ensino que haviam elaborado, a professora da disciplina os questionou quanto ao texto escolhido, apontando que além dele trazer os aspectos sócio-histórico e didático poderia também ter o epistemológico, o qual os estagiários acreditavam que apareceria no desenvolvimento da prática, depois que propusessem o problema aos alunos. No entanto, a professora de MEFII apontou que essas questões poderiam surgir nesse momento da leitura e discussão do texto ou não, dependendo de como esse texto fosse trabalhado com os alunos, isto estaria ligado às ações de ensino que os licenciandos propusessem, assim, eles poderiam tornar o texto uma leitura tradicional ou como uma parte do problema que desencadearia a investigação com os alunos.

Essa questão gerou uma longa discussão com o grupo 1 e também com outros licenciandos da sala, que buscavam esclarecer os aspectos que envolviam as diferentes contextualizações, sócio-histórica, didática e epistemológica, advindas da leitura de textos de pesquisadores feita na disciplina. Porém, a professora de MEFII argumentava que na prática, nas interações em sala de aula e mesmo na organização das atividades de ensino, as etapas propostas poderiam se mesclar, assim, na contextualização vários aspectos surgiriam explícita ou implicitamente, porque os estagiários colocavam como objetivo que permeava a atividade de ensino a alfabetização científica.

No final desse excerto a professora da disciplina disse que as considerações eram boas para serem feitas, mas no momento da regência poderia não acontecer o que discutiram, as ações dos alunos, suas motivações poderiam mudar a previsão dos estagiários (no papel de professor). Com toda a discussão realizada para que pudessem esclarecer sobre a contextualização e como nela já poderiam surgir aspectos da investigação em direção ao problema proposto, pensamos que a colocação da professora de MEFII sobre a impossibilidade de garantir que a atividade de aprendizagem ocorresse na sala de aula tal e qual foi planejada foi de extrema importância para os licenciandos.

Essa situação talvez não tenha ficado tão enfatizada para os licenciandos, quanto os esclarecimentos sobre a contextualização, em seu referencial teórico e na prática. No entanto, esse é um aspecto que o futuro professor enfrentará em seu cotidiano, o que pensamos ser parte do trabalho docente, que para chegar ao conceito que se deseja objetivar, precisa perceber, colaborar e compreender que a atuação dos alunos em atividade de aprendizagem ocorre pelas interações em sala de aula e pelas representações que trazem, assim, poder-se-á estabelecer um espaço de relações e (re)significação nas/das aulas. Isso, proporciona uma 
avaliação constante da atividade de ensino, promovendo mudanças nas ações do professor e dos alunos e, em um período mais longo, podendo alterar as atividades de ambos. Smolka et al.(2007) apontam a importância do professor estar atento para o fato dos alunos atribuírem sentidos diferentes para um mesmo conceito que se deseja ensiná-los, o que traz a necessidade dele conceber que a compreensão do aluno se dá pelas relações que se estabelecem, sendo o professor um sujeito importante nesse processo. Os autores discutem que:

Se a professora tem clareza dos conceitos a serem ensinados, ela não tem controle dos sentidos que vão sendo produzidos nas relações (e que são afetados pelas condições concretas e história de vida dos sujeitos em interação). Seu trabalho demanda, assim, estar continuamente atenta aos espaços de inter(in)compreensão, como espaços em que sua escuta e sua intervenção podem se fazer particularmente necessárias e fecundas. É assim que esse conceito pode instrumentalizar o professor na relação de ensino, uma vez que pode ajudá-lo a conceber o já conhecido de uma outra forma: pode ajudá-lo a pensar o movimento de compreensão como relacional, isto é, possibilita conceber a compreensão do aluno em função da relação que se estabelece (com ele e com muitos outros) e na qual ele, professor, está profundamente implicado. Isso desloca do aluno a estrita responsabilização pelo seu (não) aprendizado, ao mesmo tempo em que faz emergir a importância de se buscar e inventar (novas) formas de ensinar (grifos do autor, Ibidem, p.33).

A discussão na sala da disciplina continua, provocada pela contextualização, proposta pelo grupo 1, o que deu oportunidade para o esclarecimento dessa questão e também para ampliação do diálogo, trazendo aspectos das relações que se dão no âmbito da sala de aula, bem como no processo de ensino e aprendizagem. O trecho abaixo mostra parte dessa discussão na disciplina de MEFII:

Aluno 1: "Pintou" uma dúvida aqui, não sei exatamente entender o que é um enfoque didático.

Profa Marina: Enfoque didático, nesse caso, seria o mais simples, é quando você pega um conceito e o trabalha. E no caso de vocês já estão buscando material que foi feito para o Ensino Médio. [...]

Aluno 1: Eu entendi. Mas não sei se concordo, acho que é uma coisa minha. Porque, pra mim, se estou na sala de aula explicando qualquer conceito independente de ser sócio-histórico ou epistemológico sempre vai ter que haver a transposição dentro do espaço da escola, na sala de aula. Então, toda maneira de lecionar é didática.

Profa Marina: Sim, porque você está em sala de aula.

P2(G1-Felipe): Pra mim não existe o enfoque apenas didático.

Profa Marina: [...] Trago essa situação para pensar o seguinte, uma pessoa que estava lá começa a perceber essa diferença (entre os ambientes) [...]. Esse processo é um processo de investigação, mas não uma investigação didática, porque ninguém pediu a ele que fizesse isso. Agora imagina que essa pessoa é seu aluno e leva isso para a sala de aula. O que você vai fazer? Vai didatizar, porque você quer trabalhar com ele o conteúdo e nesse caso vai ser a questão da acústica. Vai discutir a 
interação da onda com a matéria. Na sala de aula as coisas não são reais. Se fossem não tínhamos planejamento.

Óbvio que quando começa a interagir com o aluno vem muita incerteza e a realidade começa a acontecer aí. Mas você está preparado ou deveria estar preparado para responder essas questões. Preparado não só do ponto de vista do conteúdo científico, mas preparado na questão pedagógica: "Que interação eu faço com esse aluno?" Aceitar a resposta do aluno é um caminho essencial para que ele vá te perguntar. [...] Aluno 1: Eu entendi que era como o aluno se relaciona com o conhecimento, com aquilo que se está ensinando.

Profa Marina: Isso também, né? O professor é o mediador das relações do aluno com o conhecimento. E aí, não é só a relação na perspectiva do conteúdo científico em si, mas a relação do aluno com os outros conhecimentos, saberes, que rodeiam o conteúdo científico.

Aluno1: Mas quando a senhora falou "Interações" era nesse sentido?

Profa Marina: Quando eu falo interação aqui em sala de aula estou pensando como você interage com os conhecimentos que estamos tratando aqui, seja minha fala como professora, seja a fala dos colegas. Falo também da interação que você tem com os colegas. [...] A sua interação com o material didático é outra coisa que estou considerando também. [...]

Ao apontarem a dúvida que a contextualização didática lhes trazia os licenciandos geraram uma discussão na sala que colaborou além do planejamento do grupo 1 e da própria resposta às questões que foram colocadas, mas puderam adentrar um pouco mais ao universo da sala de aula, no qual as interações, tanto quanto os conteúdos, são partes do trabalho do professor. A professora enfatiza a escola como lugar da sistematização do conhecimento, mas também como espaço de múltiplas interações, no qual o professor precisa garantir o diálogo entre ele e os alunos, dar voz ao aluno, sobretudo respeitar suas intervenções, apontando a importância não só da compreensão do conteúdo, mas também da atitude, do posicionamento do aluno diante das situações. Essa questão foi importante naquele momento, pois ficou explícito na fala dos licenciandos uma preocupação maior com o conteúdo a ser ensinado e como fazer isso, o que é legítima para o trabalho docente, porém as interações estabelecidas em sala de aula, o papel da mediação, não eram claros nem observados com atenção pelos estagiários.

Na continuação do debate surgiu uma preocupação em compreender as interações em sala de aula, parece-nos que os licenciandos perceberam que havia mais a se considerar no contexto da sala de aula. A organização do planejamento levou-os a refletir na complexidade das relações que são estabelecidas durante a aula, que estão além de só propor o conteúdo e como desenvolvê-lo, em primeiro lugar, é necessário que o professor perceba que esse caminho não é direto, precisa ser mediado e ele é quem mais fornece as condições para essa mediação. Essa discussão, certamente, fez com que muitos dos licenciandos passassem a refletir de forma mais ampla no ensinar, como os componentes do grupo 1, que acabaram se envolvendo mais com a discussão porque ela partiu da proposta que tinham formulado. 
Assim, podemos pensar que diante dessa situação um significado foi atribuído à docência pela professora da disciplina, que ensinar implica em interações diversas que são, em geral, mediadas pelas condições geradas pelo professor. Esse momento, pensamos ter propiciado a Ricardo e para outros licenciandos a atribuição de sentidos ao ensino, como sendo um processo sempre mediado.

Para os estagiários esse aspecto é uma aprendizagem da docência que emergiu das discussões propiciadas pela proposta do planejamento, com as ações de ensino do grupo 1, no entanto, essa questão tão importante ao trabalho docente surge das contradições (Engeström, 1987, 1999; Daniels, 2003) que os sujeitos começam expressar ao refletirem sobre o processo que vivenciaram em aulas que realizaram no estágio ou como professores do ensino básico. A professora influencia a atribuição de sentidos pelos licenciandos, mas isso não ocorre de forma passiva, como se fosse uma transmissão de ideias, mas por uma reflexão mais profunda provocada por contradições internas que levam o sujeito a incorporar novos elementos a sua atividade.

No caso de Ricardo o planejamento das aulas do estágio não foi algo que estivesse fazendo pela primeira vez, mas a organização da atividade de ensino lhe trouxe novas propostas que precisaram ser apreendidas por ele para depois serem objetivadas nas aulas. No excerto da Entrevista 2, transcrito abaixo, podemos perceber como coloca os pontos que encontrou mais dificuldade, mesmo tendo passado por experiência de ensino em sala de aula.

E2(Ricardo): [...] você termina o curso é outra pessoa totalmente diferente. Por
exemplo, o fato de eu ter que planejar a aula, apesar de eu já ter feito isso lá no
Instituto de Física, então, planejar a aula não foi novidade para mim, até porque eu
já sou professor, então eu já planejava aula. Agora planejar a aula pensando na
alfabetização científica, pensando na tomada de consciência dos alunos, pensando
nos objetivos educacionais que eu queria alcançar, que têm a ver com o ensino de
ciências propriamente falando, isso foi uma coisa bem diferente. Eu tenho que
pensar numa aula agora com uma metodologia específica que é o ensino por
investigação, para mim no começo foi difícil, porque por mais que eu defendesse a
educação dialógica, foi como eu falei, eu nunca tinha visto isso sendo colocado em
prática. O que facilitou um pouco foram essas leituras que eu já tinha tido, as
experiências, enfim, mas foi difícil preparar a primeira sequência didática. E eu tinha
uma leve suspeita de que talvez não desse certo.
[...] não porque eu não acreditasse nos alunos, por exemplo, mas pelas próprias
condições da sala de aula, as condições da escola, então eu não acreditaria que talvez
desse tanto certo e para minha surpresa, graças a Deus deu.

Elaborar o planejamento com uma sequência de atividades de ensino que permitisse aos alunos a apropriação de conceitos de um dado tema de Ciência, buscando sua gênese, trabalhando de forma a investigar, resolver, um problema, bem como, possibilitar aos alunos conhecerem um pouco da evolução histórica do tema, não era uma tarefa trivial, nem mesmo 
para aqueles licenciandos que tiveram algum contato com a docência, como o caso de Ricardo.

A situação proposta pela professora da disciplina tinha um caráter intencional para o estágio e sua organização, que podemos perceber pelo objetivo colocado aos licenciandos, baseado nas reflexões realizadas em sala de aula, desencadeada pelos textos teóricos e pelas experiências que cada um trazia, que propunha que a sequência de aulas do estágio fosse norteada por um problema que levasse os alunos, do Ensino Básico, a refletirem buscando discutir e agir, coletivamente, com a intenção de investigar o que lhes foi apresentado.

Os licenciandos tinham um objetivo para a organização da atividade de ensino que, além do início com a problematização, visava os pressupostos do Ensino por Investigação e da Alfabetização Científica. Isso traziam uma maior complexidade para a elaboração das atividades de ensino e para o desenvolvimento da atividade de aprendizagem, o que pode ter gerado mais dificuldades ao planejar as aulas, como podemos verificar no relato de Ricardo que aponta ter sido difícil preparar a primeira sequência didática. A situação levava os licenciandos a refletirem em suas aulas e planejarem uma sequência didática, que nas discussões de sala de aula, trazidas pelos textos teóricos, pelas diversas experiências e discussões, julgaram importantes estar presentes nas atividades de ensino a serem elaboradas para a regência.

Ricardo, como outros licenciandos tinham alguns pontos principais estabelecidos para serem desenvolvidos com os alunos nas escolas, como partes integrantes das sequências didáticas, tais como: discutir um tema ou fenômeno partindo de uma problematização; buscar o envolvimento dos alunos para ações que visam à investigação, discussão e reflexão do tema abordado; tratar os conceitos envolvidos de maneira a alcançar sua gênese para que consigam utilizá-lo em situações distintas da trabalhada; promover ações que objetivem que os alunos retomem o que já aprenderam em suas experiências cotidianas para relacionarem à resolução do problema proposto; discutir uma visão de Ciência menos estereotipada, construída coletiva e historicamente e que se complementa ou sofre mudanças por ser produto humano. Mesmo com a clareza do que queriam trabalhar, os licenciandos julgavam difícil levar essa discussão para a prática, conseguindo organizá-la para/com os alunos, não acreditavam, inicialmente, em resultados bem sucedidos, pensavam que os alunos acostumados a trabalharem em aulas com foco em abordagens mais tradicionais de ensino não manifestariam interesse em questionar, investigar, pesquisar, discutir etc, ou pelo menos não o fariam em poucas aulas (anotações CC). 
Ricardo tomando como base as dificuldades apresentadas para elaborar atividades de ensino em uma perspectiva investigativa, por não ser inerente às suas vivências em atividades de estudo, bem como, pela maior complexidade do processo, atribuiu o sentido de desinteresse dos alunos à atividade de aprendizagem, por julgar que eles não conseguiriam mudar suas ações de um modelo de ensino mais expositivo que estavam acostumados para algo que exigisse uma participação ativa.

No excerto acima, da entrevista de Ricardo, observamos que ele suspeitava que a sequência didática que havia preparado não desse "certo" ao ser aplicada aos alunos, ou seja, que os alunos não desenvolvessem ações que levassem a interação com a atividade de aprendizagem. No entanto, essa suspeita foi superada pela imagem da grande interação dos alunos com a atividade de aprendizagem no momento da regência.

O resultado obtido com os alunos é de grande importância para o licenciando no processo de desenvolvimento de suas ações de estágio, pois lhe dá um parâmetro para balizar suas regências e refletir para a organização das futuras. No caso de Ricardo, a interação positiva durante as regências o estimulou na preparação das atividades de ensino destinadas à MEFII, como ele nos aponta no excerto abaixo:

\footnotetext{
E2(Ricardo): [...] quando eu fui preparar a segunda vez, foi muito mais tranquilo. [...] eu já estava confiante, eu já sabia que dava certo, então eu insisti, já quis trabalhar com coisas um pouquinho diferentes, quer dizer, com leituras, coisas que eu não tinha trabalhado, quer dizer, trabalhado em nenhuma das aulas no outro estágio. Agora um pouquinho mais a leitura, a construção de um experimento, não a construção de um experimento, a construção de um espectroscópio, então, que é uma atividade mais prática, quer dizer, então, eu pude diversificar mais, foi muito mais fácil, por eu já ter tido essa experiência, quer dizer se eu não tivesse tido isso, teria sido tão difícil quanto. É aquilo que eu falei, teria sido muito mais difícil mudar, mas como aquilo já se tornou uma cultura escolar para mim, vamos dizer assim, se isso faz parte de uma cultura escolar, eu tenho condições de ser autônomo, então quer dizer, o que eu aprendi eu vou levar para todos os outros.
}

Para Ricardo a preparação da segunda sequência de atividades de ensino, como parte da regência do estágio, parece ter sido algo mais confortável em relação ao semestre anterior, em MEFI, o que não entendemos como mais fácil porque consideramos sempre trabalhosa a tarefa de organizar um planejamento com atividades de ensino, principalmente, visando levar os alunos às ações de aprendizagem que os coloquem em atividade.

Nesse segundo momento de regência, pensamos que o que deixou o licenciando menos tenso para organizar seu planejamento foi ter adquirido alguma segurança nas ações desenvolvidas com os alunos, tendo assim, certo controle sobre essas ações. Isso, por um lado 
devido ao resultado positivo obtido dos alunos e por outro pela experiência adquirida, que expressa na frase: “eu já sabia mais ou menos o que eu ia ter que fazer”.

Segundo Núñez (2009), no âmbito do ensino e da aprendizagem os alunos podem desenvolver atividades, mas não terem muita consciência das ações que realizam, o que ele diz que pode ser "processos de adaptação e de regulação de sua atividade pelos objetos" (p.66), porém torna-se necessário se ter consciência para regular a ação. Assim, relacionamos o que o autor propõe com a situação apresentada pelo licenciando, pois parece-nos que na primeira parte da organização do estágio não tinha muita consciência das ações de ensino, embora fossem bem detalhadas, mas talvez não conseguisse prevê-la em relação à atividade de aprendizagem, o que adquiriu, após essa vivência, tendo assim, mais clareza do que iria fazer, organizar, como atividade de ensino.

Essa maior confiança, mencionada por Ricardo, é justificada em parte nas mudanças na preparação das atividades de ensino dos alunos, propondo ações que visavam habilidades e uma abordagem não focadas por ele na proposta anterior, o que corrobora com nossa análise de que as ações adquiridas na regência de MEFI o fortaleceram para que promovesse novas ações, sendo estas diferenciadas, colocando-o em movimento de aprendizagem. Isso ele reconheceu como sendo algo de que estava confiante que daria certo e por isso diferencia essa etapa dizendo que se tornou mais fácil, pela experiência anterior que passou a fazer parte de sua aprendizagem como professor, que expressou como fazendo parte de uma "cultura escolar", proporcionando-lhe a interiorização do processo, o que o possibilitaria levar o que aprendeu a outros.

A elaboração do planejamento e os resultados que obteve com os alunos no primeiro semestre de MEF fez com que Ricardo atribuísse o sentido de atividade para a abordagem didática que utilizou, pois ela passa a ser uma meta, com novas ações que ele ia introduzindo para ampliar sua abrangência e possibilitar o uso de recursos diversos.

Além da organização do estágio pelos licenciandos da qual depende as regências na escola, há também a atividade de ensino elaborada para o estágio, para a formação para a docência, que é desenvolvida pela professora da disciplina, que Ricardo mencionou em sua entrevista e se encontra no excerto abaixo.

E2(Ricardo): [...] uma coisa que me chamou muito a atenção é a organização do estágio pela professora. Quer dizer, ela é muito organizada em relação ao estágio, por que como eu acho que eu já tinha comentado na primeira entrevista, grande parte dos estágios na minha opinião, infelizmente, por diversos motivos não é levado a sério, ou tem-se uma impressão de que o estágio ou pela quantidade de horas nas outras disciplinas ou algo do tipo, ele não vai propiciar um aprendizado pelo aluno, 
há muita possibilidade de você burlar o estágio. Você muitas vezes não tem o incentivo do próprio professor, ou seja, de pegar uma reflexão crítica sobre a prática, isso não tem na maior parte dos estágios. Tirando esse de Metodologia, o único estágio no qual eu aprendi muito, muito mesmo, assim, que eu tive regência ou algo do tipo foi em Práticas do Ensino de Física.

A organização do estágio pela professora das disciplinas de MEF chama a atenção do estagiário, pois isto possibilitou a regência, uma reflexão crítica sobre sua prática e o levou a um aprendizado. Pontos que consideramos importantes para a formação dos licenciandos, porém Ricardo menciona que isso não foi uma constante em seus estágios, exceto em uma outra disciplina da Física. Ao encontrar uma organização do estágio, com objetivos e metas propostos, nos levou a considerar que os licenciandos passam a encarar as ações propostas com mais seriedade, como aprendizagem da docência a qual será refletida individual e coletivamente.

Essa atividade de ensino abordou pontos específicos que necessitam ser tratados na formação para docência, considerando a organização das ações que o professor da disciplina faz, pois precisa elaborá-las de tal modo que possibilite aos alunos conhecer o ambiente escolar, se relacionar com o professor da disciplina, atuar com os alunos, ter aporte teórico, organizar as regências e fazer uma reflexão sobre elas, o que busca a aprendizagem dos licenciandos. Isso faz com que Ricardo atribua ao professor das disciplinas a importância da organização do estágio, proporcionando ações que favoreçam a aprendizagem da docência pelo estagiário.

Na Entrevista 1 de Ricardo encontramos uma fala que corrobora com o que disse no excerto anterior, no qual aponta a importância da organização da atividade do estágio pela professora da disciplina para o desenvolvimento do estágio para os licenciandos. No entanto, para ele há outro aspecto forte que são alguns pontos de destaques nas aulas em sala, com os quais se identificou, pois já pensava sobre eles mas não sabia viabilizá-los.

E1(Ricardo): [...] foi outra pessoa que me identifiquei, parece que o que ela fala é o meu pensamento. [...] quando ela veio com as sequências de ensino investigativo, com a alfabetização cientifica, a coerência com, por exemplo, o fazer científico, com as habilidades do saber cientifico, eu pensei: "Agora eu sei como eu aplico isso", então ela veio com as mesmas ideias que eu tinha e me mostrou, [...] as pessoas que de alguma forma, colocam a participação ativa do aluno no diálogo, na tomada de consciência e por aí vai, que a gente constrói, por exemplo, não é só dessa forma, uma aula coerente com o Ensino de Ciências, foi quando eu me aprofundei, eu lia os textos, com bastante profundidade, participei bastante, como você pode ver, porque me interessa, porque eu gosto, porque tem a ver com as perguntas que eu tentava responder. Eu me coloquei esse desafio de propor um plano de estágio, junto com minha parceira Vera, que contemplasse esses problemas abertos, não falei: "Eu vou mudar", queria mudar a escola tradicional, vamos dizer assim, o jeito era só raciocinar, ela apresentou como eu poderia fazer com as ideias que eu gostava. 
Esse olhar para o Ensino de Ciência foi discutido nos textos teóricos lidos e debatidos em sala de aula, buscando uma reflexão sobre: "Para quê ensinar Ciências? O que ensinar? Como ensinar?". O que se apoiava na perspectiva da Alfabetização Científica, do Ensino por Investigação e diálogo em sala de aula, promovendo a argumentação, a criticidade e a reflexão nos alunos. O que Ricardo disse ter lhe feito compreender como colocar em prática aquilo que ele pensava. Isso o levou a outra ação importante em seu movimento, que foi sua dedicação e aprofundamento nas leituras dos textos. (CC)

As leituras e as discussões em sala ampliavam sua maneira de perceber como planejar atividades de ensino na perspectiva proposta. Assim, o licenciando aponta ter se colocado o desafio de elaborar um plano de estágio, com sua colega de grupo, segundo a proposta. Ele queria conseguir elaborar seu planejamento na perspectiva que acreditava, mas ainda não havia concretizado, mas não para mudar a si próprio, pois ele já estava convencido da viabilidade da proposta. No entanto, desejava apresentar sua atividade de ensino, sob a perspectiva que estava utilizando para a escola e para os alunos, com a intenção de deslocálos de uma concepção mais tradicional de ensino, isto é, queria oferecer-lhes algo diferenciado, que os motivasse e os levasse a discutir o assunto apresentado, consequentemente, apreendendo o conceito envolvido. Por isso, ele acreditava na proposta, mas não sabia se iria dar certo no contexto escolar, o que o deixava em conflito, entre o aquilo em que acreditava e pode aprender como viabilizar, frente à escola que ele conhecia e sabia que não tinha o mesmo referencial pedagógico.

\section{Síntese - Mapa dos Sentidos}

A organização do planejamento foi um aspecto importante para os lincenciando na atividade de estágio, pois os levou a pensar além dos conteúdos que queriam trabalhar com os alunos, mas como propor ações que pudessem levá-los ao seu objeto, a aprendizagem dos alunos.

A questão que se colocava era como fazer para conseguir um Ensino de Ciências que promovesse uma participação ativa e crítica dos alunos, abordasse os conteúdos científicos, o papel da Ciências na sociedade, na história, a organização do ensino, questões ambientais, o trabalho compartilhado entre alunos e também entre eles e o docente, dentre tantos outros pontos que desafiavam os licenciandos em seu planejamento de estágio. 
Esses aspectos tornaram-se motivos da atividade de estágio dos dois estagiários, os impulsionando a agir, não apenas para cumprir as regras colocadas pela professora da disciplina, mas porque tomaram a organização do ensino como uma questão importante ao seu processo de aprendizagem da docência e isso direciona o comportamento frente ao estágio. O planejamento foi se construindo como um dos momentos formativos relevantes para Ricardo e Heloisa, como coloca Davidov e Márkova (1987):

[...] o ensino se organiza levando em conta a presença das peculiaridades individuais dos alunos, porém não sobre a base da adaptação a elas, mas como projeção de novos tipos de atividade, de novos níveis de desenvolvimento dos educandos; o ensino não pode ser reduzido a transmissão de conhecimentos, a elaboração e aperfeiçoamento das ações e operações, mas é, essencialmente, a formação da personalidade do aluno, o desenvolvimento do campo que determina seu comportamento (valores, motivos, objetivos etc); o efeito sobre o desenvolvimento educativo não é garantido por qualquer atividade, mas só pela atividade de estudo formativa (p.333, tradução nossa)

Nesse processo pensamos que é preciso que o licenciando se coloque em atividade para poder refletir e desenvolver ações baseadas em motivos eficazes, que o movam em sua formação docente. Caso isto não aconteça, considerando que o licenciando tenha seu movimento dado por motivos compreensíveis, não julgamos que a aprendizagem da docência deixe de ocorrer, porém, o comprometimento com a atividade de estágio, consequentemente, com o planejamento das aulas, pode ser bem menor, o que diminui as perspectivas das ações discutidas na disciplina serem colocadas em prática no futuro, nesse caso, serão praticadas como condição da disciplina, não com consciência de uma aprendizagem para a formação docente. 
Mapa de Sentidos de Heloisa

\begin{tabular}{|c|c|c|c|c|c|c|}
\hline \\
\hline & & & isódio 3 & : Organização das Aulas de Estágio & & \\
\hline & Cod. & 3.1 Organização das Aulas MEFI & Cod. & 3.2 Organização das Aulas MEFII & Cod. & 3.3 Organização das Aulas \\
\hline \multirow{5}{*}{$\begin{array}{l}\text { Situação em } \\
\text { que atribuiu } \\
\text { sentido }\end{array}$} & 031a & $\begin{array}{l}\text { Discussões sobre os textos da disciplina - leituras } \\
\text { e discussões da disciplina e no planejamento do grupo } \\
\text { que visava enfatizar o caráter coletivo, social e } \\
\text { histórico que a Ciência se desenvolve, mostrando que } \\
\text { ela não é imutável, que ideias propostas em } \\
\text { determinados momentos podem ser questionadas e } \\
\text { modificadas, buscando fazer o aluno se perceber } \\
\text { como ser histórico que participa de todo o movimento } \\
\text { que ocorre na sociedade. }\end{array}$ & 032a & $\begin{array}{l}\text { Intervenções da professora durante a discussão } \\
\text { do planejamento - discussões do planejamento na } \\
\text { sala e as intervenções da professora da disciplina, as } \\
\text { regências na escola, o contato com os alunos, no qual } \\
\text { puderam observar que nem sempre a atividade de } \\
\text { ensino poderia se focar diretamente no assunto que } \\
\text { desejavam discutir, mas precisariam, antes, oferecer } \\
\text { condições que fornecessem subsídios necessários aos } \\
\text { alunos, para depois levá-los ao tema central de } \\
\text { estudo. }\end{array}$ & 033a & $\begin{array}{l}\text { Mediações nas ações de ensino - na mediação nos } \\
\text { processos de elaboração das aulas e pelo outro, nas } \\
\text { diversas interações, na organização das ações de } \\
\text { ensino }\end{array}$ \\
\hline & 031b & $\begin{array}{l}\text { Discussão do planejamento - a discussão do } \\
\text { planejamento, ao serem pontuadas algumas questões, } \\
\text { o grupo vai especificando mais a atividade que } \\
\text { desejam elaborar e as ações necessárias para as } \\
\text { mesmas, em função do que pretendiam trabalhar com } \\
\text { os alunos. }\end{array}$ & 032b & $\begin{array}{l}\text { Definição das ações - a professora da disciplina e } \\
\text { os colegas fazendo questionamentos auxiliam na } \\
\text { organização da atividade de ensino, o que faz com } \\
\text { que o grupo defina melhor as aços que } \\
\text { desenvolverão em sala de aula, para o aluno discutir } \\
\text { sobre o tema de estudo }\end{array}$ & 033b & $\begin{array}{l}\text { Trabalho conjunto no planejamento - o trabalho } \\
\text { conjunto no planejamento imprimiu uma característica } \\
\text { que foi se tornando própria do grupo para discussão } \\
\text { das aulas a serem organizadas e para divisão e } \\
\text { coordenação das ações, porém foi percebido por } \\
\text { Heloisa, com mais força, na ruptura que seu grupo } \\
\text { sofreu, na divisão das ações, consequentemente na } \\
\text { divisão interna de trabalho e nas regras que haviam } \\
\text { estipulado. }\end{array}$ \\
\hline & - & - & - & - & O33c & $\begin{array}{l}\text { Complexidade do planejamento - nas discussões } \\
\text { na disciplina de MEF, na própria elaboração do } \\
\text { planejamento e em sua discussão em sala de aula que } \\
\text { fez Heloisa perceber a complexidade do } \\
\text { planejamento. }\end{array}$ \\
\hline & - & - & - & - & O33d & $\begin{array}{l}\text { Momentos de conflitos ou coincidências - leitura e } \\
\text { discussões dos textos indicados na disciplina são } \\
\text { momentos de reflexão, que Heloisa chamou de } \\
\text { amadurecimento,mas acreditamos que tenha sido } \\
\text { momentos de conflito ou coincidência que podem ter } \\
\text { levado à mudança de sentido em relação ao papel e } \\
\text { ações do professor. }\end{array}$ \\
\hline & - & - & - & - & 033e & $\begin{array}{l}\text { Relações entre a docência e a argumentação - na } \\
\text { disciplina de MEF Heloisa pode ter aprofundado as } \\
\text { relações entre a docência e a argumentação, a } \\
\text { importância dada à argumentação vem desde o seu } \\
\text { ensino básico, de onde traz o sentido de que os alunos } \\
\text { devem discutir, pensar e o professor orientá-los nesse } \\
\text { processo. }\end{array}$ \\
\hline \multirow{4}{*}{ Motivo } & MB1b & aprendizagem dos alunos da escola básica & MB2b & participação dos alunos nas discussões das aulas & MB3b & aprendizagem do trabalho coletivo \\
\hline & - & - & - & - & MB3c & $\begin{array}{l}\text { aprendizagem da organização do planejamento } \\
\text { visando a aprendizagem dos alunos }\end{array}$ \\
\hline & - & - & - & - & MB3d & trabalhar com a alfabetização científica no ensino \\
\hline & - & - & - & - & MB3e & trabalhar com aargumentação no ensino \\
\hline \multirow{5}{*}{ Ações } & A31a & $\begin{array}{l}\text { elaborar o planejamento com foco em História da } \\
\text { Ciência }\end{array}$ & A32a & $\begin{array}{l}\text { elaborar atividade de ensino de apoio às necessidades } \\
\text { dos alunos }\end{array}$ & A33a & planejar as aulas \\
\hline & A31b & organizar da atividade de ensino & A32b & $\begin{array}{l}\text { promover a argumentação em sala de aula e valorizar } \\
\text { as interveções dos alunos }\end{array}$ & $\mathbf{A 3 3 b}$ & trabalhar coletivamente \\
\hline & - & - & - & - & $\mathbf{A 3 3 c}$ & organizar a atividade de ensino \\
\hline & - & - & - & - & A33d & $\begin{array}{l}\text { incorporar a Alfabetização Científica ao planejamento } \\
\text { de ensino }\end{array}$ \\
\hline & - & - & - & - & A33e & incorporar a argumentação nas atividade de ensino \\
\hline \multirow{5}{*}{$\begin{array}{c}\text { Sentido } \\
\text { atribuído }\end{array}$} & S31a & $\begin{array}{l}\text { Reconheceu ser importante enfatizar o papel dos } \\
\text { alunos como participantes críticos da sociedade, que } \\
\text { fazem parte da história, da ciência, buscando } \\
\text { provocar mudanças e estimulá-los. }\end{array}$ & S32a & $\begin{array}{l}\text { Considerou que a função docente precisa } \\
\text { proporcionar condições que possibilitem a } \\
\text { aprendizagem dos alunos. }\end{array}$ & S33a & $\begin{array}{l}\text { Considerou necessário equilibrar toda a temática a } \\
\text { ser abordada com o tempo disponível para as } \\
\text { regências. }\end{array}$ \\
\hline & S31b & $\begin{array}{l}\text { Apontou a importância discutir o tema e as ações } \\
\text { com mais detalhes com os alunos da escola. }\end{array}$ & S32b & $\begin{array}{l}\text { Considerou a argumentação importante no } \\
\text { planejamento das ações a serem desenvolvidas com } \\
\text { os alunos. }\end{array}$ & S33b & $\begin{array}{l}\text { Atribuiu importância ao trabalho compartilhado para a } \\
\text { docência. }\end{array}$ \\
\hline & - & - & - & - & S33c & $\begin{array}{l}\text { Concebeu como um ponto muito importante no } \\
\text { estágio e para a docência o planejamento que envolve } \\
\text { questões como organizar uma aula, levando a refletir } \\
\text { na escolha e organização dos conteúdos, mas vai } \\
\text { muito além deles, sendo necessário ter um objetivo } \\
\text { direcionado para o que se quer que os alunos } \\
\text { aprendam. }\end{array}$ \\
\hline & - & - & - & - & S33d & $\begin{array}{l}\text { Considerou ser relevante incorporar na atividade de } \\
\text { estágio, a opção de trabalhar com a alfabetização } \\
\text { científica ao organizar o planejamento. }\end{array}$ \\
\hline & - & - & - & - & S33e & $\begin{array}{l}\text { Incorporou a argumentação em suas atividades de } \\
\text { ensino, considerando assim como um aspecto } \\
\text { importante para a docência. }\end{array}$ \\
\hline
\end{tabular}


Mapa de Sentidos de Ricardo

Episódio 3: Organização das Aulas de Estágio

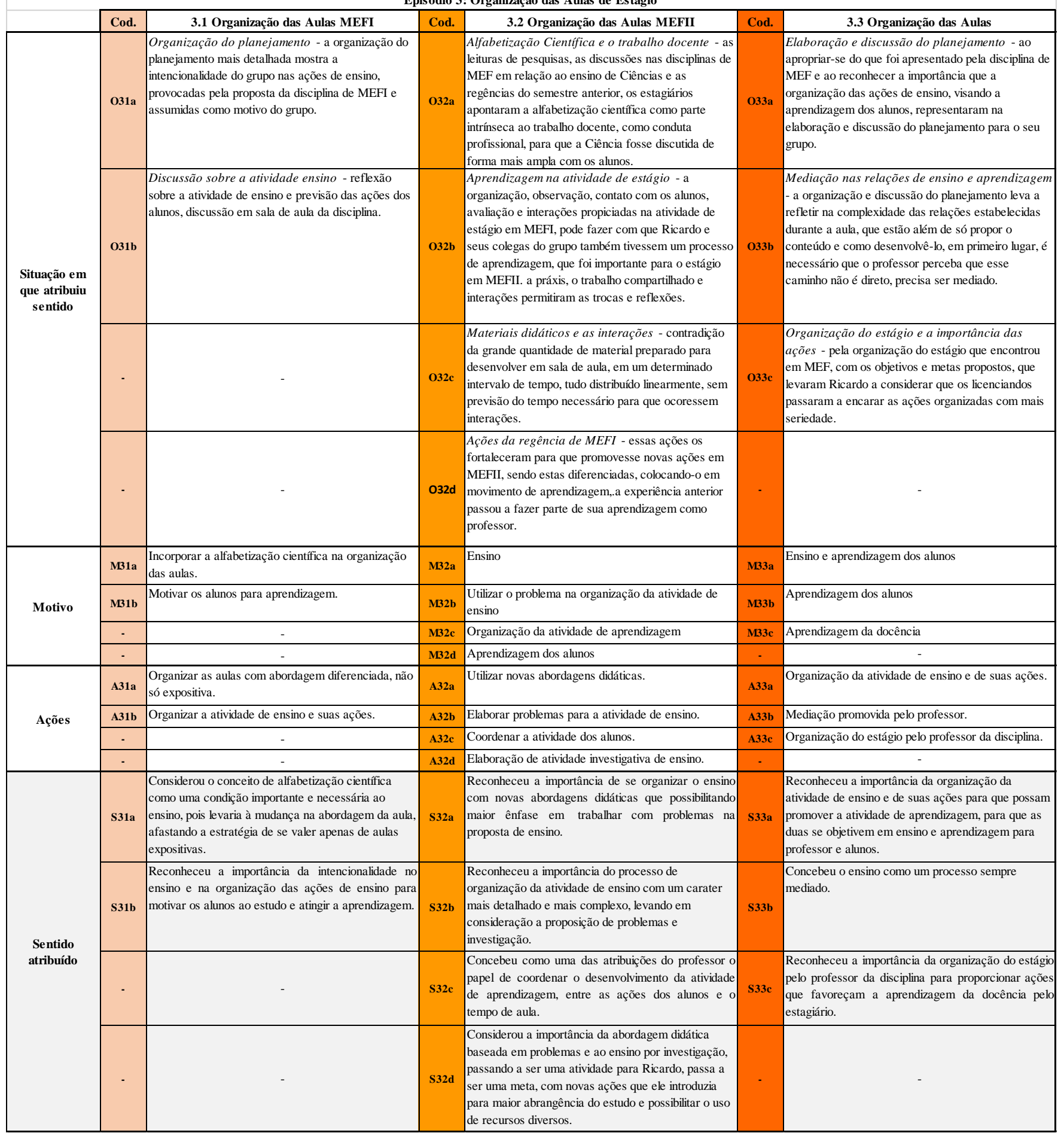




\subsubsection{Episódio 4 - Regência das aulas de estágio}

A regência é o momento em que os licenciandos colocam o planejamento em movimento com os alunos da escola, pois antes dela acontecer, a elaboração e as discussões são em função da organização dos conteúdos, estratégias e ações com bases teóricas, mas pouco conhecimento da sala e da escola, o que ocorre em ações de observação e algumas coletas de informações que proporcionam um panorama da situação do ensino, mas não como contato mais estreito com o contexto específico da escola na qual a profissão docente ocorrerá, exceto para alguns que têm experiência com a docência e que podem atuar na escola que lecionam. Assim, o contato com a sala de aula, durante as regências, passa a ser mais efetivo para a aprendizagem da docência e para colocar em prática as atividades de ensino elaboradas no estágio. Para tanto, Carvalho (2012) aponta que: "O planejamento das atividades do estágio de regência precisa ter por meta a eficiência, para fazer com que a profissão de professor não se torne, em pleno século XXI, um conjunto de experiências aleatórias de "acertos" e "erros" (p.66).

Isso gera uma expectativa grande nos licenciandos, pelo relacionamento que terão com os alunos, pela colaboração e apoio que obterão ou não do professor da classe, são situações que não podem prever. $\mathrm{O}$ impacto da sequência didática que propuseram também é uma fonte de expectativas, bem como, a reação dos alunos e suas ações diante da atividade de aprendizagem. Essa situação ao lado do trabalho proposto pela professora da disciplina, de elaboração de atividades de ensino utilizando a Alfabetização Científica e a problematização, gera certa insegurança inicial nos licenciandos que só vai diminuindo com os resultados das regências, ou às vezes, se acentua em casos de experiências negativas, os quais precisam ser refletidos para compreender as causas e buscar revertê-los no decorrer do processo da atividade de estágio.

O momento do planejamento das regências é importante para os licenciandos se apropriarem dos referenciais teóricos que discutiram e fazerem a transposição daquilo que foi considerado importante para a sala, aspectos da docência que assumiram caráter mais coletivo e que o licenciando atribui sentido ao organizar as atividades de ensino. Assim, a regência traz a prática dos conhecimentos teóricos apropriados e (re)significados pelos licenciandos, estabelecendo-se um processo dialético entre teoria e prática, para o qual as ações de regência precisam ser avaliadas e refletidas, possibilitando mudanças de sentidos para o licenciandos 
que reconfigurará sua prática continuamente, ou possibilitando outros sentidos a serem atribuídos no processo das regências.

\section{A. Caso Heloisa}

As regências feitas por Heloisa na atividade de estágio, na escola, foram acompanhadas por nós. Como o processo era feito em grupo, os estagiários dividiam as aulas e cada um deles era responsável pela regência de algumas delas, sendo assim, eles participavam de todas aulas, colaborando mutuamente e compartilhando ações, mas não eram os regentes em todos os momentos.

Para saber como era para a Heloisa o contato com os alunos na escola, em sua regência, a pesquisadora a questionou sobre o que sentia quando estava com os alunos: “[...] qual é a sensação que você tem depois que você planejou, você discutiu, na hora que você apresenta para os alunos?", ela responde observando as condições dos alunos na escola e em relação às aulas que realizaram, isso faz com que pensemos nesse processo de uma forma mais ampla, que tenhamos um olhar mais global para a questão. O excerto da entrevista com a licencianda nos mostra como ela comenta a questão:

E2(Heloisa): Olha, muitas vezes te dá a sensação de que eles estão boiando. Eu tô aqui me divertindo com o que eu tô falando, tô mostrando pra eles um monte de coisas que eu gosto, mas eles estão boiando. Mas até que no final deu certo. [...]

A gente ficou feliz com a nossa parte e também ficou angustiada com as carências que eles têm de outros aspectos, de prestar atenção na aula e conseguir anotar ao mesmo tempo em que ouve, não saber escrever um texto, dificuldade de organização, mas da parte que a gente fez foi um retorno positivo. Foi bem legal.

As aulas são organizadas para os alunos, portanto eles são o foco para os licenciandos e durante as aulas o desafio é realizar as ações planejadas, buscando obter o resultado esperado, que os alunos tenham aprendido, isto é, tenham se apropriado daquele tema trabalhado, dos conceitos envolvidos. Os licenciandos têm pouco tempo para fazer isso, pois desenvolvem algumas aulas em uma sala que conhecem pouco, não criaram vínculos, não sabem das necessidades, nem das habilidades, assim suas aulas podem não estar em consonância com o grupo de alunos. Por esses motivos, Heloisa observou que os alunos 
demonstravam não estar compreendendo tudo que haviam preparado para a aula, embora, para ela tratava-se de temas que achava muito interessante.

Ao lado de tudo isto os alunos estavam se deparando com uma organização de aula, com ações que não eram do cotidiano deles, o que fez com que levassem algum tempo para que se estabelecesse uma sintonia entre eles e os estagiários, quando isso se fez foi possível que a interação entre todo o grupo começasse a se expressar em um retorno positivo, em relação ao tema de estudo, o que estimulou Heloisa com suas aulas. No entanto, atitudes ou desempenho dos alunos a preocupavam, como o fato de se dedicarem mais a anotar tudo que ela e seus colegas abordavam do que estarem atentos a explicação, as discussões, ou a dificuldade apresentada para se expressarem com a escrita. Porém, ela se sentia impotente para colaborar em alguma coisa pelo fato do estágio ser algo muito pontual dentro da escola, o que Rodrigues (2013) esclarece como sendo um fator limitador de uma relação entre a universidade e a escola quando o estágio é alicerçado em apenas um elo, o estagiário.

A atividade de estágio para ela tinha sido muito refletida, a regência foi preparada em um processo dinâmico de organização do ensino, de definição de objetivos, detalhamento de ações dos estagiários e para os alunos, que a levou a atribuição desses processos como sentidos para docência, ou seja... Mas, não teve o mesmo objetivo, em relação ao contexto escolar, adquirindo poucas experiências naquele espaço, com aqueles alunos, o que não a deixou aprofundar as relações sobre o papel do estágio para aquela sala de aula. Para Heloisa o sentido atribuído ao estágio é de uma atividade pontual no âmbito da escola e para o estagiário não permite aprofundar as relações com os alunos.

Essa situação nos faz pensar em uma contradição nos sistemas de atividades, que se faz presente entre a atividade de estágio e a escola, no processo de inter-relações entre esses sistemas de atividades, que ao desenvolverem um trabalho em parceria necessitariam compartilhar um objeto novo, construído a partir das relações entre esses dois sistemas, como coloca Engeström (1999). Isto é, o licenciando organiza seu planejamento para as aulas de estágio na disciplina de MEF e chega à escola para colocá-lo em prática com os alunos, mas isso não é totalmente compartilhado com o professor efetivo, nem com o restante da escola. $\mathrm{O}$ processo possibilita uma aprendizagem da docência para o estagiário, mas não proporciona uma relação de colaboração com o professor daquela sala de aula e nem com outros elementos do contexto, que lhe trariam maior conhecimento das especificidades da profissão docente, o que provoca a contradição entre os sistemas, que pudemos perceber pelo acompanhamento na escola, a entrevista e as apresentações do grupo de Heloisa. 
A licencianda complementa sua fala em relação a visão que fazia dos alunos, de como percebiam o estágio:

E2(Heloisa): Eu acho que aluno, por mais que tenha toda essa rebeldia com estagiário, que acha que pode zoar, acho que os estágios são muito legais pros alunos, porque mesmo não necessariamente sendo uma coisa positiva, na minha visão de aluna ainda eu sou muito positiva, porque você vira e fala: "Não é meu professor que tá dando aula, então isso não é aula normal, não é mais essa coisa chata que eu tive o resto do ano, agora vai ser uma coisa diferente, não é meu professor, a gente não tá falando dos temas, os estagiários vem aqui, eles não dão a aula como o meu professor", então, é quase como se não fizesse parte da matéria, só que como eles não gostam da matéria, isso faz eles se interessarem mais.

Heloisa apresenta em sua fala uma ideia que acreditamos estar presente para os estagiários que é de que os alunos podem não respeitá-los pelo fato de não serem parte integrante daquele contexto escolar. Outra questão pode ser a falta de autoridade do estagiário em relação à sala por não ser o profissional que os alunos conhecem, que está com frequência com eles e também por saberem que esse estagiário ainda não é um profissional, mas está em aprendizagem e, o que faz ali é parte disto.

Apesar desses pontos que poderiam dificultar a regência, Heloisa enxerga claramente que as questões acima são superadas quando os estagiários, como foi o caso do grupo dela, levam aos alunos propostas de ensino diferenciadas daquilo que o professor da sala costuma oferecer, favorecendo o diálogo, as interações e a apropriação de novos conhecimentos, habilidades e sentidos. Parece um contra senso dizermos isto, pois não deveria existir esse descompasso entre as aulas do professor e do estagiário, mas na sala que Heloisa desenvolveu sua regência isso parece ter emergido. Durante as regências, os alunos não tiveram atitudes de desrespeito para com os estagiários, tinham interesse em ouvir o que tinham a dizer.

Essa vivência fez com que Heloisa mudasse sua atribuição de sentido em relação ao estágio de que seria uma atividade difícil dos alunos considerarem com respeito e seriedade pelo fato de não fazerem parte do contexto e ser algo pontual, para o sentido de que era uma atividade que, quando devidamente organizada, promovia o interesse dos alunos e, assim, suas atitudes eram de respeito ao estagiário.

A relevância do estágio naquele meio foi percebida pela direção e coordenação da escola, as professoras chamaram a pesquisadora para expressarem o interesse que a escola tinha em receber estagiários, dizendo que o contato deles com os alunos e professores era importante por trazerem temáticas novas para serem discutidas e outras metodologias (CC, p. 
29, 24/05/13 e p.37, 07/06/13). O que corrobora com a fala de Heloisa sobre a expectativa dos alunos de discutirem assuntos diferenciados nas aulas com os estagiários. Em relação à uma aproximação mais efetiva entre a universidade e a escola campo, Aroeira (2014) aponta que:

[...] é no sucesso das responsabilidades compartilhadas entre universidade e escola que avançamos para formação de profissionais da educação de qualidade. [...] especialmente quando a formação de professores ocorre na perspectiva de conformação entre os formadores universitários e os docentes de estabelecimentos que acolhem os estagiários (p.114).

Mesmo com toda a reflexão durante suas regências, Heloisa apontou a fala de sua colega de grupo, apresentada abaixo, que mostra a insegurança que sentem ao entrarem em sala de aula, em um contexto que conhecem pouco, propondo atividades de ensino que prepararam também saindo da zona de conforto, somado à pouca experiência, ou nenhuma, na docência.

E2(Heloisa): A gente... Antes de ir lá pela primeira vez, a Ana estava com muito medo, foi muito engraçado. Ela falava: "Ai meu Deus, será que a gente vai ser bem recebida?”. Mas problema de indisciplina a gente não teve nenhum.

Ela citou a colega, Ana, porque ela fez sua primeira regência nesse estágio, nessa escola. Novamente, há grande insegurança em relação ao comportamento dos alunos, pois os licenciandos se sentem mais preparados teoricamente, isto é, em relação aos assuntos de Ciências que discutirão, do que em relação à como os alunos reagirão diante da proposta pedagógica que escolheram. Há muita expectativa se conseguirão motivar os alunos, isto é, colocá-los em atividade de aprendizagem e fazê-los organizar suas ações. Mas ainda existia outra tensão, referente ao comportamento disciplinar dos alunos com os estagiários, como entendiam a relação hierárquica e de ensino e aprendizagem, uma vez que estavam em um curso noturno, de Ensino Médio, no qual parte dos alunos tinham idades próximas a deles. Diante desses fatores, Heloisa e Ana atribuíram à docência o sentido de dificuldade em seu início para lidar com as relações em sala de aula, principalmente, a questão disciplinar.

Nesse momento da regência, principalmente nas primeiras aulas, o professor da escola pode colaborar mais com os estagiários na questão da disciplina dos alunos. No processo de realização das atividades de aprendizagem ele não se envolvia muito, exceto por poucos comentários de caráter regulador das atitudes de seus alunos, ou para apontar aos estagiários posturas docentes, depois da aula. Como ele não participou da elaboração do planejamento e 
nem o discutiu com os licenciandos, acreditamos que não criou-se uma relação de trocas possíveis entre eles, então, o professor efetivo se colocava em uma posição apenas de controlar a disciplina da sala para que os estagiários não tivessem esse tipo de problema. Galindo (2012) aponta as ações que o professor efetivo (o qual ela chama de professor parceiro) poderia realizar atuando como formador, tais como:

[...] orientando o estagiário, preocupando-se com aspectos do trabalho docente que extrapolam a sala de aula, demonstrando inclusive o seu compromisso com essa formação. [Além disso] o professor parceiro assume, dentre outros, o papel de par mais experiente, de formador e até de professor do estagiário [...]ensinando o estagiário sobre diversos aspectos da profissão docente: o contexto, os alunos, os conteúdos escolares, o planejamento, os erros etc (p.196).

Heloisa discute essa relação entre o estagiário e o professor da escola, questionando o papel de cada um no estágio, como podemos observar pelo excerto abaixo, da Entrevista 2:

E2(Heloisa): Acho que na verdade o lance do estágio é muito mal discutido na faculdade, pra que serve o estágio? Qual o papel do estagiário? Qual o papel do professor? Qual a relação dos dois nisso? Porque o estagiário tá lá pra aprender com o professor e o professor tá lá pra aprender com o estagiário também, tem toda uma concepção diferente, várias coisas [...] com o professor $\mathrm{W}$, a gente podia fazer 10 aulas falando sobre formiga que ele ia deixar fazer isso na aula de física. A gente podia dar interpretação de contos que ele ia deixar a gente fazer isso na aula dele. A gente até teve essa preocupação, a gente falou: "Ah, professor $\mathrm{W}$, o que você tá dando pra gente fazer uma coisa mais ou menos assim", não lembro nem se ele respondeu o que ele estava dando. Acho que respondeu, mas falou "Eu já tô terminando, faz aí o que vocês quiserem que vai se encaixar". Ele não fez grande questão que isso fosse condizente com o curso dele. Às vezes parece que foi ótimo pra ele que a gente foi, porque ele se livrou ali de umas 6 aulas e teve mais uma nota pra colocar pros alunos.

O fato do professor da escola não ter um papel claro na atividade de estágio, ou melhor não ser parte ativa no processo, isto consequentemente, não o coloca em atividade, pode ter ações de colaboração que auxiliaram os estagiários, mas não fizeram parte da estrutura coletiva das ações pertencentes à organização do estágio. Isso parece demonstrar o papel do professor alienado ao processo. Pelo fato de ele não ter sido sujeito do processo na concepção da atividade de estágio, isso não justifica sua atitude, mas seu papel não estava posto no âmbito da atividade de estágio, como já no início de sua fala Heloisa questionou. $\mathrm{Na}$ atividade de estágio, na situação vivenciada, Heloisa atribui o sentido de alienação do professor efetivo em relação ao processo de estágio. 


\section{B. Caso Ricardo}

Ricardo na organização das atividades de ensino havia encontrado uma grande relação entre o que pensava, os referenciais teóricos discutidos na disciplina e a proposta da professora, porém para ele ainda restava a dúvida com a reação dos alunos diante da proposta de ensino. Após a regência em MEFI, os resultados que obteve com os alunos reforçaram sua convicção sobre sua concepção de ensino, como menciona no excerto abaixo:

E1(Ricardo): [...] E a regência, no estágio, com os resultados dos alunos, também me motivou a falar: "O que eu penso tem coerência, o que eu penso há muitos anos, que tento entender melhor, parece que tem um sentido e um sentido para os alunos".

A regência permitiu que Ricardo ao desenvolver com os alunos as atividades de aprendizagem percebesse que o que havia organizado se concretizava nas ações dos alunos, então as atividades de aprendizagem, segundo ele, fizeram sentido para os alunos e, para ele ao processo também foi atribuído sentido, de organização de atividades de ensino que a partir de um problema, colocasse os alunos em atividade na busca de soluções, desencadeando ações investigativas. Com isso, ele pode ver objetivada ideias que tinha antes da disciplina, que se tornaram concretizáveis na elaboração do planejamento do estágio.

O estagiário ao iniciar o estudo das lentes esféricas propondo um problema aberto, que possibilitou aos alunos, reunidos em pequenos grupos, discutirem e organizarem ações para buscar soluções. Para tanto, compartilhavam suas ideias, uns de forma mais desenvolta e, outros mais timidamente, mas no decorrer da atividade todos acabaram se envolvendo, resgatando o que já haviam estudado, para relacionar com os objetos disponibilizados e montar arranjos que permitissem observar o fenômeno proposto no problema.

Nessa dinâmica, enquanto os alunos organizavam ações para solucionarem e compreenderem o problema proposto, mais próximo a parte final da aula, o estagiário comenta com a pesquisadora:

$\mathrm{Na}$ verdade não sabia se um problema aberto funcionaria, achava interessante, mas não acreditava que desse certo, então fiquei entusiasmado com o resultado dos alunos de encontrarem soluções.

Mesmo preparando toda atividade, estava apreensivo, porque não sabia se os alunos conseguiriam resolvê-la, não tinha certeza, Que bom que deu certo!" (CC, p.24, 21/05/13, anotação da fala de Ricardo). 
O desenvolvimento da aula permitiu ao licenciando observar as ações dos alunos, que eram compartilhadas porque o trabalho era feito em pequenos grupos, isso o fez perceber como os alunos se relacionavam com a atividade de aprendizagem. Isso refletia em seu trabalho docente, que notamos pelo comentário com a pesquisadora, que mostrava suas expectativas e dúvidas com o motivo da atividade para alunos frente a constatação do desenvolvimento de ações organizadas desses alunos que culminavam em soluções para o problema proposto. Não era uma reflexão aprofundada, mas articulada advinda da contradição entre o que pensava e o que havia elaborado, com o que recebia como resultado, fruto de suas observações e mediações nos grupos, pois todo o tempo em que os alunos estavam trabalhando ele circulava pelos grupos dando orientações, verificando a organização e efetivação das ações(CC, p. 24, 21/05/13).

Esse momento pode ser importante para trazer elementos novos para a atribuição de sentidos em relação à organização da atividade de ensino, ligada aos referencias teóricos que embasaram o licenciando aliado à sua vivência em sala de aula. Essa dimensão trazida pela relação entre a teoria e a prática pedagógica, foi importante para a formação do licenciando e pode gerar mudanças de sentido para Ricardo e no contexto da escola, que o levou a uma situação nova, ressignificando sua aula. A importância da práxis no estágio para a formação docente é apontada por Silva Filho, Lopes e Cavalcante (2011):

O estágio supervisionado, enquanto eixo central da formação docente, deve compreender o embricamento da teoria com a prática e vice-versa, pois caso contrário ela perde a sua dimensão formativa, caindo num teoricismo [...] É do ponto de vista dessa relação entre a teoria e a prática que podemos falar da síntese dialética na formação docente cuja meta central direciona-se a uma transformação qualitativa do profissional e do contexto educacional (p.148).

Outra questão discutida por Ricardo na regência é a necessidade de materiais (cópias de textos para os alunos, materiais para alguns experimentos etc) para serem utilizados nas atividades de aprendizagem, como ele aborda no excerto a seguir:

E2(Ricardo): A escola, ela pode, por exemplo, uma coisa que eu acho que tem que é uma coisa que eu percebi, que muitas das atividades que eu desenvolvi no estágio eu não conseguiria desenvolver se não tivesse uma parceria com a universidade. No primeiro semestre, quando eu trabalhei com lentes, lasers e tudo mais, eu só consegui porque tinha professores que me ajudaram a tirar as cópias, a pegar os materiais. E aí, como é que eu faço na escola que não tem isso? Eu vou trabalhar com material de baixo custo, mas 
não tem lasers de baixo custo. Quer dizer, até tem, mas não vai ter a qualidade $[\ldots]$.

Nesse trecho de sua entrevista Ricardo aponta que o desenvolvimento da atividade de aprendizagem na regência de MEFI não poderia ter sido realizado sem a colaboração da universidade, a qual lhe emprestou materiais com os quais a escola não contava, caso contrário, não poderia fazer o que havia planejado porque a parte que envolvia experimentação dependia da aquisição do material adequado. Ele até vislumbrou uma solução viável para a escola, que seria trabalhar com materiais de baixo custo, mas como ele mesmo comentou, não se consegue utilizar esse tipo de material em algumas montagens experimentais, há casos que se tem a necessidade de materiais mais elaborados e que, em geral, a escola não dispõe.

Essa situação ocorreu na regência de Ricardo, que precisava de laser, pois trabalhou com óptica geométrica, gerando várias atividades de aprendizagem que visavam a apropriação pelos alunos de conceitos científicos relacionados ao tema. No caso, foram tratados os conceitos de: propagação da luz, características dos diferentes tipos de lentes, formação de imagem nas lentes e posição da imagem, em que se fazia necessária uma especificidade de materiais para que o fenômeno em estudo pudesse ser tratado experimentalmente, no processo da investigação do problema proposto.

Assim, os materiais eram fundamentais para que os alunos, pela manipulação, organização e montagem estratégica, percebessem os fenômenos físicos que o licenciando queria discutir, eles eram mediadores para a observação dos fenômenos pelos alunos, mas não de forma direta, necessitava-se de uma organização de ações para a investigação do problema inicialmente proposto. Porém, para a apreensão do conhecimento envolvido outras mediações eram importantes, não apenas a dos materiais, mas também a do professor e a realizada entre os próprios colegas de grupo ou entre os grupos, cuja interação se faz pelo uso de signos.

Esse processo organizado na atividade de ensino e conduzido pelas ações de licenciando e alunos nas atividades de aprendizagem é que direcionam o movimento para a apreensão do conhecimento proposto pela escola, que visa a apropriação do conhecimento acumulado pela cultura humana ao longo da história. Nesse contexto é que se insere o conceito de mediação concebido por Vigotski e que enfatizamos no processo de regência de Ricardo.

Isso nos leva a considerar a mediação como elemento que devemos colocar como fator fundamental no âmbito do ensino, pois é estruturante para os processos mentais humanos, que 
são foco na escola, para a formação de conceitos, memória, dentre outros, ou seja, desenvolvimento das funções psicológicas superiores, que se fazem aliados aos processos sócios-históricos.

Ligado ao panorama até aqui discutido, surge também na dimensão da regência a necessidade do estreitamento da ligação entre a escola e a universidade. Ricardo aborda essa questão na Entrevista 2 e fornece exemplo de uma possibilidade de interação entre as duas instâncias, como aponta o excerto abaixo:

E2(Ricardo): Quer dizer, trabalhar com esse tipo de atividade. Então, a escola ela pode desenvolver, eu acho que algumas já vem desenvolvendo com universidade, quer dizer, vem desenvolvendo, algumas escolas são as parceiras através do Pibid, através dos estágios, quer dizer, você dá o retorno, o financiamento por exemplo. Até no Pibid o professor da escola se torna supervisor, também quer dizer, ele recebe, ele tem um incentivo, você tem um material sendo levado para sala de aula, você tem produção de conhecimento sendo produzido lá e ficando para a escola. Quer dizer, a universidade tem que dar esse retorno para a escola nesse sentido, mas ela precisa primeiro rever o que entende por educação, por conhecimento, assim como a escola, o professor da turma, todo mundo. Tem que ter uma renovação aí.

O desenvolvimento de uma parceria entre as instituições de ensino, havendo um apoio por parte da universidade com a presença de estagiários na escola e a orientação de professores, bem como o envolvimento dos professores da escola no processo, visando a produção de conhecimento e a melhoria das práticas pedagógicas e a (re)significação da educação, promovendo mudanças no contexto escolar, ele aponta o Pibid como um exemplo de aproximação entre os dois contextos.

O envolvimento maior entre a universidade e a escola sempre foi desejável, no entanto, no processo de estágio a relação que se estabelece entre as duas instituições não é de um processo de ações conjuntas. A universidade oferece os estagiários às escolas, mas a ligação entre eles e essas escolas se faz dependendo do desenvolvimento do processo de estágio de cada um, do contexto de cada escola e ainda, do envolvimento de cada professor que recebe o estagiário. No caso de $\mathrm{MEF}$, o contato com a escola era feito pelo estagiário, mediante apresentação de documento escrito pela professora da disciplina solicitando a permissão para o estágio, o que também era autorizado pela coordenação da escola e aceito pelo professor da sala onde ocorreria o estágio. Porém, não se estabelecia outros elos que pudessem aproximar esses sujeitos diretamente, professor da disciplina, estagiário, professor e coordenação da escola, a ligação existia via licenciando. 
Essa situação faz com que os licenciandos não tenham uma colaboração do mesmo como um formador pela experiência profissional que já tem adquirida. Há, porém, na maior parte das vezes, a contribuição do estagiário para com os alunos, levando propostas de aulas diferenciadas, assuntos atuais para discutirem, temas que não são abordados com frequência pelos professores. Ricardo atribui o sentido à atividade de estágio de importância na relação com os alunos de apresentar propostas e temas não trabalhados pelo professor efetivo. Os professores devem transitar mais pelos temas

Ricardo comenta as contribuições que o estagiário pode fazer à escola, aos alunos na atividade de estágio:

E1(Ricardo): Bom, primeiro o estagiário está num momento de aprendizado, então ele pode mostrar, por exemplo, junto com a ajuda do professor da escola que o conhecimento é uma coisa que é construída, não é uma coisa inata, porque eu estou falando isso, porque os alunos, eu percebo pelo menos que eles, assim como eu tive, uma série de estereótipos sobre a Ciência, sobre o que é ensinar, sobre o que é aprender [...].O segundo ponto que ele pode construir, se ele tiver uma boa formação, tiver interesse e boa vontade na universidade, vai trazer outras estratégias de ensino, ele vai trazer outras formas de ver Física outras formas de ver o mundo, que podem colaborar para os alunos verem a disciplina de uma outra forma e o professor também, procurar inovar sua prática, ou repensar sua prática. [...] uma sequência investigativa, por exemplo, é uma coisa nova pra eles e pro professor também, que pode fazer com que eles passem a ver aquilo de uma forma diferente, ele pode repensar: "tudo bem, eu tenho uma série de questões que condicionam meu trabalho, limitam meu trabalho, mas o que eu posso fazer então pra tentar romper com essas condições, ou romper com essas limitações, então o estagiário pode contribuir também como se ele fosse um co-docente, como se ele fosse um professor assistente, aí está fazendo a ligação da escola com a universidade, que é uma ligação por sinal muito fraca. O muito que é produzido na academia fica na academia, muito da coisa que é vivenciada na escola fica na escola. Então, às vezes a gente parece que tem um lado muito prático, ou muito teórico. Uma teoria que é refletida, refletida, refletida, mas ela não é levada pra sala de aula. Uma prática que é praticada, praticada, praticada sem reflexão, então, quando o estagiário faz esse link, mas ele está engajado, ele está tendo uma boa formação e o professor da escola também está disposto a receber esse estagiário e essa conexão é feita, então ambos podem se comunicar.

Ao discutirem temas novos para a escola, utilizarem abordagens diferenciadas, Ricardo aponta para o fato de poder levar para a escola uma visão diferenciada da Ciência e do Ensino de Física que podem promover mudanças nos alunos e no professor da sala na qual a regência se realiza. Ele propõe o estabelecimento de uma cooperação, o estagiário como um "professor assistente" do docente da escola, proporcionando a aproximação mais aprofundada entre a universidade e a escola. Considerando uma dialética entre teoria e prática que 
colaborariam tanto para o estagiário como para o professor. Pensamos ser bastante interessante esse pensamento de Ricardo, porém o estágio, nessa perspectiva, precisa ser estendido por tempo mais longo para que essa relação possa se estabelecer e criar um movimento de trabalho colaborativo, conforme explicitado por Fulano de tal. Com essa análise, Ricardo atribui o sentido à atividade de estágio de importância na relação colaborativa entre estagiário e professor efetivo, culminando em ações conjuntas.

\section{Síntese - Mapa dos Sentidos}

No caso de Ricardo e Heloisa, eles tinham experiências com a monitoria e estágio de outra disciplina, a Prática de Ensino de Física, na qual os licenciandos preparavam aulas experimentais frequentes durante um ano para trabalhá-las com alunos do Ensino Básico. Desta forma, não estavam entrando em sala de aula pela primeira vez, mas apontaram que o estágio, nas disciplinas, de MEF lhes trouxeram elementos novos e importantes para a regência e, consequentemente, à formação docente.

Os dois licenciandos apontam que os referencias teóricos discutidos na disciplina e colocados em prática na organização do estágio, permitiram que percebessem uma maneira de concretizar algumas ideias sobre concepção de ensino que eles acreditavam colaborar na aprendizagem dos alunos, no mínimo motivando-os para o estudo da Física, mas não sabiam como viabilizá-las na prática, na sala de aula, com que abordagem didática.

Essa proposta feita pela professora da disciplina de trabalhar com a inserção de problemas para que os alunos pudessem, na atividade de aprendizagem, se mobilizarem na busca de soluções de forma investigativa, bem como as reflexões sobre a alfabetização científica como questão estruturante ao ensino de ciências e necessária de ser levada à sala de aula, encontraram a adesão dos estagiários, para serem trabalhados em seus planejamentos e, principalmente, desenvolvidos com os alunos.

Mesmo com a motivação de levarem essa nova abordagem didática e uma discussão sobre Ciências mais contextualizada, histórica e com uma visão de construção humana em movimento, não tinham segurança, especialmente, nas primeiras regências, quantos aos resultados que conseguiriam com os alunos. A situação não se tratava de propor uma modificação de estratégias didáticas aos alunos, mas uma mudança na concepção e na maneira de ensinar, pois os estagiários desejavam mudar, mas traziam em sua historicidade 
uma forma tradicional de ensino, no qual estiveram inseridos por muito tempo. No caso de Heloisa, sua trajetória foi em uma escola básica diferenciada, mas ela não tinha experiência suficiente para propor como fazer as mudanças que achava necessárias, pois, vivenciou a escola como aluna, agora sua posição havia mudado, tinha que pensar a escola como professora, ou melhor, como alguém que quer ser professor e deseja aprender sê-lo. Tudo isso fazia o processo complexo, que ao avaliarem suas próprias regências iam ganhando segurança e replanejando suas ações.

A noção que o professor efetivo também pudesse fazer parte do processo de trabalho conjunto com o estagiário não se concretizou em nem um dos dois estágios. Eles apoiaram o estágio, autorizando-o, liberando suas aulas, aceitando o planejamento dos licenciandos para as aulas, auxiliando-os no controle disciplinar dos alunos e facilitando o acesso à escola e materiais. No entanto, não houve uma interação formativa, uma relação mais aprofundada de troca entre estagiários e os professores das escolas.

O papel do professor da escola no estágio como forma de desenvolvimento profissional e formação docente para os licenciandos é enfatizado por Galindo (2012):

O desenvolvimento profissional do professor não é apenas o desenvolvimento pedagógico, o conhecimento e compreensão de si mesmo, o desenvolvimento cognitivo ou teórico, mas tudo isso ao mesmo tempo delimitado ou incrementado por uma situação profissional que permite ou impede o desenvolvimento de uma carreira docente (IMBERNÓN14, 2006, p.47). Nessa direção, o estágio como uma oportunidade de análise do processo de desenvolvimento do professor contribui diretamente para esse desenvolvimento além de oferecer os subsídios para a intervenção na formação docente dos licenciandos (p.212).

Em uma análise mais ampla não podemos dissociar esse processo de distanciamento do professor da escola em relação ao licenciando da atividade de estágio. Não há proposta de incorporação deste professor nas ações do estágio de forma a ser um colaborador no processo de formação docente dos licenciandos. As reflexões sobre o professor da escola o envolvem no planejamento das aulas, isto é, se ele está de acordo ou se deseja algum tema específico, mas parece que ele não é percebido na forma de um contato mais consistente e inserido como parte responsável por ações colaborativas na estrutura de atividade.

14IMBERNÓN, F. Formação Docente e Profissional: formar-se para mudança e a incerteza. 6. ed. São Paulo: Cortez, 2006. 
Outra questão foi a importância dada à atividade estágio em MEF que propiciou aos licenciandos a organização da atividade de ensino que permitiu que as regências fossem refletidas sobre a aprendizagem dos alunos em seu próprio contexto escolar. No entanto, a relação dos estagiários com a escola foi pontual, devido ao tempo restrito das regências e a pouca vivência da sala de aula, da escola, tornando mais difícil as inter-relações e a compreensão do movimento relacional e educacional que ocorre naquele contexto. No caso de Ricardo, ele estudou na escola onde estagiou, então conhecia o local e muito da dinâmica instaurada, mesmo com as alterações que tenha sofrido em alguns anos. Mas Heloisa fez seu estágio em uma escola que nunca havia frequentado, o que tornou seu contato limitado aos poucos momentos de atividade naquele local. Isso permite uma experiência para a formação docente que é relevante pela inserção na sala de aula, com o aluno real, mas não é suficiente para conhecer um pouco mais o contexto da escola onde o estágio ocorreu e as relações que ali se estabelecem. Por isso e por necessidade que sentiram de terem mais contato com a sala de aula é que os estagiários apontaram como um fator importante o aumento da atividade de estágio durante o curso de Licenciatura, com um repensar nesse processo. 


\begin{tabular}{|c|c|c|}
\hline \multicolumn{3}{|r|}{ Mapa de Sentidos de Heloisa } \\
\hline \multicolumn{3}{|r|}{ Episódio 4: Regências da Aula de Estágio } \\
\hline & Cod. & 4.1 Regências \\
\hline \multirow{3}{*}{$\begin{array}{l}\text { Situação em } \\
\text { que atribuiu } \\
\text { sentido }\end{array}$} & 041a & Reflexões sobre a atividade de estágio - organização e discussão do planejamento, a definição de objetivos e o detalhamento de ações dos estagiários. \\
\hline & O41b & Contextos que propiciaram valorar o estágio - nas aulas de MEF, na organização da atividade de ensino e nas regências realizadas. \\
\hline & 041c & $\begin{array}{l}\text { Insegurança durante a regência - insegurança em relação ao comportamento dos alunos, pois os licenciandos se sentiam mais preparados teoricamente, isto é, } \\
\text { em relação aos assuntos de Ciências que discutiriam, do que em relação ao como os alunos reagiriam diante da proposta pedagógica que escolheram. Havia muita } \\
\text { expectativa se conseguiriam motivar os alunos, colocando-os em atividade de aprendizagem e fazendo-os organizarem suas ações. Ainda há outra tensão, } \\
\text { referente ao comportamento disciplinar dos alunos com os estagiários }\end{array}$ \\
\hline \multirow{3}{*}{ Motivo } & M41a & aprendizagem dos alunos \\
\hline & M41b & ensino e aprendizagem dos alunos \\
\hline & M41c & aprendizagem da docência \\
\hline \multirow{3}{*}{ Ações } & A41a & organização da atividade de ensino \\
\hline & A41b & organização da atividade de ensino \\
\hline & A41c & regência na escola \\
\hline \multirow{3}{*}{$\begin{array}{c}\text { Sentido } \\
\text { atribuído }\end{array}$} & S41a & Reconheceu ser importante a organização do ensino em um processo dinâmico com definição de objetivos e detalhamento de ações. \\
\hline & S41b & $\begin{array}{l}\text { Considerou o estágio como uma atividade que, quando devidamente, organizada , leva aos alunos propostas de ensino diferenciadas daquilo que o professor da } \\
\text { sala costuma oferecer, favorecendo o diálogo, as interações e a apropriação de novos conhecimentos, habilidades e sentidos, essa vivência fez com que Heloisa } \\
\text { mudasse sua atribuição de sentido em relação ao estágio de que seria uma atividade difícil dos alunos considerarem com respeito e seriedade pelo fato de não } \\
\text { fazer parte do contexto e ser algo pontual. }\end{array}$ \\
\hline & S41c & Reconheceu a dificuldade existente no início da docência para lidar com as relações em sala de aula, principalmente, a questão disciplinar. \\
\hline
\end{tabular}




\section{Mapa de Sentidos de Ricardo}

Episódio 4: Regências da Aula de Estágio

\begin{tabular}{|c|c|c|}
\hline & Cod. & 4.1 Regências \\
\hline \multirow{4}{*}{$\begin{array}{l}\text { Situação em } \\
\text { que atribuiu } \\
\text { sentido }\end{array}$} & 041a & $\begin{array}{l}\text { Articulação da atividade de ensino - durante a organização das atividades de ensino encontrou uma grande relação entre o que pensava, os referenciais teóricos } \\
\text { discutidos na disciplina e a proposta da professora. A regência permitiu que Ricardo ao desenvolver com os alunos as atividades de aprendizagem percebesse que o } \\
\text { que havia organizado se concretizava nas ações dos alunos. }\end{array}$ \\
\hline & O41b & $\begin{array}{l}\text { Relação da teoria com a prática pedagógica - tanto os referencias teóricos que embasaram o licenciando quanto a sua vivência em sala de aula foram importantes } \\
\text { para sua prática pedagógica na organização da atividade de ensino. }\end{array}$ \\
\hline & 041c & $\begin{array}{l}\text { Relação Universidade e Escola - o estagiário aponta o Pibid como um exemplo de aproximação entre os dois contextos. Porém, apontou que no processo de estágio } \\
\text { a relação que se estabelece entre as duas instituições não é de um processo de ações conjuntas, cujo envolvimento entre a universidade e a escola precisa ser } \\
\text { repensado. }\end{array}$ \\
\hline & 041d & $\begin{array}{l}\text { Estagiário como mediador da universidade e escola - Ao discutirem temas novos para a escola, utilizarem abordagens diferenciadas, Ricardo aponta para o fato de } \\
\text { poder levar para a escola uma visão diferenciada da Ciência e do Ensino de Física que podem promover mudanças nos alunos e no professor da sala na qual a } \\
\text { regência se realiza. Ele propõe o estabelecimento de uma cooperação, o estagiário como um "professor assistente" do docente da escola, proporcionandouma relação } \\
\text { mais aprofundada entre a universidade e a escola, considerando, a dialética entre teoria e prática que colaborariam tanto para o estagiário como para o professor da } \\
\text { escola. }\end{array}$ \\
\hline \multirow{4}{*}{ Motivo } & M41a & Ensino \\
\hline & M41b & Ensino \\
\hline & M41c & Aprendizagem da docência \\
\hline & M41d & Aprendizagem da docência \\
\hline \multirow{4}{*}{ Ações } & A41a & Organização de atividades de ensino, alunos em atividade investigativa de aprendizagem \\
\hline & A41b & Organização de atividades de ensino \\
\hline & A41c & Trabalho conjunto entre universidade e escola \\
\hline & A41d & Trabalho conjunto entre o estagiário e o professor da escola \\
\hline \multirow{4}{*}{$\begin{array}{c}\text { Sentido } \\
\text { atribuído }\end{array}$} & S41a & $\begin{array}{l}\text { Concebeu como importante a organização de atividades de ensino serem planejada a partir de um problema para colocar os alunos em atividade na busca de soluções, } \\
\text { desencadeando ações investigativas. }\end{array}$ \\
\hline & S41b & Reconheceu a importância da organização da atividade de ensino. \\
\hline & S41c & Reconheceu a importância da relação universidade e escola como instuições que deveriam realizar ações conjuntas para o ensino \\
\hline & S41d & Reconheceu a importância da relação colaborativa entre estagiário e professor da escola, culminando em ações conjuntas. \\
\hline
\end{tabular}




\subsubsection{Episódio 5 - Reflexão teórico-prática sobre o estágio}

No final da atividade de estágio, em cada disciplina de MEF, os grupos, formados pelos licenciandos para organizarem o planejamento e realizarem a regência, escolhiam um episódio dentre as aulas na escola e apresentavam à sala para discutirem com a professora da disciplina e os colegas. Anteriormente à apresentação, ao selecionar o episódio, o grupo deveria fazer uma reflexão crítica sobre o mesmo, apontando o que o caracterizou como marcante e quais pontos contribuíram para a aprendizagem da docência.

Os episódios selecionados pelos licenciandos tinham características diversas, abordavam situações nas quais o foco eram os alunos, ou o professor efetivo, ou eles mesmos, com temas que envolviam desde questões de problemas diretamente ligados ao conteúdo até aos mais axiológicos. Com isso, mostravam momentos da docência que levavam à mudança ou aqueles em que se sentiram inábeis para resolverem ou interferirem, mas qualquer que fossem eles faziam parte da vivência das práticas que realizaram.

Ao trazerem tais episódios para reflexão conjunta na disciplina, ampliavam a visão daquele momento em relação às dimensões pedagógicas, aprofundando a compreensão das relações que haviam se estabelecido naquela situação, o que trazia a construção ou mudança de sentido para os sujeitos que se envolveram diretamente, para os quais tinha uma concretude. Mas, influenciava também os outros licenciandos, que mesmos distantes daquela vivência podiam ressignificá-la pelas narrativas do outro e pela discussão e toma-la para si, atribuindo-lhe sentido. Assim, pretendia-se que o processo fosse mais um momento intencionalmente organizado pela professora da disciplina para aprendizagem da docência.

\section{A. Caso Heloisa}

Para Heloisa o estágio com regência lhe permitiu planejar aulas pensando em seus objetivos e na ligação entre os mesmos ao longo do ano, estabelecendo uma proposta pedagógica mais ampla com uma sequência de aulas que se complementavam. Isto ela percebeu no decorrer da disciplina de Práticas de Ensino de Física, pois ela não conseguia notar uma coordenação entre as ações de uma prática, geralmente experimental, para outra, ela pensava que as aulas poderiam ficar soltas para os alunos sem um fio condutor, mas, mesmo assim, ela fazia intervenções nessas atividades para levá-las à sala de aula. Com o 
tempo começou a perceber que havia um projeto pensado para o ano que era o que estruturava o percurso das aulas, que ela não tinha noção clara, só tomou consciência já com o processo adiantado.

Segundo ela, isso pode ter acontecido por não ter uma base teórica maior na ocasião, o que menciona que ocorreu em MEF, o que podemos observar no excerto da Entrevista 2:

E2(Heloisa) - Então, uma das coisas mais legais que já aconteceu comigo não foi em Metodologia foi em Práticas, em que a gente passa o ano inteiro fazendo um projeto, também é pensado, qual o objetivo do ano e pra complementar esse objetivo qual vão ser os objetivos do semestre que complementam o do ano, depois dos meses e depois das aulas. Então, é um negócio bem pensado. Isso na verdade eu só fui perceber no final. Então, eu passei o ano inteiro dando aula, falando "Essas crianças não estão aprendendo nada", eu dei aula pra quinta série. "Essas crianças estão ai se divertindo, fazendo bagunça", eu achava ótimo, adoro ver crianças se divertindo, mas eles preenchiam o roteiro, mas isso não é a saída. A disciplina de Práticas teria sido completamente diferente se eu tivesse feito Metodologia antes, ia ser totalmente diferente, pra melhor, porque Metodologia pra mim deu muito mais base teórica do que Práticas. É mais ou menos isso que eu tô falando no geral.

A fala de Heloisa mostra a importância dada pela definição dos objetivos das aulas como estruturação do estágio em seu todo, isso para ela fez com que atribuísse sentido à necessidade de uma organização geral da atividade de ensino, não deixando de explicitar os objetivos de cada aula, cujo processo precisa ser consciente para o licenciando ou para o professor. Esse sentido atribuído à docência Heloisa trouxe da disciplina de Pratica de Ensino de Física, pela experiência que teve na atividade de estágio no contexto desta disciplina, que provocou uma contradição, pela relação entre o que ela tinha como objetivo e o que observava nas ações dos alunos. Ela compreendeu a coerência do planejamento de cada etapa da atividade de ensino, já no final do processo, percebendo que a coordenação das ações em cada aula estava ligada ao motivo da disciplina de aprendizagem do ensino de física para os licenciandos e a aprendizagem de conceitos, procedimentos, modelos etc de física pelos alunos da escola.

Esse sentido que surge pela contradição na disciplina que ela realizava, pensamos que teve a contribuição da memória de seu Ensino Básico, no qual a atividade de ensino estava organizada para todo percurso dos alunos e cada etapa tinha seus objetivos, suas ações direcionadas para uma meta específica, mas relacionadas ao motivo de ensino daquela escola. A relação das ações com a atividade e seu motivo é explicitada por Leontiev (2006), no excerto que ele diz que: 
[...] o objetivo de uma ação, por si mesma, não estimula a agir. Para que a ação surja e seja executada é necessário que seu objetivo apareça para o sujeito, em sua relação com o motivo da atividade da qual ele faz parte. Além disto, esta relação também é refletida pelo sujeito de uma forma bastante precisa, a saber, na forma de conhecimento do objeto de ação como um alvo. O objeto de uma ação é, por conseguinte, nada mais que seu alvo direto reconhecido (p.69).

Ao se pensar nas aulas é importante que se pense no planejamento da sequência de aulas da atividade de estágio, para assim poder ter a ideia do todo e também das ações a serem desenvolvidas em cada aula, consequentemente, podendo estabelecer o objetivo para o qual está voltado o processo geral e, especificamente, ao qual cada unidade se dirigirá, ou seja, cada aula. Esse processo faz com que o trabalho do licenciando no estágio seja intencional, visando seus objetivos que se concretizarão nas ações efetivadas com/pelos alunos, que não são imutáveis, dependem do processo desencadeado com os mesmos, mas tem um direcionamento, pois tem como fim a aprendizagem dos alunos.

Vemos essa questão com relevância para pensar o estágio uma vez que este é uma parte do processo de formação do futuro professor, para o qual a intencionalidade de seu trabalho educativo, seus objetivos nas atividades de ensino e a condução das atividades de aprendizagem devem ser pontos estruturantes e precisam ser refletidos crítica e coletivamente.

Outro ponto importante citado na fala de Heloisa foi a base teórica proporcionada pelas disciplinas de Metodologia, o que entendemos que não estava posta isoladamente, mas junto à prática formando um par necessário e indissociável à atividade de estágio, que passa a atribuir como sentido à docência. Isto podemos perceber quando Heloisa aponta que as atividades experimentais que preparava, em Prática de Ensino de Física, para apresentar em suas aulas não ficavam muito claras quanto ao objetivo que as ligavam, quanto a uma sequência estruturada para um determinado fim, pensamos que o apoio teórico que ela mencionou poderia ter colaborado para que pudesse estabelecer o diálogo entre teoria e prática caminhando para a construção da práxis. Nesse aspecto Gimeno Sacristán (1995) coloca que:

A comunicação do conhecimento e acção, entre teoria e prática, deve ser entendida não como uma relação directa entre o conhecimento e a investigação propriamente pedagógica, mas como um tráfico de influências dispersas. A mudança em educação não depende diretamente do conhecimento, porque a prática educativa é uma prática histórica e social que não se constrói a partir de um conhecimento científico, como se se tratasse de uma ampliação tecnológica. A dialética entre conhecimento e acção tem lugar em todos os contextos onde a prática acontece. 
De forma implícita, existe uma corrente de comunicação constante entre pensamento e acção, que molda a prática, de forma difusa, às vezes contraditoriamente através de diferentes tipos de comportamento e influência (p. 76-77).

A questão da base teórica que a licencianda coloca como ponto positivo, acreditamos que tenha lhe fornecido elementos para pensar e elaborar com mais segurança o plano de aula e assim, lhe trazendo mais clareza em suas atividades de ensino para o estágio, no entanto, não podemos entender esta fala como mais teoria em detrimento da prática, mas como a necessidade do par teoria-prática para a concepção das aulas e do ensino. Nesse aspecto Ribeiro e Moura (2012) ressaltam a importância da organização do ensino pelo professor da disciplina para que as ações do estágio ocorram de forma a desencadear o processo formativo. Os autores apontam para a necessidade de uma relação dialética entre as atividades de quem está na posição de formador e aquele que está em formação, pela organização do ensino, constituindo um movimento de aprendizagem da docência, como colocam:

No processo de aprendizagem da docência para a constituição da práxis, em correspondência com as ações reveladoras dos elementos reflexão, análise e planificação das ações, algumas situações podem fornecer indícios desse movimento, tanto para os estudantes quanto para os professores formadores. Naturalmente, esse movimento só pode constituir-se em sua totalidade, numa relação dialética entre a atividade dos estudantes e a atividade dos professores formadores, ou seja, as condições para que os professores desenvolvam o pensamento teórico sobre a docência estão diretamente relacionadas à própria atividade de aprendizagem da docência organizada pelo professor formador, isto é, à sua organização do ensino (p.8).

A reflexão das ações em sala de aula, realizadas pelo grupo 2 e organizadas no planejamento 1, permitiram que os estagiários fizessem a análise de um episódio ocorrido em sala de aula e compartilhassem na disciplina de MEFI. A escolha do episódio, em geral, indica uma situação que tenha sido mais marcante para os licenciandos, que nesse caso foi algo ligado à atitude do professor efetivo da sala, na escola, durante a aula dos estagiários, como mostra um trecho da apresentação e discussão do grupo:

R1(G2-Ana): Foi depois da aula, abrimos um espacinho para fazerem perguntas, até ficaram um pouco tímidos, o professor incentivou e ai uma menina fez uma pergunta.

R1(G2-Heloisa): Ela fez uma pergunta muito boa. Perguntou o porquê de Aristóteles estar na aula de Física sendo que o tinha estudado na aula de Filosofia. O professor virou e falou: "Nossa menina, você faz cada pergunta!", todo mundo começou a dar risada. E amamos a pergunta. 
R1(G2-Carlos): O pessoal da sala não ia rir dela se não fosse o professor. Ele que deu o ponta pé inicial para rirem da menina. E depois disso ela até que ficou "de boa" e achamos estranho, porque pareceu que sempre riam dela.

Profa Marina: Ela participou nas outras aulas?

R1(G2-Heloisa): Essa foi a primeira.

Profa Marina: E os outros alunos?

R1(G2-Heloisa): Calma, vamos chegar aí.

E aí, ela fez essa pergunta e quando os ânimos se acalmaram a respondemos. O professor virou e falou: "Você não sabia que era assim?".

Dissemos que naquela época não tinha diferença entre Ciências, que os filósofos eram pensadores e por isso chamavam todos de filósofos. [...]

R1(G2-Heloisa): No mínimo o que ele não fez foi reconhecer a importância da pergunta.

R1G2-(Ana): Ele incentivou as perguntas e na primeira ele cortou e acho que isso teve certo reflexo nas outras aulas, imaginamos, que ele tenha mudado um pouco.

R1(G2-Heloisa): E não só dela. Pensamos que por ela ter sido reprimida, não só pelo professor como pelos alunos, isso pode gerar timidez por parte dos outros. [...]

A pergunta feita pela aluna da sala na qual o grupo fez o estágio, ocorreu na primeira aula que eles realizaram, na qual a expectativa era grande em relação às ações que desenvolviam e como essas conseguiriam mobilizar elementos mediadores que permitissem uma boa relação inicial com os alunos. Assim, umas das interações que esperavam era que tivessem uma comunicação boa e recíproca com os alunos, o que envolvia o diálogo, que pudessem se expressar de forma livre sobre o assunto abordado. Por ser a primeira aula, pode ter ocorrido um maior distanciamento dos alunos por ainda não ficarem muito à vontade com os estagiários, o contrário também pode ter acontecido, uma menor descontração dos licenciandos por ser o contato inicial para regência. Contudo, a aluna citada fez uma pergunta pertinente ao assunto tratado na aula, o que agradou os estagiários, pois parecia ter interesse por parte dela e de alguns, bem como, o estabelecimento de uma relação de interação para o diálogo entre eles e os alunos.

A postura do professor é que gerou nos estagiários uma reação desconfortável, por ele ter um tom de deboche com a pergunta da aluna. No entanto, não podemos saber realmente a intenção que o professor teve com aquela atitude, porém, ela foi inadequada para aquele momento. Talvez possa ter pensado em chamar a atenção dos alunos para que não interrompessem a aula dos estagiários, ou porque não tenha achado a pergunta relevante, mas, seja qual for seu motivo, isso nos faz concordar com Heloisa, o fato é que ele não deu a devida importância à questão da aluna, a qual poderia gerar discussão e aprofundamento do 
assunto proporcionando aos alunos uma visão mais integrada dos temas que são tratados nas diversas disciplinas.

Diante da situação, um pouco constrangedora para os estagiários, pois não concordavam com a atitude do professor, eles responderam à questão da aluna de forma bem objetiva, sem ampliar a discussão para a sala e sem dar possibilidade de continuar gerando uma situação desagradável. Após a aula não conversaram com o professor sobre o que havia ocorrido para saber o que ele pensava sobre a pergunta da aluna. Porém, pensamos que Heloisa faz uma reflexão bastante coerente, na qual o sentindo que atribui à atitude do professor está diretamente associado a aprendizagem do aluno, ou seja o motivo do professor fosse qual fosse, não deveria perder a perspectiva do ensino, que é favorecer a aprendizagem dos alunos. Mas, durante o estágio o professor teve o papel de controlar o comportamento disciplinar dos alunos, que muitas vezes nem estavam ligados à atitude inadequada na aula, como foi o caso da aluna citada no relato do grupo 2.

Esse fato nos remete, novamente, ao aspecto a ser considerado na atividade de estágio, que é a participação mais integrada do professor efetivo da sala, isto é, há a necessidade de se estabelecer uma parceria com esse professor que recebe os licenciandos para que se possa fazer um trabalho compartilhado. A interação entre o professor da escola e os estagiários é bastante tênue e se limita ao primeiro ceder algumas aulas para a prática dos licenciandos e, às vezes, solicitar um tema específico no planejamento das aulas do estágio.

Por outro lado, os licenciandos não têm ações a serem desenvolvidas conjuntamente com o professor da escola, eles precisam de sua anuência para fazerem as regências na sala e se disporem a discutir o planejamento com ele e organizá-lo para colaborar com as aulas dele se assim for solicitado.

Com a questão da pergunta em sala de aula que o grupo 2 trouxe para reflexão, adicionaram mais outros dois aspectos que vivenciaram nas regências, um ligado também à ação do professor e dos estagiários, outro sobre a atividade de aprendizagem dos alunos. $\mathrm{O}$ relato desse outro episódio e as discussões geradas na sala de aula de MEFI está apresentado abaixo:

R1(G2-Carlos): [...] Outra coisa também, quando chegamos o professor falou, e pode ter influenciado nas nossas aulas: "Vai valer nota, então quero que vocês prestem atenção no que eles vão falar".

Outra coisa que talvez possa ter sido um erro nosso, foi quando demos as instruções para a atividade e fomos passando os slides e eles nem prestavam atenção no que estávamos falando, iam copiando. Tinha uma menina gravando nossa aula! 
R1(G2-Heloisa): Isso é outro problema também que vimos na quarta aula, em que eles tinham que redigir. Como eles não têm muitas aulas com Power Point ou muita aula explicativa, talvez não soubessem lidar com aquilo.

R1(G2-Carlos): E depois chegou na atividade em que eles tinham que fazer uma redação, e estranharam ter que fazê-la na aula de Física. Eles não sabiam fazer linha do tempo, permitimos que consultassem todo o material deles para fazer, mas eles não conseguiam escrever. Isso foi uma dificuldade.

R1(G2-Ana): Abrimos todas as portas que podíamos, permitimos que fizessem em grupos e tal, mas foi uma dificuldade. [...]

Profa Marina: Muito interessante esse primeiro acompanhamento que vocês fizeram em relação a pergunta do aluno, por isso que tem que ter relação com esse último apontamento que fizeram, os alunos não reconhecem que na aula de Física podem fazer redação. E também não reconhecem que Aristóteles que está na aula de Filosofia é o mesmo da de Física. A pergunta da menina é inteligentíssima e mostra que ela está pelo menos buscando essa relação [...].

Muitos professores que estão na sala de aula não estão preparados a fazer a discussão com os alunos, porque não tiveram essa discussão quando eram alunos. E ai ele não sabe o espaço que isso deveria ocupar na aula de Física. Parece que a aula que tem debate é a aula de História, de Geografia, porque são os temas polêmicos. Mas quantos temas da Física que não são polêmicos? Acho que todos eles.

O início do relato do episódio que trouxeram para apresentar à sala mostra uma ação do professor falando aos alunos que deveriam estar atentos às aulas dos estagiários porque o que discutissem valeria nota, portanto, seriam avaliados no final daquele processo. Essa intervenção do professor da sala perturba um pouco os estagiários, pois eles desejavam a atenção dos alunos pelo interesse no tema em discussão e pelas ações que organizaram para desenvolver em cada aula, não queriam que o motivo dos alunos estarem atentos fosse porque aquelas aulas teriam uma avaliação, sendo que esta não seria formativa, mas uma atribuição de nota sem critérios estabelecidos, nem mesmo com os estagiários. Assim, pensamos que o sentido que os estagiários atribuíam às aulas estava ligado a motivar os alunos, visavam que a atividade de ensino promovesse motivos eficazes para os alunos. Enquanto para o professor o sentido atribuído às aulas dos estagiários era o de manter os alunos atentos e disciplinados, ou melhor, sem tumultuarem a aula, quer estivessem motivados ou não, pois havia o instrumento avaliação, que da forma como foi colocado, pareceu-nos servir mais para pressioná-los do que para conscientiza-los sobre sua própria aprendizagem.

Ao lado da situação, de certo modo tensa, de assistir a aula tendo como fím à avaliação, os estagiários julgam que também corroboraram para aumentar a tensão, ao solicitarem que ficassem atentos à aula porque teriam que fazer um exercício recontando o processo histórico que estavam discutindo. Os licenciandos perceberam esse problema ao 
observarem que os alunos estavam muito preocupados em anotar o que ouviam, até chegando a gravar o que falavam. A mensagem dos estagiários não foi a mesma do professor, nem emergiu de sentidos semelhantes, mas promoveu resultados parecidos, como eles comentaram.

Esse fato pode ter acontecido, como analisou Heloisa, pelos alunos se depararem com uma aula com ações distintas das que estavam acostumados a ter com maior frequência, pois os estagiários utilizaram recursos técnicos que os alunos nem sempre têm nas aulas.

Por outro lado, fica posta a necessidade de explicitar claramente qual a tarefa de estudo que eles realizariam que envolveria aquele assunto, mencionando ações que poderiam viabilizá-la, o que talvez pudesse diminuir a ansiedade dos alunos em copiar enquanto discutiam a apresentação do tema com os estagiários. No entanto, podemos dizer que o sentido atribuído pelos estagiários à atividade de aprendizagem que haviam elaborado (que era de discutir como a concepção de universo vai mudando na Ciência, pelo papel dos homens, técnicas e instrumentos, em determinados momentos históricos), não foi o mesmo de parte dos alunos, naquele momento, pois eles se interessaram pelo tema abordado, mas o sentido que atribuíram era de cumprir a tarefa que receberiam na aula seguinte, que estava ligada à uma avaliação

Isso incomodou os licenciandos, tanto que levaram a situação para reflexão na disciplina de MEF, mas não perceberam com clareza todo o processo, deram maior ênfase às dificuldades de escrever dos alunos e ao fato de não parecer comum a eles essa atividade de aprendizagem em aula de Física. Heloisa vai um pouco mais além quando diz que a organização da aula, em Power Point por exemplo, não era algo cotidiano para os alunos da escola, o que nos permite pensar que ela percebe que a aula que apresentaram não fazia parte das ações de ensino, em geral, preparadas para esses alunos. Eles tinham que mudar de sala para terem acesso ao equipamento técnico; o professor precisava solicitar com antecedência tanto a sala como os equipamentos; a sala tinha outra disposição, era organizada em grupos, diferente da sala das aulas regulares; estavam discutindo um tema, com uma abordagem pouco utilizada no ensino médio; e a tarefa era diferente do que se costuma propor nas aulas de física (CC, p. 63, 23/10/15).

Os estagiários perceberam a problemática que se instaurou, mas no momento da aula, não viram a possibilidade de intervenção para conversar sobre a situação ou de alteração de suas próprias ações, ou seja, promover ações para solucionar o problema surgido, para depois continuar com o planejado, mesmo que com algumas modificações. 
Nesse momento o auxílio do professor da sala seria importante, pois ele tem vivências de situações similares, que poderia compartilhar com os estagiários, mas isto só seria possível se ele tivesse participação dinâmica na atividade de estágio. Sem a ação do professor da sala definida como uma das ações para concretizar a atividade de ensino, como parte de sua estrutura, ele fica sem iniciativa nas ocorrências de ensino na sala com os estagiários, no papel de cooperação (GIGLIO et al., 2011; AROEIRA, 2014).

Mesmo com as necessidades que apontamos, é legítima a discussão que os estagiários e a professora da disciplina fizeram em relação às dificuldades dos alunos da escola para redigirem um texto. A dificuldade na redação do texto é preocupante para alunos que se encontravam no final do Ensino Médio. No mesmo contexto, podemos apontar ainda, a falta de compreensão dos alunos em relação à atividade de aprendizagem, aliada a não familiaridade com a abordagem didática utilizada pelos licenciandos, como fatores geradores de dificuldades dos alunos da escola para expressarem suas ideias na escrita, com isso não deixamos de considerar a necessidade de melhoria na leitura e escrita desses alunos. Outro ponto, abordado pela professora de MEF foi a necessidade de estarem atentos e receptivos às questões colocadas pelos alunos, como sendo um fator importante à docência, que podemos entender como um sentido que ela atribui a ser professor, ser docente de Física.

Essas questões apontadas pelo grupo $2 \mathrm{fez}$ com atribuíssem sentido ao contexto escolar, mais especificamente, à aprendizagem dos alunos como sendo insuficiente em vários aspectos, como por exemplo à escrita, que observaram no decorrer das regências e das tarefas solicitadas.

A complexidade que Heloisa viu no trabalho docente e a responsabilidade que isso traz a deixa em momentos de instabilidade em relação ao sentimento de estar preparada para atuar na profissão docente, como mostra o excerto de sua entrevista:

E2(Heloisa): Você não vê nem como o pessoal se veste, o assunto que eles estão interessados, qual a relação que eles têm entre eles, enfim, tem professor que é muito alienado. Mas é difícil, é muito difícil. Acho que isso me assusta um pouco em ser professora, é muita responsabilidade pra mim, eu não me sinto capaz de formar pessoas.

E2(Heloisa): ... numa fase eu tô super corajosa e falo: "Não, vamos dar a cara pra bater, vou tentar, se eu não tentar não vou aprender"; e minha fase de agora é: "Não, não vou tentar, quando eu tiver coragem eu tento, eu aprendo".

A fala de Heloisa mostra uma oscilação entre estar ansiosa para assumir sua profissão docente e outra de angústia por pensar na responsabilidade em formar pessoas e não se sentir 
capaz, não julgar que esteja suficientemente preparada. Como ela ainda não se formou, há um tempo para se preparar, porém fica clara uma sensação de insegurança que pode estar ligada às características pessoais, a alguns estereótipos da profissão docente como de o professor ser alguém que deve saber tudo, a ter que enfrentar uma situação bastante complexa do ensino atual, a própria complexidade da profissão docente, ou ainda a necessidade de maior contato com o contexto escolar, porque não foi suficiente aquele estabelecido no curso, assegurado pela lei de estágio.

Essa última possibilidade precisa ser pensada tanto no curso como nas disciplinas com estágio, pois o trabalho quanto mais próximo e mais comprometido e compartilhado com a escola permitirá que o licenciando se familiarize mais com o contexto e as relações estabelecidas nesta instituição.

Heloisa coloca que mesmo com toda preparação, reflexão, ainda não tem uma experiência mais aproximada do que será, na realidade, a profissão docente, o que expressa em trecho da Entrevista 2:

E2(Heloisa): Não te dá uma experiência mais próxima com o que vai ser. Tudo bem é utopia falar que você vai sair da licenciatura já formada um professor, você vai fazer tudo, vai ser um ótimo professor e etc, mas acho que podia aproximar um pouquinho mais da realidade escolar. A disciplina de Práticas é a que mais faz isso.

[...] a parte da sala de aula é realmente a mais legal, então podia ter mais. Até porque, acho que deveria ser uma coisa crescente ao longo do curso de Física. No começo você faz menos parte, daí sua participação na sala de aula vai aumentando. Igual Práticas, você fica o ano inteiro, tem que se programar, semana sim, semana não, pra estar lá na escola. Eu acho isso bem legal. Tudo bem que o curso de Licenciatura não é um laboratório, mas poderia ter um pouquinho mais de participação na sala de aula. Porque, pensa, se você só vai ter essas intervenções pontuais, na sala com os alunos, quando chega pra dar aula mesmo, que você tem que, não sei, vamos supor que você pegue uma turma só, já são duas aulas por semana, durante o resto do ano, isso é muito mais coisa do que você fez durante toda sua graduação.

A licencianda reflete que pensa ser necessária uma aproximação maior da realidade escolar, para que se apreenda a profissão docente em seu contexto mais amplo e em suas especificidades, contudo, tendo claro que não será possível uma aprendizagem que se aproprie integralmente da docência, pois é um campo multifacetado e em movimento que também precisa que os licenciandos atribuam-lhe sentidos. O que, na opinião de Heloisa, há disciplina que faz uma aproximação maior com a escola, possibilitando o contato mais sistemático com a sala de aula. 
Para que haja essa maior aproximação a licencianda propõe que o estágio seja ampliado e distribuído ao longo de toda a licenciatura, se intensificando no decorrer do curso. No entanto, o número de horas de estágio em vigor, já resulta de ampliação mais recente feita por lei, o que talvez precise ser compreendido é a necessidade de maior permanência do estagiário na escola. Ela compara o número de regências no estágio com o número mínimo de aulas que um professor daria em uma escola, após formado, considerando as do estágio muito inferiores. Para tanto, ela sugere que desde o começo do curso de Física se inicie uma pequena participação em estágio e isso vá aumentando à medida que o aluno avance no curso, assim, o contato com a escola seria contínuo e crescente, passando por vários momentos de ações do licenciando. A proposta de Heloisa é interessante e mostra a necessidade do licenciando de maior interação com o contexto escolar, com a sala de aula, que é uma articulação importante e complexa para ser organizada. Heloisa atribui à atividade de estágio o sentido de necessidade de maior contato com a escola, maior tempo dos licenciandos em ações na escola em contato mais sistemático, perpassando todo o curso.

\section{B. Caso Ricardo}

Nas regências de Ricardo e Vera, sua parceira de grupo, foram realizadas atividades de ensino que propunham um trabalho por parte dos alunos, cuja maioria era feita em pequenos grupos, para isso precisavam compartilhar suas ideias, organizar suas ações, saber seus objetivos para poderem investigar a situação apresentada pelo problema, que tinha um fenômeno físico envolvido, tinham que analisar os resultados com os recursos disponíveis, os poderiam ser ampliados pelos alunos no processo da atividade, pelo próprio desenvolvimento do trabalho, pelas interações e pela intervenção do estagiário (no papel de professor). Considerando essa perspectiva é que escolheram um episódio ocorrido com um dos grupos da sala de aula para apresentarem e fazerem suas reflexões na disciplina de MEFI, o qual aconteceu no decorrer das duas primeiras regências de Ricardo (as aulas foram realizadas no mesmo dia).

Os estagiários do grupo 1, fizeram a opção por apresentar o episódio da aula de Ricardo, pois haviam feito as regências em escolas diferentes, pois a situação colocada pelos alunos os surpreendeu. $\mathrm{O}$ excerto da apresentação segue abaixo: 
R1(G1-Vera): Sobre os desafios, um era pra tentar classificar as lentes e projetar alguma coisa, e ai teve uma parte interessante.

R1(G1-Ricardo): [...] A pergunta era: "Como vocês podem classificar as lentes?", como eles iam fazer era critério deles. O segundo problema era: "Como determinar a distância focal de uma lupa?", tinham que arrumar um jeito de determiná-la. E a terceira pergunta, que é a do episódio, era: "Como projetar a imagem de três objetos escolhidos por vocês?", poderia ser uma mochila, um lápis, etc. E aí alguns estavam trabalhando, resolvendo os primeiros problemas. [...]

$\mathrm{O}$ que aconteceu? Enquanto eu passava pelos grupos vendo se estava acontecendo tudo direitinho, se estavam com alguma dificuldade, um dos grupos chegou euforicamente me perguntando se como já tinham feito todos os desafios podiam fazer outro. "Como assim outro? O que querem fazer?", "Queremos projetar a imagem de uma pessoa, é possível?"

Eu não esperava isso, porque só propus aqueles problemas, mas eles já tinham resolvido todos e chegaram com esse adicional. Falei: "O que vocês acham?" Eles acharam que era possível, mas que não sabiam como fazer. Disse que não poderia interferir, mas que achava que eles conseguiriam, mas que se falasse perderia toda a graça da atividade. Eles teriam que descobrir. Eles aceitaram o desafio e foram fazer. De repente, vem o grupo inteiro pra cima de mim dizendo que conseguiram. Eu fui ver e tinham conseguido projetar perfeitamente o rosto de uma pessoa numa folha de sulfite. Estava bem nítida.

Ai eu perguntei como tinham feito para resolver o problema e eles disseram: "A gente primeiro pegou uma lente e pegou a lanterna do celular e uma folha de sulfite"

Por que vocês acham que deu certo? "É que a gente percebeu que com a lanterna que o senhor deu a imagem saia borrada, então resolvemos usar o celular e ficou bem melhor, aí achamos de daria para fazer isso."

E eu não satisfeito perguntei por que eles achavam que a resolução tinha dado certo. E eles me deram a explicação minuciosa. Eu fiquei super feliz que eles conseguiram projetar e tal e pedi pra eles ajudarem os outros grupos nas atividades propostas e apresentar a eles o que eles produziram. Depois pedi que eles fossem para um grupo com dificuldade e fizessem uma série de perguntas que levasse a resolução, na verdade era um grupo que estava com dificuldades, os outros dois já estavam acabando. Eles fizeram e o grupo com dificuldade ficou super feliz, porque conseguiram resolver o problema com ajuda dos colegas.

[...] eu lembrei que tinha aprendido algo diferente na aula de Metodologia, então eu vou aplicar e ver no que vai dar. Essa foi a primeira impressão, de que você como professor, de certa forma, barrar um pouco esse impulso e acreditar nos alunos é fundamental para que eles consigam entender que eles também podem construir conhecimento cientifico. A segunda coisa com relação a outra pergunta que eu dei pra eles, o fato de eu ter jogado de volta a pergunta pra eles fez com que raciocinassem, acreditassem que fosse possível. Depois, pelo fato de eu encorajá-los foi determinante para se engajarem para poderem resolver o problema. [...]

R1(G1-Ricardo): Só que uma coisa interessante é que quando estávamos trabalhando aqui com as sequências investigativas sempre acreditei nessa ideia, mas nunca tinha colocado em prática. Eu me coloquei junto com a Vera esse desafio e não quis fazer de forma tradicional, porque eu não defendo isso e queria ver como acontecia na prática. Acredito nos alunos, não só nesses, mas nos outros que já dei aula. 
O episódio narrado por Ricardo, se o observarmos como um todo no ambiente da sala de aula em atividade de ensino e aprendizagem, podemos notar o movimento, que nos parecia com um movimento browniano, pois era uma movimentação dos alunos, até meio desordenada para quem olhava de fora, como pudemos acompanhar (CC, p.24, 21/05/2013), no entanto, era uma movimentação para comunicação, para interações entre os alunos e o estagiário (no papel de professor). Nesse movimento cada grupo seguia seu ritmo, também suas ações para buscar as soluções para os problemas, as quais eram diferenciadas, embora trocassem ideias entre si. Assim, como a ações propostas para resolver os problemas eram diferentes e as relações que cada grupo conseguia estabelecer com os conceitos já estudados com a professora efetiva se desenvolviam de maneira distinta, o tempo para finalizar o processo também não era o mesmo para esses grupos.

Um grupo alterou a fonte de luz e os outros grupos aderiram a essa ideia, passando a usar o celular para substituir a fonte inicial fornecida pelo estagiário. Cada grupo estava envolvido com a sua atividade, mas ao ocorrer uma mudança em algum dos grupos, isso se propagava rapidamente. Tal fato exemplifica que a sala de aula, o trabalho em pequenos grupos, funcionava como um sistema de atividades coordenado, com a mesma regra para buscar soluções para um mesmo problema, mas cada grupo coordenava suas ações, mantinha uma dinâmica interna (ENGESTRÖM, 1999).

A projeção da imagem do rosto, feita pelo grupo, parece mostrar uma relação dialética que se estabelece entre o que os alunos internalizaram do conceito científico trabalhado e o que trazem do cotidiano. No entanto, a proposta dos alunos, a projeção do rosto de um deles, é também um processo criativo, que simbolicamente pode ter uma alteração da representação dos objetos (imagens de objetos) para a representação do sujeito (imagem do rosto), colocando este último como destaque, como passaram a se destacar como sujeitos em ação naquela atividade proposta pelo estagiário.

As mediações na sala de aula não ocorreram apenas pelos objetos, mas pelas possibilidades de interações entre aluno/aluno e aluno/estagiário (no papel de professor), que pela comunicação e o trabalho compartilhado fizeram com que os grupos conseguissem organizar suas ações e aplicá-las em situações diversas, destacando-se, a projeção do rosto como narrado. Nesse caso, o apoio do estagiário em tornar a proposta do grupo um problema para eles resolverem, mostrou confiança do estagiário nos alunos e em sua proposta de ensino, mas respeitou a questão que surgiu no grupo, dando espaço para que pudessem avançar e ir 
além do que o professor propunha, que percebessem que o conhecimento também é um ato criativo e de busca constante.

Continuando a apresentação da aula que trouxeram para reflexão, Ricardo aborda outra questão que também havia sido objeto de discussão na disciplina:

R1(G1-Ricardo): Uma coisa que achei muito interessante foi o que aprendemos aqui na sala de aula, a importância de você fazer uma pergunta do "Como", como resolveriam o problema, porque eles passaram a ter consciência dos atos deles. Passaram a entender a fazer uma transição entre $o$ saber e o compreender. A passagem da parte operacional para a parte do pensamento. Isso foi muito importante para eles entenderem que fizeram todo o processo. E a segunda parte que foi quando perguntei o porquê, percebi que foi muito importante também, porque eles tiveram que explicar causalmente o que eles tinham feito e por que tinha dado certo, de forma que as explicações deles fossem coerentes com o fenômeno físico, que passa a ter função de um agente ativo e não passivo. Conseguiram não só tomar consciência das suas ações como também explicar de forma coerente o que eles observaram. Percebi que isso fez toda diferença.

Por fim, pensando em tudo o que tinha aprendido de Vygotsky acabei pedindo para que eles socializassem esse conhecimento tomando a ideia dos parceiros mais capazes. Se eu sei um pouco mais é importante que eu socialize esse conhecimento para que esse outro colega possa também aprender comigo. Eu me torno, enquanto colega desse aluno, professor dele também, assim como ele em algum momento vai poder ser o meu professor. Então, já pensando nisso foi que eu pedi a eles para socializarem o conhecimento.

Então, como conclusão chegamos a ideia de que primeiro precisamos romper com a cultura escolar tradicional se quisermos inovar. Não adianta querer aprender uma série de coisas interessantes se não acreditarmos que aquilo é possível, é importante acreditarmos nos alunos Segundo ponto, é importante fazermos com que os alunos tomem consciência dos seus atos pra que enxerguem que eles são os construtores do conhecimento e o último, é dar oportunidade deles fazerem as explicações causais. Isso tudo tem a ver com as habilidades do fazer cientifico, levantar hipóteses, testar hipóteses, e também, isso ajuda a fazer a alfabetização cientifica. [...]

Professora Marina: Achei interessante esse apontamento que vocês fizeram. [...] Quando não damos oportunidade ao aluno de tomar consciência do que ele fez, ele não tem oportunidade de tomar consciência de quais são os fatores que levaram aquela situação ocorrer daquela maneira. [...]

R1(G1-Ricardo): E ver se é coerente, né? Porque a princípio temos muitas contradições internas e eles não tomam consciência dessas contradições.

O grupo 1 aponta a importância em fazer a pergunta como para os alunos, pois isso faz com que tenham a consciência do que fizeram para obter o resultado, ou seja, remete os alunos a reconfigurarem o encadeamento de suas ações para aquele dado fim. Porém, julgamos interessante observar, que ao fazer a reconstrução do processo que cada grupo 
utilizou, pode-se ter a configuração de vários encadeamentos de ações, que na maioria das vezes não coincidem, mas se direcionam à mesma meta.

Ao perguntar por que os alunos fizeram a projeção do rosto daquela maneira, o estagiário buscou uma explicação que exigia as relações com o fenômeno físico e seu conceito. Nesses momentos, o professor pode saber o que os alunos apreenderam e o que terá que complementar na mesma aula ou em outra, portanto, é importante para avaliação do processo e também para o aluno perceber aquilo que não foi compreendido por ele.

Quando Ricardo menciona que solicitou que o grupo apresentasse o que havia feito para a sala e depois pediu que ajudassem os outros grupos, ele o fez intencionalmente e com referencial na proposta de Vigotski, o que nos leva a enfatizar a importância do estudo de teóricos e pesquisas diversas na formação docente, pois no caso de Ricardo, em sala de aula quando surgiu uma situação que o remeteu a teoria, ele pode associá-la às suas ações direcionando-as com mais clareza para aquilo que desejava obter como resultado. Isso fez com que o estagiário socializasse a ideia do grupo, mas levasse os alunos desse grupo a colaborarem com os colegas, que já estavam com suas propostas em andamento, mas com o auxílio de outros, que já haviam avançado um pouco mais (alunos do grupo e estagiário), puderam finalizar a atividade de aprendizagem. Esse processo de aprendizagem, possivelmente, favoreceu o desenvolvimento dos alunos, pois buscou ampliar a zona potencial (VIGOTSKI, 2007), o que também ocorreu com o próprio grupo que projetou a imagem do rosto, só que nesse caso, Ricardo é quem promoveu os meios mediacionais.

O estagiário colocou ainda, que a situação descrita ocorreu porque ele quis utilizar na regência uma abordagem didática que permitia o diálogo, as interações entre os indivíduos e a busca pelo conhecimento científico, de maneira a colocar os alunos em atividade de aprendizagem. Ricardo mencionou que se tivesse trabalhado em sala de aula de forma tradicional, isto é, em uma relação na qual ele fosse apenas transmitir informações aos alunos, sem muitas interações, ele supunha difícil ocorrer uma situação como a citada. No entanto, ele apontou ter sido difícil não responder diretamente à pergunta do grupo, por ter tido um ensino no qual as respostas são dadas, mas havia se proposto a colocar em prática o aprendido em MEF, que ele acreditava, mas ainda não tinha trabalhado em sala de aula. Com isso, estava atento aos resultados que obtinha com os alunos porque era importante para ele saber como aquela atividade de ensino que ele organizou favorecia a aprendizagem dos alunos.

Esse relato é bastante rico na experiência proporcionada ao licenciando para sua formação docente, acreditamos que ao ficar surpreso com a atitude dos alunos isto o fez 
pensar em questões importantes do trabalho em sala de aula, como: confiar na capacidade do aluno, permitir que o aluno avance um pouco mais do que foi proposto, não inibir sua criatividade, a socialização do conhecimento e colaboração entre os colegas para aprendizagem.

Em relação ao professor, que ele se permita sair da zona de conforto e utilizar novas abordagens didáticas, que possam fazer os alunos pensarem em como investigarem um problema, saberem utilizar perguntas do tipo como e por que para que os alunos tenham clareza de suas ações e do que compreenderam sobre um tema. Esses são novos sentidos ou sentidos ressignificados para Ricardo que no decorrer das regências foram emergindo.

Em MEFII o episódio de regência escolhido pelo grupo 1 para ser apresentado e analisado foi gravado em vídeo, em uma aula conjunta entre Ricardo e Vera, cuja condução dessa aula foi feita por Ricardo e sua colega o auxiliava. Essa aula correspondeu a uma das quais os alunos, reunidos em pequenos grupos, comparavam o espectro luminoso de uma estrela com o de vários elementos químicos, com o objetivo de responder ao problema, colocado desde o início da atividade de aprendizagem, que era verificar do que eram constituídas as estrelas. O trecho da aula exibido foi após os grupos obterem seus resultados, sendo que cada um havia recebido espectros de duas estrelas e verificado os elementos químicos que as compunham.

Os estagiários organizaram a lousa em espaços numerados correspondentes ao número de grupos, em que cada um continham espaço para inserir os dados de duas estrelas distintas, no total eram quatro que se combinavam duas a duas pelos grupos, que colocavam seus resultados na lousa. Depois disso, observando que os resultados tinham diferenças para as mesmas estrelas, Ricardo começa a discutir com os alunos como puderam encontrar elementos distintos constituintes da mesma estrela. Essa discussão é que foi objeto para reflexão na disciplina de MEFII, como podemos acompanhar, pelo trecho abaixo:

R2(G2-Ricardo): Uma coisa que eu também percebi depois de ter visto o vídeo e refletido, além da minha falta de intervenção, porque eu poderia ter intervindo de alguma forma, e é uma coisa que eu lembrei que a gente viu aqui nas aulas, foi que nesse momento eu poderia fazer uma roda com eles para conversar. Talvez, diminuísse até porque a forma como estavam organizados propiciava a discussão. Mas entra outro fator, porque estávamos com muita pressa nessa parte e se fossemos fazer de novo todo o rearranjo da sala ia demorar muito tempo. Mas tem outro lado que eu lembrei depois da reflexão, como temos uma cultura escolar estabelecida e os alunos estão inseridos nessa cultura, muitas vezes para eles se comportarem em outra atividade leva certo tempo, até para aprenderem a se comportar nesse tipo de atividade. 
Professora Marina: E têm características disso que conseguimos resolver por determinadas ações que vocês fazem, porque não é ao acaso que naquelas atividades de conhecimento físico colocamos os alunos em roda. [...] Recomendamos que os materiais sejam retirados para que eles não possam trabalhar de novo naquele material, senão vão tentar resolver o problema de novo e não vão prestar atenção na discussão que está sendo feita.

R2(G2-Ricardo): Eu achei muito estranho, a princípio, eu sabia que eles não estavam prestando atenção, mas é engraçado que nas avaliações finais, que eles apresentaram, acharam interessante, apareceu isso em algumas delas, e uma em especifico fala exatamente isso, sobre a nossa tentativa em fazer uma contextualização epistemológica, pelo menos a ideia inicial. Outras coisas semelhantes apareceram também e fiquei pensando que não estava bem desse jeito na aula.

Professora Marina: Porque talvez uma forma fosse mudar esse tipo de abordagem, primeiro discutir todos os dados que o aluno tem e a partir da discussão dos dados aparecem aspectos da natureza da Ciência, porque aí faz mais sentido, ele está trabalhando sobre aquilo que acabou de ser feito e que não é só um trabalho conceitual. É uma abordagem conceitual, mas que está trazendo junto questões da epistemologia da ciência. Aqui foi produtivo, mas pode ser que em alguns casos não seja, inverter essa ordem favorece que a discussão faça mais sentido para os alunos.

No trecho do vídeo exibido Ricardo comparava os dados dos grupos, porém os alunos não pareciam atentos à discussão, havia conversa simultânea a fala do estagiário e outras ações ocorrendo, alguns comparando novamente o espectro luminoso da estrela com o dos elementos químicos, outros fazendo parte das tarefas que teriam que entregar para os estagiários, como Vera comentou, mas tinham os que acompanhavam a ação de Ricardo de tentar refletir sobre a diferença entre os resultados dos grupos. Mesmo que no vídeo esses diferentes interesses não tenham aparecido tão claramente, pudemos percebê-los na observação presencial da regência.

Para aqueles que só assistiram ao vídeo a imagem mais presente era a de muita conversa e desatenção àquilo que estava sendo coordenado pelo estagiário. Mas, para Ricardo a percepção também foi essa, mesmo após conversa com a pesquisadora no final da regência, a exibição do vídeo, parece-nos que lhe trouxe a questão de conseguir a atenção dos alunos para a ação proposta como fator importante para o professor em sala de aula. Isso é atribuído como um sentido para a docência, que é a intervenção do professor para retomar a atenção dos alunos para que se concentrem em uma determinada ação.

$\mathrm{Na}$ reflexão do grupo, Ricardo aponta que o fator de contradição para eles estava na maneira desordenada dos alunos se comportarem, que eles consideravam desatenta, mas na avaliação escrita esses alunos disseram ter sido interessante a atividade desenvolvida, terem compreendido. O grupo atribuiu o comportamento dos alunos ao fato de não estarem 
acostumados a trabalharem com atividades de aprendizagem como a realizada, o que faz com que não tenham ações coerentes em cada momento, pois o trabalho em cada etapa vai se diferenciando no decorrer do processo e isso requer diferentes ações, tanto do estagiário (no papel de professor) como dos alunos. Assim, a avaliação que os alunos fizeram da atividade de aprendizagem, Ricardo pensou que não estava totalmente de acordo com a realização das aulas.

O estagiário reflete, ao avaliar sua regência pelo vídeo, que talvez pudesse intervir na situação da sala de aula, comenta que uma possibilidade poderia ter sido a que lhes foi mostrada em MEF, que era fazer a apresentação dos resultados e sua discussão em uma roda de conversa, o que daria maior foco a essa ação, evitando dispersão como na disposição em grupo na qual os alunos se encontravam na aula filmada.

Para essa estratégia a professora da disciplina comenta a intencionalidade que tinham com a roda de conversa na pesquisa realizada no Ensino Fundamental I, que era utilizada para os alunos explicitarem seus resultados e as explicações que davam aos mesmos, privilegiando essa discussão, a socialização das ideias e a atenção dos alunos voltada para esse objetivo, que foi apresentada e discutida com os licenciandos. No entanto, a professora de MEFII, fez outros apontamentos que também poderiam ser utilizados para que não se tivesse o comportamento disperso dos alunos, ela indicou, por exemplo, alteração na ordem de organização da atividade de ensino, o que poderia colocar os grupos em uma posição mais argumentativa, que talvez pudesse influenciar motivando-os mais na discussão dos resultados.

Essa reflexão trouxe a Ricardo a experiência de uma situação na qual o professor tem planejada uma ação, mas em função da organização das ações de aprendizagem dos alunos, há a necessidade de mudança e é preciso que o professor saiba perceber isso, ele precisa mudar suas ações, coordenando-as com as dos alunos, repensando as regras do sistema de atividade de estágio. Ao explicitar que esse processo de intervenção nas ações planejadas poderia ter ocorrido na sala de aula como parte de sua atividade de ensino Ricardo atribui mais esse sentido à docência, da necessidade de, algumas vezes, modificar as ações em função do processo desencadeado com os alunos.

A contradição em sala de aula, que pudemos presenciar pelo acompanhamento da regência, na qual o estagiário se mostrava incomodado com a conversa dos alunos e a falta de foco na discussão dos resultados, associada à premência de finalizar aquela etapa proposta pelo pouco tempo de regência que lhe restava; a avaliação dos alunos que ele apontou como contraditória; e a reflexão da aula pelo vídeo, são propulsores para que o licenciando atribua o 
sentido de necessidade de intervenção do professor em certas situações em sala de aula, mudando suas ações planejadas, para restabelecer a organização, o diálogo e o trabalho coletivo.

A professora da disciplina complementa a análise da regência de Ricardo considerando o aspecto da ação realizada como exercício da docência para o licenciando. $\mathrm{Na}$ discussão anterior isso foi analisado, mas sob o ponto de vista do estagiário diante do que havia planejado e como poderia mudar sua ação no decorrer da aula, porém, no excerto da reflexão do grupo 1, a professora de MEFII amplia a discussão colocando a situação para a sala e propondo ao grupo aprofundar aquele momento que estavam apresentando, apontando aquela ação como parte da atividade docente, não que a organização da atividade de ensino tivesse, necessariamente, que explicitá-la. Para propor a discussão aos seus alunos e chamar a atenção para a importância do momento de regência apresentado a professora Marina começou com uma pergunta:

Professora Marina: E aí gente, como vocês veem esse trabalho que o Ricardo está fazendo agora de discutir? Primeiro que isso é dificílimo, de colocar na lousa e tentar encontrar relação. Vocês já trabalharam alguma vez assim, enchendo a lousa de dados, de resultados que os alunos trazem do experimento? Ricardo, você tem alguma coisa a falar sobre isso? Como foi essa experiência?

R2(G2-Ricardo): Foi bem interessante, porque é a primeira vez que eu faço isso. Eu lecionei inglês e não tinha esse tipo de pesquisa. É difícil porque apesar da sala em si me respeitar e eu ter um bom relacionamento com eles, de alguma forma não estão acostumados com esse tipo de atividade e ai temos que ensinar aquilo que a senhora discutiu com a gente que não é só a questão dos conteúdos conceituais, mas dos conteúdos procedimentais e atitudinais. Pra mim, a princípio, foi complicado fazer esse tipo de ensino, porque eu também estava aprendendo a fazer. Como foi uma coisa nova eu ficava vendo o tempo da aula terminar, vendo que estavam conversando, impacientes, querendo comparar uma resposta com a outra e aí eu pensava: "Será que eu intervenho agora, faço isso depois?", são pensamentos muito rápidos. Então, como eu não tinha essa prática, pra mim foi difícil no começo. Eu acho que vale muito a pena, porque, mesmo que haja certa desorganização no momento, depois eles vêm perguntar pra gente coisas que não ficaram claras ou que se interessaram mais. Mas, ainda acho que preciso ter mais essa prática para aprimorar. Eu senti, obviamente, um pouco de dificuldade em fazer isso.

Professora Marina: Colocar dados do que os alunos trazem na lousa não é fácil, porque você tem essa questão forte que é o tempo e se você está colocando os dados é de uma atividade que eles já fizeram naquela aula ou na anterior, mas agora o trabalho é olhar esses dados e tentar encontrar uma ordem pra eles. Tentar entender o que está acontecendo de semelhante entre todos, ou o porquê é que tem coisas diferentes entre essas informações que eles trouxeram.

R2(G2-Ricardo): E é isso que eu não consegui fazer por falta de tempo. Se eu tivesse outra aula, por exemplo, eu conseguiria retomar essa discussão e, 
você vai ver, a princípio vai ficar uma análise um pouco superficial e como não vou ter mais aulas com eles, pensei em conversar com eles depois, pedi pra me procurarem, mandarem e-mail, porque eu sabia que não ia dar tempo, precisaria de mais uma aula para poder sistematizar, fazer a finalização.

Professora Marina: [...] Eu entendo que você estava agoniado com o tempo da aula, mas havendo mais tempo você poderia colocar isso como pergunta pros alunos: "O que aconteceu aqui? Vocês fizeram o mesmo experimento?". E ai geraria um debate entre: "Não, acho que meu grupo está certo, seu grupo fez alguma coisa que não deu certo".

R2(G2-Ricardo): Ia perguntar isso depois, mas poderia ter aberto espaço pra isso.

A professora da disciplina ressalta que a ação docente trazida pelo grupo 1, de colocar os resultados obtidos pelos alunos na lousa e buscar relacioná-los, é difícil de ser realizada em sala de aula. Para tanto, é necessário verificar cada resultado e compará-los, porém, nem sempre se tem tempo suficiente para isso. Mas, não podemos pensar nesse momento isoladamente, é evidente que requer que o professor tenha clareza de sua ação e do processo que os alunos desenvolveram, sobretudo que tenha acompanhado o trabalho dos grupos, tenha domínio do conteúdo abordado e dos objetivos que foram propostos naquela atividade de aprendizagem.

Ricardo apontou que foi a primeira vez que havia organizado sua aula com essa ação e percebeu que os alunos não estavam acostumados a trabalharem da maneira proposta, ele observou que nas aulas de MEF haviam discutido sobre abordar em sala de aula também atitudes e procedimentos, o que rememorou no momento dessa regência na escola, mas a preocupação com o pouco tempo que tinha para finalizar a atividade fez com que não trabalhasse com os alunos a atitude, mas também, porque para ele era a primeira vez que exercia aquele procedimento na discussão dos resultados. Assim, cada indivíduo teria que ter claro qual a ação que desempenhava em cada momento, tendo a noção da atividade em que estavam envolvidos e o que desejavam atingir.

Cabe observar, que Ricardo já havia se utilizado desse mesmo processo, no semestre anterior, em MEFI, porém os grupos relatavam seus resultados e ele os colocava na lousa para que pudesse discuti-los conjuntamente, relacionando-os, com os comentários e conclusões dos alunos. A diferença nesse caso, talvez possa ter sido o fato da proposta do primeiro semestre ter o objetivo de projetar a imagem de um objeto formada por uma lente, cuja meta todos os grupos alcançaram, bem como a de calcular a distância focal da lente. Antes da discussão coletiva, as interações entre os sujeitos daquele contexto já haviam ocorrido e proporcionado colaborações mútuas para que os objetivos fossem atingidos, mesmo que as ações dos grupos tivessem se organizado diferentemente. 
No caso agora em discussão, os alunos sabiam como agir para a obtenção dos resultados, mas esses precisavam de maior acuidade, sendo que os grupos, nem todos estavam com suas ações bem organizadas, pois alguns tinham problemas na comparação dos espectros, enquanto, outros faziam outras tarefas em paralelo. Os alunos tinham que entregar todos os exercícios finais de cada etapa (quem ainda não os havia entregue), inclusive o da regência anterior, porque não teriam outro contato com os estagiários. Isso gerou uma desorganização aparente na aula para a discussão dos resultados, porém, havia uma organização para cumprir todas as tarefas propostas.

O tempo restrito para discussão dos resultados também provocou uma situação conflituosa para os estagiários, eles tinham como proposta discutir os resultados dos grupos, agrupando as semelhanças e divergências, retomando os procedimentos utilizados, como os grupos agiram para chegarem aos dados apresentados, analisando assim, aspectos importantes na obtenção desses dados empíricos, como a observação, referenciais, medidas, relação entre os espectros etc, o que explicitaria o movimento das ações dos grupos. No entanto, precisavam finalizar a atividade naquela aula, porque era a última regência que haviam acordado com a professora, sendo que ela não dispunha de muitas outras aulas para ceder aos estagiários, mas talvez pudessem conseguir mais uma, porém eles próprios não tinham disponibilidade para estender as regências, devido a outros compromissos, de final de semestre, do curso de licenciatura.

Com todas as restrições, a opção foi uma discussão mais restrita dos resultados, o que pode não ter se prolongado o suficiente para os grupos se expressarem e compreenderem o que o outro havia feito, não houve muito tempo para que refletissem sobre o que haviam realizado. A professora da disciplina sugeriu que a própria diferença entre os dados obtidos pelos grupos fosse colocada para eles como uma problematização para depois ser feita a análise final. No entanto, essa sugestão demandaria também uma maior duração daquela atividade.

Essa vivência do grupo 1, na discussão na disciplina de MEFII foi ampliada para todos os licenciandos da sala, fazendo com que mesmos o que não vivenciaram a situação pudessem refletir sobre ela no âmbito do trabalho docente, a exibição do vídeo corroborou para que pudessem presenciar de forma mais abrangente a regência de Ricardo, mas como uma aprendizagem da docência para cada um, pela possibilidade desse procedimento didático se realizar em sala de aula com esses futuros professores. 
Nesses conflitos vivenciados por Ricardo, acreditamos que a situação o levou a atribuição de sentido referente ao uso de abordagens didáticas diferenciadas nas aulas pelo professor, mesmo que seja difícil, que não se saiba muito bem como os alunos organizarão suas ações, embora o trabalho docente esteja organizado de forma intencional, há a necessidade de se buscar mudanças constantes. O estagiário fez e viveu a angústia e o prazer de mudar a estrutura da aula e buscar aprender e a implementar diferentes abordagens didáticas. Essa atribuição de sentido para docência pensamos que já havia sido germinada em Ricardo em outra situação, em outro contexto, por ocasião da monitoria que realizou no Ensino Médio, mas só agora surgiu como elementos de proposta mais conscientes para mudança na organização da atividade de ensino e aprendizagem elaborada pelo professor.

A professora da disciplina aponta, não só para o grupo 1, mas generalizando para a sala toda, que ao trabalharem com os alunos daquela forma, discutindo os dados obtidos em uma atividade de aprendizagem que tinha um problema a ser resolvido, era uma situação nova para os estagiários e para os alunos:

Professora Marina: [...] Nesse caso é uma inovação curricular, inovação metodológica, mas como vocês estão em formação tem outras inovações que pra vocês é como gerenciar esse trabalho em sala de aula. [...] É complicado, porque há muito mais na sala de aula do que só o conteúdo. Tem essas relações interpessoais, que não é só professor e aluno, mas também o próprio aluno com o seu grupo, os demais alunos com os outros grupos.

A professora de MEFII enfatiza que os licenciandos ao trabalharem o planejamento considerando para elaborarem as atividades de aprendizagens um problema para que os alunos pudessem investigar possíveis soluções, como uma das regras propostas pela disciplina para o estágio, isso representou uma inovação curricular pelos temas que os licenciandos, muitas vezes, se propuseram a discutir, que nem sempre eram abordados com frequência no currículo da escola básica.

Ao lado disso, tinha-se também uma inovação metodológica, pois o desenvolvimento da atividade de aprendizagem com os alunos, bem como, sua concepção seguiam uma proposta, geralmente, diferenciada daquela dos professores da escola, onde a prevalência eram aulas expositivas sem muita participação ativa dos alunos. Apenas essas questões já se tornam bastante complexas para os estagiários se apropriarem e avaliarem seus resultados para o trabalho docente. No entanto, a professora Marina colocou que não era só o conteúdo que estava sendo trabalhado em sala de aula, especialmente, naquelas atividades investigativas de ciências, mas há as relações interpessoais, que estão sempre postas em 
qualquer que seja a atividade, assim, ela aponta que os licenciandos estavam também diante de situações de inovação para eles em relação à formação docente, de como gerenciar o desenvolvimento da atividade de aprendizagem.

Isso nos leva a pensar na importância das reflexões que a professora da disciplina propõe no decorrer das apresentações dos grupos, enfatizando situações relevantes para docência, com significados que são desejáveis aos professores, na perspectiva de um trabalho no qual conteúdo e relações interpessoais são aspectos relevantes à aprendizagem dos alunos. Assim, considerar as interações diversas em sala de aula e promovê-las faz parte do trabalho docente, ao apontar essa questão na regência de um dos estagiários e generalizando-a, a professora pode possibilitar a atribuição de sentidos pelos licenciandos. Sendo que, para o grupo 1, para os quais a reflexão já havia sido feita também antes de apresentarem o episódio, podemos dizer que atribuíram esse sentido à docência, a necessidade do professor gerenciar a aula considerando as múltiplas relações que ocorrem entre os sujeitos.

Vera complementa a discussão apontando que mesmo dentre as aulas que haviam planejado e realizado a que relataram foi diferenciada pela discussão dos resultados e por estes não coincidirem em todos os elementos encontrados, o que gerou uma certa disputa, mas que era na verdade cada grupo defendendo seus resultados. Essa questão é aprofundada pela professora da disciplina, com a intenção de mais uma vez, enfatizar aspectos importantes para o trabalho docente, como verificamos abaixo, em um excerto da apresentação:

R2(G2-Vera): Estamos falando de aulas diferentes. A maior parte das aulas, que fizemos com eles, foi dessa forma, eles reunidos em grupo e resolvendo alguma coisa. [...] Essa daí não. De repente, a diferença foi porque eles puderam comparar na hora, a gente pediu para eles colocarem na lousa, eles brigavam pelos resultados, meio que queriam competir.

Professora Marina: Sim. E é nesse sentido que ela se diferencia, porque ainda que você coloque o aluno em grupo para responder ao questionário que vai ser dado pelo professor ele responde questionários na sala de aula, inúmeros. Então, para ele a novidade é só estar em grupo. Estou exagerando, porque não é o caso que vocês fizeram, mas o fato dele estar em grupo trabalhando para resolver um problema em que o dos outros deu errado, mas ele tem plena convicção que os passos que ele usou estão certos e ai ele se sente impelido a defender as ações que o grupo tomou. Nesse momento você acaba criando com o aluno uma questão que a gente pouco aborda em sala de aula, que é a autoestima do aluno que está sendo ali trabalhada, do fato dele reconhecer que ele foi capaz de responder um problema que foi dado a ele, que ele foi capaz de discutir com o colega sobre aquilo e que ainda que o resultado dele não seja o que foi esperado ele entendeu como proceder para resolver [...]

Eu acho que essa aula foi tão bem avaliada pelos alunos, porque ela contribuiu com outras questões que não são avaliadas normalmente na aula 
de física ou qualquer que seja. A oportunidade dada ao aluno para que ele de fato utilize da sua liberdade intelectual é pouca, normalmente, não acontece. Quando o aluno tem liberdade intelectual ele vê que é capaz. A escola se tornou, ou melhor, sempre foi um lugar em que você se porta como incapaz, o aluno está lá para receber formação. [...]

Monitor: Talvez seja bobagem o que eu vou falar, mas do ponto de vista do seu planejamento, Ricardo, do grupo no caso, tinha um objetivo ali que acho que vocês pensaram em discutir os dados depois, o que deu certo, o que não deu, é que foi boicotado pelo sinal da aula. No entanto, acho que os alunos, do ponto de vista da estrutura escolar que temos hoje, chegam à sala de aula para o professor ensiná-los, não para aprender. Os seus alunos aprenderam tanto que se sentiram capazes de divulgar os resultados deles. Então, talvez do seu objetivo geral não tenha sido como vocês esperavam, mas para eles foi muito mais do que costumam ter. O conflito que você apresentou talvez pudesse ser justificado por esse lado. Quantas e quantas aulas eles saem de lá do mesmo jeito que entraram?

Professora Marina: Essa oportunidade conferida a eles, ainda que naquela aula eles possam não ter aprendido aquele conteúdo conceitual que vocês tinham como objetivo, foi dada a oportunidade para trabalhar outros tipos de procedimentos que são possíveis de em outras situações eles buscarem solução para aquele problema. Uma vez que ele fez essa análise do espectro ele sabe mais ou menos como funciona, se ele quiser se aprofundar já tem um caminho que se sente seguro.

A professora de MEFII discute o aspecto do professor promover um espaço de discussão em sala de aula no qual os alunos possam argumentar sobre os resultados de suas investigações, mesmo que esses não sejam os previstos e na análise tenham que ser ponderados ou revistos, no entanto, permite que os alunos compreendam o processo que os levou a encontrá-los, as ações que executaram, conseguem retomá-las, no caso, isso fez com que defendessem seus resultados, porque tinham domínio do que haviam feito, sabiam onde queriam chegar. Para esse processo como um todo é que a professora da disciplina chama a atenção dos licenciandos, para que percebam que envolve a autoestima dos alunos, pois eles se sentem capazes de solucionar o problema e explicá-lo, se apropriam do processo e de conteúdos que são necessários no decorrer das etapas, mesmo que não tenham ainda chegado na síntese da atividade. A professora menciona que a regência apresentada abordou uma dimensão também importante para o trabalho docente que é a dimensão emocional dos alunos, que está presente sempre, mas que na maioria das aulas é desconsiderada pelos professores, ou tratada de forma ingênua, ou ao contrário, é utilizada como mecanismo de controle que desestimula o aluno. Toassa (2011) comenta o papel do social na emoção das crianças proposto por Vigotski:

A transformação das emoções dos pequenos a partir das relações com as pessoas mais desenvolvidas representa, também, sua gradativa impregnação 
com respeito aos discursos e práticas acumulados na cultura que os rodeia e a diversificação de suas emoções, de um papel padronizado e reflexo, para a formação de novas estruturas mentais, cujo conteúdo ideacional relaciona-se à existência social da criança (Ibid., p. 243).

A concepção da dimensão emocional nas relações entre professor e alunos no processo de ensino, tomada na perspectiva que se desenvolve com os meios sociais permite que seja considerada no contexto escolar, nas interações e nas ações estabelecidas pela atividade de ensino, emergindo na atividade de aprendizagem e nela se modificando.

Assim, a dimensão emocional apontada como um significado da docência pela professora de MEFII, para que permita que os alunos se sintam capazes de desenvolverem ações organizadas que favoreçam a busca de soluções para problemas, a argumentação e a aprendizagem, possibilitou a atribuição de sentidos pelos licenciandos. No caso de Ricardo e Vera, que tiveram essa experiência, pensamos que conseguiram atribuir esse sentido à docência, após essa discussão, pois anteriormente, isso não estava claro para eles, estavam um pouco confusos com a atitude deles próprios, por não terem conseguido finalizar a aula como previam, fazendo a síntese da atividade de aprendizagem. Com a reflexão conjunta foram percebendo a complexidade das relações que ocorrem em uma aula e a importância da dimensão emocional que mobilizaram.

A fala do monitor da disciplina reflete bem o que Ricardo expressava, seu incômodo de não ter conseguido finalizar a proposta com os alunos conforme havia planejado, para o que atribuiu o sentido de não ter conduzido a aula de forma adequada, por não ter muita experiência em trabalhar com atividades de aprendizagens com tantos aspectos a serem enfatizados, pela complexidade a atividade de ensino e o resultado que ele queria ver objetivados em seu estágio. Antes desse aprofundamento da reflexão, o sentido que ele elaborou vinha da contradição vivenciada por ele na sala de aula, referente ao seu controle na condução da aula para facilitar fazer alterações na organização de suas ações e dos alunos no decurso do processo, situação que o monitor da disciplina expressa com clareza, no entanto, fornece a Ricardo um outro olhar, que não exclui a contradição, mas ela evidencia uma segunda contradição.

Essa outra contradição apontada pelo monitor coloca em relevância a relação dos estagiários com as escolas que os recebeu, com a sala de aula que fizeram a regência, a importância daquilo que organizaram para trabalhar com os alunos, como isso pode ser um fator que os motive para a aprendizagem daquele tema proposto, como a abordagem didática pode colaborar para colocá-los em atividade, situação essa que, na maioria dos casos, não 
coincide com o que os alunos vivenciam no cotidiano escolar. $\mathrm{O}$ fato dos alunos terem a compreensão daquilo que aprenderam, daquilo que conseguiram realizar é para eles um fator de autoestima, liberdade intelectual, mas sobretudo a satisfação de compreenderem aquilo que fazem que está apoiado em um referencial do conhecimento científico, que surge como produto da atividade de estudo, que é sua própria aprendizagem. Como abordam Davidov e Márkova (1987):

[...] o estudo não é apenas o domínio dos conhecimentos nem tampouco aquelas ações ou transformações feitas pelo aluno no curso da aquisição de conhecimentos, mas, acima de tudo, as mudanças, as reestruturações, o enriquecimento da própria criança. Tal modelo abre o caminho para analisar a atividade do sujeito no processo de estudo e permite, em certa medida, superar o intelectualismo na compreensão deste processo (p.324).

Essa relação com os alunos, com a escola, pode provocar contradições em relação aos sentidos do licenciando para com a docência, o que o faz atribuir novos sentidos, no caso, pensamos que Ricardo pode ter ressignificado o sentido que havia atribuído a esse momento da aula com essas discussões em face a sua vivência e pelo seu motivo que era o de que os alunos aprendessem. A professora da disciplina esclarece que mesmo que os alunos não tenham se apropriado do conceito que o grupo gostaria para que pudesse concluir aquela atividade, eles adquiriram as condições para retomarem aquele processo e se aprofundarem sozinhos, pois tinham claro o que haviam trabalhado e como fizeram. A situação passa a ter o sentido de um processo que foi eficaz para com os alunos e que lidou com aspectos emocionais importantes para a aprendizagem também, além da organização de ações que podem permitir que restabeleçam o processo e avancem sem a intervenção dos estagiários.

Outro ponto que era polêmico nos estágios se referia a avaliação, não uma avaliação do processo, como os estagiários, em geral, propunham aos alunos para que eles avaliassem as aulas indicando prós e contras, mas a avaliação formal da professora efetiva que solicitava a inclusão de questões ou a atribuição de uma menção pela atividade dos alunos para que incorporassem a média final dos mesmos. Essa situação vivenciada pelo grupo 1, foi apontada por Ricardo:

R2(G2-Ricardo): É engraçado. Minha vontade é que eu não queria que eles tivessem que fazer uma prova relacionada com o que eles estavam trabalhando e a primeira coisa que a professora falou foi que eles deveriam prestar atenção porque teriam uma prova e que ia cair o conteúdo visto. Putz, matou tudo o que queríamos fazer. Depois eu conversei com ela e disse que 
nossa proposta era outra, ela, a princípio, aboliu as questões do nosso conteúdo.

Só que aí numa conversa com a pesquisadora ela demonstrou que poderia ser interessante e perguntou se já tínhamos pensado que talvez tudo o que estávamos trabalhando fosse o que mais faria sentido pra eles, se tivesse que cair alguma coisa na prova talvez eles gostassem que caísse o que nós trabalhamos: "Porque vocês não perguntam pra eles?", aí passaram alguns alunos e a Vera foi falar com eles, o que achavam se algumas questões do que trabalhamos fosse incluída na prova, eles disseram que seria ótimo porque estavam manjando.

Professora Marina: O fato de estarem "manjando" é a autoestima sendo explicitada, na linguagem deles.

A professora da escola ao ceder as aulas para os estagiários fez um alerta aos alunos, que deveriam estar atentos às regências porque o conteúdo que fosse abordado faria parte da prova que eles teriam posteriormente, já agendada como parte do planejamento da professora e das ações da escola. Isso para ela, pensamos que era uma forma que usava para tentar garantir a atenção dos alunos para os estagiários, assim, se eles não se motivassem pelas aulas espontaneamente, ou seja, se não tivessem um motivo eficaz, teriam um motivo compreensível, o conteúdo estaria nas questões da prova. Essa intervenção da professora efetiva incomodou Ricardo e Vera, pois eles tinham organizado as atividades de aprendizagem buscando a investigação dos alunos em relação a um tema, com a mediação de objetos, textos e outros elementos, bem como a interação entre o grupo e deste com eles, com uma dinâmica de diálogo e reflexões constantes que levavam a avaliação do processo, assim não desejavam uma outra avaliação associada, ainda com características diferenciadas, com algumas perguntas mais informativa.

Em um primeiro momento, os estagiários conversaram com a professora explicando que a maneira como trabalhariam não caberia uma avaliação com perguntas no final do processo, a professora pareceu não insistir e não se falou mais sobre isso. Na penúltima ida à escola, a professora perguntou se eles fariam as questões para prova e os estagiários ficaram de pensar melhor sobre esse assunto, mas não concordavam em colocar algumas questões de conteúdo, achavam que isso não verificaria a aprendizagem dos alunos. Em conversa com eles, questionamos se para os alunos talvez não fosse algo que preferissem ao invés de só terem na prova o que trabalharam com a professora efetiva, no entanto, não precisariam ser perguntas com respostas prontas que os alunos não precisassem estabelecer relações. (CC, p. $69,06 / 11 / 15)$

Ao pensarmos isso, tínhamos refletido sobre as aulas que acompanhamos e na participação ativa dos alunos que presenciamos, nas conversas depois das aulas que eles 
vinham fazer com Ricardo, interessados no assunto da aula ou em outros, ou ainda nas informações sobre a universidade, o curso de graduação. Assim, acreditávamos que as aulas dos estagiários tinham um sentido de busca de conhecimento para os alunos, o que os levaria à aprendizagem, sendo uns mais envolvidos, outros menos, mas havia um interesse da maioria. Porém, surgiram contradições, que alguns expressavam após às aulas, em relação à organização das aulas dos professores da escola e de demandas que a escola não atendia. Por isso, tínhamos a convicção, pelo acompanhamento e por nossa experiência docente, que os alunos dariam preferência a questões na prova do tema que tinham buscado aprofundar seus conhecimentos. Ao questionarem os alunos a resposta que obtiveram coincidiu com nossa premissa. Isso reitera o fato de terem feito uma avaliação positiva das aulas de Ricardo.

Essa situação trouxe Ricardo para pensar na avaliação como uma ferramenta que pode servir como um parâmetro para os alunos refletirem sobre aquilo que estudaram e do que se apropriaram, mas isso está associado ao desenvolvimento das aulas, das inter-relações ocorridas, aos sentidos que atribuíram a cada aspecto relacionado aquela aprendizagem no decorrer do processo e nas relações estabelecidas com suas vivências, o que mobiliza os alunos cognitivamente, mas também, emocional e socialmente, bem como, permite ao professor avaliar também parte de seu trabalho. Essa contradição que se apresentou a Ricardo pode ter contribuído para que atribuísse o sentido da avaliação no processo de ensino como uma ferramenta para reflexão e formação dos alunos e do próprio trabalho docente, não como algo que não auxilia em nada o processo de ensino.

Ricardo aborda outros pontos cuja relevância permite discutir questões importantes para o desenvolvimento da atividade de estágio no curso de Licenciatura em Física ou mesmo nas Licenciaturas em geral, como mostra um trecho de sua entrevista:

E2 (Ricardo) - Se eu fosse professor da Faculdade de Educação e tivesse o poder de organizar os estágios e interferir nas leis, enfim, algo do gênero, eu aumentaria primeiro toda a carga horária de todos os estágios porque eu acho que 20 horas é muito pouco e, todos deveriam ter regência na minha opinião. Eu sei que muitos professores, principalmente os mais antigos, que por diversos motivos acreditam que o estágio tem que ser por observação, eu discordo dessa posição, acho observação importante, mas ela deve ser muito pequena em relação a regência por exemplo. Desde o começo do curso eu acho que todas as matérias de ensino e de educação deveriam ter estágio com uma carga horária maior e com uma grande participação, uma grande regência dos alunos e também uma reflexão prática, perdão, uma reflexão crítica sobre essa prática com o docente responsável pela formação, com o docente da escola, os alunos da turma e você mesmo. 
A sugestão que o licenciando fez sobre o aumento do número de horas para o estágio, está ligada à uma maior parte dedicada à regência dentre o total das horas destinadas ao estágio, ou seja, uma priorização das regências em relação às outras ações.

Ricardo propõe que as ações de estágio, principalmente, a regência comece no início do curso, como também sugeriu Heloisa, para que pudessem adquirir mais experiência e, como ele diz, terem condições de fazer um processo de reflexão crítica durante os vários estágios desenvolvidos nas disciplinas diretamente voltadas ao ensino, envolvendo os licenciandos, o professor da disciplina e o professor da escola que recebe este licenciando.

A nosso ver, quanto mais cedo o licenciando começar a ter contato com o ambiente escolar, podendo discutir e planejar as ações que realizará na escola em conjunto com seus pares e também os professores da disciplina e da escola que os recebe, mais possibilidades terá de conhecer a escola e a sala de aula em suas complexidades. O que acontecendo de forma sistemática e com o comprometimento de todos, pode resultar em um aprendizado da docência com uma estrutura mais integrada, proporcionando a coordenação entre os sistemas de atividade, da licenciatura, do estágio e da escola.

Corrobora com essa ideia a pesquisa de Silvestre (2011) na qual ao entrevistar uma licencianda obteve sua reflexão sobre as contribuições do estágio para sua formação, propondo o estágio como um dos eixos dos cursos de formação docente com uma ligação mais estreita entre a universidade e a escola na qual o estágio ocorre, ela diz: "Poderíamos alcançar resultados satisfatórios se esse exercício fosse assumido, regularmente, pela universidade e pelas escolas-campo e a mediação do professor formador se tornasse intencional e não espontânea [...] (Ibidem, p.183)".

Esse processo pode trazer ao licenciando maior segurança para seu futuro trabalho como docente, maior compreensão das condições nas quais seu trabalho ocorrerá. A possibilidade de refletir conjuntamente sobre ações que possam ser viabilizadas na escola real, ter maior aproximação dos alunos da escola e refletir como mobilizá-los, como transformar a aprendizagem de conceitos de Física como motivo para esses alunos, como elaborar as atividades de ensino para desencadear essa aprendizagem, são pontos fundamentais na formação do professor, o que não pode ser uma tarefa de reflexão individual do licenciando, mas um trabalho coletivo, com participantes de diferentes níveis hierárquicos dentro dessa relação, que traz consciência da atividade pelo sujeito (SILVA, 2013). Com isso, podemos possibilitar as trocas e o movimento constante na estrutura da atividade potencializando a criação de novas necessidades e novos motivos para os licenciandos. 
Desse modo, os licenciandos poderiam atuar mais ativamente nas escolas, desenvolvendo ações conjuntas com o professor efetivo da sala que os recebe, como uma das partes de sua formação para docência. Como nos coloca Moura (2004), as ações realizadas pelos sujeitos no processo de formação podem possibilitar perceber suas próprias mudanças, o autor fala do professor já em exercício de sua profissão, mas podemos transpor para o professor em formação.

[...] o conjunto de ações, dos que a realizam, pode permitir a análise dos avanços da formação do professor que busca compreender a prática e o desenvolvimento de sua formação. É no coletivo que se terá o referencial da qualidade das ações do indivíduo e da coletividade; são as ações dos sujeitos indicadores de mudanças na qualidade de ser professor (p.270-271).

Outra questão não explicitada na fala de Ricardo mas que decorre dela é a necessidade da aproximação do professor da escola nas ações do estágio, para permitir que a regência ocorra e para facilitar o contato com a sala de aula, mas como elemento fundamental na formação do licenciando que pode colaborar em parceria com o docente da disciplina da universidade.

A organização do estágio é outro fator fundamental para que este tenha suas ações coordenadas aos objetivos das disciplinas de MEF, isto é, tendo como meta para o licenciando sua aprendizagem para a docência, como podemos observar no excerto da entrevista de Ricardo:

E1(Ricardo):- [...] a professora organizou as atividades de estágios para que elas não fossem burladas, para que elas fossem cumpridas de forma decente, que eu tivesse que fazer uma reflexão sobre aquilo. Então, a orientação dela, o papel dela como parceiro mais capaz, como diria o Vigotsky, foi essencial, porque se ela fosse uma professora como outros professores fazem de ignorar o estágio, falam: "Faz aí, faz na escola", mas não dá uma orientação, eu por conta própria, como aluno, mesmo tendo a monitoria, não iria conseguir fazer que aquilo fizesse sentido pra mim. Então, a orientação dela, a forma como ela estruturou o curso as discussões, fizeram com que eu fosse encaminhado, ou seja, que eu cumprisse o estágio, e o meu gosto por ensinar fizeram com que me comprometesse mais uma vez de uma forma muito bacana com o estágio, que tinha tudo a ver com o que eu me perguntava.

No trecho citado, Ricardo aponta que foi possível fazer o estágio da forma como se realizou por causa da maneira como este foi estruturado pela professora da disciplina de MEF, isso mostra como a organização do docente em sua atividade de ensino é importante para a realização das ações dos alunos, resultando na coordenação de ações de aprendizagem. O que 
corrobora com reflexões anteriores de que é necessário que os educadores ao elaborarem uma atividade de ensino organizem suas ações de forma intencional e conscientes do processo no qual estão inseridos, pois organizam ações para os alunos visando a aprendizagem, como discute Nascimento (2010):

Para que as ações de aprendizagem ocorram e para que a própria atividade de aprendizagem se dê, é preciso que esses processos sejam conscientes e intencionalmente criados. Essa tarefa cabe ao educador, por meio de sua atividade de ensino. Assim, pensar nas ações dos educandos nos obriga a pensar nas ações dos educadores que irão criar e coordenar os estudantes em suas atividades de aprendizagem (p.100).

Essa situação nos levou a pensar a professora da disciplina em atividade, organizando ações de ensino que mobilizavam os licenciandos para o planejamento do estágio, com ações de regência, com as quais precisavam se envolver de forma reflexiva, criticamente, para também elaborarem suas ações de ensino para os alunos das escolas. Consideramos essencial, nesse processo de aprendizagem docente, o papel do professor que se coloca em atividade de ensino, como aborda Moura et al. (2010):

O professor que se coloca, assim, em atividade de ensino continua se apropriando de conhecimentos teóricos que lhe permitem organizar ações que possibilitem ao estudante a apropriação dos conhecimentos teóricos explicativos da realidade e o desenvolvimento de seu pensamento teórico, ou seja, ações que promovam a atividade de aprendizagem de seus estudantes (p.90).

Em suas reflexões sobre as ações realizadas nas disciplinas de MEF I e II, Ricardo coloca um sentido fortemente atribuído por ele ao papel da educação:

E1(Ricardo):[58'23'’] - [...] pra mim a educação é uma luta social, é muito importante a transformação da sociedade, gosto do que faço, amo por mais que tenha todos os problemas de condição social e financeira, desvalorização e por aí vai. Amo o curso. Defendo o curso até o fim, defendo os professores da Faculdade de Educação mesmo discordando muitas vezes deles. Defendo os professores de ensino do Instituto de Física, critico os professores que não gostam de ser professor.

O licenciando traz uma visão de educação como um processo de intervenção social, que busca a transformação da sociedade e dos indivíduos, assim ele atribui um sentido à docência que coincide com o significado dado a educação. A escola é um espaço privilegiado para a apropriação do conhecimento, discussões, atribuições de valores, desenvolvimento 
ético, buscando assim, a transformação do indivíduo, no entanto, essa instituição enfrenta desestruturas que afetam seu significado social.

\section{Síntese - Mapa dos Sentidos}

Pelas falas dos licenciandos podemos perceber que a atividade de estágio com a regência faz diferença na aprendizagem para a docência, permite que eles mudem suas ações. No entanto, para essas mudanças das ações na atividade eles apontam alguns elementos importantes, como: a reflexão sobre o planejamento das aulas e sobre as aulas, sendo esta feita com o professor da disciplina e com os colegas de classe; o aumento de horas de regência; o envolvimento do docente da escola na reflexão crítica do estágio; subentende-se também que refletir o estágio envolve seu planejamento; a base teórica necessária associada à prática; bem como o estreitamento das relações entre professor da disciplina, licenciando e professor da escola.

O movimento de Heloisa e Ricardo foi acompanhado durante suas apresentações em classe, nas regências e pelas entrevistas e pode-se perceber que o motivo que os movia estava ligado à aprendizagem para docência, como também acontecia com os outros licenciandos. Nesse aspecto, a professora da disciplina, pela organização do ensino e das ações que propôs aos alunos, os colocou em movimento de aprendizagem e no estágio essa meta se complexifica e se objetiva na coordenação das ações para a aprendizagem da docência. No entanto, nem todos tinham a aprendizagem da docência como motivo eficaz, para alguns era um motivo compreensível, pois a docência era uma meta a atingir mas não a profissão almejada. Como discutem Barbosa, Ursi e Mattos (2011) para a formação de professores em um curso a distância o interesse dos sujeitos ligados a suas diferenças individuais propiciam motivos diferenciados, que:

Se considerarmos a multivocalidade presente nesses sujeitos, decorrente das diferenças individuais, teremos como resultados múltiplas necessidades e motivações, e não apenas uma, como representado. Podemos ter, por exemplo, cursistas que se interessam pelo certificado que receberá ao final do curso, cursistas que buscam o aprimoramento profissional, cursistas que gostariam apenas de encontrar um sentido para sua prática docente ou, ainda, outros que buscam melhores estratégias didáticas para serem utilizadas em sala de aula (p.13). 
No caso de Heloisa e Ricardo pode-se estabelecer um movimento ensino e aprendizagem que foi sendo estabelecido pelas reflexões conjuntas, pelas intervenções da professora da disciplina, pela práxis e pelas contradições vivenciadas, que impulsionavam mudanças ou novas reflexões, que em parte eram objetivadas nas regências, mas muito desse processo julgamos que se objetivará na profissão docente. Como coloca Azzi (2012) sobre o processo de ensino para aquele que ensina e aquele que é o objeto desse processo, o aluno:

O processo de ensino, em sua estrutura e funcionamento, caracteriza-se como práxis, na qual teoria e prática se determinam, gerando juntamente com o objeto-sujeito desse processo - o aluno - um saber próprio da atividade docente que, ao incorporar-se àquele que exerce sua ação sobre um determinado objeto visando à sua transformação, transforma também esse sujeito - no caso, o professor, que se enriquece durante o processo. $\mathrm{O}$ trabalho docente é um processo de objetivação do professor (p.54).

No contexto das disciplinas de MEF I e II pudemos perceber, pelo processo de análise de Heloisa e Ricardo, que as ações realizadas promoveram a reflexão e provocaram mudanças nos licenciandos, referentes à aprendizagem da docência, o que levou a atribuição de sentidos em vários aspectos da docência. O que ocorreu no movimento dos estagiários e das relações estabelecidas é histórico e social, se dá nas interações com o outro, porém, é diferente para cada sujeito. 
Mapa de Sentidos de Heloisa

\begin{tabular}{|c|c|c|c|c|c|c|}
\hline \multicolumn{7}{|c|}{ Mapa de Sentidos de Heloisa } \\
\hline \multicolumn{7}{|c|}{ Episódio 5: Reflexão Teórico-prática sobre o Estágio } \\
\hline & Cod. & 5.1 Reflexão MEFI & Cod. & 5.2 Reflexão MEFII & Cod. & 5.3 Reflexão \\
\hline \multirow{3}{*}{$\begin{array}{l}\text { Situação em } \\
\text { que atribuiu } \\
\text { sentido }\end{array}$} & $051 \mathrm{a}$ & \begin{tabular}{|l|} 
Questão colocada pelos alunos - o fato é que ele \\
não deu a devida importância à questão da aluna, que \\
poderia ter gerado discussão e aprofundamento do \\
tema, proporcionando aos alunos uma vis̃ão mais \\
integrada entre as diferentes disciplinas.
\end{tabular} & 052a & $\begin{array}{l}\text { Aproximação da realidade escolar } \text { - a licencianda } \\
\text { reflete que pensa ser necessária uma aproximação } \\
\text { maior da realidade escolar, para que se apreenda a } \\
\text { profissão docente em seu contexto mais amplo e em } \\
\text { suas especificidades, contudo, tendo claro que não } \\
\text { será possível uma aprendizagem que se aproprie } \\
\text { integralmente da docência, pois é um campo } \\
\text { multifacetado e em movimento contínuo. }\end{array}$ & 053a & \begin{tabular}{|l|} 
Contradição entre o objetivo da estagiária e as \\
aç̃̃es dos alunos da escola - na disciplina que cursou \\
anteriormente, a experiência que teve na atividade de \\
estágio provocou uma contradição, pela relação entre o \\
que ela tinha como objetivo e o que observava nas \\
ações dos alunos.
\end{tabular} \\
\hline & 051b & \begin{tabular}{|l|} 
A intervenção do professor da escola - a \\
intervenção do professor da escola causa uma \\
perturbação, pois os estagiários desejavam a atenção \\
dos alunos pelo interesse ao tema e pelas ações que \\
organizaram, não queriam que o motivo de estarem \\
atentos fosse porque teriam uma avaliação, sendo \\
que esta não seria formativa.
\end{tabular} & - & - & 053b & \begin{tabular}{|l|} 
Falta de clareza nos objetivos das atividades \\
práticas - a estagiária aponta que as atividades \\
experimentais que preparava para apresentar em suas \\
aulas, na disciplina que cursou anteriormente, não \\
ficavam muito claras quanto ao objetivo que as ligavam, \\
quanto a uma sequência estruturada para um \\
determinado fim, para o que acreditava que the faltou \\
apoio teórico, que mencionou ter sido uma colaboração \\
de MEF, para que pudesse estabelecer o diálogo entre \\
teoria e prática caminhando para a construção da \\
\end{tabular} \\
\hline & $051 \mathrm{c}$ & $\begin{array}{l}\text { Dificuldade dos alunos - a dificuldade na redação } \\
\text { de textos foi preocupante para alunos que se } \\
\text { encontravam no final do Ensino Médio. No mesmo } \\
\text { contexto, podemos apontar ainda, a falta de } \\
\text { compreensão dos alunos em relação à atividade de } \\
\text { aprendizagem, aliada a não familiaridade com a } \\
\text { abordagem didática, como fatores geradores de } \\
\text { dificuldades para expressarem suas ideias na escrita. }\end{array}$ & - & - & & - \\
\hline \multirow{3}{*}{ Motivo } & M51a & Proporcionar a parcipação dos alunos nas aulas & M52a & Aprendizagem da docência & M53a & Aprendizagem da docência \\
\hline & M51b & Aprendizagem dos alunos & - & - & M53b & Aprendizagem da docência \\
\hline & M51c & & - & - & - & - \\
\hline \multirow{3}{*}{ Ações } & A51a & Ouvir a opinião, comentários e dúvidas dos alunos & A52a & Regências, acompanhamento das aulas, participação & A53a & Regência \\
\hline & A51b & Motivar os alunos & - & - & A53b & Organização da atividade de ensino \\
\hline & A51c & & - & - & - & - \\
\hline \multirow{3}{*}{$\begin{array}{l}\text { Sentido } \\
\text { atribuído }\end{array}$} & S51a & $\begin{array}{l}\text { Reconheceu que a atitude do professor está } \\
\text { associada a motivação que gera no aluno, ou seja, o } \\
\text { motivo do professor não deveria perder a perspectiva } \\
\text { do ensino. }\end{array}$ & S52a & $\begin{array}{l}\text { Atribuiu a importância de ter maior contato com a } \\
\text { escola, mais tempo dos licenciandos dedicado às } \\
\text { ações na escola de formas sistemática, perpassando } \\
\text { toda a licenciatura. }\end{array}$ & S53a & $\begin{array}{l}\text { Reconheceu a relavância de uma organização geral da } \\
\text { atividade de ensino, não deixando de explicitar os } \\
\text { objetivos de cada aula. }\end{array}$ \\
\hline & S51b & \begin{tabular}{|l|} 
Concebeu como importante a regência no estágio \\
para motivar os alunos, visando que a atividade de \\
ensino promovesse motivos eficazes para os alunos, \\
porém, para o professor da escola nas aulas dos \\
estagiários, seu motivo foi o de manter os alunos
\end{tabular} & - & 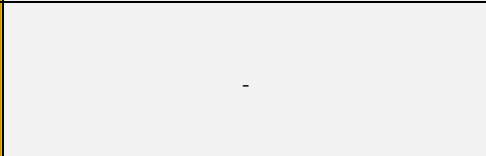 & S53b & $\begin{array}{l}\text { Reconheceu que a base teórica proporcionada pelas } \\
\text { disciplinas de MEFF não estavam postas isoladamente, } \\
\text { mas junto à prática, formando um par necessário e } \\
\text { indissociável à atividade de estágio. }\end{array}$ \\
\hline & S51c & $\begin{array}{l}\text { Reconheceu que o contexto escolar é importante de } \\
\text { ser levado em conta durante a organização do ensino, } \\
\text { pois se depararam com uma situação na qual os } \\
\text { alunos não tinham domínio suficiente sob vários } \\
\text { aspectos do conhecimento. }\end{array}$ & - & - & & - \\
\hline
\end{tabular}


Mapa de Sentidos de Ricardo - Parte A

Episódio 5: Reflexão Teórico-prática sobre o Estágio

\begin{tabular}{|c|c|c|c|c|c|c|}
\hline & Cod. & 5.1 Reflexão MEFI & Cod. & 5.2 Reflexão MEFII & Cod. & 5.3 Reflexão \\
\hline \multirow[t]{2}{*}{$\begin{array}{l}\text { Situação em } \\
\text { que atribuiu } \\
\text { sentido }\end{array}$} & 051a & $\begin{array}{l}\text { Utilização da abordagem didática dialógica - na } \\
\text { regência utilizou uma abordagem didática que } \\
\text { permitiu o diálogo, as interações entre os indivíduos e } \\
\text { a busca pelo conhecimento científico, de maneira a } \\
\text { colocar os alunos em atividade de aprendizagem. } \\
\text { Ricardo mencionou que se tivesse trabalhado em sala } \\
\text { de aula de forma tradicional, apenas transmitindo } \\
\text { informações, sem muitas interações, supunha difícil } \\
\text { ocorrer uma situação de motivação e de criação } \\
\text { como os alunos apresentaram, era importante para } \\
\text { ele saber como aquela atividade de ensino que ele } \\
\text { organizou favorecia a aprendizagem dos alunos. }\end{array}$ & 052a & $\begin{array}{l}\text { Atenção dos alunos - a exibição de vídeo, trouxe a } \\
\text { questão de conseguir a atenção dos alunos para a } \\
\text { ação proposta - fator importante na reflexão do } \\
\text { grupo. }\end{array}$ & 053a & $\begin{array}{l}\text { Reflexões sobre situações relevantes à docência - a } \\
\text { importância das reflexões que a professora da disciplina } \\
\text { propõe, com significados que são desejáveis aos } \\
\text { professores, na perspectiva de um trabalho no qual } \\
\text { conteúdo e relações interpessoais são aspectos relevantes } \\
\text { à docência e, assim, a aprendizagem dos alunos. Ao } \\
\text { apontaressa questão na regência de um dos estagiários e } \\
\text { generalizando-a, a professora pode possibilitar a } \\
\text { atribuição de sentidos pelos licenciandos. }\end{array}$ \\
\hline & 051b & $\begin{array}{l}\text { Mediações em sala de aula - as mediações na sala } \\
\text { de aula não ocorream apenas pelos objetos, mas } \\
\text { pelas possibilidades de interações entre aluno/aluno e } \\
\text { aluno/estagiário, pela comunicação e o trabalho } \\
\text { compartilhado. Na proposta de ensino a importância } \\
\text { do estudo de teóricos e pesquisas diversas na } \\
\text { formação docente, permitiu que ao surgir, em sala de } \\
\text { aula uma situação que o remeteu à teoria, Ricardo } \\
\text { pode associá-la às suas ações. }\end{array}$ & 052b & $\begin{array}{l}\text { Alteração na atividade de ensino - a reflexão em } \\
\text { uma nova situação proposta para os alunos e os } \\
\text { apontamentos que a professora de MEFII fez } \\
\text { colaboraram para a alteração do planejamento, no } \\
\text { caso de uma dispersão dos alunos, ela indicou, por } \\
\text { exemplo, a mudança na ordem de organização da } \\
\text { atividade de ensino. }\end{array}$ & 053b & $\begin{array}{l}\text { Aprendizagem dos alunos - Ricardo ressignificou o } \\
\text { sentido que havia atribuído ao momento de sua aula com } \\
\text { as discussões na disciplina de MEF. A professora da } \\
\text { disciplina esclarece que mesmo que os alunos não tenham } \\
\text { se apropriado do conceito que o grupo gostaria para que } \\
\text { pudesse concluir aquela atividade, eles adquiriram as } \\
\text { condições para retomarem aquele processo e se } \\
\text { aprofundarem sozinhos, pois tinham claro o que haviam } \\
\text { trabahadhado e como fizeram. }\end{array}$ \\
\hline \multirow{2}{*}{ Motivo } & M51a & Ensino & M52a & Ensino e a aprendizagem dos alunos & M53a & $\begin{array}{l}\text { Ensinar - considerando as relações estabelecidas entre os } \\
\text { sujeitos }\end{array}$ \\
\hline & M51b & $\begin{array}{l}\text { Ensino - de forma a incorporar novas abordagens } \\
\text { didáticas }\end{array}$ & M52b & Ensino e a aprendizagem dos alunos & M53b & Aprendizagem dos alunos \\
\hline \multirow{2}{*}{ Ações } & A51a & Regência & A52a & $\begin{array}{l}\text { Regência - atuar para que os alunos se concentrem } \\
\text { na atividade de aprendizagem }\end{array}$ & A53a & $\begin{array}{l}\text { Coordenar a aula 'considerando as relações entre os } \\
\text { sujeitos }\end{array}$ \\
\hline & A51b & Regência & A52b & Mudanças na organização da atividade de ensino & A53b & $\begin{array}{l}\text { Coordenação da atividade de aprendizagem - } \\
\text { considerando aspectos emocionais e organizacionais }\end{array}$ \\
\hline \multirow{2}{*}{$\begin{array}{l}\text { Sentido } \\
\text { atribuído }\end{array}$} & S51a & $\begin{array}{l}\text { Reconheceu a importância de alguns pontos } \\
\text { referentes ao trabalho em sala de aula: confiar na } \\
\text { capacidade do aluno, permitir que avance além do } \\
\text { proposto pelo professor, não inibir a criatividade do } \\
\text { aluno, promover a socialização do conhecimento e a } \\
\text { colaboração entre os colegas para favorecer a } \\
\text { aprendizagem. }\end{array}$ & S52a & $\begin{array}{l}\text { Reconheceu relevante a intervenção do professor, } \\
\text { para retomar a atenção dos alunos, quando } \\
\text { necessário, para que se concentrem em uma } \\
\text { determinada ação. }\end{array}$ & S53a & $\begin{array}{l}\text { Reconheceu que a importância doo professor gerenciar a } \\
\text { aula considerando as mültiplas relações que ocorrem } \\
\text { entre os sujeitos. }\end{array}$ \\
\hline & S51b & $\begin{array}{l}\text { Reconheceu ser importante sair da zona de conforto } \\
\text { e utilizar novas abordagens didáticas, que possam } \\
\text { fazer os alunos pensarem em como investigarem um } \\
\text { problema, saberem utilizar como e por que para que } \\
\text { tenham clareza de suas ações e do que } \\
\text { compreenderam sobre o tema que estudaram. }\end{array}$ & S52b & $\begin{array}{l}\text { Reconheceu ter que, algumas vezes, modificar as } \\
\text { suas ações em função do processo desencadeado } \\
\text { com os alunos. }\end{array}$ & S53b & $\begin{array}{l}\text { Reconheceu que a importância dos aspectos emocionais } \\
\text { para a aprendizagem, como a autoestima, além da } \\
\text { organização de ações que possam permitir aos alunos que } \\
\text { avancem sem a intervenção dos estagiários. }\end{array}$ \\
\hline
\end{tabular}


Mapa de Sentidos de Ricardo - Parte B

Episódio 5: Reflexão Teórico-prática sobre o Estágio

\begin{tabular}{|c|c|c|c|c|c|c|}
\hline & Cod. & 5.1 Reflexão MEFI & Cod. & 5.2 Reflexão MEFII & Cod. & 5.3 Reflexão \\
\hline \multirow{3}{*}{$\begin{array}{l}\text { Situação em } \\
\text { que atribuiu } \\
\text { sentido }\end{array}$} & - & - & $052 \mathrm{c}$ & $\begin{array}{l}\text { Reflexão da regência na disciplina - na análise da } \\
\text { situação de ensino a professora da disciplina sugeriu } \\
\text { que a diferença entre os dados obtidos pelos grupos } \\
\text { de alunos da escola fosse colocada para eles como } \\
\text { uma problematização para depois ser feita a análise } \\
\text { final. Essa vivência do grupo 1, na discussão na } \\
\text { disciplina de MEFII foi ampliada para todos os } \\
\text { licenciandos da sala, fazendo com que mesmos o que } \\
\text { não vivenciaram a situação pudessem refletir sobre } \\
\text { ela no âmbito do trabalho docente. }\end{array}$ & O53c & $\begin{array}{l}\text { Intervenção da professora da escola } \text { - Ricardo e Vera } \\
\text { ficam incomodados com a proposta da professora da } \\
\text { escola de dizer aos alunos que o assunto faria parte da } \\
\text { prova. pois eles tinham organizado as atividades de } \\
\text { aprendizagem buscando a investigação dos alunos em } \\
\text { relação a um tema, com a mediação de objetos, textos e } \\
\text { outros elementos, bem como a interação entre o grupo e } \\
\text { deste com eles, com uma dinâmica de diálogo e reflexões } \\
\text { constantes que levavam a avaliação do processo, assim } \\
\text { não desejavam uma outra avaliação associada. Em } \\
\text { conversa com a pesquisadora, foram questionados se } \\
\text { para os alunos fosse algo que preferissem. }\end{array}$ \\
\hline & - & - & 052d & $\begin{array}{l}\text { Complexidade de implementar aulas - O grupo de } \\
\text { Ricardo esatavacom uma avaliação regular da última } \\
\text { regência por não terem conseguido finalizá-la como } \\
\text { previam, fazendo a síntese da atividade de } \\
\text { aprendizagem, mas com a reflexão conjunta, com os } \\
\text { apontamentos da professora da disciplina, foram } \\
\text { percebendo a complexidade das relações que } \\
\text { ocorrem em uma aula e a importância da dimensão } \\
\text { emocional que mobilizaram mesmo não tendo } \\
\text { terminado como gostariam. }\end{array}$ & O53d & Vivências de Ricardo \\
\hline & & - & $052 \mathrm{e}$ & $\begin{array}{l}\text { Discussão dos resultados da investigação dos } \\
\text { alunos - os grupos dos alunos da escola, nem todos } \\
\text { estavam com suas ações bem organizadas, enquanto, } \\
\text { outros faziam tarefas em paralelo, o que gerou uma } \\
\text { desorganização aparente na aula para a discussão } \\
\text { dos resultados, mas havia interesse dos alunos, porém } \\
\text { não tinha tempo suficiente para discutir esses } \\
\text { resultados. }\end{array}$ & & - \\
\hline \multirow{3}{*}{ Motivo } & - & - & M52c & $\begin{array}{l}\text { Ensino - utilizando novas abordagens didáticas } \\
\text { Aprendizagem dos alunos de novas ações }\end{array}$ & M53c & $\begin{array}{l}\text { Aprendizagem dos alunos - avaliação feita no processo } \\
\text { de ensino e aprendizagem }\end{array}$ \\
\hline & - & - & M52d & $\begin{array}{l}\text { Ensino - considerando a dimensão emocional } \\
\text { Aprendizagem dos alunos }\end{array}$ & M53d & Ensino - como transformação do indivíduo e da sociedade \\
\hline & - & - & M52e & $\begin{array}{l}\text { Ensino - com a complexidade da atividade de } \\
\text { aprendizagem }\end{array}$ & - & ( \\
\hline \multirow{3}{*}{ Ações } & - & - & A52c & $\begin{array}{l}\text { Regência com maior complexidade da atividade de } \\
\text { ensino }\end{array}$ & A53c & Avaliação formativa do tema trabalhado \\
\hline & - & - & A52d & Regência - motivando os alunos & A53d & $\begin{array}{l}\text { Regências } \\
\text { Participação nos espaços de docência }\end{array}$ \\
\hline & - & - & A52e & $\begin{array}{l}\text { Regência - direcionada à discussão do resultado da } \\
\text { investigação }\end{array}$ & - & - \\
\hline \multirow{3}{*}{$\begin{array}{l}\text { Sentido } \\
\text { atribuído }\end{array}$} & $\cdot$ & - & S52c & $\begin{array}{l}\text { Concebeu a importância do uso de abordagens } \\
\text { didáticas diferenciadas nas aulas pelo professor, } \\
\text { mesmo sendo difícil, à principio, lidar com elas, não } \\
\text { sabendo muito bem como os alunos organizarão suas } \\
\text { ações, há a necessidade de buscar mudanças } \\
\text { constantes. }\end{array}$ & S53c & $\begin{array}{l}\text { Reconheceu a importância da avaliação no processo de } \\
\text { ensino como uma ferramenta para reflexão e formação } \\
\text { dos alunos e do próprio trabalho docente. }\end{array}$ \\
\hline & - & - & S52d & $\begin{array}{l}\text { Reconheceu a importância da dimensão emocional no } \\
\text { trabalho docente, para que permita aos alunos se } \\
\text { sintirem capazes de desenvolverem ações } \\
\text { organizadas que favoreçam a busca de soluções para } \\
\text { problemas, a argumentação e a aprendizagem. }\end{array}$ & S53d & $\begin{array}{l}\text { Considerou a educação como um processo de } \\
\text { intervenção social, que busca a transformação da } \\
\text { sociedade e dos indivíduos. }\end{array}$ \\
\hline & - & - & S52e & $\begin{array}{l}\text { Reconheceu que a falta de experiência em trabalhar } \\
\text { com atividades de aprendizagem, com tantos } \\
\text { aspectos a serem enfatizados, pela sua complexidade, } \\
\text { não permite, às vezes, a condução da aula de forma } \\
\text { adequada para o resultado que se quer ver } \\
\text { objetivado. }\end{array}$ & - & - \\
\hline
\end{tabular}




\subsection{Rede de sentidos de Heloisa e Ricardo}

Os sentidos atribuídos pelos licenciandos em cada episódio correspondem a vários aspectos referentes à docência, sendo que também se diferem para cada um dos licenciandos. Em algumas situações encontramos sentidos semelhante para Heloisa e Ricardo, mas não podemos dizer que sejam coincidentes, pois os sentidos estão ligados ao que é vivenciado pelo sujeito. Assim, estão ligados ao social e ao individual, em uma relação dialética, como explicita Rey (2004):

[...] na direção da ampliação das possibilidades de se entender o tema da significação diz respeito ao fato de que as nuanças da reflexão vygotskiana admitem inferir que o "sentido", assim como os signos, não estaria nem na mente, nem na natureza, nem em instâncias transcendentais aprioristicamente. O "sentido" se produziria nas práticas sociais, através da articulação dialética da história de constituição do mundo psicológico com a experiência atual do sujeito. Assim, abrem-se vias para que se admita a polissemia da linguagem e, consequentemente, para que se pense em múltiplas construções de sentidos. Nessas produções, por sua vez, integramse, por exemplo, dimensões cognitivas e afetivas, bem como processos coletivos e individuais [...] (REY, 2004, p.50).

Em consonância com estas ideias, pensamos que os sentidos atribuídos por um licenciando à docência se relacionam e formam uma rede dinâmica, pois os sentidos mudam. Em cada episódio que analisamos pudemos apreender alguns dos sentidos atribuídos pelos sujeitos à docência os quais explicitamos neste capítulo. Esses sentidos se articulam ao longo da história do sujeito em um tempo que chamamos de tempo histórico, no qual as relações também se alteram.

As disciplinas de MEF e o estágio ao promoverem ações, que coordenadas, levavam os licenciandos a também agirem e refletirem sobre a docência, propicionaram a atribuição de sentidos diversos relativos, permitiu a formação de uma rede de sentidos que foram atribuídos por Heloisa e Ricardo à docência, que eles vão carregar em sua formação docente, mas com mobilidade para serem transformados à medida que estão expostos a novos elementos, vivências e reflexões.

Nas Figuras 11 e 12, representamos a rede de sentidos atribuídos à docência, respectivamente, por Heloisa e Ricardo. Esta representação tem o objetivo de mostrar a complexidade do sistema, porém as relações estabelecidas pelo sujeito entre os sentidos podem não ter sido as indicadas, bem como, terem ocorrido em maior ou menor número. 
Nossa intenção é representar o movimento que é dinâmico na historicidade do sujeito e que não conseguimos capturar por completo, mas fragmentos.

Cada um dos círculos, das Figuras citadas acima, representa um sentido atribuído pelo sujeito, sendo o código indicado neles correspondente ao do mapa dos sentidos para cada episódio analisado, cujas cores também os identificam.

As setas tracejadas indicam as possíveis relações entre os sentidos, as setas contínuas representam uma mudança de sentido de uma dada situação para outra e aquelas que fazem uma quebra indicam contradições no sistema de atividade.

A rede de sentidos de cada sujeito pode interagir com a de outros sujeitos, o que leva a processos de significações tornando o sistema mais complexo, dificultando uma representação gráfica. A abordagem de rede de significações é apresentada por Rossetti-Ferreira, Amorim, Silva e Carvalho (2004) que propõem que:

O desenvolvimento humano se dá dentro de processos complexos, imerso que está em uma malha de elementos de natureza semiótica. Esses elementos são concebidos como se inter-relacionando dialeticamente. Por meio dessa articulação, aspectos das pessoas em interação e dos contextos específicos constituem-se como partes inseparáveis de um processo em mútua constituição. Dessa forma, as pessoas encontram-se imersas em, constituídas por e submetidas a essa malha e, a um só tempo, ativamente a constituem, contribuindo para circunscrição dos percursos possíveis ao seu próprio desenvolvimento, ao desenvolvimento das outras pessoas ao seu redor e da situação em que se encontram participando (p.23).

Para os sentidos atribuídos à docência a noção de rede nos possibilita um panorama desses sentidos que conseguimos apreender no decorrer da formação do sujeito, no momento das disciplinas de MEF. Isso nos fornece uma noção do movimento do sujeito em seu processo de aprendizagem da docência. Em nosso caso, com foco na coordenação das ações desenvolvidas pelos licenciandos no estágio, as quais fazem a tessitura para formação dessa rede.

Essa rede de sentidos vai compondo a aprendizagem para docência no conjunto das disciplinas da licenciatura de Física e formando o licenciando em sua incompletude, dinâmica e complexidade. 


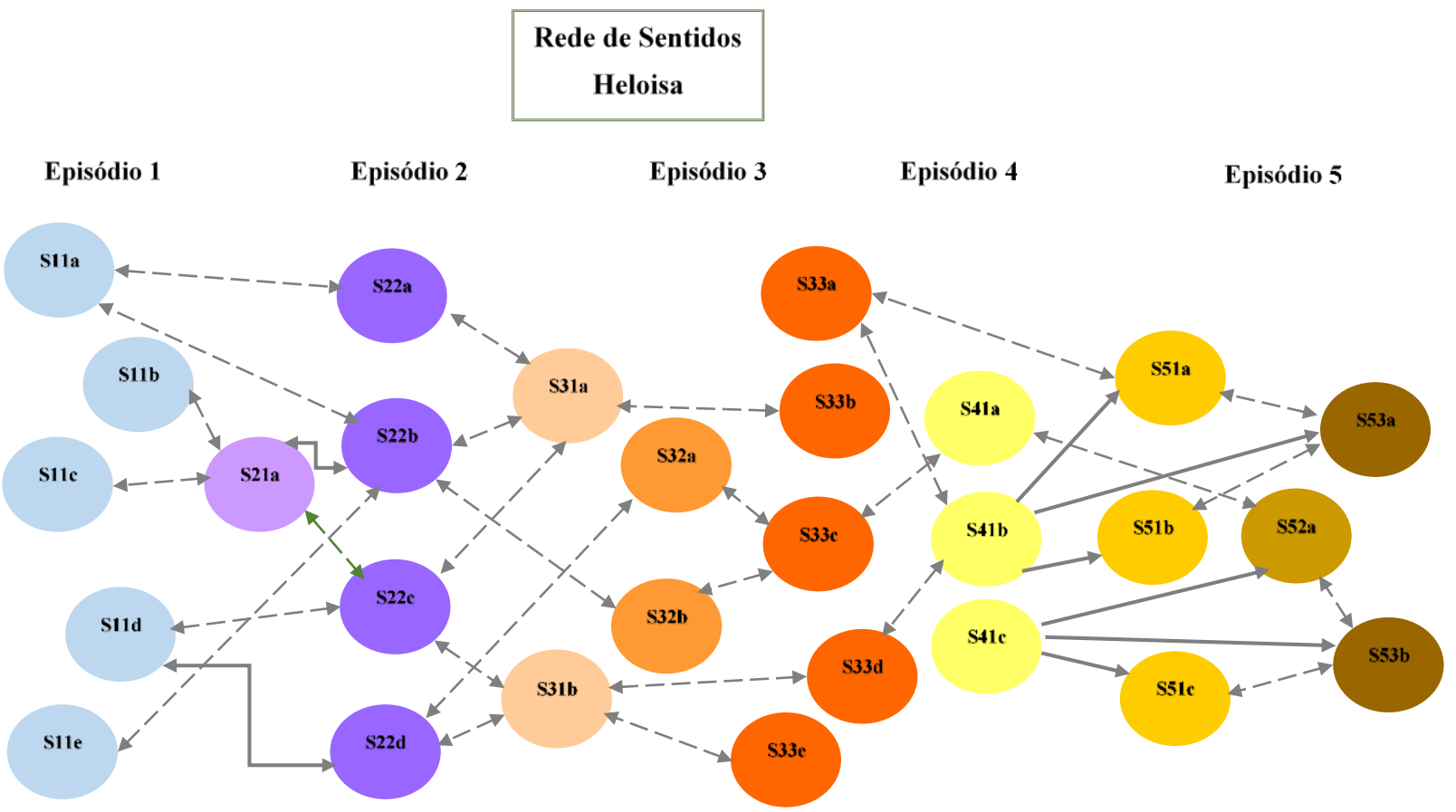

Figura 11: Representação de uma possibilidade de Rede de Sentidos atribuídos por Heloisa à docencia.

Tempo Histórico

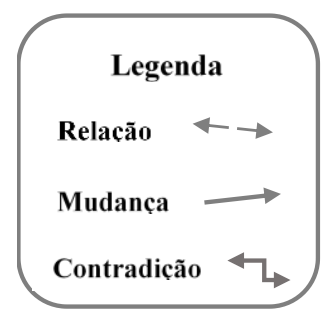

Episódio 1

Episódio 2

Episódio 3

Episódio 4

Episódio 5

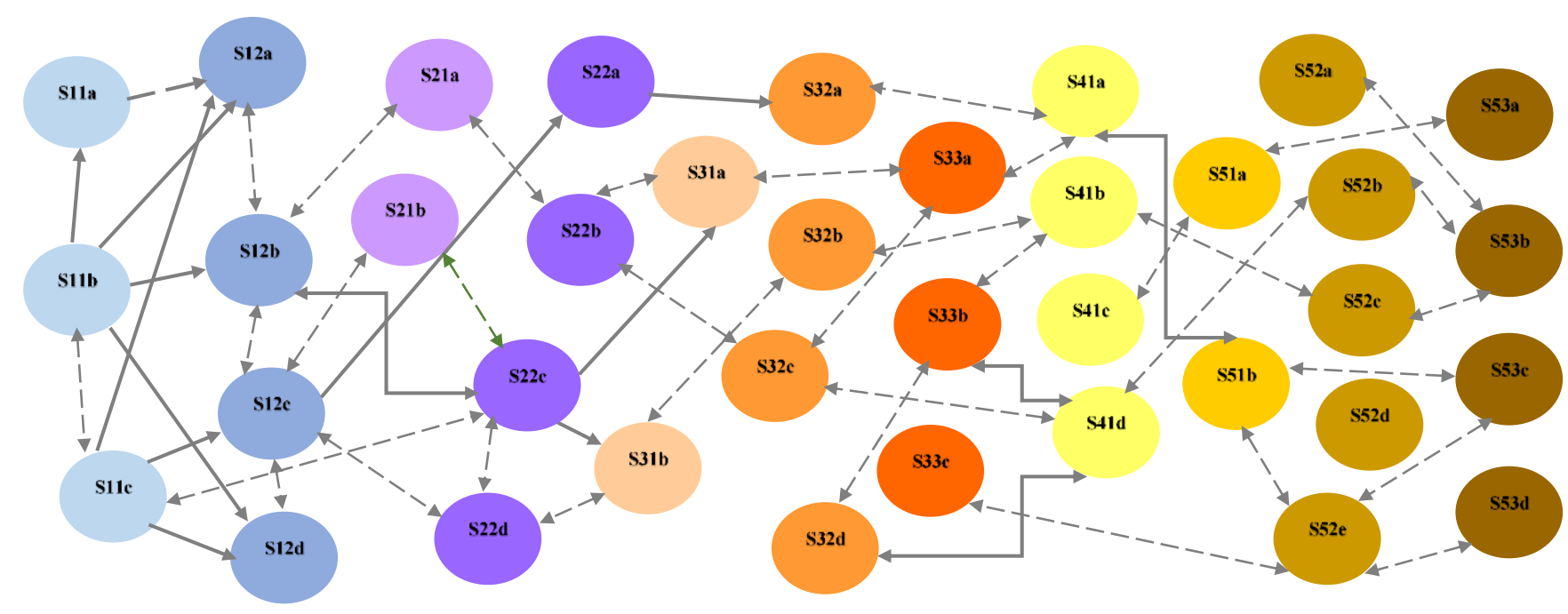

Tempo Histórico

Figura 12: Representação de uma possibilidade de Rede de Sentidos atribuídos por Ricardo à docência. 


\subsection{A aprendizagem da docência e a atribuição de sentidos}

Os licenciandos desde que ingressam no curso de Licenciatura em Física iniciam sua aprendizagem da docência. Essa aprendizagem carrega expectativas que eles trazem que estão ligadas à visão do curso, em geral, não correspondente aos objetivos definidos para o curso, pois a imagem que carregam é ingênua, estereotipada, como percebemos no questionário 1 , que apontam que se interessaram por física para compreenderem a natureza, por gostarem da área de exatas e de investigação, dentre outras. No entanto, os licenciandos também trazem imagens simbólicas que se formam, às vezes, desde a infância, ao lado de vivências que são componentes do vetor aprendizagem da docência, no caso de Ricardo e Heloisa, a monitoria no ensino básico exerceu um papel importante como a análise dos dados nos mostrou.

A formação inicial da licenciatura é multifacetada, com influências diversas, com experiências distintas e múltiplas interações, que levam às possibilidades diferentes para cada sujeito, mas que tem como objeto a aprendizagem da docência. Nesse processo, os sujeitos têm um motivo comum que é a formação docente, mas na coordenação das ações do curso ou de cada disciplina e em suas próprias ações atribuem sentidos à docência, que vão incidindo em sua aprendizagem, que pode levá-los ao desenvolvimento para docência.

A atribuição de sentidos pelo licenciando permite que esse sujeito vá se formando na docência, nessa dimensão o estágio com regência possibilita que ele concretize muito do que assumiu como importante ao trabalho docente, que vem das inter-relações estabelecidas no curso, na disciplina de MEF, nos espaços de convivência com diferentes atores (colegas, professores, familiares etc), bem como, naqueles que se configuram no contexto escolar.

Não é apenas dessas relações que o licenciando vai atribuindo sentidos à docência, mas na organização do planejamento, na discussão do mesmo na disciplina, na própria regência e em sua posterior avaliação, nas reflexões propostas pela professora de MEF e naquelas que surgem no grupo nos momentos de elaboração da atividade de ensino, nas sistematizações da professora de MEF que discute significados da docência e na direção que assume para a organização da disciplina, nas memórias que ressignifica, no contato com essa pesquisa e a pesquisadora, bem como, as possibilidades que vislumbra para o seu futuro. Palma e Moura (2012), em pesquisa realizada com licenciandos de matemática, colocam a importância das inter-relações e das diferentes vozes no sistema de atividade para a formação para docência, apontam que: 
[...] todo sistema de atividade é coletivo e constitui-se a partir das relações e das interações e da multivocalidade, isto é, das múltiplas vozes que o compõem. No desenvolvimento do processo formativo, podemos dizer que as alunas se encontravam em uma rede de interações estabelecidas em e entre o sistema de atividade de formação. Assim, nessa rede de interações, onde emergem as múltiplas vozes, as alunas puderam vivenciar diferentes experiências e começar a perceber que as relações são frutíferas para o trabalho docente, se pautadas no diálogo e na negociação (p.654).

Os licenciandos no percurso da atividade de estágio e das disciplinas de MEF se deparam com diversas situações que são contextos nos quais ocorrem as atribuições de sentidos à docência. No Quadro 14 temos uma representação dessas situações que foram apreendidas na pesquisa, no processo de atribuição de sentidos de Heloisa e Ricardo.

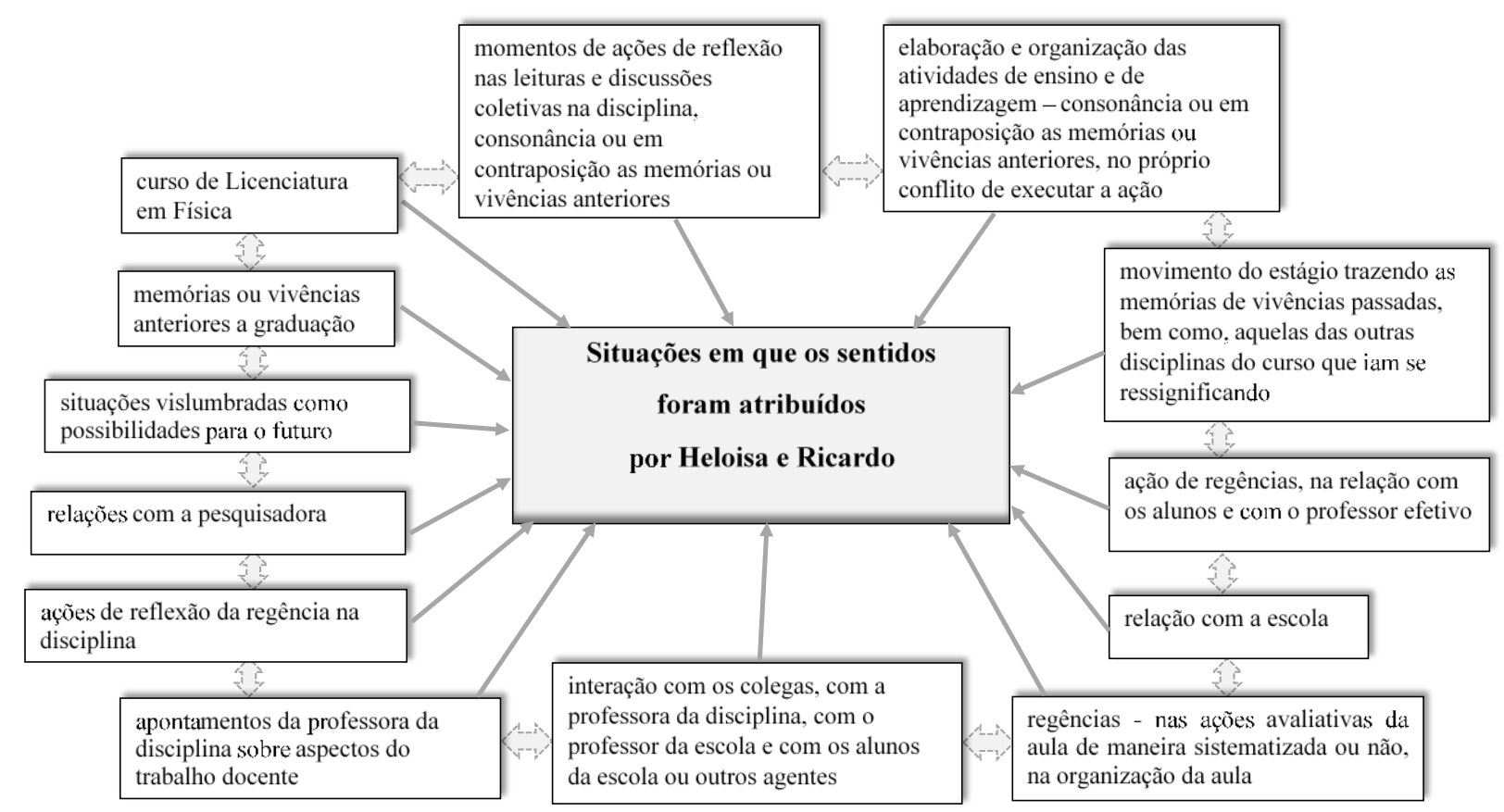

Quadro 14: Representação das situações apreendidas na pesquisa, nas quais Heloisa e Ricardo atribuíram sentidos à docência.

Todas essas situações favoreceram a atribuição de sentidos pelos licenciandos, por gerarem nos mesmos motivos eficazes para que desencadeassem suas ações com objetivos diversos que se direcionavam para a aprendizagem da docência. Porém, isso só é possível se considerarem o estágio como atividade no processo de sua formação, para que suas ações estejam coordenadas para um fim, no caso, a formação para docência. 


\subsection{Eixos articuladores da atribuição dos sentidos}

$\mathrm{Na}$ atribuição dos sentidos, que decorre das múltiplas relações estabelecidas com o outro, que se configuram nas diversas situações coletivas supracitadas é que propomos alguns eixos articuladores da atribuição dos sentidos: as vivências dos licenciandos trazidas pela memória; as mediações nas relações entre o sujeito e aprendizagem da docência; as interações entre os sujeitos e o meio social e cultural; e as contradições como impulsionadoras de mudanças, que ocorrem no movimento da aprendizagem da docência pela coordenação das ações do estágio e da disciplina.

A forma como foram estruturadas as ações de estágio pela professora da disciplina de MEF fez com que os licenciandos se engajassem na proposta de ensino, levando-os a ver seus motivos sendo contemplados nessa atividade, ou seja, se envolviam com a aprendizagem da docência. Isso favoreceu que esses licenciandos entrassem em atividade no estágio, tendo para com este, motivos eficazes em sua formação docente, que na dinâmica do processo podem mudar, implicando na mudança de sentidos.

O significado social do curso de licenciatura em Física é a aprendizagem da docência pelos licenciandos, bem como de seus conteúdos teóricos e de sua epistemologia. Nessa concepção, preparando os licenciandos para atuarem como profissionais no ensino básico. Isso está proposto e é do conhecimento dos licenciandos, mas há desdobramentos na objetivação do resultado final, pois nem sempre há coincidência com o sentido pessoal que atribuem à docência. Nesse aspecto reconhecer como esses sentidos são atribuídos pelos licenciandos e incidir na zona potencial de aprendizagem para docência favoreceria a formação docente. Para tanto, os eixos articuladores dos sentidos poderiam contribuir como ferramentas para analisar a atribuição de sentidos pelos licenciandos.

\section{- As vivências dos licenciandos trazidas pela memória}

Nas disciplinas de MEF a maioria dos alunos era do mesmo curso, do mesmo período, muitos do mesmo ano de ingresso na licenciatura, mas traziam consigo marcas de contextos e de suas relações anteriores de ensino, de trabalho, familiar e tantas outras, que associadas às suas internalizações configuravam vivências singulares, forjadas no âmbito social e cultural, compondo a historicidade dos sujeitos. O caso de Heloisa e Ricardo, representa bem essa 
situação, compartilharam o mesmo curso no início da graduação, porém, tiveram emoções e atitudes distintas ao se depararem com as dificuldades encontradas.

Quando entrevistamos os dois licenciandos eles apontaram várias situações parecidas pelas quais haviam passado, que lhes deixaram imagens positivas ou não, as quais enfrentaram de formas distintas, o que resultava em narrativas bem diferentes, indicando vivências únicas. Mas, as semelhanças nas situações só emergiram ao trabalharmos os dados das entrevistas.

A memória que trazem da atividade de estudo no Ensino Básico e as vivências da própria Licenciatura podem apontar elementos importantes para a discussão do ensino, mas sobretudo para a atribuição de sentidos à docência, que permitiu ao licenciando refletir sobre suas concepções de ensino e aprendizagem e avaliá-las frente a novos referenciais teóricos, práticas e relações que puderam estabelecer na disciplina de MEF. Isso ocorreu para o sujeito em um tempo ontológico que o fez reelaborar motivos, ações e sentidos de memórias e vivências do passado e também permitiu criar perspectivas para o futuro, mas foi no presente, na disciplina e no estágio, que ocorrem as atribuições de sentidos.

A vivência dos licenciandos carrega memória, que é ativada nas inter-relação estabelecida entre o passado e presente, à medida que o sujeito precisa mobilizar ações já conhecidas para ressignificá-las em novas situações. Essa memória é elaborada socialmente e nos processos de atribuição de sentidos ela é acionada, no entanto, não mais como a mesma ocorrência, mas com potencial de mudança.

A memória de ações vividas, carregada de sentidos, não traz estes mesmos para as situações do presente, mas permite que atribua novos sentidos quando acionadas partes dessa vivência. Isso pode colocar o licenciando em atividade, ou promover mudanças no sistema de atividade, ou reiterando o sentido já atribuído.

A ativação da memória e vivências pode ser um eixo articulador utilizado na formação docente que mobilize ações que coloquem o licenciando em processo de aprendizagem da docência.

\section{- As mediações nas relações entre o sujeito e aprendizagem da docência}

Nas disciplinas, nas quais destacamos a atividade de estágio, os processos mediacionais eram estabelecidos entre os diferentes atores e entre estes e os objetos de suas atividades, em que a aprendizagem docente era o foco principal. No caso, o ensino de ciências 
é que viabilizava o diálogo entre o sujeito e sua aprendizagem para docência, por vários instrumentos e pela linguagem, no processo de apropriação do trabalho docente.

Esse movimento não ocorria espontaneamente, mas desencadeado pela atividade de ensino proposta nas disciplinas de MEF, pela professora. Nesse processo de mediação, estabelecido entre a professora e os licenciandos, viabilizava-se a reflexão pelas leituras, pelas práticas nas regências, por algumas palestras e por tarefas organizadas para o trabalho em grupo.

Os dois licenciandos ao organizarem as atividades de ensino para o estágio passaram a refletir sobre o que ensinar, como ensinar, o que lhes trouxe as atribuições de sentidos ao papel do professor na importância da intencionalidade daquilo que selecionam para o ensino, quais abordagens didáticas escolhem para trabalharem com os alunos, dentre outros aspectos. Isso levou-os a buscarem trabalhar com os alunos uma visão de Ciências como construção coletiva, histórica e que se transforma pela ação do homem, bem como, ensinar conceitos científicos se utilizando da aprendizagem de novas propostas, como coloca Ricardo, saindo da zona de conforto, de aulas expositivas e exercícios de aplicação direta apenas. Assim, buscando elaborar atividades de ensino que levassem os alunos a agirem, ou seja, que promovessem neles motivos eficazes para desenvolvê-las, com o objetivo da apropriação dos conceitos científicos, de novas atitudes e criatividade.

Assim, os instrumentos mediadores selecionados pela professora de MEF (textos, montagens experimentais, trechos específicos de livros sobre um determinado assunto, preparação de materiais para regências, dentre outros) tiveram papel importante na aprendizagem da docência pelos licenciandos. Desta forma, a organização do ensino nesta disciplina foi crucial para o processo de atribuição de novos sentidos pelos licenciandos, na medida que os mesmos tinham seus motivos realizados, no caso, a aprendizagem da docência, que se fazia pelas ações do estágio e da disciplina.

Isso coloca os processos mediacionais como importante eixo articulador na análise para apreender a aprendizagem da docência pelos licenciandos, tomando a partir deles as ações desencadeadas e os sentidos que são atribuídos à docência por esses licenciandos.

\section{- As interações entre os sujeitos e o meio social e cultural}

As múltiplas interações fomentadas pelas ações organizadas nas disciplinas de MEF permitiram que os licenciandos estabelecessem relações diversas e sob diferentes aspectos que 
levaram às atribuições de sentidos à docência. As interações entre os sujeitos e o meio social e cultural se fazem de forma dialética, levando ao movimento constante de modificação de um sobre o outro.

As interações promovem relações diversas e em uma rede complexa que se modifica no movimento do sujeito, assim são coletivas, ocorrem em um contexto social e culturalmente situados, porém são singulares para cada sujeito.

$\mathrm{Na}$ atividade de estágio, um dos contextos fundamentais da aprendizagem da docência nas disciplinas de MEF, as interações ocorreram em várias instâncias: professor da disciplina e licenciandos, licenciandos entre si, professor da escola e licenciandos, alunos da escola e licenciandos, dentre tantas outras possibilidades, o que gerou um universo de relações que dinamizava e complexificava esse sistema de atividade. Porém, foi nesse processo que as mudanças foram viabilizadas, pois os licenciandos modificavam o meio onde atuavam, a sala de aula, a disciplina de MEF e o próprio estágio, modificando também a si mesmos, continuamente.

Pelos relatos dos licenciandos pudemos perceber que o estágio com regência fez diferença nas ações para a docência, permitindo que organizassem e se apropriassem de novas ações, ao mudarem seus motivos e sentidos. No entanto, para essas mudanças eles apontaram alguns elementos importantes e necessários, como: a reflexão sobre o planejamento das aulas e sobre as aulas, sendo esta feita com o professor da disciplina e com os colegas de classe; o aumento de horas de regência; o envolvimento do professor efetivo da escola na reflexão crítica do estágio e a relação com os alunos da escola. Isso aponta para a relevância das interações no estabelecimento de e ações e processos reflexivos realizados de forma compartilhada, que possibilitam a aprendizagem da docência, levando à atribuição de sentidos.

As interações proporcionam situações que podem despertar relações múltiplas e dinâmicas, que na formação para docência corroboram para a aprendizagem, pelo estabelecimento de relações de trabalho conjunto, diálogo, conhecimento e outros instrumentos, que permitirão a atribuição de sentidos à docência.

Isso faz com que as interações estabelecidas no processo de aprendizagem docente como eixo articulador de análise, para atribuição de sentidos à docência, possa viabilizar a compreensão do movimento de relações do licenciando em sua formação docente na disciplina 


\section{- As contradições como impulsionadoras de mudanças}

As contradições ocorrem ao longo das disciplinas de MEF e do estágio em diversos momentos do processo, elas se dão entre os elementos que compõem as atividades e também entre as atividades de estágio e da escola.

Essas contradições são também articuladoras para atribuições de sentidos à docência pelos licenciandos. Ao se estabelecer uma contradição no sistema de atividades, ou entre sistemas de atividades, isto leva os licenciandos a tomarem consciência de uma dada tensão, que de alguma forma desarticula o sistema. O licenciando ao percebê-la pode buscar soluções, se possível, mas o que importa é que o movimento dos sujeitos de se conscientizarem das contradições, que são fontes propulsoras de mudança do sistema de atividade, que pode ocorrer a longo prazo.

Isso torna fundamental perceber onde se dão as contradições no sistema de atividades, pois ali estará o potencial para mudança, mas é preciso que ele seja reconhecido pelo sujeito.

No caso do estágio, os sistemas de atividades, universidade e escola, têm regras próprias de funcionamento, dentre as quais esse estágio faz uma correlação, sendo as regras da licenciatura voltadas para a apropriação do contexto escolar, de suas especificidades, levando os estagiários à prática docente para sua aprendizagem. Da forma como o estágio foi organizado permitiu ao estagiário buscar estabelecer os nexos entre teoria e prática, de maneira a não dissociá-las, trazendo movimento ao estágio. No entanto, na escola não houve a participação do professor efetivo, ele autoriza o estágio em uma de suas salas de aula, porém, não toma parte ativa no processo. A ele é apresentado o planejamento a ser desenvolvido com os alunos, como ele também é consultado sobre o que gostaria que fosse discutido nesse planejamento. Mas, pouco se envolve nessas escolhas ou na organização das regências. Esse panorama do professor efetivo como um espectador das regências ocorreu nos estágios de Heloisa e Ricardo. A situação exemplifica uma contradição entre sistemas de atividades, no caso, a disciplina, o estágio e a escola.

Cabe esclarecer que as contradições não seguem somente o padrão do exemplo citado, mas pode ocorrer também quando elementos novos são introduzidos no sistema de atividades, um elemento culturalmente mais avançado se insere no sistema, ou ainda na tensão entre o valor de uso e de troca do objeto (ENGESTRÖM,1999).

As contradições permitem que os licenciandos se coloquem frente a situações de ensino que os levam a refletir, avaliar, se contraporem e assim atribuírem sentidos à docência, 
fazendo se coloquem em movimento de aprendizagem, mas para tanto, elas precisam ser conscientes, então estarão em atividade e com possibilidades à mudança, que pode a vir interferir no sistema de atividades.

Por esses aspectos, as contradições podem ser importantes como eixo articulador na análise da atribuição de sentidos à docência, o que pode propiciar perceber o potencial de mudança de motivos no processo de aprendizagem da docência.

\section{- Uma representação dos eixos articuladores de sentidos e os sistemas de atividade dos sujeitos}

O ciclo que se estabeleceu no movimento de atribuição de sentido dos licenciandos está intrinsecamente articulado às condições e alterações nos sistemas de atividades, que buscamos representar no Quadro 15. Cabe salientar, que esse movimento é mais complexo, pois o sujeito ao mudar seu motivo, não perpassa pelas mesmas situações vivenciadas, portanto, sua trajetória não é a mesma, ele pode atribuir sentidos semelhantes a alguns aspectos da docência, mas em situações distintas, ou vice-versa.

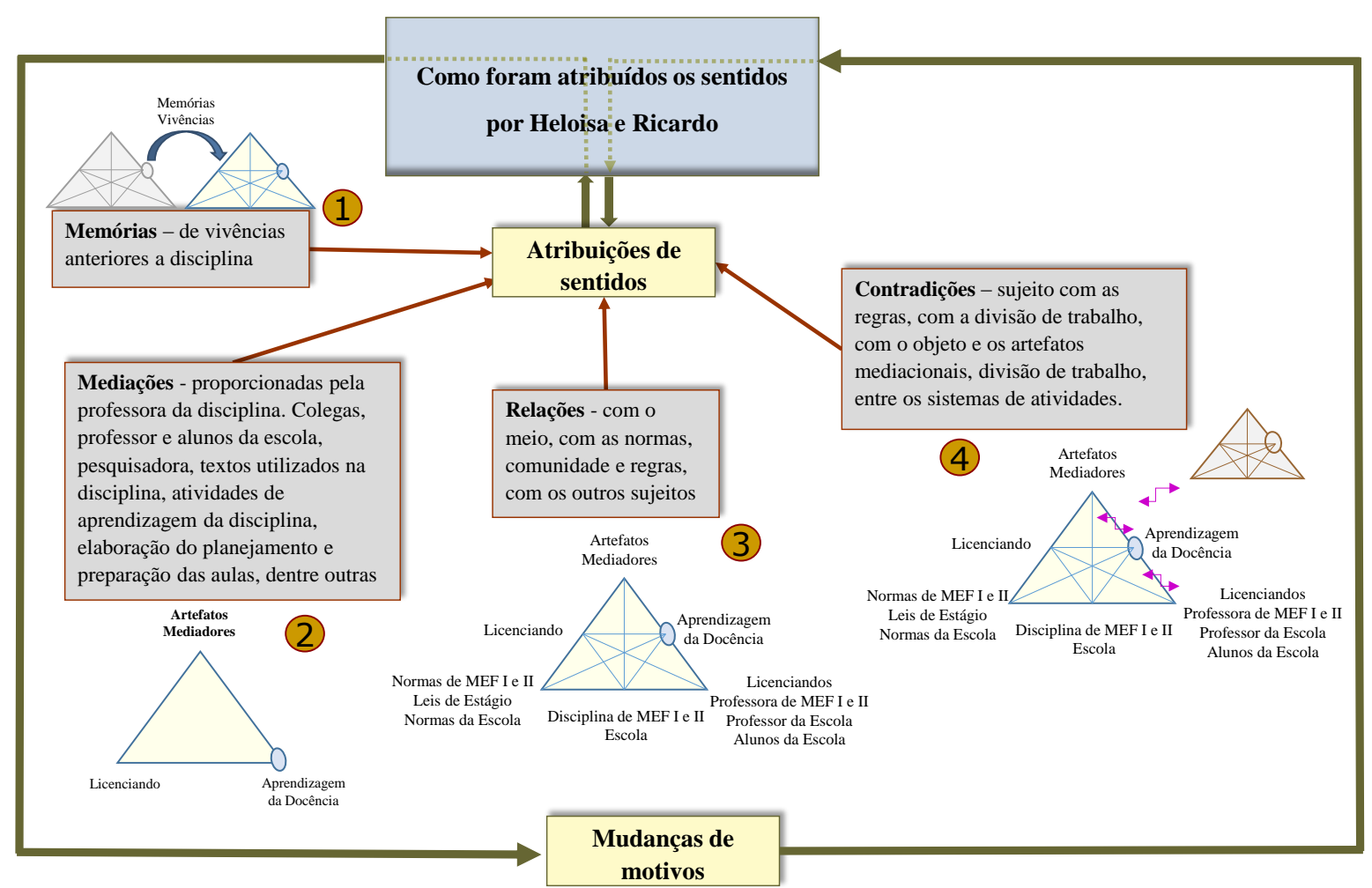

Quadro 15: Representação dos eixos articuladores da atribuição de sentidos por Heloisa e Ricardo e os sistemas de atividades. 
Os fatores que levaram às atribuições de sentidos estão acompanhados no Quadro pelos sistemas de atividades que representam as relações estabelecidas em cada caso, sendo indicados por um número para serem localizados.

Na situação 1, as memórias que os licenciandos trazem do Ensino Básico e suas vivências são fontes de atribuições de sentidos para a docência no presente, porém ressignificando as ações passadas. Desta forma, a atividade de estudo do sujeito efetivada no passado estabelece uma conexão com sua atividade de estudo atual, a graduação em Física, no caso dessa pesquisa, conectada com o sistema de atividade das disciplinas de MEF, provocando alterações nesses sistemas e nos sentidos dos sujeitos.

No caso da mediação, situação 2 , como fator que promove a atribuição de sentidos pelos sujeitos, a contribuição de Vigotiski e a teoria da atividade mostram que a interação entre o sujeito e a aprendizagem da docência não se faz de forma direta, mas sempre mediada por instrumentos e signos. No caso da formação docente, essa mediação se faz pelas ações propostas pelo professor das disciplinas de MEF, pelas atividades de ensino elaboradas pelos licenciandos, pela regência que realizam, pelas discussões nas disciplinas de MEF, dentre outras.

Em 3, as relações dos licenciandos com os outros sujeitos e com o meio geram atribuições de sentidos à docência que se dão pelas relações estabelecidas no sistema de atividade entre os elementos que os compõe, sendo eles: licenciandos; artefatos mediadores; as disciplinas de MEF, o estágio e a escola; as normas das disciplinas de MEF, de estágio e da escola; bem como, a divisão de trabalho que é feita entre os licenciandos, professor das disciplinas de MEF, professor efetivo da escola, alunos da escola e outros atores.

No caso 4, as contradições que ocorrem no sistema de atividade são propulsoras de atribuições de sentidos à docência pelos licenciandos e são potenciais de mudanças desse sistema, essas contradições podem ocorrem entre elementos do próprio sistema de atividade ou entre dois sistemas diferentes de atividades, como o estágio e a escola. 


\title{
Capítulo 6
}

\section{Conclusões e considerações finais}

\author{
Digo: o real não está na saída nem na \\ chegada: ele se dispõe para a gente \\ é no meio da travessia
}

João Guimarães Rosa

O objetivo de identificar como os licenciandos atribuíam sentidos relativos à docência nas ações na atividade de estágio no processo das disciplinas de Metodologia do Ensino de Física nos fez optar pelos referenciais das teorias Histórico-Cultural e da Atividade. Assim, investigamos na trajetória de vida dos sujeitos em sua atividade de estudo, em sua historicidade, as interações estabelecidas entre os vários elementos, buscando compreender como as ações que realizavam, ao se coordenarem, levavam à concretização de seus motivos, no caso, a formação para docência. No entanto, no processo de aprendizagem da docência os sentidos sobre a docência eram atribuídos pelos licenciandos e isso ocorria por diversos fatores e de maneira distinta em cada situação vivenciada e para cada licenciando.

A atividade de estágio como unidade de análise definiu um espaço/tempo no qual olhamos as ações para docência, as quais abrangeram uma multiplicidade de ações e operações, que envolveram as abordagens didáticas, a organização do planejamento, as regências, as observações e coletas de dados na escola antes e após as regências, as reflexões sobre a teoria e práticas, as atividades de ensino e intervenções da professora da disciplina de MEF, bem como, as memórias do ensino básico e vivências na graduação dos licenciandos.

No sistema de atividade de uma disciplina, inserida no âmbito dos sistemas de atividades de um curso de licenciatura em Ciências, compreender o movimento da atribuição de sentidos à docência pelo licenciando e quais sentidos são mobilizados permite refletir a organização da disciplina e as atividades de ensino propostas em prol de atingir sua meta, a formação para docência. Na medida em que, os sentidos atribuídos pelo licenciando estão ligados ao seu motivo, que é a aprendizagem da docência, reconhece-los favorece que as ações da disciplina e da atividade de estágio possam neles incidir, aproximando-os dos significados sociais da docência, ensinar como um processo de humanização.

Nessa perspectiva, ao pensarmos o ensino como um processo de apropriação dos conhecimentos acumulados culturalmente, sendo a escola o locus de sistematização desses 
conhecimentos, de mudanças e de criação, que perceber o movimento de atribuição de sentidos pelos sujeitos ao fazerem uma disciplina, nos permite verificar os indícios de apropriações que fizeram dos conhecimentos nela mobilizados e de perspectivas que podem impulsioná-los para a elaboração de novas ações e conhecimentos. Desta forma, entendemos que esses não têm interesse por simples constatação de sua apreensão, mas pelas mudanças que os sujeitos podem fazem no contexto que atuam, no caso, a formação para a docência, com isso, mudando a si mesmos. Nos casos que focalizamos neste estudo, Heloisa e Ricardo já traziam sentidos relativos à docência fortemente marcados em suas trajetórias do Ensino Básico, da própria licenciatura e de suas experiências pessoais. Heloisa considerava como parte da formação do professor conceber o aluno como ser pensante, assim o docente em sua atividade de ensino não deveria dar respostas aos alunos e sim fazê-los discutir, pensar sobre o tema abordado; Ricardo julgava ser fundamental uma relação dialógica entre professor e alunos para que o processo de ensino e aprendizagem pudessem se realizar. Esses não foram os únicos sentidos que trouxeram, mas talvez os mais duradouros, pois terminaram a disciplina mantendo-os.

No processo do estágio supervisionado e em outras ações das disciplinas de MEF os sujeitos foram atribuindo outros sentidos à docência, mas como esse processo é dinâmico e não linear, esses sentidos no decorrer da pesquisa se complementavam, novos eram atribuídos e alguns mudavam. Ressaltamos, entretanto, que os sentidos que evidenciamos nesse trabalho são somente os que pudemos caracterizar nas dadas condições metodológicas da investigação. Entre eles, destacamos os diferentes sentidos atribuídos pelos licenciandos, quais sejam: o reconhecimento da importância da organização da atividade de ensino pelo professor; a intencionalidade das ações docentes; o papel do professor em coordenar as atividades de aprendizagem propondo mediações que favoreçam a apropriação dos conhecimentos; a compreensão da utilização de diferentes abordagens didáticas e estratégias em sala de aula; a importância da atividade de estágio ter ações colaborativas. Além desses, as percepções de que: a atitude do professor relaciona-se com a motivação do aluno; o contexto escolar precisa ser considerado na organização do ensino; a dimensão emocional no trabalho docente; a relevância do professor coordenar a aula considerando as múltiplas relações entre os sujeitos e a educação como um processo de transformação social e do indivíduo.

As atribuições de sentidos se fazem na dinâmica da atividade do sujeito, onde seus motivos atingem suas metas, mas também podem se alterar, mudando os sentidos. Nessa relação complexa que se estabelece entre o ensino e os sujeitos, temos um processo em que as 
ações e interações levam à modificação na atividade de ensino, mas os sujeitos não permanecem os mesmos, eles também se modificam.

No âmbito da teoria da atividade, as contradições que surgem são propulsoras de tendências às modificações nos sistemas, mas, dependendo de quais são essas perturbações, elas não provocam mudanças a curto prazo. Essas contradições fazem parte do movimento dialético da atividade, sem elas o sistema fica estagnado. Tais contradições ocorrem entre diferentes sistemas, como é o caso da relação entre a disciplina e a escola, mas também ocorrem no próprio sistema; como na objetivação das ações do planejamento na regência, que pode promover a reflexão e a sua reorganização; ou ainda na própria atividade de estudo, que na disciplina de MEF associada ao estágio, levou à mudança de sentidos sobre a docência para Heloisa e Ricardo.

A discussão na sala de aula da disciplina, fazendo desta um ambiente de troca e compartilhamento, foi um dos fatores essenciais na aprendizagem da docência, tanto na preparação da atividade de ensino como na avaliação da regência, consequentemente, possibilitou a atribuição de sentidos.

A organização do estágio como um dos fatores fundamentais para a aprendizagem da docência, o colocou como uma das ações principais das disciplinas de MEF, ao gerar motivos eficazes para os licenciandos como parte fundamental de seus aprendizados. Os dados de Heloisa e Ricardo apontam que foi possível desenvolver a atividade de estágio da forma como se realizou por causa da maneira como foram estruturadas as disciplinas de MEF pela professora, o que mostra como a organização do docente e suas ações de ensino são importantes para a mobilização das ações de aprendizagem dos licenciandos.

Nesse aspecto, a professora, por essa organização do ensino e das ações propostas aos licenciandos, os colocou em atividade de aprendizagem, e o estágio, pode tornar-se alvo das ações desses licenciandos, no qual suas propostas de ensino se objetivavam, levando-os a atingirem seu motivo principal: aprender a ensinar.

Nas ações da disciplina a proposta de trabalhar com problemas e a natureza da ciência, em uma abordagem didática investigativa, fez com que os licenciandos tivessem maior complexidade ao organizarem o planejamento de suas regências, exigindo uma elaboração detalhada ao organizarem suas atividades de ensino, prevendo e coordenando ações desencadeadas na atividade de aprendizagem pelos alunos.

O resultado do processo para Ricardo envolveu um maior domínio ao trabalhar com os alunos e aprofundamento em suas reflexões sobre as ações para docência, avançando para 
questões referentes à condução da sala de aula, atendendo às necessidades dos alunos e aquelas que, às vezes, precisam de intervenção imediata. Para Heloisa, houve um avanço nas relações entre teoria e prática e na organização da atividade de ensino.

Assim salientamos que o estágio, nas diversas disciplinas que o contemplam, se coloca como atividade necessária à aprendizagem da docência, como momento de aproximação do contexto escolar e de oportunidade de objetivar aquilo que se refletiu nas teorias, pesquisas e ações da universidade. Essa atividade não só é importante à formação docente como sua obrigatoriedade está prevista por lei e incorporada aos currículos dos cursos de licenciaturas que indicam os espaços de Ensino Básico como locais de parceria. Essa relação entre universidade e escola não se faz diretamente, mas é mediada pelas ações de estágio. Essas ações coordenadas se direcionam a uma meta a ser atingida pelos licenciandos que é a aprendizagem da docência. No entanto, o estagiário é quem realiza a conexão entre as instituições, cuja ligação se faz para o cumprimento das ações de estágio.

No entanto, cabe ressaltar que as atribuições de sentidos sobre a docência elaboradas pelos licenciandos não se iniciaram no estágio e nas disciplinas de MEF e nem se esgotam nela, mas vão compondo uma rede em constante alteração. Tais sentidos mudam e também novos são atribuídos no decorrer do tempo, estabelecendo conexões e interagindo com o de outros sujeitos. Desta forma, novos sentidos podem ser atribuídos ao longo da prática profissional, que vão se concretizando no cotidiano do professor, em seu contexto, nas interações que estabelece, nas reflexões e contradições que vivencia.

A pesquisa que desenvolvemos nos permite pensar o processo de formação docente com vistas às ações que possibilitem a vivência de situações de ensino com maior duração que possam favorecer a atribuição de sentidos dos licenciandos em consonância aos motivos relativos ao ensino. Para tanto, salientamos que há necessidade de um estágio que traga maiores condições de reflexão sobre o sucesso e as contradições evidenciadas pelos licenciandos, que são fatores que podem gerar as mudanças no sistema de atividade, na atribuição de sentido dos sujeitos. Se o professor da disciplina e os licenciandos conseguirem estabelecer uma dinâmica nas ações de estágio em que as contradições possam emergir, podem pelas mediações e interações levar a possíveis mudanças que farão com que se formem nesse processo.

Esse processo necessita de um acompanhamento mais sistemático dos licenciandos na atividade de estágio, que somente o professor da disciplina, no caso MEF, não conseguirá fazer, é importante a presença de uma equipe de educadores que colabore com esse professor 
na orientação e discussão sobre o estágio, sejam eles estudantes dos cursos de pós-graduação, ou também professores do Ensino Básico, que tenham uma formação preparatória para exercer essa função. Isso já ocorre em algumas disciplinas, mas propomos que seja mais sistemático com instâncias de discussões e estudo para preparação dos grupos.

Ao lado disso pode-se ter nessa formação a colaboração do professor efetivo da escola que recebe o estagiário, o que auxiliaria a relação do licenciando no âmbito da escola para a aprendizagem da docência. Porém, isso não poderia ser feito de forma aleatória, há que envolver esse professor nas atividades de ensino propostas na disciplina, seja com grupos de estudo e discussão, com minicurso ou outra estratégia. Cabe ressaltar que a necessidade dessa relação entre universidade e escola é recíproca, sendo importante que o professor da disciplina de MEF também estabeleça contatos graduais e sucessivos com a escola parceira, de modo a tornar as ações de estágio coordenadas e voltadas para a aprendizagem da docência. Outro ponto importante a mencionar é a relevância da negociação entre o professor da escola e os licenciandos em torno dos planos de aulas a serem implementados. Essa negociação pode possibilitar a troca de conhecimentos e experiências do professor para com os estagiários, bem como o compartilhamento de temas e abordagens diferenciadas trazidas pelos licenciados para o contexto escolar.

Sem dúvida que, ao analisarmos as atribuições de sentidos à docência de Heloisa e Ricardo, nos deparamos com outros sentidos atribuídos à estrutura necessária para o estágio, levando em consideração a importância que lhe foi dada. No entanto, os limites da pesquisa não permitem que muitas sugestões sejam feitas em relação às mudanças nas ações da escola, uma vez que não foi nosso foco de estudo. Não podemos fazer generalizações, pois temos casos situados, mas podemos considerar as questões abordadas para o processo formativo dos licenciandos em Ciências, especialmente da Física.

Como possibilidade para ampliar tal discussão, sugerimos como estudos futuros a necessidade de investigar a atividade de estágio na relação entre o licenciando e professor efetivo da escola; a intencionalidade do professor da disciplina e os sentidos atribuídos pelos licenciandos; a relação entre as regências e a atribuição de sentidos dos alunos da escola; contradições que surgem na relação dos licenciandos com a escola, dentre outras.

Em suma, afirmamos que a aprendizagem da docência não pode ser pensada sem o sujeito que aprende. Esse sujeito não pode estar fora do coletivo que o identifica, que o concebe como ser social, que o posiciona em seu contexto em suas relações, que configura suas vivências. Portanto, o sentido atribuído pelo sujeito à docência, o faz refletir sobre as 
atribuições, condições necessárias, valores e atitudes para ser professor, que se objetivarão em seu papel coletivo e social na profissão docente. Assim, defendemos que o processo de formação inicial de professores e, mais especificamente, as disciplinas que propiciam as primeiras vivências práticas de sala de aula, favoreçam a atribuição de sentidos pelos licenciandos voltados para a docência em sua significação social, com consciência sobre seu papel no ensino, de modo que resistam à situação de alienação em sua profissão e busquem um desenvolvimento profissional contínuo. 


\section{Referências Bibliográficas ${ }^{15}$}

ABIB, M.L.V.S. Em busca de uma nova formação de professores. Ciência \& Educação, Bauru, v. 3, p. 60-72, 1996.

ABIB, M. L. V. S. Formação de professores de ciências: treinamento ou cooperação? In: MATOS, C. (Org.). Conhecimento científico e vida cotidiana. São Paulo: Terceira Margem, 2003, p. 87-101.

ABIB, M. L. V. S. A pesquisa em ensino de Física e a sala de aula: articulações necessárias na formação de professores. In: GARCIA, N. M. D. et al. (ORG.). A pesquisa em ensino de Física e a sala de aula: articulações necessárias. São Paulo: Editora da Sociedade Brasileira de Física, 2009, p. 227-238.

ABIB, M. L. V. S. Avaliação e melhoria da aprendizagem em Física. In: CARVALHO, A. M. P. et al. Ensino de Física. São Paulo: Cengage Learning, 2010, p. 139-158.

ABREU, D. G. de; MOURA, M. O. de. Construção de instrumentos teóricos metodológicos para captar a formação de professores. Educação e Pesquisa, Ahead of print, out., 2013.

AGUIAR W.M.J. de A.; OZELLA, S. Apreensão dos sentidos: aprimorando a proposta dos núcleos de significação. Revista Brasileira de Estudos Pedagógicos, Brasília, v. 94, n. 236, , jan./abr, 2013. p. 299-322.

ALARCÃO, I. Professores reflexivos em uma escola reflexiva. São Paulo: Cortez, 2010.

ASBAHR, F. da S. F. Sentido pessoal e projeto político-pedagógico: análise da atividade pedagógica a partir da psicologia histórico-cultural. Dissertação (Mestrado em Psicologia da Aprendizagem, do Desenvolvimento e da Personalidade) - Instituto de Psicologia, Universidade de São Paulo, São Paulo, 2005a.

ASBAHR, F. da S. F. A pesquisa sobre a atividade pedagógica: contribuições da teoria da atividade. Revista Brasileira de Educação, n. 29, 2005b. Disponível em: <http://www.scielo.br/pdf/rbedu/n29/n29a09>. Acesso em: 10 Mar. 2014.

${ }^{15}$ De acordo com a Associação Brasileira de Normas Técnicas. NBR 6023. 
ASBAHR, F. da S. F. Sentido pessoal, significado social e atividade de estudo: uma revisão teórica. In: ENCONTRO BRASILEIRO DE EDUCAÇÃO E MARXISMO: educação e emancipação humana, 5., 2011, Florianópolis. Anais eletrônicos... Florianópolis: UFSC, 2011. Disponível em: <http://5ebem.ufsc.br/trabalhos/eixo_04/e04c_t001.pdf>. Acesso em: 21Mai. 2013.

AZEVEDO, M. N. Mediação discursiva em aulas de Ciências: motivos e sentidos no desenvolvimento profissional docente. Tese (Doutorado em Ensino de Ciências e Matemática) - Faculdade de Educação, Universidade de São Paulo, São Paulo, 2013.

AZZI, S. Trabalho docente: autonomia didática e construção do saber pedagógico. In: PIMENTA, S. G. (ORG.) Saberes pedagógicos e atividade docente. 8.ed. São Paulo. Cortez, 2012.

BAQUERO, R. Vygotsky e a aprendizagem escolar. Porto Alegre: Artes Médicas, 1998.

BARBOSA, P. P; URSI, S.; MATTOS, C. R. Teoria da atividade e a formação de professores na educação a distância. VIII Congresso Brasileiro de Ensino Superior a Distância. UNIREDE, Ouro Preto, out., 2011.

BARROS, J. P. P. et al. O conceito de "sentido" em Vygotsky: considerações epistemológicas e suas implicações para a investigação psicológica. Psicologia \& Sociedade, Fortaleza, v. 21, n. 2, p. 174-181, 2009.

BERGAMASCHI, M. A.; ALMEIDA, D. B. Memoriais escolares e processos de iniciação à docência. Educação em Revista, Belo Horizonte, v. 29, n. 02, 2013. p. 15-41.

BERNARDES, M. E. M. Ensino e aprendizagem como unidade dialética na atividade pedagógica. Revista Semestral da Associação Brasileira de Psicologia Escolar e Educacional (ABRAPEE), v.13, n.2, jul/dez, 2009. p.235-242.

BIZERRA, A. F. Atividade de aprendizagem em museus de ciências. Tese (Doutorado em Ensino de Ciências e Matemática) - Faculdade de Educação, Universidade de São Paulo, São Paulo, 2009. 
BOCK, A. M. B. A perspectiva sócio-histórica de Leontiev e a crítica à naturalização da formação do ser humano: a adolescência em questão. In: A psicologia de A. N. Leontiev e a educação na sociedade contemporânea. Cadernos CEDES, v.24, n. 62. Campinas, São Paulo: Cortez, 2004. p. 26-43.

BOGDAN, R.; BIKLEN, S. K. Características da investigação qualitativa. In: Investigação qualitativa em educação: fundamentos, métodos e técnicas. Portugal: Porto Editora, 1982.

BORGES, R. de C.M. B. O professor reflexivo-crítico como mediador do processo de inter-relação da leitura-escrita. In: PIMENTA, S. G.; GHEDIN, E. (ORG.). Professor reflexivo no Brasil: gênese e crítica de um conceito. São Paulo: Cortez, 2010. p. 201-218.

BRAGA, E. S. A constituição social da memória: uma perspectiva histórico-cultural. Ijuí: Ed. Ijuí, 2000.

BRAGA, E. S. A constituição social do desenvolvimento. In: REGO, T. C. (ORG.) Lev Vigotski. História da Pedagogia Lev Vigotski. Revista Educação, 2010a.

BRAGA, E. S. Tensões eu/outro: na memória, no sujeito, na escola. In: SMOLKA, A. L. B.; NOGUEIRA, A. L. H. (ORG.) Questões de desenvolvimento humano: práticas e sentidos. Campinas: Mercado de Letras. 2010b. p. 151-170.

CACHAPUZ, A. et al. A necessária renovação do ensino das Ciências. São Paulo: Cortez, 2005.

CAMILLO, J.; MATTOS, C. R. Educação em ciências e a teoria da atividade culturalhistórica: contribuições para a reflexão sobre tensões na prática educativa. Belo Horizonte. Revista Ensaio, v.16, n. 01, p. 211-230, 2014.

CANDAU, V. M. A Formação de educadores: uma perspectiva multidimensional. In: CANDAU, V. M. (Org.) Rumo a uma nova didática. Vozes, Petrópolis, 2010. 
CARVALHO, A. M. P. Os estágios nos cursos de licenciatura. São Paulo: Cengage Learning, 2012.

CARVALHO, A. M. P.; GIL-PÉREZ, D. Formação de professores de Ciências. São Paulo: Cortez, 1993.

CEDRO, W. L. O motivo e a atividade de aprendizagem do professor de Matemática: uma perspectiva histórico-cultural. Tese (Doutorado em Ensino de Ciências e Matemática) - Faculdade de Educação, Universidade de São Paulo, São Paulo, 2008.

CEDRO, W. L.; MORAES, S. P. G.; ROSA, J. E. A atividade de ensino e o desenvolvimento do pensamento teórico em matemática. Ciência \& Educação, v. 16, n.2, 2010, p. 427-445.

CONTRERAS, J. A autonomia de professores. Tradução: Sandra Trabucco Valenzuela. São Paulo: Cortez, 2002.

DANIELS. H. Vygotsky e a pedagogia. São Paulo: Edições Loyola, 2003.

DAVIDOV, V. V. Problemas do ensino desenvolvimental - a experiência da pesquisa teórica e experimental na psicologia. Tradução: José Carlos Libâneo e Raquel A. M. da Madeira Freitas. Moscou: Editorial Progreso, 1988.

DAVIDOV, V.; MARKOVA, S. La concepcion de la actividad de estúdio de los escolares. In: La psicologia evolutiva y pedagógica en la URSS. Moscú: Editorial Progreso, 1987.

DAVIS, C. Piaget ou Vygotsky: uma falsa questão. Viver Mente \& Cérebro - Coleção Memória da Pedagogia - Lev Semenovich Vygotsky: uma educação dialética. São Paulo, v. 2, p. 38-49, 2005.

DINIZ-PEREIRA, J. E. O ovo ou a galinha: a crise da profissão docente e a aparente falta de perspectiva para a educação brasileira. Revista Brasileira de Estudos Pedagógicos. Brasília, v.92, n. 230, jan./abr. 2011. p. 34-51.

ENGESTRÖM, Y. Learning by expanding: an activity-theoretical approach to developmental research. Helsinki: Orienta-Konsultit, 1987. 
ENGESTROM, Y. Activity theory and individual and social transformation. In: ENGESTROM, Y et al. Perspectivies on activity theory. 3 Ed. New York: Cabridge University Press, 1999. p. 19-38.

ENGESTRÖM, Y.Activity theory and the social construction of knowledge: a story of four umpires. San Carlos: University of California and the Academy of Finland, 2000. Online version: http://org.sagepub.com/content/7/2/301. Acesso em: 09 Out. 2014.

ESTEVE, J. M. Mudanças sociais e função docente. In: NOVOA, A., et al. (ORG.) Profissão professor. Porto: Porto Editora, 1999, p.93-124.

EZPEletA, J. e ROCKWELl, E. Pesquisa Participante. São Paulo: Cortez Autores Associados, 1986.

FACCI, M. G. D. Da apropriação da Cultura ao processo de humanização: o desenvolvimento das funções psicológicas superiores. Anais. II Encontro Brasileiro de Educação e Marxismo. Curitiba. 2006.

FOUREZ, G. Crise no ensino de ciências? Investigações em ensino de ciências, Porto Alegre, v.8, n. 2, p. 109-123, ago. 2003. Disponível em: <http://www.if.ufrgs.br/ienci/artigos/ Artigo_ID99/v8_n2_a2003.pdf>. Acesso em: 3 Set. 2011.

FREIRE, P. Pedagogia da Autonomia: saberes necessários à prática educativa. São Paulo: Paz e Terra, 1996.

FREIRE, P. Conscientização: teoria e prática da libertação: uma introdução ao pensamento de Paulo Freire. São Paulo: Centauro, 2001.

FURLANETTO, F. R. O movimento de mudança de sentido pessoal na formação inicial do professor. Tese (Doutorado em Ensino de Ciências e Matemática) - Faculdade de Educação, Universidade de São Paulo, São Paulo, 2013.

GALINDO, M. A. O professor da escola básica e o estágio supervisionado: sentidos atribuídos e a formação inicial docente. Tese (Doutorado em Ensino de Ciências e Matemática) - Faculdade de Educação, Universidade de São Paulo, São Paulo, 2012. 
GAMBA, L., M. F. Formação continuada de professores na perspectiva históricocultural: reflexões a partir de uma experiência na educação infantil. Dissertação (Mestrado, Área de Concentração: Ensino na Educação Brasileira) - Faculdade de Filosofia e Ciências da Universidade Estadual Paulista “Júlio de Mesquita Filho”, Marília, SP, 2009.

GHEDIN, E. Professor reflexivo: da alienação da técnica à autonomia da crítica. In: PIMENTA, S. G.; GHEDIN, E. (ORG.). Professor reflexivo no Brasil: gênese e crítica de um conceito. São Paulo: Cortez, 2010.

GHEDIN, E.; ALMEIDA, W. A. de. O estágio com pesquisa na formação do professorpesquisador para o ensino de ciências numa experiência camponesa. In: GOMES, M. de O. (ORG.) Estágios na formação de professores: possibilidades formativas entre ensino, pesquisa e extensão. São Paulo: Edições Loyola, 2011.

GIGLIO, C. M. B., et al. Residência pedagógica: diálogo permanente entre a formação inicial e a formação contínua de professores e pedagogos. In: GOMES, M. de O. (ORG.) Estágios na formação de professores: possibilidades formativas entre ensino, pesquisa e extensão. São Paulo: Edições Loyola, 2011.

GIMENO SACRISTÁN, J. Consciência e acção sobre a prática como libertação profissional dos professores. In: In NÓVOA, A. (ORG.). Profissão professor. Porto: Porto Editora, 1995. p. 64-92.

GOES, M. C. R. A abordagem microgenética na matriz histórico-cultural: Uma perspectiva para o estudo da constituição da subjetividade. Cadernos Cedes, ano XX, nº 50, Abril, 2000.

HEEMANN, C. A formação de uma comunidade virtual de aprendizagem sob a perspectiva da teoria da atividade. 259 f. Tese (Doutorado em Linguística Aplicada) Programa de Pós-Graduação em Letras, Universidade Católica de Pelotas, Pelotas, 2011.

HOBOLD, M. de S.; MENSLIN, M. S. A implicação do trabalho do formador na constituição da profissionalidade dos licenciados [I] The implication of trainer's work in the constitution of professionalism of licensed teachers Revista Diálogo Educacional, Curitiba, v. 12, n. 37, set./dez. 2012. p. 783-801. 
IANUSKIEWTZ, A. D. Significado social e sentido pessoal da atividade docente do professor de inglês da escola pública. 2009. 161 f. Dissertação (Mestrado em Linguística) Centro de Educação e Ciências Humanas, Universidade Federal de São Carlos, São Carlos, 2010.

IMBERNÓN, F. Formação Docente e Profissional: formar-se para mudança e a incerteza. 8. ed. São Paulo: Cortez, 2010.

KOSTIUK, G. S. Alguns aspectos da relação recíproca entre educação e desenvolvimento da personalidade. In: LEONTIEV, A. et al. Psicologia e pedagogia: bases psicológicas da aprendizagem e do desenvolvimento. Tradução de Rubens Eduardo Frias. São Paulo: Centauro, 2005. p.43-62.

LEONTIEV, A. N. O desenvolvimento do psiquismo. Lisboa: Livros Horizonte LDA, 1978.

LEONTIEV, A. N. Actividade, consciência e personalidad. Havana: Edições Pueblo Y Educación, 1983.

LEONTIEV, A. N. Uma contribuição à teoria do desenvolvimento da psique infantil. In: VYGOTSKY, L. S. Linguagem, desenvolvimento e aprendizagem. São Paulo: Icone, 2006, p. 59-83.

LIBÂNEO, J. C. Adeus professor, adeus professora? novas exigências educacionais e profissão docente. São Paulo: Cortez, 2010.

LIBÂNEO, J. C. A aprendizagem escolar e a formação de professores na perspectiva da psicologia histórico-cultural e da teoria da atividade. Educar em Revista, Curitiba, n. 24, p. 113-147, 2004. Disponível em: <http://ojs.c3sl.ufpr.br/ojs2/index.php/educar/article/view/2211/1854>. Acesso em: 07 Mar. 2013.

LIBÂNEO, J. C.; FREITAS, R. A. M. M. Vygotsky, Leontiev, Davidov - três aportes teóricos para a teoria histórico-cultural e suas contribuições para a didática. In: CONGRESSO BRASILEIRO DE HISTÓRIA DA EDUCAÇÃO, 4. 2006, Goiânia. Anais 
eletrônicos...Goiânia: $\quad$ SBHE, $2006 . \quad$ Disponível em: <http://www.sbhe.org.br/novo/congressos/cbhe4/ Acesso em: 08 Mar, 2013.

LIMA, M. E. C. de C. Sentidos do trabalho: a educação continuada de professores. Belo Horizonte: Autêntica, 2005.

LUCCI, M. A. A proposta de Vygotsky: a psicologia sócio-histórica. Profesorado: Revista de currículum y formación del profesorado, v. 10, n. 2, 2006. Disponível em: <http://www.ugr.es/ recfpro/rev102COL2port.pdf>. Acesso em: 15 Mai. 2013.

LÜDKE, M.; ANDRÉ, M.E.D.A. Pesquisa em Educação: abordagens qualitativas. São Paulo: EPU, 2013.

LURIA, A. R. Vigotskii. In: VIGOTSKII, L. S., LURIA, A. R., LEONTIEV, A. N. Linguagem, desenvolvimento e aprendizagem. Trad. VILLALOBOS, M. P. São Paulo: Ícone, 2006.

MARTINELI, T. A. P.; LOPES, S. M. A. Vasili V. Davidov: a concepção materialista histórica e dialética como método de análise da psicologia contemporânea. Cadernos da Pedagogia, ano 3, v.1, n.5, jan/jul, 2009.

MARTINS, L. M. Análise sócio-histórica do processo de personalização de professores. Tese (Doutorado - Programa de Pós-graduação em Educação), Faculdade de Filosofia e Ciências, UNESP. Marília, 2001.

MARTINS, L. M. A natureza histórico-social da personalidade. In: A psicologia de A. N. Leontiev e a educação na sociedade contemporânea. São Paulo: Cortez, Cadernos CEDES, Campinas, v.24, n. 62, 2004. p 82-99.

MARTINS, L. M. A personalidade do professor e a atividade educativa. In: FACCI, M. G. D.; TULESKI, S. C.; BARROCO, S. M. S. (Org.). Escola de Vigotski: contribuições para a psicologia e a educação. Maringá: Eduem, 2009. p 135-150.

MARTINS, L. M. O desenvolvimento do psiquismo e a educação escolar: contribuições à luz da Psicologia histórico cultural e da Pedagogia histórico-crítica. Tese (Livre-docência) 
- Departamento de Psicologia, Universidade Estadual Paulista "Júlio de Mesquita Filho", Bauru, 2011.

MEIRA, L. Análise microgenética e videografia: ferramentas de pesquisa em psicologia cognitiva. Temas em Psicologia, n. 3, 1994.

MOLON, S. I. Questões metodológicas de pesquisa na abordagem sócio-histórica. Informática na Educação:teoria \& prática, Porto Alegre, v.11, n.1, jan./jun, 2008.

MORETTI, V. D. Professores de matemática em atividade de ensino: uma perspectiva histórico-cultural para a formação docente. Tese (Doutorado em Ensino de Ciências e Matemática), Faculdade de Educação, Universidade de São Paulo, São Paulo, 2007.

MOURA, M. O. de (ORG.). O estágio na formação compartilhada do professor: retratos de uma experiência. São Paulo: FEUSP, 1999.

MOURA, M. O. de. Pesquisa colaborativa: um foco na ação formadora. In: BARBOSA, R. L. L. (ORG.) Trajetórias e perspectivas da formação de educadores. São Paulo: UNESP, 2004, p.257-284.

MOURA, M. O. et al. A Atividade orientadora de ensino como unidade entre ensino e aprendizagem. In: MOURA, M. O. (ORG.). A atividade pedagógica na teoria históricocultural. Brasília: Liber Livro, 2010, p. 81-109. n27, ano 1.pdf>. Acesso em: 7 Mar. 2013.

NASCIMENTO, C. P. A organização do ensino e a formação do pensamento estéticoartístico na teoria histórico-cultural. Dissertação (Mestrado em Ensino de Ciências e Matemática) - Faculdade de Educação, Universidade de São Paulo, São Paulo, 2010.

NÓVOA, A. Formação de professores e profissão docente. In: NÓVOA, A. (ORG.). Os professores e sua formação. Lisboa: Publicações Dom Quixote, 1992, p.13-33.

NUÑEZ, I. B. Vygotsky, Leontiev, Galperin: formação de conceitos e princípios didáticos. Brasília: Liber Livros, 2009. 
OLIVEIRA, M. K. Vygotsky e o processo de formação de conceitos. In: LA TAILLE, Y.; OLIVEIRA, M. K.; DANTAS, H. Piaget, Vygotsky, Wallon: teorias psicogenéticas em discussão. São Paulo: Summus, 1992.

OLIVEIRA, M. K. Vigotsky: aprendizado e desenvolvimento, um processo sóciohistórico. São Paulo: Scipione, 1993.

OLIVEIRA, M. K. de; TEIXEIRA, E. A questão da periodização do desenvolvimento psicológico. In: OLIVEIRA, M. K. de; SOUZA, D. T. R.; REGO, T. C. Psicologia, educação e as temáticas da vida contemporânea. São Paulo: Moderna, 2002.

OLIVEIRA, M. K. História, consciência e educação. Viver Mente \& Cérebro - Coleção Memória da Pedagogia - Lev Semenovich Vygotsky: uma educação dialética. São Paulo, v. 2, p. 6-13, 2005.

OLIVEIRA, M. K. de; TEIXEIRA, E. A questão da periodização do desenvolvimento psicológico. In OLIVEIRA, M. K. de. Cultura e psicologia: questões sobre a psicologia do adulto. São Paulo: Hucitec, 2009, p.331-359.

OLIVEIRA, M. K.; REGO, T. C. Revolucionário inquieto. In: REGO, T. C. (Org.) Lev Vigotski. História da Pedagogia, Revista Educação, v.2, São Paulo: Segmento, 2010.

OLIVEIRA, Z. de M. R. de. Jogo de papéis: um olhar para as brincadeiras infantis. São Paulo: Cortez, 2011.

PALMA, R. C. D.; MOURA, A. L. Formação inicial de professores e a produção de sentidos sobre o aprender e ensinar matemática. Revista Educação Pública, Cuiabá, v. 21, n. 47, , set./dez, 2012. p. 639-659

PARO, V. H. Educação com exercício do poder: crítica ao senso comum em educação. São Paulo: Cortez, 2010. 
PIMENTA, S. G. Professor reflexivo: construindo uma crítica. In: PIMENTA, S. G.; GHEDIN, E. (Org). Professor reflexivo no Brasil: gênese e crítica de um conceito. 6. ed. São Paulo: Cortez, 2010.

PIMENTA, S. G.; LIMA, M. S. L. Estágio e docência. 7 ed. São Paulo: Cortez, 2012.

PINO, A. O biológico e o cultural nos processos cognitivos. In: MORTIMER, E. F.; SMOLKA, A. L. B. (ORG.). Linguagem, Cultura e Cognição: reflexões para o ensino e a sala de aula. Belo Horizonte: Autêntica, 2001, pp. 21-50.

POZO, J. I.; CRESPO, M. A. G. A aprendizagem e o ensino de ciências: do conhecimento cotidiano ao conhecimento científico. 5. ed. Porto Alegre: Artmed, 2009.

REGO, T. C. Vygotsky: uma perspectiva histórico-cultural da educação. Petrópolis: Vozes, 1995. $138 \mathrm{p}$.

RIBEIRO, F. D.. A aprendizagem da docência na prática de ensino e no estágio: contribuições da teoria da atividade. Tese (Doutorado em Ensino de Ciências e Matemática) - Faculdade de Educação, Universidade de São Paulo, São Paulo, 2011.

RIBEIRO, F. D.; MOURA, M. O. de. A reflexão no processo formativo em prática de ensino e no estágio: contribuições da teoria da atividade. In: XVI ENCONTRO NACIONAL DE DIDÁTICA E PRÁTICAS DE ENSINO, 2012, Campinas. Disponível em: < http://www.infoteca.inf.br/endipe/smarty/templates/arquivos_template/upload_arquivos/acerv o/docs/2300b.pdf> Acesso em: 13 Mai. 2014.

RIGON, A. J; ASBAHR, F. S. F.; MORETTI, V. D. Sobre o processo de humanização. In: MOURA. M. O. (ORG.). A atividade pedagógica na teoria histórico-cultural. Brasília: Liber Livros, 2010a. p.13-44.

RIGON, A. J. ASBAHR, F. S. F.; MORETTI, V. D. O desenvolvimento psíquico e o processo educativo. In: MOURA. M. O. (ORG.). A atividade pedagógica na teoria históricocultural. Brasília: Liber Livros, 2010b. p.45-66. 
RODRIGUES, A. M. Movimento e contradição: a disciplina de práticas de ensino de Física e a formação inicial de professores de Física sob uma perspectiva históricocultural. Tese (Doutorado em Ensino de Física) - Faculdade de Educação, Instituto de Física, Instituto de Química e Instituto de Biociências, Universidade de São Paulo, São Paulo, 2013.

ROSSETI-FERREIRA, M. C.; AMORIN, K. de S.; SILVA, A. P. S. da; CARVALHO, A. M. A. (ORG.). Rede de significações: o estudo do desenvolvimento humano. Porto Alegre: Artmed, 2004.

RUBTSOV, V. A atividade de aprendizado e os problemas referentes a formação do pensamento teórico dos escolares. In: GARNIER, C.; BEDNARZ, N.; ULANOVSKAYA, I. (ORG.) Após Vygotsky e Piaget: perspectiva social e construtivista russa e ocidental. Porto Alegre: Artes Médicas, 1996.

SASSERON, L. H.; CARVALHO, A. M. P. Uma análise de referenciais teóricos sobre a estrutura do argumento para estudos de argumentação no ensino de ciências. Revista Ensaio. Belo Horizonte, v.13, n.03, set-dez, 2011a. p.243-262.

SASSERON, L. H.; CARVALHO, A. M. P. Alfabetização Científica: uma revisão bibliográfica. Investigação em Ensino de Ciências, v.16, n.1, 2011b. p.59-77.

SAVIANI, D. Pedagogia histórico-crítica. 8 ed. Campinas, SP: Autores Associados, 2003.

SCHNORR, G. M. Diferentes olhares sobre a obra de Paulo Freire: Pedagogia do oprimido. In: Paulo Freire, vida e obra. São Paulo: Expressão Popular, 2001. P. 69-100.

SEMENOVA, M. A formação teórica e científica do pensamento dos escolares. In: GARNIER, C.; BEDNARZ, N.; ULANOVSKAYA, I. (ORG.) Após Vygotsky e Piaget: perspectivas social e construtivista, escolas russas e ocidental. Porto Alegre: Artes Médicas, 1996.

SFORNI, M.S. de F. Aprendizagem conceitual e organização do ensino: contribuições da teoria da atividade. Tese (Doutorado em Educação). Faculdade de Educação, Universidade de São Paulo, 2003. 
SILVA FILHO, A. L., LOPES, F. M. N.; CAVALCANTE, M. M. D. a Dimensão ontológica da trilogia ensino, pesquisa e extensão no estágio supervisionado. In: GOMES, M. de O. Estágios na formação de professores: possibilidades formativas entre ensino, pesquisa e extensão. São Paulo: Loyola, 2011. p. 135-164.

SILVA, G. dos S. F. da. A formação de professores de física na perspectiva da teoria da atividade: análise de uma disciplina de práticas em ensino e suas implicações para a codocência. Tese (Doutorado em Ensino de Física) - Faculdade de Educação, Instituto de Física, Instituto de Química e Instituto de Biociências, Universidade de São Paulo, São Paulo, 2013.

SILVESTRE, M. A. Sentidos e significados dos estágios curriculares obrigatórios: a fala do sujeito aprendente. In: GOMES, M. de O. Estágios na formação de professores: possibilidades formativas entre ensino, pesquisa e extensão. São Paulo: Loyola, 2011. p. 165185.

SMOLKA, A. L. B.; LA PLANE, A. L. F. de; NOGUEIRA, A. L. H.; BRAGA, E. dos S. As relações de ensino na escola: por que falar em relações de ensino? Discutindo os pressupostos. Rio de Janeiro, Secretaria Municipal de Educação, Série Temas em Debate 2007.

SMOLKA, A. L. O (im)próprio e o (im)pertinente na apropriação das práticas sociais. Caderno Cedes, ano XX, n. 50, 2000.

TOASSA, G. Emoções e vivências em Vigotski. Campinas, SP: Papirus, 2011.

TORRIGLIA, P. L.; CISNE, M. F. O papel da atividade como prioridade ontológica no processo de produção/apropriação do conhecimento. In: COLÓQUIO INTERNACIONAL MARX E ENGELS, 7., 2012, Campinas. Anais eletrônicos... Campinas: UNICAMP, 2012. Disponível em: <http://www.ifch.unicamp.br/formulario_cemarx/selecao/2012/ trabalhos/7251_Torriglia_Patricia.pdf>. Acesso em: 26 Abr. 2013.

VIGOTSKI, L. S. A formação social da mente: o desenvolvimento dos processos psicológicos superiores. São Paulo: Martins Fontes, 1994. 
VIGOTSKI, L. S. O problema da consciência. In: Teoria e método em Psicologia. Trad. C. Berliner. São Paulo: Martins Fontes, 1996.

VIGOTSKI, L. S. A formação social da mente: o desenvolvimento dos processos psicológicos superiores. São Paulo: Martins Fontes, 2007.

VIGOTSKI. A construção do pensamento e da linguagem. São Paulo: WMF Martins Fontes, 2009.

VIGOTSKI. Psicologia pedagógica. São Paulo: WMF Martins Fontes, 2010a.

VIGOTSKI, L. S. Quarta aula: a questão do meio na pedologia Trad. VINHA, Márcia Pileggi. Psicol. USP [online], vol.21, n.4, 2010b. p. 681-701. http://dx.doi.org/10.1590/S0103-65642010000400003.

VYGOTSKI, L. S. La psicología y la teoría de la localización de las funciones psíquicas. In: VYGOTSKI, L. S. Obras Escogidas, Tomo 1. Madri: Machado Grupo de Distribuición, 2013. pp.133-139.

YIN, R. K. Estudo de Caso: planejamento e métodos. Trad. Ana Thorell. 4 ed. Porto Alegre: Bookman, 2010.

ZEICHNER, K. M.; TABACHINICK, B. R. Influencias individuales y contextuales en las relaciones entre las creencias del profesor y su conducta de clase: estudios de caso de dos profesores principiantes de Estados Unidos. Universidad de Wiscosin Madison - Estados Unidos, 1998. 
Anexos 


\section{Anexo A - Cronograma da disciplina Metodologia do Ensino de Física com o programa por aula.}

Metodologia do Ensino de Física I

O curso está organizado em 3 eixos temáticos cujas discussőes se entrecruzarão ao longo do curso:

Eixo A - Re-conhecendo a sala de aula de Física: Discussōes centradas nos elementos que cerceiam a organizaçăo do trabalho em sala de aula, tais como: documentos oficiais; currículo; representaçðes sobre ensino e aprendizagem; representações sobre Fisica.

Eixo B - Planejando intervençöes para a sala de aula: Pressupõe as discussões acerca de como organizar o ensino de Física.

Eixo C - Analisando intervençőes em sala de aula: $O$ que está acontecendo na sala de aula? Tendo como pressupostos as discussōes anteriores, voltaremos aos modos de observar o que, de fato, ocorre em sala de aula $e$ as interaçőes que ali acontecem.

Programa preliminar do curso:

\begin{tabular}{|c|c|c|c|c|}
\hline Aula & Data & Tema & Texto para discussāo & $\begin{array}{l}\text { Atividade de estagio a } \\
\text { ser realizada na semana }\end{array}$ \\
\hline 1 & $27 / 02$ & $\begin{array}{l}\text { Para que ensinar Fisica? Concepçöes } \\
\text { sobre ensino e sobre ciências }\end{array}$ & $1 \therefore$ & $\begin{array}{l}\text { Entrevista com egressos } \\
\text { do EM }\end{array}$ \\
\hline 2 & $06 / 03$ & $\begin{array}{l}\text { Concepça de cièncias e cientistas } \\
\text { Por que ensinar Fisica?; O que } \\
\text { ensinar sobre Fisica? }\end{array}$ & $\begin{array}{l}\text { Visoes de clénclas e sobre } \\
\text { cientistas entre estudantes do } \\
\text { Ensino Medio, Luis Kosminsky e } \\
\text { Marcelo Giordan }\end{array}$ & $\begin{array}{l}\text { Leitura e análise do PPP } \\
\text { da escola }\end{array}$ \\
\hline 3 & $13 / 03$ & Salas de aula de Fisica & $\begin{array}{l}\text { Por dentro de uma aula de Fisica, } \\
\text { Adelson Fernandes Moreira e Oto } \\
\text { Borges }\end{array}$ & $\begin{array}{l}\text { Análise de interaçōes em } \\
\text { sala de aula }\end{array}$ \\
\hline 4 & $20 / 03$ & Alfabetizaçăo Científica & $\begin{array}{l}\text { Alfabotizacilo Clentifica e } \\
\text { documontos oficlals brasilelros: } \\
\text { um dillogo ma estruturaçio do } \\
\text { Ensino da Fislca. Lúcia Helena } \\
\text { Sasseron }\end{array}$ & $\begin{array}{l}\text { Materiais didáticos } \\
\text { utilizados }\end{array}$ \\
\hline & $27 / 03$ & Semana Santa & & \\
\hline & $03 / 04$ & $\begin{array}{l}\text { Curriculo de Flsica: livros e propostas } \\
\text { didáticas } \\
\text { Contextualizacăo }\end{array}$ & & \\
\hline 6 & $10 / 04$ & Problemas abertos $\mathrm{X}$ exercicios & $\begin{array}{l}\text { Questionando didatica da } \\
\text { resoluçlo do problemas, Daniel } \\
\text { Gil Perez e colaboradores }\end{array}$ & Entrega de RO \\
\hline 7 & $17 / 04$ & $\begin{array}{l}\text { Ensino por investigaçăo: } \\
\text { pressupostos }\end{array}$ & $\begin{array}{l}\text { Ensino por investigaça: em que } \\
\text { estamos de acordo?. Marla Emilia } \\
\text { Caixeta o Danusa Munford }\end{array}$ & \\
\hline 8 & $24 / 04$ & Planejamento de atividade de estagio & & \\
\hline & $01 / 05$ & Feriado & & \\
\hline 9 & $08 / 05$ & $\begin{array}{l}\text { Apresentaçăo de proposta de } \\
\text { atividade de estagio }\end{array}$ & $1 \therefore$ & \\
\hline 10 & $15 / 05$ & $\begin{array}{l}\begin{array}{l}\text { Apresentaçăo de proposta de } \\
\text { atividade de estagio }\end{array} \\
\end{array}$ & & Entrega de PE \\
\hline 11 & $22 / 05$ & Ensino por investigaçăo: SEI & $\begin{array}{l}\text { Ensino aprendizagem de } \\
\text { clinclas: referencials tebricos } \\
\text { dados empirtcos des SEls, Anna } \\
\text { Maria Pessos de Carvalho } \\
\end{array}$ & $\begin{array}{l}\text { Implementaçăo } \\
\text { proposta }\end{array}$ \\
\hline 12 & $29 / 05$ & Matematizaçăo em aulas de Fisica & $\begin{array}{l}\text { Construindo a linguagem grafica em } \\
\text { uma aula experimental de Fisica, } \\
\text { Alex Bellucco e Anna Maria P de } \\
\text { Carvalho }\end{array}$ & $\begin{array}{l}\text { Implementaçăo } \\
\text { proposta }\end{array}$ \\
\hline 13 & $05 / 06$ & $\begin{array}{l}\text { O papel do professor na promoçắo de } \\
\text { interaços }\end{array}$ & $\begin{array}{l}\text { Interafóses discursivas } \\
\text { investigagijo om sala de aula: } 0 \\
\text { papel do professor, Lúcia Helena } \\
\text { Sasseron }\end{array}$ & $\begin{array}{l}\text { Implementaçào } \\
\text { proposta }\end{array}$ \\
\hline 14 & $12 / 06$ & Apresentacăo dos painéis & & \\
\hline 15 & $19 / 06$ & Avallaça ino individual & & \\
\hline 16 & $26 / 06$ & $\begin{array}{l}\text { Entrega de trabalhos/avaliaçăo dos } \\
\text { alunos }\end{array}$ & & \\
\hline
\end{tabular}


Parte II - $\mathbf{2}^{\mathbf{0}}$ semestre (em andamento)

\section{Metodologia do Ensino de Física II}

Dando continuidade as discussరes realizadas ao longo das aulas de Melodologia do Ensino de Física I, neste curso buscaremos açठes práticas mais diretas em sala de aula. Planejamento, implementação e análise/avaliaçăo de situaç̋̋es de ensino serão o foco de nossas atividades.

Programa preliminar do curso:

\begin{tabular}{|c|c|c|c|c|}
\hline Aula & Data & Tema & Atividade em sala de aula & Atlividade de estágio \\
\hline 1 & 07108 & Retomada do curso MEF1 & & $\begin{array}{l}\text { Levantamento dos } \\
\text { conteúdos que já } \\
\text { foram trabalhados na } \\
\text { turma em que } \\
\text { estaglaráo }\end{array}$ \\
\hline 2 & $14 / 08$ & Problematizaçăo e contextualizaçăo & $\begin{array}{l}\text { Texto "Problematizaçăo e e } \\
\text { contextualizaçấo no Ensino de } \\
\text { Flsica", Elio Carlos Ricardo }\end{array}$ & $\begin{array}{l}\text { Proposta } \text { de } \\
\text { problematizaçăo } \\
\text { sobre oo tema: } \\
\text { Atmosfera } \\
\end{array}$ \\
\hline 3 & $21 / 08$ & $\begin{array}{l}\text { Historia e Filosofia da Ciencla na } \\
\text { sala de aula }\end{array}$ & $\begin{array}{l}\text { Texto "Por uma Imagem năo } \\
\text { deformada do } \\
\text { cientifico", Daniel Gil Pérez e } \\
\text { colaboradores }\end{array}$ & \\
\hline 4 & $28 / 08$ & $\begin{array}{l}\text { Apresentaça das propostas do } \\
\text { problematizaçao/contextualizaçáo }\end{array}$ & & \\
\hline & $04 / 09$ & Semana da Pátria & & \\
\hline 5 & $11 / 09$ & $\begin{array}{l}\text { Abordagem ternatica freireana } 00 \\
\text { Ensino por Investigaça }\end{array}$ & & \\
\hline 8 & $18 / 09$ & $\begin{array}{l}\text { Apresentaça do levantamento } \\
\text { prévio } \\
\text { Elaboraçăo da proposta de estagio }\end{array}$ & & $\begin{array}{l}\text { Elaboraçáo da } \\
\text { proposta de estágio }\end{array}$ \\
\hline 7 & $25 / 09$ & $\begin{array}{l}\text { Apresentaça da proposta de } \\
\text { estâgio }\end{array}$ & & \\
\hline 8 & $02 / 10$ & $\begin{array}{l}\text { Apresentaça da proposta de } \\
\text { estágio }\end{array}$ & $\begin{array}{l}\text { Entrega da versâa final da } \\
\text { proposta de estágio }\end{array}$ & $\begin{array}{l}\text { Implementaçăo da } \\
\text { proposta de estágio }\end{array}$ \\
\hline 9 & $09 / 10$ & $\begin{array}{l}\text { Interaçes didaticas: aluno-aluno, } \\
\text { aluno-professor }\end{array}$ & $\begin{array}{l}\text { Texto "Los profesores de } \\
\text { ciencias como profesores de } \\
\text { lenguaje", Clive Sutton } \\
\text { Apresentaçao de trecho da aula: } \\
\text { Grupos } 1 \text { e } 2\end{array}$ & $\begin{array}{l}\text { Implementaçăo da } \\
\text { proposta de estágio }\end{array}$ \\
\hline 10 & $18 / 10$ & $\begin{array}{l}\text { Interaçoes didáticas: material } \\
\text { didático }\end{array}$ & $\begin{array}{l}\text { Apresentaçáo de trecho de aula: } \\
\text { Grupos } 3 \text { e } 4\end{array}$ & $\begin{array}{l}\text { Implementaçào da } \\
\text { proposta de estágio }\end{array}$ \\
\hline 11 & $23 / 10$ & $\begin{array}{l}\text { Avaliaçâ: um olhar geral: provas } \\
\text { externas Saresp. Saeb, Prova } \\
\text { Brasil, PISA }\end{array}$ & $\begin{array}{l}\text { Texto sobre avaliaçáo } \\
\text { Apresentaça de drecho da aula: } \\
\text { Grupos } 5 \text { e } 6\end{array}$ & $\begin{array}{l}\text { Implementaçăo da } \\
\text { proposta de estágio }\end{array}$ \\
\hline 12 & $30 / 10$ & $\begin{array}{l}\text { Avaliaça: um olhar especifico: } \\
\text { provas externas Saresp, Saeb, } \\
\text { Prova Brasil, PISA }\end{array}$ & $\begin{array}{l}\text { Apresentaça do trecho da aula: } \\
\text { Grupos } 7 \text { e } 8\end{array}$ & $\begin{array}{l}\text { Implementaçăo da } \\
\text { proposta de estágio }\end{array}$ \\
\hline 13 & $06 / 11$ & $\begin{array}{l}\text { Avaliaçao pedagogica: a reflexalo do } \\
\text { professor }\end{array}$ & $\begin{array}{l}\text { Apresentacalo de trecho da aula: } \\
\text { Grupos } \theta \text { e } 10\end{array}$ & $\begin{array}{l}\text { Implementaçăo da } \\
\text { proposta de estágio }\end{array}$ \\
\hline & 13/11 & Nao havera aula & & \\
\hline 14 & $20 / 11$ & $\begin{array}{l}\text { Avaliaçoes do ensino de Flsica: } \\
\text { atividades e conteúdo }\end{array}$ & $\begin{array}{l}\text { Entrega da análise da } \\
\text { implementaçăo da proposta de } \\
\text { estágio }\end{array}$ & \\
\hline 15 & $27 / 11$ & Avaliaçäo Individual & & \\
\hline 16 & $04 / 12$ & $\begin{array}{l}\text { Devoluçâo dos trabalhos aos } \\
\text { alunos; entreqa de médias }\end{array}$ & & \\
\hline
\end{tabular}




\section{Apêndices}




\section{Apêndice A}

\section{Questionário 1, aplicado aos alunos da disciplina de Metodologia do Ensino de Física.}

\begin{tabular}{|c|c|}
\hline $\begin{array}{l}\text { Non } \\
\text { Idac }\end{array}$ & $\begin{array}{l}\text { Universidade de São Paulo - Faculdade de Educação } \\
\text { Metodologia do Ensino de Física I } \\
\text { Dados para Pesquisa de Doutorado }\end{array}$ \\
\hline 1 & $\begin{array}{l}\text { Você cursou o Ensino Fundamental em escola: } \\
\begin{array}{lll}\text { ( ) Pública } & (\text { ） Particular } \quad(\quad) \text { Outra Qual? }\end{array}\end{array}$ \\
\hline 2 & $\begin{array}{l}\text { Você cursou o Ensino Médio em escola: } \\
\begin{array}{llll}\text { ( ) Pública } & (\text { ) Técnica } & (\text { ) Particular } & (\text { ) Outra Qual? }\end{array}\end{array}$ \\
\hline 3 & $\begin{array}{l}\text { Licenciatura em Física é sua } 1^{a} \text { graduação? } \\
\text { Em caso negativo qual a(as) outra(s)? }\end{array}$ \\
\hline 4 & O que o(a) levou a escolher o curso de Física? Justifique. \\
\hline 5 & O que o(a) levou a escolher a Licenciatura em Físisca? Justifique. \\
\hline 6 & $\begin{array}{l}\text { Você trabalha? } \quad(\quad) \operatorname{sim} \quad(\quad) \text { não } \\
\text { Qual sua profissão? }\end{array}$ \\
\hline 7 & O que você pretende fazer depois de terminar a graduação? Justifique. \\
\hline 8 & Você pretende ser professor(a) do Ensino Médio? Justifique. \\
\hline 9 & $\begin{array}{l}\text { Quanto tempo você julga que falta para finalizar sua Licenciatura em Física? } \\
\text { Quantas disciplinas faltam para você finalizar sua Licenciatura em Física? Quais? }\end{array}$ \\
\hline 10 & $\begin{array}{l}\text { Você já cursou Prática em ensino de Física? } \quad(\quad) \operatorname{sim} \quad(\quad) \text { não } \\
\text { Em caso afirmativo indique o ano? }\end{array}$ \\
\hline
\end{tabular}

Eu autorizo a utilização dos dados acima para pesquisa preservando minha identidade. 


\section{Questionário 2, aplicado aos alunos da disciplina de Metodologia do Ensino de Física.}

\section{Questionário2}

Nome:

e-mail:

1. Como a disciplina de Metodologia do Ensino de Física contribuiu para sua formação para docência? Quais os aspectos relevantes que você destacaria para essa formação?

2. Como o estágio contribuiu para sua formação para docência? Quais os aspectos relevantes que você destacaria para essa formação? Quais as dificuldades enfrentadas?

3. Como você pensa a escola e os(as) alunos(as) hoje, com base nas ações desenvolvidas na disciplina e no estágio? Houve alguma alteração em relação à sua visão anterior?

4. Como o contato com o(a) professor(a) da escola e alunos(as) colaboraram para a sua formação para a docência?

5. Quais as contribuições do estágio para com a escola, com o(a) professor(a) e com os(as) alunos(as)?

6. Quais os pontos mais importantes que você considera para ser professor(a)?

7. Comentários e sugestões. 


\section{Apêndice B}

Entrevista Semi Estruturada $1\left(1^{\circ}\right.$ semestre de 2013)

\section{Licenciando(a) de Metodologia do Ensino de Física}

Nome

1. Idade

2. Como foi sua vida escolar no Ensino Fundamental e Médio?

3. Quando se interessou por Física?

4. Como comenta seu curso de Física?

5. Como se interessou em fazer licenciatura para ser professor(a)? Quais as influências que teve?

6. Quais os pontos mais importantes que você considera para ser professor(a)?

7. Como você pensa a escola e os alunos?

8. Como pensa que a disciplina de Metodologia para o Ensino de Física e o Estágio com Regência podem colaborar (ou colaboram) para a sua formação como professor(a)?

9. Como o contato com o(a) professor(a) da escola e alunos podem colaborar (ou colaboram) para a sua formação como professor(a)?

10. Em que o estágio pode colaborar (ou colabora) com a escola, com o(a) professor(a) e com alunos?

11. Você se sente preparado para docência?

12. Após formado vai exercer a docência?

13. Outros comentários 
Entrevista Semi Estruturada $2\left(2^{\circ}\right.$ semestre de 2013)

\section{Licenciando(a) de Metodologia do Ensino de Física}

Nome

1. Como a disciplina MEF contribuiu para sua formação como professor? Quais os aspectos relevantes que você destacaria para sua formação?

2. Que ações foram mais significativas para você em MEF? Por quê?

3. Como o estágio contribuiu para sua formação como professor? Quais os aspectos relevantes que você destacaria para sua formação?

4. Que ações foram mais significativas para você no estágio? Por quê?

5. Como você se sentiu na sala de aula?

6. Como você pensa a escola e os alunos? Com base nas ações desenvolvidas na disciplina e no estágio houve alguma alteração em sua relação com a escola e os alunos?

7. Em que o estágio pode colaborar (ou colabora) com a escola, com o(a) professor(a) e com alunos?

8. Como o contato com o(a) professor(a) da escola e alunos colaboraram para a sua formação como professor(a)?

9. Quais os pontos mais importantes que você considera para ser professor(a)?

10. Você se sente preparado para docência?

11. Outros comentários 


\section{Apêndice C}

\section{Transcrições das entrevistas 1 de Heloisa e Ricardo}

\section{Entrevista 1 com Ricardo}

Pesquisadora - Eu gostaria que você falasse seu nome, sua idade e a ideia é que você conte um pouco de sua trajetória de estudo, de sua trajetória de vida, pra entender um pouco como você chegou até aqui.

Ricardo- Está bem.

Pesquisadora - O Ricardo hoje.

Ricardo- Necessariamente precisa falar o nome completo, essas coisas?

Pesquisadora - Pode falar.

Ricardo- Bom, sou Ricardo Alexander Machado, estou com 22 anos, minha trajetória aqui pra UNIVERSIDADE UNI foi bem peculiar, porque eu fiz ensino fundamental I e II em escola particular, então, eu tinha um tipo de ensino totalmente diferente do que o ensino que tive no ensino médio, o ensino que tenho aqui na Universidade. Tinha uma visão de mundo completamente diferente, por exemplo, questões políticas, ideológicas que eu tinha na época da minha pré-adolescência mudaram completamente da adolescência pra fase adulta, exatamente por eu ter vivenciado uma outra realidade. Então, sai da escola particular e fui para escola pública, no ensino médio, uma escola técnica, lá que eu tive o primeiro contato com o a ideia de ser professor, realmente entrar aqui na Universidade pra me formar pra professor.

O primeiro contraste que eu tive foi exatamente a realidade diferente do ensino fundamental para o ensino médio, de uma escola particular para uma escola pública. Então, foi a primeira vez que eu tive que pegar ônibus, trem sozinho, vivenciar o que era uma aula vaga, eu não sabia o quê era isso na escola particular. Você trabalhar sem você ter um sistema, por exemplo, um sistema apostilado, trabalhar com diferentes materiais, trabalhar com pessoas que vêem diversos cantos da cidade, trabalhar com pessoas que tem culturas diferentes, então tudo isso acabou influenciando, não só na minha formação como pessoa, mas na minha decisão como futuro professor.

Decidi que queria cursar uma Universidade Pública. Então, por isso que estou fazendo estes dois paralelos, escola particular no ensino fundamental e escola pública no ensino médio. Foi engraçado porque foi assim, eu não queria sair dessa escola do ensino fundamental, minha mãe tinha ouvido falar das ETEC se tal, na época eram ETEs, a gente não falava ETECs. Ela falou: tem uma escola assim e tal em Pinheiros que eu ouvi dizer que é muito famosa, sempre que vou de trem eu vejo o pessoal com o uniforme dessa escola. Comecei a me informar e eu acho que seria legal você estudar lá, tem que fazer uma espécie de prova que é um Vestibulinho. Você pode fazer um curso técnico que acho que vai ser importante pra você, pra você crescer como pessoa, porque você está num mundo muito fechado; é legal, você tem seus amigos, mas você pode ampliar um pouco seu horizonte. Eu tinha uns doze anos, treze anos na escola, minha mãe falou isso e eu fiquei bravo, não quero, eu quero ficar com meus amigos tudo e tal, mas ela foi trabalhando isso comigo, meu pai também, bastante... Aí eu falei tudo bem, vou topar essa ideia já que você está falando que é melhor. Fui comprando a ideia.

Aí o que aconteceu foi engraçado, porque eu prestei a prova, não fui aprovado na primeira chamada, fui aprovado na segunda chamada. Ela me levou para conhecer a escola, gostei da região, porque era uma região totalmente diferente aqui em Pinheiros, de onde vivo, que é o Grajaú. Uma região com, vamos dizer assim, com um pessoal de classe social totalmente diferente. Gostei no inicio das instalações da escola; mas era outra realidade, apesar de ser uma escola, a princípio, com instalações boas, não tinha nada a ver com a escola particular, aquele mundinho todo perfeitinho que eu vivia.

E foi engraçado, porque eu tive um choque cultural, social e intelectual muito grande, achava que quando os professores faziam discussões; o professor de História trazia textos de diversos pontos de vista e eu estava acostumado a seguir um livro, uma apostila. De repente a gente tinha que se posicionar, fazer debates, achava que eu não tava aprendendo a estudar, engraçado porque achava que eu estava perdendo tempo; falava como assim, não tem material, não tem livro,estou lendo textos assim, aleatórios, como 
assim? Ou então a professora de Biologia, que era uma professora excelente, mas era super disciplinar, exigia disciplina, que agente copiasse, escrevia tudo de cabeça na lousa, não usava livro nem nada. Ela fazia o texto; ela ia passando rapidinho e se você não copiasse você perdia, então foi um choque muito grande para mim, achava que não estava aprendendo. Aí eu comecei a perceber que vinha gente de tudo quanto era canto, então tinha gente de Taboão, de Cotia, que vinha com pensamentos diferentes, com culturas diferentes e eu tinha que lidar com isso. Então, o primeiro ano foi assim: "o que eu estou fazendo aqui, como isso é diferente pra mim". Eu estava acostumado com uma coisa muito certinha, como eu falei. Eu acho que tudo isso é importante porque como falei, definiu muito bem onde eu estou agora. Comecei a entender um pouquinho o sentido das aulas, porque a gente tinha mais debates; porque tinha mais discussões, porque tinha aula vaga, porque tinha professores que eram um pouco mais preparados, outros menos, os problemas da escola pública. Essa tensão escola particular e escola pública, isso foi ficando um pouco mais claro conforme o tempo ia passando pra mim; o engraçado é que aí eu fui aprendendo que os professores, no geral, a maior parte dos professores da ETEC, um grupo de professores formados pela UNIVERSIDADE UNI, então tinham uma visão diferente de mundo.

Eu passei a voltar com meus colegas, por exemplo, das aulas pra casa, então tinha que pegar trem, tinha que andar pela cidade, uma coisa que eu não estava acostumado; agente ficava, por exemplo, ia pra feira, de quinta-feira, pra comer pastel num momento desocialização. Coisas que pra mim não aconteciam, eu vivia no ensino particular dentro da escola, o ônibus trazia pra escola, o ônibus deixava em casa, então não sabia o que era andar pela cidade, conhecer outras culturas, porque era sempre o pessoal do mesmo bairro. Pesquisadora - Você não saia pelo bairro?

Ricardo- Não, não.

Pesquisadora - Você ficava dentro da escola?

Ricardo- Eu saia para outros lugares, mas sempre perto do bairro, nunca para socializar com outros alunos, então não sabia o que era isso. Eu tive isso na escola pública. Para mim foi um choque e eu fui começando a entender isso, lá nessa escola já tinham os cursos técnicos, então minha mãe falou:"porque você não faz algum curso técnico?". Meu tio trabalhava com eletrônica e conversando comigo sobre eletrônica disse: "você pode fazer isso tal, porque você não faz um curso técnico em eletrônica" e comecei a pensar. $\mathrm{Na}$ verdade ele já tinha conversado comigo antes de eu prestar ovestibulinhopra entrar no ensino médio, mas eu não tinha definido nada, quando passei por esse choque, no final do primeiro ano do ensino médio, foi quando decidi fazer o curso técnico: "vou prestar outrovestibulinhopra fazer eletrônica".

Aí eu comecei a entender qual era o jogo da escola, como deveria me portar, como deveria trabalhar,como era a nova forma de estudo. Então tive que aprender a ser mais independente, ser autônomo, porque eu não tinha mais os livros, tinha aula vaga, professor que não estava tão bem preparado. Tive que começar a lidar com isso, fui entendendo aos poucos, aí resolvi prestar o curso técnico, passei dessa vez, fui bem melhor do que na entrada do ensino médio, passei em $12^{\circ}$. Eram 40 vagas, fui bem porque já tinha entendido aquela lógica, comecei a participar, por exemplo, de olimpíadas, tinha olimpíada de Astronomia, olimpíada de Física, olimpíada de Matemática, e aí começa a entrada, vamos dizer assim, no mundo da Física, das Ciências da Natureza, aí que minha trajetória mudou, porque até então, quando tive esse choque, comecei a entender o que era essa diferença. Tinha em mente que eu queria fazer engenharia, fui influenciado por esse meu tio, meus pais até falavam que fazer engenharia era legal, eles incentivavam. Tinha um amigo meu que gostava muito de Física, então ele se preparava para as olimpíadas, eu acho que comecei a entrar para as olimpíadas por causa dele; a gente começou a estudar juntos, às vezes se o professor não tivesse passando mecânica, não tinha problema, a gente estudava mecânica sozinho; começamos a estudar muitas coisas sozinhos.

Pesquisadora - Mas isso na escola técnica?

Ricardo - Na escola técnica, isso eu não tinha na escola particular, sempre na escola técnica, e aí foi interessante porque eu, agente começou a falar "vamos entrar no ITA", a gente queria fazer Engenharia Eletrônica. Esse meu amigo começou a estudar sozinho, assim a gente viu que muitas coisas não seriam cobertas pelo programa de lá, pelos professores, principalmente na área de Ciências da Natureza, então a gente começou a estudar sozinho e aí a gente começou a participar das olimpíadas; só que não íamos bem, tinha certa defasagem, mas isso não me desanimava. Bem, vamos começar a estudar para o ITA, aí que juntando tudo isso, o choque cultural, influenciado para fazer o curso de eletrônica, ter esse meu amigo que tinhao gosto pela Física, também aí surgiu uma coisa inesperada: no final do primeiro ano, quando minha professora de Física, professora $\mathbf{B}$ me convida, convida outros alunos não só da minha 
turma, mas das outras turmas que ela dava aula, pra ser monitor de Física. Até então eu ia ser engenheiro, até então eu ia fazer o curso técnico de eletrônica, tudo bonitinho como eu tinha planejado, quando minha mãe me convenceu da importância de fazer uma escola técnica.

PROFESSORA - "Acho que seria legal se você fosse monitor; estou querendo criar um programa de monitoria porque eu vejo que o pessoal tem dificuldades, eu preciso de alguém que me dê assistência, eu não posso estar todo o tempo aqui e eu vejo que você gosta, parece que você gosta de ciências, você tem um apego pela Física você vai bem, acho você uma pessoa que fala bem; acho que você poderia ajudar esses alunos.

RICARDO - "Mas professora eu sou uma pessoa tímida, eu não sei ensinar, nunca passei por isso."

PROFESSORA - "Mas tenta, como experiência, depois se você não gostar você sai, não tem problema, não tem nenhum compromisso, mas eu preciso que alguém que comece."

RICARDO - "Aí eu pensei, mas como é que eu vou fazer esse trabalho, eu vou ter que resolver exercícios?"

PROFESSORA - "Bom o intuito é assim você ficar num horário extra, depois da aula, você vê quais as dúvidas que os alunos estão tendo e vê o jeito que você acha melhor pra trabalhar aquilo, se você vai resolver exercício, se você vai falar com eles, enfim você vaiexperimentare aí a gente vai conversando.“

RICARDO- Está bem.

Ricardo- E aí eu descobri alguns amigos em comum, que iam participar e que tinham sido convidados. A gente ficou meio assim, eles não levaram...não vou dizer que eles não levaram muito a sério, mas foi uma coisa que me chamou a atenção, que pra eles não virou uma responsabilidade, mas que pra mim virou, porque eu sempre fui uma pessoa meio certinha. Se alguém me fala alguma coisa pra fazer, eu vou e faço; eu quero dar o meu máximo, independentemente de saber aquilo ou não, talvez até pelo fato de ter estudado numa escola particular, vamos dizer assim, que me disciplinou, pra eu sempre fazer as coisas perfeitinhas, tudo organizadinho, então eu tive essa responsabilidade. E eu tomei aquilo como uma coisa muito forte pra mim. Eu falei se eu vou dar aula, vou dar monitoria, vou precisar aprender o quê é dar aula. Foi essa a pergunta que essa professora deixou comigo, mas como que se dá aula? Foi a primeira pergunta que eu fiz. E como é que vou fazer com que meus alunos aprendam? Aí eu fiquei pensado bom, tenho que responder essas perguntas pra mim de alguma forma. Mas, tem outro lado, porque, aí eu me perguntei: porque os alunos têm dificuldades? Aí eu comecei a perceber que não adiantava resolver os exercícios com eles - "se ficar resolvendo exercícios será que eles vão entender? Porque parece que eles não entendem a exposição do professor, então não vai adiantar resolver exercícios eles vão sem saber a Física que está por trás. E se eu tentasse ser professor mesmo, se eu tentasse dar aula?’- Eu pensei assim, mas pensei,será que a professora não vai se sentir ofendida, será que ela vai gostar, vai apoiar, enfim eu fiquei pensando tudo isso. Aí eu falei com a professora:"Professora, eu pensei bastante na proposta eu aceito tudo, mas eu penso uma coisa, acho que os alunos não estão apreendendo não porque eles não saibam fazer os exercícios, mas porque parece que de alguma forma aquelas fórmulas, aquelas coisas não fazem sentido pra eles. Eu estava pensando em dar aula mesmo, em ser professor e não ficar resolvendo exercícios. Tudo bem pra senhora? O que a senhora acha?

PROFESSORA - "Perfeito, mas como eu falei pra você, como você vai fazer eu não sei, mas você tem essa liberdade de fazer."

RICARDO- "Então tá bom, a gente vai conversando."

Aí eu voltei e me perguntei: Como é que eu dou aula? Já decidi que não vou ser resolvedor de exercícios, eu vou chegar e vou dar aula. Como é que eu dou aula? Eu não sei. Aí eu falei, bom, minha mãe é psicóloga...Falei: Mãe eu vou dar aula, a professora me convidou pra ser professor assim, assado, você pode me dar umas dicas?"

MÃE - "Posso. Falou assim, você vai trabalhar com quem, com criança ou adolescente?"

RICARDO- "Não, eu vou trabalhar só com adolescente."

MÃE - "Ah, então você pode começar lendo alguns livros, talvez sobre educação, ou sobre psicologia. Não, nada muito complicado, mas pode começar lendo essas coisas, tem algumas coisas básicas, por exemplo, você ouvir o aluno, você questionar os alunos, enfim vocênão ficar sempre repetindo as mesmas coisas, você não ficar com algo maçante, você não ficar sempre no mesmo tom de voz, essas coisas básicas, coisas mais técnicas. Você ouvir mais."

Ricardo- Minha mãe sempre falou assim pra mim que é importante que agente ouça mais as outras pessoas e fale menos. 
MÃE - Então procure mais ouvir o que eles têm pra dizer, porque eles estão com dúvidas, então quanto mais você procurar conhecê-los, quanto mais você procurar ouvi-los, mais você vai aprender como você vai ter que trabalhar com eles.

Ricardo- Aí porcoincidência, acho que um pouco depois, ou na mesma época, não lembro muito bem, ela me apresentou um autor que hoje em dia acho que ele é de uma certa forma banalizado ou criticado por educadores, pela academia no geral, mas teve uma influência muito grande na minha formação, me fez iniciar a leitura em educação.Foi Augusto Cury. Ela me deu um livro dele chamado "Nunca desista dos seus sonhos", a forma como ele escrevia era simples, ele falava de teorias psicológicas, falava um pouco da insistência de você lutar por aquilo que você acredita, gostei da leitura, foi uma leitura totalmente diferente do que estava acostumado. Aí eu tive gosto pela leitura dele, descobri outros dois livros dele, só que não eram de psicologia,eram livros que falavam sobre educação. Esses livros foram determinantes pra eu decidir também ser professor, que foram: "Pais brilhantes, professores fascinantes" e o outro chamado "Filhos brilhantes, alunos fascinantes".

No primeiro, "Pais brilhantes, professores fascinantes" ele fala um pouco, na primeira parte, sobre a educação familiar, então foi a primeira coisa que li sobre educação. Ele fala um pouco sobre os hábitos dos pais;sobre os sete pecados capitais dos pais, às vezes o pais corrigem em público, o pai dá presentes, mas ele não está presente com a criança. Então ele tratava questões de forma muito mais simples para leigo, ele fala um pouco sobre educação familiar, em diversos aspectos. $\mathrm{Na}$ segunda parte do livro ele fala sobre a educação escolar, e fala algumas técnicas de ensino, então fala muito sobre o diálogo em sala de aula, incrivelmente hoje a minha monografia e a minha intenção de fazer o mestrado é sobre o diálogo na sala de aula, a primeira vez que eu li sobre diálogo foi com ele, ele falava da importância do diálogo na sala de aula, de você fazer uma exposição. Ele apresentava uma técnica que era uma exposição interrogada, a segunda técnica era a exposição dialogada, falava da importância de você sentar em semicírculo, então foram as primeiras ideias que vi sobre educação, com16 anos, 15 anos.

Ele criticava muito o sistemacapitalista, por exemplo, no livro falava da nossa falta de questionamento da sociedade, sociedade acrítica. Então tinha um viés um pouco político também, mas ele não é um autor, depois eu fui descobrir que ele não é um autor da academia, é um autor que inclusive critica a academia. Só que isso me aproximou, terminei a leitura e falei: "Noosssaaaa! Que legal, parece que ele está falando minha língua". Tudo que eu criticava no sistema, parecia que ele falava minha língua, então amei. Aí eu vi que tinha esse outro livro "Filhos brilhantes, alunos fascinantes". Esse livro foi que me deu um norte pra ser monitor, porque esse livro fala da história de um professor de Física. Falava de um professor fictício chamado, como é que era o nome dele... Agora eu não vou lembrar, era um professor russo. A história fictícia era mais ou menos assim:Era um professor que tinha trabalhado numa escola, chamada escola dos pesadelos, essa escola era a pior escola de todas, tinha todo tipo de problema e esse professor tinha entrado em depressão, tinha praticamente desistido de educar, até que ele toma forças e vai para outra escola e começa a fazer diferença na escola. Ele trabalha a Física de uma forma humana, ele trabalhava a Física sob outra ótica; começa a contaminar outros professores, começa a questionar os alunos, tratava os alunos de forma diferente.Isso me chamou a atenção, porque calhou exatamente no que eu precisava. Eu não sabia o que era ser professor, eu fui convidado a ser monitor de Física e a história tratava sobre um professor de Física, que fazia diferença na sala de aula. E aí o mais engraçado é que o primeiro episódio que ele conta no livro é que ele entra na sala de aula, a sala de aula está uma zona, aí um dos alunos coloca uma lixeira pra ele tropeçar. Ele tropeça, como aluno, você espera que o professor brigue com o aluno, ponha-o pra fora da sala.Esse professor é descrito como o professorRomanovo nome dele...uma pessoa baixinha, meio mirradinho, então não teria um controle da sala de aula.Assim os alunos esperando que tivesse uma reação, totalmente, tradicional, mandasse alguém pra fora, elesimplesmenterespira fundo, entra em silêncio não fala nada começa a fazer uns movimentos com os braços e as pernas, alguma luta, umKungfuou karatê; os alunos ficam olhando, de repente ele lança uma pergunta para os alunos: Quem me agride, no caso é uma pessoa forte ou uma pessoa fraca? E começa a questionar os alunos, mas sem expor o aluno que tinha colocado a lixeira. Falou assim: algum de vocêscolocou uma lixeira pra me provocar ou pra fazer com que eu caísse,eu gostaria de saber quem foi? Aí ninguém fala nada.Ele fala assim: eu não vou brigar com essa pessoa, pode falar, porque eu não estou aqui pra ser um inimigo de vocês, eu estou aqui pra ser uma pessoa, pra mostrar um mundo diferente, um mundo novo. E volta a perguntar: quem agride é uma pessoa forte ou fraca? É mais ou menos assim, não lembro muito bem. Aí a pessoa levanta a mão e fala que foi ela, ele pergunta o nome da pessoa, fala: "fulano, se você me permite eu gostaria de cumprimentá-lo e parabenizá-lo por você ter tido a coragem de ter me desafiado, se você me permitir eu quero não ser só um professor pra você; eu quero ser um amigo, um amigo que vai te 
mostrar um mundo novo, mas isso se você me permitir, porque eu estou aqui como intuito de ser um professor que vai mostrar um caminho diferente pra vocês, não estou aqui como inimigo de vocês.

Isso me chamou a atenção porque eu nunca tinha visto isso na Educação, era uma abordagem diferente; resumindo a história, ele vai tendo atitudes bem parecidas com essa na sala de aula, eles vão se tornando pessoas críticas e essas atitudes vão contaminando outros professores, e vai contaminando a escola de uma forma geral. Ele sempre partiu pro questionamento, ele sempre usava a reflexão com os alunos, ele questionava, ele dialogava, eu lembro uma parte do livro que foi muito marcante pra mim, como futuro professor, que era quando uma aluna falava assim: "Professor,o que adianta a gente estar estudando aqui as Leis da Gravitação Universal...falava um pedaço do Newton, a teoria newtoniana, se eu não consigo resolver os meus próprios problemas pessoais, se eu tenho problema em casa?". Aí o professor trata durante as aulas de problemas pessoais dos alunos, então ele começa a introduzir no livro algumas coisas que os professores têm que trabalhar com os alunos, não só a Física, a Ciências, a disciplina que ele está trabalhando em si.Tem umas outras questões que às vezes fogem do escopo, do âmbito profissional dele, questões psicológicas, questões pessoais, esses conflitos. Então, ele estava iniciando pra mim ali, porque vou ensinar Física?Para quê? O que vou ensinar?O que é relevante? Que foram coisas que depois fiz ligação na Universidade, nas matérias de Ensino. Essa parte do diálogo, essa parte dos questionamentos me influenciaram de forma muito grande, pra no final começar a trabalhar da mesma forma com os alunos. Eu tive na primeira aula dois alunos, uma vez por semana, na sexta-feira, durava uma hora, uma hora e meia a aula. Na segunda semana vieram cinco alunos. Na outra semana vieram 10 alunos; na outra vieram vinte, na outra trintaaté que eu estava com 40 alunos semanalmente.

Pesquisadora - Quase a sala toda.

Ricardo- Quase a sala toda. A sala toda. Vinha gente de tudo quanto era tipo, era incrível. Gente do primeiro, segundo e terceiro ano. Aí eu vi que havia uma necessidade de organizar o que ia trabalhar.

Pesquisadora - Ah, não eram só do primeiro ano?

Ricardo- Não, eram de outros, como eu já estava no segundo ano quando comecei a fazer isso, então, acho que estava lidando com o pessoal do primeiro ano e do segundo ano, agora não lembro muito bem, do terceiro não, porque não sabia a matéria, obviamente. Mas, depois quando eu fui para o segundo, para o terceiro ano, eu trabalhei com todos os anos. No começo eu lembro que eu trabalhei com Mecânica, Ótica e Termologia, então chegava lá e: "Bom dia, classe", escrevia na lousa e ficava lá uma vez por semana

Pesquisadora - Vinham todos, não era uma turma?

Ricardo- Vinha, vinha. Aí, eu comecei a usar essas idéias que eu vi no livro.

Pesquisadora - E você tinha que organizar o assunto na sala e dividir a turma?

Ricardo- Não, não dividia no começo, quando veio gente de outras turmas, foi quando eu percebi a necessidade de separar por disciplina. Como tinham os outros, porque assim no começo eles vinham perguntavam uma coisa de Mecânica;uma outra deTerminologia, não queria fazer isso, lembra? Não queria resolver exercícios, eu queria dar aula. Aí como tinham os outros monitores, os meus colegas, a gente fez uma reunião informal e falouvocê vai ficar com Mecânica, você vai ficar comTerminologia, você vai ficar com Ótica.

Pesquisadora $-\mathrm{Ah}$ !

Ricardo- Eu fiquei com Mecânica. Aí foi quando organizou sexta-feira tal horário vai ser a minha aula.

Pesquisadora -Ah, vocês tiveram que organizar isso pra dividir a demanda.

Ricardo- Isso, exatamente. E aí no caso,quando isso começou, eu vi que o pessoal começou a vir em peso, eu comecei a usar as idéias do livro e as dicas que minha mãe dava. E foi quando eu comecei a ler mais sobre Educação, passei desse livro pra outros que ele tinha escrito

Pesquisadora - Mas, esse livro, você teve uma identidade com o livro, mesmo sem ser professor ainda, sem estar lidando com a turma, você foi ler o livro pra poder lidar com a turma?

Ricardo- Sim.

Pesquisadora - Mas, você teve umaidentificaçãocom o livro?

Ricardo- Sim, porque ele falavapor exemplo, ele contava um pouco a históriapessoal dele, falando que ele era um aluno que tinha dificuldade e que o pessoal falava que ele ia ser tipoum ninguém. Assim ele chegou ao ensino médio,ele notava muito as coisas,ele achava totalmente chato as aulas expositivas, ficava cansado, não conseguia se concentrar;eu me identifiquei com isso, porque eu fazia algumas anotações, mas achava um saco, até hoje eu acho, odeio aula expositiva, por isso estou querendo pesquisar em diálogo, a importância do diálogo na sala de aula, por causa dessa influência. Porque acho um saco quando o aluno não participa, não tem produção de conhecimento, acho que tem um momento de reflexão que você pode 
estar lá ouvindo a pessoa, você tem momento de reflexão, mas ela dura pouco, isso era uma das coisas que ele batia muito fortemente no livro. Ele contava essa história pessoal e falava que o aluno tinha que participar ativamente; depois fui descobrir que tinha relação com as teorias construtivistas, sóciointeracionistas. Mas eu me identifiquei, ele criticava o sistema capitalista, a sociedade produz pessoas assim, as pessoas estão estressadas, as pessoas estão com problemas, ele falava de um jeito que eu pensava:"é verdade eu tenho dor de cabeça porque eu estou estressado, meus pais estão assim por causa disso". Então começava a ligar os pontos, parece que ele estava falando aquilo que eu estava pensando e isso eu descobri que é uma marca da escrita dele, por exemplo, a crítica ao sistema, a crítica a diversas coisas, então comecei a me identificar; foi o que você falou, de alguma forma eu me identifiquei mesmo não sendo professor. E como era uma linguagem não técnica, ele falava umas frases bonitas, ele tem um apelo meio para o emocional, algo mais idealizado, meio platônico, então isso me chamou a atenção, porque naquela idade não era uma coisa técnica que me chamava atenção.

E foi quando a gente dividiu, cada um dos alunos ficou com uma turma, uma área da Física, eu comecei a pegar gosto, porque eu comecei a ligar não só o livro, o que eu estava aprendendo no livro, mas os exemplos de professores que eu tive. Eu admirava alguma coisa em cada professor, mesmo os que a princípioeu odiava, depois passei a amar esses professores, foram os que tiveram mais influencia em mim. Aquele professor de História que eu falei que odiava, falava: "eu não estou aprendendo História", foi um dos professores que mais me influenciou. Por quê? Porque ele trazia debates para a sala de aula, ele trazia os textos com opiniões diferentes, pra gente estudaro capitalismo; estudávamoso capitalismo sob a ótica dos historiadores conservadores, historiadores marxistas, historiadores evolucionistas, a gente tinha que colocar a nossa própria opinião, então eu sentava, entrava na sala de aula, não ia para o quadro negro, sentava a mesa e começava a contar história.

Pesquisadora - Por que você achava que não estava aprendendo História?

Ricardo - Porque eu vinha daquela tradição de escola particular que você está todoenfileiradinho, bonitinho, você tem que ter uma organização pedagógica, tinha agenda, a minha agenda que eravistada por um inspetor da escola;a agenda ia para os meus pais, mas nunca meus pais cobraram alguma coisa. A escola tinha esse sistema muito disciplinar, muito organizado. Eu tinha apostila, tinha que resolver um número de exercícios, tinha que fazer uma leitura, era muito organizadinho. Tinha uma única visão de mundo, até construir a minha própria opinião, com textos diferentes não tinha um livro didático pra seguir, eu fiquei desesperado. Nunca fuiconvidadoapensar, nunca fuiconvidadoaexpor a minha opinião, construir minha opinião, construir meu conhecimento e daí tinha que fazer isso.Então, eu acho que foi por isso que eu tive a ideia que não estava aprendendo, estava em choque, não só não só um choque cultural, mas um choque escolar,de cultura escolar, uma cultura que dizia: $\mathrm{O}$ que é aprender. O que é ensinar. O que é educação. E a outra que falava: isso daqui não é educação, isso não é aprender de verdade, mas depois dessas leituras, aí que eu comecei a entender porque o professor fazia isso, eu comecei a ligar os pontos.

Aí eu comecei a testar as várias metodologias. Então, por um tempo eu fiz debate com os alunos. Aí, um outro tempo aquela professora que copiava tudo bonitinho, vou ser foda que nem ela, então eu vou fazer tudo de cabeça, eu preparava minha aula, fazia plano de aula. Então naquela época com 16 anos eu preparava o que, quais eram os objetivos, o que eu ia passar, como ia passar, então eu fazia plano de aula naquela época. Aí eu falei agora eu só vou escrever e ficava testando as metodologias. Ah! Dessa vez eu vou resolver só exercício, dessa vez eu vou fazer isso, ai eu comecei a ver o que dava mais certo, o que não dava,o que estimulava mais os alunos. Eu percebi quanto mais eu perguntava pra eles, quanto mais eu envolvia os alunos naparticipação da aula, mais eles apareciam, mais eles se engajavam e eles comentavam: Ah! A aula do Ricardo não sei o quê... então vinha muita gente. Aí eu fiquei com esse trabalho durante os três anos do ensino médio; eu comecei no inicio do segundo e fiquei dois anos lá, e aí no final do terceiro ano a professora, as professoras de Física, inclusive a professora $\mathbf{N}$ depois entrou na escola, elas me deram a oportunidade de nas últimas aulas, eu dar aula no lugar delas. Então não estava mais fora da sala de aula, elas me colocaram como uma espécie de estagiário com a docente, pra ser professor, e os alunos gostaram. Tanto que no final da aula eles falaram: porque você não vem dar aula? Porque sou aluno ainda não posso. Então eles davam resultados bem positivos; acabei tendo umfeedbackbem positivo. Acabei formando amizades com esses meus, entre aspas, alunos. A gente ia depois pra feira comer pastel, então eu fiz amizade e passei a socializar e aí foi quando eu cheguei ao final do terceiro ano. Fiz o curso técnico em Engenharia Eletrônica. Gostei bastante. Estagiei numa empresa de engenharia que fica lá na Paulista, só que eu estagiei na frente de um computador, era um estresse desgraçado. E aí eu comecei a gostar tanto, gostar tanto, tanto desse ato de dar aula, de estar com pessoas, 
eu era uma pessoa muito tímida, então isso fez eu me soltar bastante. Fez eu me socializar bastante, tinha um reconhecimento; aí o negócio estressante da engenharia...foi quando falei: "putz,será que eu quero ser mesmo engenheiro?” Eu fiquei meio balançado, conversei com meus pais, meus pais falaram que me apoiariam naquilo que eu decidisse, mas devia saber que a profissão de professor não era valorizada, engenharia era mais valorizada, nessa indecisão, eu falei: "putz não sei o que faço".

Aí a professora $\mathbf{N}$ levou a gente pro Show de Física. Quando eu conheci o Instituto de Física, quando vi aquilo, eu falei é aqui que quero estar. Eu quero ser professor. Eu vi o Instituto, eu vi as pessoas estudando, lembro que vi um aluno com um livro, naquelas mesinhas da lanchonete, estava com um livro de Cosmologia, vi a foto do Universo, eu falei: "quero ser professor". Aí, nessa mesma época, que eu estava balançando, veio um grupo de alunos do Instituto de Física que estavamfazendo estágio para Metodologia de Ensino, eles tinham que fazer um minicurso, eles foram na ETECconvidar a gente pra participar desse minicurso, aos sábados na Faculdade de Educação, que era sobre Física Moderna, sobre a Luz, o que é a Luz. A professora $\mathbf{N}$ tinha acabado de passar um vídeo sobre esse tema: sobre o que é a Luz, Física Moderna. E eu estava ensinando isso também pro meus alunos de monitoria e ia conhecer a Faculdade de Educação. Aí foi quando eu participei, tinha mais experiência em dar aula do que os estagiários queestavam em Metodologia de Ensino; eles estavaminseguros, lembro que eram uma moça e um rapaz. A moça falou de fótons e ela pensou pra falar porque uma coisa assim, super complicada eu e meus amigos que também eram monitores...fótons tem outra teoria, a gente começou a dissertar sobre isso. Como assim, é a primeira vez que vocês tão dando aula, ainda eu lembro que eu falei: e a primeira vez que vocês tão dando aula? Ela disse: é. Ah! É porque eu já sou monitor da escola eu dou aula; eu já estou acostumado, você pode,aí eu comecei a dar dicas pra eles de como eles podiam trabalhar o assunto. Eu lembro que agente leu um texto, e eles estavam na universidade se formando. E eu tava na posição de aluno que veio para ver o curso. Adorei o curso. Eu descobri depois que quem estava supervisionando lá na salaera o professor W nem fazia ideia quem era na época. Sabia queconheci a Faculdade de Educação, o Instituto de Física obviamente que tudo isso me influenciou de formasignificativapra depois eu decidir que queria ser professor, mas eu não tinha decidido até então. De teimoso, questões econômicas pensando no meu futuro,eu não prestei vestibular aqui praFuvest, pra Unicamp e nem pra outros vestibulares; eu prestei pra UFSCar e prestei em Engenharia Física. Eu falei eu vou ligar uma coisa que eu gosto que é Física, Engenharia que é o que vai me dar, entre aspas, estabilidade; e eu percebi que poderia ser professor sendo engenheiro, porque eu tive professores no técnico que, no curso de Engenharia Eletrônica que eram engenheiros. Bom, quero dar aula. Posso, tenho outra opção de ganhar bem: vou fazer tudo isso sendo engenheiro. Prestei, não passei, graças a Deus. Não passei na Ufscar, engenheiro físico. Não passei, chorei, enfim fiquei super decepcionado, foi aí que eu falei: não. Vou pedir ajuda pros meus pais tudo, vou querer fazer cursinho, quero prestar agora vários vestibulares. Vou prestar UNIVERSIDADE UNI, vou prestar Unicamp, Unesp e Ufscar, mas só que agora eu quero ser professor. Eu posso ser engenheiro, mas eu vou aprender as matérias de Educação. Será que eu não estou fugindo daquilo que eu realmente gosto! Foram os planos que eu fiz pra mim, sei lá não vou ficar fugindo vou fazer o que eu gosto. E qual o curso que se chama pra formar professores de Física, falei pra minha mãe? Ahh! Licenciatura. Então, Licenciatura; vou prestar. Prestei aqui na UNIVERSIDADE UNI, na Unesp, na Unicamp e na Unesp era Bacharelado e Licenciatura ao mesmo tempo, aqui era licenciatura, na Unicamp era Licenciatura, e de teimoso eu vou passar em engenharia só pro pessoal não falar que eu não passei em engenharia não é? Meio aquela coisa de, de competição. Aí estudei com o objetivo de entrar pra ser professor. Passei nos quatro, nas quatro vestibulares: eheh, falei,entrei na UNIVERSIDADE UNI. Então, entrei com toda essa influencia esse choque cultural entre as duas escolas, as leituras Augusto Cury, ai não falei foi lendo não só Augusto Cury, mas fui lendo outros autores. Aí comecei a ler com 16, 17 anos, 18 Paulo Freire, meu pai me deu livros de Paulo Freire então já li Pedagogia da Autonomia, Pedagogia do Oprimido, a vida e obra dele já li, por exemplo, Professora, Tia não. Então, foram, foram obras que reforçavam o que o Augusto falava, de diálogo; estou fazendo minha monografia de diálogo, não é? Depois li um pouco sobre Piaget, porque minha mãe tinha uns livros de Piaget, porque ela é psicóloga. Li o Nascimento da Inteligênciana Criança um pedaço, ai tinha os Seis Estudos de Psicologia, Li os Seis Estudo de Psicologia. Eh, eh, aí eu fui conhecer um pouco de Vigotsky, mas não entrei muito, não sabia muito bem o quem era. Peguei mais livros do Augusto Cury, os livros mais técnicos dele, que ele falava sobre Psicologia, então eu vi um pouco de Psicologia de Aprendizagem, do Desenvolvimento. Aí, comecei a me interessar pelas teorias behavioristas,porque minha mãe falava um pouco das experiências dela na faculdade, então eu aprendi um pouco sobre Skinner, Watson, sobre esses caras. Aí comecei a ter outro contato, me deixe ver, além do Paulo Freire como educador, os psicólogos, ai quem mais eu comecei a 
ver, putz, agora eu não estou lembrando; mas eu lembro que teve outros, outros educadores, eu comecei a ler coisas sobre Educação em si; eu não lembro agora os autores que, que eu li, mas eu me interessei. Então, eu entrei na UNIVERSIDADE UNI com o intuito de ser professor. Então quando eu falei: putz eu vou ter Didática, vou ter Psicologia, vou ter Políticas Educacionais, eu olhava aquilo com gosto porque eu já tinha vivenciado. Aí fiz POEB, adorei. Fiz Didática amei. Comecei a fazer os estágios, fui me aprofundando e eu amo as matérias de Ensino. Aí, falei vou fazer Iniciação Cientifica em Educação, aí foi quando que eu descobri que havia a possibilidade de fazer mestrado na área de Ensino, doutorado em Educação, então eu já entrei consciente do que eu queria ser. Então eu não tive problema, eu não tive crise de curso, não tive.

Pesquisadora - Você já entrou com essa idéia?

Ricardo - Já entrei com foco, porque eu vivenciei antes, acho que isso teve uma importância muito grande; fui direcionadopelos meus pais, pelos meus amigos e principalmente pela professora. Por um convite, por uma responsabilidade que eu tomei pra mim, porque se eu não tivesse tomado talvez não tivesse seguido esse caminho. Quando eu tomei pra mim aquilo, com uma responsabilidade muito grande, acho que tive influência da escola particular; então por isso resolvi contar um pouco dela também, aí eu acho que decidi ser professor de Física, amei Física, sempre gostei de Ciências, assistia o Mundo deBeakman, essas coisas, via e dizia: “vou ser cientista também”. Queria ser detetive quando pequeno, então, de certa forma eu estava sempre com a parte deinvestigação, descobri que sempre estava com a parte de investigação e sempre lidando com pessoas. Eu tinha, esqueci de falar, uma coisa que me influenciou com certeza: minha mãe me deu umalousinha, quando eu era pequeno, e eu gostava de escrever na lousinha.

Pesquisadora - Poxa, lembrei de uma minha.

Ricardo- Ela começou, por exemplo, me colocar pra fazer piano, curso de piano, pra eu desenvolver a minha timidez;então de alguma forma, e eu por causa disso, eu ia bem em Matemática; aproximação harmônica lá da Música com a Matemática, da Física, então eu acho que de alguma forma tudo isso contribuiu pra eu saber e continuar sabendo o que que eu quero.

Pesquisadora - Você fez Iniciação com quem?

Ricardo - Eu comecei a fazer uma Iniciação, mas era meio informal, não tinha um caráter formal, fiz com a professora $\mathbf{Y}$ que depois eu descobri que era mãe de uma colega minha de ensino médio. Ou seja, a filha dela estudava no Guaraci Silveira. E eu sempre ouvia falar bem tudo, pessoa que me influenciou muito a professora Y, aí eu falei:professora eu queria fazer uma Iniciação Cientifica, eu acho que tava no inicio do terceiro ano; quero fazer Iniciação Cientifica, só que assim, queria mais na área de Educação assim: eu queria muito estudar diálogo. Eu queria estudar diálogo, formação do professor, alguma coisa assim. Ela falou: Ahh! Eu estou com um projeto numa escola pública aqui da região, a Amorim Lima. Uma escola diferente, é uma escola democrática, totalmente diferente do ensino tradicional e eu quero fazer rodas de conversa, com, com os alunos de lá o pessoal do fundamental: É! Aí você pode participar; vê se você quer isso mesmo não é? Aí participaram eu e outros alunos de graduação, e o professor $\mathbf{X}$ que hoje é meu orientador na monografia. Eu trabalho com ele noPibid; a gente começou a ir nas escolas depois do horário, da deles ali a noite, das seis à sete, a cada quinze dias. A gente conversava com eles sobre o que acontecia na escola, os problemas da escola, o que acontecia na, na sala, nas aulas de Física, então era uma coisa assim pra dá voz pra eles. Aí foi que eu descobri, comecei a ler coisas de pesquisa sobre o ensino de Física; eu descobri que era uma metodologia de pesquisa que é do Toben, que é professor da universidade da cidade de Nova Iorque; foi quando eu comecei a me aproximar da área. E hoje meu trabalho de monografia sobre diálogo é investigar essa metodologia de pesquisa aplicada nas escolas. Então,agora eu estou em uma escola, cada quinze dias a gente vai lá num grupo de pesquisa; agora o professor $\mathbf{X}$ que continua esse projeto comigo, a professor $\mathbf{Y}$ não pode continuar mais. Ele recebeu Pibid resolveu me convidar pra participar disso, então eu acabei dando continuidade; então a cada quinze dias a gente vai, faz uma reunião com os alunos, e eles falam um pouco sobre as aulas de Física, as coisas que eles estão gostando, do que eles não estão gostando, sugestões deles, as críticas, então a gente faz uma reflexão sobre o Ensino. Eu descobri depois isso que obviamente é uma metodologia, que tinha umas coisas interessantes; a gente grava as aulas, a gente faz todo um trabalho bem metódico sobre isso ai, obviamente isso me influenciou a continuar com a questão do diálogo, então hoje eu quero entender a importância do diálogo no ensino de Física. Eu quero continuar nessa área, e daí entendendo isso, eu quero expandir no mestrado no ensino de Física, e depois eu quero fazer um doutorado em Educação na Formação de Professores. Porque agora entendendo o diálogo, eu quero saber como eu posso formar professores de 
uma forma diferente que seja contra, vamos dizer assim, o ensino tradicional. Quero entender porque o ensino tradicional, de certa forma, ele falha em diversos aspectos, mas ele continua; ele é reproduzido até hoje, e de como o diálogo quebra com isso, se é que ele quebra! Como é que, alunos formados por uma aula que tem muito diálogo qual é a diferença, por exemplo, do ensino tradicional. Talvez seja uma pergunta de vida, assim pra eu responder na minha vida, mas é uma coisa que veio, veio dessa trajetória que eu contei.

Pesquisadora - Os alunos também te deram uma força pra continuar, as resposta dos alunos quando você fez a monitoria no ensino médio, também te deu uma força pra que você continuassequerendo ser professor, motivado praisso?

Ricardo-Sim, porque eles sempre me davam resultados positivos, o que estava fazendo,estava atingido eles de alguma forma; então pelo fato de ver que o trabalho meu estava sendo reconhecido, por ver que eles estavamaprendendo, eles estavam gostando, queriam que eu,com aquela idade, fosse professor deles; pra mim isso indicava que havia descoberto alguma coisa que eu sabia fazer. Hoje, naquela época eu via como um talento, hoje eu sei que não é um talento, é alguma coisa que eu construí, ou quer dizer, me ajudaram a construir.

Pesquisadora - Outra questão seria em relação à disciplina de Metodologia de Ensino de Física, como a disciplina e a regência, o estágio, colaboram, ou não, em relação a essa construçãosua como professor?

Ricardo- Nossa! Primeiro porque eu acho as aulas da Marina sensacionais, amei. Assim, foi outra pessoa que me identifiquei, parece que o que ela fala é o meu pensamento. Por quê? Porque eu já lia Paulo Freire, Piaget e tal, ela tem muito influência principalmente dos dois, mais do Piaget, que era um autor que eu gostava bastante, achava bem difíceis, mas falava da importância da construção do conhecimento, dos diversos estágios de desenvolvimento. Só que eu sempre pensava como que eu ia usar isso pra ser professor, tudo bem, a gente tem que usar diálogo, as fases do desenvolvimento humano. O Piaget se preocupou em responder como os homens constroem o conhecimento, mas eu não sabia bem como colocar isso na prática; quando ela veio com as sequências de ensino investigativo, com a alfabetização cientifica, a coerência com, por exemplo, o fazer científico, com as habilidades do saber cientifico,eu pensei:"agora eu sei como eu aplico isso". E então ela veio com as mesmas ideias que eu tinha e me mostrou, olha vocês podem fazer, assim, que o Piaget, oVigotsky, o Paulo Freire, as pessoas que de alguma forma, colocam aparticipaçãoativa do aluno no diálogo, na tomada de consciência e por aívai. $\mathrm{O}$ que a gente constrói, por exemplo, não é só dessa forma, uma aula coerente com o ensino de Ciências; foi quando eu me aprofundei, eu lia os textos com bastante profundidade; participei bastante, como você pode ver, porque me interessa, porque eu gosto, porque tem haver com as perguntas que eu tentava responder. Eu me coloquei esse desafio de propor um plano de estágio, junto com minha parceira, que contemplasse esses problemas abertos, não falei eu vou mudar, queria mudar a escola tradicional, vamos dizer assim. O jeito era só raciocinar, ela apresentou como eu poderia fazer com as ideias que eu gostava. Fiz, aparentementedeu certo; lógico que tem muita coisa para aprender, mas contribuíram 100\%, acho que é uma excelente professora, excelentes aulas. E a regência nos estágios, com resultados dos alunos, também me motivou a falar: "o que eu penso tem coerência", o que eu penso há muitos anos, que tento entender melhor, parece que tem um sentido e um sentido para os alunos.

Pesquisadora -Você tinha dito que na hora ficou um pouco reticente em relação à aplicação isso com os alunos...

Ricardo- Sim.

Pesquisadora -Pode falar.

Ricardo- Desculpa, você ia completar.

Pesquisadora - Em relação aos resultados?

Ricardo- Sim, porque acho que tem relação um pouco com que eu já discuti com o professor $\mathbf{X}$ quando ele me orientou em algumas coisas; até mesmo em discussões com os amigos aqui na faculdade, porque por mais que eu tenha esse pensamento de querer romper com o tradicional eu fiz parte dele. Eu ainda faço parte desse processo, essa cultura escolar, eromper com a cultura escolar é um pouco difícil. A gente fica, por mais que eu já tenha dado aula de inglês que é uma outra área, você fica com receio: "será que vai dar certo isso?" Você acredita que não vai dar muito certo. Porque você está com uma cultura escolar que você aprendeu reproduzir aquilo; por mais que você acredite numa outra coisa; é uma coisa que apesar de ter sido monitor, ter trabalho com debates tudo, agora está ficando uma coisa séria, é uma coisa formal. "Vai funcionar?Estou planejando um estágio formal pra ensinar Física usando tudo que eu aprendi na universidade. Vai dar certo?" Então, por isso que eu fiquei reticente, mas depois que eu vi o ensino aplicado eu desencanei, agora isso me reforçou; então a matéria nesse sentido, a regência me fez, o estágio 
me fez enxergar não realmente o ensino que eu estou aprendendo, mas tem uma coisa importante, porque eu me propus a isso, porque eu já entrei gostando e querendo ser professor. E porque também a professora organizou as atividades de estágios para que elas não fossem burladas, para que elas fossem cumpridas de forma decente, que eu tivesse que fazer uma reflexão sobre aquilo. Então, a orientação dela, o papel dela como parceiro mais capaz, como diria o Vigotsky, foi essencial, porque se ela fosse uma professora como outros professores fazem de ignorar o estágio, falam: "faz aí, faz na escola", mas não dá uma orientação, eu por conta própria, como aluno, mesmo tendo a monitoria, não iria conseguir fazer que aquilo fizesse sentido pra mim. Então, a orientação dela, a forma como ela estruturou o curso, as discussões, fez com que eu fosse encaminhado, ou seja, que eu cumprisse o estágio; e, o meu gosto por ensinar fizeram com que me comprometesse mais uma vez de uma forma muito bacana com o estágio, que tinha tudo a ver com o que eu me perguntava.

Pesquisadora - Outra coisa,como você acha que o estágio pode colaborar com a escola,com os alunos, com o professor da escola?

Ricardo- Bom, primeiro, o estagiário está num momento de aprendizado, entãoele pode mostrar, por exemplo, junto com a ajuda do professor da escola que o conhecimento é uma coisa que é construída, não é uma coisa inata; porque eu estou falando isso, porque os alunos, eu percebo pelo menos, que eles, assim como eu, tiveuma série de estereótipos sobre a Ciência, sobre o que é ensinar, sobre o que é aprender, concepções espontâneas que oVigotskyfala. Quando ele entra lá com uma pessoa que esta pra aprender tem um conhecimento limitado eu acho isso já uma forma de colaborar pra uma quebra dessa visão. Não estou falando que vai ser uma coisa imediata, uma coisa construída, esse é o primeiro ponto. O segundo ponto que ele pode construir, se ele tiver uma boa formação, tiver interesse e boa vontade na universidade, vai trazer outras estratégias de ensino, ele vai trazer outras formas de ver Física outras formas de ver o mundo, que podem colaborar para os alunos verem a disciplina de uma outra forma, e o professor também procurar inovar sua prática, ou repensar sua prática. Então, por exemplo,como a professora $\mathbf{Z}$ devido a diversas condições estruturais da escola, condições de trabalho, número de aulas enorme, eu levando experimentos que é uma coisa queela gostaria de fazer, mas não podia; experimentos, mas dentro de uma sequencia investigativa, por exemplo, é uma coisa nova pra eles e pro professor também, que pode fazer com que eles passem a ver aquilo de uma forma diferente. Ela pode repensar: "Tudo bem, eu tenho uma série de questões que condicionam meu trabalho, limitam meu trabalho, mas o que eu posso fazer então pra tentar romper com essas condições, ou romper com essas limitações; então o estagiário pode contribuir também como se ele fosse um co-docente, como se ele fosse um professor assistente, aí está fazendo a ligação da escola com a universidade, que é uma ligação por sinal muito fraca. O muito que é produzido na academia fica na academia, muito da coisa que é vivenciada na escola fica na escola. Então, às vezes a gente parece que tem um lado muito prático, ou muito teórico. Uma teoria que é refletida, refletida, refletida, mas ela não é levada pra sala de aula. Uma prática que é praticada, praticada, praticada sem reflexão, então quando o estagiário faz esselink, mas ele está engajado, ele está tendo uma boa formação e o professor da escola também está disposto a receber esse estagiário e essa conexão é feita, então ambos podem se comunicar.

Pesquisadora - E o professor poderia ajudar o estagiário também nesse processo?

Ricardo - Pode, não, eu acho que ele deve. Eu tive a sorte nessa escola, por eu ser ex-aluno, por eu ter participado desse projeto, tá e tal; os professores sempre me apoiaram, apoiaram e me deram liberdade e espaço suficiente pra poder fazer isso, me orientar até. Como elas já me orientavam no ensino médio hoje elas não tem necessidade de me orientar de novo, porque elas sabem que fizeram uma formação muito boa. Apesar disso troquei e-mails com a professora $\mathbf{B}$ falando: olha eu estou querendo fazer isso, então teve uma conversa, teve um diálogo né. Mas como elas já me conheciam, já tinham enfim já sabiam como eu trabalhava, porque foram elas que me introduziram a isso então não tinha por que. Mas, por exemplo, teve outra escola que eu estagiei a disciplina de Práticas; a professora superbacana deu liberdade pra gente, mas num tinha um diálogo, não tinha uma comunicação, num tinha assim, um: Ahh! Isso tá legal. Vocês fizeram isso aqui, não tá legal. Olha! Vocês podem trabalhar com isso, isso daqui...não tinha diálogo. E é uma crítica que eu faço, por exemplo, aos estágios, não só, nesse caso da disciplina de Práticas, mas da faculdade de Educação. Você não tem uma relação estreita com da Universidade com a Escola. Não tem um acompanhamento, não digo nem em termos defiscalizaçãouma coisa disciplinar, mas um acompanhamento, uma preparação, alguém que esteja lá, alguém mais experiente, um parceiro mais capaz, de Vigotsky, falando assim: "O quê você está fazendo está certo: vai em frente. Deixando a pessoa fazer, mas com orientação e intervenção pedagógica; não tem isso. $\mathrm{O}$ aluno é botado na fogueira e se vira, por isso eu acho que muitos aqui acabam desistindo, por exemplo, dalicenciaturaou encontram situações que 
eles pela primeira vez eles tão tendo que dá aula não passaram pela experiência que eu tive de ser monitor, são jogados lá e o professor da escola não ajuda, o professor da universidade faz uma série de reflexões é um cara super inteligente e tal, mas não ta lá na sala de aula com ele.

Pesquisadora -Naquele momento

Ricardo - naquele momento então, aí a formação obviamente se perde. Eu acho que boa parte da desistência do curso, mas isso realmente é minha opinião, tem haver é lógico com as condições de trabalho tudo, a pessoa não gosta de ser professor e para, mas também o fato de não ser esse acompanhando mais de perto. Assim, como por exemplo, um médico ele tem um hospital dentro da Universidade pra ele trabalhar, e ele é acompanhado por médicos experientes, o professor deveria ter uma escola em minha opinião; devia ter uma escola como a escola de Aplicação que ele fosse trabalhar ali, com aquela população, e fosse acompanhado. Que tivesse alguém, não digo na sala de aula em si, mas que estivesse lá acompanhando se o que ele preparou está coerente, se aquilo faz sentido pra discutir os problemas, tentar trabalhar com que ele tem.

Pesquisadora - Uma pessoa que ajudasse, um supervisor?

Ricardo - Sim,

Pesquisadora - Alguma coisa nesse sentido, que pudesse fazer esse elo, talvez.

Ricardo - Sim, sim, não no sentido disciplinar, no sentido pedagógico

Pesquisadora - Pedagógico claro, claro, pode ser; não é no sentido de fiscalização.

Ricardo - Só pra saber,tem muito mais perguntas?

Pesquisadora - Não, não. Só mais uma pra finalizar, você se sente preparado para a docência?

Ricardo-Sim, comcerteza.

Pesquisadora - E terminando o curso, obviamente você vai para o ensino?

Ricardo- Sim, eu entrei com esse objetivo. Vou sair com esse objetivo; pra mim a educação é uma luta social; é muito importante a transformação dasociedade. Gosto do que faço, amo por mais que tenha todos os problemas de condição social e financeira, desvalorização; e por aí vai. Amo o curso. Defendo o curso até o fim, defendo os professores da Faculdade de Educação mesmo discordando muitas vezes deles. Defendo os professores de ensino daqui critico os professores que não gostam de ser professores. Então, porque eu acho que ser professor, principalmente os que lidam no geral - não generalizando os professores que dão a Física pra gente - a falta de relação deles com o ensino. E assim, um descaso muitas vezes; é grotesco, isso eu tenho como uma critica com relação ao curso, mas quando eu entro numa disciplina que eu vejo o professor que ele tem uma preocupação pedagógica, e fala assim não vocês vão aprender porque vocês vão ser professores. As matérias de ensino mesmo quando eu falo das críticas do próprio estágio da Faculdade de Educação, até os professores da Faculdade de Educação eu olho com olhar crítico, mas também eu gosto, eu acho que essa provocação ela deve ser feita como uma coisa positiva

Pesquisadora -No sentido de você agregar ...

Ricardo-Sim.

Pesquisadora - Melhorias para o curso.

Ricardo- Resumindo, apesar dos problemas do curso eu amo o curso, como eu entrei, mas eu acho que tem uma diferença por ter vivenciado isso antes; entrar sabendo que eu queria ser professor só contribuiu para eu poder ter gostado do curso e defende-lo. Enfim porque eu acho que se eu não tivesse passado por essa experiência, tivesse sido como meus amigos, nas disciplinas de estágio, talvez eu não tivesse esse pensamento. Acho que tem muitas coisas que precisam ser melhoradaspra poder ser uma coisa mais... Acho que os professores são só pesquisadores, são só bacharéis. Acho que pra você ser professoruniversitáriodeveria cursar umas matérias de Educação; não quer dizer que você vai ser um bom professor cursando, mas você vai ter contato direto com o pensar da educação. Acho que os estágios tanto na Faculdade de Educação quanto no IF da UNIVERSIDADE UNI, apesar de que aqui já é bem diferente, o estágio prático ele é mais organizado, ele tem um contato direto com a escola. Mas eu acho que deveria ser uma coisa parecida com a Medicina, você fazer uma espécie de residência, por exemplo, num sentido lógico, há uma diferença, mas no sentido de formação. Você tem um acompanhamento, poderia ser igual, acho que tem um pouco a ver com a desvalorização social da profissão e do curso. Mas uma coisa que acho bizarra, que é importante ressaltar, tem impacto muito grande na formação, é o fato de alguns professores tanto da Faculdade de Educação quanto do Instituto de Física da Universidade em si, não terem vivenciado a escola pública, a sala de aula. Muitas vezes são professores que passaram pelo mestrado fizeram ensino, amam o que fazem, não estou tirando o mérito disso, são excelentes pesquisadores, vão para o doutorado fazem o doutorado, mas não estão vivenciando a sala de aula. A 
importância da práxis, da ação e da reflexão, nem teoria só, que virablábláblá, livresco e por aí vai. Nem só prática sem reflexão, que você vai fazer a mesma coisa sempre, tem que ter os dois: o pesquisador da área de ensino, da área de educação tem que estar constantemente na sala de aula; seja para vivenciar aquilo de uma forma sem se distanciar do objeto de estudo dele, seja num momento que depois ele vai trabalhar ele vai se distanciar daquilo pra entender melhor, pra depois reformar a prática dele. Acho que enquanto a gente tiver nesse distanciamento entre teoria e prática, por exemplo, eu acho que é isso vai impactar na formação doslicenciandos; porque as pessoas, às vezes,o licenciado pela oportunidade de trabalhar durante o curso dele como professor, porque falta professor ele vem de uma realidade e quando vai fazer a discussão na sala, aquele professor com a melhor boa intenção que tenha, por melhor que ele seja não está vivenciado aquilo, não sabe o que é aquilo, por mais que ele tenha toda a teoria, ele tem umas outras práticas.Dificilmente vai ter aquela aula, naquela escola, naquele contexto, aí que esse choque entre culturas, cultura intelectual; a cultura muitas vezes de massa enfim qualquer outro tipo de cultura que não seja dominante, se nesse choque, nesse embate,se ele souber trabalhar bem, mas se ele procurar até vivenciar aquilo muito mais a fundo, eu acho que a formação vai ter um impacto diferente nele. $\mathrm{Na}$ formação do futuro professor, principalmente, porque nessa formação ele está desenvolvendo junto com os alunos uma visão de mundo uma visão de ciências, que tem a ver com o que eleexperimentou, muitas vezes ele aprendeu na teoria, muitas vezes isso é transferido para o aluno, ou reproduzido.

Pesquisadora - Mais alguma coisa que você queira dizer?

Ricardo- Não, só agradecer. Gosto de conversar sobre essas coisas; foi um prazer. Então espero que tenha contribuído em alguma coisa.

Pesquisadora - Eu que agradeço.

Ricardo- Fui muitodemorado?

Pesquisadora - Não.

\section{Entrevista 1 com Heloisa}

Heloisa - Meu nome é Heloisa, tenho 21 anos.

Pesquisadora - Heloisa eu gostaria que você falasse um pouco da sua trajetória no ensino, ensino fundamental, médio, como foi essa sua trajetória até chegar na Física.

Heloisa - Eu estudei no colégio X que é um colégio aqui em São Paulo que tem uma proposta de ser diferente dos colégios tradicionais. Ele tem método construtivista não sei o que, sempre fui muito envolvida com a escola, sempre gostei muito da escola e ia bem. Fiz lá desde a primeira, em todos os anos desde a primeira série até o segundo colegial a gente tem trabalhos de campo que a gente sai, por exemplo, a gente foi visitar Cubatão para estudar o Pólo Industrial, visitamos Ribeirão para ver a cultura da cana da açúcar, e todo do mercado sucroalcooleiro, a gente foi para São Carlos para ver tecnologias, para Parati ver a época colonial, fomos pra Tiradentes para ver a época Barroca. Então a gente sempre teve essas viagens, nessa viagem tinha uns monitores que eram pessoas, do terceiro colegial, $3^{\circ}$ ano colegial, que tinha toda uma preparação, que iam monitorar a gente trabalha em pequenos grupos para estudar as coisas. Daí a primeira oportunidade, pelo que eu me lembro, quando a gente tá no primeiro ano do colegial tem uma atividade de monitoria de matemática pro pessoal da oitava, e aí eu sempre fazia parte, sempre fazia parte dessas coisas, então eu era monitora no primeiro para ajudar o pessoal da oitava com matemática, no segundo fui monitora para ajudar o primeiro ano em matemática, e no terceiro fui monitora para ajudar o primeiro também em Matemática e Física então sempre gostei de ensinar e ter contato.

Pesquisadora - Na parte de exatas?

Heloisa - E porque não tinha isso na parte de humanas, a parte de humanas na verdade era muito forte lá na escola a gente tinha oito aulas de história e duas de física, entendeu.

Pesquisadora - Ah, tinha menos.

Heloisa - É o meu colégio sempre foi muito voltado para as humanas, é muito raro alguém sair de lá ir para as exatas.

Pesquisadora - Engraçado porque eu fiz o ensino médio no X também.

Heloisa - Ah é,que legal. 
Pesquisadora - Mas tinham mais a aulas de física.

Heloisa - Então eles estão com esquema que no terceiro ano você tem três aulas de física, no primeiro parece que fica uma aula sobrando, esta aula a mais vai para Química, no segundo vai para Biologia e no terceiro para Física.

Pesquisadora - Mas agora eles devem dar um foco maior pra humanas.

Heloisa - Sempre na verdade,o X foi mais humana.

Pesquisadora - A gente tinha muita aulas é que faz tempo. Era equilibrado, a gente tinha muitas aulas de física, tinha de química também tinha os laboratórios a tarde.

Heloisa - Ah não.

Pesquisadora - De Física, de Química.

Heloisa - Ah é. Aula tarde a gente não tinha.

Pesquisadora - Tinha alguns dias a gente ficava a tarde.

Heloisa - Eu estudei toda a minha vida no X eu entrei tipo no maternal 1, no IBG, que era associado, daí fiz o maternal 1 até a $4^{a}$ série no IBG, era quase a mesma coisa assim, IBG e X. Agora é tudo junto, mais antes tinha essa diferença, por causa do prédio, eram tipo dois prédios. E daí na $5^{a}$ série eu entrei no $\mathrm{X}$. $\mathrm{X}$ mesmo, o nome X. Daí no $3^{\circ}$ colegial tem essa atividade pra você monitorar os alunos da outras séries, tem curso preparatório pra isso. E foi um momento de esclarecimento na minha cabeça, porque, na primeira série a gente tem sete anos, você não sabe nem direito o que tá acontecendo e você faz um projeto para conhecer o Rio Pinheiros, a nascente do Rio Pinheiros você faz um trabalho assim. E daí, no segundo ano a gente vai visitar o Rio Pinheiros também, então foi um momento que eu vi que toda a minha trajetória na escola tinha sido muito bem pensada. Sabe, tudo fazia sentido, tudo tava muito conectado, por exemplo, minhas aulas da quarta série foram muito usadas nas minhas aulas do $3^{\circ}$ colegial. Foi uma coisa incrível assim, eu gostei muito, muito de saber disso, entendeu? Eu fui monitora da $4^{a}$ série que foi pro Centro, e da $7^{\mathrm{a}}$ série que foi pra Parati. Porque, a gente não monitorava todos, porque eram muitas pessoas querendo, então eles alocavam as pessoas. Eu sempre tive muita vontade de ser professora. Pesquisadora - E essa monitória te incentivou a pensar em ser professora, ou você já tinha essa idéia?

Heloisa - Bastante, já tinha na verdade, acho que desde criança, porque sempre fui muito bem na escola, então sempre ajudava as outras pessoas. Eu gosto disso, eu gosto, porque quando você está com um colega que você ajuda, você é professora, acho que não é muito bem ajuda a palavra.

Pesquisadora - E essa monitoria orientava pra você direcionar um pouco como ajudar os colegas, como você fazer?

Heloisa - Sim, a gente, primeiro tinha uma preparação geral todos os monitores e depois tinha uma formação específica, daí junta os monitores da $4^{a}$ série com a professora da $4^{a}$ série, e com a coordenadora, pra falar quais são os objetivos daquele projeto, qual vai ser a metodologia como que as coisas vão funcionar, tal. Daí agente lia o roteiro que tinha, e tipo uma apostilhinha, com perguntas e tal isso na $4^{a}$ série, que era um projeto de um dia só. Você ia visitava o Centro e voltava. Daí na, na $7^{a}$ série o projeto começa a ficar mais encorpado são três dias, visitando várias coisas lá em Parati e arredores. Daí o legal no $\mathrm{X}$ no final de cada dia, à noite depois do jantar tem um negócio que chama plenária, que é uma pergunta polêmica, que os alunos têm que arranjar alguma alternativa, tem que resolver o problema, assim usando tudo que eles aprenderam durante o dia, e daí, a gente tá lá pra, pra orientar né, tipo a gente não vai dar a resposta, a gente quer que eles pensem, então a nossa ação era mais de orientar. Por isso que, eu tenho extrema dificuldade de dar resposta para os alunos. Não consigo, não consigo sempre to perguntando pra fazer eles pensarem. O X me ajudou extremamente, O X me formou de uma forma muito boa. E daí, eu me interessei por Física, mais no $3^{a}$ colegial. Hoje em dia eu percebo o quanto imatura você é com 17 anos, tem que escolher alguma coisa para você fazer.

$\mathrm{Na}$ verdade eu não queria entrar na faculdade. Não pro resto da vida. Eu queria, saí do $3^{\circ}$ ano muito rebelde. Falei nossa não aguento mais estudar, não aguento mais escola, não sei o quê. Quero passar um tempo sei lá, vou fazer um intercâmbio, vou viajar, e daí no segundo semestre eu faço um cursinho, e resolvo o que vou fazer da vida.Mas, eu nunca tinha feito vestibular, nunca tinha feito nem um simulado. Eu falei tá eu vou fazer a Fuvest, para eu saber como é. E daí eu já pensava em fazer Física. Falei com a minha professora ela falou para eu fazer licenciatura em vez de bacharelado, eu confiei nela. Eu entrei aqui muito perdida na verdade, agora eu vejo isso, na hora você não acha muito. Daí, fui lá e prestei e passei. Daí você fala: tá bom, não vou recusar uma vaga na UNIVERSIDADE UNI, aí comecei a fazer, mas agora eu sou feliz.

Pesquisadora - E por quê ela falou licenciatura? 
Heloisa - Ela fez bacharelado e licenciatura. Eu não sei se na época dela já existia essa separação, mas acho que sim. Ela gostava muito mais do curso de licenciatura. E ela falou assim, como você é do X, vendo mais ou menos o seu perfil, acho que você vai gostar mais de licenciatura, licenciatura dá mais oportunidades, qualquer coisa você pega o bacharelado depois , pega as outras matérias do bacharelado, não tem necessidade de fazer bacharelado, licenciatura é muito melhor.E talvez eu, sei lá, acho que eu nem sabia direito a diferença entre licenciatura e bacharelado. E daí, é isso. Entrei na faculdade, e só fui pegar matéria relacionada com educação, porque a primeira matéria relacionada à educação é POEB, no segundo semestre, não peguei fiquei com preguiça. Então, não tava dando muita atenção para isso ainda. Daí no segundo ano eu peguei Didática, esse semestre eu tô praticamente só com matérias relacionadas à educação, só com uma matéria da Física, Física Física que é o laboratório, de resto só educação, tô muito mais envolvida com isso.

Pesquisadora - $\mathrm{O}$ curso atendeu às suas expectativas, era o curso que você queria? Você pode avaliar isso? Heloisa - É difícil falar, né. Eu entrei muito despreparada ainda, então tive que estudar muito, é difícil no primeiro ano é assim, eu não tava muito certa do que tinha tido em Física e Matemática no colegial. A nossa professora de Física quando a gente tava no primeiro ano, foi o primeiro ano dela na escola também, então nossa... a gente brigava com ela o tempo inteiro no primeiro ano, coitada a gente fez ela sofrer. No segundo ano a gente deu uma acalmada, e no terceiro ano tava tudo bem. E daí, por exemplo, trigonometria que é cobrado bastante, funções em Cálculo 1, eu tive no colegial, mas não lembrava, não tava muito firme na minha cabeça, então eu tive que correr atrás disso. Daí, o primeiro semestre a gente faz de boa, é divertido. O segundo semestre tudo bem, daí o terceiro semestre do curso é muito decepcionante. É porque eu acho que, o curso de Física ainda tá organizado de uma maneira que era organizado há muito tempo. Por exemplo, primeiro Mecânica, depois Relatividade, depois Física Moderna eu acho que tudo isso tinha que tá muito mais interligado, entendeu? Acho que dentro do curso de Física a gente ainda departamentaliza muito tudo. Acho que tinha que misturar mais, não tô falando pra vê Física Moderna no primeiro ano, mas todo mundo que entra em Física gosta mais dessa parte. A gente quer saber de Física Quântica, Relatividade, Cosmologia isso você só vai ver no final do curso, tanto que até o $3^{\circ}$ ano eu pensei em sair da Física, porque o curso tava muito chato, só tava tirando nota ruim. Os professores eram muito ruins. Passei em várias matérias com cinco, assim raspando. Eu acho que o curso de Física ainda é muito ruim. Mas, também não sei ações efetivas pra mudar. Eu teria que saber mais, enfim tinha que estar lá dentro mesmo. Eu respondi pergunta.

Pesquisadora - E aí o que te segurou pra continuar, o que fez você continuar?

Heloisa - Nossa boa pergunta. A falta de coragem para ir embora. Precisa de coragem pra abandonar um curso. A promessa de que quando você visse Quântica tudo isso iria melhorar, tenho muito isso na minha cabeça, que uma menina mais velha ela me falou, ela faz Bacharelado na verdade, ela já se formou, ela falou, espera chegar em Física Moderna tudo, tudo melhora, sabe as coisas são lindas, é muito lindo. Daí eu falei vai tá, vou dar uma última chance pro curso, e também porque eu sei o que é o curso de Física, não é daqueles que vai ficando mais fácil, conforme passa o tempo. Mas, eu já tava no terceiro ano, entendeu, teoricamente só faltaria mais um, não tive coragem de largar. Se eu largasse ia fazer o quê? Não sei porque eu já tava muito envolvida com a Física, então teria que ser alguma coisa parecida. Pensei em Geofísica, pensei em Engenharia Ambiental que eu tava gostando muito dessas coisas mais ambientais na época.

Pesquisadora - Mas o que te chateava era a questão da estrutura e de como as aulas eram dadas?

Heloisa - É. O curso de Física é muito ingrato. Nossa você estuda, estuda, estuda e vai lá e tira nota ruim, e parece que você não aprende. Eu tenho essa sensação até hoje, que parece que muitas coisas eu não aprendi. A parte conceitual mesmo, também tem uma grande crítica que no curso de Física você aprende a fazer exercício. Então, a gente meio que decora como um exercício tem que ser resolvido, se muda um pouco, se pede alguma coisa mais conceitual a gente se perde. Eu falo isso muito baseada em Eletromag, Eletromag é a matéria dos demônios. Eu passei com cinco bola (5.0). Não sei como. Acho que a professora me deu uns pontinhos. Mas nossa, não entendi o que foi ensinado lá, não entendi. É muito estranho. Mas Eletromag parece que mesmo com o melhor professor, que é o Navarra, parece que é tipo super puxado, não sei o que é, é realmente muito difícil de entender. E realmente isso é verdade, porque se você for pensar, talvez mesmo os pesquisadores não tenham essa compreensão mais filosófica da coisa. Eles sabem fazer as contas, eles sabem causa e efeito, mas na hora que você vai explicar o que é carga ... sei lá, porque acontece isso, sei lá,eu sei que acontece. E eu não sou assim.

Pesquisadora - E as matérias da Educação em que elas colaboraram pra você, como foi essa visão em relação as matérias da educação? 
Heloisa - Ah, Didática achei bem chato, porque como lá no $\mathrm{X}$ a gente discutia muito as coisas, gente assim, querendo ou não tem uma formação diferente, isso é impossível negar. A gente lê, a gente leu o Capital no colegial, a gente lê Descartes, Spinoza tudo isso no colegial.

Pesquisadora - Sei.

Heloisa - Então eu pegava, pegava um texto, e pra fazer uma resenha sobre o texto, pra era muito fácil, e às vezes, só que, só que minha escola ela é exceção, praticamente exceção a regra. E daí, eu acho que tô sendo meio prepotente ao falar isso, mas, por exemplo, numa sala como a professora ela já tá acostumada a dar cursos da educação pra Exatas, primeiro tem muita gente que tá na licenciatura que acha as matérias da educação chatas, que não tem interesse, ehh e sabe são discussões relevantes. Realmente eu achei que Didática foi chato, mas tinha discussões relevantes entendeu, achei chato porque pra mim não passou um nível que eu já tinha, eu num, a matéria não me acrescentou muito. Daí eu fiz Psicanálise Educação e Cultura, e me apaixonei, me apaixonei extremamente. Adorei a matéria, adorei os conteúdos, adorei as reflexões, até pensei em ir pra esse lado, mas eu sou muito volátil, extremamente volátil. Assim, tipo primeiro semestre eu pensava em ir, ir pra área de Meio Ambiente, mas daí depois passou já tava pensado em ir pra área de Psicologia, mas daí passou eu já tava pensado em ir para área histórica, não sei o que vai vir semestre que vem agora.

Pesquisadora - Daí você acha que isso é do X?

Heloisa - Pois é né, na hora de escolher a carreira, você fala Meu eu gosto de História, gosto de Física, gosto de Matemática, Filosofia, Artes, gosto de tudo, quero fazer tudo. Mesmo dentro da Física, eu gosto de tudo quero fazer tudo. E daí, nossa Psicologia foi, nossa foi maravilhoso. Psicologia não Psicanálise, ainda não fiz Psicologia. Daí agora eu não peguei Elementos no, no período certo, estou fazendo Elementos, Elementos agora. E também, nossa tá sendo muito legal, tá sendo muito legal mesmo. Umas discussões interessantes, ahh eu sentia muita falta, eu falava Meu todo mundo fala de Piaget, Vygotsky essas coisas, e eu num, num vi nada disso, mas daí foi realmente como eu não tinha pego no período ideal, eu realmente eu não tinha visto, mas foi culpa minha, porque no curso de Elementos eles dão. Daí eu comecei a ver Piaget, Vigotski teoria de aprendizagem, achei isso muito legal.

Pesquisadora - Quais mais têm?

Heloisa - POEB to fazendo agora, é a professora muito boa. Discussões muito boas. Pesquisadora Como que você vê isso pra sua formação? Como professora, pra sua formação docente. Como você vê esse conjunto de disciplinasé, tanto da Física como da Educação, você acha que elas te estruturam pra docência, ou o que faltaria nisso ainda pra sua formação como docente?

Heloisa - Eu ao contrário de muitas pessoas gosto muito da teoria da Educação assim, porque tem gente que lê Piaget, Vygotsky, Mortimer e fica de boa, não vê uma utilidade naquilo, porque na prática tudo é diferente. Eu, eu não vejo isso. Eu vejo assim, na prática tudo é diferente porque a maioria das matérias tão tendo agora, realmente é diferente disso, mas eu não quero fazer o ensino tradicional. Então eu vou usar todos esses pensadores que me deram de base, pra tipo fazer um curso diferente, uma maneira diferente de ensinar Física. Por exemplo, a, a alfabetização científica da, da Lúcia são, é uma coisa que eu já pensava antes, foi a mesma coisa que o Yuri falou ontem, ele falou exatamente o que eu pensava. Que eram coisas que eu já pensava antes, mais foi muito legal vê alguém tipo escrevendo sabe uma coisa que você pensa, mas você não consegue organizar, você não sabe bem, uma idéia que você tem. Daí foi muito legal lê um projeto disso, uma justificativa.

Pesquisadora - Aí você tem um referencial?

Heloisa - É porque eu gosto de pessoas que escrevem o que eu penso, assim.Porque eu tenho muita dificuldade de formalizar as coisas que eu penso, então eu, eu gosto bastante. Claro que gosto de ler coisas novas, coisas que eu não penso, óbvio. Que mais, e daí eu aproveito muito dessas matérias, essas matérias são muito importantes pra mim, nesse sentido da mudança, então eu vejo muito sentido nelas. Eu acho que as pessoas que não vêem sentido nelas são as pessoas que não tão comprometidas com uma mudança. Pesquisadora - Você diz as matérias da educação?

Heloisa - As matérias da educação, e educação ligadas tipo Elementos, Metodologia. O que falta nelas? Olha, eu não sei o que a maioria das pessoas fala, e que falta prática você fica vendo muita teoria, e falta prática. Só que ser professor é uma coisa muito pessoal, é uma prática muito pessoal, porque se, a formação do professor ficar unicamente na mão da universidade você vai formar 30 professores iguais, e eu não vejo isso como algo positivo. Acho a prática ajuda sim, mas acho que você tem que pegar esses conhecimentos que são apresentados na aula, que são refletidos nessas aulas, pra formar você como professor, você porque senão, se a Universidade vira e fala aceite tudo isso que a gente falou e aplique, você vai tá formando professores iguais, e num caso extremo assim sem identidade. Então, eu, eu acho 
que as pessoas têm que ser totalmente livres pra pegar isso que foi dado ver oque tem sentido para elas, o que elas acreditam como elas querem fazer, discutir qual o objetivo desta atuação dela não sei o que, e se inventar como professor.

Pesquisadora - E a questão do estágio, você ia à escola, você fazer um plano, isso colabora? Em que sentido colabora, assim o quanto colabora pra essa formação sua?

Heloisa - Eu acho que a hora do estágio é justamente uma hora que Universidade pode te encaminhar assim no sentido do professor que ela quer formar. Não é aquele sentido de pegue tudo isso faça desse jeito. Mas, por exemplo, Práticas foi muito importante pra mim pra reconhecer e fazer na prática o planejamento da aula, que é muito importante, eu sabia que era importante, mas ao fazer você vê que realmente, eu agora não penso em fazer uma aula sem planejar, porque não tem sentido uma aula sem planejamento. Então você fazer o planejamento de uma aula. Você fazer uma reflexão de como foi sua aula. Se você atingiu os objetivos que você queria, tal. E pensar uma, não só em uma aula, como uma seqüência de aulas, o que você propôs também, acho que isso.

Pesquisadora - E em Metodologia esse que você fez, esse contato que você teve isso também te fez refletir essa prática?

Heloisa - Sim, porque em Práticas era muito você fazer planejamento de uma aula e o relato dessa aula. Agora em, em Metodologia a gente fez quatro aulas, então era tipo, além de cada, do planejamento e do relato de cada aula tinha os objetivos gerais das quatro, e a reflexão sobre as quatro aulas. O que deu, deu uma continuidade assim, talvez em Práticas era muito pontual a ação, pelo menos é o que pareceu, em alguns, no final do, do ano eu consegui perceber que realmente tinha uma seqüência entre os experimentos, mas enquanto eu fazia isso ficou bem perdido. Em Metodologia não, tinha um planejamento para seqüência de aulas.

Pesquisadora -Você viu uma seqüência toda?

Heloisa - É, que eu pensei logo na seqüência de uma vez, que é o que eu penso em fazer como professora. Primeiro você tem que pensar qual o objetivo, por exemplo, da Física no primeiro ano. Qual o objetivo, como eu posso trabalhar no primeiro semestre idem segundo né, pra esse objetivo, dentro desse semestre como eu trabalho em cada bimestre ou trimestre, depois como eu trabalho em cada aula, entendeu. Porque, senão fica isso, fica aulas perdidas, é não. É um curso, é uma seqüência de aulas, que tem que ter objetivo geral e um objetivo específico, um para cada período de tempo.

Pesquisadora - E nesse período curto, que é uma coisa que você falou, foram poucas aulas, mas deu pra você, pegando o que você viu na disciplina e o que você já conhecia de outras, claro que não é só da disciplina, mas deu pra você fazer essa ponte que você disse, que é se inventar como professora? Começa a surgir uma invenção da Gabi professora?

Heloisa - É acho que primeiramente acho que sim, primeiramente pelo, pelo tema proposto que reflete muito, reflete o que eu gosto na Física. Reflete na maneira como agente organizou as aulas. Reflete como que eu quero trabalhar esse conhecimento, que agente escolheu a perspectiva histórica e filosófica, que eu acho uma maneira super, hiper mega válida. E mais ainda na, na hora que eu fui dar a minha aula né, porque daí era eu lá na frente com os alunos, então eu tinha que agir como professora.

Pesquisadora - E que sensação isso te trouxe?

Heloisa - Ah, é muito bom. Eu gosto muito, eu gosto, eu gosto muito.

Pesquisadora - E o que achou da sala em relação à toda a escola? Como você vê esse contexto, lidar com esse contexto todo?

Heloisa - Como assim?

Pesquisadora - Lidar com o contexto da escola dos alunos te toda essaestrutura, da escola?

Heloisa - Tá, vouresponder, eu não sei se entendi muito bem sua pergunta, vou responder se não for muito isso você me fala. Que algumas dificuldades que eu vejo, não só por este estagio, mas por todos, todos acho que não teve uma exceção, por todos os outros, eu só fiz estágio em escola pública, nunca quis fazer na escola particular. Falta muito uma unidade Escola.E que é assim, eu tenho um péssimo exemplo, eu tenho o X como exemplo, o X era uma escola, era um grupo de professor, todos eles trabalhavam no mesmo sentido, todos eles tinham um, uma visão crítica, um jeito diferente tinham propostas diferentes, era tudo pensado diferente. Então, eu sou um péssimo exemplo. Mas assim, falta muito uma unidade Escola. Falta muito uma unidade grupo de professores. Uma matéria é totalmente desconexa uma da outra, os professores eu não sei eu não acompanhei nenhum, por exemplo, HTPC não sei se pode acompanhar.

Pesquisadora - Não sei, talvez até possa, mas eu não sei. Precisa perguntar pra a Marina. 
Heloisa - Mas falta, no X tinha reunião de professores toda semana. Era toda segunda-feira a noite tinha reunião dos professores entendeu. Pra, eu não sei o que eles faziam, porque também, serviço secreto, mas tem que refletir sobre o que tá fazendo. Tem que criar um objetivo para escola, tem que, tem que propor coisas não dá pra, ô professor chega lá faça sua ação pontual na sala de aula, vai embora, falta muito isso. Professor que não se conhecem dentro da escola. Sei lá, isso, isso não é certo.

Pesquisadora - Você acha que o estágio poderia trazer alguma colaboração pra a escola além, além do que trás pros alunos, parece que isso que a gente viu que teve um reflexo, a gente não sabe o quanto, mas teve uma resposta, imediata ai, mas o estágio ele poderia trazer, uma contribuição pra a instituição mesmo?

Heloisa - Só voltando pra outra questão, pra dar um exemplo, se os professores tivessem um trabalho mais conjunto agente não teria tanta dificuldade em propor uma redação numa aula de Física. Não seria um problema tão grande quanto na minha perspectiva foi.

Agora quanto ao estágio pra isso, não consigo pensar como. Porque você, assim, é difícil você entrar numa escola. Primeiro precisaria de um acompanhamento mais duradouro, se de fato você quisesse mudar alguma coisa. Não i lá e dá, dáuma palestra: "Como uma escola deve ser", que a escola vai mudar. Eu acho que, por exemplo, precisa de mais orientação nas escolas, eu acho até que a universidade poderia ajudar isso. Em ter profissionais da universidade que fizessem um trabalho de, vou falar uma palavra feia que talvez tipo consultoria assim, na escola, pra tentar melhorar o que eles fazem. Pra, tem professor eu não sei se eles nunca tiveram ou se agora perderam, mas eles, eles perdem o significado dá pratica deles. Eu não sei mais, se eles sabem por que dão aula? Entendeu. I isso não tôfalando que é culpa deles. Por exemplo, que realmente se você pega uma escola que tem um monte de problema de violência, que você não consegue dar a sua aula direito sabe, se você só vai tapa na cara, tapa na cara, tapa na cara é completamente natural, professor é ser humano. Você não vai querer se empenhar numa coisa que você não tá tendo resultado. Mas, esse estágio, que, acho que é muito pontual, que agente faz, não vejo como, não. A gente até,porque também, a gente vai lá nossa proposta e dá quatro aulas, ou sei lá, no caso de Práticas dá uma aula, a cada, a cada 15 dias, ao longo do ano inteiro. Agente não tem liberdade assim, agente não tem porque, vai ser muito feio se agente entra lá dentro i começar a apontar os defeitos, e começar a falar você está fazendo errado, não sei o quê.

Pesquisadora - Eu perguntei isso porque a diretora pediu, quando a gente foi lá, que nos aproximássemos mais. Vocês vão continuar no segundo semestre? Podem usar o diurno também.

Heloisa - É então.

Pesquisadora - A gente tá aberto. Pode usar Química, pode usar aula de Matemática a gente tá precisando de ajuda.

Heloisa - Eu acho que justamente esse, esse ânimo que tem na faculdade. Que todo mundo que tá na faculdade gosta de trabalhar com isso, assim falando mais da parte dos professores, não tanto da parte dos alunos. Mas, se os professores elas estão nas áreas que elas tão, eu espero muito que eles gostem do que eles fazem, porque eles escolheram enfim. Se já tem 30 anos, se você não tá fazendo o que você gosta, você é bobo. Assim, na universidade admitindo que quem tá aqui realmente é uma elite e tá fazendo o quê quer, enfim, xiii perdi o fio da meada.

Pesquisadora -Eu estava falando da diretora, e aí você falou que os professores estão fazendo o quê querem, o que a diretora tinha pedido.

Heloisa - Ah, então, então os professores é mesmo os alunos eles tem esse ímpeto de melhorar as coisas, eles tem essa vontade de melhorar as coisas, eles querem que as coisas melhorem. Então, levar essa, essa alegria esse otimismo, pra dentro, tá faltando otimismo dentro da escola. Pronto acabei de definir: tá faltando otimismo dentro da escola. E tá faltando vontade de fazer as coisas melhores, com esperança que dá pra fazer as coisas melhor, nossa eu só pego professor que fala: não tem jeito, eu tô cansado, assim nada vai mudar. Eu sei é difícil mas se agente peder isso, não dá para fazer nada, se você não tem vontade de fazer, se você perde esse ímpeto da mudança, assim. Então eu acho que como isso é muito forte nos professores, acho que uma ação da universidade dentro da escola só tem como algo positivo, porque,na minha opinião, os professores que a UNIVERSIDADE UNI quer formar são professores alternativos, assim. A UNIVERSIDADE UNI não quer formar o professor da Educação Bancária. Ele é ótimo, esse é só um lado positivo da história. quer formar o professor da Educação Libertadora, então isso pra mim Pesquisadora - Você se sente preparada pra, pra ser professora?

Heloisa - Me sinto. Assim ainda falta muito, por exemplo, pensar uma seqüência de aula, pensar um plano de aula, pegar e ver o que eu vou fazer mesmo na prática, quando eu tiver lá na frente da sala. Mas, eu sinto com total preparo pra pelo menos pensar em como eu vou fazer isso. E sinto, por exemplo, todos os professores aqui da faculdade são muito disposto a ajudar. Se eu for preparar uma aula eu me sinto à 
vontade de bater na porta da Marina e vira: Marina eu agora eu tenho que dar Quantidade e Movimento tem algum experimento que eu possa fazer, até porque, por exemplo, a minha proposta do site né, que agente estava conversando agora é justamente pra, prá levar essa proposta, levar os experimentos pra as outras pessoas que nunca tiveram contato aqui na UNIVERSIDADE UNI, pro exemplo, pra. E acho que as reflexões de, pra que serve um experimento, não é só lá, não é só fazer uma demonstração e ir embora. Enfim eu acho que todas as reflexões me permitem pensar o jeito que eu vou fazer as coisas.

Pesquisadora - A gente pode até conversar com a Marina vê se a hora que você tiver um tempinho se pode ficar aqui montar também.

Heloisa - É que eu não sei montar site.

Pesquisadora - Não, não precisava ser o site você pode montar e ver alguém que possa colocar no site.

Heloisa -É.

Pesquisadora - Precisava ver o que tem aqui.

Heloisa É, não é gente.

Pesquisadora - E daí organizar

Heloisa - Experimento baixo custo se entra na internet tem vários entendeu, eu acho legal, Física UNIVERSIDADE UNI ter um, um espaço dela também, para pessoas consultarem.

Pesquisadora - Aí o que eu puder ajudar eu ajudo, quando eu tiver por aqui a gente pode conversa com ela. E pensar nisso e aí a gente vai vendo o que tem, organizar e ver, e depois tem que ver como, acho que o site é a melhor maneira de disponibilizar.

Heloisa - De passar pra todo mundo

Pesquisadora - Porque aqui eu não sei, ou também se eles pegarem aqui pode ser um jeito, mas daí a gente teria que ver.

Heloisa - Como vai fazer esse controle.

Pesquisadora - Tem que ter alguém

Heloisa - É

Pesquisadora - Daí tem esse controle. Na Estação Ciências tinha isso, tinha um controle. Só que como foi transferido tudo pra UNIVERSIDADE UNI LESTE, então a gente não tem mais.

Heloisa - Estação Ciências fechou?

Pesquisadora - Fechou pra entrar em reforma. Então não sei quando reabre.

Heloisa - Entendi.

Pesquisadora - Os professores pediam, quando iam lá não era só retirar, eles pediam para você dar uma orientação, pra como ele usar.

Heloisa - Por exemplo, isso no site pode ter. Inclusive acho necessário ter. Além, não ser só um site de tipo: experimentos. Ser tipo o que é um experimento? Qual a finalidade? Como podemos trabalhar? Acho isso extremamente necessário.

Pesquisadora - É

Heloisa - Senão perde todo o propósito.

Pesquisadora - A gente fazia também, vez ou outra, um ou dois dias você fazia uns momentos de conversa com os professores. Montava-se alguma coisa. Mostrava pra eles o que tinha e preparar a tipo um, não é bem minicurso, mas alguma coisa que você conversava com ele. Você podia trabalhar não de uma forma tão fechada, mas de uma forma que você podia colocar questões para eles aberta, mais ou menos como ahh Lúcia trabalha. E eles poderem fazer uma discussão com os alunos, e daí utilizar o experimento, ou as vezes, quando eles não têm muito recurso como eles poderiam fazer. Então a gente fazia isso. Agente também pode propor alguma coisa assim, mas que não é sempre, você não pode fazer toda semana, entendeu. Você faz a cada dois meses isso. A gente pode propor isso pra ela, também.

Pesquisadora - Mais alguma coisa que você queira dizer.

Heloisa - Não. Mais alguma coisa que você queira perguntar.

Pesquisadora - Não. Quero entrevistar mais vezes, depois no decorrer do segundo semestre.

Heloisa - Tá bom. Com certeza, sem problema.

Pesquisadora - Obrigada

Heloisa - Imagina. 


\section{Transcrições das Entrevistas 2 de Heloisa e Ricardo}

\section{Entrevista 2 com Ricardo}

Pesquisadora: Mas eu vou fazer algumas perguntas para ir norteando aqui, em geral algumas coisas você acaba falando. Segunda entrevista com Ricardo. Em uma das questões Ricardo eu ressenti um pouco sobre as contribuições da disciplina para você, para a sua formação como docente, então para sua formação como professor, como que a disciplina de metodologia contribuiu, se ela contribuiu, como que ela contribuiu, em que sentido. Você tem as contribuições que o curso traz, claro que a hora que você trouxer essas contribuições, algumas vem desde o início do seu curso de física, mas e a disciplina, tem alguns pontos relevantes que são... Que a disciplina pode te fazer ver mais claramente, trouxe de novo, para sua formação docente?

Ricardo: Sim, nossa foram várias, inclusive esse foi um dos cursos que eu mais gostei durante a graduação inteira, foi um dos cursos em que eu mais aprendi, mais trabalhei, que eu tive uma série de oportunidade de realizar coisas que eu mesmo defendia, rever algumas outras ideias que eu já tinha, ou coisas novas, uma delas foi em relação aos próprios conceitos envolvidos na disciplina, por exemplo, a alfabetização científica é uma coisa que eu nunca tinha ouvido falar, e no último semestre, não é?! Quer dizer, no meu último ano de graduação por que tem metodologia 1 e 2 . A alfabetização científica eu achei que era uma coisa muito interessante, uma coisa que até me interessa não só como professor, mas como futuro pesquisador, entender que nos temos responsabilidade de alfabetizar os alunos cientificamente, entender isso como um processo de colocar os alunos em contato com a cultura científica, fazer com que eles se tornem consentidos de suas ações por meio dessa cultura ele consiga intervir na sociedade, daí por diante... Gostei muito de ter aprendido a metodologia de ensino de ciências por investigação, uma metodologia que eu achei sensacional que tem muito a ver com os referenciais teóricos que eu admiro, principalmente muitas inspirações, eu acho que... Até do Paulo Freire, do Piaget, que tem esse lado de o aluno ter um papel ativo na sala de aula, do aluno participar, dele estar sempre se questionando, ele realizar uma investigação, quer dizer, é uma metodologia coerente com a alfabetização científica, é uma metodologia coerente com os objetivos do ensino de ciência. Então, achei muito, muito legal mesmo, achei um aprendizado muito importante, principalmente por que assim, é uma metodologia que sai do tradicional, fazendo uma série de críticas ao ensino tradicional, eu sempre prezei pelo educação dialógica até pelas minhas influências de leituras, reflexões e dai por diante, então pra mim, assim, foi um... Nossa, isso realmente existe, dá para fazer, que nem eu tinha comentado na entrevista anterior sobre as minhas influências, como é que eu quis ser professor,as críticas ao ensino tradicional, de fazer uma educação dialógica, então quer dizer, eu tinha visto tudo aquilo, eu tinha refletido, assim como as disciplinas de ensino e educação, tanto daqui do Fiuesp quanto lá do Física, mas eu nunca tinha visto isso sido colocado em prática, então, quer dizer, é uma educação dialógica, é uma educação que o aluno participa, e tinha minhas dúvidas se isso é possível, depois de realizar os estágios, tanto no primeiro semestre, quanto no segundo, eu percebi que realmente é possível, basta você acreditar e criar as condições, lutar para que essas condições que necessitam ser efetivadas na sala de aula para que essa proposta vingue, acho que isso, você precisa lutar e acreditar nela. Então eu aprendi bastante, com relação a alfabetização e o ensino por investigação eu acho que bastante isso. Uma coisa que eu achei muito interessante e que se concretizou foi que na realização dos meus estágios, tinha uma coisa que eu aprendi aqui e eu tinha discutido bem pouco isso em uma das matérias que eu fiz lá na física foi a questão de tentar refletir sobre o que é ciência, as visões de ciência e de cientistas que não só os professores mas principalmente os alunos constroem 
durante a sua formação, quer dizer, é uma das responsabilidades que muitas vezes do próprio processo de ensino-aprendizagem e quer dizer, o professor tem uma responsabilidade muito grande para desconstruir essas visões estereotipadas que muitas vezes por omissão essas visões foram construídas. $\mathrm{E}$ as vezes até pela falta de conhecimento da natureza da ciência e da filosofia da ciência em si e etc. Então, discutir no curso o que é ciência, quais são suas visões, e por ai vai são muito interessantes, foi uma coisa muito boa e foi que eu conseguir levar um pouco, pelo menos acredito, dos meus estágios para os alunos, tanto que um deles, um dos alunos, um não, alguns alunos nas avaliações que eu fiz agora no último estágio apontaram exatamente isso, que eles tinham uma visão que a ciência é uma atividade neutra, feita por gênios, em que você tinha uma objetividade, um método científico universal absoluto, que você não teria questões subjetivas envolvidas e por ai vai. E a pessoa depois falou que os alunos falavam que conseguiam ver que não é bem assim, então, isso graças obviamente a tentativa de trabalhar contextualização epistemológica em sala de aula, contextualização didática, problematização, trabalharcom sequência investigativa, então para mim teve uma série de resultados, tanto no primeiro semestre, quanto no segundo. Nas avaliações, os alunos mostraram que, ficaram muitos satisfeitos, gostaram muito, não houve críticas, por exemplo, se houve foi com relação, por exemplo, pelaprópria organização da escola, a estrutura da escola, mas de resto só elogios, então você vê que realmente é uma coisa que vale a pena lutar por, por que realmente não é trabalhado em outros cursos. É uma... É um diferencial que o curso de metodologia proporciona. Além disso, uma coisa que me chamou muito a atenção é a organização do estágio pela professora. Quer dizer, ela é muito organizada em relação ao estágio, por que como eu acho que eu já tinha comentado na primeira entrevista, grande parte dos estágios na minha opinião, infelizmente, por diversos motivos não é levado a sério, ou tem-se uma impressão de que o estágio ou pela quantidade de horas nas outras disciplinas ou algo do tipo, ele não vai propiciar um aprendizado pelo aluno, há muita possibilidade de você burlar o estágio. Você muitas vezes não tem o incentivo do próprio professor, ou seja, de pegar aquelas informações, aquilo que foi trabalhado, discutir aquilo com os alunos, fazer uma reflexão crítica sobre a prática, isso não tem na maior parte dos estágios. Tirando esse de metodologia, o único estágio no qual eu aprendi muito, muito mesmo, assim, que eu tive regência ou algo do tipo foi em práticas do ensino de física lá no Instituto de Física. Então para mim, esses dois foram os estágios mais sensacionais que eu fiz por que eu aprendi muito, eu estava lá lecionando,eu preparei, eu tive conversa, discuti, eu refletia sobre a minha prática, que eu acho que é mais importante, o retorno. $\mathrm{O}$ retorno está sempre por parte do professor que está te formando aqui como por parte dos seus colegas de turma que acompanham essa sua trajetória e também do professor da escola e os alunos, quer dizer, tem que ter todo esse diálogo no meio do processo, se eu pudesse, por exemplo, se eu fosse professor da faculdade de educação e tivesse o poder de organizar os estágios e interferir nas leis, enfim, algo do gênero, eu aumentaria primeiro todas a carga horária de todos os estágios por que eu acho que 20 horas é muito pouco, e todos deveriam ter regência na minha opinião. Eu sei que muitos professores, principalmente os mais antigos que por diversos motivos acreditam que o estágio tem que ser por observação. Eu discordo dessa posição, eu acho observação importante, mas ela deve ser muito pequena em relação a regência, por exemplo, desde o começo do curso eu acho que todas as matéria de ensino e de educação deveria ter estágio com uma carga horária maior e com uma grande participação e uma grande regência dos alunos e também uma reflexão prática, perdão, uma reflexão crítica sobre essa prática com relação ao docente responsável pela formação, com o docente da escola, os alunos da turma e você mesmo. Então, por exemplo, o fato da Marina pedir para gente agora analisar os vídeos, a gente produzir os vídeos e refletir com a turma sobre aquilo, quer dizer, é o retorno final, é a avaliação final, quer dizer, é a avaliação da minha própria prática da aprendizagem dos alunos e do próprio processo de ensino. Sendo que teve toda uma preparação, a gente preparou as aulas com os colegas, discutiu essas aulas nas aulas de metodologia, a professora propôs algumas correções e alguns encaminhamentos, ela falou o que estava legal e o que não estava, quer dizer, os alunos da turma também fizeram isso, então quer dizer, não foi uma coisa jogada, foi uma coisa muito bem planejada, muito bem estruturada, com uma grande reflexão 
em todo o processo, então para mim isso foi fantástico. Eu aprendi muito, foi como eu falei, foi um dos cursos que eu mais aprendi. E também os textos eu achei muito legal, quer dizer, muitos textos acadêmicos, muitos artigos, a professora sempre procura fundamentar as discussões, quer dizer, ela sempre tenta fazer com que a gente argumente o que é da própria linha de pesquisa dela, desenvolve argumentação na sala de aula, e então isso eu acho sensacional, quer dizer, é uma coisa que eu prezo, a educação dialógica o tempo todo, reflexiva, crítica, que é uma coisa que muitas vezes é esquecida infelizmente. Muitas vezes eu vejo tentativas de debates e discussões na sala de aula, só que essas discussões fazem com que muitas vezes os alunos permaneçam no senso comum ou como Paulo Freire diria, na curiosidade ingênua. Os professores, eles não, pela discussão, eles não organizam esse debate e tentamfazer com que os alunos por esse processo dialógico passem da curiosidade ingênua para a curiosidade epistemológica. Quer dizer, pelo menos entenda que as concepções espontâneas, elas são válidas num contexto, enquanto que as concepções científicas são as quais eles devem adquirir pelo processo de ensino-aprendizagem, são validadas num outro contexto, num contexto científico. Então para mim essa é uma coisa que me chamou muita atenção no curso. Outros temas, por exemplo que foram abordados, o professor de ciências como um professor de linguagem, uma coisa que eu nunca tinha visto, então, quer dizer, pensar o professor de ciências por essa perspectiva também. Eu achei sensacional, intrigante, os textos, como eu falei, muitostextos foram muito legais, uns que discutiam a natureza da ciência, a filosofia da ciência, que tem a veraté com uns dos interesses particulares meus, os próprios textos de ensino por investigação e de alfabetização científica, os de avaliação por exemplo. A avaliação foi uma das coisas que eu mais gostei por que raramente é abordada nos cursos. Eu só tive discussão de avaliação em um seminário em duas aulas.. Qual que era a matéria? Eu acho que foi de Elementos e Estratégias ou em Propostas de Projeto lá na física, e foram dois seminários da Maria Regina que foram sensacionais. Assim, mas foi o único momento da graduação tirando agora a matéria de metodologia que eu tive uma reflexão sobre o que é avaliar. Então é engraçado, por que isso surgiu antes no instituto de física, não na faculdade de educação, aliás, muitas coisas, por mais que eu ame a faculdade de educação, eu gosto e defendo aqui até a morte, mas incrivelmente muitas das coisas discutidas sobre educação que eu tive uma reflexão muito mais crítica não surgiram aqui, surgiram no Instituto de Física. A primeira vez que eu discuti Paulo Freire não foi aqui, foi lá no Instituto de Física, a primeira vez que eu discuti sobre Vygotisky, sobre Piaget não foi aqui, foi no Instituto de Física, então, um tanto quanto contraditório, a princípio. Então quer dizer, os principais ou pedagogos, ou educadores, ou psicólogos, enfim, filósofos da educação que eram para ser nos cursos daqui, por algum motivo não são, eu não sei por que. Mas é uma crítica sutil que eu tenho, mas os cursos daqui eu gostei bastante também, só para fazer uma comparação com o curso de metodologia, mas ai eu retomei essas ideias do Piaget, um pouco do Vygotisky. Assim, mais um pouco mais na prática, então isso foi muito legal e ah, sempre o apoio do professor, ela é uma professora super solista, ela preza para que a gente fala, e para que a gente de a nossa opinião, questione, indague, quer dizer, ela é super coerente com todos os processos de avaliação, ela dá oportunidade de você desenvolver diversas habilidades e competências por meio das atividades, quer dizer, tem resenha, tem análise de proposta de estágio, tem para você fazer a prova, uma prova com consulta, é uma prova reflexiva, não é uma prova de memorização, então, isso para mim é sensacional.

Pesquisadora: E essas ações, assim, que você citou, elas compõem, elas te dão um... como que eu vou te dizer, elas amarram um todo para você? Essas ações que ela propôs assim, o texto, a discussão do texto, deixar você falar, ou falar no grupo, falar com os colegas, depois você preparar uma aula, então você preparar o seu planejamento, você fazer uma resenha, isso tudo faz você sentido para você em relação a criar um todo que vá dando, que vá aumentando a sua visão daqueles conteúdos que ela quer que você discuta, que vocêreflita?

Ricardo:Sim, para mim faz todo o sentido. Tanto que desde o primeiro semestreforam uma das coisas mais diferentes que eu tive, um dos cursos que eu mais aprendi, que nem eu falei e para mim faz todo o 
sentido, faz todo o sentido por que eu já era engajado também eu acho que na discussão de educação em si eu gosto muito, é uma coisa que eu tenho muita paixão, então é uma coisa que faz todo sentido agora, eu não sei se faz sentido para as outras pessoas, por que eu acho que para fazer sentido também não tem a relação só do professor com o aluno, tem a do aluno com o professor e do professor...e do aluno com o "ser" professor. Do aluno com a disciplina, com a vontade dele ser esse profissional. Por que, por exemplo, talvez não esteja muito claro para todos por que a ênfase dela de ensino por investigação e de alfabetização científica. Do por que ela está batendo nessa tecla, por exemplo. para mim faz sentido. Por eu já estudei outras coisas que fizeram lincar com as coisas que ela estava defendendo. Eu gosto, eu leio por fora, tem outras obras de educação que eu li, de psicologia enfim, não foram aqui que eu vi na faculdade de educação nem no Instituto de Física, foi por conta própria por que eu gosto, então para mim faz todo sentido. Também já faço pesquisa na área, então para mim faz todo sentido, agora não sei se para esses meus amigos talvez quem não queira ser professor, se tornar um professor, talvez...eu não sei se a pessoa viu sentido, até por que os textos que ela passa não são fáceis. São textos bem difíceis, exige uma maturidade intelectual, todo um processo reflexivo muito grande para que você consiga compreender por que que aquele texto faz sentido com a prática que você desenvolve em sala de aula. Então, eu não sei, por exemplo, se você não tem a leitura de maior parte dos textos também, se você não se engajou nas discussões, se você não tem esse processo reflexivo, se você não faz o estágio de uma forma bacana, eu não sei se você consegue ver sentido nisso. Eu não sei se você... Por mais que a professora seja uma professora excelente talvez a matéria em si não faça sentido para a pessoa, mas por fatores em direção externa a própria aula, ao próprio curso em si.

Pesquisadora: Então, ai vem, assim, uma outra questão, aí você...que visão que você tem de você enquanto professor em relação a isso que você...a esses aspectos que você colheu, como que você relaciona isso, com que tipo de professor que você está caminhando para construir?

Ricardo: Pensando no ponto de vista agora do professor, do Ricardo professor?

Pesquisadora:É, do Ricardo professor.

Ricardo: Como é que eu vejo,por exemplo, o que talvez não faça sentido para outros alunos?

Pesquisadora: Não, para você, o que para você fez sentido, que tipo de professor você está caminhando, que construção que...

Ricardo: Que tipo de prática?

Pesquisadora:É, que tipo de prática...

Ricardo: Para mim, eu estou caminhando para uma prática dialógica, que é eu defendo, como eu falei, só reforçou aquilo que eu defendia, uma prática em que eu atuo como professor e ensino e aprendo ao mesmo tempo com os meus alunos, eu estou caminhando para uma prática em que eu vou dar a possibilidade para que meus alunos, para os meus alunos desenvolverem investigações na sala de aula. Eu vou ter consciência do meu papel como alfabetizador de alunos em termos científicos, quer dizer, trazer aspectos da natureza da ciência, a importância de contextualizar, problematizar, quer dizer, são coisas que eu já estou desenvolvendo nas minhas aulas, eu desenvolvi no estágio, está presente nas minhas aulas. As leituras, trabalhar com leituras, muitas das atividades que eu vi aqui no curso ou então que eu aprendi aqui no curso, eu estou levando para sala de aula, então, quer dizer, é uma relação direta, eu vejo...quer dizer, o que eu estou aprendendo, o que eu vi aqui de exemplo eu estou levando, por isso que eu acho que não só nesse curso de ensino, de educação, mas nos cursos de física eu deveria ter esse tipo de atividade, de reflexões para que eu tivesse esse exemplo e conseguisse criar outras coisas na sala de aula, eu acho que é muito difícil para o professor que não passa por isso, que está sempre no ensino tradicional ele conseguir 
sair desse referencial, e por outro construir coisas diferentes, coisas novas. Dificilmente, eu tenho a crença na hipótese de que provavelmente ele vai reproduzir muito daquilo que ele aprendeu com os professores dele. Por mais inteligente, reflexivo e crítico que ele seja.

Pesquisadora: Mas se ele não passar por isso ele vai, até ele vislumbrar alguma outra coisa...

Ricardo: Vai demorar, vai ser difícil, vai ser uma prática mais ingênua, não vai ser uma prática consciente, então, é nisso que eu vejo sentido...(pausa). Mas não sei se eu respondi sua pergunta.

Pesquisadora: Não, respondeu que é essa questão mesmo, de como você está, de como isso está influenciando em relação ao que você está construindo para a sua docência. Para o seu ser docente. Aí eu queria que você falasse um pouquinho mais em relação ao estágio, em relação a regência, por que ela está ligada, você falou um pouco, ela está ligada a disciplina. Então, ela faz parte da disciplina e você disse que a professora colocou de uma forma onde você não podia escapar dessa regência, e você tinha que tanto você fazer as regências e não era só a observação, mas também você tinha que fazer uma reflexão sobre ela, depois, tanto na hora de preparar, como depois de realizada, não é? E essa regência, assim, o que que ela trouxe para você, você já tinha uma certa prática, por que você já tinha vivenciado um pouco dar aula, mas o que que ela trouxe para você como essa experiência de preparação para a docência?

Ricardo: Ah, ela trouxe exatamente, eu acho que basicamente o que eu tinha falado da importância de refletir sobre a minha própria prática, ela trouxe a ideia de que é possível sair do ensino tradicional, para isso é o que é mais importante, ver que é possível não só dar aula expositiva, o curso inteiro de física para mim já é um dos grandes aprendizados. Perceber que a leitura é importante, fazer discussões com os alunos é importante, da espaço para eles é importante, ouvir a avaliação deles também sobre mim é importante, ter o contato com os alunos e eles falarem que eles gostaram muito mais dessa metodologia, de trabalhar em grupo, de, deles ficarem engajados, se sentirem engajados e motivados pelas minhas aulas, deles terem construído um espectroscópio, de ter refletido sobre, por exemplo,numa das atividades sobre isso, quer dizer, me trouxe várias esperanças e várias utopias que muitas vezes são aniquiladas por diversos discursos ideológicos, então para mim é possível educar de uma forma diferente, eu acho que esse foi o grande aprendizado, além do que é obvio de ter passado por uma experiência pedagógica séria que dá oportunidade de refletir sobre minha prática tudo, mas eu acho que mostrou caminhos, mostrou possibilidades que eu sei que são realmente eficazes, são efetivas e que precisam ser defendidos e lutados não só nos estágios em si, mas eu acho que a gente tem que disseminar um pouco no sentido de reflexão de metodologia, de prática nas outras escolas, por exemplo, isso é muito pouco difundido, muito pouco divulgado, esse tipo de prática que nem eu falei da reflexão, do planejamento, etc. isso daí é quase raro, e só que isso exige uma certa assimilação por parte das pessoas, um processo ainda de aprendizagem em ver por que esse tipo de coisa é importante.

Pesquisadora: E você tá falando na escola onde há o estágio mesmo, com os professores?

Ricardo: isso, não só na escola, na universidade, por que assim, são vários os problemas, eu acho. A formação do professor na universidade, a formação inicial, a formação continuada, as condições em sala de aula, por exemplo, quais as condições que eu preciso ter para desenvolver esse tipo de metodologia, o ensino por investigação, como é que eu trabalho isso em sala de aula, eu tenho que ter condições próprias para isso, se eu não tiver, por exemplo, uma coisa que um dos alunos apontou na avaliação que falou que gostou muito das aulas e de ter trabalhado em grupos, tal, mas assim, puta, só que a minha escola não tem uma estrutura adequada para isso, por que toda vez a gente tem que mobilizar as carteiras, mudar de lugar, a gente perde tempo, quer dizer, as aulas são uma atrás das outras, não tem um espaço, então quer dizer, se precisa mudar para ter um tipo de educação diferenciada você precisa mudar a escola, você precisa mudar a avaliação, você precisa mudar a concepção de educação, a concepção deconhecimento, quer 
dizer, tem que ver quais as condições para aquilo funcionar. Eu defendo a educação dialógica, não vai adiantar chegar numa escola, apostilado, numa escola religiosa que eu não vou conseguir desenvolver esse diálogo.

Pesquisadora: Que vai te engessando cada vez mais...

Ricardo: Exatamente, não tem essa liberdade, acreditar nessa liberdade, nessa autonomia de pensamento vai ser fundamental, por exemplo.

Pesquisadora: E da preparação da primeira aula de estágio para a última, você vê mudanças no que você fez, assim em relação a primeira preparação para essa, você acha que houve diferença, houve um...foi ficando mais fácil, foi ficando diferente essa relação...?

Ricardo:Foi, lógico, por que começa o curso é uma coisa, você termina o curso é outra pessoa totalmente diferente. Por exemplo, o fato de eu ter que planejar a aula, apesar de eu já ter feito isso lá no Instituto de física, então, planejar a aula não foi novidade para mim, até por que eu já sou professor, então eu já planejava aula. Agora planejar a aula pensando na alfabetização científica, pensando na tomada de consciência dos alunos, pensando nos objetivos educacionais que eu queria alcançar que tem a ver com o ensino de ciências propriamente falando, isso foi uma coisa bem diferente. Eu tenho que pensar numa aula agora com uma metodologia específica que é o ensino por investigação, para mim no começo foi difícil. Por que, por mais que eu defendesse a educação dialógica, foi como eu falei, eu não, eu nunca tinha visto isso sendo colocado em prática. O que facilitou um pouco foi essas leituras que eu já tinha tido, as experiências, enfim, mas foi difícil preparar a primeira sequência didática. E eu tinha uma leve sUNIeita de que talvez não desse certo.

\section{Pesquisadora: Com os alunos?}

Ricardo: Com os alunos, não por que eu não acreditasse nos alunos, por exemplo, mas pelas próprias condições da sala de aula, as condições da escola, então eu não acreditaria que talvez desse tanto certo e para minha surpresa, graças a Deus deu. E aí obviamente,quando eu fui preparar par a segunda vez, foi muito mais tranquilo, foi muito mais...

Pesquisadora: Você estava mais confiante?

Ricardo: Eu já sabia mais ou menos o que eu ia ter que fazer a mesma coisa, eu já estava confiante, eu já sabia que dava certo, então eu insisti, já quis...trabalhar com coisas um pouquinho diferentes, quer dizer, com leituras, coisas que eu não tinha trabalhado, quer dizer, trabalhado em uma das aulas no outro estágio, agora um pouquinho mais a leitura, a construção de um experimento, não a construção de um experimento, a construção de um espectroscópio, então, que é uma atividade mais prática, quer dizer,então eu pude diversificar mais, foi muito mais fácil, por eu já ter tido essa experiência, quer dizer se eu não tivesse tido isso, teria sido tão difícil quanto, é aquilo que eu falei, teria sido muito mais mudar, mas como aquilo já se tornou uma cultura escolar para mim, vamos dizer assim, se isso faz parte de uma cultura escolar, eu tenho condições de ser autônomo, então quer dizer, o que eu aprendi eu vou levar para todos os outros...

Pesquisadora: E você conseguiu diferenciar um pouco mais a aula, então você conseguiu introduzir a leitura, você conseguiu introduzir uma construção de um instrumento?

Ricardo: Sim, a gente conseguiu multiplicar aquilo que eu aprendi, eu consegui transferir para outras instâncias, para outros, quer dizer, é uma ideia de você problematizar, quer dizer, a função da problematização da forma como eu entendo, você tem um problema inicial que você precisa resolver,você 
precisa...é uma situação problema que você precisa encarar e no final você conseguir, aquilo que você resolveu você conseguir transpor em outras instâncias, em outros momentos da sua prática, quer dizer, eu tenho, como eu falei acho na primeira entrevista eu disse que eu não estava preparado para ser professor, eu falei que estava, agora se você me perguntar isso de novo eu falo, eu estou mais ainda. Estou mais ainda, estou mais preparado, mais consciente da minha prática, mais engajado, mais motivado, mais esperançoso.

Pesquisadora: Então você está sempre preparado, mas sempre se preparando, preparado se preparando!

Ricardo: Sim, preparado no sentido, quando eu falo, de que eu não tenho medo de daquilo que eu vou enfrentar, mas...

Pesquisadora:Sem nunca estar parado.

Ricardo: Sim, exatamente. Eu estou sempre refletindo, eu estou sempre querendo entender mais a minha prática, eu não vou sair daqui e ter uma atitude mecânica com os meus alunos, por exemplo, eu não vou sair daqui e "Meus Deus, os meus alunos são indisciplinados, o que eu faço. Meu Deus, um aluno meu é, sei lá, traficante" Isso não me assusta, entendeu? Eu sei o que eu posso fazer, eu tenho consciência, eu sei quais as minhas possibilidades, quais as minhas limitações, quais os problemas que eu posso enfrentar, quais as burocracias.

Pesquisadora: E a diversidade!

Ricardo: Então, esse tipo de coisa eu não tenho receio, quer dizer, a minha perguntaé como é que eu, por exemplo, como é que eu consigo manter esse tipo de reflexão no decorrer na minha prática, por que as vezes, dependendo do local que você trabalha você tem mecanismos que vão fazendo com que...a minha pergunta é a seguinte, como é que eu consigo subverter isso, como é que eu vou conseguir a todo momento subverter, por que as vezes você está tanto no sistema que se você não sair, se você não se distanciar epistemologicamente, você morre, você é engolido. Você tem que ter esse processo de reflexão sim. Ter e conseguir sair.

Pesquisadora: E tentar, eu acho que também um trabalho coletivo, não é?

Ricardo: Sempre.

Pesquisadora: Por que isso também é difícil na escola. Uma outra questão, aproveitando que entrou nisso é a questão do estágio na escola, a relação, o que que o estágiopode levar para a escola, você falou um pouco, não é? Mas em relação ao professor, que relação é essa que o estágio poderia, se estabelece e se poderia estabelecer com o professor, em relação de uma troca entre a universidade e a escola?

Ricardo: Tá, bom, primeiro que tem que ter um diálogo muito mais efetivo entre a escola e a universidade, isso é fato. Engraçado que pensando em termos de educação, a gente está mais atrasado do que, por exemplo, na medicina. Quer dizer, na medicina você já tem um hospital universitário do curso, quer dizer, os estagiários vão lá, os residentes vão lá, estão com a supervisão ali do lado, dos médicos, na sua atuação e tem uma responsabilidade extremamente grande de estar lidando com vidas. Na educação você está lidando com vidas também, mas eu acho que não tem essa compreensão de que a sua ação pode ser letal também, sua ação pode ser mortal, por que a gente não consegue ver isso por que a gente não mata os alunos aos poucos, a gente mata...não mata de uma vez só, a gente mata aos poucos, é todo um processo mais longo, a gente consegue ver essa responsabilidade do professor. Então, eu acho que deveria, por exemplo, nos estágios, ter uma relação em termos parecido com a medicina, você ter residentes, residentes atuando numa escola, conveniada com a universidade, mas quando eu digo 
conveniada, não é conveniada da forma como a gente tem aqui, um convênio no sentido de que os professores da universidade estão te acompanhando lá, os educadores ligados a disciplina estão lá com você, o professor da turma na qual você vai estagiar tem uma relação de planejamento com você do estágio, um diálogo, estar presente, o cara ele ver, se ver como formador. Então, quer dizer, o professor daqui é formador, na universidade, o professor na escola é formador, e o aluno estagiário também é formador dos alunos e os alunos são formadores também do estagiário em atuação. Então, quer dizer, para mim, um primeiro passo que eu vejo que é essencial é o que está acontecendo na disciplina de práticas lá no Instituto de Física, a gente ter o contato direto com os educadores, para mim isso foi...

Pesquisadora: Então tem, isso tem uma outra instância, que são entre o professor da disciplina tem os educadores que tem a relação entre vocês e a escola?

Ricardo: Sim, exatamente, eu acho que essa mediação, para mim, é o primeiro passo, um passo muito importante, foi como eu falei, eu gostei muito da disciplina de práticas por que eu tive essa mediação muito forte, quer dizer, eu estava lá, eu tive gente para me ajudar a preparar aula, eu levei para a escola o material, a gente levou para a escola o material, a gente tinha conversa depois da aula sobre essa prática, a gente tinha que fazer relatório dos estágios, quer dizer, então, assim como teve em metodologia, práticas de ensino teve, mas teve uma diferença, práticas de ensino tinha escolas que eram conveniadas com o Instituto de Física e os professores, tanto os pesquisadores quanto os educadores estavam lá para conversar com os professores caso tivesse algum pepino, caso... quer dizer, aqui na faculdade de educação não vai ter isso.

Pesquisadora: É, que nem, essa disciplina que eu estou falando que eu faço a supervisão, ela...a supervisão é uma instância entre o professor e os estagiários.

Ricardo: Mas ela tem, por exemplo, que nem nas aulas de práticas em todas as aulas que você tem a preparação das aulas, os educadores estão com os alunos, vão na escola?

Pesquisadora: Então, a gente não vai a escola, mas você ajuda na preparação das aulas.

Ricardo: Então, já é um outro passo importante, mas por exemplo, mas ainda acho que os educadores tm que estar lá.

Pesquisadora:Ir na escola é um passo que você faz um elo, não é?

Ricardo:É, na escola quando eu digo assim, não necessariamente com você lá na sala de aula, o que seria para mim essencial, mas se não é possível, que tenha pelo menos um contato direto, saiba quem que é o professor, para você chegar assim e "olha, eu estou tendo problema com esse professor, você pode ir lá conversar com ele?” Vai lá e conversa, e daí por diante.

Pesquisadora: Mas na aula, você acha que ajuda também, se tiver na aula?

Ricardo: Sim, até, por exemplo, se você quiser trabalhar com atividades práticas, dialógicas, em grupos, tem 40 alunos na sala, 50, você não dá conta de fazer isso, você tem que tem o co-docente, você tem que pensar a co-docência que para mim é importante. Mas daí tem que mudar a concepção de educação, tem que mudar a concepção de conhecimento, tem que repensar os papeis de cada um na sala de aula.

Pesquisadora: Aí é uma pessoal que realmente está acompanhando mesmo o estágio em todos os momentos?

Ricardo: Sim, é o cara que se eu falar uma besteira lá na sala de aula, se eu fizer alguma coisa, o cara vai entrar para intervir, ele tem a obrigação, como é que eu vou saber que eu estou atuando de forma certa se 
eu não estou matando um monte de aluno ali se eu não tiver alguém para me orientar naquilo? As vezes eu estou achando que eu estou falando tudo correto, tudo certinho, ou então eu estou construindo uma aula legal, se eu estou tendo voz, mas na verdade eu estou não estou tendo, então, as vezes eu posso, com essa pessoa que está ajudando lá, eu estou achando que eu estou sendo o cara mais dialógico do mundo quando na verdade eu estou negando a palavra a todo momento.

Pesquisadora: E você não esta percebendo!

Ricardo: Eu não estou percebendo, eu não tenho essa consciência. Como o próprio Piaget diz, a gente precisa de alguém para muitas vezes tomar consciência das nossas próprias ações. Então, ou então, pegar o Vygotisky pela interação, será mais capaz de criar condições de aprender ou até pensando no papel da intervenção pedagógica o cara atuar na minha zona de desenvolvimento proximal a todo momento, se não tem intervenção pedagógica eu não vou construir nada espontaneamente. Um construtivismo ingênuo. Então seria nesse sentido.

Pesquisadora:É, alguém que faça, depois mesmo uma mediação com o que você fez na sala de aula. Na verdade é um educador mesmo que está trabalhando junto com o docente, na verdade é mais ou menos um...

Ricardo: É um conjunto, é uma X, quer dizer, ela é ministrada pela X, euacho isso fundamental. E quer dizer, eu não gosto de usar essa palavra, mas, por exemplo, aqui os próprios professores, os próprios docentesde alguma forma tem um controle sobre o que está acontecendo, quer dizer, não um controle, mas uma ciência, uma consciência do que está acontecendo com os alunos, possa dar um atendimento mais individualizado, eu penso que se é uma $\mathrm{X}$ agora no ministrar aulas por $\mathrm{X}$, quer dizer, ter uma $\mathrm{X}$ ali que ajuda aquela disciplina acontecer, as coisas fluem muito mais facilmente, não sobrecarrega o docente, por que também ele é humano, ele não tem como da conta de tudo.

Pesquisadora: E isso incluiria o professor da escola, a aproximação com o professor da escola também?

Ricardo: Por isso que eu falo, mas aí a gente tá pensando assim, as escolas...É isso que é engraçado, dentro da própria universidade eu acho que deveria ter essas escolas, ou uma escola universitária, por que se fala em hospital universitário e não se fala em escola universitária, ou escola dos universitários? Não se pensa, quer dizer, engraçado que até umas ideias educacionais surgiram antes na medicina do que na própria educação, não é?! Maria Montessori que o diga e enfim, coisas do próprio Freud, é muito engraçado, coisas externas a educação que pautam, as ciências externas a educação que muitas vezes pautam o que a gente (inaudível) pedagógicas, não é?!

Pesquisadora: É verdade.

Ricardo:São ciências da educação, só um comentário.

Pesquisadora: Mas mesmo assim, nessas escolas, você, mesmo fora, você pode ter uma contribuição com as escolas se um professor, ele participar, não é?

Ricardo: Sim, eu estou falando do ponto de vista da minha formação como aluno, mas se eu for pensar, lógico que a escola tem que dar um retorno para aquela escola até, por exemplo, na própria formação do professor. Uma coisa que me fez refletir foi, por exemplo, quando você estava ajudando. Você, na verdade, por conta do trabalho acabou me acompanhando como supervisora de uma certa forma, não como supervisora, mas você estava lá para me ajudar com qualquer coisa, um parceiro mais capaz ali que estava, a gente podia conversar, podia trocar ideia, podia refletir, vários conselhos, varias ideias daquilo que eu estava fazendo, coisas que eu não conseguia enxergar, a fazer com que eu voltasse a acreditar em 
algumas coisas, então isso é importante, por exemplo, você, por exemplo, foi minha formadora nesse processo, mas coincidentemente foi por causa do seu trabalho de pesquisa, mas se fosse educadora da disciplina e todos tivessem essas oportunidade, muito melhor, quer dizer, aí o retorno, quer dizer, quando você falou assim. "Mas Ricardo, você pensou em querer, entre aspas, ensinar para a professora as contas que ela talvez não soubesse, tudo?" Aí que me veio também como eu como formador, eu como formador do professor, mas quer dizer, teve alguém para me falar e pensar sobre isso. Quer dizer, o estagiário quando ele aprende esse processo, ele pode também ser formador daquele professor de alguma forma e dos alunos, assim como os alunos do professor e vice-versa. A escola, ela pode, por exemplo, uma coisa que eu acho que tem que é uma coisa que eu percebi, que,muitas das atividades que eu desenvolvi, muitas das atividades que eu desenvolvi no estágio eu não conseguiria desenvolver se não tiver uma parceria com a universidade. No primeiro semestre, quando eu trabalhei com lentes, lasers e tudo mais, eu só consegui por que tinha professores que me ajudaram a tirar as cópias, a pegar os materiais. E aí, como é que eu faço na escola que não tem isso? Eu vou trabalhar com material de baixo custo, mas não tem lasers de baixo custo. Quer dizer, até tem, mas não vai ter a qualidade...

Pesquisadora:É, você não vai conseguir fazer...

Ricardo: Quer dizer, trabalhar com esse tipo de atividade. Então, a escola ela pode desenvolver, eu acho que algumas já vem desenvolvendo na universidade, quer dizer, vem desenvolvendo com algumas escolas são as parcerias, através do Pibid, através dos estágios, quer dizer, você dá o retorno, o financiamento, por exemplo. Até no Pibid o professor da escola se torna supervisor também, quer dizer, ele recebe para também... ele tem um incentivo, você tem um material sendo levado para sala de aula, você tem produção de conhecimento sendo produzido lá e ficando para a escola, quer dizer, a escola tem, a universidade tem que dar esse retorno para a escola nesse sentido, mas ela precisa primeiro rever o que eu entendo por educação, entende por conhecimento, assim como a escola, o professor da turma, todo mundo. Tem que ter uma renovação aí.

Pesquisadora: E o professor aí, na turma que você acompanhou, você sentiu o professor envolvido com o estágio?

Ricardo: Na atuação, na minha atuação na sala de aula não, por que, eu acho, tem vários motivos aí, mas noprocesso de planejamento e de autonomia sim, inegável. Tanto no primeiro semestre quanto no segundo, tanto o professor da universidade quanto... me deram liberdade, eu já tinha sido aluno delas, elas confiavam no meu trabalho, me deram autoridade de professor, autoridade epistêmica como você fala, quer dizer, elas me reconheceram como professor, como uma pessoa capaz, eu acho que até por isso que elas não intervieram em muitos momentos na sala de aula, quer dizer, eu planejei, eu falei, por exemplo, para a Cristiana, eu falei, eu quero trabalhar com vídeo, a senhora pode conseguir reservar, ela foi e reservou, liguei para ela diversas vezes. "Oh, eu gostaria de trabalhar com isso, isso...", mandei planejamento. Ela falou, não, tudo bem, ela se envolveu em todo processo em si, na sala de aula não, mas eu acho que por que na visão dela, ela precisava me dar essa autonomia.

Pesquisadora: Ela tinha que te deixar sozinho.

Ricardo: Ela tinha que me deixar sozinho. Foi a decisão dela, mas eu liguei, quantas vezes eu não liguei para ela, na casa dela, assim por exemplo, olha professora, eu gostaria de desenvolver isso, fazer isso, então vamos ver, quando que a gente pode marcar as aulas, então quer dizer eu tive todo um arcabouço que meus amigos aqui reclamam que eles não tem com nenhuma professora. Quer dizer, eu tive essa relação.

Pesquisadora: Ela te dar todo o apoio. 
Ricardo: Todo o apoio, eu tive muito apoio, tanto dela quanto da Susete no primeiro semestre, "Ricardo você pode fazer o que você quiser, pode, enfim, trabalhar com que você achar mais necessário", quer dizer, esse foi o lado bom, mas o apoio em si, o planejamento, a parte da estrutura, a autonomia, isso foi desenvolvido. Agora, lógico que eu sinto falta um pouquinhodo retorno da aula em si. Retorno de saber se você está indo ou não no caminho certo, se não está. Por que as vezes você pode estar na ilusão de estar indo no caminho certo já que ninguém intervier. Mas graças a Deus, pelo menos, nas avaliações isso parece que...

Pesquisadora: Você tem essas avaliações dos alunos ainda com você?

Ricardo: Tenho as no ano passado, as do semestre passado e eu estou com as daqui, desse semestre.

Pesquisadora: Eu queria tirar cópia também...

Ricardo:(...) As críticas que apareceram foram assim, tipo, ah as aulas foram super legais, mas só não concordo que tenha trabalho toda aula, por que os trabalhos são complexos, exigem tempo e tal.

Pesquisadora: Eu acho que é um pouco, eu acho que eles já tem muito trabalho.

Ricardo: É, ou eles tem alguma...Mas sempre eram acompanhadas, mesmo as críticas eram acompanhadas de alguma forma por elogios. Aí tem outra, por exemplo, Ah, foi muito legal trabalhar, gostei muito das aulas, mas infelizmente a escola não tem estrutura para trabalhar sempre em grupo, por que... Esse seria o ideal, mas como na escola, a gente tem que mover as carteiras para ter espaço para isso, tem pouco tempo de aula, troca uma aula e vai para outra rapidinho, então, quer dizer, eles estavam refletindo sobre a própria estrutura da escola. Isso é uma coisa bacana.

Pesquisadora: Mas eles poderem ter aula dobradinha, que na época que eu dava aula a gente usava muito isso.

Ricardo:Então, esse tipo de coisa é legal, o retorno que eles dão, aí você vê também que você está fazendo uma coisa bacana. Eles não estão fazendo por eles, não estão falando isso para te agradar, mas estão falando sinceramente.

Pesquisadora: E uma outra coisa, o que você considera importante para você ser professor, assim, os pontos que você acha importante para você ser professor?

Ricardo: Primeiro de tudo o diálogo. Segundo, interação, terceiro, reflexão, mas assim, não tem uma ordem hierárquica, só estou falando (...)mesmo. Interação, reflexão, crítica, curiosidade, motivação, gostar daquilo que você faz, de ser professor, ser um questionador, indagador e promover isso tudo com os alunos, quando eu falo isso do professor eu falo que são características que o professor tem que ter, mas tem que desenvolver isso com os alunos. Ele precisa ser um professor que ouça muito os alunos, os alunos nunca são ouvidos, tem que ouvir bastante. É preciso prover investigações, alfabetização científica, é preciso me valer de diversas estratégias de ensino, eu preciso ter uma reflexão mais fundamentada como quando fizemos uma sequência didática, ela não pode ser uma sequência didática qualquer, eu tenho que ter reflexões epistemológicas por trás. Eu posse me valer de diversas outras áreas de pesquisa, história e filosofia da ciência, refletir sobre ensino-aprendizagem, educação formal, refletir sobre diversos recursos didáticos, eu tenho que está sempre me atualizando para trabalhar com tecnologias educacionais, por exemplo, trabalhar muito com imersão no sentido de fazer visitas a museus, espaços diferenciados de educação, trabalhar com... Procurar fazer uma coisa que o Paulo Freire nos ensinou bastante, tentar compreender a realidade dos meus alunos, entendê-los como indivíduos singulares, para eu poder começar a desenvolver os temas geradores, ver a realidade dos meus alunos. Pensar, eu acho que o professor tem 
que está sempre pensando sobre o conhecimento, sobre o que que ele entende, sobre o que que é conhecimento, o que que ele entende sobre educação, sobre o que que ele entende sobre o que que é ensinar, o que que é aprender, ele tem que saber muito, para mim é uma coisa muito falha na universidade, tem que manjar muito de psicologia do desenvolvimento, de psicologia da aprendizagem para que a prática dele seja mais coerente, fundamentada e tem que querer bem os educandos, quer dizer, tem muitas coisas que me inspira, eu me inspiro na pedagogia da autonomia do Freire que cada capítulo ele fala, ensinar exige alguma coisa. Ensinar exige querer bem os educandos, ensinar exige entender que educação é uma forma de intervenção no mundo, ensinar exige compreender que a mudança é possível, ensinar exige criticidade, ensinar exige pesquisa, quer dizer, não há docência sem discência, ensinar não é transferir conhecimento, para mim tudo isso é o que me inspira. Eu sou inspirado muito pelo Freire, espero ser coerente sempre na minha prática com aquilo que eu acredito. Para mim esse é um dos melhores livros de educação que infelizmente não é trabalhado. Para mim é sensacional, quer dizer, querer bem os educandos, escutar, ter o diálogo. Bom é isso que eu tenho para falar das coisas que eu gosto. Ah, por exemplo, o professor tem que ter consciência muito grande das diferenças culturais que os alunos trazem das diversas...das diferentes identidades, diversidades, está sempre atento a inclusão, respeitar as diferenças de cada um, eu tenho colegas, por exemplo que são extremamente preconceituosos, não que eu não seja em algum aspecto de você ir e não perceber por exemplo, mas que tentam até legitimar o preconceito e a gente vive num mundo e você tem de tudo e você tem que saber lidar, tem que ter respeito pelas pessoas.

Pesquisadora: Tem que respeitar.

Ricardo: Tem que saber trabalhar, quer dizer, eu tenho diferentes alunos de diferentes lugares, com diferentes ideias, de diferentes perspectivas, e aí como é que eu trabalho? Então, eu não vou ter essa preocupação de produção em termos de disciplina, eu não vou ficar desesperado com uma sala em que um é branco e o outro é negro, o outro é amarelo ou um vem da periferia e outro vem da classe alta, o outro é dos Estados Unidos o outro é das Filipinas. Se eu tiver isso um dia na minha sala, eu vou ficar desesperado, eu sei o que que eu tenho que refletir primeiro para começar a trabalhar com eles. Eu sei quais são as posturas que eu devo ter, principalmente para começar esse diálogo, para começar...quer dizer, tem que ter uma coisa muito forte que as vezes não se tem na universidade, é uma reflexão sobre o que é currículo, quer dizer, as diferentes concepções de currículo, eu tenho que saber muito de sociologia da educação, eu tenho que saber muito da história da educação, eu tenho que saber muito de filosofia da educação, eu tenho que saber muito de sociologia da ciência, eu tenho que saber muito de filosofia da ciência, eu tenho que saber muito de história da ciência, eu tenho que saber muito de física. Eu tenho que, primeiro, dar a oportunidade de aprender para os meus alunos, fazerem eles ver que eu consigo aprender com eles, eu preciso ver que eles podem ser meus professores em diversos momentos, eu preciso dar oportunidade de maior parte das aulas eles estarem produzindo, eles estarem refletindo, eles estarem pensando, agindo, eu tenho que gostar de ser professor, eu tenho que amar aquilo, eu tenho que...eu não posso desrespeitar, eu não posso... eu tenho que entender que, por exemplo, a minha prática não é neutra, eu tenho que entender que a minha prática é política, eu tenho que entender como professor que avaliar é sempre julgar, para mim. Eu tenho que está sempre refletindo sobre o que que é avaliação, eu tenho que ver que eu não preciso literalmente concordar com aquilo que os professores me ensinam, mas eu posso desenvolver outras ideias, eu posso desenvolver outras críticas, eu tenho que ter uma coisa até que o Paulo Freire fala, eu tenho que reconhecer que eu sou condicionado, mas que eu não sou um ser determinado e quando eu falo isso, tudo o que eu tenho que ter é uma coisa que eu também tenho que desenvolver com os meus alunos, quer dizer, eu tenho que criar condições de espaço, de possibilidades, para que eles também comecem a enxergar tudo isso, e querer bem, querer bem os alunos, eu acho que, sei lá, eu acho que eu falei muita coisa.

Pesquisadora: Então agora você já está, você já acabou as disciplinas? 
Ricardo: Basicamente, eu só preciso fazer a apresentação de hoje e tem uma prova de história da matemática e depois eu tenho que entregar a minha monografia e receber o resultado do mestrado.

Pesquisadora: Então já é professor!

Ricardo: Sim, ah não, mas eu já me vejo como professor desde quando eu entrei aqui, até por causa da minha trajetória que eu contei na primeira entrevista. Eu já me vejo como professor, mas mais engajado ainda. Habilitado formalmente.

Pesquisadora: Habilitado formalmente mesmo.

Ricardo: Habilitado formalmente!

Pesquisadora: Ricardo, olha, o que eu vou te pedir é que você me deixe seu e-mail por que se eu precisar, eu vou fazer assim, o que nós pensamos era fazer duas entrevistas mas a medida que você transcreve dependendo do trabalho, pode ser que você queira saber mais alguma coisa, você viu que eu não vou largar tão cedo do seu pé.

Ricardo: Não! Para mim é excelente.

Pesquisadora: E daí eu posso te procurar. Se a gente tiver que complementar, por que o trabalho ele é meio que vai fluindo assim, você vê, você analisa e as vezes precisa de alguma complementação. Então daí a gente faz algum...alguma outra se precisar.

Ricardo: Tá bom, você quer anotar agora?

Pesquisadora: Eu quero, e também depois eu mando para você, depois, assim de transcrito para você ver a entrevista, daí você fala "Ah, tal parte eu não quero...daí você também...”.

Ricardo: Não, pode colocar tudo...

Pesquisadora: Tem pessoas que as vezes não...

Ricardo: Não, eu gosto, eu entendo a importância da relação pesquisa e ensino.

Pesquisadora: Então tudo bem.

Ricardo: Não tem problema não, até por que se eu estiver...tá falando alguma besteira ou cometendo algum equívoco, eu quero aprender com isso, pode colocar tudo.

Pesquisadora: Então tá bom, é que tem gente que as veze fala algumas partes, mas não quer que coloque, então...

Ricardo: Não, até, as críticas, pode colocar, eu gosto, eu gosto de lenha na fogueira.

Pesquisadora: Então o seu e-mail é qual?

Ricardo: xxx@gmail.com. Eu preciso anotar o seu, incrivelmente eu não tenho o seu...

Pesquisadora: O meu é yyy@gmail.com.

Ricardo: Mas respondi tudo que você queria?

Pesquisadora: Não, tudo. É que assim, eu faço várias perguntas, mas na medida que você vai respondendo, daí eu vou pulando, por que depende, assim, da pessoa. Então quando a pessoa já vai 
respondendo...eu já vou pulando, eu vou fazendo, eu não gosto de fazer ela muito assim por perguntinhas, entendeu? Nem de dar um roteiro para a pessoa e a pessoa ficar presa naquele roteiro. Então eu gosto mais quando a pessoa vai falando a vontade e eu vou olhando aqui o que ela já falou e o que ela não falou e eu vou perguntando, eu prefiro assim.

Ricardo: O único... que é uma sugestão na verdade que eu acho é que isso não deveria ser exclusividade da disciplina de metodologia, podia ser trabalhado em alguma outra disciplina de ensino lá da física, para que não ficasse falando de uma metodologia, por exemplo. Aqui a gente está aprendendo um, a disciplina, prefiro aprender ela bem, então eu acho que não tem problema, mas se eu tivesse oportunidade de ver outras metodologias de ensino, por exemplo...

\section{Pesquisadora: Diversificar?}

Ricardo: Sim, eu ter condições de pensar em outras possibilidades, o PBL, o PBL eu não faço ideia do que seja, mas eu mesmo sei que existe. Então eu vou ter que ler por conta para poder entender o que que é, por exemplo. Então, até mesmo as metodologias antigas, quer dizer, pega a didática da Idade Média, é uma coisa, para mim, interessantíssima. Acho que até mais atual do que hoje em muitos aspectos, quer dizer, entender esse tipo de coisa eu acho que é fundamental, mas isso aí é só uma sugestão para outras discussões, não necessariamente em metodologia.

\section{Entrevista 2 com Heloisa}

Heloisa: Então, eu na verdade eu agora estou num momento meio angustiada, o curso é fogo, você tem altos e baixos, uma hora você fala "Nossa, com certeza eu quero ser professora" e nos outros fala "Putz, não sei, não sei se estou preparada". Eu já entrei na sala de aula algumas vezes pra fazer estágio, mas o estágio de observação de outras disciplinas, e eu entrava sozinha. Já me deram a turma problemática da escola pra dar aula. Eu não sou uma pessoa tão inexperiente assim, mas no começo do ano me ligaram oferecendo um emprego pra dar aula e eu falei: "Não, não consigo, não vou dar aula".

Pesquisadora: Mas porquê?

Heloisa: Não sei, insegurança, não sei o que fazer. Então, eu estou nesse momento.

Pesquisadora: Mas você nem tentou ir pra escola pra ver como é?

Heloisa: Não. Eu falei no telefone "Não, estou sem horário", em parte é verdade, porque o horário que precisava eu não tinha. Mas não sei, eu fiquei com medo de entrar na sala de aula, fiquei insegura, achando que... Um papel muito importante e eu não estou preparada pra isso. Não sei, entrei nesse pensamento. Mas,... Eu vou me formar esse ano e eu estava vendo a grade do curso pra ver o que eu precisava fazer ainda e eu vi que metodologia II é a única obrigatória do ultimo semestre (porque eu deveria ter me formado semestre passado). Eu falei: "Faz muito sentido isso", porque semestre passado foi horrível pra mim, eu peguei muita coisa, muita matéria, não estava dando conta de nenhuma matéria direito e eu queria ter me dedicado, até metodologia eu faltava na primeira metade e só chegava na segunda, porque peguei matéria no mesmo horário. Então, queria ter me dedicado mais pra metodologia, até porque uma das minhas propostas era mais tempo em sala de aula. É a hora da vivência, é a hora mais legal. Mas também com o curso todo bagunçado, se eu tivesse que ter feito mais tempo em sala de aula não ia dar. 
Pesquisadora: Mas você acha que essa insegurança veio de você não ter tido tanta vivência em sala de aula? O que você tá sentindo?

Heloisa: Não sei, sabia? Eu acho que pode ser coisa mais da minha cabeça. Eu sou...eu tenho umas fases que sou super segura, "pode vir o que vier que eu dou conta" e tem outras fases "Não quero fazer nada, me deixa sozinha, não consigo". Mas não sei como poderia ter ajudado ou não. Não sei se teve a ver com falta de experiência. Mas é que a parte da sala de aula é realmente a mais legal, então podia ter mais. Até porque, acho que deveria ser uma coisa crescente ao longo do curso de física. No começo você faz menos parte, dai sua participação na sala de aula vai aumentando. Igual Práticas, você fica o ano inteiro, tem que se programar, semana sim semana não, pra estar lá na escola. Eu acho isso bem legal. Tudo bem que o curso de licenciatura não é um laboratório, mas poderia ter um pouquinho mais de participação da sala de aula. Porque, pensa, se você só vai ter essas intervenções pontuais, na sala com os alunos, quando chega pra dar aula mesmo que você tem que, não sei... Vamos supor que você pegue uma turma só, já são duas aulas por semana, durante o resto do ano, isso é muito mais coisa do que você fez durante toda sua graduação.

Pesquisadora: Como assim? Se você pega uma turma pra...?

Heloisa: Pra dar aula mesmo. Se você pega na escola, vai à escola, o mínimo que você vai pegar é uma turma. É raro até, normalmente você já pega o colegial inteiro. Então são ai, não mais duas, mas 6 aulas por semana que você tem que dar. Então, você tem que planejar rápido, cumprir rápido e fazer avaliação rápido.

Pesquisadora: E daí, quando você estava na graduação você não chegou a fazer. Você fez uma pitadinha disso?

Heloisa: Uma pitadinha, foi pontual a participação lá. Porque mesmo que nosso estágio a gente pegou 6/10 aulas seguidas, a gente teve todo um tempo antes pra preparar essas 6 aulas, fez seguidinho e teve todo um tempo pra avaliar depois. Mas lá, na vida real, é um seguido do outro. Ai eu não me sinto preparada, me sinto até insegura, mas pode ser só uma fase.

Pesquisadora: Isso não te dá tempo de preparo pra você? É isso que você fala?

Heloisa: Não te dá uma experiência mais próxima com o que vai ser. Tudo bem é utopia falar que você vai sair da licenciatura já formada um professor, você vai fazer tudo, vai ser um ótimo professor e etc, mas acho que podia aproximar um pouquinho mais da realidade escolar. A disciplina de Práticas é a que mais faz isso.

Pesquisadora: A que mais te deixa próxima da escola?

Heloisa: É, do teu cotidiano escolar e das práticas, de você ter que planejar, executar e avaliar uma aula assim, sendo que pra próxima semana você já tem que ter preparado uma outra aula, vai ter que aplicar e depois avaliar. E depois mais outra semana você vai ter que fazer a mesma coisa. É bem seguido.

Pesquisadora: Você vai toda semana à escola?

Heloisa: É, na verdade semana sim, semana não.

Pesquisadora: Então, a cada 15 dias você vai à escola? Você tá sempre no contato com a escola, durante 1 ano?

Heloisa: É. 
Pesquisadora: Entendi. Ai na situação de metodologia você não consegue isso. É essa comparação que você tá fazendo?

Heloisa: É. É como se você fosse... É uma sala muito pontual, você vai lá na escola, faz o seu projeto e vai embora. Isso sem contar a vontade dos professores em receber estagiário. $\mathrm{O} W$ não fez questão nenhuma de saber como foi, como estava indo, qual a avaliação que a gente faz, enfim. Ele tá no direito dele, digamos.

Pesquisadora: Então assim, vamos dividir essa questão. Em relação a pontos relevantes pra sua formação, uma questão seria que precisaria um contato mais continuo com a escola; e em relação ao que foi significativo pra você, em relação à metodologia, que contribuiu pra você como...

Heloisa: As aulas aqui, a leitura dos textos, as discussões, todo esse contato com a alfabetização científica, sempre uma investigação que eu gostei bastante e amadureceu várias coisas na minha cabeça, de como fazer a sua aula, qual o objetivo da sua aula, como alcançar esse objetivo, quer dizer, não como você vai alcançar, mas como os alunos irão alcançar. Como vai ser a sua postura em sala de aula pra que isso aconteça, o que você tem que fazer pra estimular argumentação. Essa parte da argumentação eu achei maravilhosa.

Pesquisadora: E isso contribui no sentido de formação pra você, pra sua aula, pra preparação da sua aula?

Heloisa: Pra preparação e na aula mesmo também.

Pesquisadora: Tanto preparação e condução da sua aula.

Heloisa: Porque a parte da avaliação depois é... Acho que toda avaliação é igual, depende dos seus objetivos, se você mudar seus objetivos sua avaliação vai ser pautada em outras coisas.

Pesquisadora: E esse é um ponto que mais colaborou com você em relação à disciplina, essa questão.

Uma outra questão, que você falou um pouco, mas na questão referente a aula estágio, ainda, o que foi significativo nele pra você?

Heloisa: Exclusivamente a prática do estágio?

Pesquisadora: É.

Heloisa: Mas só em sala de aula ou não?

Pesquisadora: Não, em tudo referente ao estágio.

Heloisa: A parte que eu mais gostei do estágio foi de preparar a aula.

Pesquisadora: Mas porque isso em relação a preparar a aula? Por que esse envolvimento?

Heloisa: Putz, não sei sabia? Eu gosto de coisas difíceis. E toda vez que eu ia preparar a aula, pra pensar o projeto, nossa, eu e a Maia, a gente discutia, e ficava na questão e mudava e voltava pra delimitar muito bem. A gente fazia uma coisa muito pensada, era muito legal. E mesmo quando cada uma ia planejar sua aula ou quando a gente fazia junta... Nossa, teve um dia em que eu estava preparando a aula e eu simplesmente travei no meio. Eu tinha feito uns 4 slides, sabia mais ou menos o que ia falar, de repente eu travei. Eu falei: "Eu não sei o que eu faço mais, acho que a aula não tá boa, não tem nada a ver com os objetivos". Deu uma desesperada na hora, mas depois um amigo meu sentou do meu lado e falou: "Não, calma você está pirando" dai eu consegui fazer o resto da aula. 
Pesquisadora: Mas o que você sentia com isso, que você acha...?

Heloisa: Não sei, eu tenho muita dificuldade de focar num ponto. Eu sempre quero falar de muita coisa ao mesmo tempo e na aula não dá, porque a gente... Por exemplo, o estágio do primeiro semestre do ano passado que a gente estava falando do Big Ben, e a parte que eu ia falar era justamente a parte do Big Ben, evolução do universo, e eu comecei a preparar a aula e eu estava já falando do sistema solar, da vida na Terra, dos modelos de expansão do Universo, de Einstein, do Emetri?, eu já queria falar de tudo e não dava, não ia dar tempo de falar na aula e também não tinha nada a ver. Tinha que recortar, tinha que falar: "Não, vida na Terra não era um dos nossos objetivos". Modelo de Universo também não, ia confundir a cabeça das crianças. Daí eu falei só da evolução do Universo, desde o Big Ben até agora. E no final dei só uma pincelada pra deixar no ar "E ai, tá se expandindo ou vai contrair", mas foi só pra dar aquela discussão no final da aula, pra eles poderem escrever o texto depois. É muito difícil você ter que recortar pra falar das coisas.

Pesquisadora: E esse trabalho sendo em grupo ajudou?

Heloisa: Se ajudou? Acho que ajudou, porque esse dia que travei eu estava sozinha e a Maia não estava nem na faculdade e normalmente ela tá preparando, quando ela ia dar aula, ela preparava a aula dela lá e estava com duvida a gente discutia como ia ser a aula, mas na hora mesmo de preparar os slides, ver figuras era só uma que fazia, a outra estava lá do lado pra ajudar de vez em quando. Nesse dia eu estava preparando a aula e ela não estava então, eu não tinha discutido antes como ia ser a aula e na hora eu não tinha ela pra virar e falar: "Amiga, travei". Eu comecei a chorar, foi engraçado, mas eu estava desesperada também por outras razões, terminei o ano muito mal. E na hora de planejar, com certeza, se não tivesse a Maia eu ia fazer aquele apanhado das coisas pra dar em 6 aulas, mas não, eu tinha que focar, até a Dulce ajudou bastante a gente, porque a gente falou: "Ai Dulce a gente vai falar disso, disso e disso" e ela falou: "Então meninas, vamos falar só disso, em 6 aulas, porque é esse o projeto".

Pesquisadora: E quando você apresenta pros alunos, ai qual é a sensação que você tem depois que você planejou, você discutiu, na hora que você apresenta pros alunos?

Heloisa: Olha, muitas vezes te dá a sensação de que eles estão boiando. Eu to aqui me divertindo com o que eu to falando, to mostrando pra eles um monte de coisas que eu gosto, mas eles estão boiando. Mas até que no final deu certo.

Pesquisadora: Mas na hora que vocês viram os resultados deles, principalmente na parte 1 de metodologia I?

Heloisa: É, porque foi o resultado que a gente teve. A parte 2 a gente não teve resultados.

- A gente ficou feliz com a nossa parte e também ficou angustiada com as carências que eles têm de outros aspectos, de prestar atenção na aula e conseguir anotar ao mesmo tempo em que ouve, não saber escrever um texto, dificuldade de organização, mas da parte que a gente fez foi um retorno positivo. Foi bem legal.

Pesquisadora: E isso, que sensação te traz quando você pensa em dar aula? Como isso pesa pra você na hora?

Heloisa: Ah, não sei. Então, uma das coisas mais legais que já aconteceu comigo não foi em Metodologia, foi em Práticas em que a gente passa o ano inteiro fazendo um projeto, também é pensado, qual o objetivo do ano e pra complementar esse objetivo qual vão ser os objetivos do semestre que complementam o do ano, depois dos meses e depois das aulas. Então é um negócio bem pensado. Isso na verdade eu só fui perceber no final. 
Então, eu passei o ano inteiro dando aula, falando "Essas crianças não estão aprendendo nada (eu dou aula pra quinta série), essas crianças estão ai se divertindo, fazendo bagunça (eu achava ótimo, adoro ver criança se divertindo), mas eles preenchiam o roteiro, mas isso não é a saída". A disciplina de Práticas teria sido completamente diferente se eu tivesse feito Metodologia antes, ia ser totalmente diferente pra melhor, porque Metodologia pra mim deu muito mais base teórica do que prática. É mais ou menos isso que eu to falando no geral. E dai depois de todo ano, no final eles tiveram que fazer uma feira de ciências, que deu muito trabalho, eu tive que correr atrás de muitas coisas em pouco tempo, porque eles iam apresentar pras outras salas, pros pais.

Pesquisadora: Mas a escola que propôs isso ou já era de praxe?

Heloisa: A escola junto com Práticas, eu acho, não sei direito como foi essa parte.

Daí eu cheguei lá no dia, ajudei eles a fazerem os projetos e no dia da apresentação eu estava de visitando e falei: "Me explica ai o seu projeto?" e foi muito lindinho eles dizendo tudo, o que eles aprenderam em 1 semestre e eu achando que eles estavam boiando, que não tinham entendido nada e não eles estão aqui falando direitinho, só espero que não estejam repetindo o discurso, que isso realmente esteja na cabeça deles e isso foi o que me fez mais feliz, falei "Nossa, a disciplina de Práticas é um inferno, mas eu esqueci tudo o que eu passei durante o ano por causa desse acontecimento final de ter dado tudo certo. Foi bem engraçado, ilusão de Pesquisadora, sofre o ano inteiro, mas tem uma recompensa positiva e você já encanta de novo.

Pesquisadora: Interessante isso, você falar que a Metodologia deveria vir antes.

Heloisa: Ia fazer uma grande diferença. A Maia tá fazendo Práticas agora, vamos ver como vai ser durante o semestre dela, ai a gente fica sabendo, porque com certeza ela vai... Porque eu já era enxerida, a gente em Práticas já recebe o roteiro pronto como base, você pode fazer modificações, mas a maioria do pessoal não fazia, pegava aquele roteiro pronto, que era o que tinha que fazer, e chegava lá e aplicava. E eu não, eu pegava (eu tava sozinha, não tinha dupla), o roteiro e pensava: "Não quero fazer isso, vou mudar tudo isso aqui” e já mexia no negócio pra ele ficar mais com a minha cara ou alguma coisa que achava que ia ser melhor. Levei uns tapas na cara, porque a aula mais legal que eu mais tinha planejado, que eu mais tinha gostado foi a aula que as crianças ficaram assim a aula inteira "Nossa, que a gente ta lendo na aula de ciências, não tem nada a ver", enfim...e eu já reformava aquele negócio pra deixar com a minha cara, então se eu tivesse toda essa base de metodologia as aulas seriam completamente diferente do que planejei, do que estava no roteiro também, com certeza. Diferente pra melhor, em minha opinião.

Pesquisadora: Então, essa coisa te deu uma estruturação da aula, uma organização, um planejamento.

Heloisa: Isso, um planejamento, um objetivo e a metodologia pra você chegar nesse objetivo, que é o que mais conta.

Pesquisadora: Por que dai no caso seria tanto um pensar na alfabetização cientifica, mas também no ensino por investigação.

Heloisa: É, a prática.

Pesquisadora: E você falou um pouco da escola, das relações na escola e nessas relações que, tanto as que se estabelecem lá na escola e as relações com o professor, em relação ao estágio de vocês. E isso, o jeito que você colocou, ela não... Não que ela não seja acolhedora, ela é acolhedora, o professor te acolheu, mas ele não se envolve. Como você vê isso no sentido de poder, talvez, resignificar isso dentro do estágio pra que essa relação pudesse mudar? 
Heloisa: Não sei se eu vou tá sendo muito...tirando o nosso da reta, mas não sei como a gente pode mudar isso.

Pesquisadora: Não, não vocês. O que poderia... já tem...existe também ali uma estrutura que...a gente tem ali a escola, numa estrutura dela, mas tem uma relação da universidade com a escola na medida que você chega lá, você vê alguma coisa que possa ser estabelecida ali, que possa envolver esse professor, que possa ser feito? Você falou que ele não discutiu com vocês...

Heloisa: Não. E você vê mesmo que durante as aulas ele nem estava lá.

- Como assim, eu não entendi ainda?

Pesquisadora: É, alguma coisa que pudesse aproximar esse professor de vocês...

Heloisa: Ah, eu acho que isso só dependeria dele, sabia? Eu já discuti isso com outras pessoas. Eu estava discutindo justamente com uma menina, ela é jovem, acabou de sair da faculdade...não, acabou de sair faculdade não, não sei se ela agora tá fazendo mestrado ou doutorado; e ela era professora aqui do $\mathbf{A}$ acho e recebia o pessoal de Práticas.

Acho que na verdade o lance do estágio é muito mal discutido na faculdade, pra que serve o estágio? Qual o papel do estagiário? Qual o papel do professor? Qual a relação dos dois nisso? Porque o estagiário tá lá pra aprender com o professor e o professor tá lá pra aprender com o estagiário também, tem toda uma concepção diferente, várias coisas... e essa mulher estava falando que ela não deixa o estagiário dela sozinho, ela tá lá sempre, porque ela tem que dar esse suporte pro estagiário e não quer que ele faça umas coisas nada a ver com o que ela tá dando, porque...o W, a gente podia fazer 10 aulas falando sobre formiga que ele ia deixar fazer isso na aula de física. A gente podia dar interpretação de contos que ele ia deixar a gente fazer isso na aula dele. A gente até teve essa preocupação, a gente falou: "Ah, W, o que você tá dando pra gente fazer uma coisa mais ou menos assim”, não lembro nem se ele respondeu o que ele estava dando. Acho que respondeu, mas falou "Eu já to terminando, faz ai o que vocês quiserem que vai se encaixar". Ele não fez grande questão que isso fosse condizente com o curso dele. Às vezes parece que foi ótimo pra ele que a gente foi, porque ele se livrou ali de umas 6 aulas e teve mais uma nota pra colocar pros alunos.

Pesquisadora: Agora pros alunos isso passa a ser algo que colabora ou não?

Heloisa: Eu acho que aluno, por mais que tenha toda essa rebeldia com estagiário, que acha que pode zoar, acho que os estágios são muito legais pros alunos, porque mesmo não necessariamente sendo uma coisa positiva, na minha visão de aluna ainda eu sou muito positiva, porque você vira e fala "Não é meu professor que tá dando aula, então isso não é aula normal, não é mais essa coisa chata que eu tive o resto do ano, agora vai ser uma coisa diferente, não é meu professor, a gente não tá falando dos temas, os estagiários vem aqui pra...eles não dão a aula que nem o meu professor"...então, é quase como se não fizesse parte da matéria, só que como eles não gostam da matéria, isso faz eles se interessarem mais.

Pesquisadora: Então, não teria um problema de indisciplina, porque eles não ficam indisciplinados.

Heloisa: Não, não. A gente... Antes de ir lá pela primeira vez, a Maia estava com muito medo, foi muito engraçado. Ela falava: "Ai meu deus, será que a gente vai ser bem recebida?". Mas problema de indisciplina a gente não teve nenhum.

Pesquisadora: Outra questão, quais os pontos você acha mais importante pra ser professor? Pra sua formação. Você pode mudar esses pontos ao decorrer da sua formação, da sua vida... e vai mudar, ne? 
Heloisa: Como assim os pontos mais importantes?

Pesquisadora: É... Que você viu durante a disciplina e que você pensa, julga ser importante para ser um professor.

Heloisa: Putz, com certeza esse lance do planejamento, de objetivo, planejamento da aula e avaliação, acho que é uma das coisas mais importantes, porque no final você já está pensando em tudo, sua aula vai ter um objetivo que vai refletir no que você quer que eles aprendam, não só de conteúdo, mas de modo de fazer ou de postura de vida, de reflexões que você quer que eles tenham, enfim...abrange um monte de coisas. $\mathrm{Na}$ hora de preparar a aula você tem $\mathrm{N}$ jeitos de preparar, você pode dar uma aula só na lousa, dar aula de experimentos, pode dar uma aula que combine os dois, pode dar uma aula de filme, enfim, todas as possibilidades de aula e a parte da avaliação, que vai fazer você ser um professor...

Heloisa: Eu estava falando da parte da avaliação que vai fazer você ser um professor pra cada sala e... você saber moldar os assuntos com o jeito de aula, porque pra várias salas aula experimental não funciona, então você já planeja um outro tipo de aula pra essa sala.

Pesquisadora: Você tem sempre que ter uma avaliação constante nessa sala pra você poder caminhando e sabendo o que preparar de novo, o que planejar.

Heloisa: Ah, com certeza. É, porque se os alunos mais gostam, mais aproveitam... maior envolvimento. Isso tudo faz muita diferença, porque não adianta de nada você ser um professor que vai sempre fazer a mesma coisa não importando qual sala é, você dá sempre aquela aula de mecânica pro $1^{\circ}$, não importa se é o $1^{\circ}$ ano de 2003, 2004, 2005 são pessoas totalmente diferentes, ou pior ainda, você dá a mesma aula desde os anos 70, que as coisas nem são as mesmas, as pessoas não tem nem a mesma mentalidade e você continua lá na sua aula do tempo em que a galera não tinha tv em casa pra galera que tem tv, tá aqui na palma da mão.

Pesquisadora: Você nem olha pro rosto das pessoas...

Heloisa: Você não vê nem como o pessoal se veste, o assunto que eles estão interessados, qual a relação que eles tem entre eles, enfim, tem professor que é muito alienado. Mas é difícil, é muito difícil. Acho que isso me assusta um pouco em ser professora, é muita responsabilidade pra mim, eu não me sinto capaz de formar pessoas.

Pesquisadora: Mas qualquer outra profissão você vai ter que estar sempre estudando, sempre se atualizando, não tem jeito.

Heloisa: Sim, ai vem essas minhas fases, numa fase eu to super corajosa e falo "não, vamos dar a cara pra bater, vou tentar, se eu não tentar não vou aprender"; e minha fase de agora que é "não, não vou tentar, quando eu tiver coragem eu tento, eu aprendo".

Pesquisadora: Mas é assim mesmo, é desse jeito, é assim com todo mundo, Gabi.

Pesquisadora: Agora eu tenho uma pergunta que não vou poder escapar dela, você responde como você quiser. No final do ano o grupo de vocês teve um impasse, principalmente na ultima aula de fechamento na escola, como você avalia esse impasse? Tanto do ponto de vista pra vocês enquanto grupo, pra você enquanto pessoa e pro próprio contexto, pra própria aula, estágio, como você avalia isso, o que você aprendeu com isso?

Heloisa: Foi "difícil", porque eu e a Maia não devíamos ter pegado pra fazer tudo desde o começo, ter carregado o Carlos nas costas, não ter reclamado, não ter falado nada... Mas foi horrível da parte do Carlos 
virar no meio do projeto e se rebelar ou não se inteirar do projeto, não sei, ele viajou na maionese. Quando ele ia planejar aula dele colocava umas coisas e a gente falava: "Carlos, isso não tá nem no objetivo do nosso trabalho, a gente já conversou isso com você". Ele é muito vinculado ao ensino tradicional e é difícil pra ele largar disso.

Pesquisadora: Mas como você vê isso em relação ao contexto, pros alunos, o que você tira? Você aprendeu com isso?

Heloisa: Eu ainda não sei o que aprendi com isso, porque na hora não sei se tinha outra coisa que a gente poderia ter feito. Acho que a gente poderia virar pro Carlos e falar: "Cai fora daqui, essa é a última aula é nossa e a gente vai fazer do jeito que a gente quiser". Fizemos isso uma vez e ele falava: "Eu to de frente", ou seja, mesmo que a gente tentasse fazer um fechamento do jeito que tínhamos pensado ou pelo menos fizesse sentido com o objetivo do projeto, mesmo que a gente tentasse fazer isso ele estava lá e não queria que fosse feito. Foi na quinta aula que a gente ligou pra ele e falou: "A gente vai fazer isso, isso e isso", porque já tinha dado coisa errada na quarta aula e a gente teve que refazer o projeto rápido e eu e a Maia pensamos num jeito que ficasse bom, que encadeasse e ainda tivesse dentro do objetivo. "Então o Carlos, por telefone, falou: "Não, vocês não vão fazer isso, ainda dá pra fazer do outro jeito" e falamos:" Carlos, não precisa, você não precisa nem ir à escola, pode deixar a gente da conta disso e ele falou: "Não, eu vou na escola". E ai a Maia falou: "Se você for eu não vou". E no final ele acabou indo e a gente não foi. Ele não deu o braço a torcer.

Pesquisadora: Então, acho que foi o problema foi muito pra frente e acabou indo até...

Heloisa: Sim, um problema que começou na quarta aula foi até a sexta aula.

Pesquisadora: ...Essas coisas acontecem muito na escola e ai elas têm que se resolver, porque é uma coisa que avoluma muito.

Heloisa: Então, eu estava pensando, não sei se daria pra fazer de outro jeito essas ultimas aulas. A gente não gostou de o Carlos ter fechado, a gente não gostou do fechamento dele, mas também não faço ideia de como a gente poderia ter encaminhado isso de outra forma. Ficou num impasse, que nenhum dos ia ceder e os dois acabaram cedendo.

Pesquisadora: Não, porque era um impasse, de qualquer jeito ia ser um impasse.

Heloisa: Então, eu realmente não sei o que eu aprendi disso...

Pesquisadora: Tem que pensar um pouco, porque na escola vocês vão ter situações tensas assim.

Heloisa: O problema não é ter que mudar o planejamento, o problema não é ter que mudar a aula, o problema não é ter que diminuir o numero de aula ou aumentar o numero de aula. O problema é não ter alguém compreensivo pra te ajudar ou pra fazer junto. Acho que é isso.

Pesquisadora: É uma situação assim, foi levada ao impasse. Acho que tem que selecionar muito antes dela chegar nisso, porque na hora que você chega nisso...

Heloisa: Ai vai dar briga de qualquer jeito.

Pesquisadora: Não tem jeito.

- Tem mais alguma coisa que você queira falar?

Heloisa: Não sei. Tem mais alguma coisa que você queira perguntar? 
Pesquisadora: Bom, eu perguntei várias coisas...

Heloisa: Eu falei mais ou menos de tudo? O que ficou faltando?

Pesquisadora: Daqui o que eu tinha eu fui perguntando. Agora posso te amolar mais se eu tiver mais alguma coisa? Porque eu vou analisar e depois da análise, às vezes ainda ficam faltando ainda algumas coisas. Ou às vezes surgem alguns pontos que a gente quer depois investir neles, dai a gente costuma procurar as pessoas, encher um pouco as paciências. Depois da análise que você vê os pontos que vai seguir.

Heloisa: É, que você achar mais interessante, mais polêmico.

Pesquisadora: É. Por enquanto fica assim muito aberto, vou fazer uma primeira leitura de todas e depois que a gente segue uma análise, mas ainda demora um pouco.

Heloisa: Sem problema nenhum. Você viu que como eu sou um pouco enrolada, marcar horário, ficar desmarcando, marcar de novo, mas agora eu tenho seu telefone. 


\section{Apêndice D}

\section{Transcrição da apresentação do planejamento nas disciplinas de Metodologia do Ensino de Física I e II}

\section{Planejamento do estágio na disciplina MEF I ( $1^{\circ}$ semestre 2013$)$ Grupo 1 de Ricardo}

Ricardo: A gente vai apresentar nossa proposta de estágio, com relação a dois temas em especifico. O primeiro é sobre lentes esféricas e filtros polarizadores, o primeiro refere-se a ótica geométrica e o segundo refere-se a ótica física. Então a ideia é que a gente trabalhe duas aulas com ótica geométrica e duas aulas com relação à ótica física, conforme sugestão da professora, para que possamos comparar a diferença entre as duas áreas da física.

... alunos do terceiro ano do ensino médio de uma escola técnica G S, a escola onde eu estudei, e a gente planejou 4 aulas pra o desenvolvimento dessas atividades.

Bom, quais são os objetivos gerais com a implementação da nossa proposta? Primeiro, a gente quer desenvolver um estudo fenomenológico e investigativo com os alunos, tomando como base aquilo que a gente aprendeu na disciplina, principalmente com o que diz respeito aos problemas abertos e a alfabetização cientifica. A gente vai desenvolver esse estudo tomando como base as lentes esféricas e os filtros polarizadores, de forma que os alunos possam levantar hipóteses, testar hipóteses, tomar dados, possam analisar séries de informações, organizá-las, classificá-las, ver uma série de evidências e tirar algumas conclusões, então a gente vai tentar fazer com que eles comecem a interagir com essa nova cultura que é a cultura cientifica, o fazer cientifico. Pra isso vamos utilizar problemas abertos. E obviamente nas atividades que vamos propor eles também vão ter que fazer proposições de modelo explicativo e justificar porque estão fazendo isso.

A justificativa da proposta. Comumente a gente vê que o ensino de física é permeado por uma série de mitos, estereótipos, muitas vezes as aulas são teóricas, elas não são conectadas com o cotidiano dos alunos; e também a gente tem a questão da aula expositiva, queremos quebrar de certa forma um pouco isso e ver como funciona. A gente quer sair da zona de conforto, estamos tão acostumados com esse tipo de aula que queremos trazer a alfabetização cientifica pro nosso lado. Então, como vamos fazer? A gente entende que o ensinar física e aprender física, esses dois atos, exigem que haja um espaço de discussão dentro da sala de aula e que os alunos possam fazer teste de hipóteses, levantamento de hipótese, procurar evidências, analisar série de informações, organizá-las, classificá-las, propondo modelos explicativos. Então a gente acredita que se o ato de ensinar e o ato de aprender física estão diretamente relacionados com as características do fazer cientifico e que promove a alfabetização cientifica nada mais óbvio do que a gente utilizar problemas abertos e análise por parte dos alunos pra gente fazer esse tipo de objetivo geral ser alcançado.

A aula 1 a gente pegou como tema lentes esféricas e os conteúdos específicos são os tipos de lentes, as classificações das lentes, distância focal, projeção de imagens e suas características. Os objetivos específicos são desenvolver de forma fenomenológica e investigativa o conceito de lentes esféricas e suas classificações pra própria distância focal, projeção de imagens e as suas características. Então vamos chegando nos momentos da aula, mas antes disso vamos ver os recursos. A gente já conseguiu esses materiais com o Professor F e o professor? da física. Então a gente tem 5 lentes esféricas com diferentes formas, um suporte pra lupa de isopor, régua, uma vela, um fósforo, dois lasers e uma lanterna. Isso tudo pra cada grupo. Cada grupo vai receber um conjunto desses materiais. A aula vai ser dividida em 3 momentos de aproximadamente 5 minutos. As aulas, nessa escola, têm certa de 50 minutos e como os alunos são bem engajados, tem uma certa facilidade, não tem muito a perda de tempo pra começar a aula. Então estamos propondo 3 momentos distintos, 3 atividades. A primeira seria a da classificação das lentes. Como vamos fazer isso? Vamos distribuir uma série de materiais pra eles e a princípio vamos distribuir 5 lentes com formatos diferentes; vamos lançar um problema aberto pra eles tentarem resolver. Esse problema aberto é como classificar as lentes dadas. Como eles podem classificar, porque têm diversas. Posso classificar de acordo com as bordas, finas, grossas. Posso classificar de acordo com a convergência e divergência dos pontos luz. Posso classificar de acordo com o formato delas, côncava, convexa, etc. A 
ideia é que eles tentem resolver isso, não vamos dar dicas, porque é um problema aberto, não tem um caminho fácil pra ser resolvido. Então eles vão ter que testar hipóteses, levantar hipótese, organizar informações, classifica-las e propor modelo explicativo praquilo. Obviamente eles já trabalharam esses conteúdos de forma teórica com a professora regular da turma. A ideia é ver se eles conseguem ver isso de uma forma investigativa e fenomenológica, uma abordagem um pouco diferente. Isso duraria cerca de 15 minutos, essa é a nossa ideia.

Segundo momento da aula, determinação da distância focal da lupa. Mais ou menos vamos apresentar um problema, junto com os materiais dados, como determinar a distância focal da lupa? Então eles vão ter que resolver de alguma forma. Eu tenho uma série de materiais, quais eu preciso usar? Uma régua, uma lupa? Posso usar as outras lentes, preciso usar os lasers? A vela? Então eles vão selecionar os materiais relevantes e fazer o modelo explicativo pra isso. Espera-se, obviamente, que de uma forma mais simples eles projetem a imagem, por exemplo, da luminária com a lupa, e a partir disso, com a régua eles determinem a distância focal. Esse é um jeito, mas pode ser que eles usem a equação de Gauss ou qualquer outro tipo de abordagem para que eles resolvam isso. Então fica a critério deles.

Profa. Marina: Eles já tiveram ótica?

Ricardo: Já. A professora tá terminando o estudo de lentes esféricas com eles. Então teoricamente já tiveram tudo isso, mas queremos ver se conseguem fazer essa transposição para outro tipo de abordagem. Ai no terceiro momento da aula a projeção de imagens de efeitos ...escolhidos pelos alunos e sua classificação, então a ideia é que eles peguem coisas da própria mesa, um estojo, uma figura de um caderno e eles projetem imagens. Como eles vão fazer isso vai ser determinado por eles. Que materiais vão usar, como vão fazer as hipóteses, levantamento de dados, etc, tudo com eles. A gente vai entregar uma folha contendo essas perguntas e que eles façam anotações que sejam relevantes pra depois a gente fazer uma discussão, que vai ser na outra aula. Mas ai espera-se que eles observem que com a lupa os objetos vão ser projetados com suas imagens invertidas. A gente quer que eles cheguem mais ou menos nessa ideia, da forma deles, mas também que eles classifiquem essa imagem e expliquem o porquê isso acontece. Quer dizer, o porquê eles vão ver em todos os momentos da aula, a classificação das lentes, por que eles classificaram daquela forma, como classificaram. A determinação da distância focal, mais uma vez, como e por que.

Ai na aula dois, também de lentes esféricas. Agora os conteúdos e princípios são os mesmos e os objetivos específicos agora é reconstruir as etapas e procedimentos, o que eles fizeram, através de perguntas chave. Então foi o que a gente viu, no caso, das crianças do ensino fundamental trabalhando com a bolinha, quando a gente fez aquela atividade na sala de aula. A gente quer que eles reconstruam o que eles desenvolveram nos três problemas. Primeiro passo, a gente vai fazer a pergunta como. Como é que eles fizeram pra solucionar cada um dos problemas. Então vão ter que reconstruir a atividades, os passos, os procedimentos que utilizaram. E depois a gente vai perguntar por que aquele fenômeno ocorre, por que é possível determinar a distância focal, por que é possível projetar imagens. Agora vai dar uma relação causal pra cada um dos problemas.

Profa. Marina: Quanto tempo vai ter entre uma aula e outra?

Ricardo: Vai ser no mesmo dia, uma antes do intervalo e outra depois.

Profa. Marina: Porque senão essas informações vão se perder. Tem que dar um jeito de registrar.

Ricardo: Não, a gente teve essa preocupação, vai ser no mesmo dia. A distância vai ser bem curta.

Bom, os recursos que a gente vai utilizar agora serão projetor de slides, notebook, caixa de sons, livro didático, lousa e giz. E assim como na aula 1, a gente vai ter a divisão da aula $2 \mathrm{em}$ três momentos. Como vai ser essa questão da exposição do livro didático? O Professor F, como o Aluno E falou, na última aula de tecnologia do ensino de física lá no Instituto, ele passou um vídeo da enciclopédia britânica chamado Luz e cor, e é muito interessante porque ele pega diversos momentos da ótica, então cada vídeo nos primeiros minutos eles tratam da ótica geométrica de uma forma bem didática, bem bacana e um pouco resumida, mas que é fundamental pro que estamos trabalhando, no caso as lentes esféricas. E ai, a gente vai trabalhar com esse vídeo, não vai ter nenhuma pergunta a princípio que eles necessitem responder ou pensar durante o vídeo. A gente só quer que eles assistam e anotem as coisas importantes que relacionem com os problemas desenvolvidos, essa vai ser a orientação, eles anotarem as informações importantes, relevantes para que haja uma discussão com relação aos problemas apresentados. Ai no segundo momento da aula, cada um mais ou menos com 15 minutos. Essa reconstrução, mais uma vez com a pergunta chave, como você solucionou os problemas e por que esses fenômenos acontecem? Mais uma vez pra eles reconstruírem todos os procedimentos, todas as etapas, falarem...

Profa. Marina: Por que o vídeo vai antes da discussão? 
Ricardo: Porque eles vão ter um relacionamento do conteúdo teórico, vão fazer a ligação desse conteúdo com o que eles trabalharam nos problemas. Uma forma de enriquecer a sistematização que a gente vai fazer depois.

Profa. Marina: Mas não pode ser o contrário? Vocês fazem as perguntas pra eles lembrarem das atividades, mostram o vídeo e depois sintetizam. Será que mudou alguma coisa, que a gente não fez?

Ricardo: A ideia é que você vai diminuindo um pouco a distância do pensamento.

Profa. Marina: Além disso, você possibilita uma construção que é muito mais deles com o que eles experimentaram. Porque senão eles vão de alguma maneira querer forçar colocar informações no vídeo no que eles fizeram, de maneira irrefletida e às vezes pode criar uma confusão. Você pega uma informação que eles obtiveram do experimento e agora eles têm uma informação sistematizada, que eles tão tendo disponibilidade e ai a resposta vai querer ser muito mais aproximada ao que o vídeo traz e não vai exprimir tanto o que eles experimentaram. Entende?

... É, trocar o momento 2 pelo 1, começar com a discussão deles, porque ai eles expõem o que eles fizeram. Senão vão tentar expor aquilo que tá no vídeo, sem fazer relação direta com o experimento.

Ricardo: A gente tinha pensado em fazer isso também. A princípio pensamos em discutir aqui mesmo qual seria a melhor abordagem, pensamos nessa interferência do vídeo, mas depois não achamos que fosse significativo, por isso deixamos dessa forma.

Profa. Marina: Ia ser muito. Porque assim mostra uma resposta que seria esperada.

Ricardo: É, exatamente.

E ai a última parte da aula seria a sistematização do que foi desenvolvido e aprendido. Então invertendo agora, eles fizeram a discussão, explicaram pra gente porque aquilo acontece, ai passamos o vídeo, orientamos os alunos a estabelecer uma relação do vídeo com aquilo que foi trabalhado e depois pedimos que façam uma sistematização do que foi desenvolvido e aprendido nas duas aulas. Como é essa sistematização? Que eles façam um pequeno parágrafo, meia página, resumindo, sintetizando tudo o que foi aprendido, de forma que eles possam reelaborar mais uma vez aquilo que eles trabalharam. E obviamente eles podem colocar outras sugestões, outras críticas, algo que seja relevante em relação a aula.

Vera: A aula três e a quatro o tema é sobre os filtros polarizadores e os conteúdos específicos são a polarização da luz e aplicação dos filtros polarizadores. A terceira aula tem como objetivo introduzir os alunos a ótica física, a partir do estudo fenomenológico, textual e investigativo dos filtros polarizadores. Como isso vai ser feito? Com uso de filtros polarizadores e um texto didático e a aula vai ser dividida em quatro momentos, sendo que no primeiro distribuímos os filtros, dois pra cada grupo, e o problema de como eles vão bloquear a luz com o uso desses dois filtros. A partir daí vão criar hipóteses, pegar dados, e com isso, num segundo momento da aula, a gente entra com a discussão de como eles fizeram pra solucionar aquele problema.

Profa. Marina: Seria interessante... Vocês vão fazer isso dentro da sala de aula? Vocês podem falar como bloquear a passagem de luz aqui dentro da sala de aula e depois ir pra fora. Porque eles podem ficar com a ideia de que o filtro bloqueou, porque essa luz é fraca. E se tiver um dia ensolarado, ótimo. Ver diferentes lâmpadas. Tem diferença diferentes lâmpadas?

Ricardo: É por isso que a gente ainda tem a folga.... no mesmo dia vai ter os materiais, a vela por exemplo. A gente ta com lanterna também, eles podem usar dessa forma e depois levar eles pra fora se tiver condição.

Aluna 1: Eles podem ter as outras opções de fonte de luz...?

Ricardo: É. Porque a gente vai levar numa caixinha o material, as opções estarão lá, então eles podem usar também a lanterna pra verificar isso, além disso a gente vai levar pra fora.

Vera: E a partir disso eles podem reconstruir o que foi feito, como eles fizeram pra solucionar o problema e a questão de por que o fenômeno aconteceu, pra ver se eles conseguem explicar, se entenderam o que é o fenômeno. Como eles ainda não tiveram isso, a gente entra com um texto didático, que eles vão fazer a leitura individualmente, grifar, marcar o que acharem importante pra discussão na sequência. Esse texto explica o fenômeno da polarização da luz e traz exemplos de aplicação tecnológica em LCD, etc.

Ricardo: $\mathrm{O}$ texto na verdade é uma apostila que o professorProfessor $\mathrm{F}$ fez com outros colaboradores, então é um texto bem voltado pro ensino médio. Ele explora a luz através de experimentos simples, física com demonstrações. Tem 5 páginas, bem curtinho. Tem algumas imagens, fala sobre o processo, explica depois o problema que a gente propôs. Explica como acontece, o que acontece então. Como eles estão vendo ótica física pela primeira vez, porque a professora não trabalha com nada em ótica física, então o primeiro contato a gente gostaria que eles realmente tivessem uma certa ideia um pouco mais precisa do 
fenômeno, que não ficasse alguma coisa errada. Então a discussão desse texto, através das imagens possibilite isso, além de entender melhor o problema que foi dado.

Vera: Com isso na quarta aula a gente vai trabalhar com a reconstrução de tudo o que já foi trabalhar na aula anterior, e pra isso vamos dividir a aula em três momentos pra apresentar o vídeo didático, que vai trazer a explicação do fenômeno e de novo a gente entra com as questões do como e do por que, pra eles relacionarem o que eles leram no texto, o vídeo e com o problema que eles já tentaram resolver. A partir daí a gente fecha com a proposição de escreverem uma síntese, um texto do que eles aprenderam.

Profa. Marina: A questão da explicação tecnológica não tá bem colocado ai não. Não sei como vocês vão trabalhar isso. Quer falar alguma coisa Yuri?

Ricardo: Isso é uma sugestão na verdade. É muito fácil de ver, funciona muito bem.Com fotografias existem filtros polarizadores, você consegue encontrar imagens na internet da mesma fotografia tirada com um polarizador na lente e uma não. Por exemplo, tira foto de um automóvel sem polarizador o fotógrafo aparece com o polarizador os reflexos sobre o automóvel diminuem consideravelmente, então essas duas imagens chamam muito a atenção.

Aluno 2: Esses exemplos que você deu tem no vídeo. Tem um reflexo de uma porta, uma mesa de vidro. Tem a questão do texto do LCD. Fala no vídeo e no texto sobre os óculos polarizadores. Então as aplicações tecnológicas surgiram tanto no vídeo quanto no texto. $\mathrm{E}$ ai pela discussão que a gente vai fazer o desenvolvimento dos conceitos. Inclusive como o vídeo é um pouco antigo ele mostra aquelas câmeras bem antigas, eles trocando os polarizadores. É bem legal.

A ideia foi trabalhar realmente com problemas abertos, investigativos, alfabetização. A gente percebeu o quanto é difícil tentar planejar isso, porque a gente ta tão acostumado com o ensino expositivo teórico que é difícil quebrar isso. Primeiro a gente pensa que não vai dar certo. A princípio a gente ia propor um problema só, na primeira aula, invés dos três problemas de ótica geométrica. "putz, mas vai ser muito rápido, eles vão sacar muito rápido". Então a gente não tá acostumado a trabalhar nessa linha investigativa, é complicado no começa, mas dá pra ver, espero que de resultados positivos. E tem a construção do próprio fazer cientifico.

Profa. Marina: E essas atividades que vocês estão levando são... você facilmente obtém o efeito que você quer e o fato de se obter facilmente o que você quer ajuda depois no momento de reconstrução das ideias pra chegar a conceituação disso. Acho que não vai ter grandes problemas não.

O grande problema da polarização é o aluno entender que tem que passar aquela?, como é que se entende isso? De repente vocês podem levar uma peneira construída. Já fiz isso uma vez, pegar um aro, um quadrado que é só o desenho dele e passar o arame numa única direção. Jogar espeto de churrasco ali, por exemplo. Quais vão passar? Vai passar um mínimo. Da pra se fazer uma relação com o próprio filtro. Não sei se o vídeo mostra alguma coisa nesse sentido. Acho que é interessante essa passagem, como é que o polarizador filtra a luz.

Aluno 2: Mostra. Inclusive ele tem essa imagem com um arame, é didático. Algo mais palpável.

Profa. Marina: Tá joia. Obrigada.

\section{Planejamento do estágio na disciplina MEF II (2ºmestre 2013) Grupo 1 de Ricardo}

Ricardo: Boa noite, pessoal.

Nosso planejamento de proposta de atividade de regência vai ser sobre espectroscopia e formação de estrelas. Por quê? Depois vamos chegar a esse ponto.

Nosso público alvo vão ser alunos do segundo e terceiro ano do ensino médio, devido as escolas públicas que vamos trabalhar, e o número de aulas que planejamos com essa proposta são 6 . Antes de falar sobre as aulas em si vamos falar sobre os objetivos gerais.

Primeiro, já desenvolvemos um estudo problematizado e contextualizado com os alunos, que trabalhamos no outro semestre do curso. Desta forma, vamos fazer isso através de um estudo da formação de estrelas e espectroscopia, por meio da discussão de alguns textos, que são do livro do Professor M.P. através de um debate sobre um vídeo e, também, através de uma atividade prática que realizaremos com os alunos. 
A ideia é problematizar e contextualizar sobre dois enfoques, que são o sócio-histórico e o didático. Tudo isso por opção nossa, porque como já trabalhamos o enfoque epistemológico agora queríamos trabalhar esses dois mais a fundo.

Profa. Marina: Me diz uma coisa, aí estão destrinchados os aspectos da alfabetização científica que vocês vão trabalhar, e esses aspectos de certa maneira estão ligados ao epistemológico?

Ricardo: Sim. Mas não vão ser nossos enfoques para a contextualização. Essa é a ideia. A epistemologia entra ai, mas não com apelo forte. Aqui um dos aspectos é a alfabetização científica que gostaríamos de trabalhar em específico, mas não significa que esses aspectos vão ser trabalhados em forma de contextualização. Eles podem aparecer, por exemplo, numa problematização, num problema aberto, em algumas etapas das atividades que vamos propor, mas não necessariamente esses aspectos vão ter o papel de contextualizar o tema sob esse enfoque.

Profa. Marina Eu entendo sua colocação, mas não sei se concordo com ela, porque quando você fala em contextualizar não precisa ser só uma maneira de apresentar a temática, até mesmo a forma como a temática vem sendo desenvolvida.

Ricardo: Exatamente. Porque a ideia é que nos textos a contextualização feita, principalmente sóciohistórica e didática, então, pela leitura dos textos não temos os aspectos relacionados à alfabetização cientifica. Pelo menos não como da forma que o professor P. expõe. Agora, quando formos propor as atividades, por um problema aberto ou outro, esses aspectos aparecerão, por isso estou tentando defender como uma contextualização.

Profa. Marina: Tudo bem, mas eu ainda não sei se concordo, vamos vendo ao longo de cada uma das aulas, porque uma atividade de leitura pode ser tradicionalíssima, mas pode ser uma atividade com interação entre os alunos e o próprio texto ou entre o professor e os alunos. Se ela for uma atividade que vocês propõem uma pergunta para que o aluno comece a ler o texto de alguma maneira esse problema qualquer já foi dado aos alunos. Então eles não lerão o texto de maneira passiva. O que eu quero dizer com isso é que eles não lerão o texto só para decifrar informação, lerão buscando algum tipo de resposta para a questão que vocês colocaram para eles.

Ricardo: Ai nesse sentido então a senhora diz que já estaria acontecendo a contextualização epistemológica.

Profa. Marina: Pode ser que sim.

Ricardo: É isso que meu grupo acreditava que não, porque o texto inteiro faz uma contextualização forte sócio-histórica, então ... é nesse sentido.

Profa. Marina: Uma coisa não é excludente da outra. Você pode ter um texto que por si o caráter dele traz essa abordagem sócio-histórica muito forte, como buscar a história do Einstein, mas a maneira como ele está sendo proposto aos alunos não nos permite que aconteça essa contextualização epistemológica.

O que estou querendo dizer é que vocês podem não ter pensando na questão da contextualização epistemológica para planejar essas aulas, mas na hora da implementação dessas aulas ela pode acontecer porque vocês estão falando na questão da alfabetização científica. Ainda que vocês não tenham planejado com essa ideia, se vocês estão falando em dar oportunidade para que os alunos resolvam problemas abertos, a epistemologia está ai escancarada.

Ricardo: Tínhamos entendido que precisaria estar trabalhado no texto para realmente ser uma contextualização. Pensamos que os problemas trabalhariam esses aspectos, mas isso não seria uma contextualização. Foi dessa forma que entendemos, mas pelo que a senhora falou já está acontecendo mesmo de forma implícita.

Profa. Marina: Eu acho interessantíssimo isso que estamos discutindo, porque a contextualização vai ter um aspecto que não é só do material que é fornecido aos alunos, mas é também de como é que o professor está se preparando para implementar aquele material. Então, se o professor está preparado para dar uma aula em que ele vai discutir com os alunos, ele vai de alguma maneira fazer com que eles se coloquem frente a uma investigação, porque estamos falando em Ciência, e a investigação é própria da Ciência, a questão epistemológica da ciência vai aparecer. 
Ricardo: Então podemos colocar, inclusive, o epistemológico.

Profa. Marina: Não sei. Do que você está me dizendo me causou estranheza. Você traz: "Problematizar, contextualizar sob os enfoques didático e sócio-histórico" e depois fala para trabalhar os aspectos da alfabetização cientifica e os dois primeiros são problemas abertos e levantamento de hipótese, isso já, na minha leitura, pressupõe uma investigação por parte dos alunos.

Ricardo: A gente acreditava que não necessariamente. Ai está a confusão.

Profa. Marina: Mas isso é bem bacana de considerarmos, porque pode ser que quando for implementar nada disso aconteça.

Aluno 1: "Pintou" uma dúvida aqui, não sei exatamente entender o que é um enfoque didático.

Profa. Marina: Enfoque didático, nesse caso, seria o mais simples, é quando você pega um conceito e o trabalha. E no caso de vocês já estão buscando material que foi feito para o ensino médio. Agora o grupo do Aluno E e Reinaldo está buscando um material que não existe completamente no material do ensino médio. Então, essa questão didática, para eles, aparece ainda mais porque eles estão tendo que fazer essa transposição do que está no livro de nível superior para transformar numa abordagem didática do ensino médio.

Aluno 1: Então, o enfoque didático tem a ver com o trabalho do professor e não como o aluno vai receber isso, porque na minha cabeça, para o aluno tudo é didático.

Profa. Marina: Não sei dizer isso, se para o aluno tudo é didático. Talvez para ele seja "vamos fazer escola e ver o que está acontecendo ai".

Aluno 1: Não entendo quando você falou que é apresentação didática do conceito, é abstrato assim tanto quanto parece? Pra mim é muito abstrato. Quando você fala enfoque sócio-histórico tem um viés quando vai abordar determinado objeto. Agora quando fala didático soa redundante. Abordar didaticamente alguma coisa é redundância, é isso mesmo?

Profa. Marina: Tá. Você vai abordar didaticamente de qualquer maneira, porque é o conceito que você está colocando ali. Agora, de que maneira essa abordagem didática vai ser feita é o ponto chave. Você pode abordar didaticamente tradicional, pegar bloquinhos e fazer resolução de exercício. Essa é uma abordagem didática e operacionalizante do conceito, porque você exclui esse conceito de qualquer outra situação. Tanto é que o aluno não sabe reconhecer a Física na vida, pelas entrevistas que fizeram no começo do ano, porque ela é muito específica da escola.

Ricardo: Então, se eu fizer uma contextualização em relação às aplicações, daquele conceito do nosso dia a dia, isso seria uma contextualização didática só que não de uma forma tradicional? Porque eu estou pegando aquele conceito e tirando a origem do desenvolvimento dele e não estou falando sobre a parte histórica, nem a questão epistemológica, mas eu estou contextualizando didaticamente em outro aspecto.

Profa. Marina: Sim. E você poderia dizer que está contextualizando socialmente, é a questão da tecnologia vinda a reboque.

Ricardo: Pegando os conceitos que o professor Hélio traz seria o didático?

Profa. Marina: Sim, mas um didático com forte aspecto social e tecnológico, é o GREF.

Felipe: Eu não consigo pensar o enfoque didático não tradicional. Será que o GREF não tem uma contextualização sócio-histórica?

Profa. Marina: Em alguns momentos o histórico não está tão trabalhado, mas a questão do social sim. 
Aluno 2: E ai a questão do didático não tradicional, como seria a abordagem fora da educação tradicional?

Profa. Marina: Quando fazemos um estudo por investigação, uma abordagem por projetos você está saindo do tradicional.

Aluno 1: Mas ai não é epistemológico?

Profa. Marina: Esse é o ponto, né? Você não está deixando de fazer o didático, ele está acontecendo, é a pergunta do Aluno 1.

Que bom que é, senão você não aborda conceito em sala de aula. Até porque você está dentro da sala de aula.

Aluno 1: Mas como vou chegar na sala de aula e não ser didático se minha função é ser didático?

Profa. Marina: Não, você tem que ser didático.

Aluno 1: Justo. Então, como eu consigo dar um enfoque não didático? Todos os enfoques são didáticos uma vez que estou explicando conceito, faz sentido?

Ricardo Não. Vou tentar te ajudar. O sócio-histórico e o epistemológico serão um subconjunto do didático, então qualquer contextualização que você fizer será didática. Quando lemos o texto do XX ele separa o didático, o epistemológico e o sócio-histórico, porque quando você faz uma contextualização sócio-histórica fala como que aquele conceito se desenvolveu historicamente na sociedade da época, etc. Isso seria, por exemplo, a contextualização sócio-histórica. Não quer dizer que você esteja fazendo uma contextualização epistemológica, porque não está entrando no que é a natureza da ciência, por exemplo, como ela se desenvolve, como se reproduz, quais os paradigmas, etc. A didática, por exemplo, quando temos o saber cientifico produzido na academia, pelos pesquisadores, esses saberes quando chegam à sala de aula sofrem a transposição didática, não são os mesmos saberes que ensinamos para os alunos, são saberes didatizados. Então, para que isso aconteça temos que fazer uma contextualização, por exemplo, didática. Por isso eu vejo separado.

Aluno 1: Eu entendi. Mas não sei se concordo, acho que é uma coisa minha. Porque, pra mim, se estou na sala de aula explicando qualquer conceito independente de ser sócio-histórico ou epistemológico sempre vai ter que haver a transposição dentro do espaço da escola, na sala de aula. Então, toda maneira de lecionar é didática.

Profa. Marina: Sim, porque você está em sala de aula.

Aluno 1: Pra mim não existe o enfoque apenas didático.

Profa. Marina: Existe.

Aluno 1: Seria o que, por exemplo?

Profa. Marina: Seria, por exemplo, a resolução de exercícios do bloquinho.

Aluno 1: Ah, tá. Eu fiz a transposição e não a resignifiquei no espaço?

A visão que estou tendo é que o enfoque didático é outra palavra para a educação tradicional, porque a transposição didática do conhecimento da academia já acontece tradicionalmente.

Profa. Marina: Sim, mas preste atenção. Não sei se vocês estudaram a fundo a transposição didática. Pessoalmente não é um tema que me agrada muito, porque a questão da transposição didática deixa de fora o aluno, olha para o saber em si só. É interessante? Sim. Mas pensando na educação como processo em que pessoas estão dialogando, construindo entendimento sobre o mundo, estão se formando deixar de fora o aluno me parece uma loucura. Parece que estamos apenas nos ocupando do conceito sem imaginar que aquele conceito faz sentido para um aluno numa situação x. Se andarmos na escala do tempo amanhã 
pode ser que aquilo não faça mais sentido para o aluno. Ou então, isso que não fazia sentido hoje amanhã faça, porque ele experimentou alguma coisa na vida, teve uma aula que aquilo começou a fazer sentido. Então, falar em transposição didática é olharmos para o conteúdo sem imaginar quem são os interlocutores desse conteúdo. Tudo bem, a transposição didática vai dizer que ela considera a questão da esfera social, quem é e onde é que estou trabalhando esse conteúdo. Quem é a comunidade com a qual estou trabalhando. Mas ela não considera as interações que as pessoas têm com esse conteúdo.

Desse ponto de vista podemos imaginar que quando estamos trabalhando em sala de aula estamos sempre fazendo a questão didática, porque a sala de aula é o lugar onde ensinamos alguém sobre alguma coisa, de forma tradicional ou não. Agora podemos pensar que, por exemplo, ... nem precisamos ir para um museu, estamos andando, de repente, num parque ou avenida e começamos a pensar nas sensações que tem ali, como: Por quê está tão quente?

Ontem de manhã eu estava assistindo o Bom Dia São Paulo e a repórter mediu quantos decibéis ela ouvia numa avenida, dava em torno de 85, 90. Ela andou 20 metros e entrou num parque, dentro dele o som ficava entre 73, 75 decibéis. Ela estava mostrando isso para dizer que as árvores têm a importância de barrar o som. Como é mais agradável estar num ambiente mais tranquilo para discutir a questão do estresse.

Trago essa situação para pensar o seguinte, uma pessoa que estava lá começa a perceber essa diferença, entre os ambientes [...]. Esse processo é um processo de investigação, mas não uma investigação didática, porque ninguém pediu a ele que fizesse isso. Agora imagina que essa pessoa é seu aluno e leva isso para a sala de aula. O que você vai fazer? Vai didatizar, porque você quer trabalhar com ele o conteúdo e nesse caso vai ser a questão da acústica. Vai discutir a interação da onda com a matéria. Na sala de aula as coisas não são reais. Se fossem não tínhamos planejamento.

Óbvio que quando começa a interagir com o aluno vem muita incerteza e a realidade começa a acontecer ai. Mas você está preparado ou deveria estar preparado para responder essas questões. Preparado não só do ponto de vista do conteúdo científico, mas preparado na questão pedagógica. Que interação eu faço com esse aluno? Aceitar a resposta do aluno é um caminho essencial para que ele vá te perguntar. Mesmo que ele fale uma bobagem gigantesca. Respeitar que não é só a questão do conteúdo, do teor da fala dele, mas a maneira como ele se posiciona.

Tenho certeza que na experiência de vocês, seja na sala de aula ou estágio, encontraram alunos que têm dificuldade para se expressar. Não porque não saibam o conteúdo, mas porque são tímidos, porque tem dificuldade para falar em público. Agora, se você não der oportunidade para aquele aluno falar e quando isso acontecer começar aquelas risadinhas e você não mostrar que está interessado nele, nunca mais ele fala. Talvez vocês tenham vivenciado isso em determinada aula, pensar em não falar com o professor porque ele ia acabar com vocês. O professor é respeitoso, escuta o que você está dizendo, mesmo que demore um tempo. Imagine uma fala sua que não está conseguindo organizar direito e fique ali uns 5 minutos tentando organizá-la, na sala de aula será uma eternidade. Se o professor é respeitoso você participa sempre da aula dele e se sente acolhido.

Então, é nesse sentido que estou falando, Aluno 1. Não sei se me fiz clara, mas a questão da didática estando na sala de aula deve sempre aparecer. Mas temos outras situações de educação que não são da sala de aula e ai levamos até para a questão da educação não formal. Quantas e quantas visitas são feitas ao Cata-vento sem olharmos aquelas plaquinhas que são colocadas lá? As placas têm uma intenção didática, a visita em si não precisa ter necessariamente.

Ricardo: No caso da transposição didática, a crítica que a senhora faz, eu acabei pensando que ela pressupõe uma verticalidade na relação professor-aluno. Não se fala na interação entre esses agentes, porque, pelo que entendi, há esse pressuposto de que quem tem que fazer essa ação é o professor.

Profa. Marina: É que não está no escopo da teoria. A transposição didática não está interessada em fazer essa interação. Vamos fazer uma analogia muito simples. Se um cientista for analisar todas as variáveis que estão em torno de um fenômeno ele não consegue analisar. Então, você já cerca de tal maneira que vai ver só uma coisa. Por exemplo, coloca só um filtro de ouro para ver como é que interagindo com ele as partículas reagem. A transposição didática está fazendo isso, porque se ela for olhar para a interação não vai dar conta de saber como é que o conteúdo vai para a sala de aula.

Aluno 3: Professora, quando a senhora fala da interação do aluno com o conteúdo, para mim não ficou claro o porquê está dizendo isso. Se o aluno vai aprender ou não? É isso que é interação? 
Profa. Marina: A interação do aluno em sala de aula com o professor, com os colegas e com os conteúdos.

Aluno 2: Eu entendi que era como o aluno se relaciona com o conhecimento, com aquilo que se está ensinando.

Profa. Marina: Isso também, né? O professor é o mediador das relações do aluno com o conhecimento. E ai, não é só a relação na perspectiva do conteúdo científico em si, mas a relação do aluno com os outros conhecimentos, saberes, que rodeiam o conteúdo científico.

Aluno1: Mas quando a senhora falou "Interações" era nesse sentido?

Proa. Marina: Quando eu falo interação aqui em sala de aula estou pensando como você interage com os conhecimentos que estamos tratando aqui, seja minha fala como professora, seja a fala dos colegas. Falo também da interação que você tem com os colegas. Agora a pouco você estava falando com o Felipe, estavam falando em sala de aula e isso não estava sendo mediado por mim, mas certamente chegaram a algum tipo de consenso ou ideia nova sobre o que estavam conversando. Isso é outro tipo de interação que também é da sala de aula. A sua interação com o material didático é outra coisa que estou considerando também. Não só o material didático manipulativo de resolver um problema, mas um material, por exemplo, no nosso caso um curso que tem muito texto, vemos que novamente voltamos ao conhecimento.

Nesse ponto de vista, não sei se você tem interesse, mas um autor interessante de ver é o Bakhtin, que traz muitas coisas bacanas e uma delas é a questão da dialogia. Quando falamos dialogia pensamos em duas pessoas e ele coloca a questão da dialogia de você com você mesmo. Como você constrói conhecimento a partir do que você já sabe, internalizando novos pontos de vista, refletindo sobre o que você já sabe. Já fazemos isso o tempo todo, às vezes sem se dar conta. Quantas e quantas vezes você passou por um curso de eletromagnetismo e ai numa outra situação, conversando com alguém sobre outra coisa e entende aquilo. Ai a dialogia está aparecendo muito clara.

Quando estou falando interação penso nisso. Qualquer possibilidade de construir relações seja interpessoal ou como conhecimento.

Ricardo: Ai, a nossa justificativa como proposta. Primeiro quando aplicamos os questionários semana passada surgiu o tema de astronomia, temas relacionados à astronomia. Então, como apareceu no diagnóstico o interesse pelos alunos em aprender esses temas temos a justificativa para fazer esse trabalho. O interessante é que as próprias justificativas dos alunos em querer aprender os sistemas relacionados à astronomia tinham a ver com questões emocionais, a questão da curiosidade, do interesse, alguns pensavam em fazer faculdade de astronomia. Então, é interessante por que eles não estão atrelados à questão do vestibular.

E ai, quando estávamos discutindo a questão dos saberes científicos, que superam a transposição didática por uma série de processos [...] surgiu a necessidade de que eles sejam problematizados, contextualizados para que aquilo faça algum sentido para os alunos. Essa é uma justificativa do por que desenvolvemos uma proposta problematizada e contextualizada.

E os aspectos da alfabetização científica, como já estudamos no primeiro semestre e retomamos agora, são aspectos que constituem os objetivos de Ciência, então, trabalhá-los é um dever como professores.

Agora sobre as aulas. A primeira aula é sobre espectros luminosos. E os conteúdos específicos são espectros de emissão e de absorção. E os objetivos específicos é fazer com que os alunos entrem em contato com esse sistema, de uma forma problematizada e contextualizada, e os recursos didáticos que vamos utilizar são os textos didáticos, o giz e a lousa. Esse texto didático é da coleção do professor M. P. sobre espectroscopia. Então, vamos pegar algumas partes importantes, capítulos, sobre espectroscopia, e a primeira parte fala muito sobre isso: espectros luminosos.

A primeira parte da aula seria a análise e desenvolvimento de um problema aberto por parte dos alunos. Jogaríamos o seguinte problema para eles investigarem: Como podemos conbecer as estrelas a partir da análise de sua luг que chega até nós? $\mathrm{O}$ texto desenvolve isso, mas gostaríamos de trabalhar isso com eles primeiro.

Ai vem a questão de um dos aspectos da alfabetização científica. Nossa ideia é que eles primeiro expressem as concepções espontâneas que eles têm sobre o assunto, porque, de acordo com nosso 
questionário diagnóstico, eles não trabalharam com nada relacionado a isso. Então, queremos que eles proponham um modelo explicativo para responder essa pergunta.

Profa. Marina: Por que você está chamando de problema aberto?

Ricardo: Porque eles nunca viram aquilo, eles não teriam um caminho para direcionar...

Profa. Marina: Concordo com isso, mas podemos chamar só de problema. Eu imagino que vocês pegaram essa expressão "problema aberto" daquele texto que discutimos semestre passado, do Gil Peres, Questionando a didática de resolução de problemas, não foi? Lá ele vai falar que o problema aberto é um problema que depois acaba indo para a questão da matemática.

Felipe: Nós entendemos "problema aberto" como aberto a várias formas de tentar resolver.

Ricardo: Agora estou confuso, porque nós não discutimos o semestre inteiro que um problema aberto seria um problema...?

Profa. Marina: Um problema, não aberto. Lembra que eu não usei a expressão "problema aberto". Eu falo sempre problema.

Ricardo: Eu digo, porque no semestre passado apresentamos um problema exatamente como esse como "problema aberto" e não...

Proa. Marina: Não. Vocês apresentaram "problema aberto" semestre passado naquela linha dos temas que fiz para vocês mudarem o enunciado tradicional para o aberto, lembra?

Ricardo: Quando apresentamos nossa proposta de estágio colocamos isso e a senhora não...

Profa. Marina: Então passou batido.

Felipe: Pensei que "problema aberto" seria aberto a forma de pensar.

Profa. Marina: Isso é detalhe "boboca", que não está mudando o mérito do que vocês estão apresentando aqui. Só achei interessante chamar a atenção, porque se você vai apresentar para a comunidade acadêmica podem usar isso como um demérito do seu trabalho, que não é, de maneira alguma. Mas a ideia do "problema aberto" para o Gil Perez, que imagino que seja a referência, está associado ao fato de você pegar um enunciado que é tradicional, que leva a "algebrização" do tema. E aqui não é o caso. Porque ele é um problema e bastante genuíno, porque o aluno não sabe mesmo a resposta.

Se vocês estão falando que vão tratar a questão da formação das estrelas e da espectroscopia, me parece que esse problema vai ser discutido ao longo de toda sequência.

Felipe: $\mathrm{Na}$ verdade esse problema vai ser o desfeche de todo o trabalho. Porque na atividade final é que eles vão perceber como que fazemos para olhar para a estrela e dizer como ela é feita.

Profa. Marina Isso é interessante. [...] quando estamos imaginando uma sequência de ensino ela não é chamada assim porque é um nome bonito, é porque as atividades deveriam estar sequenciadas de tal maneira que você vai trabalhando a complexidade daquele tema ao longo de diferentes aulas. Então, um problema que perpassa toda sequência de ensino tem que estar claro, senão para o aluno, para você como professor. Para você sempre voltar a atividade que dê conta do aluno resolver esse problema.

Felipe: Eu imagino que eles vão ler o texto e não vão chegar à resposta. Só vão chegar quando fizermos a atividade, dai ficará claro.

Profa. Marina: Vocês têm que ter muito claro que você fala em luz para o aluno, mas o que é luz? Luz para ele é tudo. Aquela luz brilhando na caixinha de som é a mesma luz. Ele não vai diferenciar que aquela 
pode ser diferente dessa. Até porque você não deu material intelectual a ele para fazer isso. A construção que vocês estão fazendo vai ter que perpassar por isso.

Então, a questão do espectroscópio entra nesse sentido de fornecer material intelectual e físico para que o aluno resolva o problema.

Felipe: Para que o aluno possa perceber que uma luz é diferente da outra.

Profa. Marina: E que o que não percebemos como luz também é luz.

Ricardo: O segundo momento da aula seria de reconstrução e análise ou de tomada de consciência, como já trabalhamos no primeiro semestre, porque nem sempre tomamos consciência das próprias ações. Então, é importante que algumas perguntas sejam estabelecidas. A primeira é Como fizeram para solucionar o problema e Por que propuseram esse modelo explicativo e qual a fundamentação.

E a penúltima parte é a leitura e discussão do texto sobre espectroscopia em pequenos grupos e depois uma discussão aberta com todos, sobre os pontos mais importantes, dúvidas que eles possam ter.

$\mathrm{Na}$ aula 02 vamos fazer uma sistematização. Os temas, conteúdos específicos, objetivos são os mesmos e limitam-se simplesmente a fazer essa sistematização do que foi desenvolvido e aprendido. Os recursos didáticos que vamos usar agora são, além dos mesmos da primeira aula, as questões problematizadoras e contextualizadoras. Ainda não definimos quais serão essas questões, porque o professor Professor $\mathrm{P}$ sugere algumas questões, mas são ou conceituais ou de tomada de consciência.

Profa. Marina: Você falou que é uma atividade de sistematização, mas eu acho que parte dela vocês já fizeram na aula anterior quando fazem a pergunta para os alunos de como resolveram aquele problema. Aqui ainda que possa ser uma retomada dessa sistematização eu entendo que é muito mais uma aplicação dessa ideia em outras situações, pelo que você está me dizendo que vai trabalhar.

Ricardo: Aqui (mostra no slide) a pergunta não é trabalhada diretamente no texto, ele apresenta outros conceitos. A primeira parte fala sobre os espectros luminosos; faz uma pergunta para o aluno se ele observa que existem várias fontes de luz no cotidiano dele e se essas fontes de luz apresentam espectros diferentes. A partir daí entrar nos aspectos de absorção e emissão. Ele vai falar sobre conceitos, que tem a parte matemática dos espectros, vai falar um pouco do que ... Então, precisamos fazer, não é suficiente.

Profa. Marina: Entendi. Eu estava achando que naquela aula você ia fazer a sistematização da pergunta.

Ricardo: Não, é de toda aula.

Profa. Marina: Então não vai dar tempo. Tem um aluno que acabou de defender o mestrado e pra defender ele foi à aula dele cronometrar quanto tempo os alunos levam para ler um texto. Um texto de 6 páginas os alunos levam 15 minutos.

Ricardo: Semestre passado quando aplicamos deu tempo.

Profa. Marina: Mas esse texto ai? O texto é bom, cheio de informação, é difícil de ler. Eles terão parado para pensar numa questão que é difícil, terão discutido essa questão com o professor, lerão o texto e ainda terá a discussão aberta. Acho que não dá tempo.

Ricardo: Mas se continuarmos na próxima aula e fizermos a sistematização?

Profa. Marina Tudo bem. Você está me colocando que é a aula 1 e a 2.

Felipe: Nós vamos dar 6 aulas e se estender uma aula ou duas não tem problema. A dúvida é se lá no colégio não teremos problemas.

Profa. Marina: Não sei, mas estão cientes de que pode ser que demore muito mais. Essa pergunta não é fácil.

Ricardo: A nossa ideia é que a gente controle o tempo que eles terão para pensar sobre isso, porque como vai ser desenvolvido pelo resto das atividades, não vamos querer que eles pensem tanto no primeiro dia, ai 
que entra o papel do professor. No caso, quando formos escrever precisamos explicitar que talvez não de tempo?

Profa. Marina: $\mathrm{O}$ que estou falando aqui vocês vão ter que falar lá com o coordenador, sobre precisar de mais aulas de repente.

Ricardo: Mas isso eu acho que conseguimos se precisar de mais aulas.

Profa. Marina: Qual o teu objetivo com aquela aula? Porque vocês disseram que ainda não pensaram na questão problematizadora. De repente falando sobre os objetivos que vocês têm possamos ajudá-los a pensar.

Felipe: $\mathrm{O}$ objetivo é ver o que o aluno entendeu do texto, porque a leitura do primeiro texto não estará ligada a pergunta geral, que é a formação da estrela, mas o texto falará sobre a espectroscopia.

Profa. Marina Então, essas questões problematizadoras são questões para nortear a leitura do texto, é isso?

Felipe: Isso. Para que ele possa entender o que leu.

Profa. Marina: Façam perguntas iniciais para que eles busquem informações que vocês destacam como sendo as mais importantes do texto e as outras vem para buscar relação entre essas ideias.

Ricardo: Uma pergunta de problematização exatamente para isso e outra pelo menos que faça conta da exceção. Aqui ele vai falar um pouco sobre o desenvolvimento, quem foram os cientistas e tal. Então, pelo menos que eles tenham essa compreensão, que a questão em si proporcionasse essa contextualização.

Profa. Marina: esse que é o ponto, vocês estão falando em questão de problematização e de contextualização, não tem problema nenhum quanto a isso, o que tem problema é o aluno responder isso sem antes ter uma diretriz pra onde ele está indo. Com isso quero dizer que a pergunta de problematização vai fazer sentido para o aluno se ele souber sobre o que ele está discutindo.

Ricardo: Então, é a pergunta de tomada de consciência.

Profa. Marina: As perguntas anteriores vêm de tomada de consciência, quais são as informações relevantes no texto que vão ajudá-lo a resolver essa problematização.

Ricardo: Essa é a questão, com relação as perguntas com tomada de consciência já temos, que são as apresentadas pelo professor P. Ainda falta fazer as perguntas de problematização e contextualização.

Felipe: $\mathrm{Na}$ verdade tem as perguntas do P., mas elas são muito diretas.

Ricardo: Mas não queremos usar só elas, queremos fazer as de problematização e contextualização.

Aluno 1: Esse conteúdo específico é para uma aula?

Ricardo: Vamos explicar como ele vai aparecer, tem mais coisa ainda, mas ele vai aparecer de outra forma. Vamos entender por que.

Os objetivos específicos é só fazer uma introdução da formação das estrelas através da apresentação de um vídeo didático. Nele vai falar sobre tudo isso, é o Vida e morte das estrelas, da Discovery Chanel, que tem certa de 40 minutos. Pesamos bastante se ele deveria entrar e achamos que vale a pena, porque a sala de vídeo é bem usada e a professora ajuda bastante.

O vídeo faz uma introdução bem legal da formação, explica o que é sequencia principal, fala da nebulosa de Eagle, fala de pulsar e ele trata de forma bem didática, com desenhos muito bons.

A princípio vamos pedir que eles façam algumas anotações sobre os pontos que eles acham mais importantes, interessantes e ai ...

Profa. Marina: O ponto que eles acham mais interessante é aberto demais. Vide um texto. Assim como um texto, é interessante antes de apresentar fazer uma discussão com os alunos sobre qual é, mais ou 
menos, a ideia que vai ser discutida. Vida e morte de estrelas? O que é morte de estrelas? Será que ele já parou para pensar que uma estrela morre? Ou como uma estrela nasce? Nasce pequena e cresce? Será que o mecanismo de vida de uma estrela é igual ao nosso? Se apaga de uma hora para outra? Discussões como essa você pode fazer com os alunos e não precisa pedir para ele anotar o que ele acha mais interessante, vocês podem fazer perguntas que vão direcionar o olhar do aluno para questões que vocês julgam mais importantes.

Ricardo: De certa forma não estou talhando o aluno? Pode ser que uma coisa que ele ache interessante eu não estou considerando.

Profa. Marina: Não. O que estou propondo não é conflitante com isso não. Estou pedindo que vocês façam perguntas aos alunos para que eles possam prestar atenção naquilo que vocês querem. Depois na discussão geral você vai abordar isso que quer, mas vai dar espaço para ele trazer o que ele acha interessante;

Ricardo: Pensamos em fazer o oposto, porque ali a ideia é não dar um olhar direcionado, isso foi proposital. Por quê? A discussão do vídeo, as atividades, o direcionamento aconteceria na segunda aula.

Profa. Marina: Mas o que estou querendo salientar é que um vídeo de 40 minutos é longo, você não vai passar de novo esse vídeo, ele não vai ver em casa novamente, então se você de alguma maneira já não der um direcionamento no olhar vai ter alguma coisa que era essencial que ele não prestou atenção, porque nessa hora ele estava disperso, conversou um pouquinho com o colega, deu uma cochilada, isso acontece em sala de aula.

Ricardo: Eu sou reticente em relação a isso, porque de certa forma se eu direcionar o olhar dele nessa aula pode ser que apareçam outras coisas interessantes, que ele ache interessante, mas que não vai julgar importante porque eu tirei o direcionamento.

Profa. Marina: De novo, eu não estou dizendo que é conflitante. Você pode pedir ao aluno para que ele destaque o que é mais interessante, mas não deixe também de dar um tipo de sugestão, apontando algumas coisas. [...]

Ricardo: Esse tipo de fala estava pressupondo antes de passar o vídeo.

Profa. Marina: É isso que estou pedindo para você.

Ricardo: Então, temos que explicitar isso aqui.

Ai na quarta aula pretendemos fazer uma sistematização do que foi aprendido na aula 03. A ideia é fazer uma discussão sobre o vídeo, tirar dúvidas sobre os pontos mais importantes, agora com olhar direcionado. E o recurso didático seria o giz e a lousa.

Felipe: Bom, aqui no segundo momento da aula pretendemos fazer uma discussão sobre o vídeo apresentado na aula 03 e fazer a sistematização sobre o que foi aprendido e desenvolvido na discussão e no vídeo, e depois na aula 05 o tema é espectroscopia das estrelas, das galáxias, tipos espectrais, os aspectos das estrelas e das galáxias. Os objetivos específicos são desenvolver o estudo contextualizado e problematizado sobre a espectroscopia das estrelas e das galáxias através da análise e discussão de um texto didático.

Ricardo: É uma continuação do capítulo que tem o título Escrito nas estrelas.

Felipe: É esse texto que eles vão ler ...

Profa. Marina: Eu não sei onde estão pensando em colocar o espectroscópio, mas talvez seja logo depois da aula 04 , porque você olha para ele de maneira mais genérica, conceitual, bonitinha e depois vai para o Balmer, que já é uma coisa mais rigorosa de análise do espectro. 
Ricardo: Antes da aula 4?

Profa. Marina: Depois da 04, porque a 03 foi o vídeo, a 04 a discussão sobre o vídeo, ou seja, a questão da luz voltou à tona para discutir a estrela. Você está falando de luz, de estrela, então pode pedir para eles olharem com o espectroscópio para o sol, para as lâmpadas. Traz esse link com a luz de maneira muito forte.

Felipe: Então, vamos fazer uma discussão sobre o texto para tirar as dúvidas e vamos para a aula final, que continua a espectroscopia das estrelas.

Profa. Marina: De novo, se vocês colocam entre as aulas 04 e 05 , então você usou de maneira genérica e depois vem o Balmer com uma análise mais rigorosa e agora você vai fazer um estudo disso, mesclando o que ele viu com o espectroscópio e agora você põe a aplicação disso. Então, se olharmos o esquema do ensino por investigação você tinha primeiro um problema, que era ver quais são os espectros, você está sistematizando com a ideia do Balmer e você avalia isso na aplicação desse entendimento em outras situações.

Felipe: ... Vamos fazer a atividade que é a do Astrônomo mirim, em que pretendemos levar as folhas impressas e coloridas. Aqui temos um espectro de uma estrela e os espectros dos elementos químicos. Então, o aluno pode comparar, por exemplo, olhando a franja do ferro e a da estrela e vai achar uma franja muito parecida, assim conclui que naquela estrela tem ferro.

Profa. Marina: Vocês podem fazer isso imprimindo essas linhas dos elementos em transparência e coloca em cima. E ai não precisamos imprimir os elementos para todos, pode imprimir por grupo.

Ricardo: Não entendi a questão da transparência.

Profa. Marina: Ele pega o ferro e o iodo e coloca um em cima do outro e vê que está dando algo diferente. Com qual ele compara?

Felipe: Ele pode pegar e ir casando uma em cima da outra e vendo qual mais se aproxima.

E aqui, com essa atividade o aluno vai concluir e chegar à resposta da pergunta geral, que é como conseguimos identificar a estrela pela luz que chega.

Profa. Marina: Mas coloca a pergunta novamente no fim dessa aula.

Ricardo: Sim, estaremos sempre retomando.

Felipe: E eles vão comparando os espectros e assim, conseguem concluir que naquela estrela tem, por exemplo, ferro.

Ricardo: Isso seria a última aula.

Felipe: Ai tem o finalzinho da aula que é a sistematização e tal.

Eu acho que é um projeto ambicioso.

Profa. Marina: E ai eu volto a falar da questão epistemológica. Ela vai aparecer se vocês forem cuidadosos em seguir esse plano que estão fazendo, do tipo de pergunta que fazem ao aluno, porque a ideia que está aqui vocês têm grande possibilidade que a investigação aconteça. Mas isso não garante que de fato ela vá acontecer na sala de aula. Por isso que quero ver o vídeo de vocês na aula. Porque uma coisa é planejarmos, uma coisa é estarmos na sala de aula à frente de uma turma que não conhece direito. Um conteúdo que não é fácil de lidar e ai a ansiedade, o aluno falando um milhão de outras coisas que você não sabe responder. Pronto, você volta para o tradicional, porque ali se sente mais seguro. Isso não é condenável, mas você foge dessa perspectiva epistemológica que a princípio vocês mostram que estaria entre os objetivos de vocês trabalharem. 
Ricardo: Nas perguntas que deixamos abertas, porque não sabemos se vamos fazer a contextualização epistemológica apareceria, então colocamos lá também? E as outras duas estão claras na nossa apresentação?

Profa. Marina: Sim. A sócio-histórica entra de maneira meio marginal, você não fez uma abordagem histórica.

Ricardo: Mas o próprio texto faz.

Profa. Marina: Mas eu não vi o texto. Se ele faz tudo bem, mas a sua abordagem aqui não foi sóciohistórica. Você não me apresentou um plano em que a questão sócio-histórica está permeada, ela aparece no texto, mas e se o aluno não prestou atenção que no texto isso aparece?

Ricardo: As discussões que vamos desenvolver ...

Profa. Marina: Vai depender das discussões. Mas do que você me apresentou não está claro.

Ricardo: É interessante isso que está colocando, porque pra gente isso fica claro, que pela discussão essa contextualização, por o texto já abordar isso, vamos apresentar dessa forma.

Minha dúvida é se quando formos escrever para te entregar isso tem que estar na discussão, explicitar os aspectos sócio-históricos.

Profa. Marina: E também somar o que é no texto discutido de abordagem sócio-histórica, porque você não falou, não te pedi para detalhar o texto.

\section{Planejamento do estágio na disciplina MEF I (1 ${ }^{\circ}$ semestre 2013) Grupo 2 de Heloisa}

Heloisa: O nosso tema principal e o objetivo é a construção do conhecimento científico, e o tema que a gente escolheu pra trabalhar isso é a Evolução do Universo, que é dada no terceiro ano.

O objetivo geral é o panorama de como a evolução dos conceitos científicos a respeito da astronomia culminaram nessa ligação (quando a gente ...?) enfatizando ai a ciência da construção humana, histórica do conhecimento e método cientifico. Complementando os objetivos, a nossa justificativa pra construção da ciência ...(?), histórica, social, coletiva, da comunidade cientifica, política e filosófica...uma construção. (...??)

Carlos: Basicamente o que a gente vai fazer é uma construção histórica da evolução do comportamento cientifico e pra auxiliar isso a gente vai montando com os alunos uma linha do tempo, de como os pensamentos foram mudando, as ideias foram mudando conforme o tempo foi passando. A ideia é mostrar que a física é algo em construção, não é nada imutável. Essa é uma ideia nossa, que os alunos comecem a pensar na física de maneira que eles também possam fazer parte disso, ele também pode dar a contribuição dele. É questionável e uma hora isso pode mudar. A nossa ideia é essa, tentar mudar a mente do aluno para que no futuro ele possa fazer questionamentos e participar da construção da ciência.

Ana: Tem que deixar claro que esses conhecimentos não surgiram do nada. Tem pesquisas, conceitos, enfim, tudo partiu de uma coisa bem estruturada pra culminar no Big Ben, que é onde a gente vai terminar, que é uma construção bem legal.

Profa. Marina: Vocês estão falando de uma evolução histórica, social e que a construção do conhecimento cientifico tá permeada pela época, com características sociais, culturais. Se é assim, eu não posso pensar que o Galileu usou da mesma maneira que o cientista que trabalha no CERN pra propor as suas ideias? Carlos: Então, a gente vai tentar colocar na época "Na época do Galileu as ideias eram essas, os conhecimentos eram esses", então naquela situação o Galileu pensava dessa maneira, é isso que a gente quer frisar, em cada época as pessoas pensavam de uma maneira, porque em volta isso os influencia. Profa. Marina: ... naquele momento influencia. Eu to dizendo tudo isso, porque vocês usaram o termo método cientifico. 
Carlos: Isso. Porque mais pra frente ...pela construção. Depois de Newton a ciência mudou. As pessoas começaram... surgiu o método cientifico.

Profa. Marina: Você falou uma, esse é o problema. Não existe um. Vocês colocaram método científico.

Carlos: Ah, seria o rigor.

(Conversa incompreensível)

Carlos: A ideia que a gente quis dar é que depois de Newton, o rigor pras teorias serem aceitas na comunidade cientifica, houve muito mais rigor. Foi isso que a gente quis dizer. Um rigor que não parou o processo. Não basta você descrever um fenômeno. Você tinha que matematizá-lo e fazer diferença.

Profa. Marina: É quando começa a prática de ciência.Naquele momento a filosofia natural.

Ana: Então, como o Carlos falou, a gente vai propor pros alunos uma construção de uma linha do tempo, da evolução dos conceitos da ciência,vão deixar isso claro na primeira aula, pra eles irem pensando enquanto a gente explica.

Carlos: E montando a linha do tempo deles.

Ana: Na primeira aula a gente vai falar deheliocentrismoe geocentrismo, mas antes de começar a aula vamos seguir o conselho que a ?deu, a gente vai...é como se fosse um questionário, não elaboramos a frase certa ainda, mas é mais ou menos...uma questão. A gente vai dar uma no final e uma antes, só pra eles se situarem no que a gente tá querendo dizer. Então, a gente os questionaria nesse sentido: "Vocês sabem que o sol é o centro do sistema solar, que a gente orbita o sol, como você prova isso?". A gente sabe, todo mundo sabe.

Aluno 1: É uma pergunta pra criar um problema?

Ana: Isso. Eu entro com essa pergunta só pra eles...isso mesmo. Então todo mundo sabe que o sol é o centro do sistema solar, mas por quê? Essa é a construção.

Então a primeira aula...

Profa. Marina: Na verdade o que vocês estão fazendo é tudo estruturado já?

Ana: Ai a gente vai falar de Aristóteles, Galileu. Vamos começar a falar de Kepler, nessa primeira aula. Claro que a gente não vai conseguir entrar em detalhes das coisas, são muitos conceitos, mas o que a gente quer realmente é a construção histórico-filosófica. Como Aristóteles pensava, o que a sociedade pensava naquela época. Aristóteles colocava a Terra como simétrica, então tudo tinha que estar ao nosso redor, tudo era perfeito. Depois Galileu vem e quebra isso com as observações que eles fez. Galileu começa a ter metodologias, começa a provar coisas, então é essa construção.

Carlos: Faz experimentos, coloca ...?

Ana: Aristóteles falava que uma mola .....mais leve. Ai Galileu foi e provou outra coisa. Começou a mostrar pra população o que era aquilo.

Carlos: $\mathrm{Na}$ época experimento não era... era até mal visto. Aristóteles falava ciência eraalgo puro, não tinha que ter experimento, não tinha que provar. Ai Galileu quebrou isso dizendo que tinha que ter experimentos.

Profa. Marina: E contra muita resistência na época...

Carlos: Exato. Porque experimento era algo puro, não tinha que provar.

Ana: Ai tem toda questão religiosa da época, mas estamos tomando cuidado pra não entrar, porque senão vai dar pano pra manga. Não dá pra ignorar que ele foi julgado pela inquisição, mas também vamos entrar porque falar da igreja melhor não.

Carlos: Mas a ideia é falar das principais contribuições de Galileu...

Ana: $\mathrm{O}$ que eu pretendo passar nessa aula também é só uma ilustração, eu imprimiria uma figura do geocentrismo e do heliocentrismo, porque eu não sei desenhar isso na lousa, ficaria um pouco torno, mas é pra eles verem quais eram os modelos dos cientistas da época a respeito daquilo.

Aluno 2: Comparar os modelos...

Ana: Isso, comparar. Muito bom.

E ai a gente começa a fazer essa atividade da linha do tempo.

Profa. Marina: Será que existe algum tipo de relação que mostra como é que a gente veria os movimentos? Carlos: A gente precisa ter um tempo pra procurar...

Heloisa: A gente precisa fazer essas pesquisas mais afundo, porque a gente também não sabe a disponibilidade (que tem) o retroprojetor.

Profa. Marina: Mas eu sei que (...), porque a figura do Galileu ainda que não tenha feito essa grande revolução ela se põe mais perto do (?centrismo). O que eu não sei explicar...

Ana: (....), os modelos são muito legais, eles tem que ver.

Carlos: Pra entender que eles vão ver justamente ... 
Ana: ... A utilização dos recursos materiais pra isso que a gente tá discutindo bastante ainda o que a gente vai fazer. Os métodos...

Profa. Marina: Esse primeiro tempo, como é que vocês vão fazer?

Carlos: A gente tava pensando, cada aluno vai ter que fazer, e pensamos também em colocar papel craft na sala e ir perguntando...

Profa. Marina: Vocês viram a linha que tá aqui no corredor?

Todos: Não.

Profa. Marina: Então vocês tem que dar uma olhada...

Ana: A nossa primeira ideia foi assim, conforme a gente for explicando, a gente mesmo coloca o craft ali no fundo, já com uma linha pré-preparada e íamos completando, mas depois achamos que...

Carlos: Talvez seja melhor os alunos fazerem sua própria linha do tempo. A gente já fala pra irem montando e mostra como seria. Acho que a ideia é legal até por causa da nossa atividade final.

Ana: O trabalho é que eles entregassem o problema até o final da quarta aula.

Profa. Marina: Achei interessante essa ideia da linha do tempo é mostrar pra eles que logo depois dessa época, que viveu Newton, Malpighi lá da biologia, várias pessoas que viveram na mesma época é que você mede saltos na produção do conhecimento, na humanidade como um todo. Você vai fazer uma linha, qual vai ser a escala?

Ana: É. Por isso que tínhamos pensado antes em a gente fazer, porque eles não sabem muito bem.

A linha do tempo ia ser só um tópico, mas dai....(incompreensível)

Profa. Marina: Se vocês forem fazer assim ou no final mostrar pra eles como infla aqui no fim e que eles conseguem colocar as cores...

Carlos: É verdade, bacana. Porque a gente vai ver mais pra frente ...começa ....com o Galileu, Newton...(Não dá pra entender a fala).

Ai depois de Galileu, que fala do sistema heliocêntrico, (...). Na verdade o que a gente ta fazendo é contra isso ai. A gente vai voltar na história de Kepler que queria o tempo todo provar que o universo era geocêntrico e acaba provando o contrário, sem querer. A gente só vai falar de Kepler (...) Conceito das leis, mas nada matemático, porque não vai dar tempo, é muita coisa. A gente não pretende colocar equações.

Aluno 3: ?

Carlos: Mais a parte qualitativa das leis.

Profa. Marina: Vocês vão mencionar o fato de que ?deixou muita informação carente.

Carlos: Sim. Vamos falar todas as histórias...

Ana: $\mathrm{O}$ trabalho dele é ??...

Heloisa: ...?

Carlos: Depois vamos começar a falar de Newton e as leis, e o mais importante é a ...universal "lembra que Galileu fala....", então Newton conseguiu matematizar isso, provou através da teoria da ....universal que existe uma força puxando os dois e que essa mesma força que puxa o objeto pro chão é a mesma que faz o planeta girar em torno do sol. A gente quer...como diz o texto "Assim na Terra como no céu", essa coisa que ... tanto o movimento aqui na terra como os movimentos no universo. Essa é principal coisa que a gente quer falar da teoria de Newton. A partir dai começa o ?científico que chamam, o rigor da ciência começa a ficar muito mais forte, começam exigir matematização e experimento pra provar teorias. Depois de Newton vamos falar do Einstein e a teoria da gravitação, que é uma evolução da de Newton, a gente ta prosseguindo nessa evolução dos conceitos... Essa parte da teoria da gravidade do Einstein que tem um vídeo bacana, porque é complicado falar pros alunos sobre dispersão espaço-tempo, eles não vão entender direito. É um vídeo extremamente didático, explica muito bem.

Ana: Se a gente não conseguir o vídeo vamos fazer com ...(Carlos corta a fala)

Profa. Marina: Vocês podem também levar um dos contos do Sonhos de Einstein. Conhecem?

Todos: Não.

Profa. Marina: Lightman, acho que ele era físico de formação, mas ele ? a literatura, a literatura científica. São vários contos que você divide o universo Einsteiniano. São bem pequenos, duas ou três páginas, consegue ler numa aula.

Carlos: A gente tava pensando, com relação a dispersão espaço-tempo, em esticar um lençol e colocar um peso, porque ele dobra... é essa a ideia que a gente quer passar.

Ana: Pra falar de gravidade.

Heloisa: Qual o nome do livro?

Profa. Marina: Chama Sonhos de Einstein e o autor é Alan Lightman. 
Carlos: Bom, depois que Einstein faz a teoria geral ??, ele começa a querer calcular o tamanho do universo e supõe que ele é esférico e que não muda, pra tentar calcular a massa e o tamanho do universo. Com observações de telescópio consegue informações de que o universo está em expansão e derruba essa teoria que ele é estático. Teorias vão sendo derrubadas quando novos fatos vão surgindo, então com essas observações de que o universo está se expandindo as pessoas começaram a pensar "Bom, se ele está se expandindo antigamente ele estava menor e veio... Veio um padre e falou que o universo era muito pequeno (...? Sem sentido).

Ana: E com isso a gente chega na teoria do Big Ben, que vai ser o tema da nossa aula três junto com a origem do universo.

Profa. Marina: Já que vocês estão explorando essas questões sociais, filosóficas assim é legal falar sobre as questões religiosas, porque o próprio Einstein vai ser religioso, como o Galileu. Ai tem um livrinho bacana que fala sobre a crença de Einstein e vai dizer nos textos que ele acredita em Deus, não um Deus...uma figura paterna, uma figura pessoal, uma grande energia...

Aluno 4: Desculpa interromper, Essa questão de religião, crenças eu sempre achei muito polêmica, muito complicada falar em aula. Nunca tive uma ideia em como chegar. Eu tenho um amigo que teve uma frustração muito grande, porque ele fez um comentário... ele foi infeliz, fez uma crítica a um momento da história, sobre a igreja, e uma aluna levantou...

Profa. Marina: Acho que mostrar que essas pessoas que trabalham com ciência muitas delas têm as suas crenças só que vão se modificando, até por conta do próprio trabalho que ela tenha. Parece-me incoerente o Einstein olhar pra um Deus pessoal, ele que vem dessa ideia de um universo completamente diferente do que se tinha até determinado momento. Então onde é que estaria Deus no universo antes? A minha questão pra eles não é nem colocar em discussão se Deus existe ou não, mas mostrar que os cientistas não são descrentes.

Aluno 4: Inclusive, há duas semanas, alguém perguntou "Você faz física, e ai, você acredita em Deus?" Profa. Marina: Faz uma pesquisa lá no seu edifício, conversa com os professores.

Aluno 4: Tem a Profa. Marina...tem um professor que estuda questões relacionadas a religião.

Profa. Marina: Todos eles têm uma religião, mas o Deus que cada um crê pode ser diferente. Não é porque eles têm algum tipo de fé, crença...(?).

Ana: A partir disso a gente vai explicar a teoria do Big Ben sem os formalismos matemáticos, mais qualitativa e bem filosófica. A gente não poderia falar do Big Ben sem situar a gente nisso, então vamos falar sobre a evolução do universo, surgimento da Terra e da vida. Porque senão os alunos podem não fazer a conexão disso tudo. $\mathrm{E}$ as reflexões sobre isso a gente pensou nessas questões que também doem em nós, que incomodam. Como que essa matéria cabe num só ponto, tudo o que existe tava naquele ponto, há quanto tempo surgiu, tudo isso a gente vai levar...

Carlos: Não é pra eles fazerem. Essa linha do tempo a gente vai levar pra eles lerem, depois do Big Ben.

Aluno 5: Muito legal isso.

Ana: Dai a gente vai tentar colocar numa perspectiva temporal o surgimento de tudo e de nós. Se precisar, tem gente que já fez, de colocar a história do universo num só dia.

$\mathrm{Na}$ aula quatro a gente vai propor uma atividade de encontro com o passado, na qual os alunos vão para a época de Aristóteles e vão ter que explicar pra ele como que a ciência atual explica a origem do universo, articulando tudo o que a gente apresentou, mostrando a evolução dos conceitos, a construção do método na ciência, até que vai culminar na teoria do Big Ben.

Aluna 6: Essa seria a nossa duvida se isso poderia ser um problema, mas a gente descobriu que é um problema.

Profa. Marina: Vocês conhecem O despertar da galáxia? Se não me engano lá eles têm uma linha mais para o que vocês estão querendo. Traz várias discussões, é mais atual, não vai tanto ao passado, se não me engano.

Ana: Como assim?

Profa. Marina: Não vai lá pro Aristóteles, ele já vem pra uma astronomia mais recente.

Profa. Marina: Quanto tempo vocês vão deixar pra eles fazerem isso tudo?

Carlos: Uma aula inteira.

Ana: Um amigo nosso contou uma experiência dele de que o professor chegou na aula e disse:"tudo isso que eu falei é mentira, eu acredito no geocentrismo, me provem que eu to errado." Ai teve toda uma discussão, debate. Ai ele alertou a gente que pode ter algo que não vai precisar e preferimos fazer individual.

Profa. Marina: Ou pequenos grupos, trios. 
Ana: Mas enfim, o que vai falar, a gente tá desafiando todo mundo.

Carlos: Como cada aluno vai montar sua própria linha do tempo vamos ter registros diferentes de cada.

Profa. Marina: É muita informação pra três aulas.

Ana: Se a gente sentir necessidade de uma quinta aula, pode ser algo que mude, se a gente sentir eles...

Profa. Marina: Vocês vão fazer no...?

Carlos: Não. Em outro lugar. O professor não discute com a gente.

Ana: A gente conseguiu um colégio na Eiras Garcia, não lembro o nome agora. O professor foi gente fina, inclusive falou que o terceiro ano era melhor, eles são mais presentes. Poderia ser aplicado em qualquer um dos anos.

Aluno 7: Como vocês ...

Ana: O que a gente espera ou como a gente faria?

Aluno 7: Como vocês fariam.

Ana: Acho que seria mais o resultado do que eles conseguiram captar das aulas.

Heloisa: Não, acho que ele tá perguntando você.

Ana: Como eu faria? Eu tentaria reconstruir toda a história, você disse isso, você Aristóteles falou isso. Daqui uns anos vai ter um cara chamado Galileu que vai falar isso, e depois um cara... eu ia reconstruir.

Heloisa: Eu ia falar de experimentos, discussão da comunidade. (??? Voz muito longe e abafada).

Aluno 8: E tem a questão (...????)

Aluno 9: Fiquei pensando o quanto isso poderia colocar na imagem pros alunos de que o Aristóteles é algo ruim?

Carlos: Vamos tentar colocar "Na época dele". Sempre fazendo isso, de construção da época, tenho certeza que eles não vão pensar isso.

Aluno 9: Não é diferente pra quem deve tá lá "Vai vir um cara que vai falar isso, isso e isso". Ou tenho todo um instrumental que você e o Aristóteles têm na época e explicar pra eles? Você poderia falar da questão da experiência, como que você ia convencer ele que o experimento de fato é o caminho?

Ana: Por isso a gente colocou "explicar" e não "convencer" Aristóteles. Porque uma coisa é você explicar como as coisas vão acontecer e outra é você convencer de que é aquilo.

Aluno 9: Mas você só vai pensar a sua explicação.

Ana: Mais ou menos. Você tá sentindo ridicularizar a história?

Aluno 9: Não estou dizendo isso, só estou preocupado com o que poderia passar pra cabeça deles...

Profa. Marina: Nesse sentido eles podem evitar mencionando ao longo dessas três aulas iniciais...

Profa. Marina: Isso, é genial

Aluno 10: O que a gente tem como modelo é algo que pode mudar.

Ana: Os nossos objetivos também é a comunidade científica trabalhando junta, como você não faz sozinho. Como o conhecimento é uma construção. É exatamente isso que a gente quer que eles entendam.

Aluno 11: E depois o papel do cientista.

Ana: E não é o mais pesado sozinho, tiveram muitos outros caras pesados (?)

\section{Planejamento do estágio na disciplina MEF II (2 ${ }^{\circ}$ semestre 2013) Grupo 2 de Heloisa}

Carlos: Boa noite, pessoal. A ideia que a gente teve, em conversa com os alunos, surgiu o tema estrutura da matéria e núcleo subatômico e tudo mais, os alunos gostariam de estudar um pouco disso. E a gente achou interessante comentar sobre o elétron.

Heloisa: A gente pegou um trabalho de um orientando da profa Marina, que tinha feito o projeto e adaptamos.

Ana: Não é bem adaptou, tiramos a ideia, senão parece que a gente roubou o trabalho do cara.

Carlos: Então, a nossa ideia é falar com os alunos sobre a aula de elétron e o que a gente pensa sobre ele. Em linhas gerais falar sobre a dualidade onda-partícula do elétron, a gente vai dar aula pro $3^{\circ}$ Ano do Ensino Médio, serão 6 aulas.

Heloisa: Com a probabilidade de se estender. 
Carlos: É, provavelmente, pelo que a gente viu aqui. Então, nossos objetivos gerais: mostrar o comportamento ondulatório e corpuscular do elétron por meio de atividades e avaliação. A justificativa é apresentar duas formas distintas do mesmo objeto e contextualização histórica, porque a gente gosta dela.

Ana: Essa aula, pra começar a tratar de elétron a gente vai dar uma aula bem introdutória e de ordem de grandeza, até pra gente entender isso também é difícil, pensar em coisas micros e macros. Então, vamos começar falando sobre isso e fazer um experimento.

A atividade do papel foi sugestão da Profa. Marina e foi muito boa. Vamos dar papéis sulfite, pedir para dobrar no meio e cortar, dobra e corta, o máximo que der.

Heloisa: E com isso vai chegar uma hora que não vai dar mais, a Profa. Marina falou que são mais ou menos 17 vezes e daí a gente questiona, e se a gente continuasse cortando?

Carlos: Quer que eu mostre o vídeo? É rapidinho. (CONVERSAM SOBRE O VÍDEO).

Ana: Estamos com um pouco de medo de trabalhar esse tema, porque não sabemos até que ponto eles são fortes no que. Segundo nossas pesquisas de ibope eles não tiveram muito ondas ...

Heloisa: Ou eles não tiveram ou a gente não sabe o quanto eles tiveram...

Ana: Por isso eu coloquei revisão em itálico, porque não sabemos até que ponto vai ser uma revisão e até que ponto vai ser a primeira vez que eles vão ver. Então, vamos dar uma aula de mecânica e ondas, vai ser uma coisa bem resumida, não vamos falar tudo de mecânica, só o que a gente julgar necessário e ainda não sabemos o que vamos usar, é muita coisa e é difícil pensar nisso, talvez não leve só uma aula. É isso, uma revisão... Ah, cadê o negócio do papel? O material de apoio.

Tivemos essa ideia que eles vão fazendo anotações das aulas e vamos tentar dar exemplos, como um exercício que seja chave e que eles anotem e usem esse material mais pra frente quando falarmos de comportamento de partícula e comportamento de onda.

Ana: Vamos fazer uma abordagem mais conceitual, mais pragmática.

Ana: Essa aula vai ser bem expositiva, mas a gente julga que é necessário.

Carlos: Você vai falar sobre o experimento?

Heloisa: Acho que aprender sobre ondas é bizarro. O que são ondas? A única coisa de ondas que eu sei é na água. A gente precisa que eles saibam de interferência de difração, não necessariamente com esses nomes. Então, vamos abordar isso com uma assadeira, vamos colocar pregos, com água e bater pra fazer onda e ver como funciona a difração e interferência.

Carlos: Vão ter ideia de como as ondas interferem e como acontece a difração nos pontos.

Heloisa: Vamos pedir pra desenhar o padrão de interferência.

Ana: Essa ideia estava na tese do menino, ele que nos deu a ideia.

Carlos: Também não sei se daria tempo, mas estava pensando em fazer o experimento da dupla fenda. Nessa aula.

Heloisa: Depois vamos começar a abordagem histórica falando do experimento do Thomson, que ele usou tubo de raios catódicos e que não sabemos ainda se vamos conseguir usar, vamos pegar emprestado. Seria pra levar um pra sala inteira. Ele usou base x pra demonstrar o caráter corpuscular do elétron. E depois vamos fazer um paralelo com o mesmo experimento, só que dessa vez feito pelo G.P. que usou o mesmo aparato experimental com altas tensões, você acelera o elétron e ele forma um padrão de interferência na parede do tubo. E fazendo um paralelo com o que tínhamos falado sobre ondas, eles vão reconhecer, a gente espera, o padrão de interferência e vão ter uma ideia do comportamento ondulatório do elétron.

Profa. Marina: Será que eles vão entender o anterior?

Ana: É por isso que a gente colocou isso aqui, porque talvez a gente tenha que mudar a atividade.

Heloisa: Precisaria também de uma introdução do tubo de raios catódicos, ver o que está acontecendo lá.

Profa. Marina: Minha pergunta é anterior ainda, é se eles entendem que com uma partícula você consegue em determinado instante identificar a posição que ela está.

Heloisa: Isso nós vamos trabalhar na aula 02.

Carlos: É, na 01 e na 02, quando a gente falar de ordem de grandeza micro.

Profa. Marina: $\mathrm{Na}$ física clássica a gente garante que essa caneta está aqui nesse momento.

Ana: ... a gente não vai chegar nesse ponto, não exatamente, não calculando.

Heloisa: Vai ser assim: Partículas - como elas se caracterizam, como se comportam, quais são as interações. Isso na aula 02 e junto com ondas. Pra dai a gente usar nas 03 e 04.

Profa. Marina: Porque senão quando ele olhar lá pro tubo de raios catódicos ele não sabe...

Ana: Até chegar nesses experimentos a gente está tentando dar ferramentas suficientes para que ele consiga perceber o comportamento corpuscular... 
Carlos: ...seguindo as características isso tem uma característica de onda.

Heloisa: Ainda mais por se tratar do mesmo experimento, o mais legal é que vai ser a polêmica da aula 6 . Ana: Aula 05. Essa aula é minha favorita e se der certo ela vai ser muito boa, porque vamos fazer um debate e vai dividir a sala em dois, um vai ter que falar do comportamento corpuscular e o outro do ondulatório. Como se um defendesse a onda e o outro a partícula.

Carlos: A gente vai mediar esse debate e dar elementos.

Heloisa: Pra isso a gente usará uma entrevista que o Élcio simulou, uma com o G.P. e uma com J.J. que estamos pensando ainda como usar, que vai enriquecer esse debate pra eles terem mais argumentos.

Profa. Marina: Ele simulou, mas é real. O que ele fez foi pegar o texto que o G.P. e J.J. publicaram separadamente sobre um experimento deles. Ele buscou os principais pontos e colocou como se fosse uma entrevista, porque os textos são grandes, são meio chatos.

Ana: E pode ser bem linda essa aula.

Profa. Marina: Sim, mas pode ser um desastre também.

Ana: Na verdade depende da gente também.

Profa. Marina: É, quais são as informações que vocês vão disponibilizar pro grupo, porque eles podem não ter informação nenhuma e ficar achando que é porque é.

Ana: Esse tipo de argumento talvez venha, umas coisas assim, e essas 4 aulas vem pra isso, se forem bem executadas do jeito que a gente quer vai ser bonito. Esperamos isso.

Aluno 01: Posso dar uma sugestão. Trabalhem com um texto didático falando sobre isso pra eles terem até condições de entender melhor.

Ana: Mas isso no caso das entrevistas, né? Que texto?

Aluno 01: Qualquer texto didático, o do Professor P, o Menezes tem, etc, textos que fazem esse debate. Ai vocês fazem uma discussão com eles pra depois vocês terem um back ground.

Profa. Marina: Eu não me lembro desses textos, eles chegam a dizer qual o estado da coisa hoje em dia?

Aluno 1: Eu não me lembro.

Profa. Marina: Porque o que eles querem salientar até agora é a questão de que isso era um problema naquele momento, problema histórico.

Aluno 1: Isso o Professor P faz, ele vai traçando até o debate historicamente, mas hoje como é tratado não sei.

Heloisa: Hoje como é tratado a gente só vai fazer depois desse debate.

Aluno E: Esse subsídio que vocês estão procurando já não tem nas primeiras aulas, o fato quando você caracteriza o que é corpuscular e o que é ondulatório. ... porque na verdade esse debate vai ser esse background que eles têm, eu entendi que o experimento vai por si só levantar a lebre de que existe um debate.

Carlos: Na verdade o debate acaba sendo pra eles relembrarem e ver se realmente entenderam o que significa ser partícula e o que significa ser onda, a ponto de sustentarem aquela ideia, confrontar as ideias [...], ver que são antagônicas [...].

Heloisa: São dois pontos de vista, duas explicações possíveis pra uma mesma partícula.

Profa. Marina: E bem feita. Por isso que é bacana colocar os dois em confronto, porque tanto pai quanto filho, foram cuidadosos em apresentar as ideias.

Aluno E: Acho legal, mas na verdade parece que já está pronto. Acho que o único problema vai ser na questão de espaço, mediação, de alguém não querer participar, indisciplina.

Heloisa: Mas esperamos que isso não ocorra.

Profa. Marina: Vocês estão cientes de que, eventualmente, entre as aulas 04 e 05 vocês vão ter que estar na escola uma hora?

Ana: Por que?

Profa. Marina: Porque os alunos podem querer conversar com vocês pra organizar a fala do debate.

Ana: Não, mas não vamos falar que vai ter debate. Vamos dar dicas o tempo todo que em algum momento vai ter uma atividade que eles vão ter que explicar pra gente, do mesmo jeito que fizemos semestre passado, até mesmo porque sentimos que eles não iam anotar nada.

Heloisa: Você acha melhor que a gente deixe explicito?

Profa. Marina: Não sei. Porque eles vão se preparando. Se eu chego aqui e divido a turma em 2, um vai defender a onda e o outro a partícula, vocês vão tomar um susto gigantesco.

Aluno 1: Foi por isso que pensei no texto, numa aula de 50 os 15 primeiros trabalham com ele, fazendo revisão.

Ana: Ou podemos dar os textos pra casa, assim não ocupa o tempo nosso. 
Carlos: E fala pra eles, no dia antes do debate, se preparar.

Profa. Marina: Por isso que eu estou dizendo, porque ai eles já sabem quem é o grupo da onda e o da partícula, e pode ter eventualmente um grupo mediando.

Ana: Mas ai não precisamos dividir o grupo antes, até mesmo pra todo mundo se preparar dos dois lados.

Aluno 02: Só uma pergunta. Vocês vão trabalhar como mediadores e foi proposto, no começo, aos alunos as duas bases e foram bem fundamentadas, como a Profa. Marina falou, com textos bem enraizados. O que acontece se alguém achar os dois possíveis?

Profa. Marina: Ai é lindo.

Aluno 02: Mas ele vai ficar de que lado?

Ana: É mais o lance da argumentação não dele realmente concordar com isso.

Aluno 02: Mas ai o lance da mediação, você vai fazê-lo escolher um lado.

Carlos: A gente vai definir o lado.

Aluno 02: Tá, então pode acreditar em um e defender outro.

[ FALAS CONFUSAS]

Profa. Marina: Mas o objetivo é esse mesmo, é fazer com que os aluno se preparem pra defender independente da posição que está defendendo.

Ana: E o último, vamos unir as duas pontas, parar de falar das coisas separadas e falar que o comportamento do homem é matéria, não só de partículas. [...]

Profa. Marina: O Tonomura saiu?

Ana: Não, ele não saiu, pode ser mostrado na aula 6. Excelente.

Profa. Marina: Akira Tonomura. Morreu recentemente, era um físico que, dentre as coisas que ele fez, foi analisar a natureza do auro-elétron e ai ele faz um experimento que você vê depois de um tempo as franjas de interferência.

Heloisa: Ele faz a fenda dupla jogando como se fosse um elétron de cada vez, você vê que primeiro aparece um elétron aqui, outro ali e conforme passa o tempo você vê as franjas de interferência como se fossem ondas. Primeira a partícula, depois a onda. Bem lindo

Ana: A gente vai falar um pouquinho da antiga teoria quântica, que vai acabando em de Broglie, mas não vai passar por tudo não é só citar a história. Porque a antiga quântica é muito legal, têm muitos caras, experimentos, tem uma ordem das coisas e termina em de Broglie falando do comportamento de onda e matéria e, acabou.

Heloisa: Quem sabe cogitar uma aula 07 pedindo pra eles fazerem alguma atividade pra ver se eles entenderam o caráter dual mesmo. O debate ainda são posições.

Ana: Mas eles vão se preparar pros dois.

Heloisa: Eles defendem um e outro, mas não os dois.

Profa. Marina: Pra quem eles escreveram a carta na outra vez?

Carlos: Aristóteles.

Profa. Marina: Porque agora eles não mandam uma carta pro J.P. ou pro J.J.

Ana: É meio repetitivo, né? Com a mesma sala?

A ideia é boa, é excelente. Eu não quero não fazer, porque não dá pra perder essa oportunidade.

Heloisa: A gente não pensou ainda na atividade final.

Ana: $O$ professor vai querer alguma coisa pra nota.

Excelente Profa. Marina, obrigada. 


\section{Apêndice E}

\section{Transcrição da apresentação da reflexão de um momento da regência das aulas nas disciplinas de Metodologia de Ensino de Física I e II}

\section{Reflexão na disciplina MEF I (1 ${ }^{\circ}$ semestre 2013) Grupo 1 de Ricardo}

Vera: Nossa proposta foi levar o material de ótica pra eles resolverem os desafios. Fizemos numa escola em São Bernardo, na periferia, com o $3^{\circ}$ ano.

Sobre os desafios, um era pra tentarem classificar as lentes e projetar alguma coisa, e ai teve uma parte interessante.

Ricardo: Vou contar esse episódio. Nos três problemas propostos nessa aula, vou colocar os problemas rapidinho, o primeiro eles receberam um conjunto de lentes e tinham que classificá-las. A pergunta era: "Como vocês podem classificar as lentes?", como eles iam fazer era critério deles. O segundo problema era: "Como determinar a distância focal de uma lupa?", tinham que arrumar um jeito de determina-la. E a terceira pergunta, que é a do episódio, era: "Como projetar a imagem de três objetos escolhidos por vocês?”, poderia ser uma mochila, um lápis, etc. E aí alguns estavam trabalhando, resolvendo os primeiros problemas. O estágio foi muito bom, não tivemos problemas, só resultados positivos, então, acrescentar uma coisa que aconteceu será produtivo e válido também.

$\mathrm{O}$ que aconteceu? Enquanto eu passava pelos grupos vendo se estava acontecendo tudo direitinho, se estavam com alguma dificuldade, um dos grupos chegou euforicamente me perguntando se como já tinham feito todos os desafios podiam fazer outro.

"Como assim outro? O que querem fazer?"

"Queremos projetar a imagem de uma pessoa, é possível?"

Eu não esperava isso, porque só propus aqueles problemas, mas eles já tinham resolvido todos e chegaram com esse adicional.

Falei: "O que vocês acham?” Eles acharam que era possível, mas que não sabiam como fazer. Disse que não poderia interferir, mas que achava que eles conseguiriam, mas que se falasse perderia toda a graça da atividade. Eles teriam que descobrir. Eles aceitaram o desafio e foram fazer. De repente, vem o grupo inteiro pra cima de mim dizendo que conseguiram. Eu fui ver e tinham conseguido projetar perfeitamente o rosto de uma pessoa numa folha de sulfite. Estava bem nítida.

Ai eu perguntei como tinham feito para resolver o problema e eles disseram: "A gente primeiro pegou uma lente e pegou a lanterna do celular e uma folha de sulfite"

Por que vocês acham que deu certo?

"É que a gente percebeu que com a lanterna que o senhor deu a imagem saia borrada, então resolvemos usar o celular e ficou bem melhor, aí achamos de daria para fazer isso."

E eu não satisfeito perguntei por que eles achavam que a resolução tinha dado certo. E eles me deram a explicação minuciosa. Eu fiquei super feliz que eles conseguiram projetar e tal e pedi pra eles ajudarem os outros grupos nas atividades propostas e apresentar a eles o que eles produziram. Depois pedi que eles fossem para um grupo com dificuldade e fizessem uma série de perguntas que levasse a resolução, na verdade era um grupo que estava com dificuldades os outros dois já estavam acabando. Eles fizeram e o grupo com dificuldade ficou super feliz, porque conseguiram resolver o problema com ajuda dos colegas.

$\mathrm{Na}$ análise que fiz junto com a Vera sobre o episódio, percebi que quando eles propuseram o problema pra mim, perguntando se era possível projetar a pessoa, se eu tivesse respondido que sim e explicado como teriam que fazer, porque essa é nossa cultura escolar tradicional, meu primeiro impulso foi fazer isso, mas eu lembrei que tinha aprendido algo diferente na aula de Metodologia, então eu vou aplicar e ver no que vai dar. Essa foi a primeira impressão, de que você como professor, de certa forma, barrar um pouco esse impulso e acreditar nos alunos é fundamental para que eles consigam entender que eles também podem construir conhecimento cientifico. A segunda coisa com relação a outra pergunta que eu dei pra eles, o fato de eu ter jogado de volta a pergunta pra eles fez com que raciocinassem, acreditassem 
que fosse possível. Depois, pelo fato de eu encorajá-los foi determinante para se engajarem para poderem depois resolver o problema.

Professora Marina: Você achou que eles conseguiriam ou foi só para encorajá-los?

Ricardo: Achava. Fui com intuito. Porque por eu já não gostar da cultura escolar tradicional, por odiar aula expositiva, por exemplo, então eu sempre vou com o espirito mais aberto. Só que uma coisa interessante é que quando estávamos trabalhando aqui com as sequências investigativas sempre acreditei nessa ideia, mas nunca tinha colocado em prática. Eu me coloquei junto com a Vera esse desafio e não quis fazer de forma tradicional, porque eu não defendo isso e queria ver como acontecia na prática. Acredito nos alunos, não só nesses, mas nos outros que já dei aula.

Uma coisa que achei muito interessante foi o que aprendemos aqui na sala de aula, a importância de você fazer uma pergunta do "Como", como resolveriam o problema, porque eles passaram a ter consciência dos atos deles. Passaram a entender a fazer uma transição entre o saber e o compreender. A passagem da parte operacional para a parte do pensamento. Isso foi muito importante para eles entenderem que fizeram todo o processo. E a segunda parte que foi quando perguntei o porquê, percebi que foi muito importante também, porque eles tiveram que explicar casualmente o que eles tinham feito e por que tinha dado certo, de forma que as explicações deles fossem coerentes com o fenômeno físico, que passa a ter função de um agente ativo e não passivo. Conseguiram não só tomar consciência das suas ações como também explicar de forma coerente o que eles observaram. Percebi que isso fez toda diferença.

Por fim, pensando em tudo o que tinha aprendido de Vygotsky acabei pedindo para que eles socializassem esse conhecimento tomando a ideia dos parceiros mais capazes. Se eu sei um pouco mais é importante que eu socialize esse conhecimento para que esse outro colega possa também aprender comigo. Eu me torno, enquanto colega desse aluno, professor dele também, assim como ele em algum momento vai poder ser o meu professor. Então, já pensando nisso foi que eu pedi a eles para socializarem o conhecimento.

Então, como conclusão chegamos a ideia de que primeiro precisamos romper com a cultura escolar tradicional se quisermos inovar. Não adianta querer aprender uma série de coisas interessantes se não acreditarmos que aquilo é possível, é importante acreditarmos nos alunos Segundo ponto, é importante fazermos com que os alunos tomem consciência dos seus atos pra que enxerguem que eles são os construtores do conhecimento e o último, é dar oportunidade deles fazerem as explicações causais. Isso tudo tem a ver com as habilidades do fazer cientifico, levantar hipóteses, testar hipóteses, e também, isso ajuda a fazer a alfabetização cientifica. Se continuarmos na cultura escolar tradicional, no meu ponto de vista, vamos continuar a fazer algo incoerente com as habilidades do saber cientifico, estaremos reproduzindo máquinas e não pensadores.

Professora Marina: Achei interessante esse apontamento que vocês fizeram. Eu queria pegar esse ponto final sobre a questão que acontece em sala de aula. Muitas vezes queremos ser contra o ensino tradicional, percebemos que aula expositiva pode fazer com que o aluno não compreenda o que o professor está falando. Uma coisa é expositiva por si só e outra é expositiva dialogada, traz o aluno para a discussão. Estou falando da expositiva clássica que conhecemos e, quando queremos sair disso, às vezes, damos o passo sem saber como fazer. Essa pergunta do como que você frisou como importante é essencial. Quando não damos oportunidade ao aluno de tomar consciência do que ele fez, ele não tem oportunidade de tomar consciência de quais são os fatores que levaram aquela situação ocorrer daquela maneira.

E ai fazemos a pergunta do porquê, muitas vezes queremos trazer os alunos para a discussão, mas não damos oportunidade, não criamos tempo para que o aluno fale sobre o que ele já fez, sobre o que ele já pensou sobre aquilo. Isso é essencial para que as variáveis sejam colocadas em mesa. Se elas não são colocadas em mesa nem sabemos quais variáveis estão relacionadas.

Ricardo: E ver se é coerente, né? Porque a princípio temos muitas contradições internas e eles não tomam consciência dessas contradições.

Monitora: Com certeza o grupo que foi fazer a pergunta aprendeu mais no processo de elaborar a pergunta do que o que eles já sabiam antes de perguntar. Embora eles fossem os mais capazes nessa relação eles também, com certeza, avançaram. 


\section{Reflexão na disciplina MEF II $\left(2^{\circ}\right.$ semestre 2013) Grupo 1 de Ricardo}

Ricardo: A gente teve a abordagem de um vídeo didático falando sobre a vida e formação das estrelas. Então, desenvolvemos tanto a questão da formação e evolução estelar quanto a de espectroscopia em sim, fazendo uma relação da espectroscopia com as estrelas e com as galáxias. Ai a última aula foi de uma atividade investigativa, trabalhamos astronomia com os alunos e fornecemos um conjunto de transparências contendo espectros de alguns elementos químicos, mais ou menos três, e os espectros de algumas estrelas fictícias, dividimos os alunos em grupos e tiveram que fazer uma investigação, no sentido de tinham que, através das análises dos espectros, identificar quais elementos estavam presentes nas estrelas que eles recebiam. Cada grupo recebeu dois espectros de estrelas, trabalhamos com 4 no total e depois comparamos os resultados.

Aí, a parte que vamos mostrar pra vocês é a parte que faço junto com eles a análise do que eles propuseram. Pedimos que assim que eles terminassem de fazer a investigação eles anotassem na lousa o que responderam, pra depois fazermos uma discussão. A ideia é que nessa parte eu tentaria fazer a discussão com eles. Não sei se ficou claro. Tudo bem?

Vou tentar fazer essa discussão e essa sistematização com eles.

Aluno 1: Alunos de que escola?

Ricardo: Escola Técnica Estadual Guaraci Silveira, alunos do segundo ano do ensino médio. (ASSISTEM AO VIDEO)

Profa. Marina: Está interessante, mas perceba que os alunos não estão olhando pro Ricardo. Vocês repararam?

Vera: Tenho um comentário a respeito disso. Nesse dia, como era o último dia, eles tinham que entregar todas as atividades atrasadas, então tem muita gente pintando, e tal, mas estavam, pelo menos, ao longo das aulas que demos eles estavam ouvindo o que estávamos falando. Acho que estavam prestando atenção, porque na hora de fazer a atividade eles sabiam o que tinham que fazer, não ficavam perguntando o que já tínhamos falado.

Profa. Marina: Isso é um detalhe importante de se considerar. Os alunos tinham que entregar todas as atividades naquele dia e naquela aula. É o que acontece aqui também. Quando vocês têm que entregar alguma atividade muitas vezes vocês não estão prestando atenção no que eu faço. Estão tão preocupados em entregar aquela atividade que o como vocês estão usando esse tempo de aula é tentando otimizar para que deem conta de cumprir todas as tarefas necessárias. Isso está nítido nesse momento. A minha percepção tinha sido outra, tinha sido o fato de que como o Ricardo está explorando uma situação que para os alunos não é tão trivial, imagino eu que esses alunos podem não ter tido em nenhum outro momento da escolarização deles discussões em relação à natureza da ciência, isso pra eles não é tão significativo. E ai o que você fala apesar de ser importante o aluno não atribui esse significado de importância àquilo que está sendo dito naquele momento.

Ricardo: Uma coisa que eu também percebi depois de ter visto o vídeo e refletido, além da minha falta de intervenção, porque eu poderia ter intervindo de alguma forma, e é uma coisa que eu lembrei que a gente viu aqui nas aulas, foi que esse momento eu poderia fazer uma roda com eles para conversar. Talvez diminuísse até, porque a forma como eles estavam organizados propiciava a discussão. Mas entra outro fator, porque estávamos com muita pressa nessa parte e se fossemos fazer de novo todo o rearranjo da sala ia demorar muito tempo. Mas tem outro lado que eu lembrei depois da reflexão, como temos uma cultura escolar estabelecida e os alunos estão inseridos nessa cultura, muitas vezes para eles se comportarem em outra atividade levam certo tempo, até para aprenderem a se comportar nesse tipo de atividade. 
Profa. Marina: E tem características disso que conseguimos resolver por determinadas ações que vocês fazem, porque não é ao acaso que naquelas atividades de conhecimento físico colocamos os alunos em roda. Não é apenas para que eles vejam o que o outro está falando e vejam o colega enquanto ele fala, isso também, mas há uma outra questão ligada a isso que é o fato de que o aluno não está na sua carteira, então não há papel e lápis pra ele rabiscar. Nesse caso, o que acontece é que o papel e o lápis acabam distraindo o aluno. Recomendamos que os materiais sejam retirados para que eles não possam trabalhar de novo naquele material, senão vão tentar resolver o problema de novo e não vão prestar atenção na discussão que está sendo feita.

Ricardo: Eu achei muito estranho, a princípio, eu sabia que eles não estavam prestando atenção, mas é engraçado que nas avaliações finais, que eles aprenderam, acharam interessante, etc apareceu isso em algumas delas, e uma em especifico fala exatamente isso: "eu aprendi em uma das aulas de espectroscopia que os elementos presentes na atmosfera, no Universo, podem influenciar nas cores de forma crítica e investigativa, isso mostrou que a Ciência não é como, a princípio, eu pensava algo distante e totalmente exata ela pode ser como as Ciências Humanas que pode ter problemas investigativos", isso está ligado a nossa tentativa em fazer uma contextualização epistemológica, pelo menos a ideia inicial. Outras coisas semelhantes apareceram também e fiquei pensando que não estava bem desse jeito na aula.

Profa. Marina: Porque talvez uma forma fosse mudar esse tipo de abordagem, primeiro discutir todos os dados que o aluno tem e a partir da discussão dos dados aparecem aspectos da natureza da Ciência, porque ai faz mais sentido, ele está trabalhando sobre aquilo que acabou de ser feito e que não é só um trabalho conceitual. É uma abordagem conceitual, mas que está trazendo junto questões da epistemologia da ciência. Aqui foi produtivo, mas pode ser que em alguns casos não seja, inverter essa ordem favorece que a discussão faça mais sentido para os alunos.

Pesquisadora: Eles também tinham uma coisa que vocês iam falando, davam o resultado de um grupo e eles queriam conferir. Eles tinham um espectro e voltavam para conferir com o deles, porque não dava igual.

Profa. Marina: A conferência com o resultado do colega, né?

Pesquisadora: É, porque estava dando diferente de um grupo pro outro. Ele não estava falando ainda se eram aqueles elementos ou não, mas estava lendo um elemento de um grupo e os alunos começavam conferir com o dele (Ricardo) de novo.

Profa. Marina: Interessante essa colocação. Agora se não quisermos deixar material para o aluno uma alternativa pode ser encontrar o retro projetor, que nem sempre é fácil hoje em dia numa escola, e projetar essas transparências ali e ir acompanhando com os alunos o que eles estão falando sobre o porquê um é diferente do outro. São todas formas de encaminhar.

(CONTINUAM ASISTINDO AO VIDEO)

E ai gente, como vocês veem esse trabalho que o Ricardo está fazendo agora de discutir? Primeiro que isso é dificílimo, de colocar na lousa e tentar encontrar relação. Vocês já trabalharam alguma vez assim, enchendo a lousa de dados, de resultados que os alunos trazem do experimento?

Ricardo, você tem alguma coisa a falar sobre isso? Como foi essa experiência?

Ricardo: Foi bem interessante, porque é a primeira vez que eu faço isso. Eu lecionei inglês e não tinha esse tipo de pesquisa. É difícil porque apesar da sala em si me respeitar e eu ter um bom relacionamento com eles, de alguma forma não estão acostumados com esse tipo de atividade e ai temos que ensinar aquilo que a senhora discutiu com a gente que não só é a questão dos conteúdos conceituais, mas dos conteúdos procedimentais e atitudinais. Pra mim, a princípio, foi complicado fazer esse tipo de ensino, porque eu também estava aprendendo a fazer. Como foi uma coisa nova eu ficava vendo o tempo da aula terminar, vendo que estão conversando, impacientes, querendo comparar uma resposta com a outra e aí eu pensava: "Será que eu intervenho agora, faço isso depois?", são pensamentos muito rápidos. Então, como eu não tinha essa prática, pra mim foi difícil no começo. Eu acho que vale muito a pena, porque, mesmo que haja certa desorganização no momento, depois eles vêm perguntar pra gente coisas que não ficaram claras ou que se interessam mais. Mas ainda acho que preciso ter mais essa prática para aprimorar. Eu senti, obviamente, um pouco de dificuldade em fazer isso. 
Profa. Marina: Colocar dados do que os alunos trazem na lousa não é fácil, porque você tem essa questão forte que é o tempo e se você está colocando os dados é de uma atividade que eles já fizeram naquela aula ou na anterior, mas agora o trabalho é olhar esses dados e tentar encontrar uma ordem pra eles. Tentar entender o que está acontecendo de semelhante entre todos ou o porquê é que tem coisas diferentes entre essas informações que eles trouxeram.

Ricardo: E é isso que eu não consegui fazer por falta de tempo. Se eu tivesse outra aula, por exemplo, eu conseguiria retomar essa discussão e, você vai ver, a princípio vai ficar uma análise um pouco superficial e como não vou ter mais aulas com eles, pensei em conversar com eles depois, pedi pra me procurarem, mandarem e-mail, porque eu sabia que não ia dar tempo. Precisaria de mais uma aula para poder sistematizar, fazer a finalização.

Profa. Marina: Além desse trabalho dificultoso de analisar diferentes dados, dos diferentes grupos, numa aula como essa, tem outra que é a forma como esse trabalho vai sendo conduzido e como é que você salienta os alunos praquilo que você quer que seja salientado. Você começou a falar algo: "E agora gente?" Tem gente que tem resultados diferentes pro mesmo experimento que a gente fez. Será que erramos, será que acertamos? Como fizemos isso? Você deu todas as opções. Talvez fosse o caso de: "Gente, está tudo diferente, o que aconteceu aqui?”.

Eu entendo que você estava agoniado com o tempo da aula, mas havendo mais tempo você poderia colocar isso de pergunta pros alunos: "O que aconteceu aqui? Vocês fizeram o mesmo experimento?". E ai geraria um debate entre: "Não, acho que meu grupo está certo, seu grupo fez alguma coisa que não deu certo".

Ricardo: Vou perguntar isso depois, mas poderia ter aberto espaço pra isso.

Profa. Marina: Aqui me parece que era um espeço privilegiado pra isso começar a acontecer. Você falou que isso acontecia, eles ficaram inquietos, tanto é que você está falando e tem um menino que a voz parece muito alta. Eu não vejo a fala desse aluno como algo ruim, vejo como algo positivo, porque o que você está colocando lá deixou o menino inquieto e ele quer discutir já. Mas ai fosse o caso de colocar as perguntas para que ele pudesse discutir já e aquela fala dele não fosse encarada como um ruído na discussão geral, mas fosse encarado como uma sugestão praquilo que está sendo colocado. Percebem isso? A nuance dessa forma de intervenção do aluno? Uma coisa é quando você dá oportunidade para o aluno falar e não é encarado como bagunça. A outra coisa é, a atividade é tão interessante e mesmo que o que o aluno esteja falando seja importante pro professor, este não deu a voz àquele. E aquilo é encarado como bagunça. Isso pode gerar um clima com volume até mais alto na sala de aula, porque um vai falando por cima do outro. E como professores têm isso muito claro, precisamos manter certa ordem nos turnos de fala. Nós precisamos manter certo volume ali da sala de aula até pra não atrapalhar a turma do outro lado. Complexo, né? Nesse caso é uma inovação curricular, inovação metodológica, mas como vocês estão em formação tem outras inovações que pra vocês é como gerenciar esse trabalho em sala de aula.

(RETORNAM AO VIDEO)

O que é engraçado é o fato de você estar andando no grupo poder ter ocasionado uma falta de reconhecimento daquela discussão coletiva, porque quando você vai pra cada um dos grupos você fala individual com eles e o grupo não reconhece que aquela discussão é para todo mundo. Ai que está também a importância de colocarmos os alunos em roda. Vocês me apresentaram bons argumentos do por que não os ter colocado em roda.

Ricardo: A gente queria.

Profa. Marina: Tudo bem, mas como não tiveram tem outras maneiras de burlar e uma delas talvez fosse você ter ficado na frente da sala e organizado a discussão como um todo. Porque o que está acontecendo é que nos primeiros grupos o pessoal estava prestando atenção. Aquele grupo mais populoso me parece ser o grupo mais falante, dava pra ouvir o que eles falavam. Agora você começa a ter uma sobreposição de vozes e quando um grupo está falando os outros grupos estão falando outras coisas, porque virou uma discussão do grupo com o professor. De alguma maneira nesse momento que você vai aos grupos você individualiza a discussão. 
Monitor: E até entre os alunos, né? Porque nesse grupo anterior um falava e os outros estavam fazendo outra coisa. Aquele menino de branco ali atrás, enquanto um falava ele estava olhando para baixo. Então a discussão já não era da turma, era um responsável pelo grupo apresentando o resultado.

Profa. Marina: Você tem o porta-voz falando e é ele que dá conta do grupo. Se está certo ou errado não faz mal, quem vai ser responsabilizado é o porta-voz. Eles não se consideram mais como grupo.

É complicado, porque há muito mais na sala de aula do que só o conteúdo. Tem essas relações interpessoais, que não é só professor e aluno, mas também o próprio aluno com o seu grupo, os demais alunos com os outros grupos.

Aluno 2: Profa. Marina, eu acho que dependendo de como abrir a discussão não precisa perguntar pra cada grupo, alguém se disponibiliza a falar e só vai falar quem fizer alguma coisa diferente. Não vejo necessidade de repetir a mesma coisa várias vezes.

Profa. Marina: Quando fazemos com crianças pequenas solicitamos que todas as crianças falem, porque a criança muitas vezes não acompanha o que o colega está falando. A criança tem um comportamento centrado em si. Dependendo da faixa etária que ela está a questão egocêntrica fala mais forte. Então eu estou preocupada com o que estou falando, o que o colega está falando ainda não tem tanta importância, porque eu estou me estruturando pra falar o que eu quero.

Quando você dá oportunidade para que todos falem, primeiro ele vai ter oportunidade de ao falar se expressar, nesse momento ele vai organizar suas ideias que são muito ligadas às questões conceituais, e também estará desenvolvendo a própria linguagem. Quando a criança é pequena isso é muito necessário. À medida que vão crescendo não é tão necessário, mas é importante que se faça. Eu entendo que o grupo (Ricardo, Felipe e Vera) usou essa estratégia, porque há resultados que são conflitantes entre os grupos. Nem todo mundo chegou ao mesmo resultado. Havendo esses resultados conflitantes temos que garantir de alguma maneira se tudo o que foi feito por um grupo foi feito pelo outro. Ou se há diferença na forma de obtenção desses dados, porque se há, pode ser que esteja ai a resposta pros resultados diferentes. Mas se um grupo não ouve o que os outros grupos estão dizendo essa estratégia de que todos apresentem pra gente conflitar ou comparar deixa de ser eficiente.

Aluno 2: Ficou mais para o professor comparar ou pros alunos?

Profa. Marina: Não sei, porque não vimos o resto, mas entendo que a estratégia seja para os alunos compararem.

Ricardo: A ideia é que fosse.

Profa. Marina: E eles compararam?

Ricardo: Não, eles compararam só pelo que estava ali exposto, se alguém prestou atenção, por isso até escolhemos esse episódio, porque ele foi conflitante, a princípio, até com as respostas que eles deram nas avaliações, que foi uma das atividades que eles mais gostaram. Isso que me deixou em choque, porque eu tinha percebido que eles não estavam prestando atenção. Eu estava preocupado com o tempo, mas de alguma forma eles pelo menos colocaram outra coisa na avaliação.

Profa. Marina: Por que vocês acham isso?

Ricardo: Avaliação eu digo, não é uma prova pedimos simplesmente pra falarem o que acharam interessante em toda sequência de aulas, o que chamou atenção, se tinham críticas ou sugestões e não apareceu nenhuma nesse sentido. E isso me espantou.

Profa. Marina: Qual a opinião de vocês como grupo pra isso? De eles aparentemente dispersos terem avaliado muito positivamente essa aula.

Felipe: Acho que é porque foi uma coisa diferente do que eles estavam acostumados a fazer. 
Aluno 3: Mesmo eles não prestando atenção diretamente sempre temos a percepção de que a aula está sendo diferente. Talvez eles pudessem se dedicar um pouco mais a aula, mas eles estão cheio de trabalhos pra fazer. Eles têm essa percepção.

Felipe: $\mathrm{O}$ fato deles conversarem talvez seja porque não estejam acostumados a ficar nessa disposição. A configuração da sala é sempre fileira e mudando eles conversem mais.

Profa. Marina: Acho que se tivesse em fileira também poderia haver conversa, porque não estamos ouvindo o que eles estão conversando. Não conseguimos identificar o que o outro grupo está conversando. Pode ser que ele esteja conversando exatamente o que o outro grupo expos. Não quer dizer que essa conversa que estamos ouvindo no fundo seja sobre o jogo de futebol que aconteceu no dia anterior, pode ser, mas não é garantido que isso seja. Mas talvez a resposta para o porquê dos alunos avaliarem essa aula positivamente esteja no fato de além de ser uma atividade diferente do que eles fazem é uma atividade que eles chegaram à resposta, ainda que tratando de um tema que, a princípio, seria difícil eles conseguiram resolver o problema.

Vera: Estamos falando de aulas diferentes. A maior parte das aulas, que fizemos com eles, foi dessa forma, eles reunidos em grupo e resolvendo alguma coisa. As outras eram mais questões ou atividades para eles pensarem e resolverem em grupo e acabava ali, eles entregavam, levávamos embora e corrigíamos. Essa dai não. De repente a diferença foi porque eles puderam comparar na hora, a gente pediu para eles colocarem na lousa, eles brigavam pelos resultados, meio que queriam competir.

Profa. Marina: Sim. E é nesse sentido que ela se diferencia, porque ainda que você coloque o aluno em grupo para responder ao questionário que vai ser dado ao professor ele responde questionários na sala de aula, inúmeros. Então para ele a novidade é só estar em grupo. Estou exagerando, porque não é o caso que vocês fizeram, mas o fato dele estar em grupo trabalhando para resolver um problema em que o dos outros deu errado, mas ele tem plena convicção que os passos que ele usou estão certos e ai ele se sente impelido a defender as ações que o grupo tomou. Nesse momento você acaba criando com o aluno uma questão que a gente pouco aborda em sala de aula, que é a autoestima do aluno que está sendo ali trabalhada, do fato dele reconhecer que ele foi capaz de responder um problema que foi dado a ele, que ele foi capaz de discutir com o colega sobre aquilo e que ainda que o resultado dele não seja o que foi esperado ele entendeu como proceder para resolver. Muito diferente de quando você dá o questionário e ele leva para a casa. Pode ser que ele traga na aula seguinte, mas ai não se discute de novo. E essa questão de trabalhar "eu estou certo ou estou errado" só é feita pelo professor. Essa dimensão emocional foi muito trabalhada nessa aula.

Pesquisadora: Depois eles ficavam ainda comparando. Pegavam a filipeta com o espectro e iam olhando nos elementos, porque tinha dado diferente. Então eles continuavam a comparar. Esse menino aqui, no final, bem no final, ele encontrou uma filipeta no chão e falou "Olha, derrubaram uma", pegou e guardou pra ele, colocou dentro do caderno dele.

(RETORNAM AO VIDEO)

Profa. Marina: Acho também importante falar outra coisa. Percebam que o Ricardo começou falando do outro lado e não tinha ninguém olhando pra ele. A gente faz isso, é inconsciente, eu imagino que você não tenha pensado nisso.

Nesse momento você está com situações adversas acontecendo, mas temos que prestar atenção se às vezes em sala de aula não damos mais atenção àquele aluno que presta atenção na gente. E ai é perverso, no sentido de que você imagina que tem um grupo de alunos que senta sempre na frente, no fundo, do lado direito ou do lado esquerdo da sala e você sabe que aquele grupo trabalha. Você sabe que consegue encaminhar bem a aula se fizer perguntas praquele grupo. Esquece-se de perguntar para os outros, esquece talvez até de olhar pra ele. Não estou dizendo que isso aconteceu com você, Ricardo. Só estou usando esse exemplo para tentarmos fazer uma relação com isso. Como tem um grupo que te dá segurança você se apoia nele e esquece-se da turma como um todo. Isso é muito comum de fazermos.

Aluno 4: Tem escolas que realmente separam, observamos a segregação na sala de aula. Divide entre os bagunceiros e os mais aplicados. Já aconteceu de eu chegar na sala e o professor me dizer quem é bom e quem era ruim. 
Felipe: Essa divisão os alunos fazem entre eles. Já se acomodam na sala assim. O grupinho dos mais aplicados, o grupinho dos que mais conversam.

Aluno 3: Esses que sentam mais próximos à carteira do professor já esperam que este dê atenção a eles. E se não dá eles ficam chateados.

Profa. Marina: Vocês estão colocando um ponto central que na minha percepção é um dos aspectos do por que essa aula foi tão bem avaliada pelos alunos. Porque você começa a trabalhar com características emocionais, que nós como professores de física muitas vezes deixamos de fora. Estamos falando com pessoas em formação e estamos falando, sobretudo nessa faixa etária com a qual vocês trabalham, de pessoas que estão em transformação constante e que tem um apelo de se auto afirmar muito necessário. Ainda que alguns deixem isso explícito e demonstrem a carência para o professor, outros demonstram essa carência de outra forma, ignorando. Agora, se você acaba também ignorando aqueles alunos a autoestima deles vai ficando cada vez mais baixa e a vontade dele de não estar na aula cada vez se fortalece mais. Ouvir o aluno que sempre está interessado em falar é importante, mas buscar mecanismos de dar a voz a quem nunca falou também é essencial. Às vezes salvamos uma discussão, mas que fica restrita àquele grupo.

Felipe: Onde eu trabalho tem umas "panelas" bem divididas, e ai o que a Profa. Marina fez? Resolveu formar um círculo e os alunos bons ficaram todos de um lado da sala. Então, o que acontece, quando vamos dar aula ficamos virados para o lado de cá (dos alunos bons) e de costas para os outros alunos. Ficou pior, você fico de costas mesmo, esses alunos do oba-oba agora você não está nem vendo.

Vera: É inconsciente o professor dar atenção a quem está prestando mais atenção?

Profa. Marina: O que eu disse é que esse comportamento do Ricardo foi inconsciente, ele estava de um lado da turma que ninguém estava prestando atenção [...].

Aluno 5: Acho que faz parte daquela questão de você falar algo que alguém está compreendendo e isso te estimula a continuar.

Felipe: Isso é natural, toda vez que você faz perguntas já olha para quem vai responder.

Profa. Marina: Muitas vezes você tem que prestar atenção para que aquele aluno que sempre fala não seja o que sempre fala. O que acontece é que você não pode olhar para o aluno que sempre fala quando faz a pergunta, porque você está esperando a resposta dele. Olha para outro que nunca fala. (risos)

São coisas pequenas, mas estamos lidando com relações interpessoais e às vezes elas são estimuladas por coisas que nem imaginamos que possamos fazer para estimular. A pergunta abre a porta para o diálogo, mas não é só ela que está em jogo.

Aluno 3: É verdade, às vezes conseguimos chamar a atenção de alunos que você não estava esperando. A Bia viu a menina da nossa turma, ela só desenhava na aula e de repente falou algo [...].

Profa. Marina: Agora, Vera, voltando a sua questão. Às vezes esse comportamento do professor é inconsciente, mas é também um porto seguro que o professor encontra. Temos tanta adversidade na sala de aula, até o próprio tempo é um deles, que você quer cumprir aquilo que programou para aquela aula. Você sabe que se ficar esperando o outro grupo, que não te dá atenção, então você já fica próximo àquele que falaria.

Vou falar uma questão pessoal. Eu tinha muita dificuldade para aprender que eu precisava ouvir aquele aluno que falava aquilo que eu não queria ouvir. Normalmente quando damos um texto para os alunos lerem, minhas aulas não são de exatas, são muito mais de humanas e, para haver um diálogo tem que haver posições conflitantes. Como eu resolvo isso? Às vezes dando texto que é polêmico; às vezes escutando falas que, a princípio, não são as que eu gostaria de ouvir dos alunos, mas que são o motor propulsor da discussão. Essa experiência de ouvir todo mundo não é ao acaso. Ela é de fato para se estabelecer esses diferentes pontos de vista e ai fazer sentido. Porque numa aula de Metodologia eu não vou passar pra vocês a minha ideia, eu vou oferecer um pouco do que eu entendo que seja uma maneira 
interessante de se trabalhar física, mas o que você vai sair entendendo é a sua construção. Por isso a necessidade de haver pontos conflitantes, de quem goste de avaliação externa e de quem não goste, para você ter uma condição maior, informações maiores à disposição para você própria construir o seu caminho. No começo era muito mais fácil eu dar o aval positivo só daqueles alunos que falavam o que eu queria ouvir. E você tem que dar aval positivo para os dois, gostando ou não. Numa questão como essa, porque não estou falando em questões de exatas. É difícil mesmo, vamos aprendendo de uma aula para outra e aprimorando essa maneira de estabelecer vínculos e interações com os alunos que são muito mais do cunho social, emocional, psicológico do que uma aula de Metodologia vai dar conta de ensinar para vocês.

(RETORNAM AO VIDEO)

Profa. Marina: Vocês vão falar alguma coisa?

Ricardo: A gente escolheu exatamente porque tinha esse conflito. Do que eles nos falaram como um todo e do que aconteceu na aula em si. Lógico que na parte das avaliações estavam se referindo também às outras aulas.

Profa. Marina: Como vocês avaliam essa aula?

Ricardo: É complicado, porque ao mesmo tempo em que ninguém estava prestando atenção e participando de forma efetiva me intrigou. Não sei responder sua pergunta agora, mas eles mencionaram que foi uma das aulas que mais gostaram.

Não sei responder como avaliar, porque se eles aprenderam não foi na hora que eu estava falando alguma coisa pra eles.

Felipe: É que às vezes você ouvindo assim você acha que é bagunça, mas pra eles é perfeitamente normal.

Profa. Marina: E o resto de vocês aqui, como é que vocês avaliam isso?

Aluno 6: Eu acho difícil dizer, a respeito da aprendizagem, quando ocorreu de fato. Porque essa questão do professor e os alunos falarem ao mesmo tempo, quase desenvolvem uma habilidade extra de poder filtrar as coisas.

Eu fiz um estágio sequencial no $6^{\circ}$ ano e era um caos, mil vezes pior que isso, era situação de as crianças estarem o tempo todo em pé e a Profa. Marina passando instrução e as crianças passando por todos os lados e aquela falação muito alta. Eu estava sentado no fundo e não conseguia ouvir o que ela estava dizendo, tinha uma aluna sentada ao meu lado anotando tudo o que ela estava dizendo. Eu fiquei abismado, porque eu não estava ouvindo. Isso é só um exemplo. A outra questão é que pode ter ocorrido no processo em grupos, de eles estarem trocando palavras entre eles, o fato da linguagem deles se aproximar, talvez possa facilitar o trabalho em grupo, e até mesmo desse ouvido seletivo que alguns alunos possam ter apreendido. É difícil dizer a relação quando ocorreu essa aprendizagem.

Profa. Marina: É, é difícil. Até porque ela pode ocorrer depois. Agora essa questão do barulho é algo central. As escolas hoje em dia estão cada vez mais barulhentas. Sinal de término de aula é uma coisa horrorosa. Uma escola que eu fui tinha uma musica do Caça Fantasmas no intervalo, cada vez que tocava a música eu tinha vontade de rir, porque era uma coisa tão esquizofrênica, todo mundo estava lá entretido com alguma coisa e de repente começava a tocar aquela música e as pessoas se comportavam de forma diferente. Era ensurdecedor. Uma criança que fica todo dia exposta a um barulho como esse vai de alguma maneira desenvolvendo um comportamento de que ela pode falar mais alto, porque ela tem que falar mais alto para superar o barulho externo.

A escola se torna barulhenta e não é só por iniciativa dos alunos. O barulho mais alto para tampar o que os alunos estão falando vai subindo o volume a cada hora.

Felipe: Um precisa falar mais alto do que o outro. O professor precisa falar mais alto para o aluno poder ouvir e o aluno precisar falar mais alto para o professor poder ouvir.

Profa. Marina: E ai você tem o sinal que precisa ser mais alto para todo mundo ouvir. 
Felipe: Isso se torna um vício. Às vezes fico prestando atenção, quando você deixa os alunos sentados à vontade para conversar eles sentam grudados uns no outro e é um falatório tão alto.

Profa. Marina: Eu acho que essa aula foi tão bem avaliada pelos alunos, porque ela contribuiu com outras questões que não são avaliadas normalmente na aula de física ou qualquer que seja. A oportunidade dada ao aluno para que ele de fato utilize da sua liberdade intelectual é pouca. Normalmente não acontece. Quando o aluno tem liberdade intelectual ele vê que é capaz. A escola se tornou, ou melhor, sempre foi um lugar em que você se porta como incapaz, o aluno está lá para receber formação. O fato de ir para a escola mostra tua fragilidade, isso não é desmentido por ninguém.

Monitor: Talvez seja bobagem o que eu vou falar, mas do ponto de vista do seu planejamento, Ricardo, do grupo no caso, tinha um objetivo ali que acho que vocês pensaram em discutir os dados depois, o que deu certo, o que não deu, o que foi boicotado pelo sinal da aula. No entanto, acho que os alunos, do ponto de vista da estrutura escolar que temos hoje, chegam à sala de aula para o professor ensiná-los, não para aprender. Os seus alunos aprenderam tanto que se sentiram capazes de divulgar os resultados deles. Então, talvez do seu objetivo geral não tenha sido como vocês esperavam, mas para eles foi muito mais do que costumam ter. O conflito que você apresentou talvez pudesse ser justificado por esse lado.

Quantas e quantas aulas vocês saem de lá do mesmo jeito que entrou?

Profa. Marina: Essa oportunidade conferida a eles, ainda que naquela aula eles possam não ter aprendido aquele conteúdo conceitual que vocês tinham como objetivo, foi dada a oportunidade para trabalhar outros tipos de procedimentos que são possíveis de em outras situações eles buscarem solução para aquele problema. Uma vez que ele fez essa análise do espectro ele sabe mais ou menos como funciona, se ele quiser se aprofundar já tem um caminho que se sente seguro. Que fica claro acho que é isso, é o quanto vocês trabalharam com questões emocionais e que fica desprivilegiada muitas vezes na escola.

Pesquisadora: Inclusive até na prova eles falaram que gostariam das questões.

Ricardo: É engraçado. Minha vontade é que eu não queria que eles tivessem que fazer uma prova relacionada com o que eles estavam trabalhando e a primeira coisa que a Profa. Marina falou foi que eles deveriam prestar atenção porque teriam uma prova e que ia cair o conteúdo visto. Putz, matou tudo o que queríamos fazer. Depois eu conversei com ela e disse que nossa proposta era outra e a princípio aboliu as questões do nosso conteúdo. Só que ai numa conversa com a Bia ela demonstrou que poderia ser interessante e perguntou se já tínhamos pensado que talvez tudo o que estávamos trabalhando fosse o que mais faria sentido pra eles, se tivesse que cair alguma coisa na prova talvez eles gostassem que caísse o que nós trabalhamos: "Porque vocês não perguntam pra eles?", aí passaram alguns alunos e a Vera foi falar com eles, o que achavam se algumas questões do que trabalhamos fosse incluída na prova, eles disseram que seria ótimo porque estavam manjando.

Profa. Marina: O fato de estarem "manjando" é a autoestima sendo explicitada, na linguagem deles. Podemos ir para o outro grupo?

\section{Reflexão na disciplina MEF I (1 $1^{\circ}$ semestre 2013) Grupo 2 de Heloisa}

Heloisa: Fizemos estágio no A J, que é do ladinho ...

Carlos: Então fizemos estágio nessa escola. Havíamos planejado 4 aulas, seriam 3 aulas de conceitos e a quarta aula eles fariam uma avaliação.

O caso aconteceu logo na primeira aula, quem estava dando aula era a Ana. Você quer explicar como foi?

Ana: Foi depois da aula, abrimos um espacinho para fazerem perguntas, eles até ficaram um pouco tímidos, o professor incentivou e ai uma menina fez uma pergunta... Sempre esqueço (risos).

Heloisa: Ela fez uma pergunta muito boa. Perguntou o porquê de Aristóteles estar na aula de física sendo que o tinha estudado na aula de filosofia. 
O professor virou e falou "Nossa menina, você faz cada pergunta!" e todo mundo começou a dar risada. E amamos a pergunta.

Carlos: O pessoal da sala não ia rir dela se não fosse o professor. Ele que deu o ponta pé inicial para rirem da menina. E depois disso ela até que ficou "de boa" e achamos estranho, porque pareceu que sempre riam dela.

Profa. Marina: Ela participou nas outras aulas?

Heloisa: Essa foi a primeira.

Profa. Marina: E os outros alunos?

Heloisa: Calma, vamos chegar ai.

$\mathrm{E}$ ai, ela fez essa pergunta e quando os ânimos se acalmaram a respondemos. O professor virou e falou "Você não sabia que era assim?". Dissemos que naquela época não tinha diferença entre ciências, que os filósofos eram pensadores e por isso chamavam todos de filósofos.

Carlos: Mas com certeza, ficou claro no semblante do professor, que ele não saberia responder essa pergunta.

Ana: Não estávamos tentando julgar o cara

Carlos: Ele julgou a aluna de uma maneira que pareceu que ele não sabia responder e ai para não passar vergonha tentando responder ele "zoou" a menina. Foi isso o que eu senti.

Heloisa: No mínimo o que ele não fez foi reconhecer a importância da pergunta. A pergunta foi muito boa e ele não reconheceu isso

Ana: Ele incentivou as perguntas e na primeira ele cortou e acho que isso teve certo reflexo nas outras aulas, imaginamos, que ele tenha mudado um pouco.

Heloisa: E não só dela. Pensamos que por ela ter sido reprimida, não só pelo professor como pelos alunos, isso pode gerar timidez por parte dos outros. Se eu fizer pergunta o professor vai rir de mim? Vai me hostolizar?

Carlos: Essa foi a principal que você falou, mas eu vejo mais.

Profa. Marina: Em que sentido?

Carlos: No sentido do professor ser autoritário. Por exemplo, ele chegou pra gente e falou "Quando eu for conversar com o aluno nunca fico sentado à mesa, porque eu tenho que impor autoridade. Eu fico em pé para que o aluno se sinta inferior". Várias coisas assim que ele falou.

Ana: Nós três e a Bia escutando isso.

Heloisa: Não pode abusar, mas o professor tem que incentivar as perguntas. Tem casos e casos, né? Não dá pra fazer tanta pergunta assim por causa do tempo, mas o professor tem que incentivar a reflexão. Essa foi a nossa sugestão de mudança. Enfim, tem que ter jogo de cintura para saber lidar com muitas perguntas, saber estimular as perguntas sem que elas fiquem banais.

Carlos: A sala não era tão participativa. Essa menina que perguntou aparentemente era a mais participativa e o professor depois falou pra gente que ela era muito inteligente. Ele falou que ela tinha boas colocações, mas "zoou" ela. É uma coisa muito estranha.

Outra coisa também. Quando chegamos o professor falou, e pode ter influenciado nas nossas aulas, "Vai valer nota, então quero que vocês prestem atenção no que eles vão falar". Outra coisa que talvez possa ter sido um erro nosso, foi quando demos as instruções para a atividade e fomos passando os slides e eles nem prestavam atenção no que estávamos falando, iam copiando. Tỉnha uma menina gravando nossa aula. Heloisa: Isso é outro problema também que vimos na quarta aula, em que eles tinham que redigir o problema. Como eles não têm muitas aulas com Power point ou muita aula expositiva, talvez não soubessem lidar com aquilo.

Carlos: E depois chegou na atividade, em que eles tinham que fazer uma redação, e estranharam ter que fazê-la na aula de física. Eles não sabiam fazer linha do tempo. Permitimos que consultassem todo o material deles para fazer, mas eles não conseguiam escrever. Isso foi uma dificuldade.

Ana: Abrimos todas as portas que podíamos, permitimos que fizessem em grupos e tal, mas foi uma dificuldade.

Carlos: Teve alunos que escreveram coisas que nem pensaram para escrever. "O sol fica dentro da Terra", "O universo gira em torno da Terra", e explicamos tudo sobre isso.

Profa. Marina: Muito interessante esse primeiro acompanhamento que vocês fizeram em relação a pergunta do aluno, por isso que tem que ter relação com esse ultimo apontamento que fizeram, os alunos não reconhecem que na aula de física podem fazer redação. E também não reconhecem que Aristóteles que está na aula de filosofia é o mesmo da de física. A pergunta da menina é inteligentíssima e mostra que ela está pelo menos buscando essa relação que na escola não conseguimos, porque compartimentalizamos 
tanto que acabamos não tendo essa relação com os demais professores. Mas eu volto ainda na questão da pergunta, porque vocês disseram que era esse o episódio que tinham escolhido. Eu acho que é muito mais como o professor vai receber a pergunta do aluno, porque independe se ela vai ser boa ou ruim, se o professor quer que os alunos participem da aula ele não pode ter um comportamento como esse, de completo rechaço ao aluno. Ele pode discordar do que a aluna falou. Pode sim, mas se ele quer que os alunos participem, mesmo essa maneira de ser contra aquela pergunta, tem que acolher a pergunta do aluno.

Muitos professores que estão na sala de aula não estão preparados a fazer a discussão com os alunos, porque não tiveram essa discussão quando eram alunos. E ai ele não sabe o espaço que isso deveria ocupar na aula de física. Parece que a aula que tem debate é a aula de história, de geografia, porque são os temas polêmicos. Mas quantos temas da física que não são polêmicos? Acho que todos eles.

Carlos: Você falando de temas polêmicos, quando estávamos dando aulas passamos por um período de mais de 2 mil anos e como houve acontecimentos de ruptura de pensamento percebemos que alguns alunos não souberam dar importância a cada um de maneira apropriada. Às vezes pegavam algum evento e davam importância uma pra ele, por exemplo a igreja católica, que nem tínhamos falado muito sobre isso.

Profa. Marina: Talvez porque esteja ligado ao dia a dia deles.

Heloisa: Einstein, por exemplo, ninguém colocou.

Carlos: Simplesmente esqueceram do Einstein.

Profa. Marina: Ou porque o Einstein ainda não é histórico?

Ana: Não, mas eles colocaram outros, Hubble 